UNIVERSIDADE DE SÃO PAULO

FACULDADE DE FILOSOFIA, LETRAS E CIÊNCIAS HUMANAS

DEPARTAMENTO DE ANTROPOLOGIA

Programa de Pós-graduação em Antropologia Social

ETNOARQUEOLOGIA DOS GRAFISMOS KAINGANG:

um modelo para a compreensão das sociedades Proto-Jê meridionais

SERGIO BAPTISTA DA SILVA

Orientadora: Profa. Dra. Lux Boelitz Vidal

Tese de doutorado apresentada ao PPGAS da FFLCH da USP

São Paulo, junho de 2001. 


\section{A G R A D E C I M E N T O S}

Em primeiro lugar, agradeço a minha orientadora, Professora Lux Boelitz Vidal, cuja dedicação, amizade, seriedade e sabedoria foram imprescindíveis para a concretização desta tese.

Agradeço o apoio financeiro concedido, sob forma de bolsa de estudos (PICDT), pela Universidade Federal do Rio Grande do Sul, através da Pró-Reitoria de Pós-Graduação, com recursos oriundos do convênio UFRGS/Coordenadoria de Aperfeiçoamento do Pessoal de Ensino Superior.

Muitas pessoas e instituições museológicas e de pesquisa contribuíram com sua acolhida, seus espaços, suas disponibilidades, seus ensinamentos

suas amizades para a realização deste trabalho. A todos, meus agradecimentos.

Aos meus interlocutores Kaingang e Guarani, que tornaram possível esta tese, dirijo minha gratidão, especialmente a Karein, Arokiy, Katxô, Ningrei, Ming iãfá, Batista, Jorge Eufrásio, Kaxen mbag e a Karaí Iápuá, Djerá, Tatá tï, Turíbio Karaí, Krexú, Juarez, Yvay, Pará.

Agradeço a minha família pelo apoio, paciência e carinho. 


\title{
Etnoarqueologia dos grafismos Kaingang: um modelo para a compreensão das sociedades Proto-Jê meridionais
}

\author{
Palavras-chave: Grafismo indígena; Kaingang; \\ Etnoarqueologia; Grupos Proto-Jê do sul; cultura material.
}

\begin{abstract}
RESUMO
Este estudo realiza uma articulação entre o registro arqueológico das ditas "tradições ceramistas planálticas" do sul do Brasil (Taquara, Itararé e Casa de Pedra), as quais considero Proto-Jê meridionais, e os registros etnográfico, etno-histórico e lingüístico das sociedades Jê meridionais (Kaingang e Xokleng), para tornar possível uma mais profunda e sofisticada compreensão destas populações Proto-Jê do sul. O registro arqueológico deixado por estes grupos foi analisado do ponto de vista de sua dimensão simbólica, principalmente quando ele podia ser identificado como parte de um sistema de representações visuais (grafismos). Assim, foi empreendida uma etnoarqueologia dos grafismos Kaingang, articulando-se os registros arqueológico, etnográfico, etno-histórico e lingüístico a partir de uma abordagem cognitiva, que privilegia e interpreta a produção de significados pelas populações Proto-Jê meridionais, principalmente suas representações sobre a vida em sociedade, sobre os domínios da natureza, da sobrenatureza, e sobre a morte, tendo como base estudos etnológicos a respeito da sociedade Kaingang.
\end{abstract}

\section{Ethnoarchaeology of Kaingang graphic representations: a model to understand southern Proto-Jê societies}

Key-words: South Brazil indian graphic representations; Kaingang; ethnoarchaeology; southern Proto-Jê groups; material culture

\begin{abstract}
This study establishes a relation between archaeological record of the so called "local ceramic traditions" of the south of Brazil (Taquara, Itararé and Casa de Pedra), which I consider as southern Proto-Jê, and ethnographical, ethnohistorical, and linguistic records of southern Jê societies (Kaingang and Xokleng) aiming at a deeper and more sophisticated understanding of those southern Proto-Jê populations. Archaeological record left by those groups were analysed from the standpoint of their symbolic dimension mainly when it could be identified as part of a system of visual representations (graphic representations). Thus, an ethnoarchaeology of Kaingang graphic representations was undertaken in which the archaeological, ethnographical, ethnohistorical and linguistic records were related by mean of a cognitive approach which favours and interprets the production of meanings by southern Proto-Jê populations, especially their representations about social life, about natural and supernatural domains, and about death, based on ethnological studies of Kaingang society.
\end{abstract}


O B S E R V A Ç Õ E S

Grafou-se com trema as vogais "i", "e", "u" e "y" do idioma Kaingang (e das demais línguas indígenas que aparecem no texto), quando o correto seria fazê-lo com til, o que o editor de textos usado não permitiu.

Exceto quando indicado expressamente, as fotografias são do autor desta tese. 


\section{SUMÁRIO}

1. Introdução 6

2. Articulação entre Arqueologia e Etnologia: as bases teóricas 19

3. O horizonte cultural Proto-Jê meridional 37

3.1. As "tradições locais ceramistas planálticas": continuidade histórico-cultural e vinculação aos Jê meridionais

3.2. As "tradições" Taquara, Itararé e Casa de Pedra: suas "fases", sua cultura material e outras indicações sobre as relações entre os registros arqueológico e etnográfico

3.2.1. As "fases" da "Tradição" Taquara

3.2.2. As "fases" das "tradições" Itararé e Casa de Pedra

4. Sociedade Kaingang: concepções cosmológicas

4.1. Complementariedade: relações entre opostos 103

4.1.1. Cunhadio masculino: os iambré 103

4.1.2. Os nomes do mato: o poder oriundo do domínio da floresta 117

4.2. Representações e práticas relativas à saúde, à doença, à cura e à morte: o numbê

4.3. Mito e história: considerações sobre as origens da sociedade Kaingang atual

4.4. Representações sobre a morte e padrões de sepultamento (Proto)Jê 141

5. O sistema de representações visuais (Proto)Jê meridional 
5.1.1. Grafismos presentes nos materiais etnográficos Kaingang

5.1.2. Vein kongat: pintura corporal Kaingang

5.2. Grafismos Proto(Guarani): algumas comparações

5.2.1. Ipará Mbyá: grafismos sagrados do cosmo

5.2.2. Grafismos Proto-Guarani

5.2.3. Ysy: a antiga pintura corporal Mbyá

5.3.3. Grafismos rupestres em Santa Catarina: suas relações com o Rio Grande do Sul

6. Conclusões: o modelo Kaingang e o horizonte cultural Proto-Jê do sul 308 Bibliografia 


\section{INTRODUÇÃO}

O principal objetivo desta tese foi o de realizar uma articulação entre o registro arqueológico das chamadas "tradições ${ }^{1}$ ceramistas planálticas" do sul do Brasil - Taquara, Itararé e Casa de Pedra - (as quais considero Jê meridionais "pré-coloniais"2) e o registro etnográfico, etno-histórico e lingüístico das sociedades Jê meridionais - Kaingang e Xokleng -, para tornar possível uma mais profunda e sofisticada compreensão destas populações Jê meridionais "pré-coloniais". O registro arqueológico deixado por estes grupos populacionais foi analisado do ponto de vista de sua dimensão simbólica, principalmente quando podia ser identificado como parte de um sistema de representações visuais (grafismos).

Neste sentido, pretendi realizar uma etnoarqueologia dos grafismos Kaingang, articulando os registros arqueológico e etnográfico a partir de uma abordagem teórica cognitiva (explicitada no Capítulo 2), que privilegia e interpreta a produção de significações pelas populações Jê meridionais "précoloniais", principalmente suas representações sobre a vida em sociedade ${ }^{3}$, sobre os domínios da natureza, da sobrenatureza, e sobre a morte, tendo como base estudos etnológicos sobre a sociedade Kaingang ${ }^{4}$

A seqüência natural desta tese, no futuro, será o de testar o modelo etnoarqueológico aqui sugerido, utilizando metodologias arqueológicas próprias.

De acordo com um quadro referencial já quase totalmente aceito pela arqueologia brasileira, considero as denominadas "tradições ceramistas do Planalto Sul-Brasileiro e áreas adjacentes" ou "tradições locais planálticas" ou "tradições" Taquara, Itararé e Casa de Pedra, estudadas pela arqueologia desde um ponto de vista exclusivamente tecnológico, como uma única, ampla e homogênea tradição cultural Jê meridional "pré-colonial", que, no decorrer de um longo processo histórico-cultural de aproximadamente dois mil anos,

\footnotetext{
1 Termo que será analisado a seguir.

2 Adjetivo que será discutido logo em seguida.

3 Vide item 5.3.

4 Descritos no Capítulo 4.
} 
segundo o registro arqueológico ${ }^{5}$ desembocará nas histórica e etnograficamente conhecidas sociedades Jê meridionais Kaingang e Xokleng. Este temporal e geograficamente abrangente horizonte cultural Jê meridional "pré-colonial" será discutido e avaliado no Capítulo 3. Por hora, é necessário dizer, no entanto, que diferenças e especificidades regionais estariam nele presentes, como indicam as diferenças existentes historicamente entre as modernas populações Jê do sul.

Quanto ao registro lingüístico, Urban (1992:87), apesar de reconhecer que "a pesquisa sobre as línguas indígenas do Brasil está muito aquém do necessário para uma reconstrução", acredita que os dados disponíveis e os estudos já feitos permitem alcançar um grau mediano e relativo de certeza com relação às línguas Jê.

Segundo este autor, o método de reconstrução lingüística, desenvolvido na lingüística comparativa, permite "determinar as relações genéticas (Genética, nesse sentido, não tem nada a ver com biologia ou genes. Refere-se a processos históricos nos quais, ao longo do tempo, uma língua se diferencia em dialetos e, finalmente, em línguas derivadas distintas. A partir destas últimas, a língua-mãe pode ser reconstruída.) entre as línguas, ou seja, relações derivadas de origem histórica comum para duas ou mais línguas faladas atualmente" (Urban, 1992:87 e 102).

Deste modo, é possível estabelecer a proximidade e a distância entre línguas de um mesmo grupo, podendo-se, inclusive, avaliar em termos relativos quando as línguas de uma família se separaram, diferenciando-se umas das outras. Com relação à família Jê do Tronco lingüístico Macro-Jê, sabe-se que as línguas a ela pertencentes têm uma origem histórica comum. Entretanto, seu ramo mais meridional (línguas Kaingang e Xokleng) "separouse muito antes de ocorrer a diferenciação entre os outros membros da família" (op. cit., pág. 88).

O método da glotocronologia, utilizado no passado para estimar em termos absolutos a profundidade cronológica desta separação, hoje não é mais considerado preciso, mas pode ser substituído pela comparação entre os graus de semelhança apresentados por línguas indígenas como os que ocorrem entre

\footnotetext{
5 São as seguintes, respectivamente, as datações radiocarbônicas mais antiga e mais recente para os materiais arqueológicos vinculados às "tradições ceramistas locais planálticas": 140 \pm 85 d.C. (SI - 813) - norte do RS e

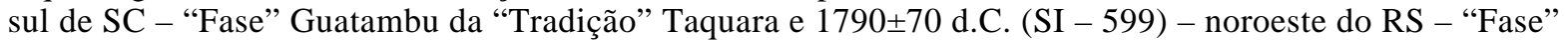
Taquaruçu da "Tradição" Taquara. Estes 1650 anos somados aos 211 que separam a data de 1790 do ano 2001 perfazem 1861 anos. Registrados arqueologicamente, são quase dois milênios de processo histórico-cultural.
} 
línguas cujo material histórico comprova sua diferenciação lingüística, como o caso indo-europeu. Tais métodos permitem, com certa segurança, ir até uma data aproximada de 4.000 anos a.C. (op. cit., pág. 88/9).

Além das cronologias, os métodos lingüísticos permitem estabelecer algumas informações quanto à distribuição espacial das línguas, isto é, fornecem hipóteses quanto "à localização das línguas no passado remoto e às migrações que levaram à sua atual distribuição". A distribuição das línguas Jê atuais sugere uma origem, há uns 2 ou 3 mil anos, entre os rios São Francisco e Tocantins. Segundo estes estudos lingüísticos, relatados por Urban, a família Jê representa um ramo relativamente recente do chamado Tronco Macro-Jê, tendo se separado deste último há uns 3 mil anos ou mais, de acordo com as semelhanças internas entre as línguas Jê atuais (Urban, 1992:89/90).

Sempre de acordo com este autor, os Jê meridionais (Kaingang e Xokleng) teriam sido os primeiros a se separarem do resto dos grupos Jê. Eles

“...teriam iniciado sua migração em direção ao sul nesse momento, há uns 3 mil anos, mas não se tem idéia de quando teriam chegado à região que atualmente ocupam no sul do Brasil. Tampouco se sabe por que migraram, embora um estudo do relevo geográfico mostre que se dirigiram a uma região de planalto semelhante ao seu hábitat originário" (Urban, 1992:90) ${ }^{6}$.

A segunda separação deu-se entre os Jê centrais e setentrionais, os últimos dirigindo-se para a bacia amazônica e expandindo-se também para oeste. Isto teria ocorrido entre 1 e 2 mil anos atrás, como sugerem as taxas de cognatos entre os ramos central e setentrional. Durante os últimos mil anos, ocorreu a diferenciação interna dos grupos central e setentrional. Nos últimos 500 anos, teriam acontecido as diferenciações internas entre os dialetos Timbira orientais (Canela, Krinkati, Pukobyê, Kranjé, Gavião e Krahô) e entre os dialetos Kayapó (Kubenkranken, Kubenkrañoti, Mekrañoti, Kokraimoro, Gorotire, Xikrin e Txukahamãe) - Urban, 1992:90.

A reconstrução lingüística sugere que as populações Jê aproximam-se mais do tipo clássico de comunidade isolada, isto é, "o contato lingüístico costuma se restringir aos membros do grupo local, e quando os grupos se

\footnotetext{
${ }^{6}$ Como foi dito anteriormente, no registro arqueológico, a datação radiocarbônica mais antiga para o horizonte Jê meridional "pré-colonial" é de menos de 2 mil anos, no norte do RS e sul de SC, regiões praticamente finais da rota migratória rumo ao sul, segundo a lingüística. No entanto, esta data não constrange o modelo lingüístico, apenas mostra a pouca quantidade de estudos arqueológicos para a região de SC, PR e SP, e, principalmente, evidencia a falta de datações absolutas para este horizonte arqueológico.
} 
dividem, aparentemente não retomam mais tarde um contato de tipo constante que possa produzir empréstimos" (op. cit., pág. 94).

Quanto à reconstrução das trajetórias e cronologias específicas dos Jê meridionais, Wiesemann (1978:199-200), estudando as línguas Kaingang e Xokleng, diferenciou cinco dialetos para a primeira ${ }^{7}$. Estes dialetos, que se diferenciam em várias partes de sua estrutura, principalmente na fonológica, estão circunscritos a regiões restritas: 1) dialeto de São Paulo, entre os rios Tietê e Paranapanema; 2) dialeto do Paraná, entre os rios Paranapanema e Iguaçu; 3) dialeto Central, entre os rios Iguaçu e Uruguai; 4) dialeto Sudoeste, ao sul do Rio Uruguai e a oeste do Rio Passo Fundo; e 5) dialeto Sudeste, ao sul do Rio Uruguai e a leste do Rio Passo Fundo.

Em suas conclusões, Wiesemann (1978:215) enfatiza que a língua Xokleng tem menos em comum com o Kaingang do que os dialetos entre si, adiantando que os falantes da segunda não compreendem os da primeira. Para a lingüista, estes fatos indicam, claramente, "que estas duas línguas se separaram há muito tempo".

Por outro lado, levando em conta as semelhanças e diferenças entre os cinco dialetos da língua Kaingang, Wiesemann (1978:215) conclui que o grupo falante do dialeto de São Paulo separou-se dos outros algum tempo depois da separação entre Kaingang e Xokleng". Segundo a autora, os falantes da língua Xokleng e do dialeto Kaingang de São Paulo não tinham mais contato com os grupos falantes dos demais dialetos Kaingang pelo menos desde 1626, data em que supostamente foi introduzida a palavra Topë ("Deus" - empréstimo do Guarani: Tupã) pelo primeiro contato estabelecido pelo Pe. A. Ruiz de Montoya com os "Gualachos", aldeados na Reducción de la Concepción de los Gualachos. Esta palavra é totalmente desconhecida no dialeto de São Paulo e na língua Xokleng (Wiesemann, 1978:211-12, 215).

Apesar da inexistência de reconstruções lingüísticas específicas para os dialetos Kaingang, a estimativa da autora equivale aproximadamente à de Urban (1992:90) para a formação dos dialetos Timbira orientais e Kayapó, que

\footnotetext{
7 Apesar de alguns pesquisadores criticarem a simplificação contida no modelo dos 5 dialetos proposto por Wiesemann, uma vez que não dá conta "da complexidade das relações lingüísticas inter-grupos e, ainda, entre grupos Kaingang e Xokleng”, conforme D’Angelis (1999:11) apud Veiga (2000:35), e mesmo admitindo-se um número maior de dialetos no passado, a síntese cronológica e que embasa a diferenciação dos grupos é satisfatória, devendo ser sofisticada com novos dados e novas abordagens, no futuro.
} 
é de 500 anos. A diferenciação entre as línguas Kaingang e Xokleng teria acontecido, portanto, bem antes desta marca.

Considerando os dados lingüísticos (diferenças e semelhanças entre o idioma Xokleng e os dialetos da língua Kaingang), a autora elaborou a seguinte hipótese para a origem, migrações e separações dos Jê meridionais propriamente ditos no decorrer de seu longo processo histórico-cultural, uma vez que, pelos estudos lingüísticos referidos por Urban (1992), o ramo meridional teria iniciado sua migração rumo ao sul há uns três mil anos:

"Depois de se separarem dos outros grupos Jê, os índios Kaingang começaram a sua migração para o sul. O primeiro grupo a se separar foram os Xokléng que emigraram até Santa Catarina e não tinham mais contato amigável com os outros grupos. Uma segunda separação aconteceu entre o grupo de SP e os outros Kaingang os últimos continuaram sua migração para o sul. Passado o rio Paranapanema não havia mais contato. Então se separaram em várias hordas; as que passaram o rio Iguaçu não tinham mais contato com os do norte deste rio. Um grupo passou vários rios em direção sudeste e não tinha mais contato com os outros (guardou a diferença ã dif. ë). Os grupos C e SO mantiveram contato esporádico depois da separação. O contato com os grupos do dialeto $\mathrm{SE}$ veio mais tarde, quando $\mathrm{C}$ e $\mathrm{SO}$ já tinham neutralizado a diferença ã dif. ë. O contato entre C, SE e SO foi bastante grande, no entanto, para ter bastante inovações em comum. O grupo PR começou várias inovações em que os outros não participaram, guardando outras diferenças que os outros perderam, mostrando que o contato foi muito parco" (Wiesemann, 1978:216).

Do ponto de vista metodológico desta tese, estas semelhanças entre os grupos falantes dos diversos dialetos Kaingang permitiram trabalhar com a cultura material de quase todos os grupos, encarando-a como oriunda de um único processo histórico de fundo cultural comum. As diferenças e especificidades seriam regionais e não-estruturais. Estudos posteriores, mais detalhados, deverão explorar estas possíveis diferenças que, como na língua, poderão existir na sua cultura material ${ }^{8}$.

De uma certa forma, as razões destas diferenças poderiam estar relacionadas parcialmente com o tipo das certamente complexas interações havidas entre as populações pré-existentes no que hoje corresponde ao sul do Brasil com os grupos Jê meridionais migrantes, como será discutido nos Capítulos 3 e 4.

\footnotetext{
8 Isto é o que parece ocorrer entre os sistemas de representação visual Kaingang e Xokleng, que somente parcialmente parecem se corresponder. Veja o Capítulo 5, adiante.
} 
Do ponto de vista conceitual, em substituição aos termos "tradição" e "subtradição", tradicionalmente usados pela arqueologia brasileira, os quais considero vagos e imprecisos, uma vez que são ordenadores essencialmente tecnológicos, não levando em conta os aspectos simbólicos da cultura material por eles agregada ${ }^{9}$, proponho o termo Proto-Jê meridiona $~^{10}$ para denominar estes grupos populacionais anteriores e antecedentes das sociedades Xokleng e Kaingang históricas, sem nenhuma associação perturbadora com o conceito lingüístico de protolíngua ("língua-mãe").

Este conceito está relacionado com o momento de consolidação da lingüística no século XIX. A moderna lingüística reconheceu a mudança contínua da língua, contrariamente à concepção estática de gramática, que dominou nos séculos anteriores. Desta forma, a descoberta de que muitas línguas da Europa e várias da Ásia têm origem comum e provêm de uma língua muitíssimo anterior - o indo-europeu - alterou o conceito de língua, que passou a ser concebida enquanto mudança lingüística, isto é, enquanto processo dinâmico, gradual e coerente. Neste ambiente científico, protolíngua surge como conceito explicativo para esta origem comum de várias línguas que sofreram esta evolução lingüística (sem a idéia de avanço para melhor, ou progresso), ao longo de seus processos diacrônicos. Esta origem comum - a protolíngua - pressupõe uma longa evolução anterior, não tendo uma unidade rígida, e já possuindo uma distribuição dialetal que prenuncia as divergências

\footnotetext{
${ }^{9}$ Por esta razão, geralmente não refletem a diversidade cultural dos grupos étnicos indígenas que podem ser correlacionados etnograficamente a uma "tradição" ou "fase". Outras vezes, por terem sido criados através de estudos exploratórios metodologicamente insuficientes, as "fases" nem ao menos correspondem a cronologias dentro das "tradições". Estas últimas, ainda, por vezes, por terem na sua origem vícios de uso exacerbado de diferenciação por critérios inexpressivos culturalmente (como, por exemplo, ausência ou presença de certo tipo de antiplástico mineral na cerâmica), dividem o homogêneo, como parece ser o caso das "tradições locais planálticas". Para Schmitz e Becker, "Fases denominam conjuntos de materiais com características semelhantes (cerâmica, artefatos de pedra ou osso, gravações ou pinturas em rochas) e que mantêm as características, isoladas como diagnósticas, dentro de um espaço e tempo reduzidos; mal comparando, abrangeriam o espaço e o tempo de uma tribo indígena. Tradições são conjuntos maiores de materiais com características semelhantes, reunindo em geral diversas fases e que mantêm as características, isoladas como diagnósticas, dentro de um tempo (e espaço) mais amplos; mal comparando, abrangeriam o espaço e o tempo de uma 'nação' indígena" (Schmitz \& Becker, 1991:256-7). Quando for necessário usá-los, grafarei estes termos entre aspas.

10 Optei por grafar Proto-Jê (com hífen), com o objetivo de ficar visível, e escrita com maiúscula inicial, a palavra Jê, apesar de a regra gramatical, neste caso, desaconselhar o uso de hífen. Segui a grafia da expressão Macro-Jê, de uso tradicional e reconhecido, que pelas regras gramaticais deveria também ser escrita sem hífen. O emprego do prefixo proto entre parêntesis, antecedendo a expressão Jê meridional, pretende abranger o que é relativo tanto aos Jê meridionais de hoje como aos primeiros Jê do sul do atual Brasil. Nesta situação particular - (Proto)Jê - omiti o hífen, já que a palavra Jê, por causa do parêntesis, pôde ser grafada com inicial maiúscula.
} 
posteriores, isto é, as duas ou mais línguas que dela se originam (Camara Jr., 1977:35-37; 290-93).

Quando usar, portanto, o termo proposto - Proto-Jê meridional -, não estarei me referindo à língua que originou as duas línguas Jê meridionais conhecidas, ou seja, não estarei me referindo à protolíngua Jê meridional. Estarei, sim, enfocando grupos populacionais com tradição tecnológica e cultural comum, mais ou menos homogênea, falantes de uma protolíngua Jê meridional, que através de processos de mudança lingüística deu origem a duas línguas: o Xokleng e o Kaingang ${ }^{11}$.

Estes grupos "pré-coloniais" - os Proto-Jê meridionais - não falavam, pois, o (idioma) Proto-Jê, mas, sim, uma língua Jê - o (idioma) Proto-Jê meridional, que deu origem tanto a língua Xokleng como a língua Kaingang.

O prefixo proto sempre será empregado no sentido de primeiro ${ }^{12}$, e sempre em relação a populações e não a línguas. Deste modo, quando escrever Proto-Jê meridionais, estarei sempre me referindo a grupos populacionais locais com tradição tecnológica e cultural comum, e não a protolínguas ou línguas. No entanto, admito que estas populações, seguramente as históricas e atuais, falam línguas da família lingüística Jê e têm, mesmo as "pré-coloniais", características sociais e culturais próprias das sociedades Jê, o que será trabalhado no Capítulo 4 e desenvolvido no Capítulo 5.

Com o mesmo sentido, quando quiser enfatizar as diferenças ainda não totalmente reconhecidas na análise e interpretação do registro arqueológico ${ }^{13}$, empregarei os termos Proto-Xokleng e Proto-Kaingang, referindo-me às sociedades indígenas Xokleng e Kaingang, já plenamente constituídas e diferentes entre si a partir de um momento dado (qual?) do período temporal

\footnotetext{
11 A cultura, necessariamente, não acompanha as mudanças lingüísticas. Veja nota 13, abaixo.

12 "Proto pref. Significa primeiro: protomártir." Conf. Enciclopédia e Dicionário ilustrado Koogan/Houaiss, 1993:684.

${ }_{13}$ Ainda não está totalmente esclarecida a possibilidade de diferenciação, pela Arqueologia, das sociedades Proto-Kaingang e Proto-Xokleng. A cerâmica das "tradições" planálticas, conforme F. Silva (s/d), não se evidencia como um bom indicador das diferenças entre Kaingang e Xokleng, pois a reconstituição etnohistórica que a autora realizou de seus processos de produção mostrou muitas semelhanças. Onde estaria o indicador arqueológico da diferença manifesta etnograficamente? Talvez parcialmente nos grafismos, pois apesar de muitas representações visuais Xokleng serem identificadas e nomeadas pelos Kaingang do Rio Grande do Sul como se Kaingang fossem, várias delas não são reconhecidas, sendo consideradas estranhas. Talvez estaria nos diferentes padrões de sepultamento. Veja capítulos 4 e 5, adiante.
} 
anterior ao contato de seus membros com as populações de origem européia ${ }^{14}$. Assim, temporalmente, as expressões Proto-Jê meridional, Proto-Xokleng e Proto-Kaingang podem estar apontando para datas relativamente recentes, de aproximadamente dois séculos atrás, como o século XIX ${ }^{15}$, por exemplo, ou para datas mais recuadas, desde o século II d.C.

A vantagem em usar o termo Proto-Jê meridional (ou Proto-Kaingang, ou Proto-Xokleng), ao invés de "grupos ligados às tradições ceramistas planálticas Taquara, Itararé e Casa de Pedra", ou, mesmo, "Jê meridional préhistórico ou pré-colonial", reside no fato de não romper o processo históricocultural contínuo que desembocou nas sociedades Kaingang e Xokleng, o que implicitamente acontece se for usado o prefixo pré (pré-histórico, précolonial, pré-contato), denotando-se, assim, uma ruptura de um processo que cultural e historicamente foi contínuo. Além disso, indica-se expressamente a vinculação destes grupos às sociedades Jê meridionais (Kaingang e Xokleng), aproximando os estudos arqueológicos do campo antropológico.

Seguindo este mesmo raciocínio, quando quiser me reportar aos Guarani do período pré-colonial, emprego a expressão Proto-Guarani, ao invés de "grupos ligados à Tradição Tupiguarani ou à Subtradição Guarani da Tradição Policroma Amazônica", como costuma-se fazer na literatura arqueológica.

Os grandes lapsos temporal (materiais arqueológicos pelo menos desde o século II d.C. até o século XIX, sendo complementados por materiais etnográficos até o final do século XX) e geográfico (RS, SC, PR e SP) que esta tese enfoca pressupõem uma dinâmica intensa do processo históricocultural dos grupos indígenas nele envolvidos, remetendo à necessidade de um controle diacrônico e geográfico das informações, que deverá ser possibilitado pelas datações radiocarbônicas existentes para as ditas "tradições locais planálticas" e pelas referências e comparações possibilitadas a partir da construção de uma etno-história e do levantamento de uma etnografia para as sociedades Jê dos quatro estados sulinos.

Para atingir o objetivo principal desta tese - a articulação dos dados arqueológicos com as informações históricas e etnográficas Kaingang e

\footnotetext{
14 Como arqueologicamente ainda não é possível separar o que é Proto-Xokleng do que é Proto-Kaingang, estas populações serão denominadas, a maioria das vezes, como Proto-Jê meridionais, englobando-as.

15 Conforme a datação radiocarbônica da "Fase" Taquaruçu da "Tradição" arqueológica Taquara, que alcança os anos oitocentos. Veja Capítulo 3.
} 
Xokleng - e, conseqüentemente, para a formulação de um modelo etnoarqueológico para a compreensão dos Proto-Jê do sul do Brasil ("Tradições" Taquara, Itararé e Casa de Pedra), foi necessário satisfazer alguns objetivos específicos:

1. realizar, na falta de um "corpus" gráfico Jê meridional, um levantamento de algumas coleções etnográficas Kaingang, depositadas em várias instituições museológicas, de pesquisa e/ou ensino $^{16}$, para proceder, juntamente com interlocutores Kaingang, a um estudo analítico-interpretativo dos materiais e de seus grafismos (armas, tecidos, trançados, etc.), encarando-os como pertencentes a um sistema de representações visuais. Veja os subitens 5.1.1 e 5.1.2;

2. fazer, em conjunto com interlocutores Kaingang, uma construção interpretativa dos materiais e estruturas arqueológicos referentes aos vários sítios Proto-Jê do sul já trabalhados, especialmente aqueles que possuem grafismos, o que permitiu encará-los teoricamente como unidades significantes de um sistema de representação visual. Tais unidades significantes são, basicamente, os grafismos oriundos das técnicas de decoração da cerâmica arqueológica e da arte parietal de alguns painéis rupestres do sul do Brasil. Como não existe, infelizmente, um "corpus" dos grafismos cerâmicos ou dos grafismos rupestres, o que facilitaria a tarefa de qualquer pesquisador, foi necessário, igualmente, criar tal "corpus" gráfico Proto-Jê do sul, através da consulta à bibliografia arqueológica (muitas vezes a partir, apenas, de descrições), de fotos e desenhos de autoria de vários pesquisadores e do levantamento em instituições museológicas e/ou ensino e pesquisa ${ }^{17}$. Os resultados deste trabalho encontram-se no Capítulo 3 e 5, especialmente no item 5.3.;

3. construir e revisar uma etno-história Kaingang que auxilie na elucidação e desvelamento da dimensão simbólica contida na sua cultura material, principalmente enquanto sistema de representações visuais e secundariamente enquanto produto de significações;

\footnotetext{
16 Museu de Arqueologia e Etnologia da USP, Museu Júlio de Castilhos-RS, Museu Antropológico do Rio Grande do Sul, Laboratório de Arqueologia e Etnologia da UFRGS.

17 Núcleo de Ensino e Pesquisa Arqueológica do Dep. de História da UFRGS, Museu de Arqueologia do Rio Grande do Sul, Laboratório de Arqueologia e Etnologia do Departamento de Antropologia da UFRGS.
} 
4. levantar e revisar etnografias Kaingang, especificamente sobre organização social, sobre cultura material (do ponto de vista da antropologia da arte, isto é, elucidando os aspectos simbólicos nela contidos) e sobre mito-cosmologia (na tentativa de explicitar as relações entre cosmologia, organização social, expressões estéticas e registro arqueológico ${ }^{18}$ ). Apesar das diferenças, originadas de minha própria pesquisa de campo, reconheço os aportes fundamentais dos trabalhos de Veiga $(1994,2000)$ e Urban $(1978,1992,1996)$ a esta tese, e sua importância para a etnoarqueologia nela realizada;

5. sintetizar, a partir da bibliografia etnológica, algumas características gerais de algumas sociedades falantes de línguas da Família lingüística Jê, a fim de compará-las com as sociedades Jê meridionais e, por via da analogia etnográfica, aos Proto-Jê do Sul;

6. fazer um estudo dos grafismos (Proto)Guarani (deste modo, tanto os atuais como os "pré-coloniais", segundo minha convenção de grafia estabelecida na nota 10), objetivando comparar e melhor compreender o sistema de representações (Proto)Jê meridional (tanto os sistemas Kaingang e Xokleng, históricos e atuais, como o "précolonial", sempre de acordo com esta convenção de grafia) e tendo em vista que minhas pesquisas e a literatura etnológica disponível, principalmente os trabalhos de Veiga (1994 e 2000), sugerem algumas semelhanças entre os Kaingang e os Tupi-Guarani, o que será trabalhado no Capítulo 4. Esta pesquisa de campo, sua metodologia e seus resultados estão detalhadamente discutidos no Capítulo 5, item 5.2.

A partir, portanto, do estabelecimento de um modelo etnoarqueológico Jê meridional, que abrange sua arte, sua estruturação social e sua mitocosmologia, pretendi colaborar para o avanço teórico e metodológico das análises arqueológicas que envolvem populações Proto-Jê do sul, especificamente no que diz respeito às relações entre cultura material/arte e estrutura social/cosmologia, enfatizando teórica e metodologicamente uma ação interpretativa, cognitiva e simbólica sobre o passado.

18 Algumas passagens e/ou descrições desta tese, especialmente nos mitos, podem parecer ou um pouco longas ou não serem totalmente relacionadas com seu tema. Entretanto, como a sua leitura dirige-se essencialmente a arqueólogos, convenci-me que deveriam constar, pois podem dar subsídios a futuros trabalhos de etnoarqueologia. 


\section{Metodologia: discurso e memória Kaingang}

O trabalho de campo realizado permitiu levantar discursos e a memória de alguns interlocutores kaingang a respeito de sua cultura material, principalmente sobre o significado dos grafismos presentes em seus trançados, em seus tecidos, em suas armas, em sua pintura corporal, em sua cerâmica e em painéis rupestres do sul do Brasil.

A pesquisa baseou-se notadamente em entrevistas abertas, realizadas tanto em aldeias como em museus de Porto Alegre e de São Paulo.

Nas primeiras, a técnica utilizada foi a de apreender o discurso dos kaingang sobre sua cultura material, a partir de sua produção artesanal feita no local da pesquisa ou através da apresentação de fotografias e desenhos de objetos Kaingang, e raramente Xokleng, e de grafismos neles constantes. Tais documentos visuais provêm das atividades de levantamento realizadas anteriormente em acervos museológicos (especialmente no Museu Júlio de Castilhos, no Museu Antropológico do Rio Grande do Sul e no Laboratório de Arqueologia e Etnologia do Departamento de Antropologia da UFRGS, todos em Porto Alegre, e no Museu de Arqueologia e Etnologia da USP, em São Paulo $\left.^{19}\right)$. As fotografias e desenhos de grafismos usados para investigar a pintura corporal e facial são oriundos ou de trabalhos feitos em várias ocasiões e cidades do Rio Grande do Sul em que os Kaingang apresentaram suas danças guerreiras ou de um jornal local de Porto Alegre.

Em inúmeras oportunidades, também foi possível trabalhar com meus interlocutores Kaingang em museus de Porto Alegre e de São Paulo, para verem e comentarem sobre objetos Kaingang de todos os tipos, a grande maioria deles datando dos fins do século XIX e inícios do século XX, o que proporcionou um grande entusiasmo nestes interlocutores, estimulando um fluxo de informações ainda não esgotado (e que provavelmente não esteja todo contido nesta tese).

Estes trabalhos, incluindo igualmente a pesquisa bibliográfica realizada, propiciaram o levantamento e sistematização de um corpus gráfico Jê meridional.

${ }^{19}$ Este último levantamento consta dos Anexos. 
Após o levantamento da etnografia referente aos grafismos e à cultura material Jê meridional, especialmente Kaingang, foram mostrados materiais e fotos de objetos e de painéis rupestres a interlocutores Kaingang que demonstraram maiores conhecimentos sobre a cultura material, em geral, e a respeito do sistema de representações visuais Kaingang, em particular. Isto aconteceu após comparar tais materiais pré-históricos ao corpus gráfico Jê do Sul e considerá-los Proto-Jê meridionais. Tal técnica mostrou-se muito produtiva, possibilitando a identificação do nome e do significado de muitos grafismos Proto-Jê do sul presentes em alguns painéis rupestres e na cerâmica arqueológica das ditas "tradições locais planálticas", além de propiciar o conhecimento das técnicas de produção de alguns artefatos ( $k r a ́$ - mão-de-pilão lítica -, nga ta kukrü - panela de barro - e pentky - tigela de barro) não mais produzidos há muitas décadas. Além disso, na Terra Indígena de Nonoai, três interlocutores Kaingang informaram a localização de três sítios arqueológicos de "Tradição" Taquara, tendo auxiliado no survey. As antigas aldeias e seus materiais arqueológicos foram analisados e interpretados pelos Kaingang. A pesquisa de campo demonstrou que os Kaingang têm critérios uniformes para designar os grafismos pré-históricos, inclusive separando o que é (Proto)Guarani.

O levantamento e sistematização de um corpus gráfico Proto-Jê do sul incluiu, também, pesquisa museológica (grafismos da cerâmica) e bibliográfica (grafismos rupestres e da cerâmica). No que diz respeito à primeira, o trabalho realizou-se, principalmente, no Núcleo de Pesquisas Arqueológicas do Departamento de História da UFRGS e em acervo do Museu de Arqueologia do Rio Grande do Sul.

As informações sobre a cultura material das denominadas "tradições locais planálticas" e o corpus gráfico Proto-Jê meridional levantado foram introduzidas no diálogo com interlocutores Kaingang. Alguns deles têm memória das vasilhas cerâmicas feitas por pessoas da geração anterior. Seus discursos sobre os grafismos presentes na cerâmica arqueológica e nos painéis rupestres constam desta tese.

Quanto a alguns grafismos rupestres, não fundamentei sua inclusão no corpus gráfico Proto-Jê do sul apenas a partir da identificação, nomeação e interpretação por parte dos Kaingang, o que poderia indicar uma apropriação cultural por parte destes. Para atingir uma compreensão dos grafismos gravados e pintados do sul do Brasil baseei-me, principalmente, na 
comparação formal entre estes e os grafismos presentes em materiais etnográficos (reconhecidamente Kaingang ou Xokleng), ou desenhados no próprio corpo dos "dançarinos" Kaingang, todos estes também identificados, denominados e interpretados pelos Kaingang atuais.

Em Porto Alegre, com intensidade quase que diária durante mais de um ano, os trabalhos de campo antropológico foram realizados na Aldeia da Agronomia e com outros indivíduos originários, como no caso da Agronomia, da Terra Indígena de Nonoai, no Planalto do Rio Grande do Sul, que por vários motivos encontravam-se (ou encontram-se) na região metropolitana de Porto Alegre (exílio por conflitos políticos; viagens de comércio de trançados; viagens de visitas a parentes ou para reivindicações a órgãos governamentais ou ongs; saída "definitiva" da T.I. de Nonoai e instalação de grupos de parentela nas periferias de Porto Alegre, a procura de melhores condições de vida, com motivação conjugada, ou não, a problemas políticos na área de origem).

Em São Paulo, entrei em contato com um pequeno grupo de Kaingang paulistas vindos do posto Indígena de Icatu, Município de Braúna, em visita ao Museu de Arqueologia e Etnologia da $\operatorname{USP}^{20}$, onde tive oportunidade de colher informações sobre cultura material e grafismos, o que enriqueceu meus dados e confirmou minhas interpretações.

Em Porto Alegre, também trabalhei com grupos kaingang da Comunidade Indígena de Inhacorá, do Município de São Valério do Sul - RS, e da Área Indígena da Guarita, Setor Missão, do Município de Redentora RS.

A pesquisa de campo, com idas e permanências nas aldeias do Planalto Sul-rio-grandense, foi reduzida, e aconteceu com interlocutores de três aldeias da Terra Indígena de Nonoai (Posto, Pinhalzinho e Bananeira). Durante estas pesquisas de campo, mantive, também, contato com famílias Kaingang no Município catarinense de Águas de Xapecó.

20 Este contato aconteceu graças ao convite das Profas. Ana Vera e Aracy Lopes da Silva. 


\section{ARTICULAÇÃO ENTRE ARQUEOLOGIA E ETNOLOGIA: AS BASES TEÓRICAS}

“...una disciplina se caracteriza por la clase de preguntas que plantea y la clase de respuestas que está dispuesta a aceptar" - Maybury-Lewis, 1975:276.

Inicialmente, gostaria de propor uma definição simples do objeto e dos processos epistemológicos relacionados com a etnoarqueologia. Como qualquer outra tentativa de definição, certamente, não contentará a todos. Trata-se de uma proposição para motivar, a seguir, uma discussão sobre as bases teóricas da articulação entre arqueologia pré-histórica e etnologia indígena. Assim:

A compreensão de artefatos, estruturas e quaisquer outros vestígios de sociedades do passado, através da utilização de dados históricos e etnográficos, dentro de um contexto histórico e cultural local muito bem definido, testados os modelos etnoarqueológicos daí surgidos por intermédio de metodologias arqueológicas próprias, constitui-se no objeto da etnoarqueologia. Na criação destes modelos etnoarqueológicos para a compreensão do passado, a interlocução com membros de sociedades indígenas e a analogia etnográfica são ferramentas metodológicas potentes.

Primeiramente, é importante enfatizar que as aproximações epistemológicas entre uma arqueologia voltada para os estudos de vertente sincrônica e com ênfase no cotidiano, através das análises espaciais e da possibilidade de estudos simbólicos da cultura material, e a etnologia são evidentes, especialmente no Brasil, como se verá adiante. No entanto, esta não é a posição da arqueologia processual brasileira, que não tem por hábito perceber a importância do trabalho etnológico sobre mito-cosmologia, etnoestética, organização social e política de sociedades indígenas atuais para a compreensão do objeto arqueológico, principalmente porque este tipo de trabalho não enfatiza particularmente a cultura material destas etnias. Em outras palavras, a inter-relação entre materialidade, de um lado, e sociedade e cultura, de outro, não costuma ser explorada pelos estudos arqueológicos. 
Entretanto, o "ménage à trois" jocosamente citado por Leach $^{1}$ (a convivência entre arqueologia, etnologia e antropologia biológica) é uma imposição para a consecução de uma arqueologia menos descritiva, menos empirista e menos historicista. Sua articulação com a etnologia (o que já foi empreendido com relação à antropologia biológica), apesar do inevitável desconforto inicial, precisa ser empreendida.

Ao contrário do que geralmente se pensa no âmbito da arqueologia brasileira, as aparentes relações perigosas, poluídas e de certa maneira incestuosas $^{2}$ podem tornar-se relações férteis e altamente produtivas.

Apesar desta posição, que é extensiva à arqueologia processual como um todo, fora e dentro de nosso país, as discussões teóricas e metodológicas sobre a utilização de dados históricos e etnográficos para o entendimento, por exemplo, de sistemas arqueológicos de representação visual (principalmente os grafismos rupestres e cerâmicos) e da esfera do sagrado, entre outros, avançaram consideravelmente nos últimos anos.

Layton (1987:211-12), ao considerar o que ele denomina de "paralelos etnográficos" para interpretar a arte parietal do Alto Paleolítico, levanta a principal dificuldade de seu uso:

"human cultures are not simply diverse; they have an inherente tendency to generate variation in behaviour and to diversity. To this extent they are unpredictable".

Além disso, a comparação sem levar em conta os contextos culturais (potencialmente diversos) dos itens envolvidos leva a "paralelos etnográficos" não-fidedignos, pois dependem unicamente da semelhança entre formas isoladas (op. cit., p.211).

Em resumo, o autor não acredita verdadeiramente nos "paralelos etnográficos", pelo menos neste que compara a cultura do Alto Paleolítico da Europa Ocidental com as culturas modernas dos caçadores-coletores San da África Meridional.

Na sua conclusão, Layton (op. cit., p.232) considera que a etnografia San penosamente sugere que a cultura do Alto Paleolítico percebeu analogias entre o comportamento social humano e animal. Dizer mais seria temerário,

\footnotetext{
${ }^{1}$ Apud Laplantine, 1987, p. 18.

${ }^{2}$ Relações incestuosas porque todas estas três áreas (arqueologia, etnologia e antropologia biológica) pertencem ao mesmo campo do saber, o antropológico.
} 
uma vez que o paralelo compara culturas separadas longamente pelo tempo e pelo espaço.

Entretanto, ao contrário da analogia anterior, que compara a arte de duas culturas bastante separadas no tempo e no espaço, Layton (1985), ao estudar o contexto cultural da arte parietal de caçadores-coletores, considera-a como textos engendrados por um sistema cultural e defende uma interpretação semiológica da arte e do mito. Seguindo Ricoeur (1979), afirma que a criação da arte parietal e a narração de mitos devem ser tratadas como performances ou textos, através dos quais a estrutura da cultura dos executores pode ser reconstruída e compreendida. Desta forma, enfatiza a relação do contexto cultural de pinturas rupestres com os mitos de caçadores-coletores da Austrália (Alawa do Gulf Country no Northern Territory) e da África do Sul (grupos San).

Com relação aos primeiros, o autor (op. cit., p. 437) observa que cada clã possui uma limitadíssima série de pinturas corporais. Estes desenhos são formas geométricas simples e discretas. Os Alawa também pintam seus motivos clânicos em abrigos-sob-rocha para mostrar a posse do sítio, particularmente quando o desenho representa o herói totêmico que criou o sítio. Os membros do clã detêm a exclusividade do uso do desenho, sendo permitido usar o motivo de outro clã apenas em ocasiões muito especiais (aliança entre dois clãs; quando da sucessão). Na sua concepção, a arte aborígena expressaria a identidade totêmica (op. cit., p. 448), cujo tema dominante seriam emblemas de clãs totêmicos (op. cit., p. 450).

O autor alerta para a multivalência dos motivos geométricos, que têm a capacidade de representar um conjunto de associações em um simples motivo. Um arco, por exemplo, - motivo exclusivo do clã $\mathrm{A}$ - pode simultaneamente representar o herói canguru e o sítio criado pelo herói. Este mesmo motivo, na pintura corporal, identifica quem o usa como membro do clã A (Layton, 1985:437-8).

A interpretação semiológica da arte parietal pré-histórica Alawa, portanto, é possível graças à possibilidade concreta da analogia etnográfica via pesquisa etnográfica.

Entretanto, adverte: 
"Rock art may allow it to outlive the artist's culture and eventually become incorporated into a new, perhaps radically different, culture that succeeds the first; so that there is no necessary connexion between the meanings now attributed to it and its significance to the original artists" (Layton, 1985: 441).

Pode-se dizer que, em relação aos Alawa, sua tradição artística enfatiza as relações socias, o que não acontece com a arte parietal dos grupos San, sulafricanos, estudados por Lewis-Williams (1980, 1982, 1987 e 1995), que teria natureza xamanística (1987:165-6) e sublinharia aspectos cosmológicos, mediando as relações com o domínio do sobrenatural.

O autor citado usa dados etnográficos e etno-históricos dos grupos San para interpretar a arte rupestre deixada por grupos anteriores, que viveram no mesmo local, e que seriam os antecedentes dos grupos San. Lewis-Williams relaciona as imagens parietais com visões provocadas pelo estado alterado de consciência, experimentado pelos xamãs em transe alucinatório.

Lewis-Williams (1987) considera que o estabelecimento da relação entre arte e xamanismo para os San (Bushman) é apenas o início de um longo projeto de pesquisa que ajudará a reconstruir a ideologia da Idade da Pedra Tardia sul-africana.

Neste sentido, autores brasileiros (como Faria, 1997, por exemplo) vêm trabalhando no sentido de identificar em grafismos de sociedades indígenas do Brasil, principalmente os geométricos, uma origem xamanística a partir de transes induzidos por substâncias alucinógenas. De qualquer forma, restaria compreender o contexto simbólico destes grafismos.

Na Venezuela, Christie-Shults (1992) constatou que os Piaroa enterram seus mortos em abrigos-sob-rocha, cujas paredes, em $95 \%$ de sua extensão são decoradas com pinturas monocromas em vermelho e, em alguns casos, policromas. A autora propõe-se a verificar se se pode estabelecer relação entre os Piaroa e a arte rupestre, apesar de não haver pesquisa arqueológica na área, nem datação segura para as pinturas, nem relatos sobre os Piaroa atuais pintarem os abrigos (op. cit., p.40). Apenas um informante da autora afirmou que os Piaroa não pararam de pintar as paredes dos abrigos (idem, p. 44). Conforme Christie-Shults, a maioria dos sítios cemitérios são decorados com "pinturas lineares geométricas e simétricas em vermelho". $\mathrm{O}$ mesmo ocorre com a pintura corporal, por meio de carimbos, das atuais mulheres Piaroa, e com os desenhos masculinos usados pelos homens em suas cestas, cujas semelhanças formais com a dos abrigos é grande. 
Mesmo sem comprovação arqueológica da continuidade históricocultural entre os artistas dos abrigos e os atuais Piaroa, é interessante compreender como se deu esta "incorporação", em tese, da arte parietal e refletir sobre os, também em tese, rearranjos simbólicos a partir daqueles significantes pré-históricos.

No Brasil, Shaan (1997) estudou "A linguagem iconográfica da cerâmica Marajoara", propondo o estabelecimento de "unidades mínimas significantes" (op. cit., p. 177), uma vez que não se propôs a identificar "unidades mínimas de significado", já que não tinha acesso aos significados dos signos marajoaras. Mesmo assim, na impossibilidade de fazer analogias etnográficas ou de usar dados históricos, a autora conseguiu avançar em relação aos tradicionais estudos descritivos de cerâmica arqueológica, tendo comprovado que a arte marajoara tem os requisitos básicos para ser considerada uma linguagem visual icônica, a exemplo de Nancy Munn (1973) com os Walbiri.

Por sua vez, Hirata (1994-95:387-88), ao estudar a "religião de origem grega que se desenvolve em uma área colonial do Mediterrâneo Ocidental: a Sicília", discute pontos teóricos e metodológicos importantes para a arqueologia pré-histórica brasileira quando da interpretação de artefatos e estruturas pertencentes a sociedades desaparecidas. Seguindo Laffineur (1988), ela discute "o confronto, no plano epistemológico, dos valores respectivos das fontes textuais e materiais para o conhecimento de comportamentos de sociedades desaparecidas". Referindo-se a textos produzidos por membros destas próprias sociedades antigas, diz que o senso comum entre historiadores do Mundo Antigo estabelece uma "relação simplista de complementariedade entre as duas categorias, reconhecendo uma primazia intrínseca às fontes escritas, especialmente no que tange aos aspectos 'subjetivos' de uma cultura". No entanto, a autora rebela-se contra esta posição, que não dá a devida importância à "carga ideológica" que subjaz nestes documentos escritos e que pode ser relacionada a determinados grupos de interesse no interior dessa mesma sociedade. Esta observação possui grande valor para o caso do uso de informações escritas pela arqueologia préhistórica brasileira, se traçarmos um paralelo entre fontes textuais nativas e documentos textuais deixados por religiosos, militares, administradores, à 
época do contato das sociedades indígenas com a sociedade ocidental e colonizadora ${ }^{3}$.

Quanto ao poder informativo dos materiais arqueológicos, a autora (op.cit., pág. 389), em conformidade com as reflexões de Renfrew e colaboradores (1985), estabelece duas "perspectivas opostas e nocivas" para a produção do conhecimento arqueológico: 1. a céptica, que desconsidera a validade de testemunhos materiais para a elucidação de questões ditas "subjetivas": os documentos materiais seriam menos confiáveis para interpretar o sagrado, em primeiro lugar, e as instituições sócio-políticas, sendo válidos para o estudo das técnicas de produção e dos níveis econômico e de subsistência; e 2. a otimista, que acredita exageradamente no poder informativo dos dados arqueológicos e desliza para interpretações baseadas em "comparativismos apressados" que postulam analogias entre dados arqueológicos de espaço geográfico e tempo histórico " $\mathrm{x}$ " com fontes escritas pertencentes a um espaço e tempo "y".

Diante destas considerações, pode-se chegar à conclusão de que o "status" do dado arqueológico (que irá embasar as teorias interpretativas) depende da sua "identificação objetiva", isto é, depende do "grau de controle sobre a validade do processo de caracterização dos implementos" (op.cit. p. 389). Esta identificação passa necessariamente pela busca do contexto histórico-cultural da informação arqueológica, que, além do contexto arqueológico propriamente dito, pode, no caso da pré-história brasileira, ser buscado através da etno-história ou da analogia etnográfica.

Obviamente, com relação à etno-história, deverão ser tomados os cuidados para não se estabelecer uma relação simplista de complementariedade entre informação e fonte escrita.

No que diz respeito à analogia etnográfica, mesmo que se esteja trabalhando com informações oriundas de sociedade indígena que é, comprovadamente, continuidade histórico-cultural do registro arqueológico, deve-se levar em consideração a possibilidade da ocorrência de "rearranjos simbólicos em resposta a uma situação histórica específica" (op.cit., p.390). É o caso citado pela autora (op. cit., p. 389-90), de "vestígios arqueológicos idênticos do ponto de vista formal [serem] considerados de análoga função, mesmo se encontrados em áreas geograficamente distantes".

\footnotetext{
${ }^{3}$ Com relação a esta tese, algumas fontes etno-históricas foram consultadas e analisadas nos capítulos seguintes.
} 
Neste sentido, o uso de fontes etno-históricas para reconstruir aspectos cognitivos do passado tem sido criticado por alguns autores que argumentam que esta abordagem metodológica simplesmente projeta o passado recente em direção à pré-história, uma vez que não se poderia saber se o passado préhistórico era igual ao passado recente (Whitley, 1998:31-32). Entretanto, Huffmann (1986:85 e 1996 apud Whitley, 1998), um arqueólogo cognitivo, apresenta duas respostas-chave a estas críticas: 1a.) mudança de qualquer tipo é um problema empírico em arqueologia; se ocorreram mudanças entre os passados recente e pré-histórico, elas devem ser reconhecidas arqueologicamente; 2a.) a combinação de pesquisas etno-históricas e arqueológicas pode permitir-nos reescrever ou aperfeiçoar a etno-história e a etnologia.

A partir destas premissas iniciais, os parágrafos seguintes remetem à discussão sobre as possibilidades teórico-metodológicas da reconstrução de aspectos cognitivos do passado pré-histórico, que é, em última análise, o objetivo central desta tese.

Arqueologia pós-processual: a abordagem cognitiva, a mente humana e o estatuto das fontes etno-históricas e da analogia etnográfica

"Podemos descobrir um passado 'real', ou simplesmente criamos o passado no presente? E podemos reconstruir os pensamentos e emoções dos povos préhistóricos, ou estamos limitados a estudar sua dieta, economia e tecnologia?" Whitley (ed.), 1998: contra-capa ${ }^{4}$.

Desde 1980, estas e perguntas semelhantes estão presentes no debate teórico da arqueologia anglo-americana:

"Que papel desempenharam a arte e o simbolismo nas atividades das sociedades pré-históricas? A arqueologia é uma ciência que pode reconstruir uma visão objetiva do passado ou, pelo contrário, apenas um reflexo do presente, usado para satisfazer nossas próprias (e freqüentemente não-reconhecidas) necessidades ideológicas?" Whitley, 1998:1.

Estas reflexões teóricas - que por um lado questionam o estatuto científico da arqueologia e por outro o seu alcance - só seriam possíveis após o esgotamento teórico da nova arqueologia ou arqueologia processual, que floresceu nos anos 60 e 70. Ela "refletiu um esforço para tornar a arqueologia

\footnotetext{
${ }^{4}$ Tradução do autor.
} 
tradicional (que era fundamentalmente descritiva e interessada em definir cultura-história) uma antropologia científica" (Whitley, op. cit., pág.3).

Entretanto, a arqueologia processual ou nova arqueologia adotou um modelo de ciência - o positivismo - e uma abordagem antropológica - o estrutural-funcionalismo e sua visão normativa de cultura - exatamente quando eles estavam em vias de ser substituídos nas ciências sociais e, particularmente, na antropologia. Igualmente, o behaviorismo, posição intelectual aliada ao positivismo, foi adotado pela arqueologia processual. Segundo esta posição, o comportamento humano é causado por eventos e causas externas. O mais importante vínculo com o behaviorismo é a perspectiva ecológica-adaptacionista, que é fundamental para a arqueologia processual:

"Desta perspectiva, a explicação dos eventos do passado humano é buscada em fatores externos e eventos tais como mudanças ambientais. Isto torna a mente humana e a cognição imensamente irrelevante" (op. cit., pág. 5).

Desde este ponto de vista, as arqueologias cognitiva e pós-processual, surgidas nos anos 80, representam um esforço de atualização teórica na direção de reconhecer a mente e a cognição humanas como fatores-chave na criação do registro arqueológico, com a rejeição do estrutural-funcionalismo e do behaviorismo. Além disso, a recusa do postulado central do positivismo dado e teoria são independentes - é uma das noções chave para as arqueologias cognitiva e pós-processual (op. cit., págs. 3, 5 e 10).

Para elas, o objetivo da ciência é, pois, não necessariamente descobrir a verdade (um passado objetivo), mas tentar chegar cada vez mais perto dela, através de um procedimento denominado "inference to the best hypothesis": usando a evidência empírica para selecionar a melhor entre uma série de hipóteses concorrentes. Isto representa um esforço para utilizar um método de ciência mais sofisticado do que o positivismo e não uma rejeição à ciência como propõe o relativismo extremo, para o qual tudo é subjetivo, inclusive sendo dado e teoria completamente equivalentes (op. cit., pág. 10-11).

Das abordagens pós-positivistas, poderíamos situar a arqueologia cognitiva numa posição moderada (embora fato e teoria estejam interrelacionados, pode-se manter uma distinção entre eles), enquanto a arqueologia pós-processual, por outro lado, estaria numa posição de relativismo extremo. Na verdade, muitos pós-processualistas advogam este 
tipo de relativismo segundo o qual o conhecimento do passado é socialmente construído e inteiramente subjetivo (op. cit., pág. 12).

Cultura, numa formulação cognitiva, conforme Whitley (1998:17-18) é: "um sistema compartilhado de símbolos, valores, significados e crenças". Por isso, conforme Flannery \& Marcus (1998:36-37; 46), a arqueologia cognitiva não é o estudo de aspectos econômicos, de dieta e de padrões de assentamentos, como querem muitos profissionais da arqueologia de subsistência/assentamento. Igualmente, ela não é o estudo de epifenômenos:

"A arqueologia cognitiva é o estudo de todos os aspectos de uma antiga cultura que são o produto da mente humana: a percepção, descrição e classificação do universo (cosmologia); a natureza do sobrenatural (religião); os princípios, filosofias, éticas e valores pelos quais as sociedades humanas são governadas (ideologia); as maneiras como aspectos do mundo, do sobrenatural ou valores humanos são transferidos para a arte (iconografia); e todas as outras formas do comportamento intelectual e simbólico que sobreviveu no registro arqueológico"5.

Os autores enfatizam que abordagens cognitivas podem ser usadas com sucesso apenas quando as condições para tal são apropriadas, isto é, quando as informações/documentos de apoio (etno-históricos, etnoarqueológicos) são suficientemente ricos (op. cit.) e advertem que

"O maior desafio que se apresenta para a arqueologia cognitiva é o de ancorar-se tão firmemente nos registros etnográfico, histórico, etno-histórico e arqueológico como o são os demais aspectos tradicionais (subsistência, assentamento) da arqueologia" (op. cit., pág. 47).

Desta forma, do ponto de vista da metodologia, para a reconstrução de aspectos cognitivos do passado, as fontes etno-históricas precisam ser consultadas e os levantamentos etnográficos precisam ser empreendidos.

Desde este ponto de vista, proponho que o estudo que realizei sobre cultura material e grafismos Kaingang, concentrado principalmente no capítulo 5 desta tese, sirva como incentivo para a compreensão simbólica de alguns objetos da cultura material e dos grafismos Proto-Jê meridionais, contribuindo para o entendimento de aspectos cognitivos importantes do passado pré-histórico destas populações.

\footnotetext{
${ }^{5}$ Tradução do autor.
} 
Como se viu, a rejeição de um modelo de ciência positiva-behaviorista e de uma abordagem estrutural-funcionalista permitiu à arqueologia cognitiva uma aproximação epistemológica às fontes etno-históricas e etnográficas e tornou concreta a possibilidade analítico-interpretativa "de todos os aspectos de uma antiga cultura que são o produto da mente humana" (cosmologia, religião, ideologia, iconografia, etc.). Esta aproximação epistemológica e esta possibilidade teórico-metodológica conectam os estudos de arqueologia cognitiva com as abordagens atuais sobre arte indígena, as quais não consideram as manifestações estéticas como esfera residual ou independente do contexto no qual aparecem.

Desta forma, os atuais estudos sobre arte indígena têm "aportado evidências importantes para a análise das idéias subjacentes a campos e domínios sociais, religiosos e cognitivos" (Vidal, 1992:13). Ainda de acordo com a autora, "manifestações simbólicas centrais para a compreensão da vida em sociedade", como concepção da pessoa humana, sua caracterização social e material, expressão da ordem cósmica, são comunicadas por este sistema altamente estruturado, que são as manifestações estéticas de uma sociedade indígena. Em outras palavras, a arte "materializa um modo de experiência que se manifesta visualmente", principalmente na decoração do corpo e no sistema de objetos, permitindo que os membros de uma sociedade vejam-se ao olhar seus grafismos e objetos (Van Velthem, 1994:86).

Neste sentido, estou considerando etnoarte ou arte indígena ${ }^{7}$ como um sistema de signos compartilhados pelo grupo e que possibilita a comunicação (Vidal \& Lopes da Silva, 1992). Estas manifestações visuais são expressão estética de identidades étnicas e culturais.

O termo etnoarte refere tanto uma "tradição plástica específica como pressupõe uma contextualização sócio-cultural da arte ao considerar os verdadeiros propósitos de seus produtores" (Silver, 1979:268, apud Van Velthem, 1994:86).

Assim, estou encarando manifestações estéticas enquanto um "mecanismo cognitivo que reflete a visão e o sentido conferido pelos membros de uma sociedade específica" (Van Velthem, 1994:84, baseada em Geertz, 1986). Lado a lado, articulando a abordagem teórica da arqueologia cognitiva

\footnotetext{
${ }_{7}^{6}$ Flannery \& Marcus, 1998:46.

${ }^{7}$ Uso, indistintamente, os termos etnoarte ou arte indígena em substituição a expressões insatisfatórias e preconceituosas como "arte primitiva", "arte tribal", "arte nativa" etc.
} 
com os pressupostos da antropologia estética de inserção da arte no seu contexto cultural, analisei a etnoarte (Proto)Kaingang (e muito parcial e incipientemente a (Proto)Guarani ${ }^{8}$ ) enquanto meio de informação sobre estas sociedades, repelindo uma abordagem técnica e formal, ligada tanto à arqueologia processual como a uma antropologia ligada ao colecionismo do século XIX.

Além disso, considerando que "as manifestações artísticas condensam significados culturais fundamentais para cada sociedade" (Vidal, 1992), esta tese, particularmente nos capítulos 4, 5 e 6, defende a hipótese de que, a exemplo das conclusões relativas à etnoarte das sociedades Kaingang e MbyáGuarani, as populações Proto-Jê meridionais e Proto-Guarani enfatizavam significados culturais diferentes através de sua arte. As primeiras sublinham, mas não com exclusividade, conceitos e representações vinculados à sociedade (relações entre pessoas e entre grupos sociais, como as metades Kaingang, por exemplo) e as segundas principalmente fazem referência ao mundo não-social (os domínios da natureza e da sobrenatureza, e conceitos cosmológicos mais gerais $)^{9}$.

Para o meu estudo específico, que pressupõe uma continuidade concreta entre o registro arqueológico e as sociedades Kaingang e Xokleng, estou interessado no conteúdo simbólico que estas manifestações estéticas expressam, uma vez que a arte significa e não apenas representa ${ }^{10}$.

Desta forma, tive por objetivo inserir os objetos e grafismos Kaingang atuais no seu contexto cultural, analisando-os a partir desta contextualização. Num segundo momento, empreendi uma tentativa de compreensão dos significados culturais dos grafismos presentes na cerâmica e na arte parietal dos Proto-Jê do sul. A mesma abordagem foi perseguida em relação à contextualização de alguns itens do sistema de objetos Proto-Jê meridional e de práticas rituais que deixam vestígios arqueológicos, principalmente as de sepultamento.

\footnotetext{
${ }^{8}$ Para fins comparativos, e de modo bastante incipiente, seguindo esta abordagem teórico-metodológica, estudei, no subitem 5.2, adiante, os grafismos atuais Mbyá-Guarani, contextualizando e interpretando tentativamente as representações gráficas Proto-Guarani presentes na cerâmica arqueológica dita de "Tradição" Tupiguarani.

${ }^{9}$ Estes assuntos vão ser trabalhados mais detalhadamente nos capítulos 4 (sobre as concepções cosmológicas da sociedade Kaingang) e 5, quando estiverem sendo enfocadas especificamente ou a etnoarte Kaingang ou a etnoarte Mbyá-Guarani.

${ }^{10}$ Conforme Lévi-Strauss.
} 
Meu quadro referencial teórico, portanto, parte do princípio do estabelecimento de um modelo da cultura material e dos grafismos Kaingang (sua visão de mundo e sua forma de sensibilidade) para o empreendimento da analogia etnográfica, ou seja, para interpretar e lançar luz sobre o sistema de representações visuais presente na cerâmica e na arte parietal dos antecedentes desta sociedade.

Meu objetivo foi o de "desvendar novas possibilidades de entendimento" 11 da cultura material das chamadas "tradições ceramistas locais" do Planalto Sul-brasileiro, enfocando aspectos cognitivos deste passado.

A analogia etnográfica é possível, pelo menos do ponto de vista da continuidade existente entre o registro arqueológico destas ditas "tradições ceramistas locais" (Taquara, Casa de Pedra e Itararé) com os falantes de línguas da família Jê (Kaingang e Xokleng). Tal continuidade acha-se comprovada por epistemologias alternativas à pronapiana ${ }^{12}$, em estudos que incorporaram informações lingüísticas, etnográficas e da antropologia biológica, os quais já foram comentados na Introdução e serão sumarizados no próximo capítulo.

$\mathrm{O}$ entendimento da etnoarte Kaingang passa necessariamente pela compreensão de sua forma de sensibilidade e de um entendimento mais profundo e amplo de outros aspectos da cultura Kaingang (Geertz, 1986:139) ${ }^{13}$. Daí meu investimento em tentar fazer uma análise da cultura Kaingang além das representações gráficas, puramente.

A partir desta premissa teórica e metodológica, foi possível criar um quadro referencial para a compreensão da etnoarte atual, ou histórica, para começar a empreender um entendimento da etnoarte pré-histórica presente na cerâmica (esta com ligação inconteste com os Kaingang atuais) e na arte parietal de alguns sítios arqueológicos do sul do Brasil, cuja ligação com os Kaingang (ou, mesmo, com os Jê do sul) é bastante controversa, segundo o entendimento da maioria dos arqueólogos brasileiros, como se verá mais adiante (item 5.3).

\footnotetext{
${ }^{11}$ Como diz Hirata (op. cit., p. 390).

${ }^{12}$ Brochado, 1984; Reis, 1997 a e 1997 b; Robrahn-González, 1989, Robrahn-González \& De Blasis, 1998; Noelli, s/d.

${ }^{13}$ Veja capítulos 4 e 5.
} 
Além disso, a compreensão de uma sociedade do passado através da utilização de informações etnográficas desta mesma sociedade, colhidas num passado muito recente e no presente, causa muito desconforto à maioria dos profissionais, principalmente aos vinculados a uma arqueologia processualista. No campo antropológico, esta mesma abordagem teórica (o estruturalfuncionalismo), no Brasil dos anos 40, 50 e 60, promoveu uma série de estudos sobre aculturação e fricção interétnica, cujos efeitos ainda estão muito presentes na arqueologia processual.

Os estudos de "aculturação" no Brasil ${ }^{14}$ tiveram, segundo Novaes (1993), as seguintes características:

a. a mudança seria promovida pela introdução de elementos estranhos às sociedades indígenas analisadas e advinha, pura e simplesmente, do contato destas sociedades com a população rural; para entender estas mudanças, procedeu-se ao inventário dos traços culturais dos grupos em contato;

b. ênfase na perspectiva sociológica. Estes estudos tendiam a captar o processo social e as mudanças do ponto de vista das instituições da sociedade minoritária (epidemias, depopulação, impossibilidade de seguir padrões matrimoniais tradicionais, alterações na divisão sexual do trabalho, etc.), em detrimento da perspectiva cultural;

c. associação dos processos de mudança nestas sociedades à decadência iminente e à descaracterização e desintegração cultural:

d. concepção de cultura como um produto acabado, um estoque de traços, sem garantia de preservação como os traços genéticos, que poderiam ser irremediavelmente perdidos.

Contrariamente ao catastrofismo inerente a este tipo de estudo, Novaes sublinha que:

"A mudança social não se dá, entretanto, como pretendiam estes autores, como um processo que vai, mecanicamente, substituindo elementos da cultura original por outros da cultura dominante, de tal modo que a cultura original gradualmente se extinga ou fique completamente descaracterizada.” Novaes, 1993:40.

\footnotetext{
${ }^{14}$ Os mais importantes são os trabalhos de Wagley e Galvão (1949) sobre os tenetehara, Wagley (1951), comparando tenetehara e tapirapé, e Schaden (1954) sobre os guarani. Este último autor muito influenciou a arqueologia praticada no sul do Brasil.
} 
$\mathrm{Na}$ verdade, é exatamente nas situações de contato intenso com os contextos nacionais que acontece o exacerbamento de identidades indígenas contrastantes. Este encontro de sociedades diferentes resulta no processo de formação de culturas de contraste e não de "desintegração cultural" das sociedades indígenas (Carneiro da Cunha, 1986).

Novaes enfatiza que estes estudos de "aculturação" possuem uma visão de mudança como uma "desintegração progressiva". Seguindo Geertz (1957), a autora põe à mostra a dificuldade dos funcionalistas em lidar com processos sociológicos e culturais, e incorpora em sua análise a proposta de Geertz para que se distinga analiticamente os aspectos sociais e culturais da vida humana, o que

“...evita a visão implícita da desintegração cultural como uma realidade inerente a todo o processo de contato entre duas sociedades em que uma é minoritária ou dominada. (....) Esta perspectiva permite perceber a situação de contato não como a destruição de modos tradicionais de vida, mas como um processo que leva à construção de um novo estilo de vida, com novas estratégias e alternativas, onde a cultura tem uma dimensão essencialmente dinâmica e adaptativa". Novaes, 1993:42.

Deste modo, uma excessiva ênfase nos aspectos sociais ("estrutura social que a ação toma, a rede de relações sociais") em detrimento total dos aspectos culturais ("significados com os quais as pessoas interpretam sua experiência e guiam sua ação") não permitiu que estes estudos funcionalistas de "aculturação" percebessem a "natureza peculiar da integração na esfera da cultura e na esfera social" (Novaes, 1993).

A resistência teórica por parte da arqueologia processual quanto ao uso de dados etno-históricos e etnográficos tem aí, nestes estudos funcionalistas de "aculturação", sua origem, uma vez que os mesmos enfatizam uma "desintegração progressiva" destas sociedades, que não poderiam, portanto, ser tomadas como modelo para a compreensão de seu passado.

De igual modo, os estudos de fricção interétnica (Cardoso de Oliveira, 1968), a partir dos anos 60, apesar de aparentemente se oporem aos estudos de "aculturação", estavam também preocupados "em entender os mecanismos que possibilitariam a inevitável integração dos índios na sociedade nacional", estudando as relações entre sociedades indígenas e a sociedade nacional do "ponto de vista quase que exclusivamente sociológico" (Novaes, 1993). 
Tais estudos de fricção interétnica, tanto como os sobre "aculturação", continuam até hoje a influenciar a arqueologia brasileira, que costuma problematizar, em alguns casos negar, o uso de fontes etno-históricas e etnográficas no estudo arqueológico, uma vez que estas sociedades indígenas já estariam "desintegradas e descaracterizadas culturalmente".

No entanto,

"É no campo da cultura e nas relações entre o poder e a cultura que as sociedades indígenas conseguem articular seus processos de resistência à sociedade envolvente" (Novaes, 1993:46).

Neste sentido, Vidal (1992) lembra que o contato interétnico intenso pode resultar em estímulo ao desenvolvimento de manifestações gráficas por parte de sociedades indígenas, uma vez que "estes povos necessitam mais do que nunca da afirmação de sua identidade cultural".

Assim, no processo de contato entre sociedades, a cultura, enquanto capital simbólico, permite resistir à dominação e às imposições da sociedade dominante. A partir dela, os elementos impostos são continuamente reinterpretados. Ao colocar o foco de entendimento sobre a esfera cultural, pode-se entender que as diferenças entre a sociedade indígena e a sociedade envolvente não são suprimidas mas continuamente reformuladas (Novaes, 1993:46).

De qualquer forma, mudança, como já foi dito, é um problema empírico em arqueologia, e, "The passage of time, however, merely makes change possible: it does not cause change" (Lewis-Williams, 1982:447).

Fique claro, entretanto, que não se quer negar a variação e a dinâmica culturais quando se abordam os sistemas indígenas de representação visual. Enquanto "expressão estética gráfica de identidades étnicas e culturais", estas manifestações visuais, como qualquer outro fenômeno cultural, são aqui encaradas como processo, no qual articulam-se estilo coletivo/repetição com capacidade criadora individual/variação (Vidal \& Lopes da Silva, 1992).

Aliás, o tema tradição e inovação tem longa história na reflexão antropológica, que busca a compreensão da relação entre passado e presente, 
além do entendimento dos mecanismos que possibilitam o exercício da criatividade, o que dá lugar à inovação e à variação no plano da cultura.

Lopes da Silva (1988), examinando as obras de Barth (1987), de Yengoyan $(1979 ; 1988)$ e de Sahlins (1985), sumariza alguns aspectos teóricometodológicos desta reflexão, enquanto aponta o posicionamento destes três autores, o que nos revela a complexidade do tema.

Barth, por exemplo, constrói sua explicação mais no nível da "interação social contextualizada" (rituais de iniciação), preocupando-se em identificar os mecanismos capazes de explicar diferenças e especificidades culturais entre sociedades vizinhas e culturalmente próximas (comunidades $O k$ de Nova Guiné). Ele propõe uma antropologia comparativa do conhecimento, enquanto aponta os rituais de iniciação como o momento (evento) em que as consciências humanas exercitam e expressam sua criatividade, possibilitando a mudança através da consolidação de inovações nas tradições de conhecimento. $\mathrm{O}$ autor prioriza as "relações indivíduo e sociedade, conhecimento e ritual, etc., enfatizando a modificação do conhecimento vigente ao longo do tempo através da participação social nos rituais de iniciação". Apesar de não desconsiderar as incorporações de instituições de povos vizinhos (difusão), Barth demonstra que internamente a um grupo social a inovação se dá através da relação entre especialista ritual e público (exibição pública do conhecimento feita para e com a platéia), e entre fantasias individuais e acervo cultural subconsciente da coletividade, retomando, assim, a oposição clássica entre indivíduo e sociedade (Lopes da Silva, 1988).

$\mathrm{Na}$ sua teoria da produção de subtradições, o autor introduz dois conceitos fundamentais à sua análise, o de tradição ("veio conglomerado de idéias e símbolos de diversas comunidades geneticamente relacionadas e que se mantêm em comunicação") e o de subtradição ("as idéias consideradas como verdadeiras pelos membros de uma comunidade local ou de um único grupo lingüístico") (Barth, 1987:1, apud Lopes da Silva, 1988:190). Ao comparar as comunidades $O k$ da Nova Guiné, Barth estabelece um continuum (as subtradições são transformações umas das outras), priorizando a noção de processo na sua explicação (Lopes da Silva, 1988:191; 193).

Desta forma, Barth "procura a irrupção da desordem, da quebra com o instituído, da variação e das novas tradições", privilegiando as estruturas 
performativas (segundo o conceito formulado por Sahlins ${ }^{15}$ ) "como fator básico que movimenta os processos sociais que levam à inovação e à variação nas tradições culturais" (Lopes da Silva, 1988:205: 197).

Já Yengoyan enfatiza a perspectiva das estruturas prescritivas, conforme o conceito formulado depois por Sahlins ${ }^{16}$, objetivando "descobrir esferas de determinação e dominância no tecido social (Lopes da Silva, 1988:205). Sua explicação é construída preferencialmente no nível estrutural; sua "teoria das compressões" (theory of constraints) salienta que "há, em cada cultura, certas esferas pervasivas, dominantes, que se sobrepõem às demais e dão à cultura a sua especificidade e identidade". Há uma relação dialética entre compressão e criatividade, sendo esta última responsável pela inovação e variação (Lopes da Silva, 1988:193/94).

Para Yengoyan, portanto, a relação entre estrutura e evento é pensada

"como relação dialética entre uma cosmologia moralizante e persistente (a estrutura) e os 'atributos comportamentais de uma sociedade' (os eventos) (Yengoyan, 1979:328). Assim, a esfera da estrutura domina o 'comportamento', ou seja, os eventos são 'retrabalhados' ou interpretados sob a ótica da estrutura. Yengoyan procura, portanto, a reafirmação da ordem" (Lopes da Silva, 1988:205).

Seu modelo apoia-se sobre a sociedade que constrange as manifestações individuais: "todo o processo social e artístico é conduzido dentro de um quadro definido por constraints orgânicos e lógicos variáveis" (Yengoyan, 1979:326, apud Lopes da Silva, 1988:202).

Sahlins, por sua vez, vê como possível a variação cultural na medida em que seja atribuído sentido à experiência, isto é, "graças à capacidade de captarse significativamente a experiência histórica" (Lopes da Silva, 1988:194). Segundo Marcus (1988:71, apud Lopes da Silva, 1988:205), na tese central de Sahlins as "estruturas estão sempre sendo tanto reproduzidas quanto transformadas".

Igualmente, a teoria da produção de subtradições de Barth incorpora as preocupações da teoria das compressões de Yengoyan uma vez em que a primeira (Barth) também leva em conta "as limitações (constraints) impostas

\footnotetext{
${ }^{15}$ Estruturas performativas: “...tendem a se assimilar às circunstâncias contingentes”, cf. Sahlins, 1985:XI e seguintes.

${ }^{16}$ Estruturas prescritivas: “...asimilam as circunstâncias a si mesmas”; “os acontecimentos são avaliados por sua semelhança ao sistema tal como constituído”, cf. Sahlins, 1985:XI e seguintes.
} 
pela práxis e pelas convenções segundo as quais tal conhecimento é aplicado de modo a fornecer um quadro preciso do uso conceitual que se faz de metáforas e modelos pelo imaginário" (Barth, 1987:68-9, apud Lopes da Silva, 1988:206).

Basicamente, uma mesma preocupação teórica passa pelas reflexões de Barth, Yengoyan e Sahlins:

"Todos eles querem compreender como convivem e se articulam as limitações e as possibilidades da inovação cultural e do exercício da criatividade na sociedade" ou, ainda, "como são produzidos e recriados os significados" (Lopes da Silva, 1988:194; 201).

De qualquer forma, a relação entre passado e presente, estrutura e evento, mito e história, tradição e inovação, é tarefa complexa e desafiante que não mais se limita, como nos moldes funcionalistas, a pseudo-questões como "perda cultural", "aculturação" ou "desintegração cultural progressiva".

Esta tese, portanto, pretende contribuir neste sentido, avançando teoricamente em relação às abordagens processualistas/funcionalistas/ empiristas em arqueologia. 


\title{
3. O HORIZONTE CULTURAL PROTO-JÊ MERIDIONAL
}

\author{
“... estar na periferia não impede de se adquirir uma nova \\ perspectiva. Como os etnógrafos sabem desde o começo deste \\ século, é bastante comum aparecer uma nova síntese na periferia da \\ distribuição de idéias mais velhas.” Tom O. Miller Jr., 1978:33.
}

\subsection{As "tradições locais ceramistas planálticas": continuidade histórico-cultural e vinculação aos Jê meridionais}

Este capítulo tem por objetivo refletir sobre a continuidade entre os registros arqueológico e etnográfico no que se refere, respectivamente, às populações pré-históricas, designadas arqueologicamente como portadoras de uma "Tradição" ceramista Taquara ${ }^{1}$, Itararé ${ }^{2}$ ou Casa de Pedra ${ }^{3}$, e às sociedades indígenas Kaingang e Xokleng, ligadas à Família lingüística Jê do Tronco Macro-Jê.

$\mathrm{O}$ estudo da continuidade entre o registro arqueológico das três ditas "tradições ceramistas locais" do Planalto Sul-Brasileiro acima citadas (Taquara, Itararé e Casa de Pedra) e o registro etnográfico das populações Jê do sul do Brasil ainda não foi devidamente sistematizado, apesar das muitas referências implícitas ou explícitas na bibliografia arqueológica desde os anos 1960.

Como exemplo das primeiras, veja-se Schmitz (1988:122 e 124):

"Apesar de haver uma série de sugestões sobre como se ligavam as populações pré-coloniais com as etno-históricas, é difícil encontrar indicadores fidedignos. (.....) Descendentes dessas populações sobrevivem, hoje, em número bastante elevado, nas reservas da FUNAI e fazem parte integrante de nossa história nacional”.

Como mostra das segundas referências, mais explícitas, tem-se, como exemplo, Becker (1988:136):

\footnotetext{
${ }^{1}$ Geograficamente localizada nas matas com pinheiros e nos campos do planalto, nos territórios hoje conhecidos como Rio Grande do Sul e como sudoeste de Santa Catarina; nas encostas, nos terraços altos e morros dos vales dos rios, no território do hoje Rio Grande do Sul; junto às lagoas costeiras sul-rio-grandenses; e no litoral, entre os atuais municípios de Tramandaí e Torres. As datações radiocarbônicas para os sítios arqueológicos desta "Tradição" percorrem um lapso temporal desde o séc. I até o séc. XIX, d.C.

${ }^{2}$ Localizada no planalto e litoral dos atuais estados de Santa Catarina, Paraná e São Paulo.

${ }^{3}$ Localizada no planalto dos atuais estados de Santa Catarina e Paraná.
} 
"Dados arqueológicos recentes (...) nos levam a acreditar que estas populações, hoje conhecidas como Kaingáng, sejam os verdadeiros descendentes dos construtores das casas subterrâneas do Planalto do Rio Grande do Sul”.

Neste sentido, algumas evidências desta continuidade costumam aparecer assistematicamente na bibliografia arqueológica mais antiga que trata destas populações ceramistas pré-históricas, sem, contudo, haver um trabalho analítico e interpretativo com maior aprofundamento no estudo das variáveis que permitiriam corroborar a continuidade deste processo histórico-cultural.

Trabalhos arqueológicos mais recentes apontam (Noelli, s/d; F. Silva, s/d) e outros comprovam (Brochado, 1984; Reis, 1997 a e b) esta direção. As importantes reflexões e contribuições destes estudos foram aqui incorporadas.

Desta forma, o principal objetivo deste capítulo consiste em articular, sistematicamente, os dados arqueológicos referentes à cultura material/ expressão estética e à ordenação do espaço das tradições ceramistas planálticas Proto-Jê meridionais, com os dados etno-históricos e etnológicos dos Jê do sul, dispersos numa bibliografia vasta e, algumas vezes, de difícil acesso ${ }^{4}$, com o fim de realizar, nos capítulos posteriores, a articulação de todas estas informações com a etnografia Kaingang levantada, de um modo particular, e com as sociedades Jê, de um modo geral, privilegiando o estudo e interpretação dos aspectos simbólicos e cognitivos presentes nos artefatos e estruturas, tanto de origem préhistórica como histórica.

A literatura arqueológica menciona três "tradições ceramistas locais" com abrangência no planalto e litoral de áreas hoje correspondentes aos quatro estados do Brasil meridional: Taquara, no Rio Grande do Sul e sul de Santa Catarina; Itararé, no planalto e litoral de São Paulo, Paraná e de Santa Catarina; e Casa de Pedra, no sul do Paraná e planalto catarinense ${ }^{5}$.

Os recipientes cerâmicos ligados a estas três "tradições locais planálticas" são usualmente pensados como utilitários e de pequeno tamanho, temperados com restos minerais e, geralmente, apresentam paredes pouco espessas ( 4 a $8 \mathrm{~mm}$, em média). Além disto, existe uma semelhança quanto às formas (basicamente de dois gêneros, um mais vertical e outro horizontal, com o corpo cônico, ovóide ou em meia-calota) e no que diz respeito à decoração ou acabamento da

\footnotetext{
${ }^{4}$ A obra de Noelli (org.), 1998, foi extremamente importante para a sistematização destas informações.

${ }^{5}$ Estranhamente, alguns sítios cerâmicos de tradição não-tupiguarani no atual Estado de São Paulo não são incluídos entre as "tradições planálticas". Muitos estão na parte central de São Paulo e foram estudados por Miller $\mathrm{Jr}$ (1972), que as vinculou expressamente aos Kaingang paulistas. Ver mais adiante.
} 
superfície (brunidura, ponteados, incisos, impressões de cestaria, de cordas, de carimbos e outros). As diferenças referem-se à técnica de produção, à forma, ao uso de antiplástico, ao tratamento de superfície e à cor da superfície.

Em síntese publicada por Schmitz (1988) tem-se uma visão de conjunto destas três "tradições locais planálticas", registrando e analisando os materiais referentes aos sítios e "fases" desta abrangente "tradição", descrita do ponto de vista estritamente tecnológico.

Outros autores, em trabalhos mais antigos, também discorreram a respeito das semelhanças entre as "tradições locais planálticas" aqui comentadas, inclusive estendendo ainda mais sua abrangência geográfica.

Segundo Becker e Schmitz (1970), os materiais cerâmicos Tipo Eldoradense de Menghin, provenientes de Misiones, Argentina, são semelhantes aos estudados por Chmyz (1967a, b; 1968a, b, c) nos estados do Paraná e Santa Catarina e denominados de "Tradição" Itararé e "Tradição" Casa de Pedra.

Chmyz (1968c) encontra semelhanças entre os materiais analisados no Planalto Meridional (Vales dos rios Itararé e Paranapanema, entre São Paulo e Paraná) com os que ocorrem nas camadas superiores de sambaquis do litoral do Paraná e Santa Catarina, ou seja, especificamente nas baías de Antonina e Paranaguá e na ilha de São Francisco (Sambaqui do Forte Marechal Luz, estudado por Alan Lyle Bryan, 1961 e 1977).

O autor citado (Chmyz, 1968c) estabelece também comparações e semelhanças entre os materiais planálticos e os de camadas superiores de sambaquis com a cerâmica de dois sítios litorâneos catarinenses: a Base Aérea (Caiacanga-Mirim) e a Praia da Tapera (Silva, 1989).

O caso de São Paulo é um tanto paradoxal, pois apesar de Miller Jr. (1972) referir-se, desde esta data, a sítios cerâmicos ligados às "tradições" Casa de Pedra e Itararé, vinculando-os, expressamente, aos Kaingang paulistas históricos, e apesar de Prous (1979) registrar a presença de casas subterrâneas no território que corresponde ao atual Estado de São Paulo, a síntese de Schmitz (1988) sobre "As tradições ceramistas do Planalto Sul-brasileiro" não faz referência a estes sítios ceramistas.

Ao contrário, a síntese de Brochado (1984) inclui estes sítios paulistas, e será comentada mais adiante, quando for tratada a questão das origens destas "tradições planálticas". 
Miller Jr. (1972), que, motivado pela semelhança entre a cerâmica arqueológica não-tupiguarani de São Paulo e aquela dos índios Kaingang paulistas contemporâneos, também estudou esta última, localizou na região central do Estado de São Paulo, ao longo dos rios, principalmente do Aguapeí ou Feio, antigas aldeias históricas dos Kaingang "com cerâmica da tradição definida arqueologicamente por Chmyz (1968 [c]), no Paraná, como de 'Tradição Casa de Pedra", afirmando, ainda, que "Os sítios pré-históricos nos municípios de Parapuã e Lucélia apresentam misturas curiosas de cerâmica, incluindo as tradições tupi-guarani, 'Casa de Pedra' e 'Itararé' (Chmyz, 1968 [c])",

Além destes sítios arqueológicos, o autor cita vários outros, sempre identificando-os como de "tradição" Itararé ou Casa de Pedra, e ligando-os aos Kaingang paulistas. São eles: sítio arqueológico de Camaquã, "perto da linha da estrada de ferro da Companhia Paulista (agora FEPASA), ao sul da estação de Camaquã"; o sítio arqueológico de Icatu, Município de Braúna; sítios arqueológicos recentes na região de Tupã, "onde os índios [Kaingang] podiam informar-nos quem morava no lugar e quando" (Miller Jr., 1972).

H. Baldus, em 1947, durante suas pesquisas junto aos Kaingang da região do Rio Feio, coletou várias panelas e tigelas cerâmicas ainda em uso naquela época. Pertencem ao acervo do Museu de Arqueologia e Etnologia da USP e serão comentadas a seguir e no Anexo (Acervo Kaingang).

Prous (1979) encontrou quatro sítios com casas subterrâneas em São Paulo, ao sul do Município de Itararé, durante apenas seis dias de trabalho de campo. Um destes sítios possuía cinco casas. A cerâmica tem espessura fina (3 a $8 \mathrm{~mm}$ ), paredes alisadas e com duas formas básicas reconstituídas: uma aberta (tigela) e a outra fechada (pote/panela). O material lítico está representado por lâminas polidas de machado, virote e mão-de-pilão. No extremo noroeste do referido Município, o autor foi informado sobre a presença de inúmeras depressões agrupadas e profundas $(2 \mathrm{~m})$, que foram terraplenadas pelos moradores locais. O autor não faz referência, em nenhuma parte de seu artigo, às "tradições locais planálticas", apesar da evidente ligação".

Trabalhos mais recentes (Robrahn, 1989; Robrahn-González \& De Blasis, 1998) enfocam a "Tradição" Itararé no Vale do Ribeira de Iguape, SP,

\footnotetext{
${ }^{6}$ Para maiores detalhes sobre a questão dos contatos entre Kaingang e Guarani, veja o capítulo 4.

${ }^{7}$ Schmitz (1980:96) agrupa estes sítios aos da "Fase" Itararé. Veja mais adiante no subitem 3.2.2.
} 
considerada "área periférica" de ocupação recente ${ }^{8}$ de grupos ceramistas horticultores Itararé provenientes do planalto. Tal ocupação teria sido motivada por conflitos ocorridos no planalto, quando, por volta do ano 1.000 d.C., agricultores Tupiguarani teriam empurrado alguns grupos ceramistas regionais para outras áreas (Robrahn-González \& De Blasis, 1998:58).

Assim, deve-se considerar que existiu no sul do Brasil, incluindo o estado de São Paulo, com abrangência em áreas adjacentes (Misiones, na Argentina, por exemplo), uma grande e homogênea "Tradição" ceramista, reconhecida arqueologicamente, o que nos autoriza a pensar, do ponto de vista do registro arqueológico, num espacial e temporalmente amplo horizonte cultural Proto-Jê do Sul, que engloba o planalto, a encosta e o litoral.

No planalto coberto pela floresta subtropical com pinheiros, muitas vezes entremeada de campos, este horizonte cultural Proto-Jê meridional apresenta três tipos de assentamento: 1. casas subterrâneas, acompanhadas ou não por espaços entaipados, túmulos de terra (montículos funerários) ou galerias escavadas no arenito; 2. acampamentos de superfície e 3. raras ocupações de abrigos naturais.

Ainda permanece viva na memória de alguns kaingang do RS a época em que habitavam casas subterrâneas, bem recente, aliás, e que remonta a meados do século XIX. Um interlocutor kaingang, originário da Terra Indígena de Nonoai, relata o seguinte:

"Meu avô, tio da minha mãe, era de Tenente Portela. Ele viveu cento e poucos anos. Ele contava como se protegia: faziam uma cavação grande pra ser coberta. Ele contando, mostrava como é que ela era, tudo o que tinha que ser feito. Ele contava que ele gostaria de voltar àquela época. Ele chegou a ver, viver junto com os pais numa casa destas. É uma escavação redonda, uma cava redonda, e as cobertas, ele mostrava, elas quase encostavam no chão pra não entrar o vento. Faziam uma valeta em roda pra água não entrar. Eram colocadas umas pedras em cima, do lado, ao redor, pro vento não estragar. Do fundo, sobe tipo uma escadinha, na parede, pra subir, volteadinha. Ali, tu saía pra fora. De noite, cobre com palha. No meio tem um tronco, tipo esteio, até uma alturinha pra fazer coberta. Aqui, é também feito fogo, dentro da casa. Só que em cima .... tem tipo um chapeuzinho de capim. Quando faz fogo, tiram. A fumaça sobe. Quando chove, botam em cima. A folha de palmeira era a cama".

Quanto ao abastecimento no planalto, a sua principal forma seria a coleta do fruto do pinheiro. Vem provavelmente daí a grande profusão de mãos-de-

${ }^{8}$ 920, 595 e 270 BP, conforme Robrahn-González \& De Blasis, 1998. 
pilão em rocha polida encontradas no planalto, além de lâminas polidas ou lascadas de machado, talhadores, raspadores e lascas. Também estão presentes ossos longos de aves e mamíferos, que poderiam ter sido utilizados como pontas de projétil. Contudo, o papel desempenhado pela agricultura, que tem sua importância geralmente subestimada pelos arqueólogos que pesquisam as populações Proto-Jê do sul, necessita ser melhor trabalhado, como se verá mais adiante.

Quanto às mãos-de-pilão líticas (pó tá krá), meus interlocutores kaingang ainda lembram do tempo em que elas estavam presentes no dia-a-dia dos afazeres da aldeia. O depoimento de Karein (88 anos), da T.I. de Nonoai, é significativo:

"Minha vó tinha pó tá krá. Mas ela disse que foi a bisavó que fez. Minha bisavó que fez a mão-de-pilão com a pedra vermelha, bem lisinha. Na ponta bem fininha, pra cá, e a outra mais grossa, pra socar. Pra velha socar pinhão. Porque não tem dente pra comer. Então socava. Também tem um preto, de pedra preta: pedra-ferro. Bem lisinho".

Os sepultamentos que foram observados no planalto são primários e encontram-se em abrigos naturais. Igualmente, há informações etnográficas a respeito de os montículos que acompanham algumas casas subterrâneas serem funerários (grupos Kaingang) e de terem sido empregadas técnicas crematórias para realizar alguns sepultamentos (grupo Xokleng). ${ }^{9}$

Já na floresta subcaducifólia subtropical e na Mata Atlântica, que recobrem a encosta do planalto e os vales dos rios que a drenam, foram observados numerosos sítios sem, contudo, ocorrerem casas subterrâneas. Trata-se de aldeias e acampamentos de superfície e raras ocupações de abrigos rochosos naturais.

A maioria dos arqueólogos acredita que neste ambiente menos frio, além da caça e da coleta generalizadas, seriam possíveis cultivos tropicais, mais efetivos. Contudo, esta visão que qualifica as populações Proto-Jê como horticultores rudimentares e incipientes necessita ser melhor investigada, nas bases que a seguir serão comentadas.

O instrumental lítico é o mesmo encontrado nas terras mais altas, exceto as pesadas mãos-de-pilão, que parecem ausentes.

\footnotetext{
${ }^{9}$ Schmitz (com. pes., 1995) vem realizando trabalhos de campo e laboratório, durante os anos de 1992 a 1995, em sítios arqueológicos litorâneos no Município de Içara-SC, com datas $\mathrm{C}^{14}$ que apontam os séculos IV e VIII d.C. O autor interpreta o sítio como um acampamento estacional, utilizado por um grupo do Planalto Meridional semelhante aos Xokleng, que o utilizava apenas no verão para a realização de rituais de sepultamento e iniciação. Dentre os sepultamentos encontram-se primários, secundários e cremados.
} 
No litoral, coberto por vegetação característica ou pela Mata Atlântica, os assentamentos costumam apresentar-se como acúmulo de restos alimentares, principalmente ossos de peixe, conchas e ossos de mamíferos, sendo frequientemente descritos como sambaquis. Geralmente, as camadas ocupacionais são pouco espessas; muitas vezes ocorrem sobre sambaquis verdadeiros (précerâmicos). No litoral do Rio Grande do Sul e no da porção meridional de Santa Catarina, estão localizados no domínio da vegetação litorânea. No litoral do Paraná e no da porção central e setentrional de Santa Catarina, estão no interface da vegetação litorânea com a Mata Atlântica. Aí, os sítios apresentam grande número de sepultamentos, o que estaria indicando aldeias estáveis, com abastecimento alimentar variado e proveniente dos recursos do mar (pesca, coleta e caça), da terra (caça) e os cultivos.

Em toda a região litorânea, aparecem sepultamentos primários, fletidos ou estendidos. Na Praia da Tapera (litoral central de Santa Catarina) e no sítio das Laranjeiras (litoral norte do mesmo estado), eles podem estar dispostos em semicírculos ou segmentos de círculo, ou em agrupamentos (Silva, 1989).

O material lítico mais característico encontrado no litoral são as numerosíssimas lâminas polidas, semipolidas ou lascadas de machados, além de percutores, bigornas e artefatos fusiformes.

Quanto à indústria óssea dos sítios litorâneos, destacam-se as pontas de projétil confeccionadas em ossos de aves, mamíferos e peixes.

Cotejando-se a localização espacial dos sítios das três "tradições regionais" com o mapa físico e da vegetação da região sul do Brasil, percebe-se que os sítios das "tradições" Itararé e Taquara estão presentes nos três domínios ambientais acima referidos. A diversidade das cerâmicas respectivas, portanto, não acompanham os domínios naturais. Por ora, apenas a duvidosa "Tradição" Casa de Pedra tem seus sítios reduzidos à região do planalto. Em outras palavras, estamos diante de uma única população, Proto-Jê meridional, explorando três ambientes diversos e contíguos.

A esta constatação estão ligadas outras duas: conforme o ambiente, ter-seão assentamentos diferenciados e a ele adaptados; os artefatos encontrados tendem, igualmente, a ser diferentes de acordo com o ambiente, uma vez que as ênfases no abastecimento modificar-se-iam segundo o meio. Esta modificação nos artefatos e a diferenciação dos assentamentos não estaria indicando populações diferentes. Ao contrário, os mesmos grupos, culturalmente 
homogêneos, estariam explorando ambientes diferentes, em estações diferentes, com diferentes artefatos e habitando diferentes tipos de assentamentos.

Diante destes elementos, poder-se-ia dizer que a forma de abastecimento destas três "Tradições" estaria integrando três ambientes diversos, ensejando assim melhores condições de sobrevivência, já que se teria, ocupando-os, possibilidades mais amplas de garantir estações menos abastecidas, especialmente se associadas a cultivos.

Esta complementação dos recursos visando a um abastecimento que cobrisse todos os períodos do ano poderia ser realizada através de migrações estacionais e/ou intercâmbio de bens e pessoas nos três ambientes naturais ocupados.

Por outro lado, pelo que se percebe dos sítios litorâneos da "Tradição" Itararé (Paraná, norte e centro de Santa Catarina), os numerosos sepultamentos que ocorrem em alguns assentamentos e a farta disponibilidade de recursos alimentares, centrados nos produtos do mar e da caça, estariam indicando aldeias estáveis e duradouras. Este fato (o número considerável de aldeias estáveis e duradouras no litoral) poderia estar indicando a possibilidade de a sociedade Xokleng, efetiva ocupante deste território antes da chegada dos Carijós (grupo falante de língua pertencente à Família Tupi-guarani) e, posteriormente, da Conquista, estar ligada diretamente às populações portadoras da "Tradição" Itararé, que também dominaram áreas do planalto dos atuais estados de Santa Catarina e do Paraná.

Além disto, a descoberta de um número cada vez maior de sítios desta "Tradição" no litoral central de Santa Catarina leva a pensar num denso e consistente povoamento destas regiões próximas ao Atlântico, antes da chegada dos grupos de "Tradição" ceramista Tupiguarani, falantes de línguas da Família lingüística Tupi-guarani.

Igualmente, parece configurar-se um povoamento estável e de certa densidade no planalto dos Estados sulinos, como atesta o grande número de sítios Proto-Jê meridionais aí registrado.

Quanto ao abastecimento destas populações portadoras das "tradições locais planálticas", assim Schmitz (1978/79/80:33-4; 48) o descreve:

“(...) é possível que devamos imaginar esses primeiros agricultores do planalto como coletores bem estabelecidos com alguma caça, onde lentamente se vão introduzindo algumas plantas, como acontece em outras áreas de cultivo. E em termos bem crassos poderiam ter sido semelhantes aos grupos de Tradição Una, Itararé e Taquara, onde 
parece predominar a coleta e haver uma pequena suplementação agrícola. Este esquema de um coletor que suplementa a sua coleta e a sua caça com um pouco de agricultura com certeza não existe mais na Tradição Aratu, um grupo agricultor que faz da planta cultivada o seu sustento básico. (.....). Os grupos parecem ter forte apoio em coleta, onde sobressaem os pinhões e os moluscos marinhos, e na caça. Seu domínio de plantas cultivadas parece ter sido pequeno e concentrado na utilização de grãos semeados, sem possibilidade de cultivar mandioca por causa do frio das alturas. Os solos pobres não lhes permitiriam expandir os cultivos, com o que se viam obrigados a explorar cuidadosamente a apropriação de produtos naturais da mata, do campo e do litoral, para cobrir o ano inteiro".

Em contrapartida, objetivando mostrar a fragilidade desta posição, como muitas outras que precisam ser revistas e relativizadas, e com a intenção de enfatizar a necessidade da continuidade das pesquisas, em todos os aspectos, outros autores, como Noelli (s/d. a), acreditam, na antiguidade da agricultura entre os Jê meridionais, principalmente entre os Kaingang. Noelli tem, justificadamente, uma posição crítica em relação a este panorama sobre o abastecimento. Esta posição está baseada, principalmente, em três pontos: 1. "a descrição do período histórico não representa a subsistência pré-histórica de certos grupos, profundamente alterada pelo contato com os europeus", 2. "as categorias ocidentais nem sempre traduzem a variedade de técnicas empregadas para manejar as plantas alimentícias" e 3. "a concepção dos não-Jê de que haveria uma centralização da subsistência em torno do pinhão de Araucaria vem causando um questionável consenso, sem um sólido apoio de resultados de pesquisas relativas e domínio absoluto dos dados publicados" (Noelli, s/d a:2-3).

A sociedade Kaingang em tempos históricos, para Veiga (2000:228), é essencialmente agrícola, não podendo ser considerada única e exclusivamente como caçadora-coletora e muito menos nômade, "porque seus rituais estão baseados em celebração das colheitas e rememorações dos mortos ligados a um espaço ritual fixo, que são os cemitérios, próximos às aldeias".

Quanto às diferenças regionais constatadas nas "tradições locais planálticas", elas estariam a indicar que estas populações, que possuem um fundo tecnológico e cultural comum, dividiam-se em territórios, os quais ocupariam e dominariam por séculos, dando condições ao aparecimento e consolidação de identidades mais ou menos diferenciadas para subgrupos populacionais específicos, ou de subtradições, conforme o conceito de Barth (1987), o que não impediria que continuassem a apresentar uma gama de aspectos comuns ligados tanto à tecnologia como à cultura (tradição, para Barth, op. cit.). Os modelos lingüísticos sugeridos por Weisemann (1978) e Urban (1992), e reproduzidos na 
Introdução, os quais demonstram uma primeira separação do grupo Jê meridional migrante (língua Xokleng) e separações subsequientes (dialetos Kaingang), são muito esclarecedores para a compreensão deste passado Proto-Jê do Sul, inclusive de suas origens no nordeste brasileiro.

O ponto de vista arqueológico sobre as origens desta "Tradição" tecnológica e cultural planáltica, que provavelmente surgiu nos primeiros séculos da era cristã, ainda é muito parcial. A maioria dos arqueólogos que trabalha no planalto sul-rio-grandense costuma realçar a semelhança do material lítico das fases pré-cerâmicas locais da "Tradição" Humaitá com a indústria lítica da "Tradição" Taquara. Da mesma forma, observa-se que o material ósseo do litoral norte e central de Santa Catarina, especialmente as pontas de projétil em osso, bem como os artefatos fusiformes confeccionados sobre pedra e outros materiais, estão se constituindo, no decorrer dos estudos em realização, em ótimos indicadores da continuidade entre os coletores pré-cerâmicos e as populações ceramistas do litoral de Santa Catarina. Encontra-se igualmente registrada pela literatura a semelhança entre a indústria lítica dos caçadores do planalto catarinense com aquela referente à "Tradição" Casa de Pedra.

Estas constatações empíricas parecem indicar que alguns grupos précerâmicos do sul do Brasil teriam entrado em contato com populações vindas do norte, que avançariam pouco a pouco através do espaço geográfico. Este modelo arqueológico não é de todo incompatível com o modelo lingüístico citado mais acima. De qualquer forma, este modelo arqueológico complexo, que inclui migração de populações Proto-Jê, contato com grupos pré-existentes de caçadores-coletores locais, eliminação de alguns e absorção de outros, com as conseqüentes transformações e permanências na cultura material dos grupos humanos que interagem neste processo, parece ser mais lógico do que aquele no qual é sugerido o total desaparecimento das populações pré-ceramistas frente a migrações de grupos invasores externos e tecnologicamente mais bem equipados ${ }^{10}$.

O modelo etnológico sugerido por Veiga $(1994,2000)$, a partir de sua interpretação do mito de origem Kaingang, do ritual do Kiki e de outras informações, é aqui desenvolvido como hipótese plausível das origens deste horizonte cultural Proto-Jê meridional, uma vez que inclui a união de grupos Proto-Jê do sul em migração com populações caçadoras e coletoras pré-

${ }^{10}$ Conforme será discutido detalhadamente no Capítulo 4. 
existentes, e a incorporação, em tempos mais recentes, de outras etnias, incluindo grupos Proto-Guarani, conforme será analisado no próximo capítulo.

Brochado (1984), baseando-se na distribuição das cerâmicas arqueológicas do leste da América do Sul, estende a discussão da origem dessas três "Tradições" ceramistas regionais sulinas, que seriam estilos da "Tradição" Pedra do Caboclo, de grande abrangência geográfica e temporal.

Recuando muito no tempo, este autor tece o seguinte panorama. As "tradições" por ele denominadas de Pedra do Caboclo e Palo Blanco seriam derivadas de dois focos de desenvolvimento cerâmico, que teriam por características formas globulares extremamente simples, localizados respectivamente na desembocadura do sistema fluvial amazônico (cerâmica Mina) e no estuário do Rio da Prata (cerâmica Palo Blanco). Estas duas "tradições" teriam se originado de uma "tradição" amazônica muito simples e mais antiga que "deverá ser encontrada com uma datação muito anterior à daquela (Mina e Palo Blanco) - talvez 5.000 a.C. - no nó de cursos fluviais da América do Sul, situado na Amazônia Central" (Brochado, 1984:540).

Ainda segundo Brochado, a "Tradição" Pedra do Caboclo teria antecedentes na cerâmica Mina (3.700 - 3.500 a.C.) e estaria relacionada aos falantes das línguas do Antigo Brasil Oriental e Kaingang (Macro-Jê) e com a Subtradição que denominou de Aratu, que estaria vinculada aos grupos Jê propriamente ditos (op.cit., pág. 570).

A primeira difusão cerâmica Pedra do Caboclo no Nordeste brasileiro teria ocorrido em 700 - 1.000 a.C.. e teria sido transmitida, "de grupo a grupo sob a forma de intrusões de unidades de traços, através das populações estáveis de falantes das línguas do Antigo Brasil Oriental; excetuando-se os Gê propriamente ditos e os Cariri; seguindo um padrão de difusão progressivamente mais ampla, chegando até os falantes Caingangue na extremidade meridional do planalto brasileiro" (Brochado, 1984:570-1).

Desta forma, a "Tradição" Pedra do Caboclo comportaria vários estilos, cujo fluxo teria ocorrido do norte para o sul: Mina, Anatuba, Pedra do Caboclo, Periperi, Una, Jataí, Taquaruçu e Taquara. Este modelo arqueológico proposto por Brochado coaduna-se, igualmente, com os modelos lingüísticos de Wiesemann (1978) e Urban (1992), inclusive no que diz respeito à data estimada por Brochado (1984:570-1) para a primeira difusão cerâmica no Nordeste brasileiro (700-1.000 a. C.), e com as considerações que faço no Capítulo 4. 
No entanto, uma arqueologia mais tradicional inclina-se a ser reticente em relação a tais proposições, uma vez que elas levam em consideração estudos, hipóteses e modelos propostos por outras disciplinas.

Assim, quando existem, na bibliografia arqueológica tradicional, considerações sobre as ligações e continuidades entre as populações pré-históricas ceramistas, aqui comentadas, com as históricas, elas ainda encontram-se no terreno das sugestões, ou da analogia etnográfica sugerida, uma vez que ela nunca foi empreendida concretamente através de uma abordagem etnoarqueológica mais sistemática.

Por exemplo, La Salvia, Schmitz e Becker (1968: 457-8), no início do período "acadêmico" da pesquisa arqueológica no Brasil, ao dar título ao artigo publicado na revista Ciência e Cultura, que descreve a cerâmica encontrada nos Campos de Cima da Serra, no Rio Grande do Sul, escrevem, simplesmente e sem detalhar suas razões, "Cerâmica Caingang - Fase Vacaria".

Becker e Schmitz (1968), descrevendo a cerâmica da Fase Itapiranga, assim se pronunciam:

"A cerâmica da fase Itapiranga faz parte de uma tradição, que se acredita ser gê, encontradiça no sul do Brasil tanto no litoral como no planalto". (...) "Se as semelhanças dentro de território pequeno são facilmente explicáveis, as de grandes áreas supõem uma tradição de um grupo extenso, que se acredita sejam os gê".

Outro exemplo de arqueólogo pioneiro na divulgação da importância do subsídio etnográfico, sugerindo-o, sem, contudo, empreendê-lo sistematicamente, foi Blasi (1973:41):

“... documentos coevos indicam que, no início da conquista, o espaço paranaense esteve ocupado por grande número de tribos indígenas, pertencentes, em esmagadora quantidade, às grandes Famílias Lingüísticas - TUPIGUARANI e CAINCANGUE.

"Boa parcela dos indícios recolhidos em sítios pré-históricos, em confronto com outros procedentes de tribos históricas, revela inconfundíveis diferenças.

"Trata-se de aspectos altamente positivos e de grande valor para o pesquisador, desde que através de complexos etno-culturais disponíveis pode ele elucidar pontos obscuros quando no trato de complexos culturais dos índios pré-históricos".

Da mesma forma, a analogia etnográfica sugerida também aparece em Miller (s/d). O autor, poucos anos após as primeiras descobertas das então chamadas "cerâmicas não-Tupiguarani do Planalto Sul Brasileiro e áreas adjacentes", relaciona-as ao "pré-Caingang no período pré-histórico e ao 
Caingang no período histórico", uma vez que esta ampla tradição ceramista "ocupa a mesma área indicada etnologicamente para a família lingüística Caingang" e que "algumas amostras arqueológicas desta tradição provém de tempos históricos e são produto do Caingang".

Por sua vez, Chmyz \& Sauner (1971:31), baseando-se em Nimuendaju, correlaciona a "Tradição" Itararé com "o grupo indígena que ele chamava de Guaianá [um dos nomes aplicados aos Coroados/Kaingang], nos vales dos rios Paranapanema e Itararé".

Constata-se, pois, que muitos arqueólogos brasileiros nas décadas de 70, e mesmo 60, indicavam como corretos e produtivos os caminhos teóricos e metodológicos da analogia etnográfica, os quais, nas décadas seguintes, perderam prestígio nos meios acadêmicos e foram escassamente trilhados pelos pesquisadores brasileiros. Isto aconteceu, principalmente, pela carência de um embasamento teórico, que começou a esboçar-se nos EUA e na Inglaterra apenas na década de 80, através das arqueologias pós-processualista e cognitiva, chegando tardiamente no Brasil na década seguinte, como foi visto no capítulo anterior.

Sem negar os obstáculos inerentes a este tipo de abordagem, impostos pelas situações de conflito sofridas pelos grupos indígenas desde o contato, e que, certamente, exerceram caráter dinâmico nestas sociedades, como discutido no final do Capítulo 2, pode-se, contudo, estabelecer algumas comparações, através de analogias etnográficas confiáveis.

Tentando verificar este tipo de ligações, três fatos interessantes foram revelados por estudo de Tom. O. Miller Jr. $(1978)^{11}$. O autor, 1. além de salientar as semelhanças entre as "tradições" Itararé e Casa de Pedra, propondo sua unificação, 2. associa, diante das evidências abaixo relacionadas, esta "Tradição" única à "[tradição cerâmica] utilizada pelos povos de fala caingángxokleng conhecidos historicamente" (Miller Jr., 1978:33), habitantes históricos da porção meridional do Brasil e pertencentes à Família lingüística Jê do Tronco Macro-Jê. 3. Igualmente, o autor comprova que a "cerâmica arqueológica nãotupiguarani encontrada no interior paulista e pertencente à tradição cerâmica denominada por I. Chmyz (1968) de Tradição Casa de Pedra, pertence àquela mesma presente entre os índios caingáng paulistas" (Miller Jr., 1978:30).

\footnotetext{
${ }^{11}$ Estudo que foi e continua sendo sistematicamente menosprezado e acusado de ser baseado "em inverdades contadas pelos índios", certamente no intuito de negar ou neutralizar sua importância. Veja Revista do CEPA, UNISC, vol. 23, no. 29, 1999, pág. 217 e 251.
} 
A verificação desta associação entre uma "Tradição" ceramista préhistórica e uma sociedade indígena atual foi possível tendo em vista, entre outros fatores, as observações e estudos de Miller Jr. com relação à cerâmica ainda confeccionada, segundo as técnicas tradicionais, por duas anciãs de grupos Kaingang paulistas: Dona Francisca do Posto Indígena de Icatu e Dona Candire do P.I. Vanuíre.

Foi usada uma argila cinzenta e "gordurenta", a qual amassaram, retirando as substâncias estranhas, foi a ela adicionado como antiplástico cacos de telhas ou tijolos moídos no pilão e peneirados ${ }^{12}$, e água. Foram confeccionadas vasilhas com uma técnica de produção que soma o modelado para as bases e o roletado para as paredes e bordas. As peças foram alisadas com pedregulho molhado durante dias (brunidura), após os quais aconteceu a queima em fogueira a céu aberto. Quando as peças adquiriam uma cor vermelho-fogo, poderiam sofrer o processo de esfumaramento: eram retiradas do fogo com uma pinça e mergulhadas em palha de milho, na qual a peça era girada, sendo envolvida por uma "nuvem de fumaça preta" (carbono) que penetrava em suas paredes, tornando-as pretas e, de acordo com a maior ou menor intensidade da brunidura, brilhantes (Miller Jr., 1978:7-13 e 18). Não foi observado o emprego de técnicas de decoração. Em alguns casos, estrias deixadas por sabugo de milho quando do alisamento da vasilha não foram abafadas, sugerindo ou um processo intencional decorativo ou uma falta de acabamento. $\mathrm{O}$ autor relata que, por vezes, D. Candire "pintou desenhos com hematite no exterior das suas peças já cozidas", sem referir-se aos seus padrões gráficos (Miller Jr., 1978: 26-27). Ao que tudo indica, o autor considera a brunidura como técnica decorativa (op. cit., p. 29).

A classificação nativa (D. Candire) das vasilhas é a seguinte: 1. vasos com colar: kokrõ; 2. tigelas cônicas e hemisféricas: pèt kyx; 3. garrafas ou vasos

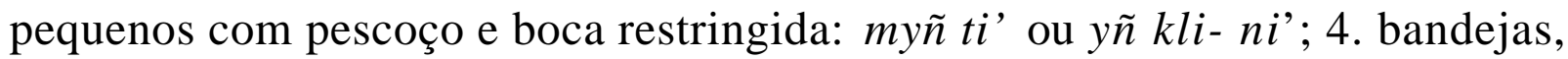
travessas ou tigelas rasas: pèto' ro' ou köñ n’y $r$ y'. Miller Jr. (1978:15-16) descarta as duas últimas formas do acervo Proto-Kaingang, pela inconsistência das formas e dos termos, bem como pelo uso de algumas técnicas decorativas estranhas à tradição (bordas pinçadas e onduladas). Uma constatação minha parece corroborar esta avaliação do autor: apenas aos termos que expressam as categorias 1 e 2 da classificação apresentada por Miller Jr. são pospostas as partículas kaingang mök (grande) e tsi (pequeno), exatamente como acontece

${ }^{12}$ Antigamente, usavam cacos de cerâmica. 
com a classificação dos Kaingang de Nonoai-RS quando designam o tamanho de suas cestas acrescentando as partículas mbág (grande) e $x \ddot{i}$ (pequeno) ${ }^{13}$. Desta forma, ambas classificações perfazem três variações de tamanho: médio (sem partícula), pequeno e grande.

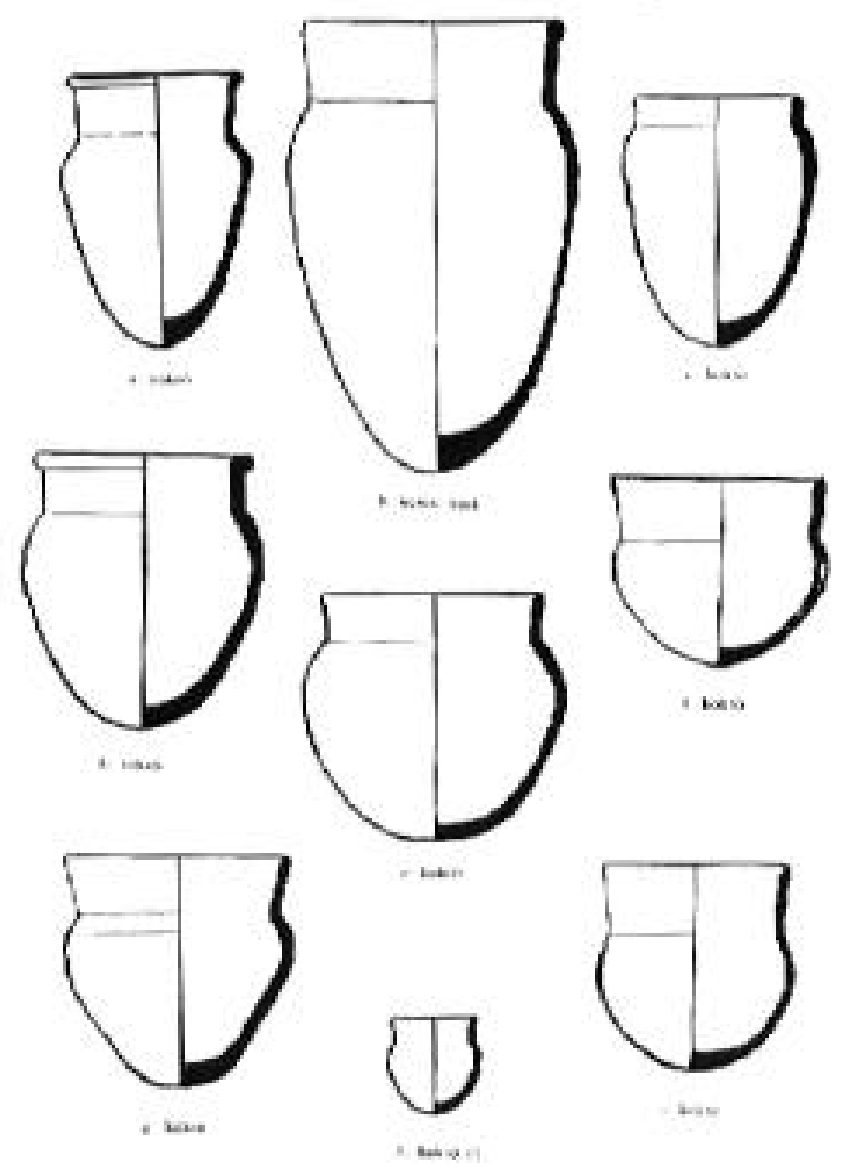

Formas da cerâmica Kaingang de São Paulo, conforme Miller Jr., 1978:49 kokrõ. 


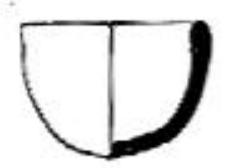

at $x+16$

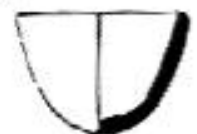

2. ond $x+2$

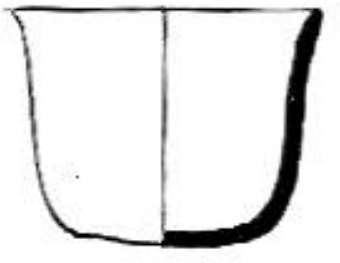

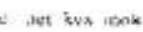

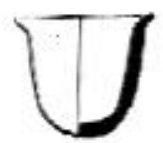

a titt kyx :

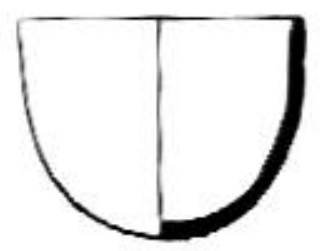

see irs nok
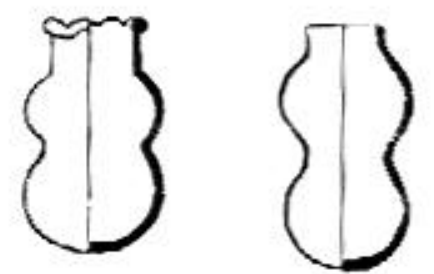

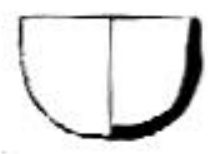

b. pet we

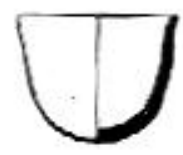

a) act as

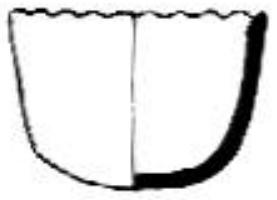

I jiel kne nxik

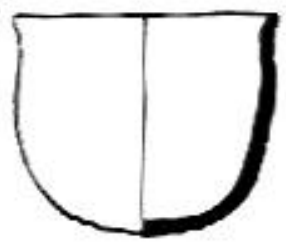

ies we arok

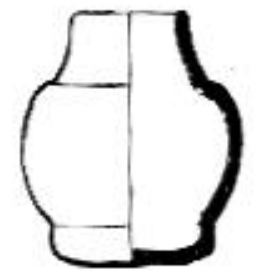

Formas da cerâmica Kaingang de São Paulo, conforme Miller Jr., 1978:50 - pèt kyx e mÿn $t i$ ‘ 

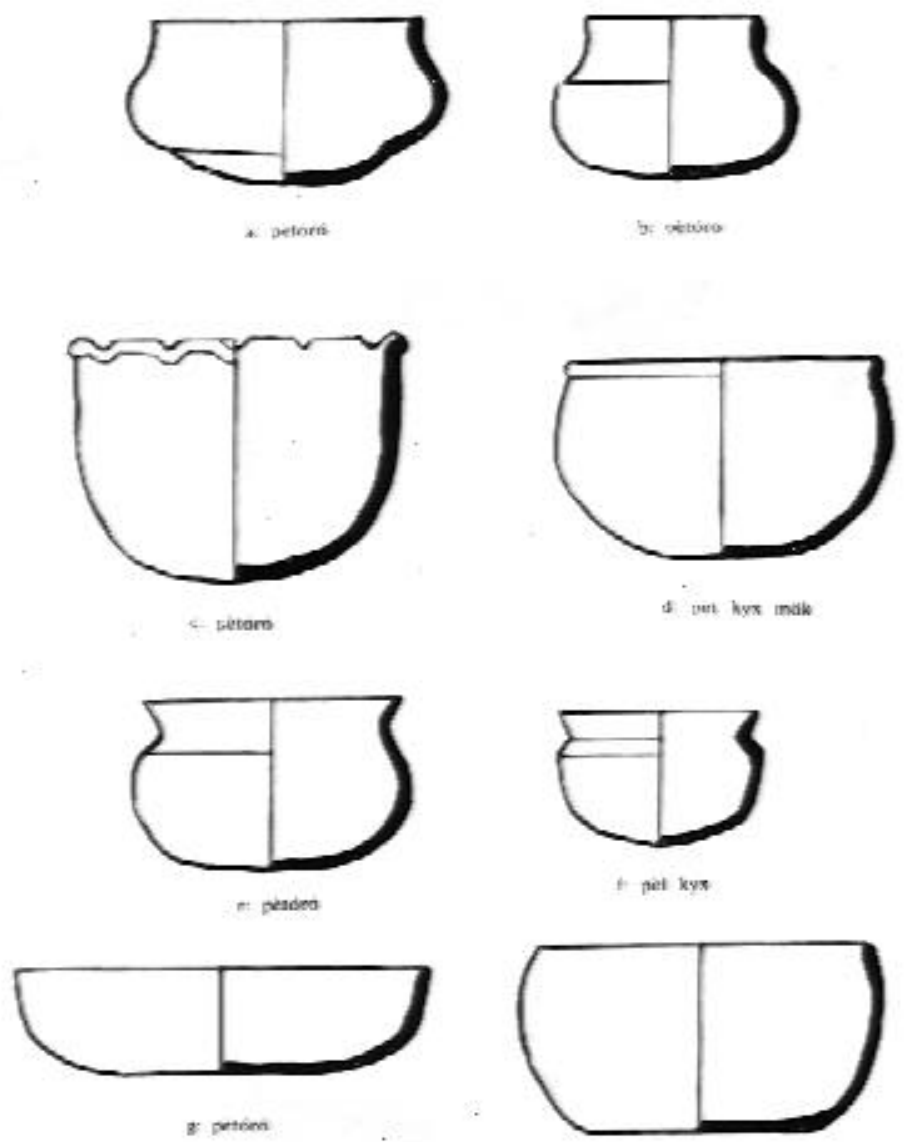

h. per kes nowk
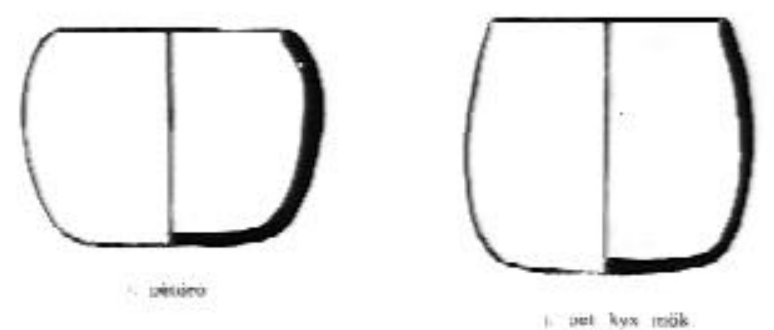

Formas da cerâmica Kaingang de São Paulo, conforme Miller Jr., 1978:51 - pèto' ro' 
Estudando as coleções de fragmentos cerâmicos históricos Kaingang coletados nos dois postos indígenas citados e comparando-as "aos poucos cacos de cerâmica não-tupiguarani coletados na região central do Estado de São Paulo"14", o autor chega à conclusão de que ambas amostras "cabem perfeitamente na mesma tradição" (Miller, 1978:24). Além disso, compara estas duas coleções às cerâmicas das "tradições" Itararé e Casa de Pedra, que conhecia bem.

Durante seu estudo sobre a tecnologia cerâmica (Proto)Jê meridional, Miller Jr. fez algumas constatações interessantes para os arqueólogos do sul do Brasil, que algumas vezes confundem banho, engobo e polimento, por um lado, e areia arredondada com antiplástico (intencional, portanto), por outro. Estas constatações diluem a propriedade do emprego de tais aspectos técnicos ${ }^{15}$ como critérios para separar em várias "tradições" um complexo cultural abrangente e homogêneo, aqui denominado de Proto-Jê meridional.

As constatações de Miller Jr. são as seguintes:

1. especificamente com relação à cor das superfícies externas - "Não podemos precisar se a cor da superfície deve-se a um banho [antes da cocção] ou a um engobo [depois dela], pois o resultado mecânico do polimento, como o engobo, deixa uma película de argila fina na superfície" (Miller Jr. (1978:21);

2. no que diz respeito ao antiplástico - "Areia de grãos arredondados não serve satisfatoriamente à função de antiplástico, pois a lisura deles não segura a estrutura escamosa molecular da argila plástica. Grãos de superfície mais irregular são necessários, sendo que os caingáng tradicionalmente utilizavam-se de caco moído, embora existam evidências arqueológicas de rocha moída como antiplástico (...). A presença de areia num número reduzido de cacos históricos pode representar a utilização de uma argila parcialmente arenosa: a interpretação permanecendo insegura ou ambígua. A citação da ocorrência de 'antiplástico de areia' no sul do Brasil, possivelmente deve ser vista deste mesmo ponto de vista; embora a presença de areia

\footnotetext{
${ }^{14}$ Sítios Paraíso (SP.CQ.12), Camaquã (SP.RC.2), Parapuã (Tupã) e outro, da mesma região, não denominado. Conforme Miller Jr., 1978:24-25.

${ }^{15}$ Uso de antiplástico, tratamento de superfície e cor de superfície, como já comentado anteriormente.
} 
possa ajudar a reduzir a proporção de encolhimento da pasta durante a secagem, essa por si só não é uma função antiplástica" (Miller Jr., 1978:25-26).

Em levantamento realizado no Museu de Arqueologia e Etnologia da Universidade de São Paulo, constatei a presença de 29 vasilhas cerâmicas Kaingang em seu acervo. Todas possuem informações precisas sobre data, local, coletor/doador, uso e confecção, que constam de suas fichas de registro ${ }^{16}$.

Das 29, 25 estão relacionadas à expedição de Herbert Baldus e Harald Schultz ao Posto Indígena de Icatu, atual Município de Braúna, São Paulo, em 1947. Elas nos informam, de acordo com as fichas de registro, que este grupo Kaingang paulista ainda usava e confeccionava cerâmica utilitária em meados do século XX. Três das vinte e nove são da época da dita "Pacificação" dos grupos Kaingang do noroeste paulista. A primeira (R.G.MAE 2.561) foi coletada em 23.11.1906, no Rio do Peixe, pela Comissão Geográfica e Geológica do Estado de São Paulo. A segunda (R.G.MAE 2.559) foi coletada por E. Garbe, em 1910, na antiga Estação Hector Legru ${ }^{17}$ da Estrada de Ferro Noroeste do Brasil. A terceira (R.G.MAE 2.566) pertenceu ao grupo do líder Kaingang Vauhin, no Rio Feio, e foi coletada pela Inspetoria do antigo Serviço de Proteção do Índio em São Paulo, na data de 19.3.1912. A vigésima nona vasilha cerâmica do acervo do MAE, de R.G. 13.549, foi confeccionada em 1978 no Posto Indígena Vanuíre, Tupã, São Paulo, pela kaingang Candira Levanhesu, de 74 anos, que a denominou de "cocran" e a classificou como usada para cozer macaco e aves grandes. (Conforme fichas de registro do MAE/USP.)

A grande importância deste acervo ${ }^{18}$ reside no fato de que, através dele, podemos fazer a ligação entre esta cerâmica, a apresentada por Maniser (1930), encontrada em 1914 entre os Kaingang do oeste paulista recém-contatados (reproduzida a seguir), a estudada por Godoy ${ }^{19}$ (1947), resgatada em montículos

\footnotetext{
${ }^{16}$ No Anexo 1, Acervo Kaingang do MAE/USP, constam individualmente todas as informações presentes em cada ficha de registro. No capítulo 4, item 4.4, veja fotos de algumas vasilhas deste acervo.

${ }^{17}$ Atual Penápolis, SP. A 2 km da Estação Hector Legru, em 1912, o SPI estabeleceu um “posto”. Lá Maniser (fins de 1914, inícios de 1915) conviveu com os Kaingang (Maniser, 1930).

18 Robrahn-Gonzáles (1997) fez uma descrição arqueológica deste conjunto de vasilhas cerâmicas, numa perspectiva tecno-morfológica. A autora parece não ter percebido a importância de tão fundamental acervo, alegando falta de documentação, o que não reflete a situação das peças cerâmicas, todas com informações precisas para local, data, coletor/doador e até mesmo para autoria (sexo do artesão) e função da maioria das peças.

${ }^{19}$ Veja fotos dos conjuntos destas vasilhas cerâmicas no Capítulo 4, item 4.4.
} 
funerários em São Paulo, e a descrita por Miller Jr $(1978)^{20}$, com a cerâmica arqueológica Proto-Kaingang de São Paulo, já que as formas, as técnicas de confecção, o tratamento das superfícies, as características das pastas, o antiplástico e a queima são idênticos.
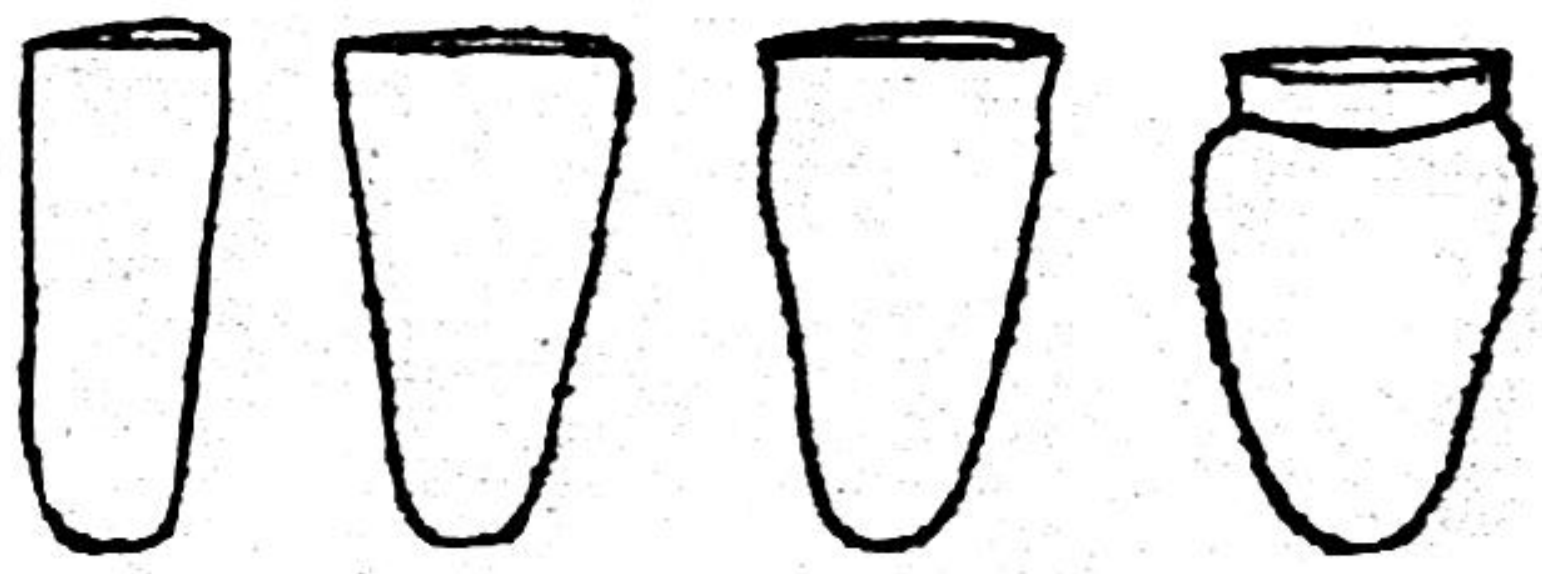

Processo de confecção da cerâmica Kaingang (kukrü). Reproduzido de Maniser,

1930:fig.4(6). Apenas o último desenho representa a forma acabada.

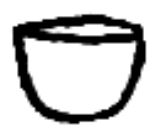

Pentky. Reproduzido de Maniser, 1930:fig. 4(18).

Meus interlocutores kaingang do Rio Grande do Sul e de São Paulo (Icatu), os primeiros vendo as fotos do acervo do MAE e os segundos frente a frente com as vasilhas no Laboratório do MAE, classificaram esta cerâmica em dois grandes grupos: 1) as formas cônicas de abertura constrita ou levemente ampliada e de contorno infletido foram denominadas de kukrü (RS) e kokrã (SP); ao todo, existem 17 vasilhas com estas características; 2) as formas semi-elipticas (tigelas rasas) ou cônicas (tigelas), ambas de contorno simples e abertura ampliada, foram chamadas de pentky (RS e SP); ao todo são seis peças ${ }^{21}$.

\footnotetext{
${ }^{20}$ Veja as pranchas das formas, reproduzidas em páginas anteriores.

${ }^{21}$ As comparações com a classificação morfológica nativa para os cestos Kaingang do RS (ver Capítulo 5) são evidentes. Como em relação aos cestos, parece que na cerâmica o discurso atual Kaingang visualiza duas formas básicas, que se opõem: uma longa, comprida (kukrü) e outra baixa, redonda (pentky). Quanto aos cestos,
} 
As outras seis vasilhas cerâmicas do acervo do MAE ou apresentam alças laterais ou têm forma de moringa ou apresentam contornos complexos. Estas não foram denominadas pelos interlocutores Kaingang. No entanto, foram confeccionadas por mulheres Kaingang (segundo as fichas de registro), de acordo com as técnicas tradicionais. As formas, porém, parecem terem sido copiadas da cultura ocidental. Esta conclusão assemelha-se à de Miller Jr. (1978:15-16), citada mais acima.

Como em Miller Jr. (op. cit.), meus interlocutores Kaingang do RS e de SP também sub-classificaram as duas categorias principais de vasos cerâmicos (krukrü/pentky) em mbág e xï, respectivamente grande e pequeno, o que, para cada categoria, resulta em três tamanhos: médio (sem adjetivo), grande e pequeno.

Quanto ao fato de alguns grupos históricos Jê meridionais não mais possuírem cerâmica, conforme as descrições de alguns cronistas, Miller Jr. (1978/79/80:90) o explica da seguinte maneira:

“(...) as pressões de invasões, primeiro de Tupis, depois de portugueses, fizeram com que os grupos Jê tivessem de se fragmentar e ficar em movimento. Isto não coaduna com cerâmica e dificulta a agricultura. Eu lanço a hipótese, a ser testada no campo, que a agricultura e a cerâmica é bastante antiga entre alguns povos Jê."

De qualquer forma, a memória de alguns kaingang do RS, com idades entre 80 e 90 anos, sobre suas nga ta kukrü (panelas de barro) e nga ta pentky (tigelas de barro) ainda continua viva. Eles fizeram uso destes recipientes, que eram produzidos por suas mães ou avós. Ainda hoje, na T.I. de Nonoai, sabem onde podem ser encontradas jazidas do barro (ngo'or) que deve ser usado na sua confecção. Segundo os kaingang, ele deve ser "gorduroso" e preto. Até hoje, recolhem, reconhecem e nomeiam os kukrü ngó (cacos de panela) que encontram na reserva.

Quanto à criação de três tradições ao invés de uma para explicar a cerâmica arqueológica Proto-Jê meridional, a principal causa para a nãocompreensão da cerâmica arqueológica Proto-Jê meridional por parte dos préhistoriadores foi a ausência ou a presença de técnicas decorativas, conforme a região de sua ocorrência na ampla área de dispersão da tradição, o que dificultou

esta oposição comprido/redondo::longo/baixo remete às categorias téi/ror, ligadas diretamente ao dualismo Kaingang (heróis civilizadores Kamé e Kainru) e às metades Kamé e Kainru-kré, conforme será visto nos capítulos 4 e 5 . 
que esta cerâmica fosse vista pelos arqueólogos como uma unidade, pertencente a uma única tradição cultural.

Apesar de alguns arqueólogos, como Miller (s/d), notarem as semelhanças em relação à forma, à tecnologia de produção, à espessura e outras "semelhanças constantes e cada vez mais numerosas" entre as cerâmicas das "tradições" Taquara, Itararé e Casa de Pedra, a ausência de grafismos no extremo norte da sua área de dispersão e a sua presença em mais de $80 \%$ dos fragmentos no extremo sudeste, levou a conclusões apresadas, não satisfatórias, e, no caso de Miller (s/d), difusionistas. Após analisar 24 amostras cerâmicas provenientes de diversas áreas de dispersão do complexo cerâmico, o autor dá como o centro, o "foco", deste amplo complexo cerâmico "de fundo cultural comum" o sudeste de sua área de dispersão.

Ao contrário, à luz das modernas informações lingüísticas (Weisemann, 1978; Urban, 1992) e dos trabalhos arqueológicos de síntese mais recentes (Brochado, 1984), é de se supor que o sudeste corresponda à porção final da dispersão dos grupos Proto-Jê meridionais, portadores destas cerâmicas. O norte (São Paulo e Paraná setentrional), com ausência de técnicas decorativas na cerâmica $^{22}$, corresponderia, segundo o mesmo modelo lingüístico, à segunda separação das populações migrantes ${ }^{23}$, sendo mais antiga do que a separação que deu origem aos grupos do sudeste da área de dispersão das "tradições" planálticas.

Motivos de outra ordem, e que talvez não mais possam ser reconstituídos, levaram os Proto-Jê meridionais do sudeste da área de dispersão a usar a cerâmica como suporte dos grafismos característicos do horizonte cultural Jê do $\mathrm{Sul}^{24}$. Uma perspectiva difusionista de análise deu ao autor (Miller, s/.d) a falsa impressão de que o "foco difusor" estava ao sudeste, pois ali encontrava-se 80 a $100 \%$ de cerâmica com técnicas decorativas. Além disso, os estudos

\footnotetext{
22 “Concordamos com a opinião de Schmitz (1968:137) de que a decoração é menos característica no norte e nos tempos recentes do que no sul e nos tempos anteriores, no sentido em que aquele estudioso entende de decoração (incisa, ungulada, ponteada), pois evidentemente ele não inclui brunida nem polida estriada como técnicas de decoração". Miller Jr., 1978:29.

${ }^{23}$ A primeira separação deu origem aos falantes da língua Xokleng. A segunda, aos falantes do dialeto Kaingang de São Paulo. Cf. Weisemann (1978) e Urban (1992).

${ }^{24}$ Os grafismos da cerâmica das "tradições planálticas" pertencem a um único e homogêneo sistema de representações visuais. Estes grafismos podem ser usados, conforme o grupo e/ou região de abrangência da tradição cultural e/ou tempo enfocado, em vários tipos de suportes: cerâmica, corpo, cestaria, paredões rochosos, armas, tecidos, etc. Para maiores detalhes, ver capítulo 5.
} 
arqueológicos recentes de Robrahn-Gonzáles em SP (Ribeira de Iguape) estão mostrando cerâmica Itararé com os grafismos característicos do sistema de representações visuais Proto-Jê meridional, conforme será discutido a seguir.

Não há, ainda, um número razoável de datações radiocarbônicas ou por termoluminiscência para se estabelecer, arqueologicamente, a cronologia deste processo, o que poderia auxiliar na compreensão da diacronia das relações interétnicas acontecidas e das possíveis incorporações étnicas ocorridas. Conforme Schmitz (1988:121), as datas absolutas que possuímos hoje podem dar uma idéia errada desta cronologia:

"Por enquanto, as fases Guatambu, Taquara e Candoi são as mais antigas, mas esta situação pode mudar quando conhecermos a idade do material de outras áreas".

\subsection{As "tradições" Taquara, Itararé e Casa de Pedra: suas "fases", sua cultura material e outras indicações sobre as relações entre os registros arqueológico e etnográfico}

Com o objetivo de dar uma visão geral, panorâmica, das populações Proto-Jê meridionais, a seguir serão comentados alguns aspectos relacionados ao ambiente, ao abastecimento, aos artefatos, às estruturas e à cronologia a elas referentes, sempre com o intuito de refletir sobre a continuidade entre os registros arqueológico e etnográfico. Além disso, aos grafismos Proto-Jê foi dada ênfase especial, principalmente aos presentes na cerâmica (os rupestres ocorrentes em sítios de alguma forma ligados às "tradições locais planálticas" serão analisados no Capítulo 5). Sempre que possível ${ }^{25}$, anexamos foto ou desenho dos grafismos, objetivando iniciar a formação de um "corpus" gráfico Proto-Jê meridional.

\subsubsection{As "fases" da "Tradição" Taquara}

O território situado no nordeste do RS, compreendendo tanto o planalto como o litoral, corresponde à "Fase" Taquara ${ }^{26}$ da "Tradição" Taquara, com

\footnotetext{
${ }^{25}$ Quando os grafismos presentes na cerâmica constavam das publicações originais ou quando nos foi possível fotografar ou desenhar os materiais arqueológicos depositados em instituições museológicas e/ou de pesquisa.

${ }^{26}$ Sinonímia: cerâmica Osório e "Fase" Caxias. A "Fase" Taquara foi trabalhada por Schmitz et alii (1967), Schmitz (1969), La Salvia (1968, 1983), La Salvia e Schmitz (1973), Miller (1967, 1974) e Ribeiro (1975).
} 
datações radiocarbônicas que vão do séc. IV - $430 \pm 90$ (SI-607); $435 \pm 105$ (SI - 805); $470 \pm 70$ (SI - 603) - até o séc. XV - $1.320 \pm 70$ (SI-6-4); $1330 \pm 90$ (SI-608).

No século XIX, quando da ocupação efetiva desta área, ali viviam os Kaingang, em grande número, liderados pelo Cacique Braga. Schmitz admite que "existe uma boa possibilidade de serem estes os descendentes da população da fase Taquara", uma vez que o grupo Kaingang tem memória de ter enterrado nesta região, pelo menos, cinco gerações de ascendentes (Schmitz, 1988:82-83).

Ainda não foram encontrados e/ou datados sítios arqueológicos dos séculos XVI e XVII, o que proporcionaria um registro contínuo da ocupação da área em questão pelos Kaingang, desde a pré-história até o momento da Conquista.

A espacialidade destas antigas aldeias, bem como a distribuição no espaço dos materiais arqueológicos e das estruturas habitacionais, não é conhecida nos seus detalhes, como, de resto, para todas as "fases" das ditas "tradições planálticas", uma vez que não foram empreendidas escavações em grandes superfícies, o que possibilitaria uma visão sincrônica, espacial e etnográfica dos sítios arqueológicos.

As populações ligadas à "Fase" Taquara exploravam, durante o período compreendido entre as datas Carbono 14 acima mencionadas, três ambientes distintos: 1) nas matas com pinheiros e nos campos do planalto, encontram-se a) casas subterrâneas circulares ou subcirculares (geralmente agrupadas e não necessariamente com ocupação sincrônica), associadas a montículos funerários ${ }^{27}$ e b) acampamentos superficiais; 2) nas encostas; nos terraços altos e morros dos vales dos rios foram registrados dois tipos de sítios: a) grandes aldeias superficiais de choças de palha e b) acampamentos em abrigos sob-rocha, também usados para depositar seus mortos; 3) junto às lagoas e planície costeiras ocorrem sítios a céu aberto entre os municípios de Torres e Tramandaí (Schmitz, 1988:81).

${ }^{27}$ Veja discussão sobre enterramentos no subitem 4.4, adiante. 
“Tradição” Taquara (conf. Brochado et alii, 1969; Schmitz, 1988; Schmitz \& Becker, 1991)

\begin{tabular}{|c|c|c|c|c|c|}
\hline $\begin{array}{l}\text { "FASES" OU } \\
\text { SÍTIOS }\end{array}$ & TERRITÓRIO & $\begin{array}{l}\text { DATAS } \\
\mathrm{C}^{14}\end{array}$ & $\begin{array}{c}\text { CONTATO } \\
\text { COM } \\
\text { "TRADIÇÃO" } \\
\text { TUPIGUARA- } \\
\text { NI }\end{array}$ & SÉC. XIX & $\begin{array}{c}\text { MATERIAL LÍTICO } \\
\text { MUITO } \\
\text { SEMELHANTE AO DA } \\
\text { "TRADIÇÃO" } \\
\text { HUMAITÁ }\end{array}$ \\
\hline $\begin{array}{l}\text { Guatambu } \\
\text { (sinonímia: } \\
\text { "Fase" Vacaria) }\end{array}$ & $\begin{array}{l}\text { N do RS (Vacaria } \\
\text { e Bom Jesus) S } \\
\text { de SC (São } \\
\text { Joaquim) }\end{array}$ & $\begin{array}{l}140 \pm 85 \mathrm{a} \\
1250 \pm 60 \\
\text { d.C. }\end{array}$ & não & $\begin{array}{l}\text { Território de } \\
\text { "Botocudos" }\end{array}$ & não \\
\hline $\begin{array}{l}\text { Guabiju } \\
\text { (muito parecida } \\
\text { com a "Fase" } \\
\text { Guatambu) }\end{array}$ & $\begin{array}{l}\text { Bacia do Rio } \\
\text { Pelotas }\end{array}$ & $\begin{array}{l}1.595 \pm 50 \\
\text { d.C. e } 1300 \pm \\
55 \text { d.C. }\end{array}$ & não & $\begin{array}{l}\text { Talvez território } \\
\text { de uma "tribo" de } \\
\text { Botocudos }\end{array}$ & não \\
\hline $\begin{array}{l}\text { Taquara } \\
\text { (sinonímia: } \\
\text { cerâmica Osório } \\
\text { e "Fase" Caxias) }\end{array}$ & $\begin{array}{l}\text { NE do RS/São } \\
\text { Francisco de } \\
\text { Paula, Caxias e } \\
\text { arredores }\end{array}$ & $\begin{array}{l}\text { Séc. IV/V ao } \\
\text { XIV/XV }\end{array}$ & não & $\begin{array}{l}23 \text { "grupos" } \\
\text { Kaingang sob a } \\
\text { coordenação do } \\
\text { cacique principal } \\
\text { Braga }\end{array}$ & não \\
\hline $\begin{array}{l}\text { Caí } \\
\text { (possivelmente } \\
\text { sinonímia de } \\
\text { "Fase" Taquara }\end{array}$ & $\begin{array}{l}\text { Vale dos rios Caí } \\
\text { e Sinos no RS }\end{array}$ & - & não & Idem anterior & não \\
\hline $\begin{array}{l}\text { Erveiras } \\
\text { (cerâmica } \\
\text { semelhante à da } \\
\text { "Fase" Taquara) }\end{array}$ & $\begin{array}{l}\text { Santa Cruz e } \\
\text { arredores no RS }\end{array}$ & $\begin{array}{l}1.035 \pm 145 \\
\text { d.C. (SI- } \\
4066)\end{array}$ & $\begin{array}{l}1 / 3 \text { dos } 40 \\
\text { sítios apresenta } \\
\text { cerâmica } \\
\text { "mestiça" com a } \\
\text { da "Tradição" } \\
\text { Tupiguarani }\end{array}$ & - & $\begin{array}{l}\text { "Fase" Pinhal da } \\
\text { "Tradição" Humaitá }\end{array}$ \\
\hline Taquaruçu & $\begin{array}{l}\text { NO do RS- } \\
\text { próximo ao Rio } \\
\text { Uruguai }\end{array}$ & $\begin{array}{l}1120 \pm 60 \\
\text { d.C. }(\text { SI-598) } \\
\text { e } 1790 \pm 70 \\
\text { d.C. }(\text { SI-599) }\end{array}$ & não & $\begin{array}{l}\text { Duas tribos, com } \\
\text { um total } \\
\text { aparentemente } \\
\text { pequeno de } \\
\text { índios, sob o } \\
\text { comando dos } \\
\text { caciques } \\
\text { principais } \\
\text { Nonohay e } \\
\text { Fongue }\end{array}$ & $\begin{array}{l}\text { "Fase" Caaguaçu (cf. } \\
\text { Miller, 1969) }\end{array}$ \\
\hline $\begin{array}{lr}\text { Giruá } \quad \text { talvez } \\
\text { sinonímia de } \\
\text { "Fase" } \\
\text { Taquaruçu) }\end{array}$ & $\begin{array}{l}\text { Margem do } \\
\text { Uruguai } \\
\text { No do RS }\end{array}$ & $\begin{array}{l}1550 \pm 100 \\
\text { d.C. (SI- } \\
600)\end{array}$ & não & Idem anterior & $\begin{array}{l}\text { "Fase" Caaguaçu da } \\
\text { "Tradição" Humaitá. }\end{array}$ \\
\hline Xaxim & $\begin{array}{l}\text { SO de SC e N do } \\
\mathrm{RS} \text { (Erexim) }\end{array}$ & $\begin{array}{l}975 \pm 95 \\
\text { d.C. (SI- } \\
825) \text { e } 1620 \\
\pm 90 \text { d.C. } \\
(\text { SI-597) }\end{array}$ & $\operatorname{sim}$ & Idem ao anterior & não \\
\hline
\end{tabular}




\begin{tabular}{|c|c|c|c|c|c|}
\hline $\begin{array}{l}\text { Itapiranga (por } \\
\text { sua localização e } \\
\text { características } \\
\text { parece idêntica à } \\
\text { "Fase" Xaxim) }\end{array}$ & $\begin{array}{l}\text { SO de } \\
\text { SC(Itapiranga) }\end{array}$ & - & sim & - & não \\
\hline $\begin{array}{l}\text { Casas } \\
\text { subterrâneas e } \\
\text { sítios aldeias do } \\
\text { Planalto de SC - } \\
\text { Reis, } 1980 \\
\end{array}$ & $\begin{array}{|lr|}\text { Planalto } & \text { de } \\
\text { Lages - SC } & \end{array}$ & - & não & - & - \\
\hline $\begin{array}{l}\text { Casas } \\
\text { subterrâneas } \\
\text { Alroino Eble }\end{array}$ & $\begin{array}{ll}\begin{array}{l}\text { Encosta } \\
\text { planalto } \\
\text { catarinense } \\
\text { Vale do Itajaí }\end{array} & - \\
\end{array}$ & - & não & - & - \\
\hline $\begin{array}{lr}\text { Casas } & \\
\text { subterrâneas } & \mathrm{e} \\
\text { sítios } & \mathrm{de} \\
\text { Jaguaruna } & \\
\end{array}$ & $\begin{array}{l}\text { Município de } \\
\text { Jaguaruna }- \text { SC }\end{array}$ & - & - & - & - \\
\hline $\begin{array}{l}\text { Casas } \\
\text { subterrâneas do } \\
\text { Pântano do Sul } \\
\end{array}$ & $\begin{array}{l}\text { Pântano do Sul - } \\
\text { SC }\end{array}$ & - & - & - & - \\
\hline
\end{tabular}

Apesar de todos estes tipos de assentamentos, a cultura material deles oriunda é tecnologicamente semelhante: 1) pequenos potes e tigelas utilitários de cerâmica, com, ao contrário das outras "fases", alta freqüência de técnicas de decoração $^{28}$ (ponteados simples, arrastados, múltiplos; ungulados verticais e horizontais; pinçados; impressões de corda, de malha e de cestaria; aplicados mamiliformes; incisos, etc.), freqüentemente combinadas na mesma peça, cobrindo-a desde o lábio até a base, e 2) artefatos líticos polidos (mãos-de-pilão e lâminas de machado) e lascados (talhadores uni e bifaciais, raspadores, lascas retocadas ou não, percutores e moedores). (Schmitz, 1988:82.)

Como já foi dito, a bibliografia arqueológica não discute as diferenças observadas quanto ao padrão de sepultamento (montículos associados a casas subterrâneas no planalto; enterramentos em abrigos rochosos na encosta) nem

\footnotetext{
${ }^{28}$ Segundo Marois \& Scatamacchia (1987:81), técnica de decoração é "a maneira como se exerce uma ação sobre um instrumento (um objeto físico, as mãos ou os dedos) para alterar a superfície de um objeto cerâmico, com o fim de criar efeitos visuais de acordo com um padrão mental culturalmente estabelecido".
} 


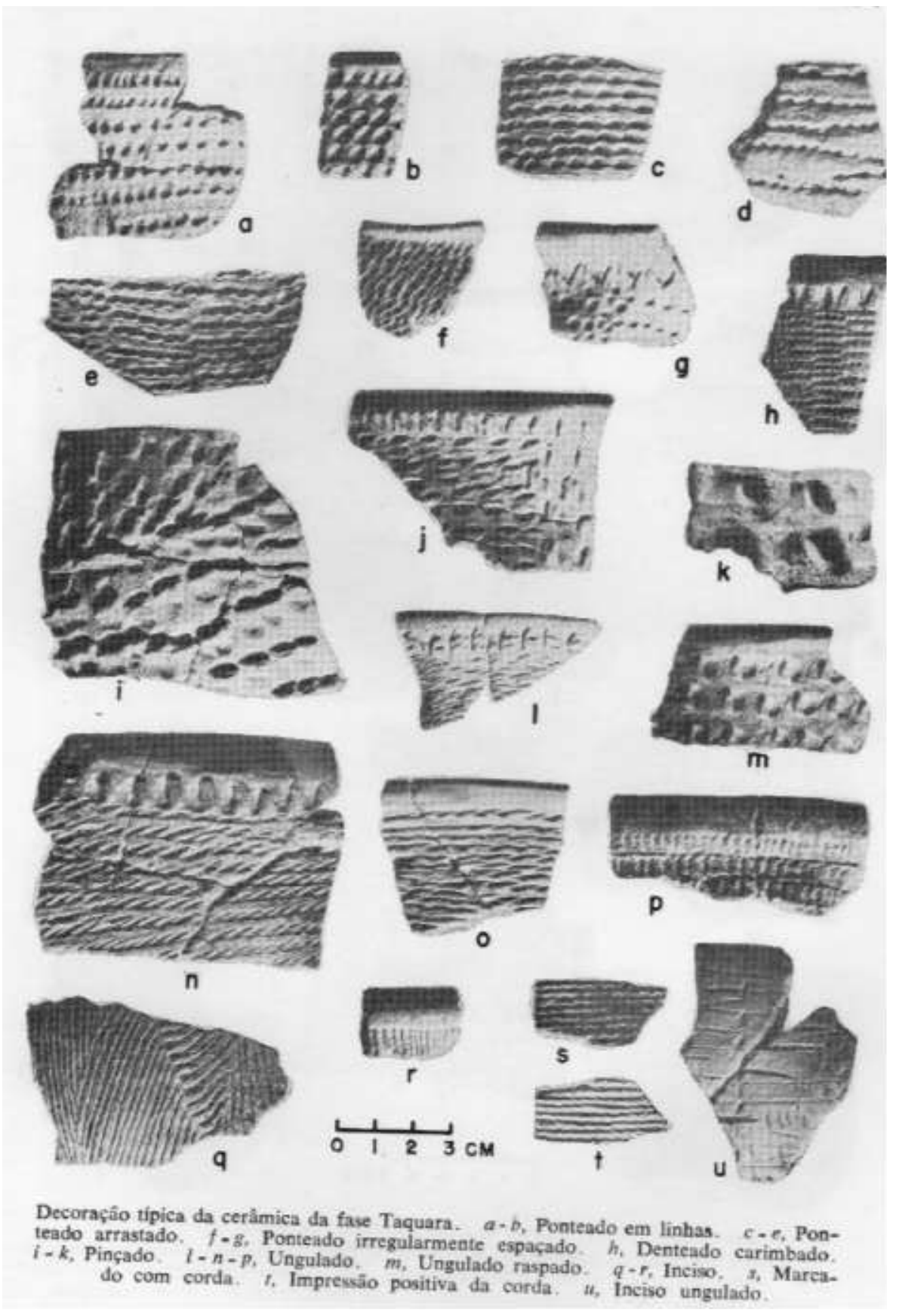

Grafismos na cerâmica da "Fase" Taquara. Reproduzido de Brochado et alii, 1969:estampa 1.

chega a estabelecer a espacialidade dos diferentes sítios, seja pela ausência de datações radiocarbônicas para a totalidade de casas subterrâneas de um determinado conjunto (que poderiam ser o registro arqueológico de várias aldeias sobrepostas), seja pela insuficiência metodológica no estabelecimento da planta 
topográfica das grandes aldeias da encosta ou dos morros e terraços altos no vale dos rios (cujos fundos de cabana não são mais percebidos, apenas vislumbrados pela distribuição dos fragmentos cerâmicos).
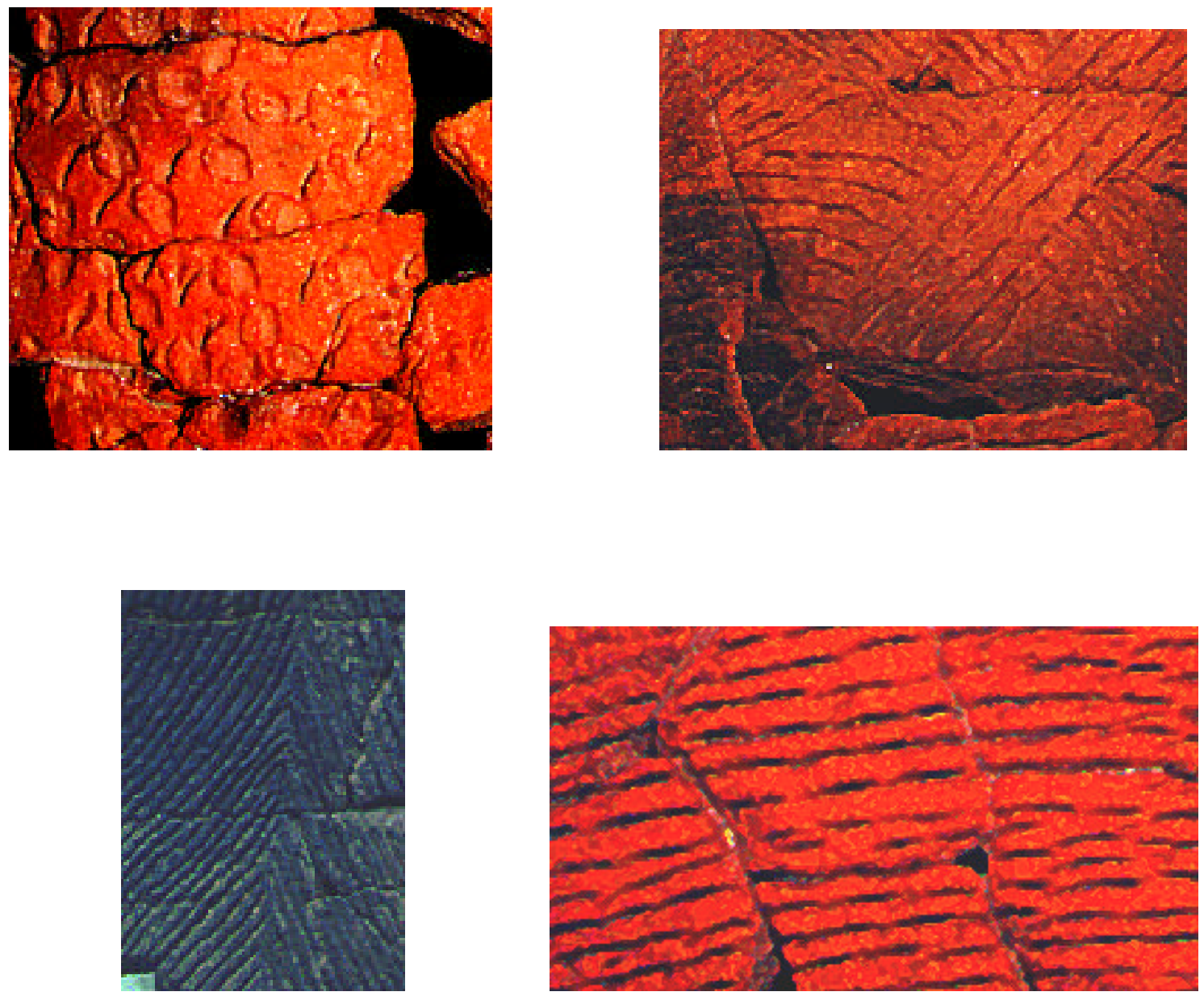

Grafismos na cerâmica da "Fase" Taquara (Sítio do Morro da Formiga). Acervo MARSUL

A “Fase" Caí, identificada por Ribeiro (1972b), está relacionada a acampamentos em abrigos dos vales dos rios Caí e Sinos no RS. Schmitz (1988:83) acredita que esta fase seja sinonímia da "Fase" Taquara. Seus sítios 
não foram datados. O Abrigo sob-rocha Bom Jardim Velho, com arte rupestre, está entre eles ${ }^{29}$.

Já no Município de Santa Cruz do Sul (RS) e arredores, mais de 40 sítios arqueológicos foram localizados tanto nas partes altas da encosta do planalto como nas suas porções mais baixas. Nas encostas altas, têm-se algumas casas subterrâneas, um aterro e galerias. Nas encostas dos rios Pardo e Taquari, mais quentes, existem taperas de pequenas choupanas de palha. Em mais ou menos 1/3 destes sítios, aparece cerâmica de "Tradição" Taquara com elementos diagnósticos da cerâmica de "Tradição" Tupiguarani, ocupante das terras baixas, nas proximidades dos rios.

Ribeiro (1980 e 1983), e Ribeiro e Silveira (1979) estabeleceram, a partir destes sítios, a "Fase" Erveiras, que possui apenas uma datação radiocarbônica: $1.035 \pm 145$ d.C. (SI-4066). Schmitz (1988), pela alta semelhança desta cerâmica com a da "fase" Taquara, prefere considerar a "Fase" Erveiras como sinonímia da "Fase" Taquara, pela acentuada semelhança da cerâmica pertencente às duas "fases".

É instigante a semelhança dos artefatos líticos da "Fase" Erveiras" com o material da "Fase" pré-cerâmica Pinhal, pertencente à "Tradição" Humaitá.

A "Fase" Guatambu ${ }^{30}$ - a mais antiga, com datações, para o RS, de 140 \pm 85 d.C. (SI-813), $1.000 \pm 80$ d.C. (SI-812) e $1.250 \pm 60$ d.C. (SI-2343) ocupa o norte do RS (Vacaria e Bom Jesus) e Sul de SC (São Joaquim). Os sítios arqueológicos estão em dois ambientes: nos campos altos foram localizados 11 conjuntos de casas subterrâneas, algumas com montículos funerários; nas várzeas dos rios das Antas e Pelotas, 41 taperas de aldeias com choças de palhas foram trabalhadas. Abrigos sob-rocha, próximos a estes rios, foram usados como cemitérios, como o do Matemático, no Município de Bom Jesus. Neste abrigo, foram encontrados objetos perecíveis conservados: trançados de fibra vegetal, artefatos de madeira, pentes de taquara, etc.

De acordo com Schmitz (1988:81), no século XIX esta área (Campos de Cima da Serra) era dominada por grupos Xokleng, "adversários férreos dos Kaingang do cacique geral Braga, que ocupava os campos e pinheirais de São Francisco de Paula, Caxias do Sul e arredores, território da fase Taquara".

\footnotetext{
${ }^{29}$ Veja subitem 5.3.2.

${ }^{30}$ Sinonímia: "Fase" Vacaria. A "Fase" Guatambu foi trabalhada por La Salvia, Schmitz \& Becker (1968, 1970), Miller (1971), Lazzarotto, Schmitz, Becker \& Steinmetz (1971) e Kern (1985).
} 
Pivetta (1974), citando informações nativas, informa que os Kaingang que estão atualmente no Município de Cacique Doble, área um pouco mais à leste da região ocupada pela "Fase" Guatambu, estavam em 1870 próximos à atual Caxias do Sul, tendo chegado por volta de 1908 ao atual Município de Cacique Doble. Estes deslocamentos históricos, dos quais temos registros orais ou escritos, estão a demonstrar a instabilidade e flexibilidade das fronteiras entre as duas sociedades, cujos avanços e recuos seguramente deixaram vestígios concretos no registro arqueológico, o qual deve ser analisado de forma mais metódica para se atingir a compreensão de sua real vinculação (Proto-Kaingang ou Proto-Xokleng).

Analisando este aspecto, é importante observar que, contraditoriamente à informação sobre a presença de grupos Xokleng no território da "Fase" Guatambu no século XIX, os "sítios-cemitérios em abrigos-sob-rocha, ligados à fase Guatambu", localizados "em paredões próximos aos rios, ao lado ou sob quedas d'água dos afluentes menores [do Pelotas e do das Antas]", apresentam enterramentos cujas "evidências foram suficientes para constatar-se que eram do tipo aterro, entrando na sua formação terra e restos vegetais de xaxim, folhas de taquara e capim. Pequenos blocos de pedra circundavam os aterros que eram alongados (máximo 70 x $180 \mathrm{~cm}$ e mínimo 60 x $30 \mathrm{~cm}$ ) e baixos" (Miller, 1971:45; minha ênfase). O autor, em nenhum momento, suspeita de cremação dos corpos, até porque os restos ósseos ainda estão presentes. O mobiliário funerário associado a estes enterramentos era constituído de restos de pequenas fogueiras, trançados de fibra vegetal e, raramente, animal, artefatos de madeira, cera animal, conchas de lamelibrânquios, panelas de cerâmica (reconstituídas por Miller, 1971:estampa 10), milho, pinhão e calabaças (porongos). Todas as evidências arqueológicas, pois, afastam a hipótese de tratar-se de enterramento Proto-Xokleng.

O padrão de sepultamento do falecido, juntamente com seus objetos pessoais, em aterro ou montículo funerário está etnograficamente vinculado aos Kaingang, ao passo que o padrão Xokleng, também registrado etnograficamente, é o de cremação dos corpos (juntamente com as cinzas dos pertences incinerados dos falecidos) ${ }^{31}$. Como compreender, então, sepultamentos do tipo Kaingang em "sítios-cemitérios em abrigos sob-rocha, ligados à fase Guatambu", de dita ascendência Xokleng?

\footnotetext{
${ }^{31}$ Veja discussão detalhada sobre os padrões de sepultamento Kaingang e Xokleng, mais adiante, no item 4.4. do Capítulo 4.
} 
Como "alguns restos ósseos de enterramento apresentaram-se ainda encobertos pelo periósteo" (Miller, 1971:45) é de se supor que o sítio-cemitério vinha sendo usado tradicionalmente (desde há quanto tempo?) até data relativamente recente, época em que certamente a área era de domínio de grupos Kaingang, falantes do dialeto do Sudeste.

Todas estas evidências remetem à hipótese de que tais sítios-cemitérios teriam sido utilizados por populações Proto-Kaingang.

O material cerâmico de "Fase" Guatambu, ao contrário da "Fase" Taquara/Caí/Erveiras, apresenta-se, majoritariamente polido na sua superfície externa. A pequena quantidade de cerâmica que apresenta técnicas de decoração aparece em faixa na metade do corpo da peça: impressões em ziguezague, incisões paralelas e/ou cruzadas, estampado denteado, pinçado, ungulado e ponteado. A superfície interna aparece polida e, às vezes, recoberta com engobe vermelho.
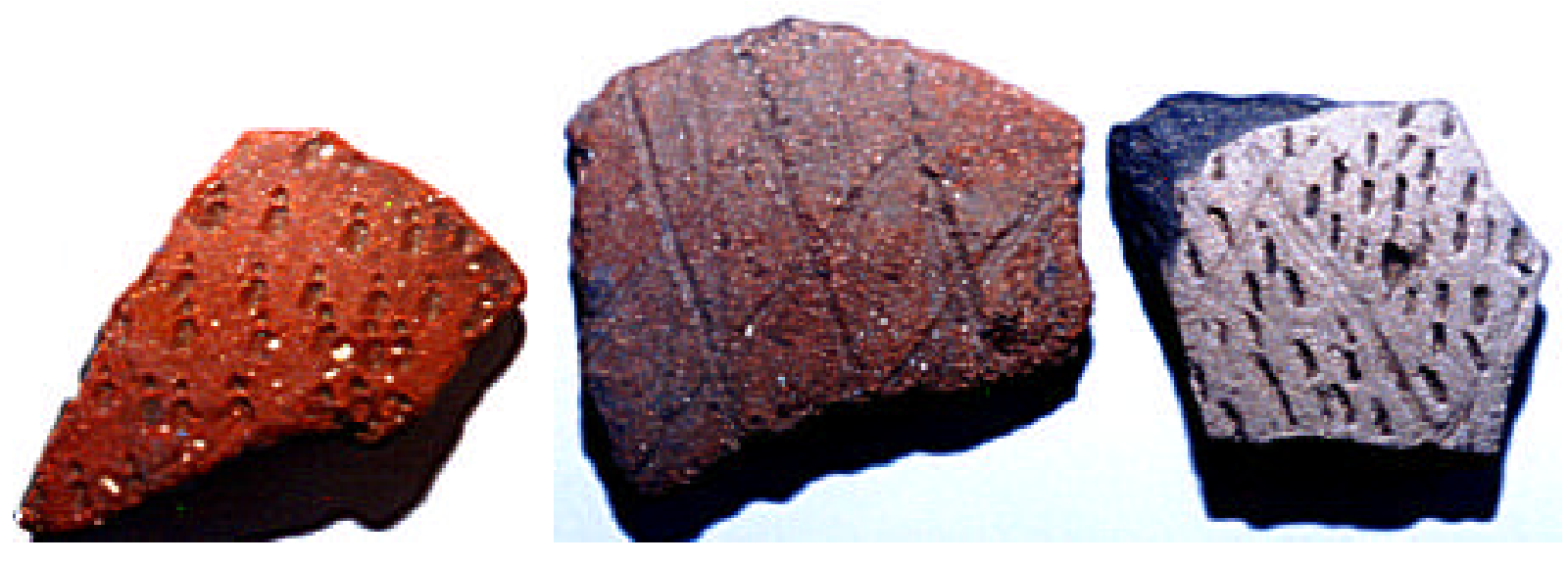

Grafismos da cerâmica da "Fase" Guatambu. Acervo MARSUL. 

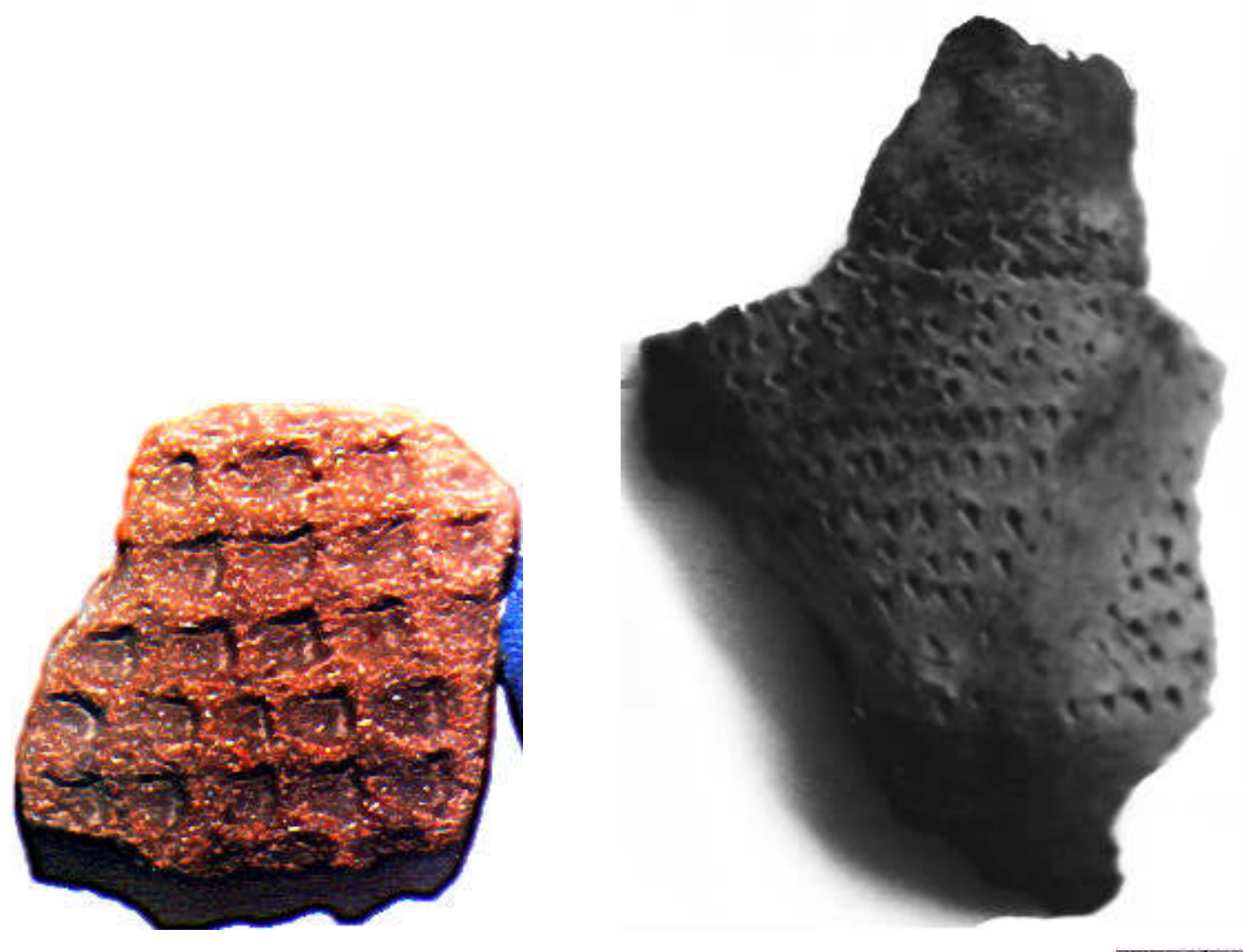

2
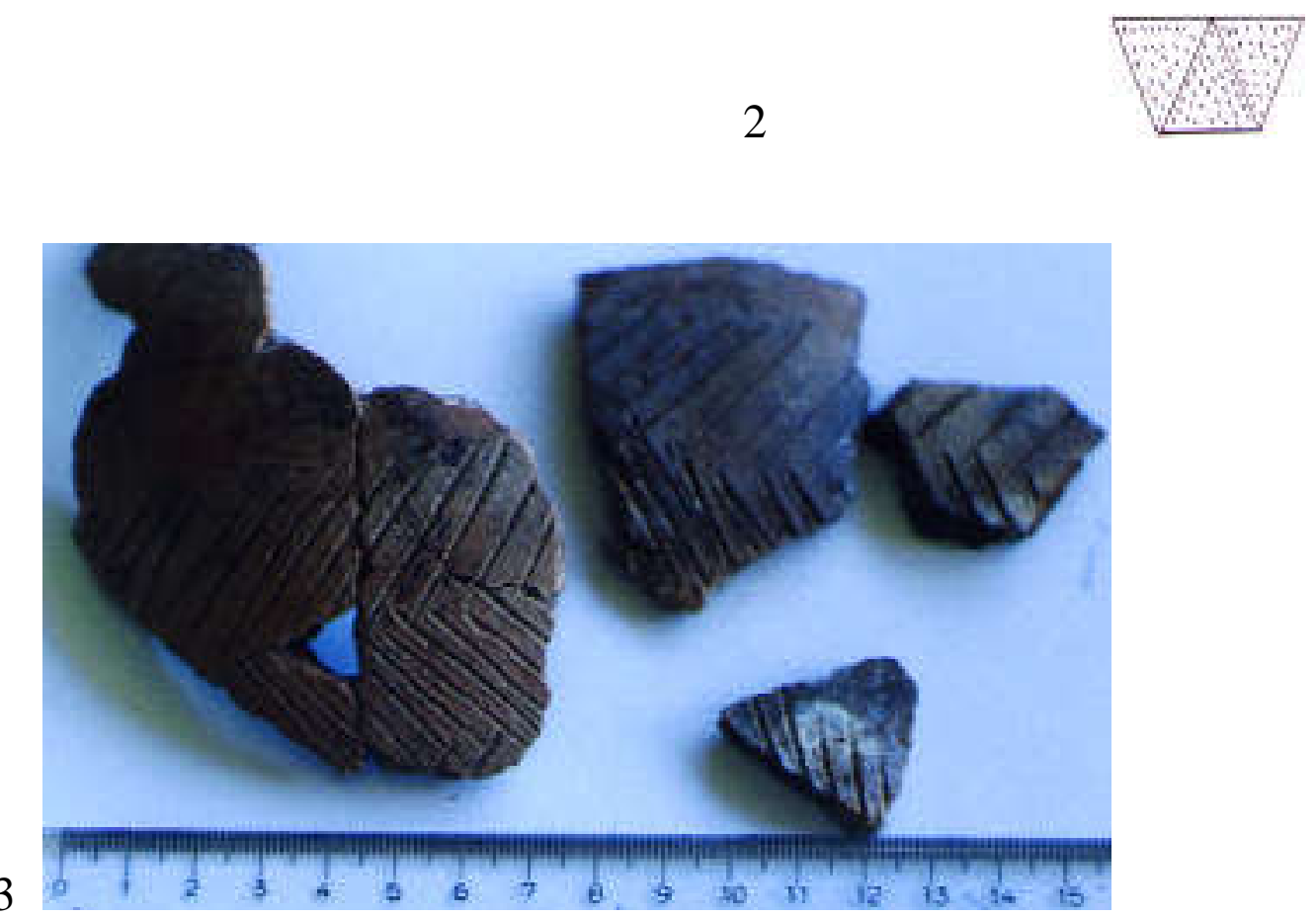

Grafismos da cerâmica da "Fase" Guatambu. Acervo MARSUL. Os fragmentos das fotos 2 e 3 são do Sítio do Matemático. Abaixo da foto 2, consta desenho da reconstituição do provável motivo gráfico do fragmento. 

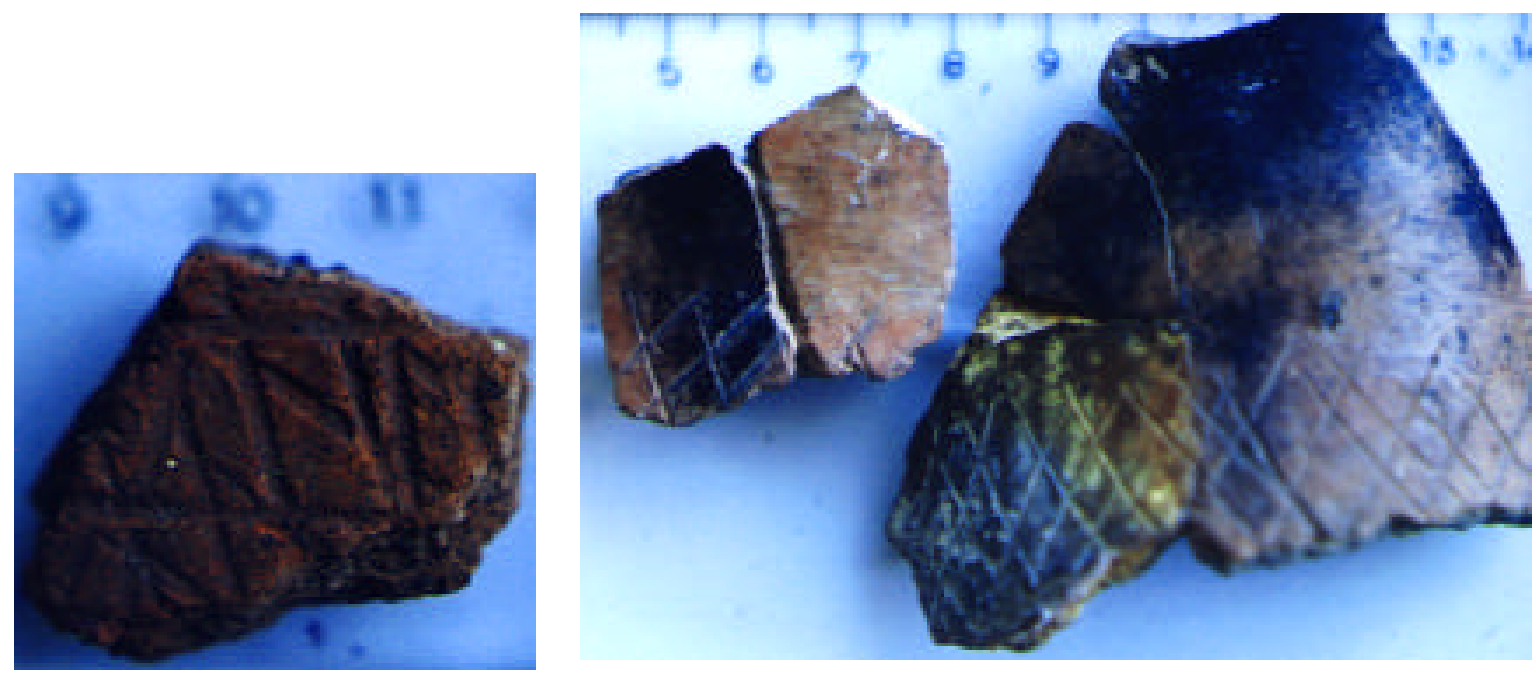

2
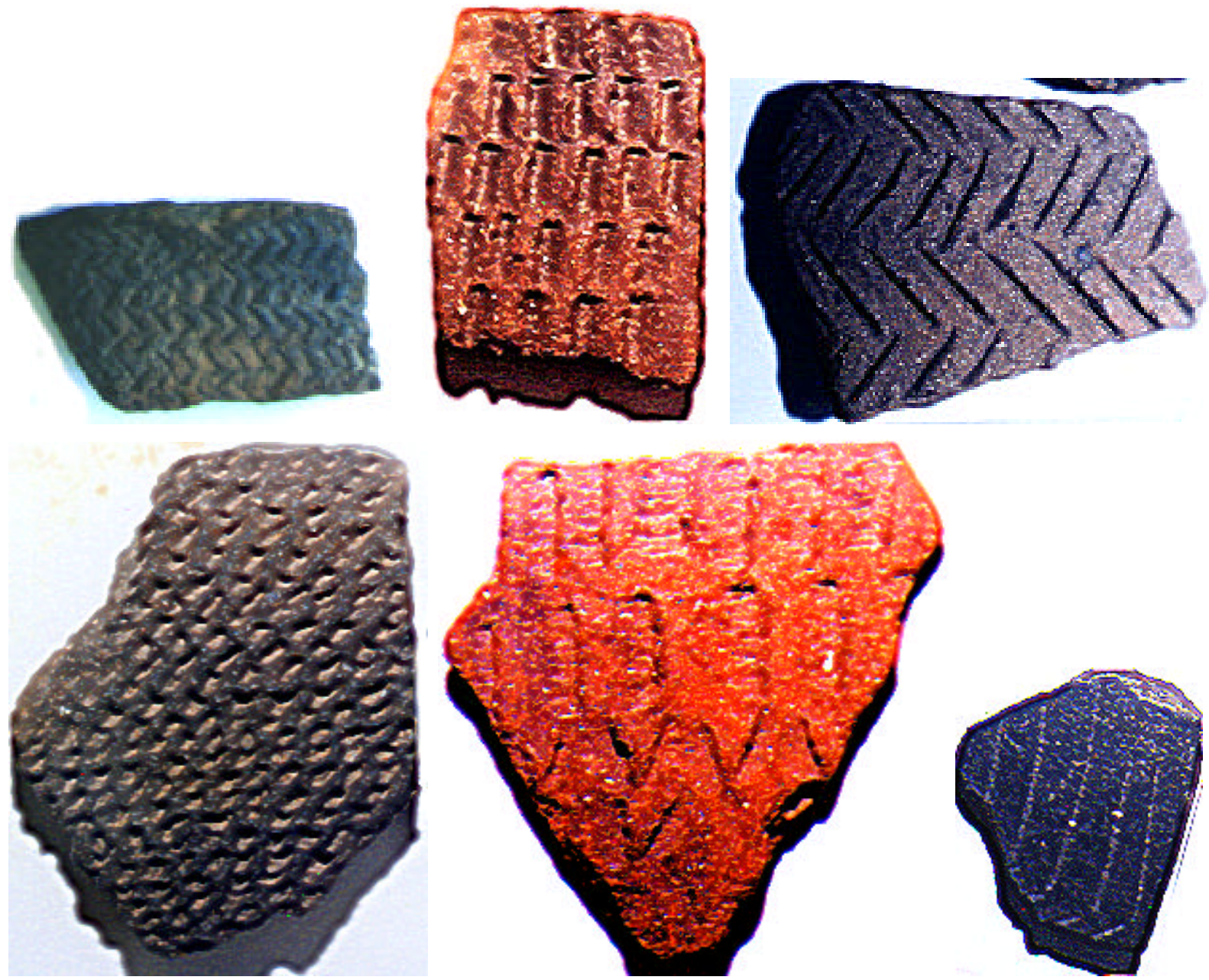

Grafismos da "Fase" Guatambu. Acervo MARSUL. Fotos 1 e 2: Sítio do Matemático. 
No final da década de sessenta, La Salvia, Schmitz e Becker (1968) noticiaram a existência de uma "fase" denominada Vacaria, localizada no RS, nos Campos de Cima da Serra, mesma região das "fases" Guatambu/Guabiju. Os autores notaram sua semelhança com as cerâmicas da Base Aérea-SC, dos sítios PR UV 1, Barracão e 13 de Mayo e aquelas incluídas por Menghin no Eldoradense. A cerâmica da "Fase" Vacaria apresenta-se simples ("alisamento estriado sem formar sulcos") em 449 fragmentos; com beliscado em 46; e com ponteado em apenas 2 fragmentos. Quanto às técnicas decorativas, é interessante notar que, apesar desta cerâmica ter sido encontrada na área da "Fase" Guatambu/Guabiju, ela não apresenta todos os tipos de grafismos descritos para a "fase" citada. Que hipóteses explicativas teríamos? Amostra arqueológica insuficiente? O "grupo populacional Vacaria" não registrou na sua cerâmica todo o acervo de grafismos do sistema de representações visuais Jê meridional? As fronteiras territoriais entre os grupos das várias "fases" seriam instáveis e estaríamos, pois, diante de um exemplo de grupo da "Fase" Taquara/Caí/Erveira dentro da área da "Fase" Guatambu/Guabiju? Ou tratar-se-ia do registro arqueológico de momentos diferentes da ocupação de um mesmo território por grupos Proto-Jê meridionais diversos? Em 1991, os autores (Schmitz \& Becker, 1991:257) admitem que a "Fase" Vacaria é sinonímia de "Fase" Guatambu.

Se correta a avaliação de que os territórios das "fases" Guatambu/Guabiju e Taquara/Caí/Erveiras estavam ocupadas por sociedades Jê meridionais diferentes, respectivamente, Xokleng e Kaingang, poder-se-ia esperar diferenças entre os grafismos nelas presentes. Entretanto, estes padrões, enquanto sistemas de representação visual, não demonstram diferenças significativas, sendo bem marcantes as semelhanças formais dos grafismos da "Fase" Taquara/Caí/Erveiras, cujo território, no séc. XIX, era de domínio de grupos Kaingang sob a liderança do cacique geral Braga, inimigos ferrenhos dos Xokleng, que historicamente ocupavam a região dos Campos de Cima da Serra, território da "Fase" Guatambu/Guabiju.

Na verdade, alguns grafismos Xokleng históricos, trabalhados nesta tese ${ }^{32}$, são formalmente muito semelhantes aos grafismos históricos Kaingang. Apenas uns $\operatorname{raros}^{33}$ são completamente estranhos ao padrão gráfico Kaingang.

\footnotetext{
${ }^{32}$ Veja Capítulo 5 e Anexos.

${ }^{33}$ Compostos por linhas curvilíneas.
} 
Ao que tudo indica, a cerâmica (produção ${ }^{34}$, formas e técnicas decorativas) não se constitui em um bom indicador material das diferenças entre Kaingang e Xokleng. Com relação a técnicas decorativas da cerâmica que não produzem grafismos, Miller (1971) cita que Botocudos/Xokleng radicados no Toldo Ligeiro (Posto Indígena Kaingang do norte do RS) informaram-lhe conhecer e praticar a técnica para o enegrecimento da cerâmica ${ }^{35}$, técnica esta registrada na década de 70 por Miller Jr. junto aos Kaingang paulistas e denominada por ele (Miller Jr., 1978) como "técnica de esfumaramento", já comentada anteriormente. Aliás, a cerâmica arqueológica de sítios litorâneos de Santa Catarina - muito provavelmente área Proto-Xokleng - apresenta esta técnica, como ocorre com o material cerâmico da Praia da Tapera (Silva, 1989).

Alguns arqueólogos admitem que as populações da "Fase" Guatambu/Guabiju teriam acesso ao litoral fronteiro de Santa Catarina (Schmitz \& Becker, 1991:258). Nesta região litorânea, Rohr (1969) pesquisou vários sítios semelhantes na cultura material aos do planalto e encosta, inclusive casas subterrâneas. Schmitz (1995, com. pes.) vem trabalhando no Município de IçaraSC em acampamentos estacionais com sepultamentos cremados (indicador Xokleng) e grande quantidade de artefatos líticos muito fragmentados.

A "Fase" Guabiju (Ribeiro \& Ribeiro, 1985) é considerada sinonímia de "Fase" Guatambu por Schmitz \& Becker (1991:264). É uma das mais recentes "fases" da "Tradição" Taquara: $1595 \pm 50$ e $1300 \pm 55$ d.C. Seu território é a bacia do Rio Pelotas. Sua cerâmica é muito semelhante à da "Fase" Guatambu: cerâmica simples, polida, na sua maioria, e com técnicas de decoração ponteada, incisa, cestaria impressa, pinçada, ungulada, malha impressa, impressão de corda, carimbada, digitada e mista.

\footnotetext{
${ }^{34}$ Conforme Fabíola Silva, s/d.

35 "Friccionamento de 'barba de pau' ou 'samambaia' sobre a superfície do pote recém-tirado da queima (por oxidação)" - Miller, 1971.
} 


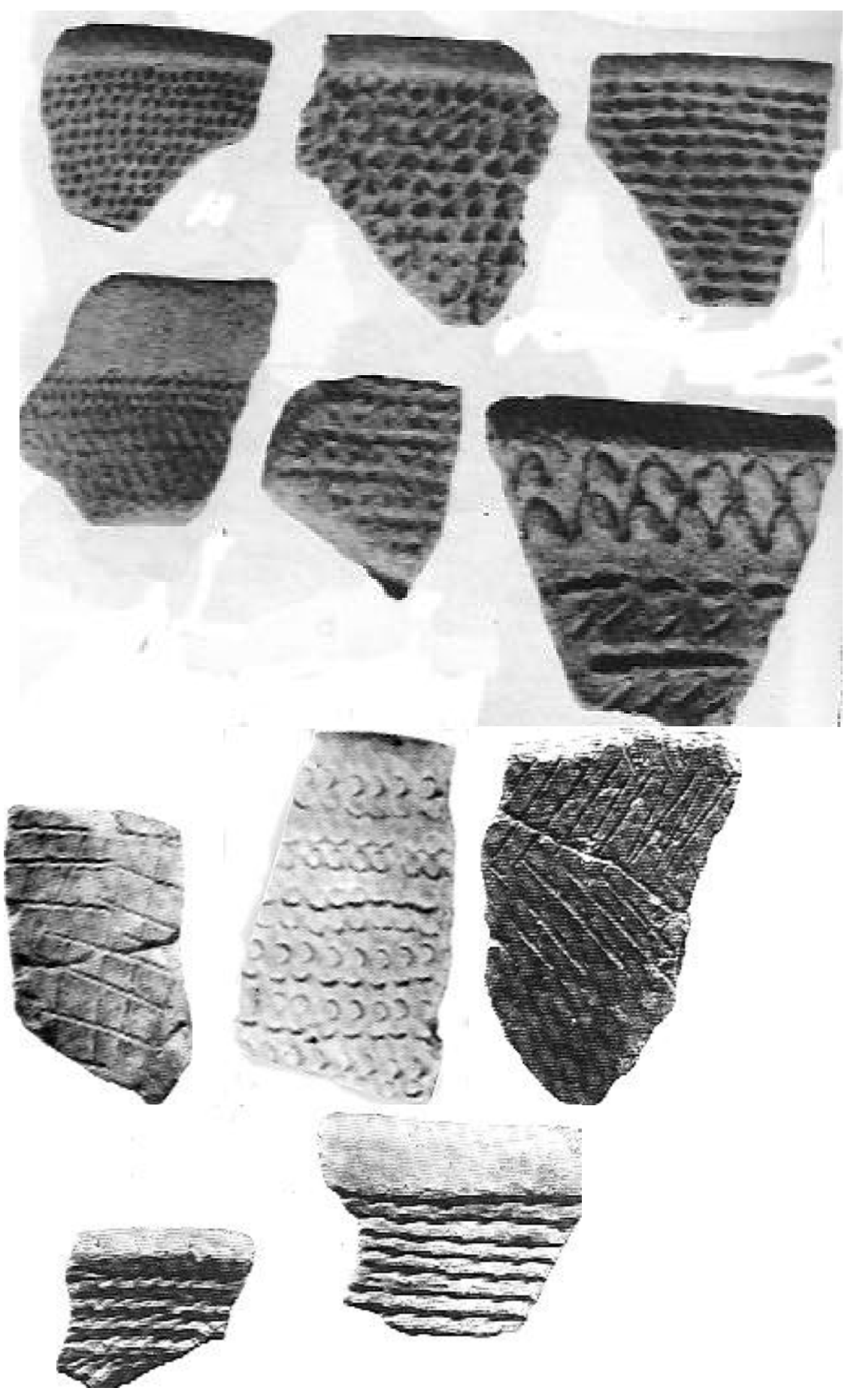

Grafismos na cerâmica da "Fase" Guabiju. Reproduzido de Ribeiro \& Ribeiro, 1985:figs. 10 e 12 (detalhes). 
A "Fase" Taquaruçu ${ }^{36}$ é a mais recente das "fases" da "Tradição" Taquara, alcançando o século XIX: $1.120 \pm 60$ d.C. (SI - 598) e $1.790 \pm 70$ d.C. (SI-599). Sua cerâmica mostra o contato com populações não-indígenas:

"Os altiplanos dos esporões serranos, com seus pinheirais mesclados à mata latifoliada e altitudes não superiores a $500 \mathrm{~m}$, mais do que outras regiões, serviu de habitat a uma fase cerâmica de tradição não guarani: a fase Taquaruçu. Os motivos plásticos da cerâmica desta fase lembram os motivos da fase Taquara, e os apliques em função de asa, aos da fase Monjolo" (Miller, 1969:42).

Este autor a considera "afiliada à fase Caaguaçu ["Tradição" Humaitá], por apresentar artefatos líticos lascados e polidos, tipologicamente assemelhados" (op. cit., pág. 37).

Os sítios desta "Fase" localizam-se a noroeste do RS. Miller (1969:37-38) descreve a cerâmica como sendo majoritariamente alisada; uma pequena quantidade tem a superfície externa decorada com ponteado, ponteado-arrastado, ungulado e aplicado. A Reserva Indígena da Guarita fica próxima aos sítios, demonstrando ser a área atual e tradicionalmente ocupada por grupos Kaingang. No século XIX, o norte e noroeste do RS estavam ocupados por dois grupos Kaingang, liderados pelos caciques principais Nonohay e Fongue (cf. Schmitz \& Becker, 1991:270/1).

A "Fase" Giruá (Miller, 1969:38), provavelmente sinonímia da "Fase" Taquaruçu ocorre a noroeste do RS, nas margens do Rio Uruguai, possuindo cerâmica alisada, ponteada ou pinçada. Os materiais líticos teriam grande semelhança com aqueles da "fase" pré-cerâmica local da "Tradição" Humaitá ("Fase" Caaguaçu), o que reforça a tese da incorporação de grupos pré-existentes por grupos Jê em seu deslocamento para o sul, já comentada, e que será detalhadamente discutida no Capítulo 4. A datação radiocarbônica de $1.550 \pm$ 100 d.C. (SI-600), assemelha-se a de "Fase" Taquaruçu.

No norte do RS (Município de Erechim) e, principalmente, a sudoeste e centro de SC, localizam-se os sítios arqueológicos da "Fase" Xaxim, que possui duas datas radiocarbônicas, a mais recente alcançando o século XVIII, o que reforça a tese, aqui defendida, da continuidade dos registros arqueológico e etnográfico: $975 \pm 95$ d.C. (SI-825) e $1.620 \pm 90$ d.C. (SI-597).

${ }^{36}$ Estudada por Miller, 1969:37-8. 
No RS, esta "fase" foi estudada por Miller (1971:49). Segundo ele, são "três sítios que com pequenas diferenças se enquadram na fase Xaxim"; "Um biface polido semilunar foi encontrado em íntima associação com a cerâmica" - e será comentado mais abaixo) e, em SC, por Piazza (1969a:60-61, oeste de SC, Município de Chapecó; 1969b:65-66, Campos de Lages- SC, áreas dos rios Pelotas e Canoas; 1971:75). Seus sítios são pequenos e encontram-se no topo ou nas encostas de morros, próximos a córregos ou nascentes, na floresta subtropical.

O material cerâmico, na sua maioria, apresenta-se alisado, com alguns poucos recipientes com técnicas de decoração incisa, ungulada, ponteada, pinçada ou incisa-ungulada. Os sítios do Município de Chapecó - SC, estudados por Piazza (1969 a) apresentam cinco tipos de técnicas decorativas incisas, pinçadas, ponteadas e unguladas; os dos Campos de Lages (Piazza, 1969b) registram técnicas unguladas, incisas e ponteadas.

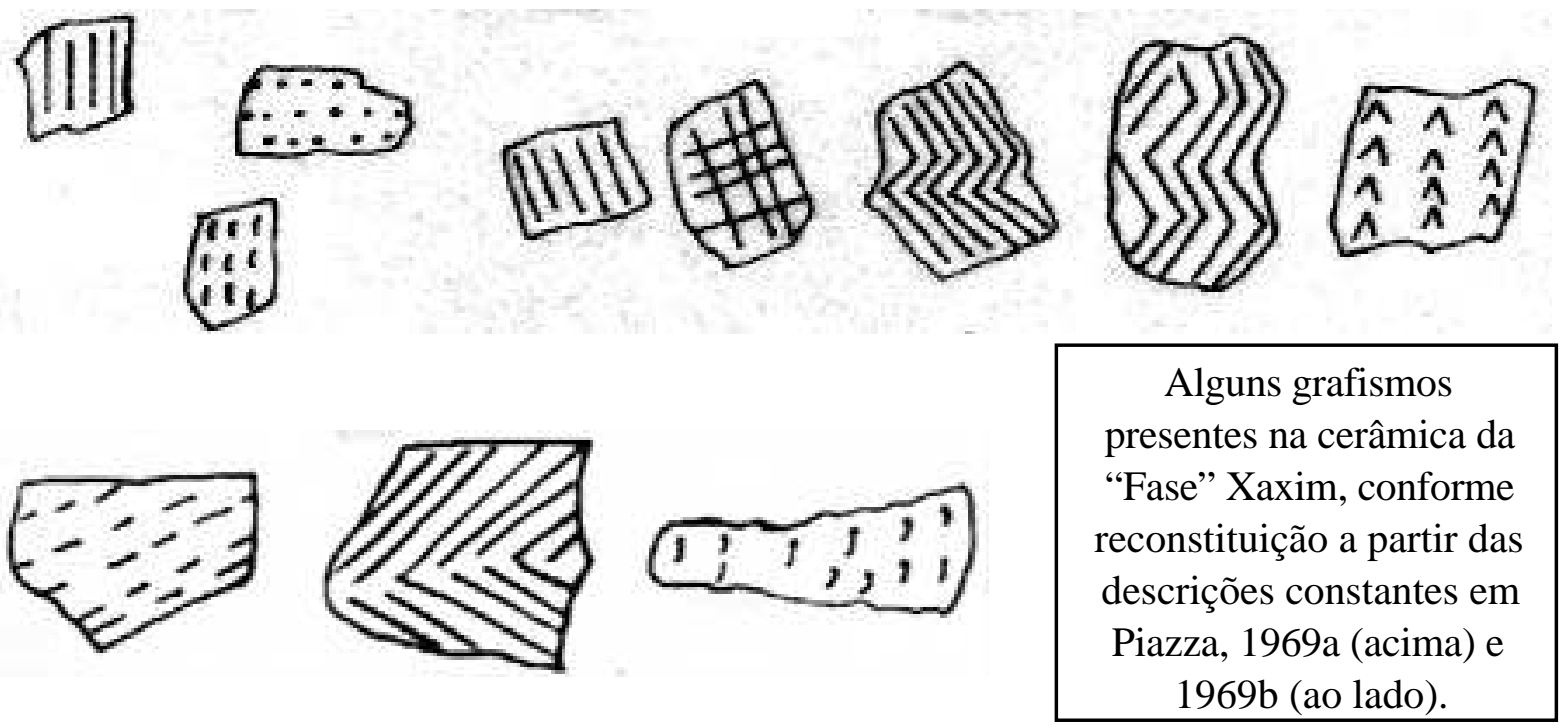

No lítico, encontrada "em íntima associação com a cerâmica" (Miller, 1971:49), uma lâmina de machado semilunar chama a atenção, por tratar-se de objeto ritual, sem uso prático/cotidiano, e por sua semelhança com o mesmo tipo de artefato dos grupos Timbira (Jê), o que nos proporciona mais um vínculo entre estas populações pré-históricas e os Jê, em geral. Segundo Carneiro da Cunha (1978:131), entre os Krahó, os machados de pedra (khoiré), eram considerados insígnias de status dos bons cantadores, sendo herdado por outro cantador. Tais 
insígnias, portanto, não eram destruídas ou enterradas com seu proprietário, como acontecia com seus demais objetos de uso pessoal ${ }^{37}$.

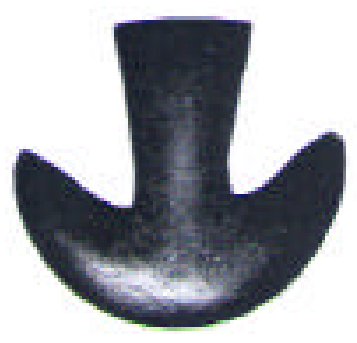

Reproduzido de Miller, 1971:estampa 8.

Segundo os arqueólogos que estudaram esta "fase" (Miller, 1971; Piazza. 1969 a e b, 1971) nela há contato marcado com populações portadoras da "Tradição" Tupiguarani ${ }^{38}$, como acontece, igualmente, com a "Fase" Itapiranga (trabalhada por Becker \& Schmitz, 1969; De Masi \& Artusi, 1985; Artusi \& De Masi, 1985), considerada sinonímia da "Fase" Xaxim por Schmitz \& Becker (1991:266).

Quanto à "Fase" Itapiranga, seu território localiza-se no Município de mesmo nome, em Santa Catarina, em área de numerosos sítios de "Tradição" Tupiguarani.

Não há datações radiocarbônicas, mas os autores principais (Becker \& Schmitz, 1969) a consideram mais recente que a ocupação Tupiguarani.

Sua cerâmica apresenta-se majoritariamente alisada, com raros ponteados, ponteados picoteados, ponteados arrastados, impressos vários, pinçados, digitados e ungulados secantes em linha.

De acordo com Schmitz \& Becker (1991:270-1), o norte e noroeste do RS, territórios das "Fases" Taquaruçu, Giruá e Xaxim estavam ocupados no século XIX por "duas tribos, com um total aparentemente pequeno de índios, (...), sob o comando dos caciques principais Nonohay e Fongue".

Reis (1980) pesquisou 83 sítios com casas subterrâneas e diversos sítiosaldeia no planalto de Lages - SC. Associados às primeiras, existem aterros circulares ou elipsóides.

\footnotetext{
${ }^{37}$ Veja discussão sobre o tema no item 4.4.

${ }^{38}$ Ocorrência de materiais arqueológicos de ambas "tradições" no mesmo sítio.
} 
A cerâmica, que não foi encontrada em abundância, é lisa, na sua maioria. 11,3\% dos fragmentos apresenta técnicas decorativas: ungulados, ponteados, incisos, digitados, marcados com corda, incisos-ungulados, pinçados, engobados de vermelho.

Schmitz (1988:89) pensa que "ela não parece igual à que Rohr encontrou no planalto de Urubici". O mesmo autor (op. cit., pág. 88) incorpora estes sítios, tentativamente, na "Tradição" Taquara.

No Vale do Rio Itajaí, em Rio do Oeste e Ituporanga, na encosta do planalto catarinense, Alroini B. Eble comunicou a Reis (1980) a existência de 7 sítios de casas subterrâneas.

Além dessas, Rohr (1969: 22-23) localizou no litoral de Santa Catarina, em Jaguaruna, um sítio com 3 casas subterrâneas e alguns concheiros, cujas camadas superficiais apresentavam cerâmica das "tradições locais planálticas". Schmitz (1988:90), que manuseou o material no Museu do Homem do Sambaqui, em Florianópolis, acredita que esta cerâmica estaria mais ligada àquela do Rio Grande do Sul ("Fase" Guatambu) do que à cerâmica dos sítios da Ilha de Santa Catarina, ligados à "Tradição" Itararé, e dos de Urubici, vinculados provavelmente à "Tradição" Casa de Pedra.

A cerâmica destes concheiros de Jaguaruna é predominantemente simples. 17\% apresenta técnicas decorativas (Prous, 1977:44).

Também no litoral catarinense, mais precisamente na parte sul da Ilha de Santa Catarina, Rohr (1971:15) localizou três casas subterrâneas nos morros que circundam o Pântano do Sul.

Como se viu, todos os territórios das chamadas quatro "fases" da "Tradição" Taquara possuem indicações históricas (início do séc. XIX) de terem sido ocupados por aldeias Kaingang e Xokleng: 1. norte do Rio Grande do Sul e sul de Santa Catarina; "Fase" Guatambu/Guabiju; habitado por "Botocudos" (Xokleng); 2. nordeste do Rio Grande do Sul, vales dos rios Caí e Sinos, Município de Santa Cruz do Sul e arredores; "Fase" Taquara/Caí/Erveiras; ocupado por 23 "grupos" Kaingang liderados pelos caciques principais Braga e Doble; e 3. noroeste e norte do Rio Grande do Sul; "Fases" Taquaruçu/Giruá e Xaxim/Itapiranga; território de duas "tribos" Kaingang sob o comando de dois caciques principais: Nonohay e Fongue (Schmitz, 1988; Schmitz \& Becker, 1991). 
Apesar de referirem-se a grupos com nomes diversos (Guaianá, Guaianã, Guananá, Waianá, Guaianaz, Gualacho, Mbiazá, Caaguá, Ibiraiara, Aweikoma, Botocudo, Coroado, etc.), informações mais antigas (séculos XVII e XVIII) também atestam que estas regiões vinham sendo ocupadas e dominadas por populações Jê meridionais desde estas épocas (Reis, 1997:46 e seguintes). Infelizmente, a pesquisa arqueológica ainda não localizou (ou datou) uma grande quantidade desses sítios mais recentes, que seriam o "elo" entre as "tradições locais planálticas" no Rio Grande do Sul (séculos XVII, XVIII e XIX) e os documentos dos inícios do século XIX, que referenciam os grupos Coroados habitando estes locais ${ }^{39}$.

É interessante notar que os sítios arqueológicos das "fases" Taquaruçu/Giruá e Xaxim/Itapiranga encontram-se na área geográfica hoje ocupada, segundo Wiesemann (1978) pelo dialeto Sudoeste da língua Kaingang. Já as "fases" Guatambu/Guabiju e Taquara/Caí/Erveiras estão situadas na área correspondente, atualmente, ao dialeto Sudeste. As duas primeiras são as mais recentes (séculos XII e X/XI, respectivamente; para as datas mais antigas obtidas em seus sítios), e as duas últimas estão mais recuadas no tempo (séculos I/II e IV/V, respectivamente; idem). Quanto aos Botocudos relacionados à "fase" Guatambu/Guabiju, cabe ressaltar que já no século XX tinham sido empurrados pelos Kaingang para além do Rio Uruguai, em território de Santa Catarina ${ }^{40}$.

\footnotetext{
${ }^{39}$ Apenas duas datações radiocarbônicas de sítios de "fases" da "Tradição" Taquara alcançam os séculos XVIII e

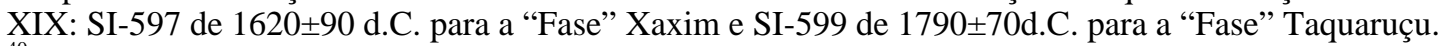

${ }^{40}$ Veja a descrição da "Fase" Guatambu, acima.
} 


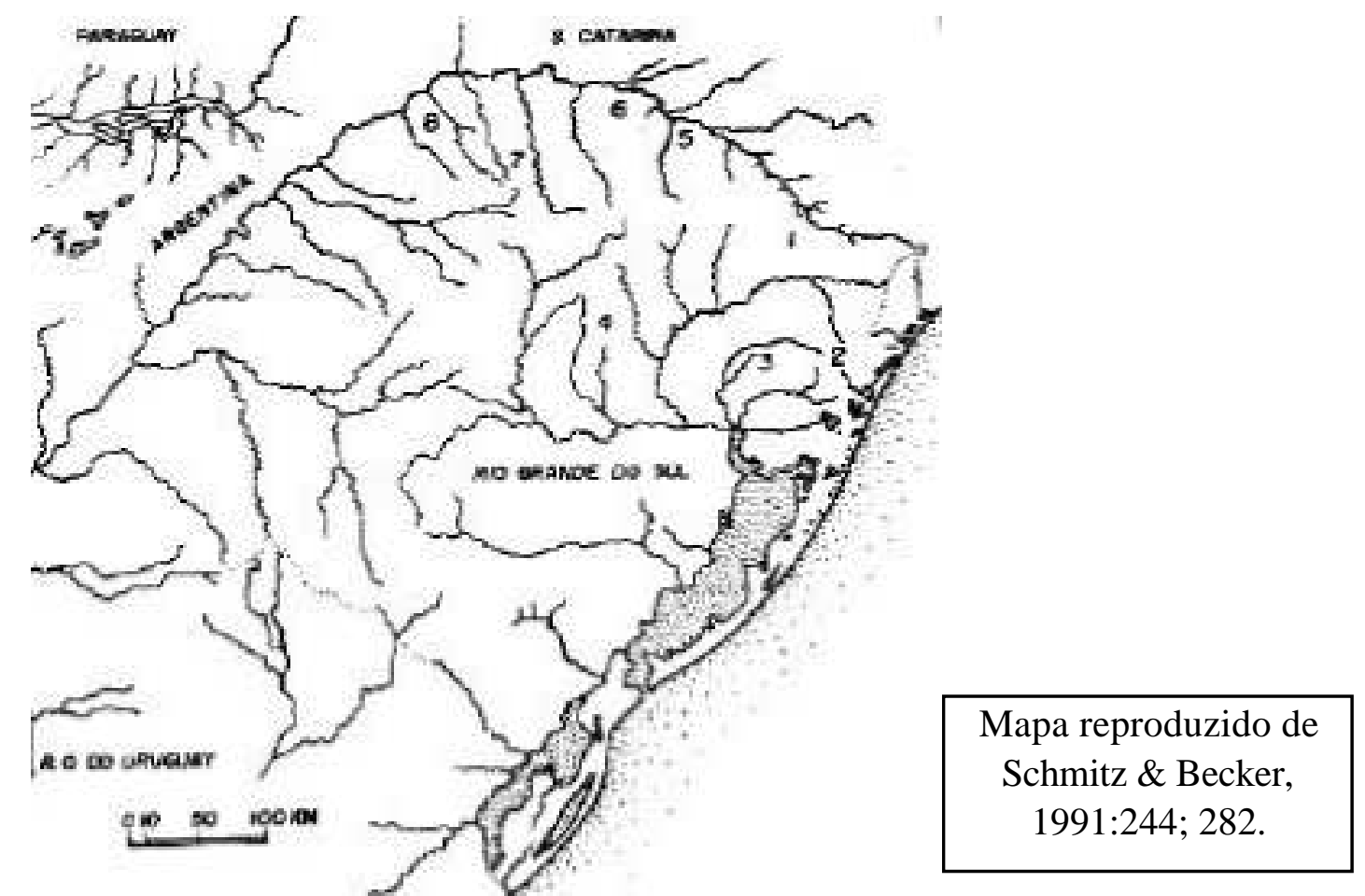

Legenda:

1. "Fase" Guatambu/Guabiju, respectivamente números 1 e 5 no mapa de Schmitz \& Becker. Datas radiocarbônicas da "fase": séc. I/II ao XVI/XVII. No séc. XIX, área dos Xokleng;

2. "Fase" Taquara/Caí/Erveiras (números 2 e 3, no mapa). Data de C14: séc. IV/V ao XIV/XV. No séc. XIX, área Kaingang do Cacique Braga;

3. "Fase" Taquaruçu/Giruá (números 7 e 8 , no mapa). Datas radiocarbônicas: séc. XII ao XIX. No séc. XIX, área Kaingang dos caciques Nonoai e Fongue;

4. "Fase" Xaxim/Itapiranga (número 6 indica a "fase" Xaxim; a "fase" Itapiranga não está indicada no mapa). As datas de C14 apontam do séc. X/XI ao XVIII). No séc. XIX, área Kaingang dos caciques Nonoai e Fongue. 
É importante salientar que, sob o ponto de vista da Arqueologia e, portanto, das características tecnológicas da cultura material, notadamente da cerâmica, territórios ocupados historicamente por duas sociedades Jê Meridionais distintas (Kaingang e Xokleng) foram relacionadas à mesma "Tradição" ceramista, apenas, ainda segundo os arqueólogos, possuindo sua cerâmica pequenas diferenças, argumento para classificá-las como "fases" distintas da "Tradição" Taquara.

Esta inclusão de duas sociedades Jê do sul distintas na mesma "Tradição" arqueológica ceramista regional sulina ainda não foi esclarecida e deve-se, notadamente, às grandes semelhanças que as cerâmicas históricas Xokleng e Kaingang apresentam quanto às suas técnicas de produção ${ }^{41}$. No futuro, estudos arqueológicos devem ser empreendidos com o objetivo de esclarecer esta questão, levando em consideração os demais materiais culturais pertencentes às "fases" e/ou analisando e interpretando aspectos simbólicos específicos destes materiais, priorizando suas diferenças.

\subsubsection{As "fases" das "Tradições" Casa de Pedra e Itararé}

A “Fase" Casa de Pedra, da "Tradição" Casa de Pedra, (Chmyz, 1969) localiza-se nas proximidades da escarpa basáltica do terceiro planalto paranaense. São dois sítios: um ocupa a camada superficial de um abrigo sobrocha (1.150 \pm 50 anos d.C. - SI-141), no vale do Rio Vermelho, e um outro, um pouco mais a leste, nas proximidades do Rio Vargem Grande, afluentes da margem direita do Iguaçu.

No segundo sítio, os vestígios cerâmicos (12 fragmentos lisos) e líticos foram encontrados na superfície, ao lado e nas proximidades de um grande bloco de diabásio, com grafismos rupestres (Chmyz, 1968d:60).

Neste trabalho de 1968, Chmyz (1968d:56-7) descreve os grafismos rupestres do Sítio Têm-Que-Vêr (PR UV 5) como sendo quatro conjuntos de linhas, representando "cruz dupla", "linhas paralelas", "linhas cruzadas", "traços curvos", "setas [inteiras ou quebradas]", "um [possível] pequeno animal", "pernas de pássaros" e "[possíveis] figuras humanas" ${ }^{42}$.

\footnotetext{
${ }^{41}$ Para maiores detalhes, ver o trabalho de Fabíola Silva (s/d.).

${ }^{42}$ Veja subitem 5.3.4., adiante.
} 
Quanto à cerâmica da "Fase Casa de Pedra", como um todo, 338 fragmentos não possuem técnicas decorativas; um tem "estrias paralelas" e outro apresenta "incisões em ambas as faces"(...), "numa face, as incisões lembram um pequeno animal estilizado, e, noutra, as ramificações de um galho de árvore" (Chmyz, 1969:116).

O autor, naquela época, achava prematuro estabelecer correlação entre a "Fase" Casa de Pedra e o registro rupestre, apesar de "perceber certa semelhança

\section{“TRADIÇÃO” CASA DE PEDRA}

\begin{tabular}{|c|c|c|c|c|c|}
\hline "FASE" & AUTOR(ES) & LOCAL & $\overline{\text { DATAS }}$ & CERÂMICA & OBS. \\
\hline \begin{tabular}{|l} 
Casa de Pedra \\
\end{tabular} & \begin{tabular}{ll|} 
Chmyz, & \\
1967b; 1968 \\
a, b, c; 1969 \\
b; 1971b.
\end{tabular} & $\begin{array}{l}\text { Vale do Rio } \\
\text { Vermelho/PR } \\
\text { e Rio Vargem } \\
\text { Grande/PR }\end{array}$ & $\begin{array}{l}1.150 \pm 50 \text { d.C. } \\
\text { (SI-141) }\end{array}$ & $\begin{array}{l}338 \text { frags. lisos; apenas um } \\
\text { com grafismos em ambas as } \\
\text { faces }\end{array}$ & $\begin{array}{lr}\text { Composta } \quad \mathrm{p} / \\
\text { apenas } & 2 \\
\text { sítios: o PR UV } \\
\text { 5, com } \\
\text { grafismos } \\
\text { rupestres, e o } \\
\text { Abrigo Casa de } \\
\text { Pedra }\end{array}$ \\
\hline $\begin{array}{lr}\text { Sítios } & \text { do } \\
\text { planalto } & \text { SC } \\
\text { Campos } & \text { de } \\
\text { Lages } & \end{array}$ & $\begin{array}{l}\text { Rohr, 1971; } \\
1972 \text { a, b }\end{array}$ & $\begin{array}{ll}\text { Campos } & \mathrm{de} \\
\text { Lages } & \end{array}$ & Não há & $\begin{array}{l}\text { Maioria lisa; } 4,4 \% \text { c/técs. } \\
\text { decorativas semelhantes à da } \\
\text { "Fase" Guatambu, cf. Schmitz, } \\
1988: 92\end{array}$ & $\begin{array}{l}\text { Galerias, } \\
\text { abrigos e casa } \\
\text { subterrânea } \\
\text { com grafismos } \\
\text { rupestres }\end{array}$ \\
\hline $\begin{array}{|lll|}\text { Sítio } & \text { PR } & \text { FI } \\
145 & & \\
\end{array}$ & \begin{tabular}{|l|} 
Chmyz \\
(Coord.),1979
\end{tabular} & $\begin{array}{l}\text { Planalto } \\
\text { paranaense } \\
\text { Margem esq. } \\
\text { do Paraná }\end{array}$ & $\begin{array}{l}\text { Recente } \\
\text { (cerâmica } \\
\text { Neobrasileira } \\
\text { intrusiva) }\end{array}$ & Lisa & \\
\hline $\begin{array}{l}\text { Outros sítios } \\
\text { da "Trad." } \\
\text { Casa de Pedra }\end{array}$ & $\begin{array}{l}\text { Chmyz } \\
\text { (Coord.),1979 } \\
\text { Blasi, } 1965\end{array}$ & $\begin{array}{ll}\text { Estado } & \text { do } \\
\text { Paraná } & \end{array}$ & Não há & - & $\begin{array}{l}\text { Nos sítios do } \\
\text { Barracão } \\
\text { Dionísio } \\
\text { Cerqueira, } \\
\text { Blasi (1965) } \\
\text { encontrou } \\
\text { "gravadores de } \\
\text { cristal", } \\
\text { possíveis } \\
\text { artefatos para } \\
\text { confeccionar } \\
\text { grafismos } \\
\text { rupestres } \\
\text { gravados }\end{array}$ \\
\hline
\end{tabular}


entre o animal estilizado no caco cerâmico e algumas figuras gravadas na rocha" (Chmyz, 1969:116).
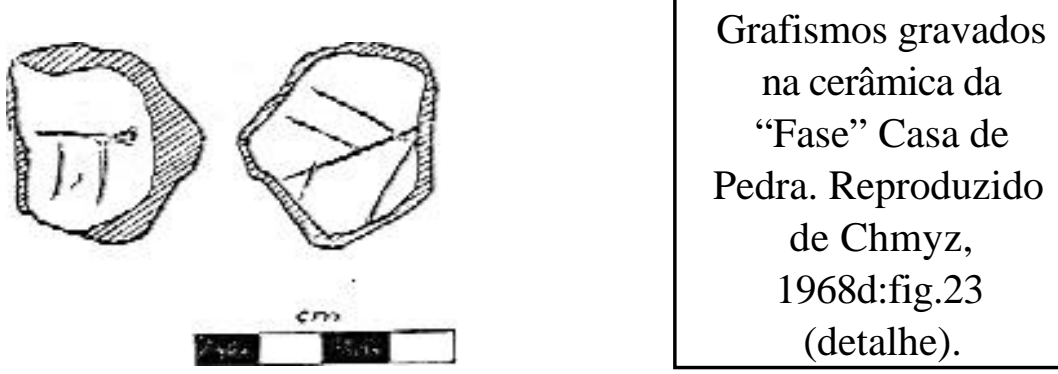

Igualmente o autor considera, "com certa cautela", que os materiais arqueológicos da camada superficial do abrigo sob-rocha do Rio Vermelho, datada de $1.150 \pm 50$ d.C., incluindo o fragmento com incisões em ambas as faces, "como de tradição Kaingáng", apoiando-se em Borba (1908) e Frich (1957). O primeiro atribui a prática de gravuras pelos índios Kaingang em chifres de boi, e o segundo "registra chifres e pedaços de madeira com gravações de animais e homens, pelos mesmos índios" (Chmyz, 1968d:58).

Estes fatos, além de demonstrar que os grupos Kaingang tradicionalmente praticaram grafismos em vários suportes, permite a comparação de grafismos pré-históricos figurativos zoomorfos com grafismos históricos, também figurativos zoomorfos e antropoformos, de origem reconhecidamente Kaingang ${ }^{43}$.

De qualquer forma, haveria uma correlação entre um grafismo zoomorfo gravado na rocha e na cerâmica das ditas "tradições locais planálticas", de cultura Proto-Jê meridional, o que alargaria o horizonte das futuras pesquisas em arte rupestre no sul do Brasil. Além disso, temos igualmente um primeiro registro na cerâmica Proto-Jê meridional de um grafismo linear com bifurcações, conhecido historicamente através de Mabilde (1983) e reconhecido e nomeado pelos Kaingang do Rio Grande do Sul, como será visto no Capítulo 5.

Além disso, é interessante observar que Chmyz (1969) aponta a presença na "Fase" Casa de Pedra de "duas pontas-de-projétil, trabalhadas em ossos

${ }^{43}$ Estes fatos serão discutidos e analisados no Capítulo5, item 5.3. 
longos", demonstrando o registro arqueológico de uma tradicional indústria óssea entre as sociedades Jê do Sull ${ }^{44}$.

Rohr (1971) localizou vários sítios nos Campos de Lages - SC, incluindo casas e galerias subterrâneas, além de sítios-aldeia. Não há datas radiocarbônicas.

A abundante cerâmica destes sítios apresenta-se lisa na maioria dos casos; 4,4\% dela possui técnicas decorativas, que cobrem apenas a porção mediana das vasilhas. Segundo Schmitz (1988:92), a superfície foi "incisa, ponteada, ungulada, inciso-ungulada, inciso-ponteada, banhada em vermelho, ou brunida sobre fina camada negra, igual à da fase Guatambu”.
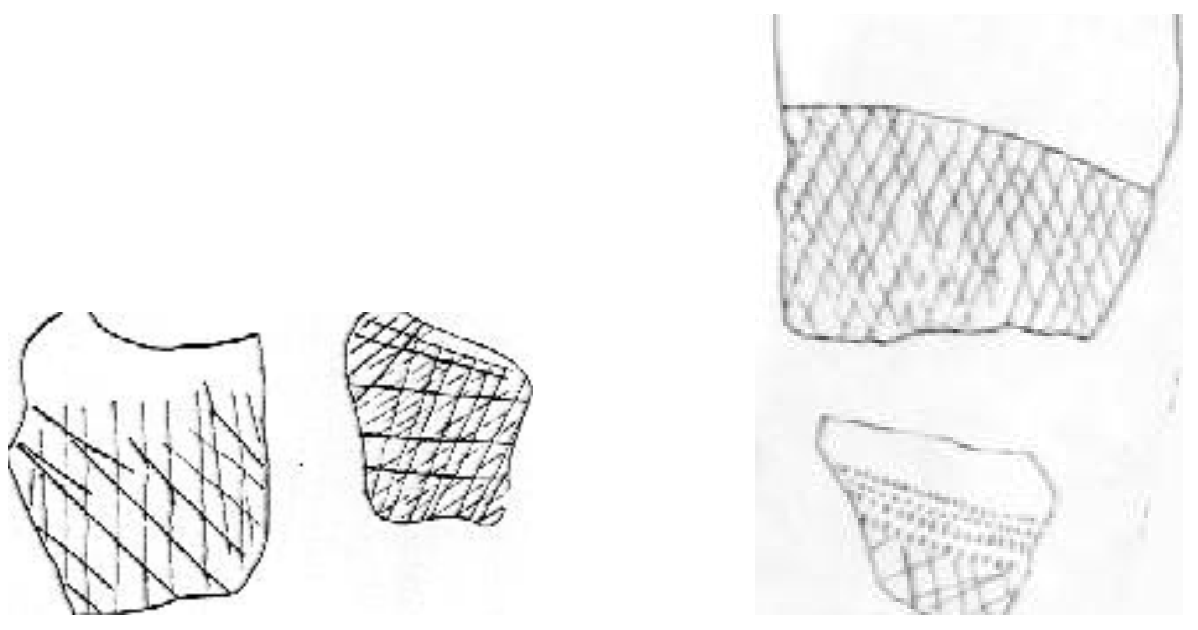

Alguns grafismos na cerâmica de Urubici (casa subterrânea SC-Urubici-11). Reproduzido de Rohr, 1971:fig. 9 (detalhe).

Os abrigos e galerias da área apresentam grafismos rupestres gravados ${ }^{45}$, muito semelhantes aos encontrados numa casa subterrânea escavada por Rohr. Isto demonstra claramente a autoria Proto-Jê meridional dos grafismos tanto da casa subterrânea como dos abrigos e galerias.

Chmyz (Coord., 1979) apresenta o Sítio PR FI 145, localizado no planalto paranaense, Município de São Miguel do Iguaçu, próximo à margem esquerda do Rio Paraná, com cerâmica lisa, o qual Schmitz, tentativamente, classifica como de "Tradição" Casa de Pedra. Pela intrusão de cerâmica Neobrasileira, deve tratar-se de sítio recente.

\footnotetext{
${ }^{44}$ Para os Jê do Sul, ver descrição das flechas (e suas pontas) no Capítulo 5, subitem 5.1.1. Para outras ocorrências de pontas-de-projéteis Proto-Jê meridionais em osso ver os sítios litorâneos catarinenses, especialmente a Praia da Tapera, estudada por S. Silva, 1989.

${ }^{45}$ Veja descrição e discussão no subitem 5.3.3., adiante.
} 
Schmitz (1988:95) fala de outros sítios da "Tradição" Casa de Pedra. Baseado em Chmyz (Coord., 1979), assegura que "em vários pontos do estado do Paraná (...) existem sítios contendo cerâmica comparável à da Casa de Pedra, como o abrigo do Wôbeto no médio Ivaí (...), bem como Barracão e Dionísio Cerqueira".

De forma intrusiva, também foi encontrada cerâmica da "Tradição" Casa de Pedra em sítios da "Fase" Umuarama ("Subtradição" Pintada Tupiguarani), e nos sítios José Vieira, Estirão Comprido, PR PG 2, o que, de acordo com Schmitz (1988:95), sugere contatos interétnicos.

Barracão e Dionísio Cerqueira, sítios estudados por Blasi (1965), localizam-se nos municípios de mesmo nome, o primeiro no sudoeste do Paraná e o segundo no noroeste de Santa Catarina. A oeste, limitam-se com a Província de Misiones, Argentina.

O ambiente de inserção destes sítios "pertence aos prolongamentos ocidentais do grande planalto meridional brasileiro" e a "paisagem florística (...) é constituída de matas de araucárias, que circundam pequenos e isolados campos" (Blasi, 1965:3-4).

Conforme este autor, o material cerâmico encontrado nos sítios é "idêntico" ao de Eldorado, na Província de Misiones, AR, investigado por Menghin em 1950 e 1957 (op. cit.,pág. 16, 22 e 23).

Menghin, apud Blasi (1965:23), procurou demonstrar que as evidências arqueológicas de Misiones correspondem a três distintas fases de povoamento pré-histórico desta província argentina. Usando a terminologia de Menghin, terse-ia: 1) Paleolítico Médio ou Altoparanaense - corresponde aos antepassados mais antigos do grande grupo lingüístico Jê; 2) Neolítico Antigo - corresponde aos Jê mais recentes e caracteriza-se pela presença de artefatos líticos polidos ou semi-polidos e por vestígios cerâmicos; 3) Neolítico recente - tipicamente Guarani, com vestígios completamente diferentes daqueles pertencentes às duas fases anteriores. Apesar da terminologia, e de suas implicações teóricas, Menghin distingue claramente ocupações Proto-Jê e Proto-Guarani, sublinhando as continuidades histórico-culturais dos dois processos.

Enfatizando sua posição sobre a etnia que deveria ter habitado os sítios arqueológicos de Barracão e Dionísio Cerqueira, Blasi (op. cit.,pág. 1) assim se refere ao material cerâmico neles presente: 
"The pottery is not similar to the Guarani one, but possibly it is of Caigang tradition, indians that already lived in that area in the XVI century"46

$\mathrm{O}$ fato verdadeiramente surpreendente da pesquisa de Blasi, esquecido e não explorado, é a presença, no Barracão e em Dionísio Cerqueira, dentre o material lítico, de artefatos de "cristal de rocha, cujas extremidades rômbicas, formadas naturalmente, foram usadas como gravadores" (Blasi, 1965:10). O autor coletou 47 "pequeno grupo" destes instrumentos "usados ao natural", que ele denomina de "gravadores de cristal de rocha" (op. cit., pág. 7).

As evidências de uso na ponta destes "gravadores" devem ter sido muito intensas para serem observadas e registradas pelo pesquisador. Ademais, a natureza da rocha - cristal - indica um uso intenso e continuado sobre material também de dureza semelhante para formar a evidência de utilização. Em outras palavras, penso precisamente no emprego destes "gravadores" em suportes de rocha para a confecção de grafismos rupestres gravados. Tal achado de Blasi coloca as populações Proto-Jê meridionais na posição de possíveis autoras de painéis rupestres gravados, já que dispunham de instrumentos para tal.

Quanto à "Tradição" Itararé, no Alto Rio Paranapanema e Rio Itararé, nos municípios paranaenses de Ribeirão Claro e Cambará, e no Município de Itararé, em São Paulo, localizam-se os sítios da “Fase” Itararé. Prous (1979) localizou, no lado paulista do Itararé, quatro sítios com casas subterrâneas, que apresentavam cerâmica lisa, cujas formas básicas eram uma aberta (tigela) e outra fechada (pote/panela). Schmitz (1988:96) classifica estes sítios como de "Fase" Itararé.

O material cerâmico da "Fase" é predominantemente liso, com aproximadamente 8\% dos fragmentos com engobo vermelho (Schmitz, 1988:96).

Não existem datas radiocarbônicas. Entretanto, há cerâmica intrusiva Itararé na "Fase" Cambará, de "Tradição" Tupiguarani, esta última datada entre 820 e 1190 d.C. (SI - 422 e 140), conforme op. cit., pág. 96.

Localizados por Chmyz (Coord., 1981) na margem direita do Rio Iguaçu (municípios paranaenses de Laranjeiras do Sul e Guarapuava), cinco sítioshabitação e acampamento fazem parte da "Fase" Xagu, da "Tradição" Itararé. Predomina a cerâmica lisa. No entanto, diferindo das características das demais

\footnotetext{
${ }^{46} \mathrm{Na}$ verdade, Ambrosetti (1894) nos fala dos Ingain de Misiones, AR, Kaingang que ainda lá habitavam no final do século XIX.

${ }^{47}$ Blasi (1965:25) encontrou associados estratigraficamente a cerâmica e o material lítico.
} 
"fases" da "Tradição" Itararé, 35,61\% dela apresenta técnicas decorativas: "incisos abundantes, ponteados, carimbados e engobados de vermelho". As formas são em meia calota, meia esfera, esférica, ovóide e cônica. O material lítico é constituído por facas, raspadores, talhadores, percutores, bigorna, mãode-pilão, triturador, lâmina de machado lascado (Schmitz, 1988:101; 102).

Não há datação radiocarbônica para esta pesquisa de Chmyz.

Os Campos de Guarapuava, nos finais do século XVIII, eram habitados por grupos Kaingang, cujas aldeias e roças foram descritas por Souza (1956 [1768 a 1774]) na "Notícia da conquista e descobrimento dos sertões do Tibagi", nos Campos de Guarapuava, atual Estado do Paraná. Apesar de este registro não trazer dados sobre os grafismos Kaingang, as informações sobre a cultura material destas populações são ricas e permitem traçar correspondências entre estes materiais ali descritos com os materiais arqueológicos de "fases" das "tradições" Itararé e Casa de Pedra, o que permitiria comprovar o caráter ProtoJê meridional das mesmas ${ }^{48}$. Além disso, indiretamente, pude comparar os grafismos constantes de um tecido Kaingang do Paraná, do final do século XIX, felizmente preservado no MAE/USP ${ }^{49}$, com os grafismos pertencentes ao sistema de representações visuais Jê meridional, e, através da analogia gráfica, com os grafismos Proto-Jê da cerâmica e da arte rupestre ${ }^{50}$.

A "Fase" Pacitá, da "Tradição" Itararé, estudada por Chmyz (Coord., 1977), está localizada na margem esquerda do Rio Paraná, no Município do planalto paranaense de Guaíra, com apenas quatro sítios. Na cerâmica, predomina o liso, com pequena quantidade de "engobado de vermelho, três variedades de carimbado e um escovado característico, executado provavelmente com o mesmo instrumento do carimbado", conforme Schmitz (1998:103).

Não há datação absoluta para a "Fase", mas em dois sítios ela está localizada em nível estratigráfico inferior ao da "Fase" Ibirajé (Tupiguarani), esta datada entre 1.000 e 1.700 d.C.

\footnotetext{
${ }^{48}$ A "Notícia..." descreve estes "alojamentos" com menção à cultura material lá encontrada: porongos, panelas e tigelas de barro, mão-de-pilão, machados, facas de lascas, armas, cestos, cochos. Igualmente, faz registros sobre o abastecimento, principalmente o proveniente da horticultura: plantações de milho, moranga..., bolo de milho, carnes cozendo nas nga ta kukrü (panelas de barro), etc.

${ }^{49}$ Veja detalhes no subitem 5.1.1.

${ }^{50}$ Confira as discussões sobre estes temas no item 5.3.
} 
A "Fase" Ibirama, da "Tradição" Itararé, composta por apenas dois sítios, identificada por Piazza e Eble (1968) no Vale do Rio Itajaí - SC, também ocorre nos Campos de Lages (Piazza, 1969 b), e é considerada pelo autor principal muito semelhante à "Fase" Xaxim:

"A posição ambiental desta fase é em tudo semelhante à fase Xaxim: sítios em encostas de montanhas, próximas a pequenos cursos de água. (...) As fases Xaxim e Ibirama apresentam contemporaneidade ou contexto cultural, a nosso ver, porquanto, há intrusão dos tipos cerâmicos Ibirama Simples e Ibirama Ungulado em um sítio da fase Xaxim" (Piazza, 1969b: 66-7).

Segundo Schmitz (1988:88) apenas um fragmento dos 241 da "Fase" possui técnica de decoração (ungulada). Como "as bordas lembram muito fortemente a cerâmica da Tapera e da Praia das Laranjeiras, da Tradição Itararé" - SC - o mesmo autor tende a inclui-la na "Tradição" citada.

É importante frisar que em 1914 o funcionário do SPI Eduardo Lima e Silva Hoerhan fez contato nesta região (mais precisamente nas margens do córrego Plate, afluente da margem esquerda do Rio Hercílio) com cerca de 400 Xokleng do "bando" Rakranò ${ }^{51}$. Ali foi fundado o Posto Indígena Duque de Caxias, mais tarde denominado P.I. Ibirama (Demarquet, 1983:12).

\section{“TRADIÇÃO” ITARARÉ}

\begin{tabular}{|c|c|c|c|c|c|}
\hline "FASE" & AUTOR(ES) & LOCAL & DATAS & CERÂMICA & $\overline{\text { OBS. }}$ \\
\hline Itararé & $\begin{array}{c}\text { Chmyz, 1967 a; } \\
\text { 1968c; 1976; } \\
\text { 1977; Chmyz et } \\
\text { alii, 1968; Prous, } \\
1979\end{array}$ & $\begin{array}{c}\text { Alto } \\
\text { Paranapanema e } \\
\text { Itararé } \\
\text { PR e SP }\end{array}$ & $\begin{array}{l}\text { 820 e } 1190 \text { d.C. } \\
\text { (SI-422 e 140) p/ } \\
\text { a "Fase" Cambará, } \\
\text { onde há cerâmica } \\
\text { Itararé intrusiva }\end{array}$ & $\begin{array}{c}\text { Lisa; } 8 \% \text { com } \\
\text { engobo vermelho }\end{array}$ & $\begin{array}{c}\text { Há cerâmica } \\
\text { Itararé na "Fase" } \\
\text { Cambará de } \\
\text { "Trad." } \\
\text { Tupiguarani ( } 820 \\
\text { e } 1190 \text { d.C.), } \\
\text { sugerindo contato } \\
\text { interétnico. }\end{array}$ \\
\hline
\end{tabular}

\footnotetext{
${ }^{51}$ Segundo Urban (1978:45), na época da "pacificação", havia em Santa Catarina 3 "bandos” Xokleng: Rakranò, no Vale do Rio Itajaí do Norte e Rio Hercílio; Ngrokòthi-tõ-prey, aldeados em São João dos Pobres; e Angydn, desaparecidos por volta de 1940.
} 


\begin{tabular}{|c|c|c|c|c|c|}
\hline Xagu & $\begin{array}{c}\text { Chmyz (Coord.), } \\
1981\end{array}$ & $\begin{array}{c}\text { Planalto } \\
\text { paranaense } \\
\text { (margem dir. do } \\
\text { Iguaçu), } \\
\text { municípios de } \\
\text { Laranjeiras do Sul } \\
\text { e Guarapuava }\end{array}$ & Não há & $\begin{array}{c}35,61 \% \text { c/técs. } \\
\text { decorativas: } \\
\text { incisa, ponteada, } \\
\text { carimbada e } \\
\text { engobada de } \\
\text { vermelho }\end{array}$ & $\begin{array}{c}\text { No final do séc. } \\
\text { XVIII, os Campos } \\
\text { de Guarapuava } \\
\text { estavam } \\
\text { habitados por } \\
\text { grupos Kaingang } \\
\text { (Souza, 1956 } \\
\text { [1768 a 1774]) }\end{array}$ \\
\hline Pacitá & $\begin{array}{c}\text { Chmyz (Coord.), } \\
1977\end{array}$ & $\begin{array}{c}\text { Margem esq. do } \\
\text { Paraná - Planalto } \\
\text { paranaense }\end{array}$ & $\begin{array}{c}\text { Estimativa: } \\
\text { Menos de } 1.000 \\
\text { d.C e menos de } \\
1.700 \text { d.C. }\end{array}$ & $\begin{array}{l}\text { Lisa, c/peq. } \\
\text { quantidade de } \\
\text { engobado, } \\
\text { carimbado e } \\
\text { escovado }\end{array}$ & \\
\hline $\begin{array}{c}\text { Ibirama } \\
\text { (considerada } \\
\text { muito semelhante } \\
\text { à "Fase" Xaxim } \\
\text { por Piazza) }\end{array}$ & $\begin{array}{c}\text { Piazza \& Eble, } \\
\text { 1968; Piazza, } \\
\text { 1969b }\end{array}$ & $\begin{array}{l}\text { Vale do Itajaí - } \\
\text { SC Campos de } \\
\text { Lages - SC }\end{array}$ & $\begin{array}{c}\text { Não há } \\
\text { Contemporânea à } \\
\text { "Fase" Xaxim, cf. } \\
\text { Piazza }\end{array}$ & $\begin{array}{l}\text { Dos } 241 \text { frags., } \\
\text { apenas um é } \\
\text { ungulado }\end{array}$ & $\begin{array}{c}\text { 1914, no Rio Plate, } 1^{\circ} \\
\text { contato c/grupo } \\
\text { Rakranò, Xokleng. } \\
\text { Schmitz inclui esta } \\
\text { "Fase" na "Trad." } \\
\text { Itararé pela } \\
\text { semelhança das } \\
\text { bordas cerâmicas } \\
\text { com as da Tapera e } \\
\text { Laranjeiras - SC }\end{array}$ \\
\hline Cotia & Piazza, 1969b & $\begin{array}{c}\text { Campos de Lages } \\
\text {-SC }\end{array}$ & Não há & $\begin{array}{c}\text { Pré-cerâmica, cf. o } \\
\text { autor }\end{array}$ & $\begin{array}{l}5 \text { sítios formados } \\
\text { por conjuntos de } \\
\text { casas subterrâneas }\end{array}$ \\
\hline Urubici & Piazza, 1969b & $\begin{array}{c}\text { Campos de Lages } \\
- \text { SC }\end{array}$ & $\begin{array}{l}\text { A.D. } 1.040 \pm 200 \\
\text { (SI-227) }\end{array}$ & $\begin{array}{l}\text { Pré-cerâmica, cf. o } \\
\text { autor }\end{array}$ & $\begin{array}{l}\text { Ocupação de } \\
\text { grutas e abrigos } \\
\text { sob-rocha; } \\
\text { associada a } \\
\text { grafismos } \\
\text { rupestres. O lítico } \\
\text { inclui mãos-de- } \\
\text { pilão polidas. }\end{array}$ \\
\hline Catanduva & $\begin{array}{c}\text { Chmyz, 1968b, } \\
1969 \mathrm{a}\end{array}$ & $\begin{array}{c}\text { Rio Iguaçu ( a } \\
\text { oeste de União da } \\
\text { Vitória - PR) }\end{array}$ & $\begin{array}{l}\text { A.D. } 1.345 \pm 120 \\
\text { (SI-691) A.D. } \\
\begin{array}{c}1.695 \pm 100 \\
692)\end{array}\end{array}$ & $\begin{array}{c}\text { Apenas } 5 \text { frags.: } 4 \\
\text { lisos e } 1 \mathrm{c} / \text { téc. } \\
\text { Decorativa } \\
\text { digitada }\end{array}$ & $\begin{array}{c}\text { Apenas nos } \\
\text { "montículos" } \\
\text { funerários } \\
\text { associados às } \\
\text { casas subterrâneas } \\
\text { havia cerâmica }\end{array}$ \\
\hline $\begin{array}{l}\text { Sítios de } \\
\text { Urussanga }\end{array}$ & Rohr, 1979-1982 & Urussanga - SC & Não há & $\begin{array}{l}\text { "De coloração } \\
\text { escura, muitas } \\
\text { vezes até negra, e } \\
\text { algumas vezes } \\
\text { decorada com } \\
\text { linhas incisas ou } \\
\text { pontilhada" } \\
\text { (op.cit.) }\end{array}$ & $\begin{array}{l}\text { Em 1878, data de } \\
\text { fundação da } \\
\text { cidade, botocudos } \\
\text { habitavam a área } \\
\text { (op.cit., pág. 51). }\end{array}$ \\
\hline Abrigo Wôbeto & Andreatta, 1968 & $\begin{array}{l}\text { Margem esq. do } \\
\text { Ivaí - Planalto } \\
\text { paranaense }\end{array}$ & Não há & $\begin{array}{l}\text { Cf. a autora, há } \\
\text { também cerâmica } \\
\text { Casa de Pedra. }\end{array}$ & \\
\hline $\begin{array}{c}\text { Sambaqui da Ilha } \\
\text { das Cobras }\end{array}$ & $\begin{array}{l}\text { Rauth, 1963; } \\
\text { Chmyz, } 1976\end{array}$ & $\begin{array}{c}\text { Baía de Paranaguá } \\
\text { - lit. paranaense }\end{array}$ & - & Cerâmica lisa & \\
\hline $\begin{array}{c}\text { Sambaqui da Ilha } \\
\text { das Pedras }\end{array}$ & Chmyz, 1967 a & $\begin{array}{c}\text { Baía de Antonina } \\
\text { - lit. paranaense }\end{array}$ & - & Cerâmica lisa & \\
\hline
\end{tabular}




\begin{tabular}{|c|c|c|c|c|c|}
\hline $\begin{array}{c}\text { Sambaquis da } \\
\text { Baía de Guaratuba }\end{array}$ & Chmyz, 1977 & $\begin{array}{c}\text { Baía de Guaratuba } \\
\text { - lit. paranaense }\end{array}$ & - & Cerâmica lisa & \\
\hline $\begin{array}{l}\text { Sambaqui do Rio } \\
\text { Pinheiros no. } 8\end{array}$ & $\begin{array}{c}\text { Tiburtius et alii, } \\
\text { 1954; Chmyz, } \\
\text { 1976, 1977; } \\
\text { Neves, } 1984\end{array}$ & Lit. Catarinense & - & $\begin{array}{c}\text { Cerâmica } \\
\text { associada a } \\
\text { enterramentos } \\
\text { fletidos }\end{array}$ & \\
\hline $\begin{array}{c}\text { Sambaqui do } \\
\text { Forte Marechal } \\
\text { Luz }\end{array}$ & $\begin{array}{c}\text { Bryan, 1961, } \\
\text { 1977; Chmyz, } \\
\text { 1976, 1977; } \\
\text { Neves, } 1984\end{array}$ & $\begin{array}{c}\text { Ilha de São } \\
\text { Francisco - SC }\end{array}$ & $\begin{array}{c}\text { 1.070 } \pm 100 \text { d.C. } \\
\text { (University of } \\
\text { Michigan, 1202) }\end{array}$ & $\begin{array}{l}\text { Algumas vezes, a } \\
\text { cerâmica está } \\
\text { associada a } \\
\text { sepultamentos }\end{array}$ & \\
\hline $\begin{array}{l}\text { Sambaqui da } \\
\text { Enseada I }\end{array}$ & $\begin{array}{c}\text { Beck, 1968, 1971, } \\
\text { 1973, 1974; Beck } \\
\text { et alii, 1970 a, } \\
\text { 1970; Neves, } \\
\text { 1984; Neves et } \\
\text { alii, } 1984\end{array}$ & $\begin{array}{c}\text { São Francisco - } \\
\text { SC }\end{array}$ & - & Cerâmica lisa & \\
\hline $\begin{array}{c}\text { Sítio da Praia das } \\
\text { Laranjeiras }\end{array}$ & $\begin{array}{c}\text { Rohr, 1977, 1978, } \\
\text { 1984: Neves, } \\
1984\end{array}$ & Camboriú, SC & - & $\begin{array}{l}\text { Cerâmica lisa } \\
\text { (brunido, banho } \\
\text { vermelho) }\end{array}$ & \\
\hline Sítio do Rio Lessa & $\begin{array}{c}\text { Beck, 1970, 1971, } \\
\text { 1973; Beck et } \\
\text { alii, } 1969\end{array}$ & Florianópolis, SC & - & $\begin{array}{l}\text { Cerâmica lisa (um } \\
\text { frag. entalhado) }\end{array}$ & \\
\hline $\begin{array}{c}\text { Sítio da Base } \\
\text { Aérea }\end{array}$ & $\begin{array}{c}\text { Rohr, } \\
\text { 1959; Schmitz, } \\
\text { 1959; Neves, } \\
1984\end{array}$ & Florianópolis, SC & $\begin{array}{c}1.150 \pm 70 \text { d.C. (SI- } \\
243)\end{array}$ & $\begin{array}{c}\text { Cerâmica lisa } \\
\text { (brunida, um frag. } \\
\text { carimbado) }\end{array}$ & \\
\hline $\begin{array}{c}\text { Sítio da Praia da } \\
\text { Tapera }\end{array}$ & $\begin{array}{c}\text { Rohr, 1966, } \\
\text { 1967/68; Neves, } \\
\text { 1984; Pereira et } \\
\text { alii, 1984; Silva, } \\
1989\end{array}$ & Florianópolis, SC & $\begin{array}{c}810 \pm 180 \text { d.C. (SI- } \\
245) \text { e } 920 \pm 180 \\
\text { d.C. }(\text { SI- } 246)\end{array}$ & $\begin{array}{l}\text { Cerâmica lisa } \\
\text { (brunida; poucos } \\
\text { fragmentos } \\
\text { pinçados e } \\
\text { ponteados }\end{array}$ & \\
\hline $\begin{array}{c}\text { Sítios do Ribeira } \\
\text { de Iguape }\end{array}$ & $\begin{array}{c}\text { Robrahn- } \\
\text { Gonzáles \& De } \\
\text { Blasis, 1998 }\end{array}$ & $\begin{array}{c}\text { Baixo Vale do Rio } \\
\text { Ribeira de Iguape } \\
\text { - SP }\end{array}$ & $\begin{array}{l}1030 \text { d.C.; } 1335 \\
\text { d.C. e } 1680 \text { d.C. }\end{array}$ & $\begin{array}{c}\text { Engobo } \\
\text { vermelho; } \\
\text { ungulada; incisa } \\
\text { paralela, } \\
\text { alternada, circular } \\
\text { e paralela em } \\
\text { direções } \\
\text { alternadas; e } \\
\text { mamilonar }\end{array}$ & \\
\hline Açungui & $\begin{array}{c}\text { Chmyz, } 1968 \text { a, b; } \\
1969 \text { a, 1976, } \\
\text { 1977; Chmyz } \\
\text { (Coord.), } 1981\end{array}$ & $\begin{array}{l}\text { Alto e Médio Rio } \\
\text { Iguaçu - PR }\end{array}$ & $\begin{array}{c}\text { Sem data C14; } \\
\text { estimativa do } \\
\text { autor: sécs. XVI e } \\
\text { XVII }\end{array}$ & $\begin{array}{l}\text { Lisa em banho } \\
\text { vermelho; apenas } \\
\text { um frag. com } \\
\text { ungulações }\end{array}$ & $\begin{array}{l}\text { Cerâmica } \\
\text { intrusiva Açungui } \\
\text { em sítio } \\
\text { Tupiguarani } \\
\text { sugere contato } \\
\text { intenso entre } \\
\text { pops. Guarani e Jê } \\
\text { meridionais. }\end{array}$ \\
\hline
\end{tabular}




\begin{tabular}{|c|c|c|c|c|c|}
\hline Candoi & $\begin{array}{c}\text { Chmyz, } 1969 \text { a, } \\
1971 \text { a, 1977; } \\
\text { Chmyz (Coord.), } \\
\text { 1977, } 1981\end{array}$ & $\begin{array}{c}\text { Médio Rio Iguaçu } \\
\text { - PR }\end{array}$ & $\begin{array}{c}\text { 475 } \pm 65 \text { d.C. } \\
\text { (SI-2197) }\end{array}$ & $\begin{array}{l}\text { Polido estriado, } \\
\text { pinçado, cestaria } \\
\text { impressa, malha } \\
\text { impressa, } \\
\text { ponteado, } \\
\text { escovado e } \\
\text { ungulado }\end{array}$ & $\begin{array}{c}\text { Abrigo Bruacas } \\
\text { com grafismos } \\
\text { rupestres; os } \\
\text { grafismos da } \\
\text { cerâmica são } \\
\text { muito } \\
\text { semelhantes aos } \\
\text { da "Trad." } \\
\text { Taquara }\end{array}$ \\
\hline Cantu & $\begin{array}{c}\text { Chmyz \& Sauner, } \\
\text { 1971; Chmyz, } \\
\text { 1976, 1977; } \\
\text { Chmyz (Coord.), } \\
\text { 1976, 1977, 1978, } \\
1979,1980\end{array}$ & $\begin{array}{c}\text { Vale do Baixo } \\
\text { Piquiri e margem } \\
\text { esq. do Rio Paraná } \\
\text { PR }\end{array}$ & $\begin{array}{c}1.105 \pm 100 \text { (SI- } \\
2193) \\
1.215 \pm 95 \text { (SI- } \\
2194) \\
1.480 \pm 95 \text { (SI- } \\
2192)\end{array}$ & $\begin{array}{l}\text { Lisa; } 5 \% \text { c/técs. } \\
\text { decorativas: } \\
\text { carimbado, } \\
\text { marcado c/ corda, } \\
\text { ponteado. Banho } \\
\text { vermelho }\end{array}$ & $\begin{array}{l}\text { Contato } \\
\text { interétnico entre } \\
\text { Guarani e Jê do } \\
\text { Sul; os grafismos } \\
\text { da cerâmica são } \\
\text { muito } \\
\text { semelhantes aos } \\
\text { da "Trad." } \\
\text { Taquara. }\end{array}$ \\
\hline
\end{tabular}




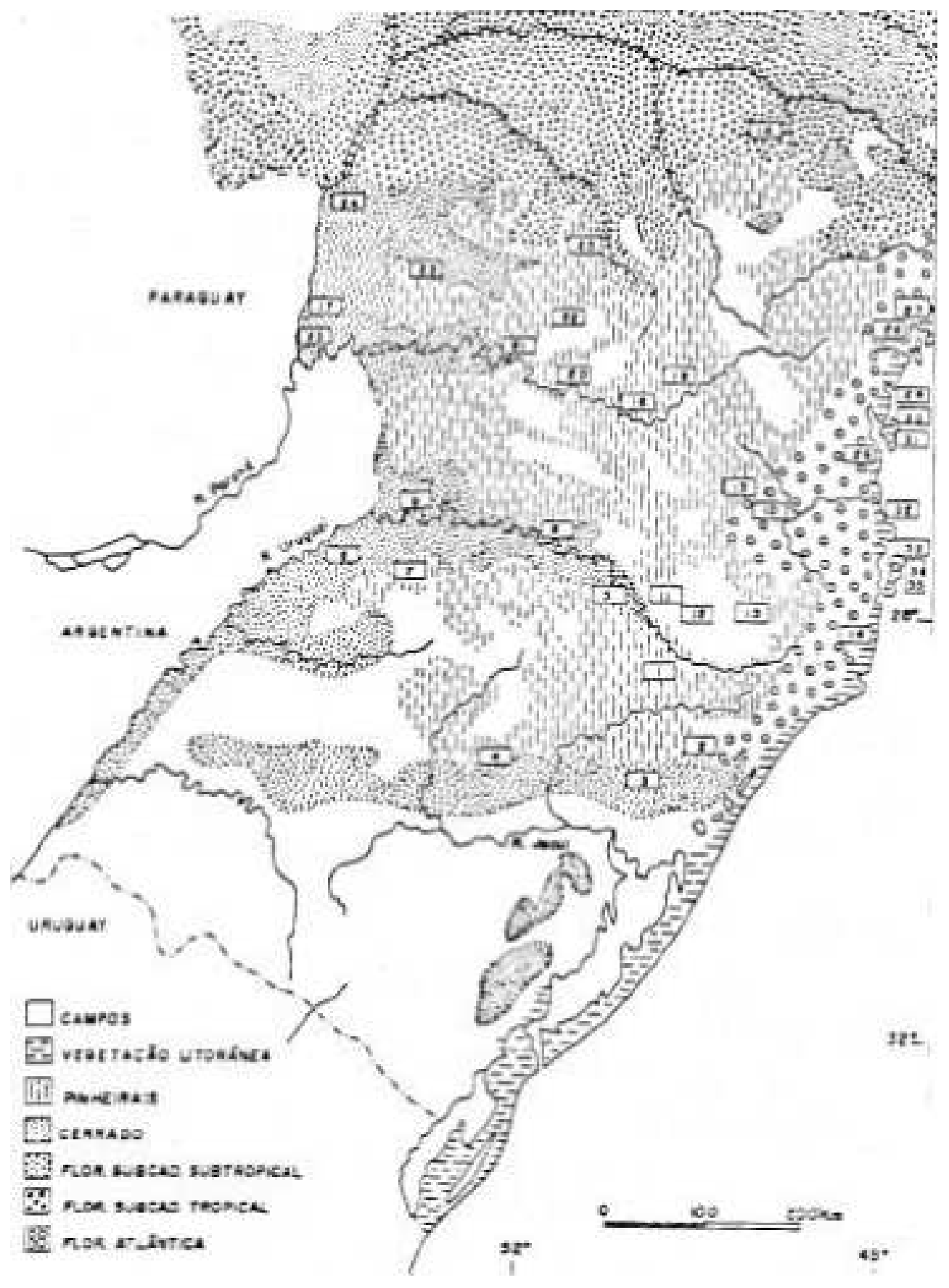

Mapa reproduzido de Schmitz, 1988:78: "Localização aproximada das fases, sítios ou locais pesquisados, tendo como fundo um mapa da vegetação".

A identificação dos números apresentados no mapa é a seguinte (op. cit., p.79): 1. Fase Guatambu; 2. Fase Taquara; 3. Fase Caí; 4. Fase Erveiras; 5. Fase Guabiju; 6. Fase Taquaruçu; 7. Fase Giruá; 8. Fase Xaxim; 9. Fase Itapiranga; 10. Fase Ibirama; 11. Casas subterrâneas Reis; 12. Fase Cotia;; 13. Casas subterrâneas Eble; 14. Casas subterrâneas Jaguaruna; 15. Casas subterrâneas Urubici; 16. Fase Casa de Pedra; 17. Sítio PR FI 145; 18. Fase Itararé; 19. Fase Açungui; 20. Fase 
Catanduva; 21. Fase Candoi; 22. Fase Xagu; 23. Fase Cantu; 24. Fase Pacitá; 25. Abrigo Wôbeto; 26. Sambaqui da Ilha das Cobras; 27. Sambaqui da Ilha das Pedras; 28. Sambaquis da Baía de Guaratuba; 29. Sambaqui do Rio Pinheiros; 30. Sambaqui do Forte Marechal Luz; 31. Sambaqui da Enseada I; 32. Sítio da Praia das Laranjeiras; 33. Sítio do Rio Lessa; 34. Sítio da Base Aérea; 35. Sítio da Praia da Tapera.

Neste mesmo contexto geográfico (Campos de Lages - SC), Piazza (1969b) reconheceu, além das "fases" cerâmicas Xaxim e Ibirama, duas outras "fases" pré-cerâmicas: Cotia e Urubici. A primeira diz respeito a cinco sítios formados por conjuntos de, cada um, 5 a 10 casas subterrâneas, habitação característica dos Proto-Jê meridionais. Já a "Fase" Urubici "liga-se à ocupação das grutas e abrigos sob-rocha e, pelo seu relacionamento, aos petróglifos que lhe são associados, totalizando cinco sítios: quatro grutas ou abrigos-sob-rocha e um petroglifo. De uma das grutas temos uma datação de C-14 de A. D. $1.040 \pm 200$ (SI-227)". Os artefatos líticos são "raspador, batedores e mão-de-pilão em basalto e diabásio - polidos e alguns com retoque" (Piazza, 1969 b).

Estas ditas "fases" pré-cerâmicas merecem um comentário. A divisão estanque e mecanicista entre períodos pré-cerâmico e cerâmico deve ser revista pela arqueologia brasileira, principalmente com relação aos Proto-Jê meridionais. Provável ausência de cerâmica não significa incluir, automaticamente, um sítio numa "fase" pré-cerâmica.

Um dos sítios da "Fase" Ibirama (Piazza, 1969b:66), por exemplo, que ocupava uma área de $1.500 \mathrm{~m} 2$, nele tendo sido recolhidos apenas 26 fragmentos cerâmicos, demonstra que, na verdade, muitos sítios Proto-Jê apresentavam pouco material cerâmico associado às habitações. Isto pode estar relacionado ao fato de as vasilhas cerâmicas - como todos os outros objetos de um falecido Proto-Kaingang - serem destruídas e/ou colocadas junto ao enterramento do adulto falecido $^{52}$. Se não houvesse nenhuma quebra acidental de um utensílio de barro em um sítio habitação, antes de seu abandono, não se teria nele nenhum vestígio cerâmico. Este parece ser o caso das duas fases "pré-cerâmicas" dos Campos de Lages - Cotia e Urubici - e, talvez, de inúmeras outras, associadas ou não a casas subterrâneas.

Nas casas subterrâneas comentadas por Chmyz \& Sauner (1971:20), pertencentes à "Fase" Cantu, da "Tradição" Itararé, no Vale do Rio Piquiri,

\footnotetext{
${ }^{52}$ Veja, mais adiante, no item 4.4., descrição dos rituais funerários Kaingang e Xokleng.
} 
discutida mais adiante, a cerâmica Proto-Jê meridional foi encontrada apenas fora das casas, fato que poderia ter levado a enganos quando da criação de inúmeras "fases" consideradas "pré-cerâmicas" para sítios de casas subterrâneas:

"A grande quantidade de cacos de cerâmica encontrada no lado de fora das casas subterrâneas, e, mesmo, mais afastado, parece indicar que a atividade normal dos habitantes daquelas aldeias era na parte externa, ao céu aberto ou protegidos por choças. Isto talvez se justifique pelas condições climáticas existentes na região: frio intenso, acompanhado por ventos fortes, durante o inverno, e calor acentuado nos meses de verão".

Muitas vezes, o pesquisador não teve a sorte de localizar cerâmica junto aos conjuntos de casas subterrâneas, fazendo-o apenas nos aterros funerários a eles associados. Este foi o caso ocorrido na "Fase" Catanduva - Itararé? -, no Rio Iguaçu, a oeste de União da Vitória - PR, (Chmyz, 1969) ${ }^{53}$, onde apenas nos aterros (montículos funerários) foram recolhidos fragmentos cerâmicos. Nas casas havia vestígios de fogões, peças líticas e buracos de estacas. A cerâmica foi encontrada apenas em dezenas de pequenos aterros que ocupavam o topo de pequenas elevações, que distavam cerca de 4 ou 5 quilômetros dos conjuntos de casas subterrâneas.

"Estes aterros medem, em geral, $1.70 \mathrm{~m}$ de comprimento, $0.60 \mathrm{~m}$ de largura e 0.40 $\mathrm{m}$ de altura. Contornando os aterros, há uma vala indicando a retirada de terra para a construção dos mesmos. Até o momento, nenhum resto humano foi encontrado nos aterros; existe apenas uma camada escura e rica em matéria orgânica, em mistura com peças arqueológicas, na base das elevações. No sítio PR UV 11, havia um muro retangular, um pouco mais alto que os aterros, limitando a ocorrência dos mesmos" (Chmyz, 1969:109-110).

Chmyz (1971) correlaciona o Sítio PR UV 19, na margem direita do Rio Iguaçu, nas proximidades do Rio de Areia, a aproximadamente $50 \mathrm{Km}$ a oeste de União da Vitória, à "Fase" Catanduva. Trata-se de sítio formado por casas subterrâneas, cuja disposição espacial no terreno é instigante, levando a pensar na típica espacialidade das aldeias Jê Central e Setentrional: a casa subterrânea maior - 10m de diâmetro por $3 \mathrm{~m}$ de profundidade - é contornada por cinco outras menores. No local foi recolhido apenas material lítico.

A cerâmica da "Fase" Catanduva (apenas 5 fragmentos) apresenta-se com superfície lisa em 4 deles e em um há técnica decorativa digitada.

${ }^{53}$ O autor não diz a que "tradição" atribui a "fase". 
Há duas datações C-14 para a "Fase" Catanduva: $1.345 \pm 120$ (SI-691) e $1695 \pm 100$ d.C. (SI-692), conforme Schmitz (1988:99).

Rohr (1979-1982) localizou vários sítios em Urussanga - SC, $128 \mathrm{~km}$ ao sul de Florianópolis, a $50 \mathrm{~m}$ acima do nível do mar. Tendo sido fundada em 1878 , os primeiros imigrantes italianos chegados no local estabeleceram-se em terras tradicionalmente habitadas pelos "botocudos", que "ocupavam as extensas matas, que se estendiam até as encostas da Serra de Araranguá" (op. cit., pág. 51).

O autor refere que no início da colonização eram encontrados cacos de cerâmica e alguma vasilha inteira. Entretanto, nas suas pesquisas em Urussanga, nenhum sítio apresentou cerâmica (Rohr, 1979-82:53), pois o solo encontrava-se intensamente trabalhado por 100 anos de agricultura.

De qualquer forma, a presença dos Jê meridionais ficou atestada pela informação da presença de cerâmica escura e, muitas vezes, negra; algumas vezes com linhas incisas ou ponteado ${ }^{54}$, dos balaios "calafetados por dentro com cera de abelhas silvestres" $" 55$ e por dois conjuntos de montículos funerários (um com três, o outro com dois montículos), que se encontravam ao lado dos sítios Urussanga 2 e Urussanga 4.

Além disso, o Sítio Urussanga 7 é um "pequeno abrigo sob-rocha de $40 \mathrm{~m}$ de comprimento, $2 \mathrm{~m}$ de altura máxima e $3 \mathrm{~m}$ de fundo, localizado atrás de uma queda de água de $14 \mathrm{~m}$ de altura" (op. cit., pág. 55). Trata-se, conforme o autor, de sítio de sepultamento, de onde, no passado, curiosos retiraram "ossadas humanas":

"Sítios, em tudo semelhantes, foram registrados no planalto catarinense, nos municípios de Bom Retiro, Urubici, Bom Jardim, Petrolândia, Imbúia, Agrolândia e Rio do Sul. No planalto estes sítios acham-se associados a casas subterrâneas e galerias subterrâneas. Em Jaguaruna, próximo à desembocadura do Rio Urussanga, os sítios de casas subterrâneas fazem contato com o litoral. No litoral de Jaguaruna foram registrados, também, dois pequenos sambaquis com cerâmica e cultura lítica análoga à encontrada nos sítios do planalto, que confirmam a hipótese de que as populações planaltinas, ocasionalmente, acorressem ao litoral para mariscar" (Rohr, 1979-1982:54).

Estas informações sobre sítios de sepultamentos (em abrigos sob-rocha e em montículos funerários) colocam um problema adicional à compreensão dos Proto-Jê no sul do Brasil: ocorrem dois padrões de sepultamento, comprovadamente Proto-Jê meridionais, um ligado aos Proto-Kaingang e o

\footnotetext{
${ }^{54}$ Cf. Rohr, 1979-82.

${ }^{55}$ Rohr, 1979-82:57.
} 
outro, aos Proto-Xokleng, na mesma área geográfica (planalto e litoral de Santa Catarina), que à época dos primeiros contatos está ocupada apenas pelos Xokleng ou Botocudos. Tem-se, ainda, um complicador, quando se pensa num terceiro padrão de sepultamento, que a literatura arqueológica costuma associar aos Xokleng: a cremação, mais difícil de ser reconhecida no registro arqueológico, e que não foi observada por Rohr nos sítios de Urussanga ${ }^{56}$.

Em onze sítios, ainda, aparece cerâmica da "Tradição" Itararé. São eles: 1) Abrigo Wôbeto, no terceiro planalto paranaense, na margem esquerda do Rio Ivaí, que segundo Andreatta (1968) também apresenta cerâmica Casa de Pedra; 2) Sambaqui da Ilha das Cobras, na Baía de Paranaguá; nos níveis superficiais ocorre cerâmica; 3) Sambaqui da Ilha das Pedras, na Baía de Antonina; cerâmica simples na camada superficial; 4) Sambaquis da Baía de Guaratuba, na Baía de mesmo nome; ocorre cerâmica na camada superficial de alguns sambaquis; 5) Sambaqui do Rio Pinheiros no. 8, no litoral catarinense; existência de cerâmica associada a enterramentos fletidos; 6) Sambaqui do Forte Marechal Luz, na Ilha de São Francisco, SC; presença de cerâmica, algumas vezes associada a sepultamentos; as camadas com cerâmica foram datadas de $1.070 \pm 100$ d.C. (University of Michigan, 1202); 7) Sambaqui de Enseada I, na cidade de São Francisco, SC; "a cerâmica é simples, de confecção rudimentar, sem decoração, de uso cotidiano, semelhante à dos outros sítios litorâneos de Santa Catarina" (Schmitz, 1988:107); não há datação; 8) Sítio da Praia das Laranjeiras, em Camboriu, SC; a cerâmica não apresenta técnicas decorativas; a maioria das paredes externas apresenta-se brunida; em raras ocorre banho vermelho; 9) Sítio do Rio Lessa, em Florianópolis, SC; a cerâmica é lisa, apenas um fragmento apresenta-se "entalhado", conforme Schmitz (1988:113); não há datação; 10) Sítio da Base Aérea, em Florianópolis, SC; a cerâmica é lisa, "às vezes preta brunida; só existe um fragmento carimbado" (Schmitz, 1988:115); $1.150 \pm 70$ d.C.; 11) Sítio da Praia da Tapera, em Florianópolis, SC; a cerâmica é quase totalmente simples; poucos fragmentos apresentam pinçados e ponteados; as fases externas costumam apresentar-se brunidas; as datas de $810 \pm 180$ d.C. (SI -245) e $920 \pm 189$ d.C. (SI - 246) correspondem à ocupação ceramista Proto-Jê meridional.

Os dez sítios litorâneos Itararé do Paraná e Santa Catarina, comentados acima, apresentam, no geral, cerâmica predominantemente lisa. Entretanto, em

\footnotetext{
${ }^{56}$ Veja mais detalhes no item 4.4., a seguir.
} 
alguns destes sítios ocorrem técnicas decorativas características das "fases" e sítios do planalto, sugerindo um uso apenas incidental da cerâmica como suporte para os grafismos do sistema de representações visuais Proto-Jê meridional, uma vez que, apesar de sua presença em quantidades muito pequenas, as características destes grafismos são claramente Proto-Jê meridionais.

Os sítios arqueológicos de "Tradição" Itararé do baixo vale do Ribeira de Iguape, SP, situam-se, conforme Robrahn-González \& De Blasis (1998:58), em área periférica, "zona de transição ecológica", que "vem integrar as regiões planálticas à planície litorânea". Especificamente, os 11 sítios do baixo vale localizam-se "sobre terraço junto à barranca" do rio, na sua maioria, ou "no topo de suaves elevações de fundo de vale" (op. cit., p.61).

A cerâmica destes sítios apresenta "uma série de características inéditas para o vale do Ribeira": engobo vermelho, técnicas de decoração (ungulada; incisa paralela; incisa circular; incisa paralela em direções alternadas; mamilonar e incisões alternadas, conforme reproduzido abaixo), antiplástico de caco moído e uma forma com contorno complexo (ombro) - Robrahn-González \& De Blasis, 1998:64.
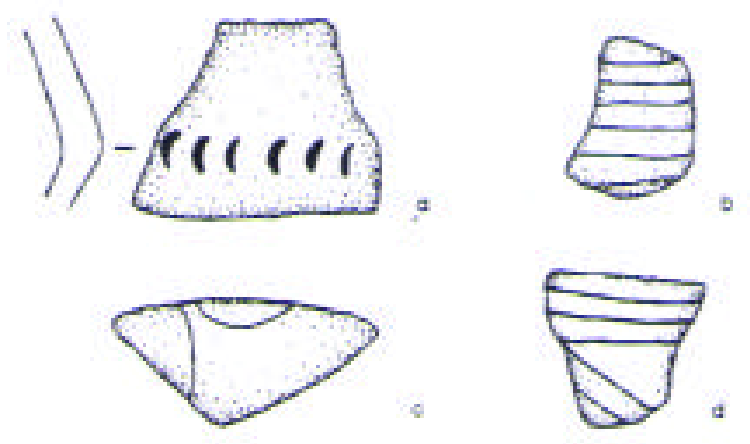

Grafismos na cerâmica do Ribeira do Iguape/SP. Reproduzido de RobranhGonzález \& De Blasis, 1998:fig. 5 (detalhes) e 6, conforme desenhos originais de Denise D.P. de Souza.
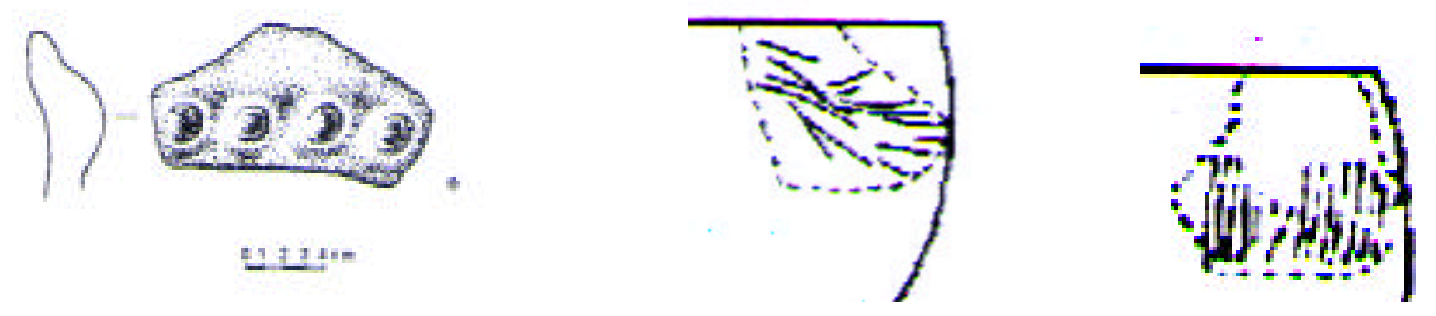

A indústria lítica lascada associada à cerâmica tem quantidades reduzidas, apresentando-se "tecno-tipologicamente bastante simples" (op. cit., p.64).

As datas para os sítios citados são 920, 595 e 270 BP, conforme os autores citados (ou 1030 d.C., 1355 d.C. e 1680 d.C.). 
A "Fase” Açungui, de "Tradição" Itararé (Chmyz, 1969), tem seus sítios dispersos ao longo do Alto e Médio Rio Iguaçu, nas proximidades de pequenos afluentes deste, mas muito afastados dele (até $15 \mathrm{Km}$ ), no flanco de pequenas elevações. Não há datação C14 para a "Fase", mas o autor faz uma estimativa para os séculos XVI e XVII. Há intrusão da cerâmica Açungui nas "fases" de "Tradição" Tupiguarani deste período na região (Imbituva e Guajuvira), indicando contato intenso entre populações Guarani e Jê meridionais, bem como os primeiros contatos com o colonizador, principalmente em relação à "Fase" Guajuvira.

A cerâmica Açungui apresenta-se alisada ou com um banho vermelho; apenas um fragmento registrou ungulações.

O material lítico das "fases" Casa de Pedra e Açungui é descrito por Chmyz (1969:116 e 118) como "não são muito características [as peças]. As que puderam ser classificadas são: raspadores, furadores, batedor e polidores planos", para a primeira, e "não há entre elas [peças] nenhum artefato elaborado. São apenas lascas e núcleos de arenito-fritado, diabásio e sílex. Alguns mostram, em suas arestas, sinais de uso, como facas ou raspadores", para a segunda "fase".

Nota-se, no geral, que os arqueólogos que descreveram o material lítico Proto-Jê meridional tem dificuldades em caracterizá-lo e, por conseqüência, classificá-lo na tipologia tradicional. Aos seus olhos, aparenta ser grosseiro e tosco, sem "formas" reconhecidas como "instrumentos".

Neste sentido, discorrendo sobre a indústria lítica dos sítios cerâmicos de "Tradição" Itararé do baixo vale do Rio Ribeira de Iguape, Robrahn-González \& De Blasis (1998:64) assim a ela se referem:

“... estudos sistemáticos (...) encontraram certa dificuldade em identificar esta indústria, tecno-tipologicamente bastante simples e que, por vezes, se resume a peças brutas sem indícios de lascamento, mas somente com sinais de utilização. (...) As coleções líticas indicam uma indústria rudimentar, de grandes proporções, sem indícios de preocupação em obter suportes específicos para os artefatos, que se resumem a seixos, detritos e fragmentos de bloco com duas ou três retiradas apenas para dar forma ao gume (...). Das 91 peças coletadas no sítio Pinheirinho, somente 5 são artefatos, havendo entretanto várias apenas com sinais de utilização".

Esta indústria lítica tecno-tipologicamente simples, característica de todas as "fases" das "tradições planálticas" e tão enfatizada pelos autores, parece ser um bom indicador da continuidade de uma tradição caçadora-coletora incorporada pelos horticultores/migrantes Proto-Jê meridionais, uma vez que 
muitos autores enfatizam as semelhanças entre o material lítico de grupos préceramistas da região com a indústria lítica das "tradições locais planálticas".

A "Fase" Candói, de "Tradição" Itararé, localiza-se no médio e baixo Rio Iguaçu, no Planalto, região onde predomina a floresta subtropical com araucária. São mais de duas dezenas de sítios.

Em 1971, seu autor descreve três sítios, afastados $10 \mathrm{Km}$ do rio, quase na nascente de pequenos afluentes: um em abrigo-sob-rocha com grafismos rupestres e duas áreas abertas, ocupando elevações pronunciadas (Chmyz, 1971).

Há uma datação radiocarbônica: $475 \pm 65$ d.C. (SI-2197).

As técnicas decorativas empregadas na cerâmica são o polido estriado, pinçado, cestaria impressa, malha impressa, ponteado, escovado e ungulado. Muitas vezes, estas técnicas aparecem somente nas porções superiores das vasilhas; a base, nestes casos, seria apenas alisada (Chmyz, 1971).

$\mathrm{O}$ aspecto e as formas da cerâmica Candói são os mesmos encontrados nas "fases" Itararé e Açungui. A novidade reside no fato de que 10\% dela possui técnicas decorativas muito semelhantes à da "Tradição" Taquara, no RS: "impressão de cestaria, de malha, de rede, ponteado e ungulação" (Chmyz, 1971:100) ${ }^{57}$. Chmyz, que já havia estudado a cerâmica da Praia da Tapera-SC e conhecia aquela proveniente da Base Aérea-SC, correlaciona as formas cerâmicas da "Tradição" Itararé e a técnica decorativa ponteada da "fase" Candói com estes sítios litorâneos catarinenses, o que viria a sugerir uma ligação das populações Proto-Jê meridionais do Médio Vale do Rio Iguaçu, no planalto, com aquelas dos citados sítios arqueológicos do litoral catarinense.

O abrigo com petroglifos, denominado Bruacas, localiza-se na escarpa basáltica que delimita o terceiro planalto paranaense. Dista apenas $12 \mathrm{~km}$ do Abrigo Casa de Pedra (PR UV 1). Nele havia indícios de fogueiras, onde, entre outros materiais, foram recuperados 384 fragmentos cerâmicos, dos quais $10 \%$ apresentavam técnicas decorativas: cestaria impressa, malha impressa, ponteado, escovado e ungulado. Os grafismos presentes nas paredes do Abrigo Bruacas são descritos como "conjuntos de pontos gravados. Estes pontos, com $2 \mathrm{~cm}$ de diâmetro, formam alinhamentos paralelos. Também ocorrem sulcos alongados,

\footnotetext{
${ }^{57}$ Poderiam representar os grupos Proto-Jê meridionais em migração para o sul e que se fixariam, ao final, no sudeste da área de dispersão das "tradições locais planálticas", onde é alta a proporção de cerâmica com técnicas decorativas.
} 
como os causados pelo polimento de artefatos de pedra" (Chmyz, 1971:98). Estes grafismos serão comentados no subitem 5.3.4.

O mesmo autor considera estes grafismos rupestres associados à "Fase" Candói diferentes das pinturas do nordeste paranaense e dos grafismos gravados na rocha da "Fase" Casa de Pedra, já comentados anteriormente. (Chmyz, 1971:101). Esta opinião, certamente deve-se ao fato de as primeiras apresentarem motivos figurativos e à particularidade de os segundos igualmente apresentarem possíveis motivos zoo e antropomorfos. Associados às pinturas e aos gravados há motivos geométricos, o que, no mínimo, sugere uso concomitante de dois estilos: figurativo e geométrico ${ }^{58}$.

A "Fase" Cantu, da "Tradição" Itararé, possui um grande número de sítios na margem esquerda do Rio Paraná (Foz do Iguaçu e Santa Helena) e no baixo Rio Piquiri. Nesta última região, mais alta, alguns sítios eram constituídos por conjuntos de casas subterrâneas e aterros funerários (Schmitz, 1988:102).

No baixo Piquiri, a cerâmica, em grande quantidade, foi encontrada apenas no lado de fora das casas subterrâneas (Chmyz \& Sauner, 1971). No geral, a cerâmica da "fase" apresenta-se alisada. Apenas aproximadamente 5\% dos fragmentos possuem técnicas decorativas: carimbado, marcado com corda, ponteado e banho vermelho. As três primeiras técnicas limitam-se à porção superior ou média das vasilhas (Schmitz, 1988:102).

Chmyz \& Sauner (1971) enfatizam a semelhança entre algumas técnicas de decoração das cerâmicas dos sítios do médio Rio Iguaçu ("Fase" Candói) e do baixo Piquiri ("Fase" Cantu), ambas de "Tradição" Itararé, com aquelas provenientes das casas subterrâneas do nordeste do Rio Grande do Sul.

As datas existentes são: $1.105 \pm 100$ d.C. (SI-2193), $1.215 \pm 95$ d.C. (SI2194) e $1.480 \pm 95$ d.C. (SI-2192). Em alguns sítios, há intrusão de cerâmica Guarani - "Fase" Sarandi; em sítios Guarani da "Fase" Itacorá ocorrem fragmentos cerâmicos da "Fase" Cantu (Schmitz, 1988:103).

No Vale do Rio Piquiri (Chmyz \& Sauner, 1971), aterros e casas subterrâneas constituíam conjuntos. Havia dois tipos de aterros: um alongado (de $120 \mathrm{~cm}$ de comprimento x $70 \mathrm{~cm}$ de largura x $40 \mathrm{~cm}$ de altura a $300 \mathrm{~cm}$ x 120 $\mathrm{cm} \times 50 \mathrm{~cm})$ e outro em forma de cone truncado $(400 \mathrm{~cm}$ de diâmetro x $150 \mathrm{~cm}$ de altura a $1300 \mathrm{~cm}$ x $200 \mathrm{~cm}$ ). Estes aterros eram sempre contornados por uma

${ }^{58}$ Remete-se o leitor à discussão sobre estilos, no Capítulo 5, item 5.3. 
vala medindo aproximadamente $40 \mathrm{~cm}$ de profundidade por $70 \mathrm{~cm}$ de largura. Os alongados eram encontrados, às vezes, às dezenas num mesmo sítio, "desordenadamente", segundo os autores (op. cit., pág. 11). Os em forma de cone truncado existiam apenas um em cada sítio, e, mesmo assim, raramente. As casas subterrâneas vinham agrupadas de duas até doze, alinhando-se em arco ou "sem muita ordem" (op. cit., pág. 12). Os autores citam que uma cova de grande diâmetro, isolada das menores, ocorria em alguns sítios (op. cit., pág. 12). Os aterros alongados apareciam ou entre as casas subterrâneas ou fora de seu agrupamento ou, mesmo, longe de quaisquer vestígios de casas subterrâneas. Já os aterros maiores, em forma de cone truncado, ocorriam no centro do sítio. Tais aldeias de casas subterrâneas localizam-se próximas de pequenos rios (Chmyz \& Sauner, 1971).

Os autores supõem que os aterros grandes tenham sido utilizados para práticas funerárias que envolvessem cremação de corpos (op. cit., p. 22). Com relação aos montículos pequenos, julgam-nos estar relacionados com práticas funerárias (idem, p. 24). Os autores consideram semelhante, externamente, o aterro funerário dos Kaingang paulistas recém-contatados, descrito por Maniser (1930), com o que eles escavaram no baixo Piquiri. No entanto, "a maneira como os corpos eram depositados, antes da construção do aterro, no interior de covas protegidas por troncos de palmeiras, difere completamente do nosso caso" (Chmyz \& Sauner, 1971:24).

Cabe perguntar, então, quais eram os padrões tradicionais de sepultamento para os Jê do sul?

Frente à grande importância que a sociedade Kaingang dá à morte e a todas as situações a ela ligadas, o que será discutido no Capítulo 4, como suas causas, xamanismo, proteção contra o espírito dos mortos, pintura corporal e grafismos utilizados em rituais funerários, formas de enterramento, ritual do Kiki, etc., e diante da decorrente produção de significados culturais, identificada diretamente com ela, tentei responder à pergunta do parágrafo anterior no intuito de perceber diferenças entre um padrão Proto-Kaingang e um padrão Proto-Xokleng e, principalmente, discutir registros arqueológicos díspares, como já ficou evidenciado nas páginas anteriores, para enterramentos Proto-Kaingang. Mas para atingir este objetivo é preciso, antes, apresentar a cosmologia Kaingang. Por esta razão, algumas tentativas para compreender os enterramentos das "tradições locais planálticas" e sua relação com o padrão Jê meridional de sepultamentos serão empreendidas no final do Capítulo 4. 


\section{SOCIEDADE KAINGANG: CONCEPÇÕES COSMOLÓGICAS}

Este capítulo foi escrito com o objetivo de estabelecer uma ligação entre o presente e o passado das sociedades Jê do sul, principalmente em relação aos Kaingang. Desta forma, partindo do estudo das concepções cosmológicas destes últimos - mitologia, dualismo, xamanismo, representações sobre a doença e a morte -, pretendi empreender outros entendimentos sobre os Proto-Jê meridionais, como a compreensão dos sistemas simbólicos relacionados à produção de significados, notadamente os grafismos, a cultura material e as estruturas enterratórias, vistas desde um ponto de vista cognitivo.

Nimuendaju (1993 [1913]), Horta Barbosa (1947), Baldus (1937; 1947), E. Schaden (1953), Métraux (1946), Becker \& Schmitz (1967), Becker (1976), Veiga $(1994,2000)$ e Crépeau $(1994 ; 1995)$ concordam que há um dualismo Kaingang, visível mais concretamente na organização social, que se caracteriza pela existência de duas metades exogâmicas ${ }^{4}$, patrilineares, complementares e assimétricas, designadas como Kamé e Kainru-krés.

No entanto, Nimuendaju (1987 [1914]:122) já afirmava que "não apenas toda a tribo Kaingygn, do Tietê ao Ijuhy, divide-se nestes dois clãs exogâmicos, segundo a sua ascendência paterna, mas toda a natureza" (grifo meu).

Na realidade, as patrimetades Kaingang representam apenas um aspecto o sociológico - de toda uma concepção dual do universo. Todos os seres, objetos e fenômenos naturais são divididos em duas categorias cosmológicas, uma ligada ao gêmeo ancestral Kamé, e a outra vinculada ao gêmeo ancestral Kainru. Principalmente, as metades são percebidas pelos Kaingang como cosmológicas, estando igualmente ligadas aos gêmeos civilizadores, os quais emprestam seus nomes a elas.

Segundo os mitos, os gêmeos ancestrais estão em relação de oposição e complementariedade um ao outro. Kainru "é de caráter fogoso, capaz de decisões rápidas, mas é instável; seu corpo é esbelto e leve". Kamé "é (...)

\footnotetext{
${ }_{5}^{4}$ Segundo Crépeau (1995, p. 20), “cette règle d'exogamie semble de moins en moins respectée aujourd'hui".

${ }^{5}$ Os autores citados registram pequenas variações terminológicas nos nomes das patrimetades. Kré significa descendência.
} 
pesado, de corpo como de espírito, mas é perseverante. A pintura corporal característica de Kañerú são manchas, a de Kamé são listras. (...) O Kaingygn distingue entre objetos delgados e grossos, manchados e listrados, como pertencentes a Kañerú ou a Kamé, feitos por este ou por aquele, e que podem assim ser usados por este ou por aquele no ritual" (Nimuendaju, 1987 [1914]:121-2).

Portanto, a bibliografia consultada e a pesquisa realizada com os Kaingang de Nonoai, Iraí e Porto Alegre, no RS, permitem estabelecer as seguintes oposições binárias que expressam este dualismo:

\begin{tabular}{|c|c|}
\hline Kainru & Kamé \\
\hline $\begin{array}{l}\text { Gêmeo ancestral denominado Kainru; } \\
\text { conforme o mito, saiu primeiro do } \\
\text { chão; lua, um ex-sol; noite; corpo fino, } \\
\text { peludo, pés pequenos; frágil, menos } \\
\text { forte; feminino; ligeiro em } \\
\text { movimentos e resoluções; menos } \\
\text { persistentes; leste }{ }^{6} \text {; baixo (parte de } \\
\text { baixo); pintura corporal redonda, } \\
\text { "fechada"; orvalho, umidade; } \\
\text { mudança; agilidade; lugares altos ; } \\
\text { seres/objetos redondos/fechados; } \\
\text { seres/objetos malhados/manchados, } \\
\text { leves ou delgados; sete sangria } \\
\text { (Simplocus parviflora }{ }^{8} \text { ). }\end{array}$ & $\begin{array}{l}\text { Gêmeo ancestral chamado Kamé; } \\
\text { conforme o mito, saiu depois do chão; } \\
\text { sol, símbolo de força e poder; dia; } \\
\text { corpo grosso, pés grandes; mais forte; } \\
\text { masculino; vagaroso em movimentos e } \\
\text { resoluções, persistentes; temperamento } \\
\text { feroz; oeste ; alto (parte de cima); } \\
\text { pintura corporal em faixas, linhas, } \\
\text { "aberta"; dureza; permanência; lugares } \\
\text { baixos7\% } 7 \text { seres/objetos } \\
\text { compridos/riscados; seres/objetos mais } \\
\text { pesados ou grossos; pinheiro } \\
\left(\text { Araucária angustifolia }{ }^{8}\right) .\end{array}$ \\
\hline
\end{tabular}

Deste modo, manifestados desde uma matriz mitológica Kaingang que cria um campo semântico de oposições a partir da vinculação a um ou outro herói

\footnotetext{
${ }^{6}$ Cf. Veiga, 1994; 2000. Já Crépeaux (1994) e Rosa (1995) remetem os kamé ao leste, e os kainru-kré ao oeste. Segundo estes autores, tais direções, durante o ritual do kiki, são invertidas com o objetivo de "enganar" as almas dos mortos presentes no ritual, já que elas representam perigo para os vivos.

${ }^{7}$ De acordo com os Kaingang de Xapecó e do Rio das Várzea, os Kamé nasceram no baixo (vale ou sopé da montanha), e os Kainru, no alto (cume da montanha); conforme Veiga (2000:79).

${ }^{8}$ Durante o Kiki, estes vegetais são depositados nas sepulturas Kainru ou Kamé, e usados como carvão para desenhar os padrões da pintura corporal.
} 
mítico, pares contrastantes marcam este dualismo, cuja abrangência engloba todo o cosmo, incluindo, entre outros, os elementos classificatórios no âmbito da natureza e de sua exploração, as relações entre os homens, a organização social e ritual do espaço, a cultura material, as representações sobre as características físicas, emocionais e psicológicas, as diferenciações de papéis sociais e os padrões gráficos representados em vários suportes. Estes pares opositores caracterizam-se por uma bipolarização contrastante, opositora e complementar, modo como se apresenta o sistema de representações visuais Kaingang ${ }^{9}$.

O dualismo Kaingang é plenamente observável durante a realização do ritual do Kiki, conhecido na literatura antropológica como "culto aos mortos", o qual

"constitue le lieu privilégié de la mise en scène de la complémentarité et de l'asymétrie présidant aux relations entre les moitiés, chacune étant appelée à traiter avec les esprits des morts de l'autre moitié afin de les libérer et de leur permettre enfin de quitter le cimetière où ils étaient confinés depuis leur décès."(Crépeau, 1994, p. 145-6).

Os Kaingang que habitam fora do Rio Grande do Sul possuem subdivisões binárias de suas patrimetades exogâmicas. Juracilda Veiga (1994:59) considera a existência de duas seções em cada metade: Kainru e Votor, na metade Kainru, e Kamé e Wonhétky, na Kamé, afirmando que a "filiação a uma metade e seção é definida patrilateralmente". Além disso, a autora salienta que:

(...) "os Wonhétky são, para alguns, considerados como o par simétrico dos Votor. Isso aparece nas pinturas e também em alguns depoimentos que consideram que os membros dessas duas seções seriam também parceiros matrimoniais preferenciais entre si”. (Veiga, 1994, p. 72).

Com relação à pintura, além dos grafismos que opõem as duas metades (riscos e marcas redondas), o Boletim do Conselho Indigenista Missionário (CIMI, 1976, p. 5) distingue quatro motivos gráficos de pintura facial dos indivíduos pertencentes a cada um dos sub-grupos mencionados a seguir, ligados, os dois primeiros, à metade Kamé, e, os dois últimos, à metade Kayru: Kamé riscos retos; Wenhniky - risco curvo; Kanhru - pontos; Votor - círculos.

\footnotetext{
${ }^{9}$ Veja no Capítulo 5, a seguir.
} 
Comparando a estrutura de dois grupos Xokleng (Kainlê e Wanyekî), Veiga conclui que os membros da seção Votor da metade Kayru Kaingang "seriam Xokleng agregados por casamento à metade de marca redonda, isto é, aos Kayru" e que os "Wonhétky (seção Kaingang) e os Wanyekí (grupo Xokleng) teriam a mesma procedência, ou seja, viriam de um mesmo povo escravizado tanto por Kaingang como por Xokleng, ou seja, os Kurutu" (Veiga, 1994, p. 69-70), sugerindo conflitos e tensões, que teriam sido resolvidos por aliança ou escravidão e poderiam ser confirmados através de estudos etnoarqueológicos explicitados mais adiante.

Como será visto nos itens seguintes, o discurso nativo, idealmente, costuma enfatizar com freqüência a complementariedade entre as metades, de um lado, e entre sociedade e natureza, de outro, sublinhando as relações aparentemente simétricas entre opostos, no primeiro caso, e marcando a possibilidade de relação entre mundos concebidos diferentemente, no segundo caso. Na verdade, este princípio dialético marca continuamente o discurso Kaingang, que aponta para a "aversão e o horror à junção de coisas iguais porque elas são estéreis" e que dissemina a idéia de que "a fertilidade vem da união dos princípios contrários" (Veiga, 2000:79).

\subsection{Complementariedade: relações entre opostos}

\subsubsection{Cunhadio masculino: os iambré}

As atualizações de mitos, colhidas durante as pesquisas de campo e aqui reproduzidas, trazem à tona e servem para ilustrar um dos princípios fundantes dos Kaingang, que está baseado na complementariedade entre as metades, na medida em que estas atualizações enfatizam, a todo o momento, as relações simétricas entre iambré (cunhados reais ou potenciais). Pertencentes a lados opostos, distintos, com características precisas, bipolares, para o conjunto dos membros de cada metade, os iambré kamé e kainru-kré desempenham papéis ideais de amizade, ajuda mútua, cooperação e complementariedade.

Segundo os interlocutores Kaingang, os iambré, homens de metade oposta, aproximadamente de mesma idade, são considerados companheiros, deles esperando-se intensa relação de camaradagem e amizade. Além disso, o conceito de iambré - cunhadio masculino na mesma categoria de idade - abarca a ênfase 
na complementariedade das metades opostas, sob dois aspectos: 1. as relações de ajuda mútua ou cooperação, no nível do indivíduo (vingança, rituais ligados à morte, etc.), e 2 . as relações de complementariedade das características psicológicas e sociais dos membros pertencentes às metades opostas, no nível da sociedade.

Além disso, o cunhadio masculino Kaingang aproxima opostos da mesma categoria de idade: meu companheiro é meu iambré, não meu iambré-xï (homem de metade oposta a de ego e de menor idade) nem meu kankré (homem de metade oposta a de ego e de idade mais avançada; sogro - real ou potencial). Ademais, é bom frisar, é uma instituição onde as relações acontecem com membros do mesmo sexo: meu companheiro é meu iambré, não minha iambré-fi (mulher da geração de ego, pertencente à metade oposta), nem minhas iambré-fi $x \ddot{i}$ (mulheres de geração inferior à de $e g o$, de metade oposta) ou $m b \tilde{a}$ (mulher de geração superior à de $e g o$, de metade oposta).

A instituição do cunhadio masculino é sócio-centrada, e pretende atuar como agregador das diferenças, domesticando e trazendo-as para a arena do sociológico: as metades são diferentes; entretanto, no nível da cooperação entre os indivíduos e no âmbito da sociedade, elas se completam, se interligam, constituindo o ideal da sociedade Kaingang.

Desta forma, vê-se que, até mesmo no nível da ajuda mútua entre indivíduos, esta se dá em momentos críticos altamente valorizados do ponto de vista da sociedade: a vingança, os rituais da morte, incluindo o ritual do kiki, apontado pela maioria dos autores como o principal e mais importante ritual para a compreensão da sociedade Kaingang.

No nível do mito de origem, as diferenças entre os iambré, que vêm da própria marca, ou seja, das metades, são assim referidas por dois interlocutores:

Karein - É sim. O bugio era gente daqui, antes do dilúvio vir pela terra. Quando o dilúvio veio, ele trepou numa árvore bem alta. Ficou lá, né? Decerto a água cobria e não baixou logo. Então, ele ficou lá, naquela ponta da árvore, mesmo, né? Ficou por ali, parado. Levou 40 dias pra baixar, parece. Ficou lá, comendo aquelas folhas. Comendo só folha. Não sei quanto tempo levou. Ficou lá, comendo aquelas folhas... A natureza da árvore, de repente deu aquela fruta. Ficou comendo aquela fruta, lá. Virou bugio, criou pêlo. 
Arokÿ - Só que o kainru-kré ficou mais inteligente que o kamé: virou kanhér (macaco).

Karein-É, kanhér. É mais inteligente. O que a gente faz, ele faz. Aquele brinquedo que a gente faz. Muito arteiro. Ele imita, ele faz também. (...) O bugio ficou mais lerdo. Quando faz as coisas, faz devagarinho.

$\mathrm{Na}$ mesma frase, a passagem do discurso de ambos os interlocutores Kaingang para uma atualização do mito é imediata:

Karein - Kainru-kré faz ligeiro. Pega as coisas e faz. Vai no pinheiro, tira aquela pinha e vai rodando até que arrebenta aquela bola: pá. Quebra e come, né? Bem ligeiro. Agora, kainru-kré tem muita inteligência. Se um kamé faz um plano, fica pensando, né? Agora, o kainru-kré quando diz alguma coisa, ele levanta: "Então vamos!".

Arokÿ - Ele pensa e faz.

Karein - Pensa e faz, né? Vai fazendo. O kamé não.

Arokÿ - (Compara dois líderes de uma certa área indígena, de épocas diferentes, um kainru-kré ["Ele pensou e foi e foi até que fez"] e outro kamé ["Ele ficou pensando, pensando, ainda. Até que tá até agora planejando"]). (...) Então existe o que?: kainru-kré é mais inteligente que o kamé. Ele pensa e faz. Já vem da marca.

Antropólogo: É por isso que o kamé sempre tem que estar junto do kainru-kré e este com o kamé?

Karein - É. Se é autoridade, assim, pra atender o serviço, então tem que ter o par, dos dois, de autoridade, também, né? Eles botavam assim: o kainru-kré e o kamé.

Arokÿ - Por exemplo, o kamé tem pouco alcance, então o kainru-kré ajuda ${ }^{10}$.

$\mathrm{Na}$ visão Kaingang, portanto, além de a diferença ser pensada como atribuição de pertencimento a metades diferentes, ela também é percebida do ponto de vista da complementariedade, isto é, uma metade só pode existir em contraposição, mas, principalmente, lado a lado com a outra.

Outro discurso mitológico que enfatiza a complementariedade, através da cooperação entre os iambré, é o da Cobra Voadora.

\footnotetext{
${ }^{10}$ Referindo-se aos Xerente (e às suas metades), e resumindo os dados de Nimuendaju, da década de 30, Lopes da Silva e Farias (1992:92) registram: "Os cargos e funções diferenciados são, em geral, duais, havendo um representante de cada metade, em cada caso. Sempre que duas pessoas aparecem aos pares, uma é sip’tato e a outra sdakrã'.
} 


\section{$\underline{\text { Pãntfér - A cobra voadora }}{ }^{11}$}

Diz que era uma vez a história do Pãntfér, que é a cobra voadora. Então, tinha um casal de índios. Ele convidou a esposa dele para ir caçar. Quando ela estava no mato, ele chamou os macacos, os micos. Ele assobiava para os micos, para eles virem até onde ele estava para ele poder matá-los.

Ele começou a chamar, a assobiar, e de repente diz que fez um barulho numa caverna que tinha no mato. Aí, ele disse para a mulher dele: - "Se esconde debaixo das folhas que eu vou matar este bicho".

Daí, de repente, ele chamando, chamando, e a esposa dele escondida, né?. E de repente diz que veio aquela cobra voadora, vieram duas. Elas vieram e não deram tempo para ele: já picaram ele, não deixaram nada, levaram, carregaram ele para a caverna, aquele índio.

Então, a mulher dele ficou olhando tudo. Mas o que ela ia fazer? Se ela se mostrasse, as cobras também iam pegar ela. Daí, ela voltou correndo para contar para os parentes dele que as cobras de asa, cobras voadoras, tinham pegado ele.

Tá. Daí, diz que ela vinha chorando de volta, sozinha, no mato. Chegou na aldeia e contou para os parentes, para os irmãos dela. Daí, eles disseram: - "Vamos lá chamar elas de novo. Vamos matar elas".

Daí, foram uns quantos: três. Foram lá, com flecha e tudo, né? Ficaram lá, no mesmo lugar onde é que ele ficou, né? Deixaram um índio alí e ficaram tudo em baixo: fizeram tipo uma casinha de folha para os bichos não enxergarem eles debaixo.

Daí, aquele um ficou chamando. De repente, quando elas vieram, aquelas cobras, aqueles índios que estavam debaixo tipo a casinha aquela, eles atiraram e derrubaram uma. Quando derrubaram esta, a outra também veio e grudou no mesmo lugar. Daí, eles atiraram de novo e daí mataram. Mataram e trouxeram os bichos, né? Levaram para mostrar para a tribo aqueles bichos que tinham pegado aquele índio. Mostraram para a sogra dele, tudo, para os parentes, filhos, os bichos que tinham matado aquele pai, aquele homem.

Então, ... aconteceu ...

Antropólogo: E quem é que foi lá ...

Arokï: Os iambré dele.

Antropólogo: Os irmãos da mulher?

Arokï: Os irmãos da mulher. Então, eles queriam fazer a vingança do iambré deles. Então, eles que foram lá, matar estes bichos.

Antropólogo: E os rengrê $\hat{e}^{12}$ do que morreu?

Arokÿ: Os rengrê do que morreu não foram, né? Tem que ser os iambré. Os iambré é que fazem a vingança. Se acontecer alguma coisa para ele (aponta para Kaxen mbág, da metade Kamé), eu é que tenho que fazer isso: sou iambré dele.

Outra narrativa Kaingang parece ser de interesse, apesar de não ser totalmente relacionada com o tema desta tese. Trata-se da longa narrativa sobre a

\footnotetext{
${ }^{11}$ Narrada por Francisco Arokÿ dos Santos, Kainru-kré, na Aldeia da Agronomia, Porto Alegre.

${ }^{12}$ Da mesma metade.
} 
"última guerra" entre Kaingang e Xokleng, contada por Karein ${ }^{13}$. Ela merece ser registrada, pois além de enfatizar a complementariedade entre membros masculinos de metades opostas, é rica em fornecer dados sobre vários aspectos da sociedade Kaingang. Ademais, parece-me que os arqueólogos, a quem a tese é essencialmente dirigida, poderão tirar grande proveito de muitas de suas passagens.

\section{Vé hi e Fág féin: os iambré curados ${ }^{14}$ para fazer vingança}

Tempo. Tempo velho. Naquele tempo, nós, os índios Kaingang, era xucro. Diz que tinha umas tribos brabas. Se encontravam. Se matavam, né? Dava guerra. Se toca flecha.

Então, eles vinham de lá, longe, bombear ${ }^{15}$ aqui. Diz que uma vez aconteceu, já, com nós. Saiu um pealo ${ }^{16}$ quando saiu um fandango ${ }^{17}$.

Daí, têm os espiões, que vêm na frente, bombear. Então, eles curavam ${ }^{18}$ os dois iambré, desde que nasciam, só para aquilo, com erva. Daí, eles não têm medo. Naquele tempo, era assim. Só tinha montanha, não tinha casa: só mato com bicho e eles não tinham medo. Levavam aquela flecha, porrete e lança. Pega madeira e faz. Bombear aqueles que estão lá.

Uma vez, mataram todos num fandango, aqui. Na aldeia antiga, na Linha Trindade ${ }^{19}$. Diz que tem um cemitério grande. Mataram todos. Aproveitaram o fandango. Os Xocrên mataram todos. Os Botocudos, que têm o buraco ${ }^{20}$. Lá em Ibirama, os Xocrên também contam esse caso. Mataram todos e pegaram duas mulheres Kaingang e levaram.

Arokÿ: Eles levam aquelas mulheres que têm dente bom.

Pra fazer kifê, continua Karein. Masca bem o milho. Faz num panelão. Canjica, mio durinho, assim, elas mascavam. Então fica doce, doce. Ferve um pouco no fogo. Daí fica doce. Hoje ninguém não faz mais. Minha filha fazia pra mim, quando era mocinha.

Então, eles levaram as mulheres pra fazer kifê para eles. Ficavam escravas. Mas diz que elas levaram escondida uma criancinha, um gurizinho. Levando naquele matão, ali. De repente, iam longe já, ele chorou. De certo, se machucou num espinho.

- Por que traz esse aí? Pincha ${ }^{21}$ fora.

Então, aquele homem pegou aquela criança e pinchou fora, longe, aquele Xocrên. Por que era um guri, né? Periga ele se criar lá, e a mãe contar que mataram todos aqui.

A mulher queria chorar.

\footnotetext{
${ }^{13}$ Narrada por João Karein dos Santos, Kainru-kré, da Área Indígena de Nonoai-RS.

${ }^{14}$ Veja nota 18.

${ }^{15}$ Espiar. Regionalismo gaúcho.

${ }^{16}$ Briga, no linguajar regional gaúcho.

${ }^{17}$ Festa, baile, no linguajar gauchesco. Karein está se referindo a uma festa do Kiki.

${ }^{18}$ Curar é expressão portuguesa usada pelos Kaingang para designar prática ritual para obtenção de poderes especiais da natureza, através da ação de ervas empregadas pelo kuiã (xamã).

${ }_{19}^{10}$ Hoje, Município de Trindade do Sul/RS.

${ }^{20}$ Refere-se ao orifício no lábio inferior para introdução de adorno labial.

${ }^{21}$ Atirar longe, jogar fora.
} 
- Não chora. Te quebro a cabeça, também!

Tinham porrete, né? Foram as duas: chorando atrás deles.

Quando eles iam longe, diz que tinha um rio cheio. Então, elas se combinaram, as duas mulheres. Elas se combinaram de fugir a nado, fingindo que estavam mortas, afogadas, quando os homens passassem elas pelas águas do rio cheio, cruzando com elas seguradas pela mão. Combinaram para poder escapar, para fazer que iam morrer n'água. Mas de certo sabiam nadar, sabiam lutar. Diz que escapou da mão do homem, mergulhou e se foi. A outra também. Escapou lá, também. Aquela correnteza toda, o rio cheio, né?: cruzaram por baixo. Diz.

- Olha, as nossas mulheres, essas mulheres, já morreram n’água, os outros disseram, né?

Então, passaram pro outro lado: corriam e atacavam.

Então, boiou, lá, aquela mulher, pra cima.

- Psiu, finge que está morta, disse uma pra outra.

E foram boiando, se escondendo, só a cabeça de fora.

Foi naquela volta do rio, né? Daí, não alcançaram mais. Dali, elas foram a nado, já, aquelas mulheres. Foram nadando, acompanhando o rio.

Daí, deixaram as mulheres.

- Morreram n'água.

Mas não morreram: escaparam. (Risos do narrador e da platéia).

Quando saíram no seco, lá, passaram pro mato. Um matão, ali. Escureceu: posar no mato, né?, sem fogo! Aí, pra passar pra cá ${ }^{22}$, né?, quando elas sairam, uma mulher perguntou pra outra:

- Não sabe onde? Não marcou o lugar onde ele pinchou o guri?

- Eu marquei. Dobrei uma vara onde ele pinchou, matou.

- Então, vamos lá. Vamos ver se descobrimos o guri.

Saíram naquele carreiro onde eles foram daqui, né? Saíram naquele carreiro e vieram vindo, procurando aquela madeira dobrada. Acharam, encontraram um pauzinho dobrado.

- Foi aqui que ele pinchou. Vamos procurar.

Foram lá em baixo, naquele mato sujo, gatinhando por baixo, procurando. Não acharam. Ficaram pensando:

- Um bicho já comeu.

De repente, ele mexendo, né? Tinha um palmitinho no mato nascido, uma palmerinha, assim, né? Táva caminhando, táva de pé. Brincando em roda.

Mas ficou.... pulou no guri. Chorou, também, a mãe dele. O peito cheio, já. Levaram pra cá. Fizeram uma alcinha pra trazer praqui.

Então, ela ficou com dó do piá, do gurizinho, né? Então, deu de mamar. Já táva coalhado, ali: dormiu sem mamar, nada. Deu aquela mamadinha, ali: mamou bastante. Morreu. Morreu por causa do leite coalhado, né?

Vinham trazendo aquele morto pro lugar onde tinham matado todos. Mataram o pai dele. Chegou lá, tá morto. Enterraram, né? Mal e mal. Olharam pro pai que mataram ali com uma paulada. Táva morto, ali. Sepultaram como par do pai dele.

\footnotetext{
${ }^{22}$ Certamente, refere-se à travessia do Rio Uruguai, em direção ao Rio Grande do Sul.
} 
- Agora, vamos avisar os outros. Em Guarita, nas outras áreas, por aí, o que tinha acontecido com eles.

Isto aconteceu em Linha Trindade. Onde fica o cemitério grande. Sempre diziam quando eu era piá. Contavam assim. Lá era a aldeia deles.

Então, prepararam dois guris que nasceram: outro era Kainru-kré, outro era Kamé. Eram companheiros.

Curaram os "piá".

Antropólogo: Com o que curam os "piá"?

Karein: Com aquela folha do mato. Traz do mato uma folha. Queima e bate no fogo, faz fumaça. Bota o piá em cima, né?, pra tomar toda aquela fumaça. Tá curado. Ele não pode comer muito: tem uma dieta pra ele. Água também é pouca. Até que se crie.

Antropólogo: Quais são os nomes dos vem nun $\operatorname{tar}^{23}$ ?

Karein: Vé hi, o Kainru-kré. O outro, o companheiro, iambré, é Fág féin ${ }^{24}$. É o Kamé. Vé hi significa entusiasmo, alegria, sem medo. Vem de ti ma hi, sempre alegre. Sai com alegria, não tem medo de nada. Sai, né? É assim: curado. Não tem medo de nada. Ti ma hi. Aí, botaram Vé hi.

Esperaram até eles terem 18, 20 anos. Daí, seguiram. Só eles, sozinhos. Só os dois. Até lá, onde estava o toldo dos outros. Aí, ... quantos anos, né? Eles lá nem se lembravam mais. Eles não vêm mais, pensavam.

Vé hi e Fág féin rodearam tudo. Entraram no meio daquela casa, daquele toldo, sempre caminhando: pensavam que eles eram de lá. Mas eram daqui. Caminhando junto com eles, de noite. Não conheciam eles: pensaram que eram dali mesmo. Tudo quieto, nem se lembravam mais daquilo que tinha acontecido. Daí, já se aprontaram e se foram. Resolveram ir pra lá, porque eles vieram contando: - Tá bem! Então, vamos matar eles, também.

Prepararam, enxergaram um lugar bom pra guerrear com ele, né ? $^{25}$

Os que foram curados foram lá fazer vingança. Daí, foi gente bastante. Um grupo grande. Vai de tudo: mulher...

Chegaram lá de madrugada. As casas eram compridas, agrupadas em povoado ${ }^{26}$. Fica limpo no meio: pra ensinar as crianças, ali no meio.

Aí, de madrugada, fizeram aquele barulho, na aldeia sitiada. Todos batiam o pé. Eles, de certo, pensaram que era uma trovoada. - He, parece que vai chover.

Toda aquela gentarada batia os pés. Os do toldo nem pensavam em nada: já tinha passado vinte anos, quem vai se lembrar mais, né?

Quando vem a barra do dia, o cabeça deles disse, o chefe disse:

- Pronto! Vamos ver. Você começa lá no canto e eu começo daqui pra lá. A gente se encontra.

A briga, já. Porrete. Távam dormindo, ainda. Caindo. Eram bom sono. Olhavam, dormindo. Parecia que eles eram de lá mesmo, então...

\footnotetext{
${ }^{23}$ Espião, homem forte.

24 "Levanta uma mulher pra ir embora. Fág é mulher. Féin é levantar", traduz Arokÿ.

${ }^{25}$ Nesta parte da narração, Karein e Arokÿ conversam sobre a vinda, posterior, de espiões Xokleng em Nonoai e na Guarita, na época em que Karein era criança. "Vieram fazer uma vingança por aî”, disse Karein.

${ }^{26} \mathrm{O}$ narrador faz um gesto no chão em forma de círculo.
} 
Os que ficam ao redor dele, do chefe, os de mais coragem, têm sono leve.

Arokÿ: Tem remédio pra isso.

Karein: Eles dormem muito leviano, né? Engolem as folhas e botam aqui no peito, também. Só com um barulhinho, acorda.

Então, tinha aquele um lá, cantando. Então, ele dizia assim:

Ndô hoin $\hat{e}^{27}$
Nént kÿn ${ }^{28}$
Kontin ra
Rongrô roni $\tilde{a}^{30}$
A vêfi ta kontin ie $e^{31}$.

Aquele que era brabo, o mais brabo. Fazia assim pra assustar. Aquele não dorme. Então, tem remédio pra isso. Hoje, não usam mais. Não sabem mais os remédios.

Arokï: Lá na Agronomia tem um pé ${ }^{32}$.

Karein: Tem uma fruta, né? Qualquer coisinha, ele tá estralando: um ventinho, quando faz barulho. Ele tá estralando. Faz assim: téc- téc.

Pega aquelas frutinhas e queima. Vai queimando. Passa nos olhos, no peito. Ninguém não vê. De noite. Acorda primeiro, vai lavar, né? Ninguém pode ver ele lavando, bem lavadinho, pra ninguém ver, pra ninguém saber. Só ele. É, antigamente era assim...

Mataram muito: deixaram só uma velha, pra avisar os outros.

- Eu tenho uns netos que moram aqui por perto, disse a velha.

- Então, a senhora avise. E eu fico esperando.

O Fág féin e o Vé hi ficaram esperando três ou quatro dias. Esperando eles.

Aquela velhinha se foi. Não mataram a velhinha: pra avisar os outros. Foi chorando.

O Fág féin e o Vé hi ficaram lá, esperando. Aquele grupo já tinha vindo embora, como vem correndo, mesmo. Nada, nada: não trouxeram ninguém. Vieram todos parece que quando o porco machuca o cachorro: então ele vai embora, não fica, some, vai longe.

Quando três ou quatro dias passaram:

- Então, vamos. Vamos embora. Atrás dos outros, no carreiro deles.

Eles não sentiam fome. Pra não passar fome, Vé hi e Fág féin têm remédio. Eles ficaram quatro dias sem comer, é! Não têm fome. É uma folha, o remédio. Chama kyn kyn. Aquele tipo de aveia que gruda, a fruta: arroz de macuco. Mastiga aquilo. Depois, tem uma madeira, também. Tira a casca e tem uma casca fina e é doce. Masca ela: não tem fome. É guajuvira, a árvore $^{33}$. Tira a embira. Uma que ficou no pau, bem fininha. É doce. Mata a fome.

Esperaram: não vieram. Quatro dias. Távam voltando. Já tavam com fome. Acharam um guaimbé ${ }^{34}$, maduro. O Fág féin trepou na árvore pra tirar. O companheiro dele,

${ }^{27}$ A flecha tá vindo.

${ }^{28} \mathrm{O}$ grupo guerreiro que trabalha no mato.

${ }^{29}$ Chamando.

${ }^{30}$ A lança tá bem preparada.

${ }^{31}$ Traz a irmã junto.

${ }^{32}$ Refere-se à Aldeia da Agronomia, em Porto Alegre.

${ }^{33}$ Uyi, em Kaingang.

${ }^{34}$ Kó mrür. Banana-de-mico. 
atrás dele, ouviu um barulho. Sabe o tovaco ${ }^{35}$ ?, tovaquinho?, do mato? É um passarinho. Ele avisa qualquer coisinha que venha vindo, ele avisa. Quando ele táva trepado lá, aquele passarinho fez: pôt-pôt-pôt. Vé hi, que táva lá embaixo, se enfiou num mato sujo. Quietinho, lá.

Chegou aquela turminha, lá. Vinham atrás, né? No rastro deles. Alcançando eles. Táva lá.

- Eia! Então tá aí, é? Então você tem coragem pra matar todos?

- $\quad$ Sou eu mesmo, disse Fág féin no alto da árvore. Que que vai fazer agora comigo?

- Então desce daí. Desce. Há térê.

- Se retire mais pra lá, então.

Fág féin foi descendo. De repente, pulou no meio deles.

- A ïxá hé rin ma? ? $^{36}$

Então, ele disse:

- Os outros todos da turma vão lutar primeiro com ele.

Então, o outro veio. Fág féin pegou ele, bateu contra uma madeira; levou pra frente, bateu nele. O Fág féin, né? Bateu ali. Veio de assim, botou o pé, voltou assim.

- Ó, não me fez nada. O que que vai fazer comigo? Então, vou te fazer, também.

Pegou. O Fág féin pegou, jogou pra baixo. Caiu no chão, né?

E daí, os outros ficaram com raiva. Muita raiva dele, porque ele fez o serviço lá, né?

Então, vieram todos juntos.

- Corta o braço dele!

Pegaram a faca dele, e cortaram pela junta: assim, né? Cortou, cortou, assim. Ele nem gritou: dava risada. Parece que não táva vendo nada.

- Ó, porque eu sou assim mesmo. Matei todos. Venci todos vocês. Vocês fizeram pra nós também. Nós quisemos fazer pra vocês.

Diz que eles judiaram ele. Parece que até cortaram o beiço dele, também. Deram kifê pra ele tomar. Decerto tinha uma mulher deles, que veio com eles, que decerto ficou com dó dele porque távam judiando com ele, em vez de matar bem ele. Então ela trouxe um machado e deu na cabeça dele, aquela mulher. Ficou com dó dele, né?

E o outro ficou escutando, o Vé hi. Ficou vendo tudo, escondido, por baixo daquela sujeira.

Daí, os Xocrên voltaram daí mesmo. Foram. O Vé hi veio para cá. Mataram o companheiro dele, o iambré dele. Mataram o kamé.

Depois daquilo, terminou, nunca mais. Mais depois daquilo, eles vinham aqui. Vêm passando pra cá, também: espião deles ${ }^{37}$.

\footnotetext{
${ }^{35}$ Pôr, em Kaingang.

${ }^{36}$ Que tu vais fazer comigo?

${ }^{37}$ Karein refere incidente acontecido há mais de 55 anos quando morava em Rodeio Bonito. Espiões Xogleng teriam rondado sua casa e perambulado pela região: "Então, de noite, saia aquele barulho, a roda da casa. Que nem macaco, que nem mico: assobiava. De noite: furôuc, furôuc, furôuc. Faziam assim”.
} 
Esta narrativa da "última guerra" suscitou uma série de comentários entre os ouvintes e o narrador. Sua tônica foi a complementariedade entre as metades, por intermédio das relações entre iambré, dos casamentos e da uxorilocalidade.

Karein: Iambré mora perto um do outro. Iambré sempre ajuda um o outro.Sempre compradre.

Arokÿ: Às vezes, nasce uma criança e eles já tratam o casamento, desde de quando nasceu a criança.

Karein: Desde de quando nasceu, é!

Arokï: Trata com o iambré pra casar. Até se criar junto.

Karein: É. Até se criar junto.

Arokÿ: Nem que não seja do gosto, né? Tem que casar.

Karein: É, é. Combina tudo naquela lei. Desde que eles nasceram.

Antropólogo: E hoje em dia, continua assim?

Karein: Não, agora não. Gosto dessa: "Como é que vai?".

Antropólogo: Continua casando kamé com kainru-kré? Ou dá casamento kamé com kamé?

Karein: É, também existe.

Arokÿ: Mas só que aqui ainda... Por exemplo: se um kamé casa com uma kamé, são condenados.

Karein: Ainda existe. Mas cada um escolhe onde tem menina moça kainru-kré. Então, kamé vai lá, né?, namorar aquela menina.Olhar passear, contando uns casos, assim. Que nem branco. Chegando, agradando o kankré, a $m b \tilde{a}^{38}$. Iambré tem que ajudar kankré. Kankré é sogro. (...) O casal ficava morando perto do sogro e da $m b \tilde{a}$ do rapaz. Perto da casa do pai da moça. Eles não vão no pai dele. Agora, se ele quiser, se a mulher dele quiser, se ele tem as coisas, a nora pode levar pro kankré dela.

Antropólogo: Então, geralmente, o homem faz a casa mais perto do sogro dele?

Karein: É; do sogro dele, sim.

Antropólogo: Iambré tem que ajudar iambré. Mas na estória que o senhor contou, o Vé $h i$ não ajudou. Ficou escondido: não ajudou o iambré dele.

Karein: Mas ele não ajudou porque o grupo era grande, né?

Arokÿ: E ele tinha que vir contar, aqui. Tinha que voltar vivo. E se matassem os dois lá, aí ninguém ia saber.

Ainda ilustrando a grande ênfase que o pensamento Kaingang dá à complementariedade entre as metades, a narrativa mitológica sobre Sol e Lua demonstra como surgiu o cunhadio masculino.

\footnotetext{
${ }^{38}$ Sogra, ou forma de tratamento empregada para qualquer mulher da metade e geração da mãe de um homem.
} 


\section{$\underline{\text { Sol e Lua }}{ }^{39}$}

"O sol é kainru-kré. A lua é kamé. Tem uma história que diz que é assim. Diz que lá tem tigre, também. Lá no céu. Então, naqueles tempos, os antigos me contavam uma história, que eu vou contar. Os velhos me contavam, os antigos. Diz que ele tinha uma flecha. Então, ele disse: "Eu tô com vontade de ir lá no céu pra ver como é que tá. Qual é que atira lá no céu nossa flecha?". Então, ficou cravada lá. Hahãn, é que é história... história. Então, os outros atiravam flechas daqui, né?: bem reto. Daí, atirou a flecha. Ficaram escutando lá. E a flecha não caiu. Ficou lá.

- Eu vou atirar de novo!

"Atirou a flecha de novo, bem na ponta da outra flecha: cravou. Não voltou, né?

- Eu vou atirar outra!

"Outro atirou também. Atirou bem na ponta, também.

"Então, aquelas flechas vinham chegando aqui na terra.

"Quando vê, no outro dia, diz que era feito uma escada. Aquelas flechas deles ficaram feito uma escada.

"Então, antes dele trepar naquela escada, o tigre ${ }^{40}$ trepou antes. Então, tem tigre lá: no

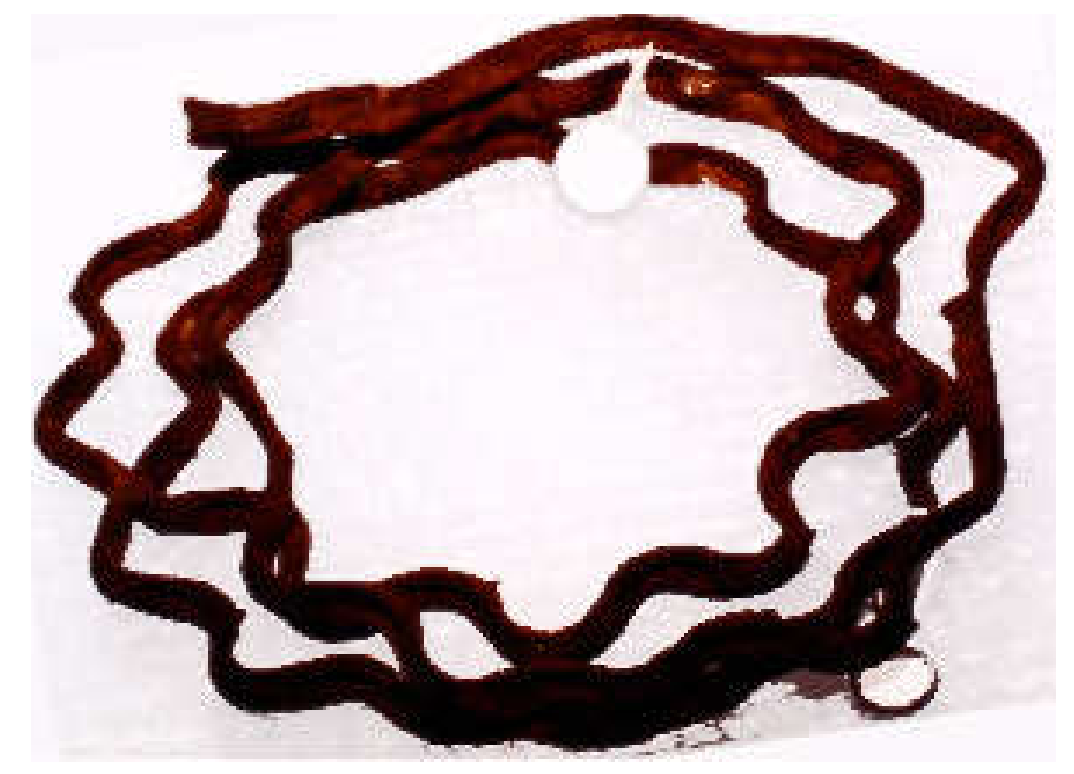

Cipó escada. MAE/USP RG

13.770. Coletado por

Baldus, en 1947.

céu tem tigre. Então, sempre me contavam esta história quando eu era pequeno. Tem tigre lá: foi adiante dele e ficou lá. E daí quando ele viu aquela flecha, ficou uma escada. "Tem um cipó feito uma escada, no mato, diz que é aquele. Eu sempre chamo de cipó escada. É uma escada larga; tem uma larga, assim. Diz que virou aquilo, aquelas flechas.

\footnotetext{
${ }^{39}$ Narrado por João Karein dos Santos - Nonoai - RS. Apesar de o interlocutor considerar Sol como pertencente à metade kainru-kré e Lua à kamé, o que contraria a literatura a respeito, a dualidade acha-se preservada.

${ }^{40}$ A onça (panthera onca) é denominada, em português, de tigre pelos Kaingang.
} 
"Como diziam os velhos antigamente, diz que aquela lua quando dá eclipse, fica só um pedacinho, só uma beiradinha. Diz que é o tigre que tá pegando, tá comendo a lua.

"Então, daqui, naquele tempo, daqui mesmo, eles atiravam de espingarda. Já vi. Atiravam debalde, assim, pra soltar a lua. Atiravam debalde, pra assustar o tigre. E daqui os Kaingang dizem assim: Iambré tô véin ra. Mïn, iambré tô véin ra, véin. Iambré ki ri. Iambré tô rãin $\hat{e}$.

"Então, vai soltando devagarinho, vem trazendo de novo.

"Chamam a lua de iambré: não deixa o meu iambré com o tigre.

Antropólogo: Quem chama a lua de iambré?

"Os kainru-kré. Então diz iambré pra lua.

Antropólogo: E a lua é homem ou mulher?

"Pois é, eu acho que é homem, né?

Antropólogo: E o sol?

"O sol é kainru-kré e é homem também.

"O Kaingang que atirou as flechas não subiu, porque o tigre tinha ido adiante. Não foi lá”.

Ainda com o objetivo de mostrar o alcance e a importância do conceito de cunhadio masculino no pensamento kaingang, passo a relatar os comentários do Capitão Jorge Eufrásio, da Aldeia do Pinhalzinho, na Área Indígena de NonoaiRS. Nesta aldeia, através de indicações precisas dos moradores kaingang, localizei uma aldeia pré-histórica de "Tradição" Taquara, Proto-Jê meridional. O kaingang Jorge Eufrásio, que me acompanhava, comentou que nessa antiga aldeia (o sítio arqueológico) "talvez morassem dois iambré, juntos". Segundo seu discurso, ambos sairiam para caçar, buscar barro (antes, há seis quilômetros dalí, tínhamos descoberto uma jazida de barro preto - ngo'or -, tradicionalmente usado na confecção de utensílios de cerâmica), para melar (buscar mel). Quando, de longe, vimos uma segunda colina, ao lado da que abriga o Sítio arqueológico que denominei "das Lages", brincou mais uma vez: "ali é que morava o iambré dele".

O discurso do Capitão Jorge é marcado pela ênfase e positivação das relações entre iambré, chegando, como se viu, a interpretar o passado préhistórico, projetando estas relações no passado. 
Outros homens kaingang também demonstraram esta ênfase das relações entre iambré: as estórias de Karein, o comportamento do iambré do José Campolim, pedindo as fotos do iambré ausente e distante.

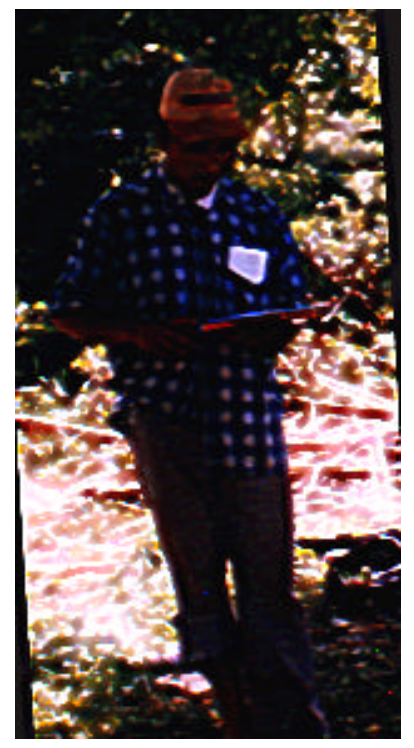

Fotos que aproximam iambré distantes:

Na Aldeia das Bananeiras, Marcolino, o iambré de José Campolim, da Aldeia da Agronomia, vê e pede as fotos de seu iambré ausente e distante.

Foto: PRCNPortal

Possuir relações de aliança, noção importante em todas as sociedades sulamericanas, é idéia fundamental para a compreensão Kaingang de qualquer fenômeno, seja ele de ordem social ou cósmica. Por exemplo, o entendimento Kaingang de um fenômeno meteorológico como o surgimento de dois arco-íris no céu, após a chuva, passa pela idéia de aliança, uma vez que o primeiro arcoíris é denominado ta ndo e o segundo, ti prun, sua esposa.

Da mesma forma, a compreensão Kaingang de um aspecto básico das religiões cristãs, a volta do filho de Deus, distorce a teologia ocidental, na medida em que Jesus Cristo precisa de relações de aliança, casar no outro lado, ter seus iambré, para ser entendido pela tradição nativa. Pelo menos, é assim que as músicas em língua Kaingang, cantadas por Kaingang da Igreja da Assembléia de Deus, referem-se à sua volta: "Jesus Cristo em breve vem / buscar sua noiva querida".

A análise de uma importante classe cerimonial, a dos pêin, também ajuda na compreensão da ênfase posta pela tradição Kaingang nas relações aparentemente simétricas entre opostos. Os pêin têm por função cerimonial preparar o morto para os rituais de enterramento e para aqueles que o antecedem; somente os pêin podem tocar o/a falecido/a; somente eles podem cavar a terra 
para fazer a cova onde será enterrado o morto. São escolhidos desde pequenos, desde suas nominações. Seus nomes indicam sua função cerimonial, uma vez que levam, necessariamente, em sua composição, palavras que indicam a terra (nga) para nomes masculinos ou taquara (ven) para nomes femininos, isto é, que se referem às suas atividades cerimoniais para com o morto: cavar a sepultura, no caso dos homens, ou trançar a mortalha (esteira feita de lasca de taquara), no das mulheres. Existem nomes de pêin kamé e nomes de pêin kainru-krée ${ }^{41}$. A nominação acontece durante um banho ritual de ervas do mato ${ }^{42}$ no nominado, essencial para o nominador ${ }^{43}$ "saber" que nome escolher e para protegê-los contra os vein kuprin (alma) dos falecidos.

O aspecto que aqui nos interessa é que os pêin, em suas atividades rituais, sempre trabalhavam ${ }^{44}$ aos pares: "então, eles se marcavam, né?: tem o ra téi (marca comprida), tem o ra ror (marca redonda); tem o pêin e o iambré dele; então, eles se ajudam, ali" ${ }^{45}$. A principal ajuda que os pêin iambré prestavam um ao outro consistia em não permitir que o vein kuprin (alma) do falecido levasse o vein kuprin do pêin iambré. O momento crucial deste perigo apresentava-se no momento da feitura da cova: quando aquele que estava cavando saía de dentro da cova, seu iambré o puxava pelo braço e proferia palavras rituais ${ }^{46}$ para tirá-lo, arrancá-lo dali, juntamente com sua alma ${ }^{47}$.

\footnotetext{
${ }^{41}$ Nga uóng xï (Aquele ser pequeno que mexe na terra; nome masculino kainru-kré), Nga uókan (Aquele que mexe e chupa a umidade da terra), Nga tén - da patrimetade kamé (Espírito feminino da terra), Nga okã (Aquele que chupa a umidade da terra), Ven hi (nome feminino kainru-kré), Ven iá (nome feminino kainru-kré), Nga kóg (Cova rasa, para criança; nome masculino kainru-kré), Nga kóg téi (Cova funda, para adulto; nome masculino kamé).

${ }^{42}$ Veja subitem 4.1.2., adiante.

${ }^{43}$ No caso que conheço, o nominador era irmão da mãe do pai do nominado.

${ }^{44}$ Apesar de ainda existir indivíduos adultos maduros com nomes que identificam sua pertença à classe de pêin (conheço apenas um caso de criança pequena com nome de pêin), atualmente não mais desempenham suas funções cerimoniais: "Agora não tem mais. Não existe mais aqui, também. A gente sabe o nome, mas... Então, hoje em dia, qualquer um pega ali, é sim" - João Karein dos Santos.

${ }^{45}$ Conforme João Karein.

46 "Há konko tã, iambré” - Sai pra fora, cunhado. "Pra não ficar lá dentro do buraco a alma dele, o espírito dele. Ele não dura, né?. Não dura". João Karein.

${ }^{47}$ Veja o item 4.2., sobre "representações e práticas relativas à saúde, à doença, à cura e à morte", mais adiante.
} 


\section{Disputa ritual dos iambré: cantos no kiki}

Estas relações entre opostos também aconteciam durante a cerimônia do kiki, na qual havia disputas rituais de voz e canto entre os iambré, que se alternavam entre si cantando versos alegres e fanfarrões, que causavam risos e descontração na platéia ${ }^{48}$. Aqui também, mais uma vez, a ênfase recai sobre a complementariedade entre opostos.

Resumindo, cunhadio masculino, complementariedade entre opostos, ou melhor dizendo, a possibilidade de estabelecer relação entre opostos, este parece ser, sem dúvida, um princípio fundante Kaingang.

Esta concepção dualista de idealmente buscar simetria nas relações entre opostos vai se refletir nas formas de sensibilidade estética Kaingang e, conseqüentemente, no sistema de representações visuais, já que as "marcas" (grafismos) opõem e, ao mesmo tempo, aproximam os opostos ${ }^{49}$.

\subsubsection{Os nomes do mato: o poder oriundo do domínio da floresta}

As representações relativas ao mato - o "matão" Kaingang - são de uso comum e referidas com bastante regularidade. As ervas - os remédios - vêm do mato; o iangrë $\ddot{~}^{50}$ - ser que dá poder ao kuiã (xamã) - é do mato, necessita ser selvagem, não podendo ser bicho "inteligente" ou bom, isto é, não pode ter semelhança simbólica com o mundo social; nas orações ou rezas, especialmente as ligadas a rituais de morte, os nomes de animais do mato são inúmeras vezes repetidos; nas "curas"

\footnotetext{
${ }^{48}$ E causam até hoje, conforme simulação feita por Albino Mïng iaffá Kainheró: "Pra cantar isto daqui, tem que ter kainru-kré e kamé do outro lado. Os iambré. Um canta um cântigo e o iambré responde. Que nem trova. Só que no idioma".

${ }^{49}$ Veja Capítulo 5, a seguir.

${ }^{50}$ Iangrë é a forma feminina de iangrõ. Uso, indistintamente, uma ou outra forma, inclusive quando a palavra deveria estar flexionada no pural.

51 "Curar" é expressão portuguesa usada pelos Kaingang para designar prática ritual para obtenção de poderes especiais da natureza, através da ação de ervas empregadas pelo kuiãa, através de um banho ritual em cuja água o remédio foi fervido, por intermédio da fumaça proveniente da erva, ou de seu pó, após a queima. Os pêin são "curados" com banhos rituais. Da mesma forma o são os espiões para a guerra, os que se quer que sejam bons caçadores e o futuro kuiã.
} 
nomes masculinos e femininos Kaingang provêm do mato; e a própria pintura corporal, que é obtida do carvão de certas plantas ${ }^{52}$, é simbolicamente proteção que tem origem no mato. São, todas estas invocações simbólicas de forças e poderes oriundos do "matão". Paradoxal e compreensivelmente, o "matão" causa grande temor aos Kaingang ${ }^{53}$.

O kuiã apresenta-se, então, como o elemento domesticador desta força, usada por ele como poder para prevenir, proteger, curar e prever. Seu poder vem do "matão" (e tudo o que nele está contido - remédios ${ }^{54}$, venenos ${ }^{55}$, iangrë, nomes ${ }^{56}$ ); o domínio da floresta representa todos os recursos simbólicos que podem ser por ele utilizados. O kuiã, portanto, detém um poder oriundo de outros domínios do cosmo: só ele ousa e consegue domesticar estas forças. Daí vem seu prestígio e poder social.

Serrano já dizia, referindo-se aos Caaró $^{57}$ e afins, que "seus feiticeiros se jactavam de poder dominar as forças da natureza e exercer influência sobre as feras" (1936:56).

De qualquer forma, sociedade e natureza, humanos e não-humanos, não representam mundos estanques, completamente separados (Veiga, 2000). A cosmologia Kaingang compartilha com as cosmologias amazônicas o fato de plantas e animais possuírem espírito (tom, conforme os Kaingang). Descola (1998:25)) sublinha que estas cosmologias "estabelecem uma diferença de grau, não de natureza, entre os homens, as plantas e os animais".

\footnotetext{
${ }^{52}$ Ngrã (samambainha) é considerada kainru-kré; fãg (pinheiro) é classificado como kamé. As tintas originadas dos carvões destas plantas são usadas para marcar (pintar com ra ror ou ra téi, respectivamente) os participantes do kiki de Xapecó-SC.

${ }^{53} \mathrm{O}$ que é reconhecidamente uma concepção partilhada com os demais Jê, e que difere da dos Guarani, os quais são comentados no item 5.2, adiante.

${ }^{54}$ Por exemplo, a folha kó mbó, usada nas mãos e na ponta da flecha para ter "tiro certeiro", para "curar" a flecha (ky tóm - flecha "curada para matar").

${ }^{55}$ Por exemplo, o veneno para as ndo (flechas) provem do espinho, queimado e moído, da ven venxá (taquara braba).

${ }^{56}$ Vejam-se alguns nomes tradicionais Kaingang e seus significados. Nomes masculinos Kamé: Kafer (Casca de pau), Ningrei (Local no mato), Pr̈̈g (Abelha preta braba), Dorcocô (Coruja), Kaxen mbag (Rato do mato grande), Mufé (Folha de cipó), Poxï (Pedra pequena), Katui (Nome de madeira), Kóvi (Banana de mico); Nomes femininos Kamé: Kokui (Beija-flor), Wenxó (Folha do mato), Katxô (Nome de madeira), Kóiód (Nome de pássaro), Kamonky (Nome de madeira); Nomes masculinos Kainru-kré: Kaxú (Nome de madeira), Kóioi (Piriquito), Kainhér (Macaco), Karein (Juá - planta com espinho), Ven iü (Taquara Braba); Nomes femininos Kainru-kré: Ven kadér (Taquara lisa), Kuadmé (Nome de passarinho).

${ }^{57}$ Antiga denominação para os grupos Coroados (Kaingang).
} 

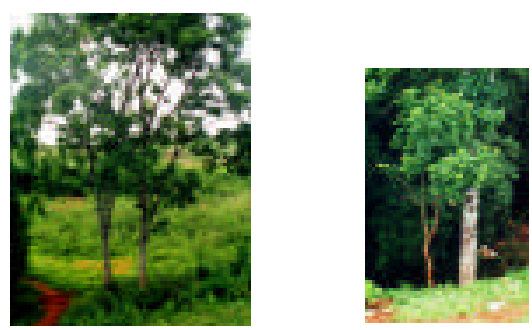

À esq., duas árvores kentuxá (timbó), classificadas como kamé ("tem folhas compridas"). À dir., árvore denominada kenten (canela guaicá); é considerada kainru-kré. Posto Indígena de Nonoai.

De acordo com esta concepção do cosmo, a "natureza" - plantas, bichos, seres inanimados - passa a ser vista de uma forma dividida, dual, exatamente como acontece na sociedade: de um lado, plantas, bichos e seres inanimados kamé; de outro, plantas, bichos e seres inanimados kainru-kré.

Seres e objetos da natureza interpenetram o mundo social, sob o domínio do kuiã, para benefício exclusivo da sociedade Kaingang. Em outras palavras, o poder do kuiã vem de sua capacidade de interlocução com os espíritos dos iangrë. Ele é encarado enquanto personagem social única para estabelecer a intermediação entre mundos concebidos diferentemente, mas não separados radicalmente.

À natureza - aos seus seres e objetos - impõe-se o dualismo cosmológico Kaingang. Animais, plantas, seres inanimados, corpos celestes, enfim, todos os integrantes do mundo natural têm lugar preciso nas conceptualizações do discurso $^{58}$ : ou pertencem à metade kamé ou à metade kainru-kré, sofrendo todas as conseqüências desta ordenação ${ }^{59}$.

\footnotetext{
${ }_{59}^{58}$ Cujas origens estão no nível dos discursos mitológicos.

${ }^{59}$ Até mesmo os mais simples cantos Kaingang, sobre o "kiki dos bichos", de caráter infantil - são ensinados às crianças pequenas como forma de diversão -, enfatizam o domínio da natureza: são homenagens a animais, cujo comportamento é observado e cuja classificação na metade kamé ou kainru-kré é bem sabida por todos. Alguns exemplos: 1. Fëfën ié / İ kané xin ta ui / Ï ni ié xin ta ui / Ï kané xin ta ui / İ ni ié xin ta ui / Krongron kêtare xa ii (A cantiga do tatu / Meus olhos são pequenos / Meu nariz é pequeno / Eu caio na toca; faz barulho). O tatu é considerado Kamé; 2. Pétkrin ié / Andê te ti ni / Batata féi vë / Andê te ti ni / Ximbôra féi vë / Andê te ti ni / Manioca féi vë (A cantiga fa formiga / O que eu carrego? / Folha de batata / ... / Folha de cebola / ... / Folha de mandioca). Pétkrin tar - a formiga cortadeira - é kamé. 3. Krãg ié / Pondói pondói / iang mbá / térê térê xa tï / ngoi iôr / kringgran kringgran / kêkutõ / kêkuto xa tï (A cantiga do porco-do-mato / Serra serra / subindo / descendo do outro lado / a sanga sinuosa / som que imita o barulho quando ele atravessa a água / Eu atravessei). O porco-do-mato é considerado Kainru-kré. 4. Ien rui ru ié / Bên bê rôniô / Ï ré komé imbré kên mu / rén ko kêmu ué. (A cantiga da ratinha - o menor dos ratos / Som que ela faz cantando / Eu, ninguém me come, os que estão juntos comigo é que são comidos). O ien rui ru é classificado como kamé). 5. Xóren ié / İ é ta kënxé kéin (A cantiga da pomba-do-mato - tem o bico bem mole / Meu bico lasca nó-de-pinho). Xóren é kainru-kré. 6. Pãn / I ninron nira ié / iytinka ta kranké / kê um ué (A cobra / Se eu estivesse escutando eu ia onde tinha barulho para picar). Pãn é kamé.
} 
Da natureza, através de ensinamentos originários de seres do mato (os iangrë) e transmitidos aos kuiã, provêm os remédios, as curas e os augúrios benéficos e maléficos. Ademais, o iangrë (espírito auxiliar) do xamã deve ser da metade oposta à do kuiã (Veiga, 2000:78), evidenciando, mais uma vez, a complementariedade entre as metades.

É interessante notar que o fogo - elemento ligado ao mundo social - está sempre presente no momento da obtenção dos poderes vindos da natureza: a erva queimada, a fumaça do remédio do mato que sobe "pra atropelar as enfermidades" $", 60$, a erva usada em pó, depois de queimada, o carvão da samambainha e do pinheiro para a pintura corporal no $k i k i^{61}$. O fogo parece ser o elemento social que ativa, potencializa e domestica o remédio que vem do mato.

Do mesmo modo, a maioria dos nomes masculinos e femininos Kaingang são "nomes do mato" 62 . A imposição de nomes - esta importante instituição social entre os Jê - está intrinsecamente relacionada com este domínio ${ }^{63}$.

Antes de tudo, em um nível mais profundo, a apropriação da natureza representa uma das possibilidades de se estabelecer relação entre mundos concebidos diferentemente. A filosofia de estabelecer relações idealmente harmoniosas entre opostos é uma das expressões mais marcantes do pensamento Kaingang.

\footnotetext{
${ }^{60}$ Antes de iniciar o ritual do kiki, Albino Müng Iãfá Kainheró conta que "eles faziam aquele remédio. Amontoavam aquele cupim do mato que dá na madeira. Eles botam o cupim debaixo da folha de remédio e botam fogo em baixo. Então, aquilo é remédio pros índios Kaingang. Aquele cupim, com remédio, com folha de remédio, que bota em cima, né?, então aquele fogo, pegava tudo em cima, assim, e daí aquela fumaça bate tudo no corpo daquelas pessoas que tão ali. Pra não pegar doença e pra proteger dos vein kuprin [espírito dos mortos] também. Uns ficavam em cima daquele fogo, saindo fumaça, vão tomar remédio. Daí, eles tomavam; daí, eles cantavam em cima daquele fogo, daquela fumaceira de remédio. Dançavam em cima daquela fumaça pra proteger todo o corpo. A fumaça subia pra atropelar as enfermidades".

61 “Aquele kuiã, finado Chico Kainheró, o meu avô, tinha uma plantinha que ele moia, aquele remédio, ele queimava aquele remédio. Então, com a brasinha, ele botava naquele pilão. Então ele moia com uma mãozinhade-pilão -, chacoalhava, assim, bem moído na água, bem moidinho, e já encravava, assim - faz um gesto de rotação alternada, direita, esquerda, com a ponta do indicador esticado -, no rosto, assim”. Albino Müng Iãfá Kainheró explicando a marca ra ror (marca redonda dos kainru-kré).

${ }^{62}$ Diferentemente dos nomes Mbya-Guarani, que provêm das relações com os deuses.

${ }^{63} \mathrm{O}$ ritual de nominação acontece durante um banho com ervas, o que propicia ao nominador - referido pelo interlocutor Kaingang (Batista) como "pessoa mais velha"- a escolha do nome apropriado. Veja, também, nota 43.
} 
A seguir, apresentamos três exemplos nos quais são ritual e simbolicamente enfatizadas as relações de complementariedade entre estes opostos concebidos nas suas diferenças.

Estas percepções nativas, isto é, o ideal de buscar simetria nas relações que ocorrem num mundo concebido dual, dividido ${ }^{64}$, irão se refletir nas formas de sensibilidade estética, nos mitos, e, em conseqüência, no sistema de representações visuais Kaingang, como será discutido no Capítulo 5.

\section{Primeiro exemplo: ritual ligado à morte ${ }^{65}$}

"Naquele tempo, quando morria um velho, uma velha, não usava reza, rezar em cima. Então, a reza dele era aquele guizo, chocalho, chocalhação. Tinha tôn nun feito com taquara grossa - taquaruçu - preparada. Faz o eco mais pequeno e mais grande: tum, tum, tum. Batia em roda daquele morto para fazer ele subir para o céu. Então, ele diz assim, enquanto todos rodeiam o morto:

$$
\begin{aligned}
& \text { Iô pë, iô pë, iô pë } \ddot{e}^{66} \\
& \text { Ôiôr, ôiôr, ôiôr, ôiôr, ôiôr, ôiôr, ôiôor }{ }^{67} \\
& \text { Mó ru, mó ru, mó ru, mó ru, mó ru } \\
& \text { Ngô kai, Ngố kai, Ngô kai, Ngô kai, Ngô kai }{ }^{69} \text {. }
\end{aligned}
$$

"Fazia assim. Vinha os nomes do mato, naquele canto, ali. Que nem verso, assim, que nem canto dos brancos. Então disseram assim:
Ôiôr, ôiôr, ôiôr, ôiôr
Ngô kai, Ngô kai, Ngô kai
Mó ru, mó ru, mó ru, mó ru
Ngô kai, Ngô kai, Ngô kai, Ngô kai
Mó ru, mó ru, mó ru
Mun ngrei, Mun ngrei, Mun ngrei ${ }^{70}$.

"Fizeram assim, estes cantos, para começar a subir aquela alma. Aquela alma do morto. Para não sofrer aqui em baixo. Porque alma perdida vem perdida, não rezando bem, pra subir. Fica assim, né? Tem uma alma perdida, fica assobiando, de noite, né? Então, vem assobiando. Não achou o caminho dela. Esse é o perigo. Então, eles faziam assim, para subir reto, prá lá.

\footnotetext{
${ }^{64}$ Como afirma Da Matta (1976) em relação aos Apinajé.

${ }^{65}$ Narrado por João Karein dos Santos, kainru-kré. Área Indígena de Nonoai-RS.

${ }^{66}$ Nome de árvore de grande porte. Tradução para o português desconhecida.

${ }^{67}$ Anta.

${ }^{68}$ Milho de pipoca.

${ }^{69}$ Nome masculino da metade Kainru-kré: ngog (bugio) e kai (está trepado).

${ }^{70}$ Nome feminino da metade Kamé, significa andar (mun) e descançar (ngrei). Entre os Kayapó, Ngrei é nome feminino ligado à anta, conforme informação de Lux Boelitz Vidal.
} 
Então, com aquele canto, ela vai reto prá lá, pro céu, Deus, lá, reto pra cima. Vai ficar com Topë ${ }^{71}$, lá.

Antropólogo: Quem cantou esta canção? Foi o kuiã?

Karein: Não. Qualquer um que sabe pode fazer. Agora, ninguém não sabe. Tempo, tempo velho. Naquele tempo, nós, o índio Kaingang era xucro. Era xucro”.

Neste relato, pode-se perceber ainda a relação entre a anta e a metade kamé.

Segundo exemplo: “curado” para ser bom caçador ${ }^{72}$

Quando Karein era criança, seu tio paterno costumava fazer-lhe pequenas flechas para que pudesse brincar. Ainda pequeno, foi com o tio, "e dois cachorros que gostavam de correr tateto ${ }^{73}$ no mato", caçar num pinhalzinho.

- "Óia, fio, bamo lá. Se os cachorro corre tateto pra nóis, matemo".

Karein relata:

"Ele entoca o tateto. Eu fui junto. Chegando naquele pinhalzinho, tinha aquela rataiada: o pinhão debulhava e os bichos iam comendo. Soltamos os cachorros, e eles foram, atrás. O tio foi atrás dos cachorros. O tio disse: - Fica aqui, firme aqui".

Um tateto perdido parou bem perto de Karein. Este pensou consigo: "Vou experimentar atirar com minha flechinha”.

"Botei no arquinho e atirei bem na volta da paleta. O bicho saiu correndo pelo mato, fazendo barulho", conta Karein.

Com muito medo, ele foi olhando o bicho se batendo, até parar. Estava com sangue na boca: tinha acertado bem no coração.

Gritava pelo tio, que veio, preocupado.

Karein mostrou-lhe o tateto morto. O tio ficou faceiro: - "Mas, então, você atirou bem, meu fio".

O tio proibiu-lhe de comer o tateto: - "O primeiro tiro que a gente mata, ele não deixa comer. Não pode. Se comendo, porque você matou ele, você não dura, morre logo", disse-lhe o tio.

"Eles ficaram churrasqueando, comendo o tateto bem gordo, que nem porco", relata Karein. "Daí, ele me curou, naquele tempo, com a flecha mesmo

\footnotetext{
${ }^{71}$ Tupã : forma como os jesuítas missionários designaram o Deus católico para os guarani reduzidos. A forma Topë é usada pelos Kaingang para nomear esse mesmo Deus católico.

${ }_{72}^{72}$ Narrado por João Karein dos Santos, kainru-kré. Área Indígena de Nonoai-RS.

${ }^{73}$ Porco-do-mato, caititu.
} 
ele me curou. Como eu estava pra ficar bom na caça, quando vai matar tem que sempre ter sorte, né? Não perde a viagem, quando ia caçar. Mata. Sai no mato, assim, sozinho, encontra o bicho e mata. Não perde a viagem. Então, ele me curou, o velho aquele. Ele perguntou: - 'Qual é a flecha que matou?'. Aí, mostrei. - 'Vem cá', disse o velho, bem velho, o vô ${ }^{74}$. 'Vou te curar. Me traz aquela flecha que o senhor atirou', disse o vô. - 'Senta aqui”. Ele ficou atrás. Me bateu atrás, na cabeça, com a flechinha, onde tinha fincado no bicho. Fazia (não sei se é oração)... Então, ele cantava. Ele disse assim:

'Ndô kombó, nhió mó, ndô kombó, nhió mó ${ }^{75}$

Koin bar ky kon ta tarê $\hat{}^{76}$

Kakã ta ti mba kontïn ${ }^{77}$

Hõ ta kai kõki Kuikui kêti ${ }^{78}$

Ki kon tarê ka ta kiunon ki kamba kontïn ti ${ }^{79}$.

"Disseram assim, bem, pra mim: - 'Tá bem curado, agora'. Faziam farra de mim, que não estava comendo. Virei um bom caçador. Eu fui curado para caçar. Depois, eu fiquei caçador: não tem medo. Aquela coragem de entrar no mato sozinho. Um matão. Não tem medo, não tem medo. Só que não encontrei tigre, ainda. Mïng konggãrr ${ }^{80}$. Tem o müng kuxun $^{81}$, gato vermelho, sem manchas. O mïng konggãr é kainru-kré, tem ra ror, bem pintadinho, assim. Acho que o mïng kuxun é kamé, não tem manchas".

Mïng kuxun. Reproduzido de Flávio Silva, 1984:115.

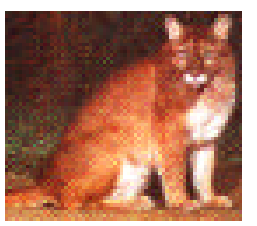

\footnotetext{
${ }^{74}$ Velho kuiã que invoca seu iangrë, o gavião.

${ }_{75}^{75}$ Flecha curada com a folha kó mbó, focinho do bicho.

${ }^{76}$ Para vir outra caça, logo, de novo.

${ }^{77} \mathrm{O}$ gavião vai trazer outro remédio/caça para ti.

${ }_{78}^{78} \mathrm{O}$ gavião sobe até o céu e vem te curar, para ser um bom caçador.

${ }^{79}$ Ele desce do céu, ele morde a caça e traz para ti.

${ }^{80}$ Onça pintada (Panthera onca).

81 "Puma", "Leão baio", "onça parda" e "sussuarana" são algumas das denominações vulgares atribuídas no Rio Grande do Sul ao Felis concolor.
} 


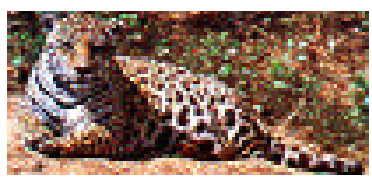

Mïng konggãr. Reproduzido de Flávio Silva, 1984:127.

Terceiro exemplo: "curado" para ser kuia ${ }^{82}$

"Diz que o vô dele, que era kuiã, deu aquele nome pra ele (Mïng iãfá - Fezes de onça) porque sabia que ele ia ter um problema de saúde e deu o banho pra ele um dia ser kuiã. O banho de erva é pra chamar os iangrë dele. Chega uma época que esses iangrë vão vir nele. $\mathrm{O}$ kombê $\hat{}^{83}$ era o iangrë dele. Demorou pra ele aparecer, o iangrë. De longe, ele aparece como um veado. Quando chega pra conversar, ele se transforma em Nossa Senhora. Acho que pra ele não se assustar. O bugio quis ficar iangrë dele. Este que mostrou as ervas, a medicina, pra ele. A mulher dele se assustou: os iangrë apareciam dentro de casa. Ela pediu pra parar".

Nestes três exemplos ficou marcado o ideal de buscar simetria nas relações que ocorrem em um mundo concebido dualmente. Esta percepção irá se refletir no sistema de representações visuais kaingang.

\subsection{Representações e práticas relativas à saúde, à doença, à cura e à morte: o numbê}

Com o objetivo de subsidiar interpretações arqueológicas mais sofisticadas sobre a sociedade Proto-Kaingang, principalmente para um melhor entendimento de suas estruturas funerárias, comentadas a seguir, e da cultura material, me propus a levantar uma etnografia que dê conta das representações Kaingang sobre doença e morte. Além disso, como será visto neste subitem, as práticas curativas também enfatizam as relações entre opostos. A compreensão destas representações auxilia nosso entendimento do pensamento Kaingang, sofisticando as hipóteses e interpretações sobre o passado.

\footnotetext{
${ }^{82}$ Narrado por Francisco Arokÿ dos Santos.

${ }^{83}$ Veado macho.
} 
A doença origina-se fora do mundo social ou, melhor ainda, a doença não tem origem nas relações sociais perturbadas, como em muitas sociedades onde as acusações de feitiçaria são comuns.

No entanto, elas também não provêm da natureza. Sua origem está fora da sociedade como igualmente está fora do mundo natural. Aliás, é na natureza que se encontram os poderes para prevenir e curar.

Os Kaingang acreditam que as enfermidades e sua conseqüência derradeira provêm do mundo que existe depois da morte: o numbê, a aldeia dos mortos.

As doenças, e sua consequiência última - a morte -, têm por causa básica os vein kuprin ou keinbég (espíritos, almas, dos mortos). O vein kuprin de um parente próximo - pai, esposo, avô - apega-se, por exemplo, ao filho, ou esposa, ou neto, causando enfermidades ao vivo e podendo, no limite, levâ-lo à morte. Se o doente não for tratado a tempo pelo kuiã e seu iangrë, que vai combater o vein kuprin e levá-lo para o numbê, a morte é certa.

Se o kuiã constatar que o vein kuprin é proveniente do oeste, local onde está situado o numbêe, não há cura possível para o doente. Ao contrário, se vier do leste, há possibilidade de cura.

Muitos tabus rituais eram respeitados com relação à morte e, especialmente, no que diz respeito ao corpo do morto, com o intuito de evitar doenças e a morte dos vivos:

"Antigamente era assim. Se deixava em casa todas as crianças. Não era pra olhar, nem ir ao cemitério. Depois, fecha a casa, fecham todas as portas pra não ouvirem os gritos, pra o vein kuprin do morto não vir ali, perdido, e entrar numa pessoa. Fecham as portas. Quando morre o marido, a viúva não pode entrar dentro do velório. Deve deixar ela lá no mato. Faz fogo lá no mato. Ficava uns sete dias lá no mato. Iambré dela cuidava dela: faz uma casinha, faz um foguinho ${ }^{84}$. Depois de sete dias, ela vem pra casa. Mas não dá pra olhar assim: levantar a cabeça. Cabeça baixa: não pode olhar pra nenhuma pessoa. Se ela olhar pra criança, aquela criança não dura: fica fraca, pega doença, logo" 85 .

\footnotetext{
${ }^{84}$ Mais uma vez, estamos diante de relações de complementariedade entre opostos, neste caso, obrigações rituais.

${ }^{85}$ Conforme João Karein e Francisco Arokÿ.
} 
Segundo meus interlocutores, o kuiã exerce seu poder de cura e prevenção através de seu iangrë e dos "remédios do mato". Sua própria morte só pode acontecer quando ele falha em suas funções: seu iangrë "toma" sua alma. Os kaingang dizem que há diferenças hierárquicas entre os iangrë. A onça seria o mais forte.

A escolha e iniciação de um novo kuiã parte do kuiã em atividade, que escolhe uma criança para substitui-lo. No caso que conheço, a escolha aconteceu durante a nominação. Ao dar o banho de ervas ritual para saber o nome apropriado, o kuiã detecta, através de seu iangrë, que o nominado teria no futuro grave doença que poderia levâ-lo à morte. Recebe, então, o nome de Mïng iãfá - Fezes de onça - de seu nominador-kuiã para "assustar a doença" prevista. São os chamados yiyi korég (nomes feios), usados como prevenção contra a crise vislumbrada ${ }^{86}$. Ao mesmo tempo, neste caso que conheço, o nominado recebeu um banho ritual "para chamar os iangrë dele" e, portanto, tornar-se, no futuro, kuiã:

"O velho contou. Contou depois. Eu era piazote quando ele me deu este banho. Daí, eu fui crescendo, fui crescendo... Foi depois que eu casei, me casei, e foi depois que eu tinha essa piazada aqui, esses piá que tão aí. Mas daí que deu esse sonho, ${ }^{\circledR 87}$.

O sonho, ou a visão, como é denominada pelos kaingang, é a manifestação do iangrë:

"A minha visão, que deu pra mim, foi assim, ó: quando eu táva lá no patrão, trabalhando lá uma semana. Me deu aquela visão, sonho, né?. Táva Nossa Senhora junto, com aqueles homens de vestido branco, né? Que era em cima de uma água, com onda. Estavam aquelas pessoas unidas, ajuntadas em cima daquela água. Esse sonho sempre, né? Sempre aparece pra mim. Agora, de vez em quando, me aparece pra mim, essas pessoas no sonho. Elas usam esses cadernos, livros, assim, e lêem pra mim, no sonho. Eles contam pra mim que é oração boa" ${ }^{\sharp 8}$.

\footnotetext{
86 "Meu filho tem nome feio pra proteger da doença", Karein. "E a doença tem medo do nome dele e não vem", Arokÿ. Alguns exemplos de nomes considerados yiyi korég: Jaguá (cachorro, em Guarani), Kikô, Ndér ror (Nádegas ...), Fãgngrétü (Sem vagina, nome masculino kainru-kré).

${ }^{87}$ Conforme Albino Mïng iãfá.

${ }^{88}$ Conforme Albino Müng iãfá. Na visão de Albino, seu iangrõ (forma masculina para iangrë) aparece inicialmente, de longe, como um kõmbê (veado macho). Quando ele se aproxima para conversar, se transforma em Nossa Senhora, provavelmente para ele (Albino) não se assustar (informações de Francisco Arokì).
} 
As manifestações do iangrë, após a primeira visão, repetem-se sempre que necessário, ou seja, na prevenção, na cura, na procura de "remédio do mato", no "encaminhamento" do vein kuprin ao numbe $e^{89}$.

As práticas curativas enfatizam as relações entre opostos, marcando, mais uma vez, o que o discurso kaingang evidencia continuamente: a fertilidade (e eficiência) simbólica da junção de princípios contrários. O poder dos remédios oriundos da natureza é potencializado na medida em que são usados, lado a lado, ao mesmo tempo, dois componentes diversos, um considerado kamé, o outro, kainru-kré.

Além disso, para serem utilizados, estes remédios necessitam ser macerados, moídos, por pilões e mãos-de-pilão, preferencialmente confeccionados em pedra ${ }^{90}$. Esta matéria-prima, por sua dureza e longa duração, constitui, intrinsecamente, um poder curativo ou preventivo. Por outro lado, num nível maior de abstração, pode-se notar que o poder simbólico do pilão e da mão-de-pilão para processar o remédio fica acrescido do fato de neste ato estar contida uma relação/união entre opostos: a mão-de-pilão, considerada kamé (comprida e delgada) e o pilão ${ }^{91}$, concebido como kainru-kré (baixo, arredondado ou circular, forma fechada ${ }^{92}$ ).

Kern (1994:94-96), comentando "a elaboração e o acabamento trabalhoso e refinado" das mãos-de-pilão, consideradas como "os artefatos mais característicos" dos "caçadores-coletores-horticultores do planalto meridional", já sugeriu o seu uso ritual. Na verdade, tudo indica seu uso no processamento

\footnotetext{
89 “Quando eu benzi, ela se endireitou e saiu pra fora. Eu fiz outro benzimento pra ela e fui dormir: me deu sono. E lá umas horas da noite, me acordei. Me levantei e daí aquela mulher táva prosseando [conversando] com aqueles espíritos, com aqueles vein kuprin, daqueles que tinham morrido antes: o avô e a mãe dela. Eu vi quando eles távam conversando com ela. Ela disse pra ela: - Muna, muna, fia. Kor kontin. (Vamos, filha. Vem.) Ele táva de pé, assim, aquele velho. Daí, eu fiz outra oração. Me acordei bem e fiz outra oração. Ela dormiu de novo, daí. Aqueles espíritos sumiram”. Conforme Albino Mïng iãfá.

90 "Os velhos Kanhgág esmagavam as folhas das ervas torradas usando pedras e, durante o esmagamento ritual, os velhos cantavam e pediam para que os remédios deixassem as suas crianças fortes como a pedra que usavam, e que as crianças tivessem uma vida como a da pedra, que nunca morre" (Kagrër, 1997:155). "Aquele kuiã, finado Chico, o meu avô, tinha uma plantinha que ele moia, aquele remédio, ele queimava aquele remédio. Então, com a brasinha, ele botava naquele pilão. Então, ele moia com uma mãozinha-de-pilão, chacoalhava, bem moído na água, bem moidinho" Cf. Mïng iãfá.

${ }_{91}$ Kréi (Pilão), inclusive, é nome masculino do estoque kainru-kré.

92 "O pilão é kainru-kré; tem buraco redondo". Cf. Arokÿ.
} 
utilitário e ritual ${ }^{93}$ de folhas ou raízes, cujos poderes curativos seriam potencializados, tanto pelo contato com os instrumentos de pedra como pela união eficazmente simbólica destes dois artefatos concebidos como contrários.

Os remédios Kaingang operam por homologia, isto é, por transmissão ritual de suas qualidades ao paciente, nos casos que me foram relatados.

Madeiras fortes, "que não secam debalde, que duram" ${ }^{94}$, são consideradas como possuidoras de poder curativo ou preventivo de doenças. Por exemplo, a árvore denominada ken ta iú (açoita cavalo) é concebida como remédio porque "não pega doença", e, quando cortada, brota rapidamente, "não se termina". Já a figueira (ken ven fi), por "espremer, abafar, matar e tomar o lugar de outras árvores" ${ }^{95}$, é percebida como "remédio brabo", isto é, para "ficar brabo, lutar". A ponta do pinheiro (carbonizada ou em forma de chá) é usada para ter destreza e não escorregar ao subir nele. O "carvãozinho" ou o chá são passados nos pés do indivíduo. Os cupins do mato, por atacarem madeiras duras, fortes, são utilizados para fortalecer o corpo e proteger contra a doença. Os cupins, juntamente com ervas-remédio, são queimados. A fumaça daí proveniente é usada "para atropelar" 96 a doença dos corpos que a ela são expostos.

A água corrente, que nunca seca, tem força preventiva e curativa ${ }^{97}$. Algumas plantas aquáticas são consideradas um bom remédio, pois crescem "por cima da água, boiando", adquirindo dela seu poder, que as faz "não se terminarem nunca" (conf. Karein).

Dentro deste mesmo princípio de homologia ou transmissão ritual de qualidades e características, as "pedras d'água", alisadas pela ação da corrente, são usadas como preventivo contra rugas: "fica velho, mas fica sempre que

\footnotetext{
${ }^{93} \mathrm{O}$ desgaste provocado nas porções ativas das mãos-de-pilão usadas para moer substâncias consideradas como remédio é infinitamente pequeno, podendo aparentar, aos olhos do arqueólogo, como uma continuidade do acabamento polido do instrumento, e o seu não-uso prático.

${ }^{94}$ Conf. depoimento de Karein.

${ }^{95}$ Conf. depoimento de Mïng iãfá.

${ }^{96}$ Conf. depoimento de Arokÿ.

${ }^{97}$ Segundo Sales (1997:92), o futuro "benzedor e curador", no seu processo de aprendizagem, "teria que se banhar em águas correntes ou águas de cachoeira com folhas de remédios do mato”. Kagrër (1997:156) relata o seguinte: "Ao se lavarem no rio antes dos pássaros, as crianças pegavam toda a força que vinha da correnteza de água pura, porque depois que os pássaros bebessem e se lavassem na água, toda a força era deles e assim deixavam a água contaminada para quem a usasse depois".
} 
parece novo". Além disso, a palavra Pó (Pedra) é utilizada como nome masculino (Pó ronga, Póxï) para prevenir doenças, "pois é dura, não acaba mais, não termina" (conf. Arok̈̈).

Pequenos animaizinhos que se agitam rapidamente sobre as águas paradas (иӧ̈-иої) são indicados para quem quer ter destreza na luta contra inimigos, transmitindo para o paciente o poder de defesa contra seus golpes e flechas. São aplicados sobre os olhos, esmagados previamente em pilão e mão-de-pilão de pedra.

Seguindo princípios de homologia e de acordo com uma concepção de eficácia simbólica da junção de contrários, plantas, animais e objetos são percebidos como proteção contra doenças. Alguns nomes (Kréi, Pó) também. Igualmente, referi acima que os yiyi korég são assim concebidos ${ }^{98}$. Com relação às pinturas corporais ${ }^{99}$, elas também, durante a realização de rituais no cemitério, protegem contra os vein kuprin (almas dos falecidos), entidades que podem causar doenças e a morte, uma vez que, impulsionadas pela saudade de seus parentes próximos, pretendem levá-los para o numbê (aldeia dos mortos). A pintura corporal torna a pessoa invisível em relação aos espíritos dos mortos.

A maioria dos fatos referidos neste item (4.2.) já está suficientemente analisada em monografias que tratam de outros povos Jê, como os Kayapó, os Xavante, etc. Ao registrar, nesta tese, estas representações e práticas entre os Kaingang, meu objetivo foi o de refletir sobre o vínculo entre cultura material e cosmologia, e, desta forma, contribuir para outros entendimentos do registro arqueológico Proto-Jê meridional, especialmente no que diz respeito a uma abordagem cognitiva deste registro.

\footnotetext{
${ }^{98}$ Veiga (2000, especialmente pág. 167) parece considerar pêin todas as pessoas com yiyi korég. Meus dados demonstram que os yiyi korég são usados para afastar, à época da nominação, a doença antevista. O nome dos pêin parece pertencer a um outro estoque, específico, conforme já discutido na página 117.

${ }^{99}$ Veja Capítulo 5, adiante.
} 


\subsection{Mito e história: considerações sobre as origens da sociedade Kaingang atual}

Partindo do pressuposto teórico de que o mito é historicamente condicionado (Sullivan, 1988:17), e seguindo o entendimento de Hill (1988), Veiga (2000) enfatiza que mito e história não deveriam ser separados, mas compreendidos como "duas formas diferentes de narrar os fatos", ou seja, "tanto a história é organizada dentro do esquema mitológico, quanto os mitos contêm também fatos de história".

Wüst (1992:22), referindo-se ao corpus mitológico Bororo, apesar de reconhecer que os mitos não podem ser tratados como documentos históricos ocidentais, sublinha que eles podem "conter elementos que, por meio de relatos de supostas origens, venham a reforçar a identidade étnica", não podendo, algumas de suas passagens, "ser consideradas como meras construções do imaginário, mas que retratam, de forma às vezes metafórica, um processo sóciopolítico intimamente relacionado a sua sobrevivência física e cultural".

Na verdade, o "mito de origem" Kaingang, recolhido por Telêmaco Borba (1908), e a seguir reproduzido, possui muitos elementos que possibilitam um melhor entendimento do passado e da cosmologia desta sociedade.

"Em tempos imemoriais deu-se um dilúvio que cobriu a terra inteira, habitada de nossos antepassados.

"Somente o cume da serra Krinjinjimbé (Serra do Mar) sobressaía das águas diluviais.

"Os Kaingáng, Kaiurucré e Kamé nadavam na direção dela, cada um com um luminoso tição entre os dentes.

"Os Kaiurucré e os Kamé cansaram, afundaram-se e pereceram; suas almas foram habitar o interior da montanha.

"Os Kaingáng e uns poucos Curutons atingiram com dificuldade o cume da serra Krinjinjimbé, onde permaneceram uns no chão, outros nos ramos das árvores, porque não acharam mais lugar; lá passaram uns dias, sem que as águas descaíssem e sem alimento. Já esperavam a morte, quando ouviram o canto de saracuras, que traziam cestinhos de terra, que deitavam nas águas; estas começaram a recuar devagar.

"Os Kaingáng clamavam às saracuras que se apressassem; estas redobravam suas vozes e convidavam os patos que as ajudassem. Em pouco tempo conseguiram formar uma planície espaçosa no monte, que dava bastante campo aos Kaingáng com exceção daqueles que se tinham refugiado às árvores; estes foram transformados em monitós ou macacos e os Curutons em caroias, macacos urradores. 
"As saracuras tinham começado o seu trabalho do lado onde sai o sol; é a razão por que os nossos rios e arroios tomam seus curso na costa e desembocam no grande Paraná.

"Desaparecida a grande inundação, os Kaingáng estabeleceram-se nas proximidades da Serra do Mar.

"Os Kaiurucré e os Kamé, cujas almas moravam no interior da Serra, começaram a abrir caminhos. Depois de muitos trabalhos e fadigas, uns puderam sair de um lado, os outros do outro.

"Na abertura donde saíram os Kaiurucré, teve sua nascente um belo arroio e lá não havia pedras; daí veio que eles têm os pés pequenos. Pelo contrário o caminho dos Kamé levava sobre terreno pedregoso, de sorte que feriram os pés e estes durante a marcha inchavam; daí veio que eles têm os pés compridos até o dia de hoje. No caminho que tinham aberto, não havia água; sofreram sede e viram-se obrigados a pedi-la ao Kaiurucré que lhes concedeu a necessária. Ao saírem do interior do monte os Curutons, ordenaram-lhes os Kaingáng que buscassem as cestas e cascas de abóbora, que antes da inundação tinham deixado no vale. Foram os Curutons; mas preguiçosos demais, como eram, para subir a Serra, ficaram em baixo, onde estavam, e não queriam mais voltar aos Kaingáng; por isso, quando os encontramos, apoderamo-nos deles como de nossos escravos fugidos, que são. Na noite em que tinham saído da abertura da Serra, acenderam fogo e Kaiurucré formou de cinzas e carvão tigres e lhes disse: Ide e devorai homens e animais! E os tigres se foram rugindo. Não tendo mais carvão para pintar, fez então de cinza as antas e ordenou-lhes: Ide e procurai caça! A estas, porém, tinham saído mal os ouvidos e não entenderam a ordem e perguntaram que deviam fazer. Kaiurucré, que estava a formar outro animal, gritou-lhes zangado: Ide e comei folhas e ramos! Desta vez entenderam a ordem e se foram; isto é a razão por que as antas se alimentam somente de folhas, ramos e frutos silvestres. Kaiurucré estava outra vez a formar animal; faltavam a este ainda os dentes, a língua e umas garras, quando apontou o dia, e não tendo força de dia, pôs-lhe depressa uma vara na boca e disse-lhe: Não tendo dentes, vive de formigas! Isto é a razão por que o tamanduá é animal não acabado e imperfeito.

"Na noite seguinte continuou e formou muitos animais, entre eles as abelhas boas.

"Ao mesmo tempo que Kaiurucré produzia estes animais, Kamé também fez animais, porém diversos, para combater aqueles; ele fez os leões americanos, as cobras venenosas e as vespas. Acabado este trabalho marcharam para se unirem com os Kaingáng; viram, porém, que os tigres eram muito ferozes e devoravam muita gente; então lançaram sobre um rio profundo uma ponte ou antes um tronco de árvore e, depois de terem todos passado, disse Kaiurucré a Kamé que, quando os tigres estavam na ponte, a retirasse com toda a força, a fim de que aqueles caíssem na água e se afogassem. Assim fez Kamé; dos tigres uns caíram na água e afundaram-se, outros, porém, pularam à margem e seguraram-se com as garras. Kamé quis precipitá-los na água; quando, porém, os tigres urravam e mostravam os dentes, tinha medo e deixou-os subir à terra; daí que os tigres podem viver tanto na água como na terra. 
"Depois de terem chegado a uma grande planície, reuniram-se e aconselharam-se como deviam casar os filhos. Casaram primeiro os Kaiurucré com as filhas dos Kamé, e vice-versa. Quando porém restavam ainda muitos jovens, casaram-nos com as filhas dos Kaingáng e daí veio que os Kaiurucré, os Kaingáng e Kamé são parentes e amigos”.

Como comentário inicial, nota-se que o mito traz características físicas de Kamé e Kainru-kré como se na verdade tivessem características fenótipas diferentes. Inclusive suas posições geográficas diversas estão expressamente colocadas. Como já se viu anteriormente, uma série de oposições entre ambos são dadas: animais feitos por Kamé (Ming kuxum = leão americano; cobra) são considerados e ditos atualmente como Kamé; já Kainru faz "tigre" (ming konggãr), dito kainru-kré. Além disso, o mito registra o ato de pintar com carvão como saber tradicional, o que se contrapõe à afirmação de muitos arqueólogos de que os Kaingang nunca empregaram tradicionalmente a pintura e o desenho. Somado a este registro do mito, que isoladamente não pode ser tomado como referência para um tempo cronologicamente mais antigo, tem-se as evidências concretas de "gravadores" líticos nas "tradições locais planáticas", já comentadas no Capítulo 3, provavelmente usados na confecção de grafismos rupestres ${ }^{100}$.

A leitura deste mito permite constatar que ele narra a destruição de um mundo preexistente, cuja formação não é referida. Na verdade, o relato refere-se às origens da sociedade Kaingang atual (Veiga, 2000:224).

Veiga (1994:67 e segs.) faz uma leitura desta narrativa mitológica. Nela, verifica-se a ocorrência de quatro grupos humanos distintos: os Kayru, os Kamé, os Kaingang e os Kurutu. Veiga admite que não é por acaso que as seções Kaingang são em número de quatro. A autora diz que Kamé e Kayru são, simultaneamente, os pais ancestrais e as metades clânicas e as duas seções (Votor, ligada aos Kayru, e Wonhétki, ligada aos Kamé) seriam numericamente minoritárias do ponto de vista dos indivíduos que a elas pertencem e, além disso, exerciam funções cerimoniais. Na sua leitura do mito, Veiga estabelece que as duas metades clânicas, Kamé e Kayru, num determinado momento da história do grupo, teriam feito aliança com um terceiro grupo, os Kaingang, e teriam incorporado, através de processos guerreiros, como escravos, o grupo dos Kurutu. A autora estabelece para a palavra Kurutu a significação de "sem roupa",

\footnotetext{
${ }^{100}$ Ver mais adiante, no Capítulo 5, discussão sobre grafismos rupestres.
} 
onde Kuru seria roupa, tecido próprio dos Kaingang e tu, partícula de negação. Ela estabelece que o termo Kaingang, Kaingâg ou Kôinggégn, conforme os dialetos locais da região do sul do Brasil, significa e é usado do ponto de vista de um termo geral para designar "gente, pessoa, homem ou pessoa de nossa gente". Argumenta que Henry, que esteve entre os Xokleng entre 1932 e 1934, denomina o grupo que ele trabalhou de Kaingang, afirmando tratarem-se de tribos que falam Kaingang e dialetos Kaingang e que habitam o interior do Estado de São Paulo e do Brasil sul, até a Argentina. Sabe-se que foi Borba, em 1882, que atribuiu o termo geral Kaingang aos que hoje se assumem como tal. Não resignada com esta denominação genérica, Veiga cita o exemplo da índia Mariana, do grupo do Rio do Peixe, que se auto-identificou pelo termo "yakwa(n)dagtéye", conforme Nimuendaju \& Guérios (1948:222), dizendo que o termo "téye" significa comprido e "yakwa(n)", embora não possa ser traduzido, chama a atenção para os termos "Akuen" e A'wê/Auwê, autodenominação, respectivamente, dos Xerente e Xavante de acordo com MayburyLewis (1984: 40). Veiga admite que os Kaingang do mito recolhido por Telêmaco Borba seria uma designação sinônima do que hoje se conhece como grupo Xokleng e que os Kamé e Kayru teriam ido buscar mulheres entre este grupo. Como comprovação diz que os Kaingang atuais do Posto Xapecó ainda possuem nas suas narrativas históricas memórias de guerras e de alianças por casamento deles com outros grupos Kaingang e com os Xokleng. Inclusive nas genealogias do P.I. Xapecó, a autora encontra diversas pessoas identificadas como Botocudos (denominação genérica para os Xokleng). Muitas destas pessoas, que têm três a quatro gerações de ascendência Xokleng, pertencem à seção Votor. A hipótese é que os Votor teriam se originado desta aliança entre Kaingang e Xokleng. Deste ponto de vista, os Votor seriam Xokleng agregados por casamento à metade de marca redonda, isto é, aos Kayru. Os Wonhétki (seção pertencente à metade Kamé - Kaingang) e os Wanyekí (grupo Xokleng), segundo Veiga, teriam a mesma procedência, ou seja, vêm de um mesmo povo escravizado tanto pelos Kaingang como pelos Xokleng, ou seja, os Kurutu (os sem roupa $)^{101}$.

A autora, a partir das relações assimétricas na sociedade Kaingang, considerando-se as posições das seções Votor e Wonhétki e admitindo, também, que os membros dessas seções podem casar dentro do seu subgrupo, tendo-se

\footnotetext{
${ }^{101}$ Von Ihering (1895), referindo-se aos Oti-Xavante de São Paulo, relata que "Os Coroados os chamam de Curuton, que quer dizer nú, sem camisa e, talvez, figuradamente, sem morada, vagabundo".
} 
uma endogamia de metade, sugere, portanto, que tais seções foram assimiladas por processos diferentes na sociedade Kaingang: aliança, no caso dos Votor, e escravidão, no segundo caso: os Wonhétki.

Veiga lembra uma série de relações conflituosas entre os grupos Kaingang e entre os grupos Kaingang e Xokleng, estabelecidos a partir de relatos de guerras, como também lembra o fato da escravização de muitos grupos não-Jê, como grupos de língua Tupi-guarani, pelos Kaingang, que eram confundidos com os Botocudos por usarem tembetá.

A partir desta possível incorporação ou assimilação à sociedade, os grupos estrangeiros deveriam ser distinguidos daqueles que são os autênticos Kaingang, ou seja, daqueles que têm uma descendência a partir dos pais ancestrais. A partir deste princípio, dentro da metade Kayru, distingue-se os Kayru (grafismos da pintura corporal em pontos) dos Votor (pintura corporal em círculos). Na metade clânica Kamé, distinguem-se os Kamé (pintura corporal em traços verticais) dos Wonhétki (pintura corporal em traços curvos, da boca até a orelha). (Veiga, 1994: 71).

Desta forma, os Votor não seriam tão Kayru, e os Wonhétki não seriam tão Kamé. Segundo os informantes de Veiga, os Wonhétki não poderiam ser enterrados no cemitério da aldeia. Atualmente, esta restrição não é mais colocada em prática.

A autora estabeleceu, idealmente, a posição no cemitério, através de seus informantes, das seções, onde os Votor teriam espaços definidos em relação aos Kayru, e os Wonhétki, espaços definidos e separados dos Kamé, as duas metades exogâmicas estando localizadas a leste e a oeste.

Veiga, igualmente, faz uma correlação entre os Xerente (grupo Jê) e os Kaingang, dizendo que entre os primeiros também existem seções incorporadas ou agregadas às metades exogâmicas. Nimuendaju (1942, apud Veiga, 1994:75) afirma que os clãs Xerente Prasé e Krozaké seriam tribos incorporadas às metades Siptató ou Doi, cuja pintura corporal é marcada por círculos, e Sdakrã ou Wairí, cuja pintura é distinguida por traços ${ }^{102}$. Segundo Nimuendaju:

\footnotetext{
${ }^{102}$ Veja mais detalhes sobre a pintura corporal Xerente em comparação com a Kaingang no subitem 5.1.2.
} 
"no caso Xerente parece explícito que esses dois clãs não são considerados membros plenos da tribo, razão pela qual a não observância das regras de exogamia de metade por eles não constitui um escândalo." (Nimuendaju, 1942 apud Veiga, 1944:75).

Além disso, voltando ao caso Kaingang, a ênfase extremada de seu discurso nativo sobre a complementariedade entre membros de metades opostas, e entre o mundo social e o domínio da "natureza", concebidos como diferentes, como foi visto mais acima, lembra o comentário de Lévi-Strauss (1967:158), que adverte:

"mesmo num tipo de estrutura social simétrica (ao menos em aparência) como a organização dualista, a relação entre as metades nunca é estática, nem tão recíproca quanto tenderíamos a representá-la".

Subdividindo as estruturas dualistas entre aquelas que concebem o plano de suas aldeias como estrutura diametral ou como estrutura concêntrica, o autor caracteriza a primeira como um dualismo "concebido, parece, como resultante de uma dicotomia simétrica e equilibrada entre grupos sociais, aspectos do mundo físico e atributos morais ou metafísicos" (op. cit., p. 163), mesmo admitindo que "os elementos de uma estrutura diametral possam ser desiguais". O segundo tipo de estrutura conceberia o dualismo "numa perspectiva concêntrica, com a diferença de que os termos da oposição são necessariamente desiguais, na questão do prestígio social ou religioso ou em ambos ao mesmo tempo" (op. cit., p. 163).

Lévi-Strauss admite que a maioria das estruturas diametrais "apresenta um caráter assimétrico em contradição aparente com sua natureza (reciprocidade), colocando-as, por conseguinte, a meio-caminho entre as raras formas diametrais absolutamente simétricas e as estruturas concêntricas que são sempre assimétricas" (op. cit., p. 163).

Neste sentido, revisitando a advertência expressa pelo antropólogo francês (op. cit., p. 370), quando refere que a estrutura real de uma sociedade muitas vezes difere extremamente da idéia que os nativos fazem dela, é essencial que se observe suas análises sobre os Bororo. 
Estudando a planta da aldeia Bororo, o autor distingue nela uma estrutura concêntrica e duas estruturas diametrais, sublinhando que:

"estas diversas manifestações de dualismo dão lugar a uma tríade. Com um efeito, cada um dos oito clãs divide-se em três classes que chamarei: superior, média e inferior. (...) Mostrei num outro trabalho que a regra pela qual um superior de uma metade esposa, obrigatoriamente, um superior da outra, um médio casa-se com um médio e um inferior com um inferior, convertia a sociedade Bororo, de um sistema aparente de exogamia dualista, num sistema real de endogamia triádica. Pois estamos diante de três sub-sociedades, cada uma formada de indivíduos sem relação de parentesco com os membros das outras duas: os superiores, os médios e os inferiores. Enfim, no mesmo trabalho, uma comparação rápida entre a sociedade Bororo e a dos Jê centrais e orientais (Apinajé, Xerente, Timbira) permitiu postular para o conjunto uma organização social do mesmo tipo" (op. cit., p. 167-8).

Coincidentemente, ou não, os estudos sobre etnoarqueologia Bororo, realizados por Wüst (1992:22), apontam para um "processo de fusão de grupos culturalmente distintos": tradição ceramista Uru, Tupiguarani e Bororo, propriamente dito. Seu trabalho inter-disciplinar, que levou em conta informações etnográficas, lingüísticas, etno-históricas e arqueológicas, sugere que "os Bororo atuais seriam o resultado de um processo de incorporação de grupos étnicos e culturais distintos e que esta sociedade, sob sua forma etnograficamente conhecida, conta com uma profundidade temporal relativamente limitada" (op. cit., p. 23).

Com relação ao caso Kaingang, Veiga recentemente (2000:78-9; 123-4), seguindo Dumont (1992 [1966]), tece algumas considerações sobre a noção de hierarquia com englobamento do termo contrário. O desequilíbrio dinâmico das metades Kaingang propicia que este englobamento seja permutável, isto é, às vezes Kamé engloba Kainru-kré e, em outras, Kainru-kré engloba Kamé (Veiga, 2000:78-9), ou seja, voltando a Lévi-Strauss, "a relação entre as metades nunca é estática, nem tão recíproca quanto tenderíamos a representá-la" (Lévi-Strauss, 1967:158) ou, ainda, "a metade que ganha a primazia em um plano a concede à metade oposta num outro" (Lévi-Strauss, 1993:213).

$\mathrm{O}$ ideal Kaingang de reconhecer simetria entre membros de metades opostas, a ênfase do discurso nativo numa aparente harmonia dessas relações, demonstra que, subjacente a esta simetria e complementariedade, no cotidiano 
das relações sociais manifestam-se noções de hierarquia e englobamento de contrários.

Todas estas constatações acima comentadas são de grande importância teórica no caso dos Kaingang e Xokleng (e conseqüentemente dos Proto-Jê meridionais) se pensarmos "como boas para pensar" a interpretação de Veiga (1994) sobre o mito de origem Kaingang e suas informações sobre as alianças matrimoniais das seções Votor e Wonhétki.

As hipóteses de Veiga, baseadas em seus dados etnográficos, e nos dados de uma outra sociedade Jê, os Xerente, nos permitem várias considerações. A Arqueologia dos Proto-Jê no sul do Brasil parece indicar algumas possibilidades para uma tentativa de esclarecimento das hipóteses levantadas por Veiga, principalmente quando se observa que as "tradições" Humaitá e Taquara no Rio Grande do Sul são diferenciadas apenas pela inclusão de uma cerâmica característica nos materiais relacionados à última "Tradição" arqueológica citada, sendo o lítico proveniente dos sítios arqueológicos de ambas assemelhado em alguns casos. Este fato poderia estar indicando uma transformação cultural, originada desde fora, na "Tradição" Humaitá, pré-cerâmica, do Planalto Sul Brasileiro, usualmente caracterizada como formada por grupos de caçadorescoletores. Especialmente no RS, esta transformação poderia estar indicando a incorporação de grupos pré-cerâmicos por uma sociedade ceramista, produtora de alimentos através da horticultura, que teria se deslocado de regiões mais ao norte até as regiões mais meridionais do Brasil, como sugerem os estudos lingüísticos já comentados.

O caso específico das casas subterrâneas do sul do Brasil é paradigmático, na medida em que as mais antigas não possuem material cerâmico, e as mais recentes, do início do primeiro milênio depois de Cristo (140 \pm 85 d.C. (SI813), para a "Fase" Guatambu, "Tradição" Taquara, nos municípios de Bom Jesus e Vacaria - RS e São Joaquim - SC), contêm cerâmica.

A arqueologia no sul do Brasil também tem constatado a presença em sítios arqueológicos da "Tradição" Taquara de materiais cerâmicos da "Tradição" Tupiguarani, isoladamente e em espaços restritos da aldeia, indicando uma provável aliança com os grupos indígenas daquela "Tradição", ou o rapto de mulheres pelos membros da "Tradição" Taquara, mulheres essas que deveriam 
ser incorporadas, com o passar do tempo, às metades patrilineares, já que os filhos destas mulheres estrangeiras seriam incorporados à metade do pai (neste caso, um Proto-Jê do sul) ${ }^{103}$.

Os relatos de guerra entre Xokleng (Botocudos) e Kaingang no RS (que teriam como motivação e/ou conseqüência rapto de mulheres) são bastante comuns e recorrentes na bibliografia do séc. XIX e primeiras décadas no séc. $\mathrm{XX}$, conforme narrativa registrada no subitem 4.1.2.

Retomando o mito de criação da sociedade Kaingang, vimos que a destruição de um mundo já existente pela inundação provoca a morte por afogamento dos pais ancestrais, Kamé e Kainru, indo suas almas habitar o "interior da montanha" Krinjinjimbé, a Serra do Mar. As versões deste mito, registradas por Veiga (2000:223), além da identificação das metades com os espaços relacionais ao nascer e ao ocaso do sol, permitiram que a autora afirme que os dois heróis civilizadores saíram do centro desta serra "por caminhos diferentes: os kamé pelo oeste, e os kaïru pelo leste" (op. cit., p. 223). Ademais, na festa do kiki, rememoração deste momento de origem da sociedade Kaingang, esta oposição espacial e a reconstituição dos caminhos diferentes dos pais ancestrais são refeitas em várias ocasiões durante o ritual (op. cit., p. 231-2).

Além disso, explicitamente,

"Os Kaingang de Rio da Várzea (RS) e do Xapecó (SC) afirmam que os Kaïru nasceram no alto e os Kamé na baixada. Se pensarmos na topografia do território Kaingang e na relação que eles fazem dos Kaïru como povo do leste, e que possuía água, e dos Kamé como do oeste, que tiveram que pedir água aos Kaïru, se pode ver que Kaïru está relacionado às nascentes: todos os grandes rios do território Kaingang nascem a leste e correm para o oeste (a maioria, indo para o grande rio Paraná ou para a Bacia do Prata)" Veiga, 2000:230.

\footnotetext{
${ }^{103} \mathrm{Na}$ Aldeia da Estiva, em Viamão-RS, os "sistemas” Mbyá e Kaingang convivem no mesmo espaço. Lá vive um grupo de parentela composto pelo líder da comunidade (casado com mulher Mbyá-Guarani) e seus consangüíneos (casados com mulheres Kaingang). O líder e seus irmãos são filhos de um casamento interétnico mãe Kaingang e pai Mbyá-Guarani. A mulher do líder tem várias irmãs casadas com Mbyá-Guarani (seus pais são Mbyá-Guarani). Quando os casamentos são interétnicos, os filhos são criados dentro do "sistema" do pai ou da mãe, conforme o caso. No pátio, as mulheres confeccionam suas cestas, tradicionalmente e conforme sua tradição.
} 
Todos estes indícios, de ordens diferentes (arqueológica, lingüística, etnohistórica, etnográfica), tornam plausível a hipótese de que a atual sociedade Kaingang seria uma grande confederação que inclui, num passado mais recuado, a união de um povo Jê, oriundo do norte e do oeste - a metade Kamé -, com um povo já estabelecido no Planalto Sul-brasileiro, provavelmente as populações conhecidas arqueologicamente como de "Tradição" Humaitá, localizadas a leste - a metade Kainru-kré -, e de incorporações mais recentes, de membros de outras duas etnias, uma delas Guarani, que são englobados separadamente em subdivisões (seções) das metades, como se viu anteriormente ${ }^{104}$, o que, de resto, não foge à tradição Jê de incorporar o diferente, torná-lo semelhante, mas de maneira diferenciada ${ }^{105}$.

A versão do mito de origem do milho, contada na Comunidade Indígena de Inhacorá (Veiga, 2000:228), registra que foi do corpo de Kamé que ele surgiu. Esta narrativa mitológica reforça a hipótese de que populações Jê horticultoras em migração, vindas do norte/oeste, teriam incorporado grupos coletores-caçadores, do leste, estabelecidos a longo tempo no Planalto Sulbrasileiro. Como o mito de origem da sociedade Kaingang relata, resolveram casar entre si suas mulheres. Desta última etnia só teriam restado as informações arqueológicas, já que teriam sido integrados ao "sistema" Jê, sob a forma de metade Kainru ${ }^{106}$.

É bem certo que este modelo etnoarqueológico necessita ser testado e comprovado por metodologias arqueológicas. Entretanto, além da semelhança entre o material lítico das "tradições" Humaitá e Taquara, e da existência de casas subterrâneas pré-cerâmicas e cerâmicas, muitas outras evidências arqueológicas, que já foram levantadas pela pesquisa, embasam esta hipótese de incorporações sucessivas. A mais conhecida de todas, já comentada no capítulo 3 , é aquela que constata a presença de materiais arqueológicos de "Tradição" Tupiguarani(cerâmica) em vários sítios de "tradições locais planálticas", principalmente em regiões que se situam no sul de Santa Catarina para o norte,

\footnotetext{
${ }^{104}$ Coincidentemente, "a palavra que inicia (e dá nome) ao canto dos Wonhétky, durante o ritual do Kiki, nas noites que antecedem a ida ao cemitério" (Veiga, 2000:229), é omanõ, termo que entre os Asurini significa morrer. A autora (op. cit.) acredita "que alguns cantos podem ter sido aprendidos ou trazidos por cativos, de língua da família Tupi-Guarani”. Na verdade, o Vocabulário Guarani-Português de M. Arnaud Sampaio (1986:119) traz o verbete omanova: cadáver, defunto, mortal.

${ }^{105}$ Os casos dos Bororo e dos Xerente, já referidos, parecem ser paradigmáticos.

${ }^{106}$ É interessante notar que a maior parte dos cantos e recitações do Kiki não seja compreensível, indicando, talvez, uma origem lingüística estranha à língua Kaingang (Jê).
} 
até São Paulo. Coincidentemente, ou não, apenas fora do Rio Grande do Sul foram constatadas as presenças de subdivisões das patrimetades (seções).

A evidência de ordem etnológica (Veiga, 1994; 2000) demonstra que os membros da seção Wonhétky da metade Kamé são considerados Kaingang nãoverdadeiros, possuidores de marcação específica no sistema de representações visuais, de cantos funerários próprios e de local de sepultamento fora do cemitério da aldeia.

Estes dados arqueológicos e etnológicos legitimam os comentários que seguem. Imagine-se a estranheza que os Kaingang teriam sentido ao constatar o modo como os Guarani tratavam os inimigos ritualmente mortos. Seus corpos canibalizados contrastavam frontalmente com todas as regras e percepções Kaingang de respeito e temor em relação ao espírito dos falecidos, como demonstram os seus rituais, que enfatizam a proteção contra seu espírito (pintura corporal, vokrê - purificação do(a) viúvo(a) -, destruição dos bens do morto e enterramento dos objetos pessoais do falecido - para que ele não volte para recuperá-los -) e a sua incorporação ao mundo dos mortos (numbê), com sua separação definitiva do mundo dos vivos ocorrendo durante o ritual do Kiki. A existência de categorias rituais específicas como a dos pêin (considerados possuidores de força especial e, portanto, únicos que poderiam tratar e enterrar os mortos) e a dos tamper (dançarinos encarregados de impedir que os mortos bebessem junto com os vivos no Kiki) também demonstram claramente esta ênfase Kaingang na separação entre vivos e mortos. Esta estranheza, pois, justificaria a marcação especial dos membros da etnia Guarani que teriam sido incorporados à estrutura social e às regras culturais Kaingang: a pintura facial em linha que realça e aumenta o tamanho da boca, e a proibição de sepultamento dos descendentes destes incorporados nos cemitérios Kaingang, pois poderiam canibalizar os espíritos dos mortos ${ }^{107}$.

Esta possível confederação Kaingang, através da incorporação do outro (e dos objetos culturais do outro), tem manifestações pontuais nas semelhanças que apresenta com outras etnias vizinhas (Guarani, Terena, Guayaqui), e não necessariamente somente com outros povos Jê Centrais ou Setentrionais, como bem observa Veiga (2000:106). As bebidas fermentadas, os tecidos

\footnotetext{
${ }^{107}$ Este foi o motivo dado pelos atuais Kaingang para justificar a proibição (Veiga, 1994; 2000).
} 
confeccionados com fio de urtiga, seriam os exemplos mais evidentes. Pelo menos uma forma de cesto Kaingang, o kre kõpó, e uma técnica de confecção de trançados, denominada pelos Kaingang de tipiti, parecem indicar incorporações antigas da cultura material Guarani.

Quanto à organização ritual do espaço Kaingang, é interessante enfatizar que no Kiki e principalmente em relação à espacialidade do cemitério existe uma separação das metades entre leste e oeste, que foi observada por Veiga (1984), Crépeau (1994, 1995) e Rosa (1995).

O estudo dos cemitérios Proto-Jê meridional também poderia demonstrar que esta espacialidade, do ponto de vista de separação dos mortos, também estaria presente no passado. Um estudo diacrônico dos sítios Taquara, levando em conta as hipóteses em relação às incorporações sucessivas de grupos estranhos à estrutura social dos grupos Jê migrantes, seja por aliança ou por escravidão, poderia igualmente demonstrar os momentos exatos nos quais tais possíveis assimilações teriam acontecido, estando subjacente a este estudo a interpretação da cultura material desta "Tradição", com a conseqüente incorporação de objetos, além do processo que culmina com o surgimento de grafismos corporais identificadores destes grupos englobados, como é o caso etnograficamente registrado das populações Jê meridionais dos atuais estados de Santa Catarina, Paraná e São Paulo ${ }^{108}$.

\subsection{Representações sobre a morte e padrões de sepultamento (Proto)Jê}

"O lugar do enterramento significa a porta invisível que liga um dos planos do mundo Kaingang a outro; o nível terreno e mortal ao subterrâneo, nível mítico do mundo dos ancestrais" (Veiga, 2000:227).

Por tratarem-se de testemunhos arqueológicos importantes, presentes nos sítios das "tradições locais planálticas", e, principalmente, pelo seu caráter simbólico e por sua ligação direta com as representações sobre a morte e o

\footnotetext{
${ }^{108}$ Como para o período pré-colonial não conhecemos as fronteiras destes grupos Jê meridionais, possivelmente também no Rio Grande do Sul estas incorporações à estrutura social Jê poderiam ter ocorrido.
} 
mundo mítico e da sobrenatureza, propus-me a revisar a literatura sobre as estruturas enterratórias destas "tradições", comparando-as com as informações históricas para os grupos Jê meridionais e analisando-as à luz dos dados etnológicos. Além disso, tais estruturas podem indicar importantes caminhos para a diferenciação arqueológica das sociedades Kaingang e Xokleng précoloniais.

Os relatos da primeira hora, se comparados, diferenciam os enterramentos Kaingang dos sepultamentos Xokleng. Como a cerâmica Jê meridional précolonial (sua produção, formas e técnicas decorativas) não parece ser um bom indicador para a separação dos assentamentos Proto-Kaingang daqueles ProtoXokleng, pelas razões já expostas, as diferentes práticas funerárias das duas sociedades, registradas etnograficamente, poderiam ser de alguma utilidade para a diferenciação arqueológica.

De acordo com Becker (1976 e 1994:65-66), os enterramentos Kaingang mais antigos "eram feitos no cemitério que, segundo a tradição antiga, seria um para cada aldeia. Nele os mortos eram enterrados numa vala aberta ex-professo. A esse enterramento sob o solo davam forma piramidal, resultante do amontoado de terra ou de terra e pedras. Resultava num montículo(...)". Lamentavelmente, as informações relativas aos primeiros momentos do contato não contêm dados sobre a espacialidade dos cemitérios e a separação, no seu espaço, dos mortos pertencentes às metades Kamé e Kainru-kré, registrada na etnografia trabalhada neste capítulo.

A primeira informação sobre uma sepultura Kaingang parece ser a referida por Lozano (1873-74, 1:423 apud Métraux, 1946:465), que registrou o mesmo tipo de túmulo para os Guayaná do século XVIII, ancestrais dos Kaingang:

"forman un género de cementério, que conservan muy limpio; y en él abren sus sepulturas, y en enterrando a alguno, ponen sobre cada una un montón de tierra em figura piramidal, em cuyu remate sientan un médio calabazo, y al pié conservan de contínuo un fuego lento que van acebar todos los dias com leña muy tenue, sus mas cercanos parientes. El calabazo, dicen, es para que no falte al difunto con que beber, si le afligiera la sed: y el fuego para que ahuyente las moscas."

O principal e mais detalhado registro etnográfico, realizado entre 1914 e 1915, para os rituais funerários dos Kaingang paulistas é aquele de Maniser, publicado postumamente em 1930, e repetido por Métraux, em 1946. Para a 
mesma etnia, desta vez da região de Palmas - centro-sul do Paraná - tem-se o trabalho de Leão (1910) e de Fernandes (1941), este último baseado nas informações de sertanista companheiro de Telêmaco Borba.

Com relação às práticas funerárias Xokleng, tem-se o importante depoimento do índio Vamblé, transcrito por Henry (1964), e os relatos de Vasconcellos (1912), Tavares (1910), Boiteux (1911), Paula (1924) e Kempf (1947).

Desde o início das pesquisas arqueológicas realizadas no sul do Brasil, os arqueólogos que trabalharam com o horizonte cultural Proto-Jê meridional vêm utilizando a analogia etnográfica para explicar as estruturas arqueológicas em forma de aterros.

Schmitz e colaboradores (Schmitz, 1967:7) escavaram um aterro próximo de casas subterrâneas, no nordeste do Rio Grande do Sul. Esta estrutura foi comparada ao túmulo Kaingang descrito por Métraux (1946:466), apenas em função de seu aspecto externo, pois no seu interior não foram encontrados restos humanos e sim níveis de terra humosa, com carvão, cerâmica do tipo das casas subterrâneas e artefatos líticos.

A inexistência de restos ósseos humanos em tais estruturas, geralmente associadas a casas subterrâneas, sempre foi motivo de ressalvas e reticências quanto à aceitação sem restrições da analogia com as práticas funerárias Kaingang. Rohr (1973:58), referindo-se a estas estruturas arqueológicas Proto-Jê meridionais, toca no ponto fundamental da discussão:

"Segundo a tradição, estes montículos seriam sepulturas dos índios caingang, os mesmos que consideramos os construtores das casas subterrâneas. Escavações destes montículos revelaram a presença de carvão e cerâmica das casas subterrâneas, mas nenhuma ossada. Isto, talvez, devido à acidez do solo" (ênfase minha).

Como demonstrarei nas páginas que se seguem, através de dois exemplos de enterramentos arqueológicos relativamente recentes e seguramente ligados às "tradições planálticas", existe um elo concreto entre os aterros pré-coloniais associados a casas subterrâneas e as práticas funerárias Kaingang. Ambos exemplos possuem restos ósseos humanos, têm mobiliário funerário composto por itens de cultura material plenamente identificável como Proto-Kaingang, e a 
reconstituição de seus ritos corresponde exatamente às descrições das práticas funerárias Kaingang dos relatos da primeira hora.

O primeiro exemplo, já descrito no capítulo anterior (páginas 66 e 67), trata dos enterramentos descritos por Miller (1971:45) para a "Fase" Guatambu, cuja cerâmica associada, quebrada, e, pós-escavação, reconstituída pelo arqueólogo, pode ser vista na página 151, a seguir.

O segundo, diz respeito a um conjunto de "Esqueletos e utensílios de índios encontrados no Estado de São Paulo", descritos e analisados por Godoy (1947), professor de Antropologia Criminal da Escola de Polícia de São Paulo e médico-antropologista do Serviço de Identificação do mesmo Estado. Ele publica em 1947 seus pareceres sobre esqueletos e utensílios encontrados em São Paulo, dois anos antes. O primeiro sepultamento por ele examinado é tipicamente Proto-Guarani: deposição secundária em urna funerária corrugada, coberta por outra vasilha cerâmica que lhe servia de tampa. Não havia nenhum mobiliário funerário. $\mathrm{O}$ autor o confunde com sepultamento Kaingang, porque "a opinião dominante é que o interior de São Paulo, Paraná e Santa Catarina foi habitado", exclusivamente, pelo grupo Jê (Godoy:1947:210).

No entanto, os sepultamentos em montículos, e seus mobiliários funerários, provenientes de Guararapes-SP são certamente Kaingang, imediatamente pós-contato, o que possibilita ligar os aterros relacionados a casas subterrâneas das "tradições locais planálticas" com grupos Kaingang. No local, foram

"descobertos alguns esqueletos num pequeno monte de terra. Posteriormente, por determinação do sr. Delegado de Polícia foram realizadas novas escavações (...) em dois montes de terra de $5 \mathrm{~m}$ de diâmetro por $3 \mathrm{~m}$ de altura, sendo constatada a existência de vários crânios humanos e diversos ossos esparsos, já bastante friáveis pela ação do tempo" (Godoy, 1947:211).

Os sepultamentos nos três montículos funerários foram provavelmente realizados entre 1912 (ano da "Pacificação" dos Kaingang paulistas) e 1945 (data do achado), pois junto aos ossos humanos foram encontrados, além de itens tradicionais da cultura material Kaingang, enxadas, facas, machado, diversas pontas-de-projétil (provavelmente de lança) triangulares, arame e porções de arco de barril. 
Dentre os itens de cultura material tradicional, atestando a origem Kaingang dos sepultamentos, também foram encontrados junto aos ossos dez peças cerâmicas, trinta e cinco pontas ósseas bi-determinadas ${ }^{109}$ (ainda com vestígios do "cordel que as prendia à flecha" - Godoy, 1947:212) e "dois pedaços de madeira fina de seção aproximadamente triangular e com restos de fibras que o envolviam no sentido transversal" (Godoy, 1947:213).

Idêntica cerâmica, tanto as cinco tigelas como os cinco vasos piriformes do mobiliário funerário de Guararapes, foi coletada entre os Kaingang paulistas em dois momentos: 1. pelas expedições da Comissão Geológica e Geográfica de São Paulo, em 1906, durante os trabalhos de construção da Estrada de Ferro do Noroeste e 2. por Baldus, em 1947, no Posto Indígena de Icatu-SP ${ }^{110}$. Igualmente, é notável a semelhança entre as formas que ocorrem no mobiliário funerário de Guararapes com aquelas registradas por Maniser (1930:774-776 e figs. 4 (6) e 4(18), já reproduzidas no Capítulo 3). Estas duas formas, tigelas e vasos piriformes, foram nomeadas pelos Kaingang observados por Maniser de pentky e kukru, respectivamente (Maniser, 1930:776).
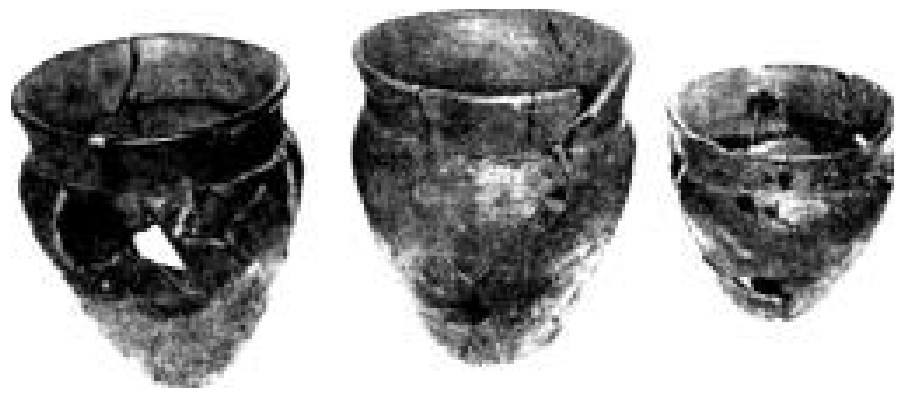

Peças cerâmicas quebradas, associadas a sepultamentos em montículos (Guararapes-SP). Reconstituídas pós-escavação. Formas identificadas como kukrü pelos Kaingang paulistas e de Nonoai-RS. Reproduzido de Godoy, 1947.

Em pesquisa realizada no MAE-USP com os Kaingang paulistas do Posto de Icatu, em agosto de 1999, os mesmos confirmaram tais nomes, afirmando que os primeiros (pentky) eram utilizados para servir porções individuais de alimentos, e os segundos (kukru), para fazer ensopado de quati com palmito. Os Kaingang de Nonoai - RS também usaram as mesmas palavras para designar as tigelas e os vasos piriformes (que viram em fotografias) do acervo do MAE.

\footnotetext{
${ }^{109}$ Veja, no capítulo seguinte, estudo sobre as flechas kaingang.

${ }^{110}$ Atualmente, este acervo cerâmico encontra-se no Museu de Arqueologia e Etnologia da USP, e será trabalhado nesta tese mais adiante e no Apêndice.
} 


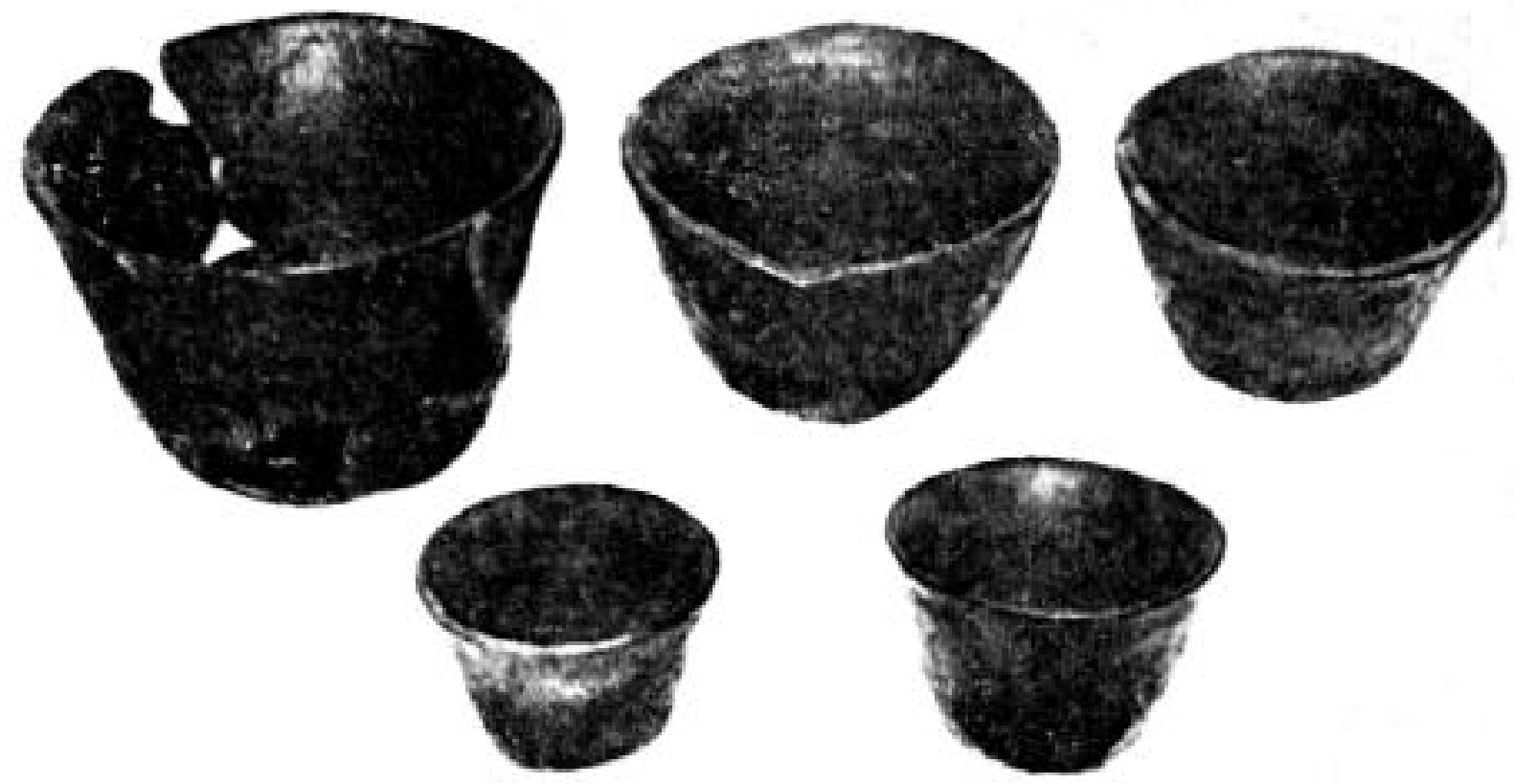

Peças cerâmicas associadas a sepultamentos em montículos (Guararapes-SP). A maior foi reconstituída pós-escavação. Formas identificadas como pentky pelos Kaingang paulistas e de Nonoai-RS. Foto reproduzida de Godoy, 1947.

As pontas ósseas bi-determinadas do mobiliário funerário dos sepultamentos de Guararapes são idênticas às estudadas no Capítulo 5, do acervo do MAE-USP, como também o são àquelas apresentadas por Maniser no seu estudo de 1914/15 entre os Kaingang paulistas (Maniser, 1930:772 e fig. 4 a), o que também comprova que o enterramento é Kaingang. 


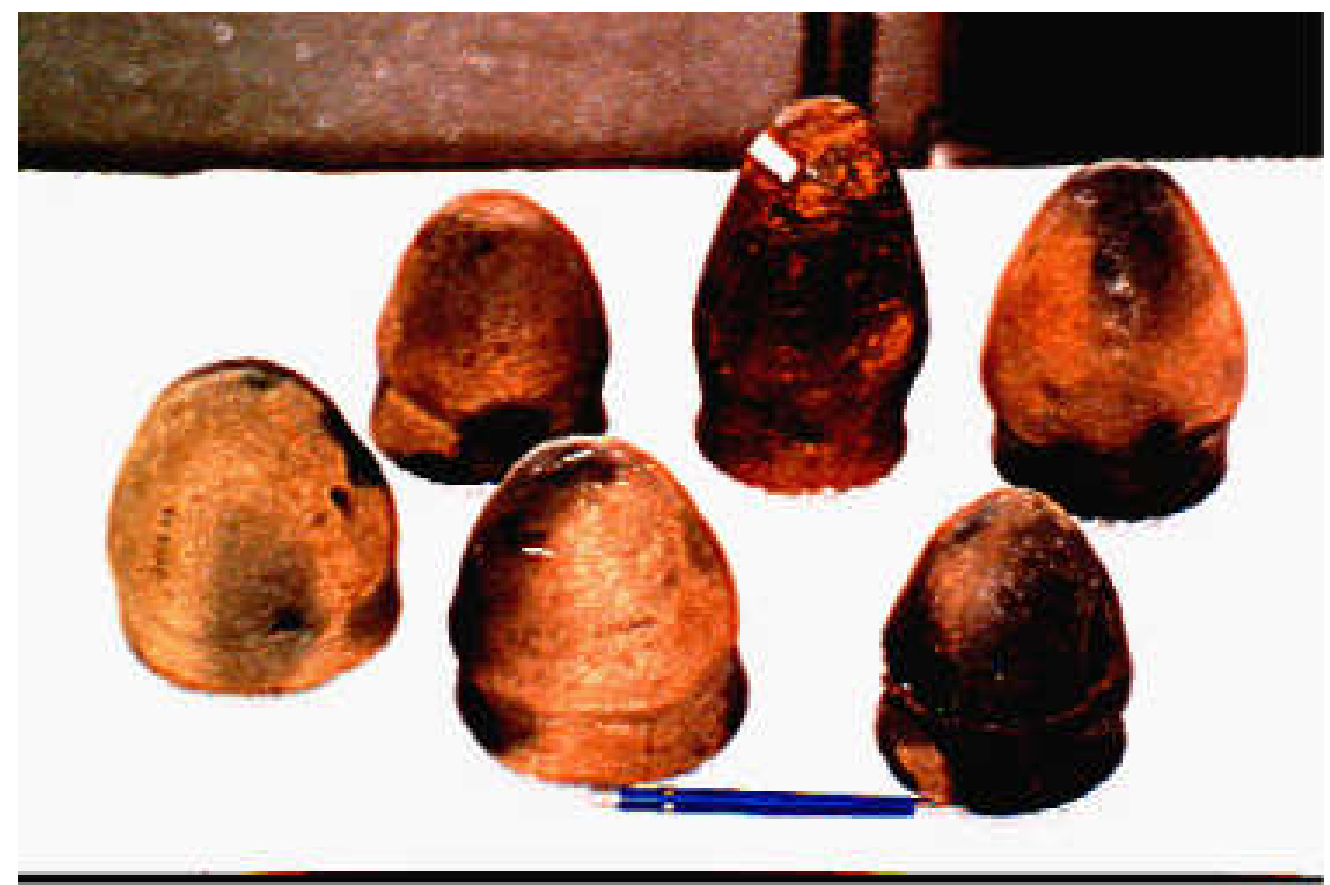

Panelas de barro Kaingang de São Paulo - Acervo MAE/USP. Coletadas por Baldus, 1947. Identificadas como kukrü, pelos kaingang paulistas e de Nonoai-RS.

As estruturas funerárias (montículos de terra) e os objetos associados aos sepultamentos de Guararapes (armas e cerâmica de uso pessoal do falecido) conferem precisamente com as descrições de Maniser (1930) para o enterramento kaingang por ele observado em São Paulo, dois anos após a "Pacificação", o que vem a indicar que os primeiros são efetivamente kaingang. Além disso, materiais históricos comprovadamente de origem kaingang (cerâmica, armas) são iguais a materiais arqueológicos de mesma espécie, ficando, assim, estabelecida a relação direta entre os montículos pré-coloniais ligados a casas subterrâneas das ditas "tradições locais planálticas" com grupos kaingang e suas práticas funerárias características. 


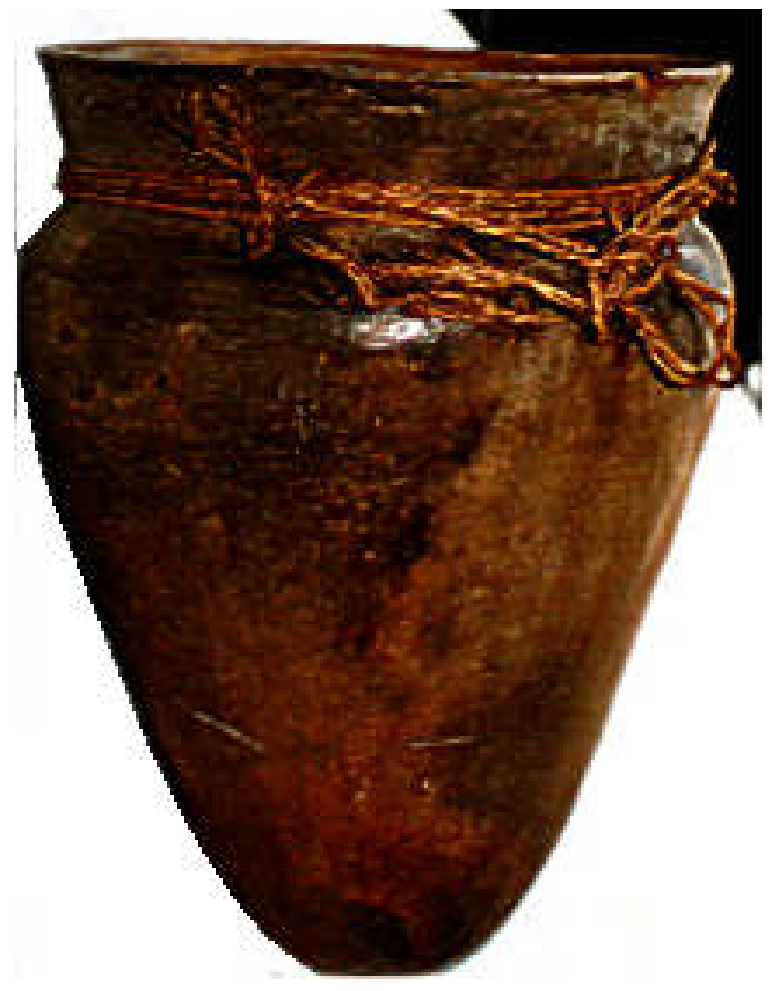

Panela de barro (nga ta kukrü) Kaingang de São Paulo. Coletada em 1947. Acervo MAE-USP. RG.2.564.

Infelizmente, não se pode tirar maior proveito dos sepultamentos de Guararapes. Por tratar-se de trabalho de "escavação" não realizado por arqueólogos, não houve preocupação em identificar o número de sepultamentos por montículo, a associação individual de cada enterramento com o mobiliário funerário, nem a relação temporal entre os sepultamentos.

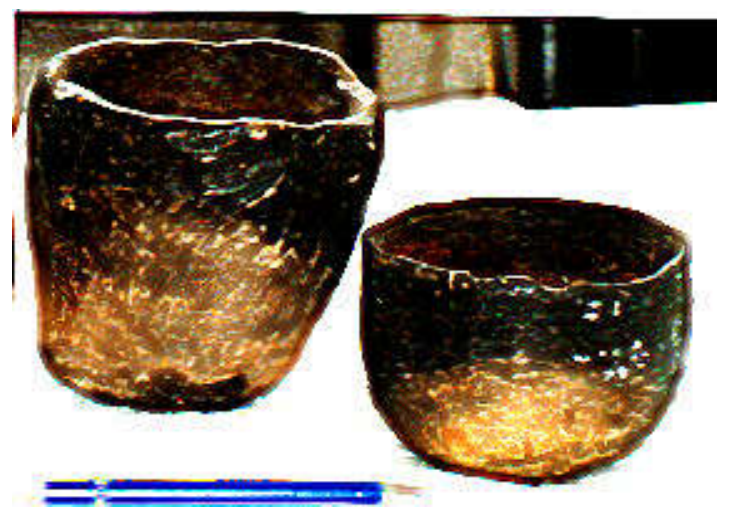

Acervo do MAE/USP. Coletadas por Baldus, 1947. Identificadas como pentky pelos Kaingang paulistas e de NonoaiRS. 
Entretanto, Godoy (1947) chega à conclusão que no mínimo tem-se o sepultamento de dez pessoas (cinco de idade inferior a 19 anos e cinco adultos), distribuídas entre os três aterros, o que justifica considerá-los de uso coletivo. Além disso, os esqueletos tinham diferença nos seus estados de conservação: "uns ainda com a estrutura óssea normal e outros já terrosos e extremamente friáveis", o que indica um lapso temporal relativamente longo de uso continuado do mesmo conjunto de montículos funerários e, talvez, a presença de sepultamentos pré-contato.

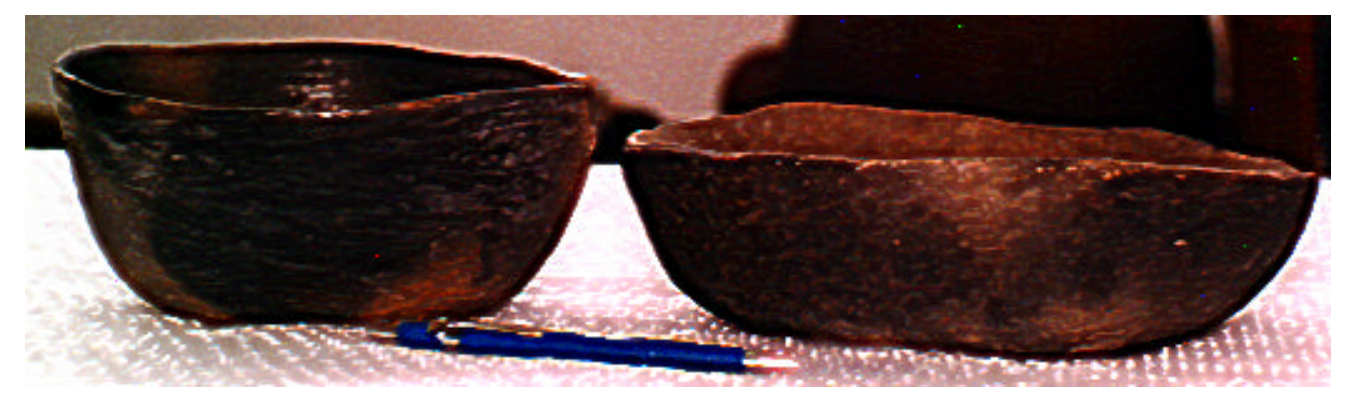

Acervo do MAE/USP. Coletadas por Baldus, 1947. Identificadas como pentky pelos Kaingang paulistas e de Nonoai-RS.

Mas como era o padrão tradicional de sepultamento Kaingang? O que dizem os relatos dos primeiros momentos pós-contato, quando ainda era seguido o padrão funerário tradicional?

Com relação ao mobiliário funerário, sua razão de ser é facilmente compreendida:

“...para que os mortos não venham em busca do que lhes pertence, suas roças eram destruídas, panelas quebradas, animais sacrificados e objetos de uso pessoal enterrados com o morto" (Veiga, 2000:155).

Este procedimento fica bem explicitado em Maniser (1930), sendo detectável perfeitamente bem nos sepultamentos de São Paulo, estudados por Godoy (1947), graças aos poucos anos passados entre os sepultamentos e a escavação. 


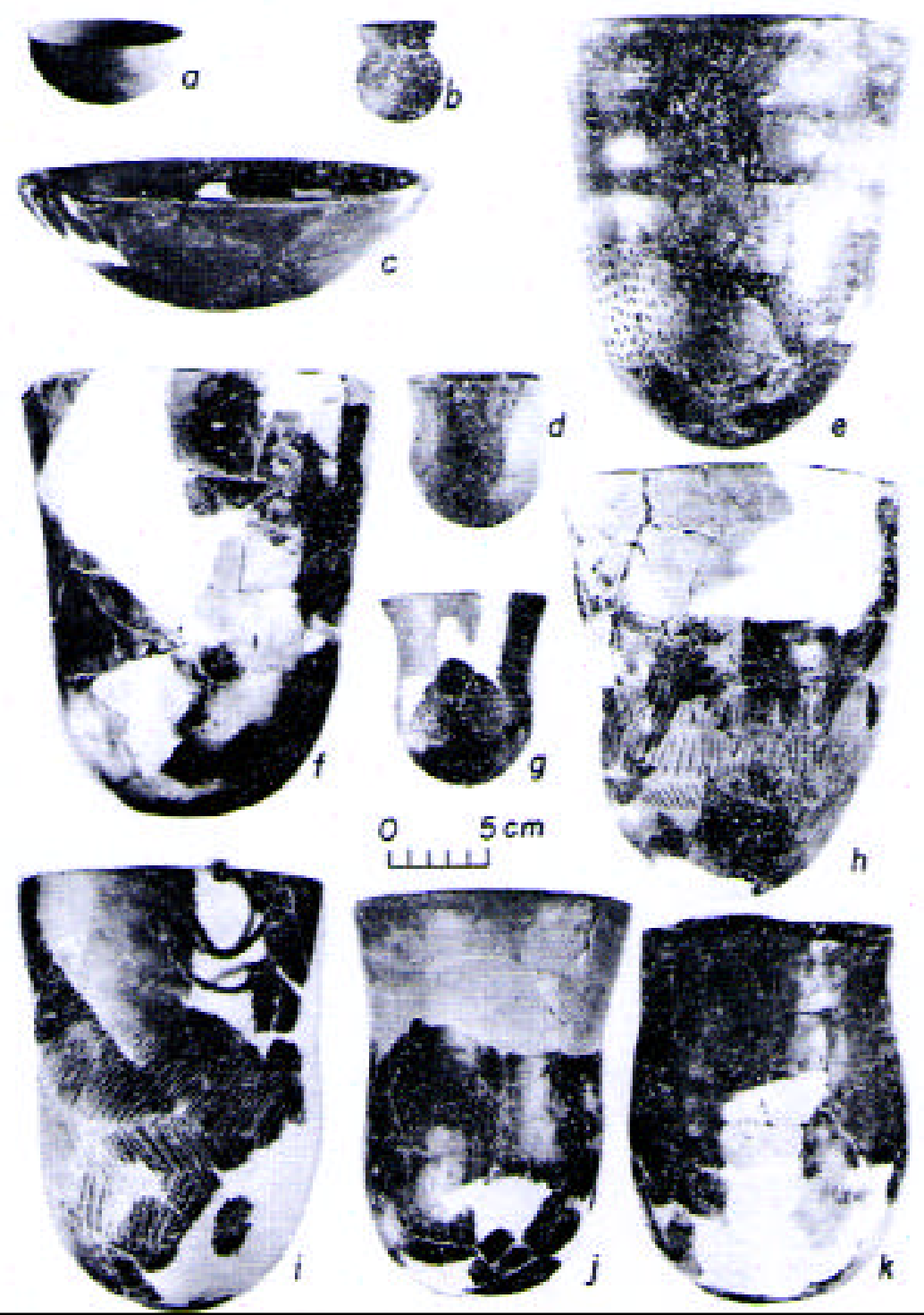

Cerâmica da "Fase" Guatambu, associada a enterramentos em montículos em abrigos-sob-rocha no RS. Como todos os recipientes puderam ser reconstituídos, isto indica ou que foram depositados inteiros ou quebrados, ritualmente, no local dos sepultamentos. Reproduzido de Miller, 1971:estampa 10.

Leão (1910:10), que observou os Kaingang de Palmas, região centro-sul do Paraná, no início do século XX, assim o descreve:

“...introduziam o cadáver numa cova forrada com paus e cascas. A cova media sete palmos de comprimento, três de largura e quatro de profundidade. Com o corpo eram depositados os objetos que lhe pertenceram e um facho aceso. Após protegerem a abertura da cova com paus, levantavam um montículo de terra com dez a vinte palmos de altura". 
Na mesma região de Palmas, algumas dezenas de anos mais tarde, Baldus (1937) e Fernandes (1941) já não mais observaram este padrão, e sim o sepultamento em cova simples de 4 a 6 palmos de profundidade, sem montículo sobre a mesma. Porém, Fernandes (1941:203-4), sem revelar suas fontes ${ }^{111}$, descreve o antigo padrão, que culmina com o montículo de terra:

"Fazem hoje covas profundas, como os sertanejos vizinhos, e não levantam sobre o túmulo montículos de terra como faziam seus avós. Estes não cavavam profundas covas; tinham no máximo 3 a 4 palmos, forravam-nas com folhas de palmeira e pedaços de córtex de árvore, depositando aí o cadáver amortalhado no seu curú ${ }^{112}$, cobrindo-o com outros pedaços de córtex.

"Do lado direito do morto, eram colocadas as armas usadas em vida: arcos, flechas, lanças e os ornatos, penas, colares, etc. À esquerda, panelas com farinha, nós de taquara contendo água e um tição.

(...)

"Acima do cadáver, nas vizinhanças das bordas da cova, faziam uma armação de galhos de árvores, a qual, depois de bem forrada com folhas de samambaia, constituía um verdadeiro teto protetor dessa espécie de câmara funerária sobre a qual era colocada espessa camada de terra.

"Sendo o enterramento feito em cova superficial era sobre esta levantado um túmulo de terra. Tem forma cônica e uma altura de 10 a 12 palmos. Há em Palmas um antigo cemitério na margem esquerda do rio Cachoeira, onde ainda é possível ver uma série de montículos de terra.

"Queimavam o rancho, e o outro cônjuge ia para a casa dos pais ou dos filhos" (Fernandes, 1941:102-3).

A ausência arqueológica de restos ósseos nos montículos é, também, por vezes, motivo para compreensão não correta da estrutura. Como não são encontrados vestígios esqueletais, pensa-se, de imediato, em cremação e, por via de conseqüência, em ritos funerários Xokleng, uma vez que estes últimos também elevavam um aterro sobre o local onde sepultavam seus mortos.

\footnotetext{
${ }^{111}$ Porém, na página 204 (op. cit.), o autor diz que contou com "depoimentos fidedignos de pessoas contemporâneas de fatos culturais já extintos", referindo-se ao sertanista Manoel A. Gomes, companheiro de Telêmaco Borba. Este último, assim descreve os rituais funerários: "Se morre, imediatamente o enterram, deitado, com seu arco, flechas, curú e machado, em uma cova superficial, forrada e coberta com madeiras e terra por cima destas; fazem seus vinhos [quiqui] e convidam os vizinhos para levantar a sepultura, carregando terra em cestos, deitando-a sobre esta, até a forma de uma pirâmede cônica, de dois a quatro metros de altura e seis a oito de diâmetro na base" (Borba, 1098:13).

${ }^{112}$ Tecido nativo feito com fio de urtiga.
} 
As informações etnográficas constantes em Vasconcellos (1912:19), que observou as estruturas funerárias Xokleng, corroboram esta informação:

"Nos cemitérios destes selvagens não se pode conseguir crânios e ossos, visto o uso que eles fazem da cremação dos corpos, não só daqueles que morrem pacificamente no seio da tribo, como também dos que são mortos nos ataques e ficam no campo inimigo; pois os que escapam pela fuga, voltam mais tarde para conduzir os corpos dos seus. As sepulturas em que depositam as cinzas de cada corpo que cremam consistem em buracos feitos cuidadosamente na terra, com a forma de uma panela de barro; e conforme a categoria do morto dão maior ou menor altura na terra que elevam os mesmos buracos, cujo diâmetro na parte superior é de $30 \mathrm{~cm}$, o do bojo de $50 \mathrm{~cm}$ e de altura 56 $\mathrm{cm}$; tendo o monte que elevam a forma de um cone truncado com a altura variável de 50 a $60 \mathrm{~cm}$, sendo estas as dos caciques".

Henry (1964 apud Lavina, 1994:69/70) traz um depoimento do índio Vamblé, sobre os ritos funerários Xokleng:

"O morto era envolvido em um cobertor, com seu arco e flechas próximos. O acordoamento do arco é cortado e este, juntamente com as flechas, é quebrado e o conjunto é amarrado com os restos do acordoamento. Em um local preparado, são empilhados pedaços de madeira até a altura da cintura de um homem e sobre esta estrutura é depositado o cadáver com seus objetos pessoais. O morto é orientado com a cabeça para oeste e em suas mãos são postas oferendas de mel e carne assada. A seguir o cadáver é recoberto com madeira até a pilha alcançar a altura de um homem, sendo o conjunto escorado com estacas para não desmoronar. Após acender a pira com um bambu incandescente, as pessoas se retiram, voltando um dia depois. Caso o cadáver não esteja completamente cremado, o processo é repetido. Quando os ossos estão calcinados, são recolhidos em um cesto forrado com folhas de xaxim e transportado em uma padiola para o local do enterramento, que consiste em uma área limpa de vegetação com uma cova em seu centro. Os cestos com os restos da cremação são ali depositados e enterrados. Sobre este local, o cônjuge sobrevivente constrói um pequeno abrigo".

Vê-se, pois, que devido aos quatro fatores a seguir listados, os enterramentos pré-coloniais Kaingang e Xokleng podem ser confundidos pelo pesquisador menos avisado: 1. alta acidez do solo que destrói completamente os materiais orgânicos, tanto os restos humanos como o mobiliário funerário dos 
enterramentos Proto-Kaingang ${ }^{113} ; 2$. a presença de aterro tanto sobre os sepultamentos pré-coloniais Kaingang como naqueles Xokleng pré-contato; 3. os objetos pertencentes ao falecido Xokleng, no período pré-contato e imediatamente pós-contato, são incinerados, ou seja, não restam evidências daqueles feitos de materiais orgânicos e 4. muitas vezes era colocado um "facho acesso" junto à câmara mortuária Kaingang, o que poderia produzir falsas evidências arqueológicas de cremação, pois o arqueólogo constataria vestígios de combustão no interior da cova. Este último procedimento é descrito por Maniser (1930:781-2), que relata ser a cova queimada antes da introdução do(a) falecido(a) e de seus objetos pessoais. Conforme Veiga (2000:166), isto é feito para "obrigar os espíritos dos coveiros a sair de dentro dele [buraco], antes que o corpo do defunto [fosse] ali colocado".

Entretanto, as diferenças entre as duas estruturas existem: 1. apenas os sepultamentos Proto-Kaingang possuem câmaras para depositar o falecido; 2. uma vez que recebem apenas cinzas, as estruturas Proto-Xokleng tenderiam a ser menores que as Proto-Kaingang; 3 . sobre as estruturas Xokleng poderiam ser construídos pequenos abrigos, cujos vestígios arqueológicos podem ser detectados.

De qualquer forma, as diferenças não parecem se manifestar de forma assim tão cristalina. Borba (1904:124-5, apud Chmyz \& Sauner, 1971), descrevendo suas escavações em montículos da região de Tibagi - leste do Paraná -, relata a presença, na mesma estrutura arqueológica, de vestígios de cremação e de câmara mortuária. $O$ autor chega à conclusão que "estes montículos são túmulos ou sepulturas de uma nação ou tribo que usava a cremação de seus mortos", pois em suas escavações sempre se deparava "com uma laje de $40 \mathrm{~cm}$ de comprimento sobre 30 de largura" e "removendo-a encontramos: carvão e cinzas sobrepostos a uma laje horizontal, e duas em sentido vertical".

É bom frisar que, neste relato, estamos diante de Borba "arqueólogo", que muito provavelmente não empregava técnicas confiáveis, e não do sertanista, bom observador dos fatos etnográficos.

\footnotetext{
113 "Duma relação escrita no século passado, sobre índios kaingang do Rio Grande do Sul e publicada por Antonio Serrano, consta que em alguns túmulos, cuja idade foi calculada em 30 anos ou pouco mais, os ossos também já tinham desaparecido" (Drumond \& Philipson, 1947:390).
} 
Os relatos etnográficos estabelecem claramente a diferença entre os padrões de sepultamento Kaingang e Xokleng. Respectivamente, temos, de um lado, deposição primária em cova revestida (câmara mortuária), com associação de mobiliário funerário (objetos pessoais do falecido) e montículo de terra sobre a sepultura, e, de outro, deposição das cinzas do corpo e dos objetos pessoais do morto em cova simples, com montículo de terra sobre a sepultura. Do ponto de vista arqueológico, entretanto, o problema reside na visibilidade concreta desta diferença no registro arqueológico.

Em outras palavras, apesar de algumas certezas, a própria limitação do dado arqueológico gera outras tantas dúvidas que reduzem a possibilidade de termos os padrões de sepultamento Kaingang e Xokleng como indicadores arqueológicos seguros desta diferença.

O caso dos montículos escavados por Chmyz \& Sauner, no Vale do Rio Piquiri-PR e associados à "Fase" Cantu, é paradigmático. Baseado na ausência de restos ósseos e na presença de cinzas e carvão, que foram analisados por peritos, os autores supõem que o

"aterro grande foi utilizado para práticas funerárias envolvendo cremações. (...) As amostras das presumíveis cremações atestaram quantidades consideráveis de óxidos de cálcio e ferro e anidrido fosfórico, reforçando as nossas suposições iniciais" (Chmyz \& Sauner, 1971:30).

Esta conclusão, no entanto, é bastante discutível. Em primeiro lugar, as quantidades dos elementos óxido de ferro e anidrido fosfórico, apontados como indicadores das possíveis cremações, são superiores para o primeiro elemento e praticamente igual para o segundo nas amostras designadas pelos autores como "escórias minerais", conforme se vê abaixo (Chmyz \& Sauner, 1971:32):

óxido de ferro

óxido de cálcio

anidrido fosfórico

$$
\text { "cremações" }
$$

$6,72 \%$

$35,28 \%$

$2,83 \%$ "escórias minerais"

$20,48 \%$

$4,93 \%$

$2,53 \%$ 
Ademais, os peritos do Instituto de Biologia e Pesquisas Tecnológicas do Estado do Paraná constataram em ambos tipos de amostras os mesmos elementos, em quantidades semelhantes ${ }^{114}$.

Some-se a estes fatos, a constatação dos autores de que a "escória mineral, aplicada em camadas sobre as lajes de argila queimada no aterro grande do sítio PR UB 4" (...) "revelavam um alto teor de óxidos de ferro e alumínio e sílica, sugerindo processamento em fornos de fundição deficientes" (Chmyz \& Sauner, 1971:30), o que "pode significar o contato desta fase de tradição Itararé e o elemento europeu por volta de 1620 da nossa era. Ou, talvez, logo após o abandono da área pelos militares e religiosos, com as investidas das bandeiras paulistas entre 1632/33" (Chmyz \& Sauner, 1971:31).

Os autores coletaram escórias semelhantes na Ciudad Real de Guairá e as amostras do mesmo local, colhidas por Salvador Lizaraldi, "indicaram uma tentativa de fusão de ferro-manganês, mas que por deficiência de calor e redutor, não houve redução de óxidos" (Chmyz \& Sauner, 1971:30-1).

Estes fatos parecem indicar uma não-confiabilidade das informações que levam à suposição de um possível emprego de práticas crematórias na "Fase" Cantu.

No futuro, outras técnicas mais confiáveis, tanto do ponto de vista da escavação como laboratorial, deverão ser utilizadas para que se possa testar o uso do reconhecimento do padrão de enterramento pré-colonial como indicador da diferença Kaingang e Xokleng.

Além disso, dados etnográficos sobre os Kaingang revelam diferenças internas nas formas de sepultar, que poderiam gerar confusões de interpretação.

Os membros da categoria cerimonial dos pêin e os pertencentes à seção Wonhétky da metade Kamé eram enterrados fora do cemitério da aldeia: "eles comem os outros espíritos", segundo o discurso nativo (Veiga, 2000:156).

Os enterramentos infantis também costumavam ser diferenciados:

\footnotetext{
${ }^{114}$ Além dos três elementos já citados, temos: sílica, óxido de alumínio, de manganês, de titânio, de magnésio, de sódio e de potássio, cf. Chmyz \& Sauner, 1971:32.
} 
"Para as crianças não constroem estas pirâmides: enterram-nas em covas rasas e não fazem festa" (Borba, 1908:13) ${ }^{115}$.

Este procedimento talvez deva-se ao fato de estas crianças, por sua pouca idade, não representarem perigo para a comunidade, não havendo necessidade, pois, de realizar a festa do Kiki. Aliás, a este respeito, Veiga (2000:160) traz o mesmo dado para a área indígena de Xapecó, único local onde ainda é realizado o Kiki, pois, segundo um kuiã da área, ela não tem espírito ainda.

Muitos procedimentos funerários, inclusive, diferenciavam-se pelo "status" e pela idade do falecido ${ }^{116}$. Isto, possivelmente, irá se refletir na estrutura mortuária analisada pelo arqueólogo.

Com relação à estrutura funerária tradicional Kaingang, Veiga (2000:163) observa que sua parte externa (o montículo, a pirâmide) lembra a montanha primordial $^{117}$, salvadora, do mito de origem da sociedade Kaingang, primeira sepultura dos heróis míticos Kamé e Kainru, quando morreram após a grande inundação. A vala que circunda o túmulo, tantas vezes descrita pelos arqueólogos do sul do Brasil que escavaram estes "montículos", segundo interpretação de Veiga (op.cit., p. 163), "se enche de água com as chuvas" e simboliza "o rio que a alma deve atravessar para chegar ao mundo dos mortos".

Para finalizar este capítulo, objetivando comparar as informações existentes sobre padrões de sepultamento de outras sociedades falantes de línguas da Família Jê com os dados etnográficos para os Jê meridionais, passo a sumariar o padrão de sepultamento dos Suyá, relatado por Frikel (1991), dos Kayapó,

\footnotetext{
115 “O mesmo modo de enterrar, sem deixar vestígios exteriores era também conhecido entre os 'Coroados', descritos por von Koenigswald, mas apenas quando se tratava de crianças”, cf. Drumond \& Philipson, $1947: 392$. "Para as crianças não constroem estas pirâmedes; enterram-nas em covas rasas e não fazem festa", segundo Borba, 1908:13.

116 "Quanto mais velho o morto, maiores perigos representa para a comunidade, porque possui mais conhecimento, mais poder e mais relações, portanto há um investimento maior na separação dele da comunidade" (Veiga, 2000:160).

117 "Não se pode deixar de ver nessa montanha, e no buraco que, por ela, comunica os dois mundos - buraco (nga'ndor, também sepultura), esse que é simbolicamente reaberto e, posteriormente, fechado durante o ritual do Kiki - um dos símbolos típicos de um axis mundi (...). O lugar do enterramento significa a porta invisível que liga um dos planos do mundo Kaingang a outro; o nível terreno e mortal, ao subterrâneo, nível mítico do mundo dos ancestrais" Veiga, 2000:227.
} 
registrado por Vidal (1977) e dos Krahó, estudado por Carneiro da Cunha. (1978).

Quanto aos Suyá, Frikel registra o uso do choro cerimonial dos parentes próximos, após a constatação da morte. Descreve, igualmente, as atividades para enfeitar e pintar o morto. Ponto de maior interesse para este trabalho, no entanto, é a descrição da sepultura e do modo de enterramento tradicionais suyá, cuja semelhança com o dos Kaingang é bastante visível.

Segundo Frikel (1991:19-20), a sepultura consiste em

"uma cova redonda de $1 \mathrm{~m}$ de profundidade aproximadamente. Revestem-se as paredes da cova com folhas de palmeiras ou, mais vezes ainda, com esteiras. Põe-se um banquinho sobre o qual o cadáver será sentado. Em seguida vão buscas o defunto que vem carregado nos braços. Quem carrega defunto para a sepultura - seja ele homem ou mulher - sempre é homem, a saber os 'amigos cerimoniais' ou outros parentes mais afastados, pois os pais, irmãos e filhos ficam só chorando, não fazem enterro. Afinal, o cadáver é colocado na cova e sentado sobre o banco, mas sempre com o rosto para o lado do nascente. Para o cadáver ficar em posição de sentado, fincam-se uns paus de forquilhas dentro da sepultura, de maneira que dois apóiam as axilas e outro o queixo, sustentando a cabeça e os ombros. Pernas e braços não são amarrados. As mãos são colocadas no colo.

"Terminados estes preparativos, põem-se os pertences do falecido na sepultura ou, quando os objetos são muitos, de todos somente alguns. Também objetos de nossa civilização, como roupas, etc. são colocados, nunca porém armas. Bordunas, flechas e arcos são quebrados e queimados, exceção feita a carabinas e espingardas que, hoje em dia, vão de herança de pai para filho. Coisa semelhante se dá com a cerâmica. As panelas da mulher defunta são quebradas e jogadas fora, mas os seus objetos de uso particular sempre se coloca na sepultura.

"Por fim, fecha-se a sepultura fazendo uma grade de varas sobre a abertura, sobre as quais são colocadas esteiras ou folhas de bananeiras para não deixar cair terra para dentro da pequena câmara mortuária que assim se criou. Cobre-se tudo com terra e batese bem a terra em cima da sepultura para ficar dura. As sepulturas são feitas normalmente ou na roça ou no próprio terreiro da aldeia, nunca dentro das casas. Existiam cinco sepulturas na aldeia suiá, mais ou menos no centro do terreiro, um pouco desviadas para o lado norte. Chamam-nas wükáke".

As semelhanças entre o padrão Suyá e o padrão Proto-Kaingang são muitas: revestimento das paredes da cova; cobertura da cova para formar câmara mortuária; pertences do falecido na cova; quem carrega o falecido para a 
sepultura pertence a uma classe cerimonial, que no caso dos Kaingang (os pêin) sabe-se que destinada exclusivamente para lidar com a morte.

O caso Kayapó é assim descrito por Vidal (1977:170-72):

"Uma pessoa morre quando seu mekarõn (espírito, imagem) o abandona definitivamente. Coloca-se então o seu corpo numa esteira com as pernas dobradas. (...)

"Os ritos mortuários e a aldeia dos mortos. São os jovens menõrõnu (ou um deles), isto é, os que não têm filhos, que cavam a sepultura, chocando-se em seguida contra um jatobá (moy), recurso mágico para não morrer e fortalecer-se internamente. (..)

"O morto é enterrado num cemitério que se encontra a uns trezentos metros da aldeia. Às vezes, também no barracão de alguma roça. A sepultura é arredondada ou retangular. O morto é deitado com as pernas dobradas e com o tronco inclinado, como se estivesse sentado. Sua cabeça é colocada em direção a leste porque a aldeia dos mortos está sempre localizada a oeste. É envolto numa esteira ou rede, nos dias atuais. Enterram-se junto os seus pertences, para que o seu espírito (mekarõn) não venha importunar os vivos. Colocam-se varas em cima do fosso que são recobertas, em seguida, com uma esteira. A terra é amontoada por cima em forma de cúpula (pukakrã). (...)

"Sobre a sepultura coloca-se algum objeto pessoal do morto e os cabelos da mulher que observa o resguardo (esposa ou mãe). (...) Às vezes, seu cachorro é morto, pois o mekarõn de seu dono poderia sentir sua falta. (...)

"Acende-se um fogo, ou dois, ao lado da sepultura, reavivado durante várias semanas, para que o morto não sinta frio e não volte à aldeia. O cemitério está infestado de mekarõn e nenhum índio se atreveria a passar a noite, sozinho, perto dele. Ao passar por ali, de tarde, as mulheres cospem de modo típico para afastar os mekarõn. Assim também procedem quando deixam suas roças, ou de noite, nas casas, antes de deitar. (...)

"A dança dos mortos é realizada para incitar o espírito a afastar-se da aldeia dos vivos. Quando morre uma criança deixa-se-lhe uma cuia de leite para que não volte a procurar a mãe. Alguns informantes dizem que também deixam água e comida para os adultos, para que fiquem fortes e achem facilmente o caminho que leva à aldeia dos mortos". 


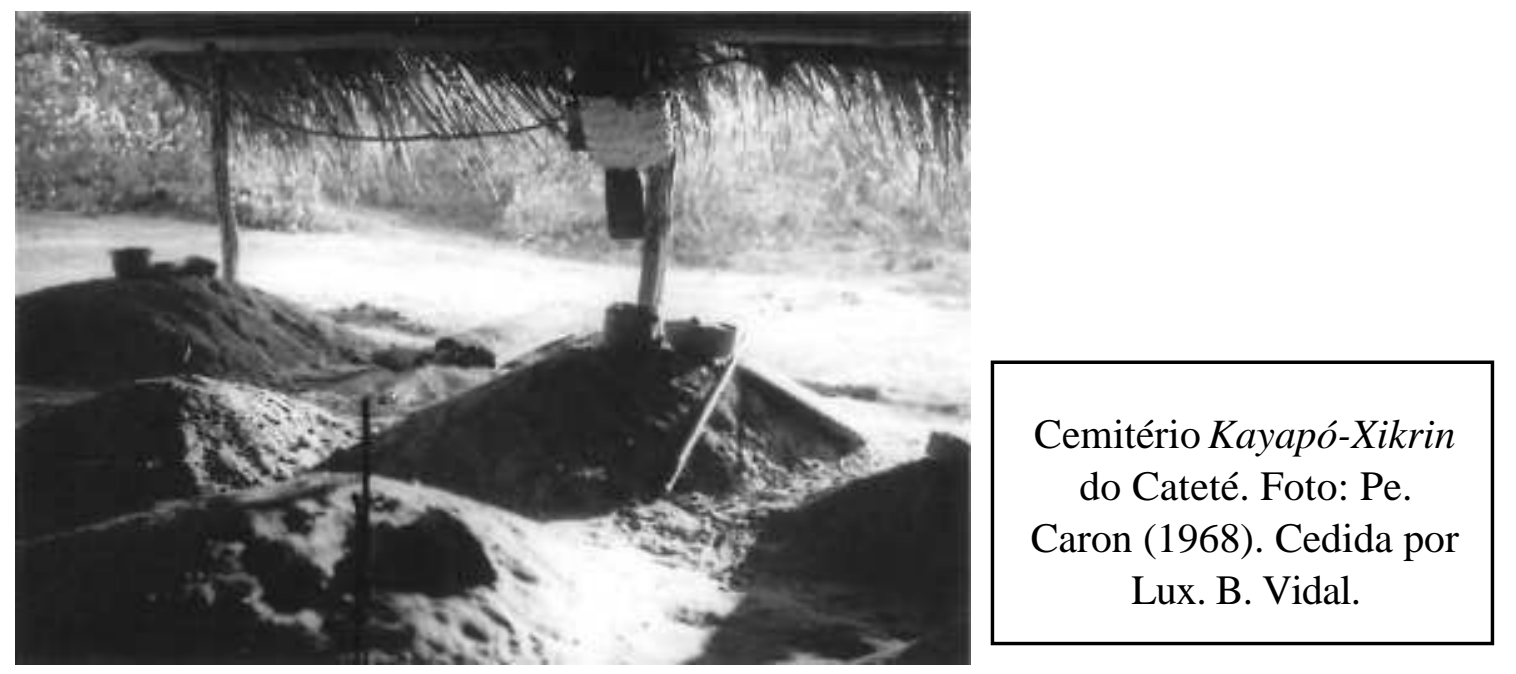

Apesar de não haver uma classe ritual específica para tratar dos mortos como entre os Kaingang, a posição do morto Kayapó, o mobiliário funerário, a câmara mortuária, o "aterro" em forma de cúpula sobre a sepultura, os alimentos para fortalecer o mekarõn na sua jornada até a aldeia dos mortos, os cuidados rituais e os recursos mágicos para afastar os malefícios do espírito do morto, tudo leva a pensar num padrão Jê de representações sobre a morte e o morto, que, conseqüentemente, estarão simbolicamente presentes nos rituais e na materialidade da estrutura de sepultamento.

Os Krahó também utilizam uma espécie de câmara mortuária nos seus sepultamentos, cuja cova é

“forrada com paus fortes (...) por todos os lados. (...) O fundo da cova é forrado com pati da chapada. (...) Por cima destas folhas costuma-se colocar uma esteira nova fornecida pelos coveiros, depois o morto, ou eventualmente o caixão de talos de buriti; em seguida troncos longitudinais tapando a cova, recobertos por mais folhas de pati, eventualmente panos e cobertores do morto, a esteira habitual do morto e por fim a terra é jogada por todos os homens com as mãos" (Carneiro da Cunha, 1978:33-34).

A autora não registra montículo de terra sobre a cova.

Quanto ao mobiliário funerário, Carneiro da Cunha assinala que como tradicionalmente ocorre "em quase todas as tribos Jê, a propriedade de um indivíduo era ou destruída ou enterrada com seu proprietário ou tomada por estranhos" (1978:131), principalmente as insígnias de status. Estas são tomadas por outro krahó, não-consangüíneo, e já possuidor do mesmo status. Um 
machado de pedra (khoiré), insígnia de bons cantadores, será herdado por outro cantador; um maracá de um chefe de rituais será tomado por alguém do mesmo status, etc.

"Tudo se passa como se, à morte do krahó, se procedesse a uma 'hecatombe', a uma destruição ou dispersão do que se relacionava com seu corpo, sua aparência, seu organismo.

"Poderíamos pensar os objetos destruídos como fazendo parte do indivíduo, de um indivíduo com suas 'extensões metonímicas' (...), que as distingue da propriedade no sentido lato: aquilo que o homem faz com suas próprias mãos, aquilo que manuseia, aquilo que o adorna fariam parte de sua individualidade. (...)

"Os objetos do morto são tidos por terem perdido o karõ [duplo, espírito] e consequientemente se quebrarem ou gastarem muito depressa. Teoricamente, é vedado aos parentes conservarem os pertences do morto, sob pena de incorrerem em sua ira e ele os atacar quando estiverem sós no mato. Mas a proibição visivelmente não inclui objetos mais cobiçados, conhecidos desde o contato com os regionais" (Carneiro da Cunha, 1978:132-33).

Diante destas representações sobre a morte e sobre o morto, a autora reflete sobre os objetos que poderiam fazer parte do mobiliário funerário de um krahó. Sem muita temeridade, e de acordo com os dados já registrados neste subitem, pode-se estender esta conclusão a quase todas as sociedades Jê:

"Tudo concorre, parece-nos, para apontar novamente a absoluta estranheza que caracteriza o morto. Ele se tornou 'outro', e seus bens, pelo menos os que chamaríamos pessoais, adquirem juntamente com ele esse atributo da alteridade. Daí a equivalência entre acompanharem o morto sendo enterrados com ele, serem destruídos como ele o foi, ou pertencer doravante a estranhos já que estranhos eles próprios se tornaram. A herança não poderia portanto concernir senão bens que não fossem concebidos como parte da pessoa" (op. cit., p.134).

Neste sentido é que devem ser compreendidas as localizações possíveis do sepultamento krahó e suas implicações simbólicas, já que, como enfatiza, genericamente, Carneiro da Cunha (op. cit., pág. 35), "o lugar do enterro é carregado de significado". Atualmente, há vários locais possíveis para sepultamentos: os cemitérios, de tradição ocidental, uso já antigo, mas não generalizado; atrás das casas, quando pais, em sinal de afeição enterram aí filhos, mesmo adultos; cemitérios só de crianças, perto do círculo das casas ou em aldeias abandonadas. 
Entretanto, antigamente, vigorava entre os krahó o enterro secundário. Ao que parece, o enterro primário era realizado dentro das casas - somente para crianças e já que estas não tinham acesso ao segundo enterro - ou atrás da casa materna. Após desenterrados, os ossos eram lavados e pintados. O segundo sepultamento era praticado ou na casa materna, de origem, do morto, ou no pátio da aldeia, apenas para personagens de destaque - chefes, prefeitos, cantadores, etc. (op. cit., pág. 36).

Anthony Seeger informou à autora (junho de 1973) que os suyá - que não usam enterros secundários - praticam "um enterro dentro da casa, no lugar onde o morto dormia ou perto da porta, a não ser para os chefes e seus filhos e filhas que são inumados no pátio" (idem, pág. 36) ${ }^{118}$.

Este modelo krahó/suyá de localização espacial do cadáver está ligado ao "duplo aspecto de todo krahó": "por um lado ele foi membro (...) de um segmento residencial, onde desenvolveu e tramou o que chamaríamos suas atividades privadas (...); por outro lado, ele foi eventualmente um personagem público, isto é, investido de valores da sociedade como um todo" (idem, pág. 37).

Resumindo, a localização do tradicional enterro definitivo está intimamente relacionada à categoria dual de entendimento da persona krahó/suyá, que possui dois tipos de relacionamento: as relações fisiológicas, desenvolvidas a partir de um grupo de subsistência, vinculadas ao espaço doméstico; e as relações cerimoniais, baseadas no nome, ligadas ao espaço público; ou seja, de um lado, indivíduo, de outro, pessoa ${ }^{119}$.

Ao que tudo indica, estamos diante de um padrão Jê de sepultamento, com pequenas variações de uma sociedade em relação à outra ou com diferenças de detalhes entre regiões habitadas pela mesma sociedade. O padrão de enterramento Proto-Xokleng, pelo uso de cremação do corpo e incineração de todos os objetos pessoais do falecido, parece ser o que mais se diferencia do

\footnotetext{
${ }^{118}$ Em 1989, em minha dissertação de mestrado sobre a aldeia pré-histórica da Tapera-SC, habitada por grupos Proto-Jê do sul, interpretei a existência de dois padrões de sepultamento - um dentro das casas, ao longo das paredes; outro fora delas, no que poderia ser o "pátio" da aldeia - como pertencentes a dois grupos Proto-Jê (o mobiliário funerário de ambos "padrões" é idêntico) que teriam habitado, em épocas diferentes, o mesmo lugar. Hoje, não tenho mais tanta certeza disto ...

${ }^{119}$ Veja discussão mais detalhada sobre a noção de persona Jê no subitem 5.1.2: Vein kongat: pintura corporal Kaingang.
} 
padrão geral Jê, o que poderia estar vinculando-o a grupos norte amazônicos. Isto talvez também se deva ao fato de ter sido o primeiro grupo Jê em migração a separar-se no longo caminho rumo ao sul, bem como à perda de contato pacífico com os demais grupos migrantes ${ }^{120}$.

${ }^{120}$ Conforme os modelos lingüísticos de Wiesemann (1978) e de Urban, e o modelo arqueológico de Brochado (1984), já comentados neste capítulo e na Introdução. 


\title{
5. O SISTEMA DE REPRESENTAÇÕES VISUAIS (PROTO)JÊ MERIDIONAL
}

\begin{abstract}
"Nas culturas pré-letradas ou proto-letradas, o símbolo artístico se torna o fato; isto é, ele representa, define e manifesta, simultaneamente, seus referentes. Nessas culturas, os objetos de arte e os eventos são os meios de resgatar a informação, em lugar dos livros."(Otten, 1971, XIV).
\end{abstract}

B. Ribeiro (1987), em artigo que focaliza “A linguagem simbólica da cultura material", sintetiza os aspectos teóricos e metodológicos dos estudos sobre arte indígena. A maior parte dos parágrafos que seguem foram baseados nas reflexões ali contidas.

Por sistema de representação visual entende-se todo grafismo (pintura corporal, arte parietal, etc.), objetos rituais ou de adorno, padrões decorativos, tipos e motivos de trançados ou plumária, ordenação do espaço, etc. Tais sistemas visuais, enquanto código cultural, "são mecanismos de ordenação e de comunicação da experiência, culturalmente determinados". (B. Ribeiro, 1987, p. 22).

Estas manifestações estéticas indígenas são sistemas de representação que procuram explicar como a sociedade pensa a si própria e o mundo que a rodeia.

Neste sentido, as expressões estéticas Proto-Jê e Jê meridionais foram encaradas como um código visual de comunicação, estrapolando uma análise estilística e/ou descritiva (tão comum nos trabalhos arqueológicos), para desvelar seus conteúdos semânticos.

O desconhecimento do conteúdo simbólico dos grafismos, padrões decorativos cerâmicos, tipos e motivos de trançados, objetos de adorno e rituais, ordenação espacial, relacionado aos Proto-Jê meridionais não me desencorajou em estudar este sistema gráfico e estes códigos visuais enquanto códigos culturais. A possibilidade desta análise tornou-se concreta com a hipótese de continuidade entre os registros arqueológico ("tradições locais 
planálticas") e etnográfico (Kaingang e Xokleng), admitindo-se, portanto, a construção de uma etnoarqueologia Proto-Jê do sul - articulação do estudo desses dois registros-, através de analogias etnográficas possibilitadas através da contextualização dos sistemas gráficos e demais linguagens visuais Kaingang e Xokleng.

Por outro lado, este estudo associou o sistema de representação visual Jê meridional com outros sistemas simbólicos de seu contexto cultural, tais como o social e o mito-cosmológico.

Partiu-se da hipótese de que as manifestações estéticas Jê meridionais são um veículo de idéias que funcionam como uma iconografia, como um sistema de representações visuais ligadas à organização social e à mitocosmologia.

Neste sentido, sistemas de representação visual são aqui entendidos como códigos simbólicos percebidos pela visão, incluindo todo tipo de grafismos, morfologias de artefatos culturais e organizações do espaço, construídos por um grupo humano, e que veiculam significações estruturadas cultural e localmente.

Este seria também o pensamento de Geertz $(1986)^{1}$. Este autor critica o formalismo estético, baseado numa abordagem técnica do discurso sobre a arte, que enfatizaria a progressão tonal, a relação entre as cores ou as formas prosódicas, com o objetivo de "créer un langage technique capable de représenter les rapports internes des mythes, des poèmes, des danses ou des mélodies en termes abstraits, transposables" (op.cit., pág. 120-21). Isto para esta tese é importante, uma vez que na arqueologia tradicional costuma-se priorizar a descrição formal e técnica das espressões estéticas de sociedades do passado, sem grandes investimentos na análise de seus possíveis significados, mesmo quando se tem a continuidade do processo histórico-cultural que engendrou tais expressões, e a possibilidade concreta estabelecer-se analogias etnográficas.

\footnotetext{
${ }^{1}$ Apesar de todos os trabalhos já empreendidos para dircutir arte, tomo apenas o de Geertz, já que ele sintetiza o que quero fazer e demonstrar nesta tese.
} 
A partir de sua constatação, Geertz reduz a eficácia compreensiva do discurso técnico sobre a arte, afirmando sua ineficiência para uma total compreensão do fenômeno artístico, já que "le secret du pouvoir esthétique [ne] se situe [pas] dans les relations formelles entre les sons, les images, les volumes, les thèmes ou les gestes" (op. cit., pág. 121).

Onde se encontra, então, o "poder estético"? Para Geertz, ele deve ser procurado nas relações da arte com outros modos de atividade social, na sua incorporação ao contexto local de um tipo particular de vida, enfatizando que "le fait de situer les oeuvres d'art, de leur donner une signification culturelle est toujours une affaire locale" (op. cit., pág. 122).

Um ataque frontal às análises que privilegiam um critério estético, formalista, e àquelas que sublinham os arranjos sintáticos das formas puras é empreendido por Geertz. Conforme ele, tal abordagem atém-se apenas ao exterior do fenômeno, pois "les méthodes d'un art et le sentiment pour la vie qui l'anime sont inséparables" (op. cit., pág. 124). Em outras palavras, não se pode compreender a arte como um arranjo de formas puras, como não se pode compreender a linguagem como uma vitrine de variações sintáticas, ou o mito como um conjunto de transformações estruturais.

Neste sentido, as formas e seus arranjos não glorificam a estrutura social; "elles matérialisent un mode d'experience, apportent une tournure d'esprit particulière dans le monde des objets, où les hommes peuvent les regarder" (op.cit., pág. 126).

No entanto, Geertz não propõe um desinteresse pela forma, mas sugere a procura das raízes da forma na construção e desconstrução de sistemas simbólicos, na medida em que os indivíduos e os grupos de indivíduos esforçam-se em dar um sentido às coisas que lhes acontecem.

Para se compreender a arte, Geertz afirma que é necessário ter-se em conta que seu estudo está vinculado diretamente à compreensão de uma sensibilidade específica, de formação coletiva, cujas bases são tão vastas e profundas como a existência social (op. cit., pág. 125).

O desaparecimento de uma preocupação estética particular em qualquer sociedade não a faria sossobrar ou sofrer mudanças importantes. 
De acordo com Geertz, simplesmente certas sensações e sentimentos não poderiam ser ditos e, após um tempo, não poderiam mais, talvez, ser sentidos. Isto significa afirmar que a relação central entre arte e vida coletiva não se encontra sobre o plano instrumental, mas, sim, sobre um plano semiótico.

Deste modo, Geertz afirma que os signos que compõem um sistema semiótico ou estético não se encontram em relação mecânica com a sociedade onde os encontramos. Eles são documentos primários, não ilustrações de concepções já em vigor, mas concepções que procuram elas próprias um lugar que tenha um sentido no repertório de outros documentos, igualmente primários. Os signos, portanto, "sont significatifs parce qu'ils se relient à une sensibilité qu'ils contribuent à créer" (op. cit., p.127-28).

A tematização da história, uma das características do paradigma hermenêutico, aparece com força no pensamento de Geertz sobre a arte, uma vez que o tempo histórico particular é essencial para a compreensão desta sensibilidade:

"Chartres é feita de pedra e vidro, mas não é apenas pedra e vidro, é uma catedral particular, construída num tempo particular por certos membros de uma sociedade particular. Para compreender o que isso significa, para perceber o que isso é exatamente, você precisa conhecer mais do que as propriedades genéricas da pedra e do vidro e bem mais do que é comum a todas as catedrais. Você precisa compreender também - e, em minha opinião, da forma mais crítica - os conceitos específicos das relações entre Deus, o homem e arquitetura que ela incorpora, uma vez que foram eles que governaram a sua criação. Não é diferente com os homens: eles também, até o último deles, são artefatos culturais" (Geertz, 1978:62-63).

Como se apreende da citação acima, muitos domínios culturais reagem uns sobre os outros para produzir a sensibilidade na qual a arte de uma sociedade em um tempo histórico dado se formou e existiu. Além disso, fica claro, nela, a contestação às análises puramente formais e técnicas, como costuma acontecer em algumas abordagens arqueológicas.

Como conclusão, pode-se afirmar que se existe algo comum entre todas as artes, em todos os lugares, que justifique englobá-las em torno de um conceito forjado no Ocidente, este "algo" não poderia ser que elas fazem apelo a um senso universal do belo: 
"S'il y a un élément commun il se trouve dans le fait que certaines activités semblent partout destinées spécifiquement à démontrer que les idées sont visibles, audibles, et - il faut le mentionner ici - touchables, qu'elles peuvent être moulées en formes auquelles les sens, et à travers les sens les émotions, peuvent répondre" (Geertz, 1986:150).

Após estas reflexões, passo a analisar os grafismos Kaingang, agrupando-os, para melhor exposição, de acordo com o suporte no qual eles estão presentes.

\subsection{Grafismos Kaingang}

Os grafismos ocorrem em uma grande variedade de suportes: trançados, tecidos, armas, utensílios confeccionados em cabaças, troncos de pinheiros, etc., e nos corpos dos kaingang. No subitem 5.1.1., a seguir, descrevo e analiso os que ocorrem em materiais etnográficos de todo tipo. Já no 5.1.2., somente os da pintura corporal.

\subsubsection{Grafismos presentes nos materiais etnográficos Kaingang}

Para os Kaingang em geral, e especialmente para aqueles que estão fora das reservas administradas pela FUNAI no Planalto sul-rio-grandense, seus trançados constituem-se em referências visuais claras de sua alteridade em relação à sociedade nacional envolvente e à outra etnia indígena com quem dividem o palco da pluri-etnicidade no Rio Grande do Sul: os Mbyá-Guarani. Aos olhos leigos da grande maioria dos membros da sociedade nacional, estas duas etnias, e principalmente os Kaingang, no âmbito de sua exterioridade aparente (roupas, comportamentos, etc.), não mais se distinguem da população branca de baixa renda, mesmo que os biótipos tipicamente indígenas estejam fortemente presentes e se revelem no âmbito desta mesma exterioridade, que é usada, desde fora, para velar, escamotear e, até mesmo, negar a sua identidade. Por outro lado, nos seus trançados estão presentes as marcas visíveis desta alteridade, pressentida por poucos membros da sociedade regional ou urbana e sentida, verdadeiramente, pelos Kaingang. 
Trançando diferenças e tramas sociais

Os trançados expostos nas cidades, nas feiras de domingo, na beira de estradas ou em qualquer lugar em que esteja um Kaingang, não são apenas wõgfy (trançados em geral, que podem ser kre - cestos - ou tugfy - trançados aplicados a objetos os mais variados, como garrafas, flechas, arcos -): são marcas visíveis da diferença, uma vez que são parte de um sistema de representações visuais (as formas tradicionais dos kre, os grafismos tradicionais presentes), originados por um tradicional e específico sistema cultural Kaingang. Além disso, seus trançados revelam formas e grafismos vinculados à percepção dual Kaingang do cosmo, enfatizando e sintetizando sua organização social baseada em duas metades.

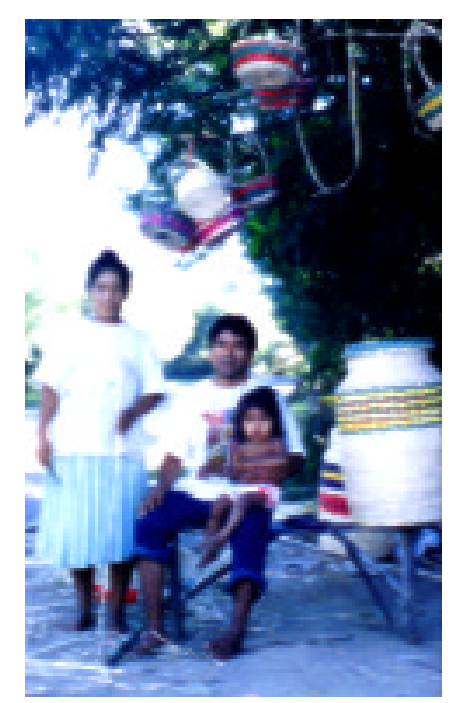

O interlocutor Kaingang Ningrei, sua esposa, Kuadmé, e a filha Kóiód - Aldeia da Agronomia/RS

1998

No entanto, as aparentes perdas originadas por um longo e difícil processo histórico-cultural de contato deixaram suas marcas. Uma parte expressiva dos Kaingang com quem trabalhei, principalmente os jovens, não tem mais conhecimento de algumas técnicas de confecção do trançado e/ou não reconhecem os objetos antigos, pertencentes a acervos museológicos, cujas fotografias foram mostradas, apesar de quase todos saberem confeccionar cestos para a venda aos fóg (brancos). Entretanto, uma boa parte deles reconhece e reproduz nos seus wõgfy técnicas de trançado e grafismos, que, muitas vezes, sabem nomear. De qualquer forma, apenas uma minoria 
deles pôde me dar respostas para que eu pudesse fazer esta tentativa de compreensão de seu sistema de representações visuais e seu relacionamento com outros sistemas culturais Kaingang ${ }^{2}$.

Os Kaingang classificam seus cestos ( $k r e$ ) segundo sua morfologia ou de acordo com sua função.

A tipologia morfológica Kaingang para seus cestos (kre) resume-se a três formas básicas: kre téi, kre ror e kre kõpó, que correspondem às expressões em português cesto comprido (ou longo), cesto redondo (ou baixo) e cesto quadrado.

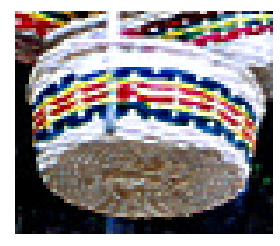

Kre ror

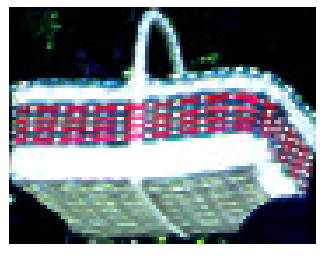

Kre kõpó

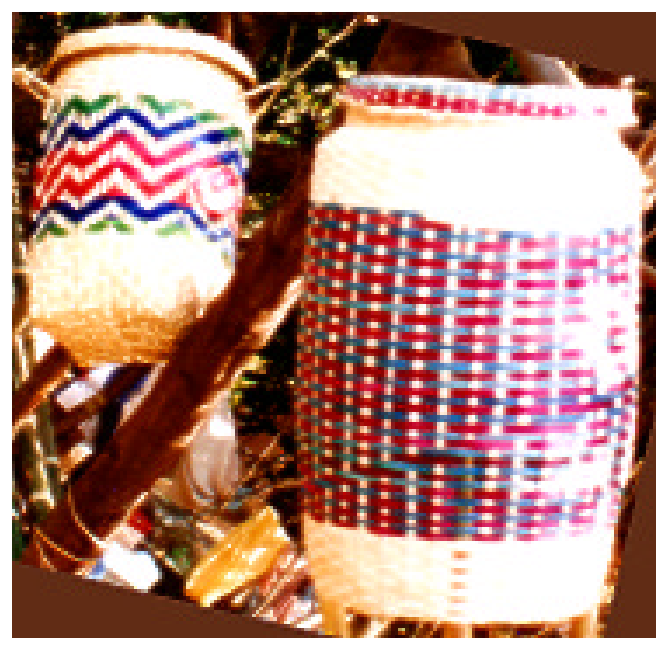

Kre téi

Os nomes dos cestos (kre): classificação morfológica

\footnotetext{
${ }^{2}$ Este fato pode indicar tanto que os jovens estão se afastando dos aspectos "tradicionais" de sua sociedade como que o conhecimento de tais questões depende da idade do interlocutor, isto é, este conhecimento vai ser adquirido mais tarde, na maturidade, por exemplo.
} 
A palavra Kaingang kõpó, entretanto, não pode ser traduzida como "quadrado", apesar de se entender seu emprego na "tradução" da expressão kre kõpó, pois a base deste tipo de cesto é, realmente, quadrangular. Atualmente, a expressão para designar este tipo de cesto é kre iyr, que quer dizer cesto com alça. Em Kaingang, kõpó é pulga. Kre kõpó é uma denominação antiga, quase não sendo mais usada no cotidiano Kaingang, principalmente entre os jovens. De qualquer forma, esta terceira forma da classificação morfológica nativa sempre é referida a partir dos adjetivos téi/ror, conforme o caso, o que indica tratar-se de um kre kõpo téi ou de um kre kõpó ror.

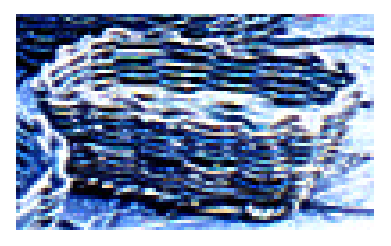

Kre kõpó ror

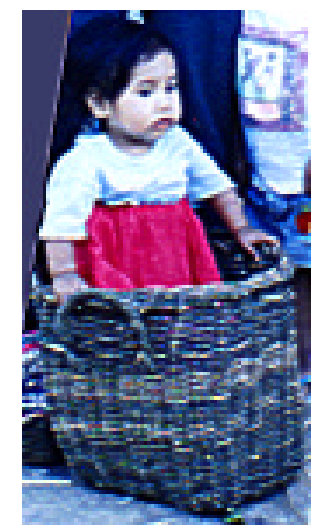

Kre kõpó téi

Desta forma, a expressão visual representada pelos nomes das duas primeiras formas básicas de wõfy (trançado) referidas (kre téi e kre ror), e a sub-classificação nativa da terceira forma básica (kre kõpó téi/kre kõpó ror), remete diretamente à cosmologia dual da sociedade Kaingang: Kamé e Kainru, demonstrando uma tendência cultural importante à bipolarização de caráter contrastante, opositor e complementar. O discurso Kaingang também procede assim, pois à forma comprida/longa de cesto (kre téi) e ao vocábulo téi está relacionada indissociavelmente a metade Kamé. Por sua vez, à forma redonda/baixa (kre ror) e à palavra ror está vinculada a metade ligada a Kainru.

A tipologia funcional Kaingang para seus kre baseia-se na função desempenhada por cada um. Somente denominações para os kre cargueiros 
foram obtidas. Como o nome indica, tais cestos são usados para carregar grandes pesos, às costas. Possuem tira de embira (yer), que fica apoiada na testa das pessoas que deles fazem uso.

1. konty: cesto cargueiro revestido/impermeabilizado internamente com cerol (ndéi), com função de transportar/armazenar líquidos, principalmente água e mel;

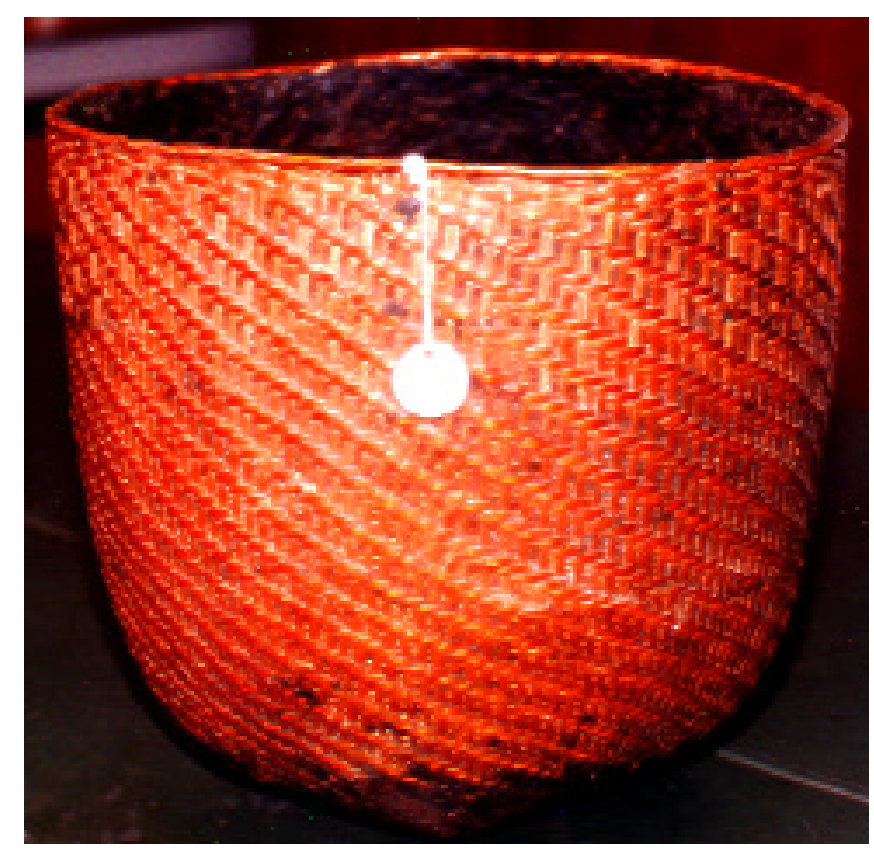

MAE/USP 2580

2. kuä̈pé: cesto cargueiro confeccionado com taquara mansa (ven pë), usado para transportar objetos pesados;

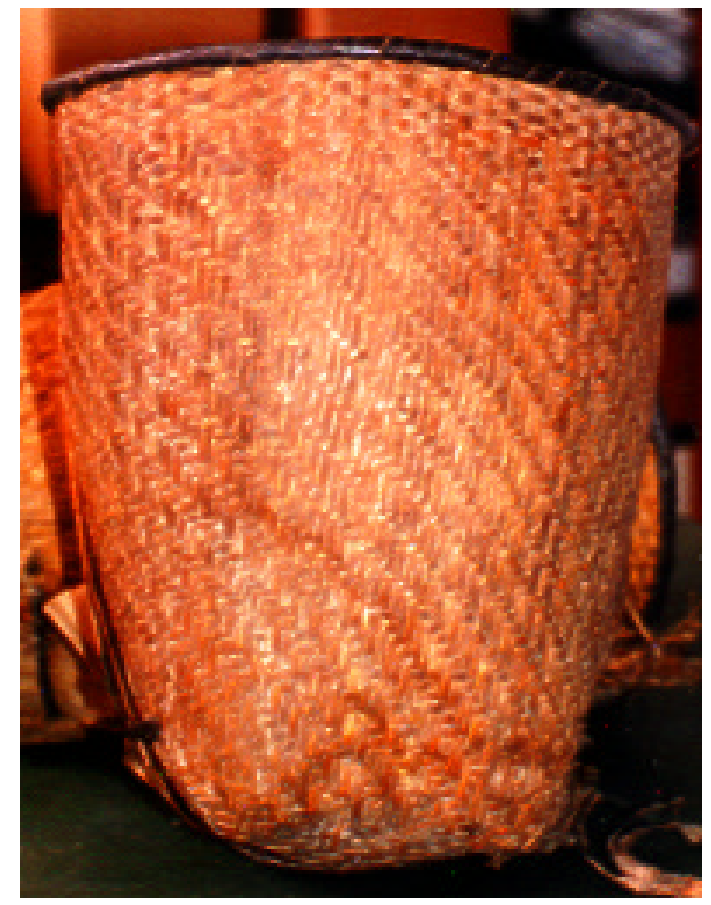

MAE/USP 4097 
3. kóïn: cesto cargueiro simples, sem kong-gãr (grafismo), feito com ven kupar (lasca grosseira de taquara) e utilizado no transporte de espigas de milho

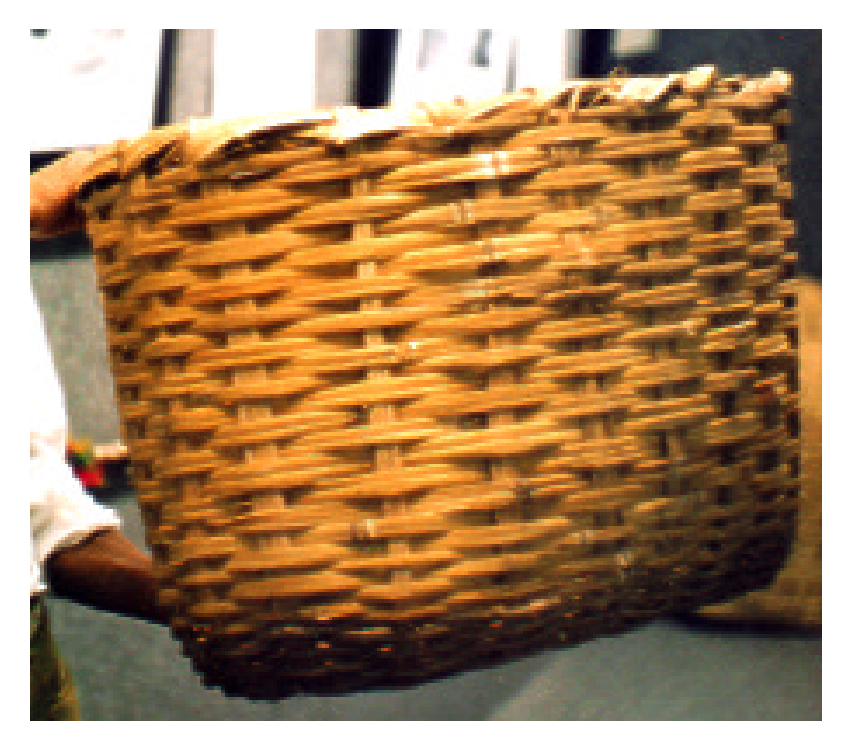

MARS 541

O sistema de representações visuais Kaingang parece atuar em, pelo menos, três níveis, todos eles sendo caracterizados pela bipolarização contrastante, opositora e complementar:

1. um nível morfológico enfatizaria a oposição e a complementariedade entre quaisquer formas longas/compridas/abertas (téi) e quaisquer formas redondas/baixas/fechadas (ror), sejam elas da natureza ou oriundas do universo cultural;

2. um nível gráfico ressaltaria a oposição e a complementariedade entre quaisquer grafismos (kong-gãr) ou marcas ( $r a)$ redondos/fechados (ror) e quaisquer grafismos (kong-gãr) ou marcas ( $r a$ ) compridos/abertos (téi), sejam eles da natureza ou originários do mundo da cultura;

3. um nível de posição e/ou espacialidade priorizaria a oposição e a complementariedade entre posições altas e a leste (Kamé) e posições baixas e a oeste (Kainru-kré). Esta é uma inferência minha (não comprovada em campo, pois os interlocutores não mais tinham memória), originada de 
conversa com outros pesquisadores ${ }^{3}$, que presenciaram o ritual do kiki, onde os kuiã (xamãs) Kamé rezam na parte superior da árvore derrubada para fazer o cocho onde será preparada a bebida (kiki). Os kuiã kainru-kré, por sua vez, agem sobre sua parte inferior. Além disso, no cemitério, os kamé seriam enterrados na sua porção oeste, e os kainru-kré, no seu lado leste.

Este sistema bipolar de representações visuais, em todos os seus níveis de atuação, é reforçado cotidianamente pelo sistema lingüístico Kaingang, como será visto mais adiante.

Quanto ao nível gráfico, seguindo o nível morfológico do sistema de representações visuais, cabe ressaltar que os grafismos (kong-gãr) presentes nos wõgfy (kre ou tufy), e pintados nos corpos e outros objetos, como flechas - ndo, nda -, arcos - uyi -, cabaças - run-ia -, mortalhas - kurã -, etc., e, mesmo, os grafismos presentes na cultura material pré-histórica das ditas "tradições locais planálticas" (Taquara/Itararé/Casa de Pedra) do sul do Brasil, como painéis rupestres ou cerâmica arqueológica (nga ta kukrü $)^{4}$, são sempre referidos e classificados por meus interlocutores Kaingang como téi ou ror.

Téi e ror são os nomes das marcas ( $r a$ ) ou grafismos (kong-gãr) que identificam, respectivamente, as metades Kamé e Kainru-kré, percebidas como um sistema que organiza o universo Kaingang.

Evidentemente, que muitas marcas ( $r a$ ) ou grafismos (kong-gãr) recebem nomes específicos. No entanto, mesmo estes grafismos que possuem nomes próprios são considerados ou téi ou ror e estão vinculados (e isto é dito expressamente por meus interlocutores) a uma das duas metades.

De qualquer forma, estas duas palavras (téi e ror) são categorias Kaingang fundamentais, uma vez que a cada uma delas está amalgamado um conjunto de outras palavras-noções que, junto com téi e ror, formam estas duas categorias contrastantes, opositoras e complementares.

As marcas téi/ror nos trançados (wõgfy) são geralmente obtidas através do uso de duas matérias-primas diferentes na confecção do cesto (kre) ou do trançado aplicado (tufy): kó mrür fãr/kré (casca de cipó imbé/criciuma); kó

\footnotetext{
${ }^{3}$ Rogério Rosa e José Octávio Catafesto de Souza, ligados à UFRGS, e Juracilda Veiga.

${ }^{4}$ Veja, mais adiante, item 5.3, sobre grafismos Proto-Jê meridionais.
} 
mrür fãr/ven iuiar (casca de cipó imbé/tiras de taquara), etc. ${ }^{5}$. Entretanto, a própria técnica de confecção do trançado pode revelar no nível gráfico do wõfy a marca téi ou ror, ou seja, grafismos compridos/abertos ou fechados/quadrangulares (no trançado não é possível obter-se grafismos redondos ou circulares).

A primeira técnica de trançado denomina-se wõfy ra téi, a segunda, wõfy ra ror, como será visto em detalhes, a seguir.

O nível gráfico, obviamente, se sobressai sobre o morfológico para avaliar a posição de um membro da sociedade Kaingang, uma vez que na cultura material existem objetos/artefatos longos e redondos que devem ser usados tanto por Kamé como por Kainru-kre (exs.: krá [mão-de-pilão], ngret [peneira]). Do mesmo modo, os cestos presentes na casa de um homem Kamé poderiam ser tanto kre téi como kre ror, pois as funções diferenciadas destes tipos morfológicos diferentes de cestos exigiriam sua presença nela. As marcas presentes nos cestos (e nos outros objetos) é que definiriam o pertencimento de seu possuidor a uma ou outra metade. Em outras palavras, e conforme a reconstituição de um passado não muito distante por parte de meus interlocutores, os objetos pessoais de um indivíduo deveriam possuir, idealmente, a marca de sua metade. Durante os rituais, esta situação é muito mais marcada, até hoje.

O sistema de representações visuais Kaingang marca e acentua, nos rituais o pertencimento dos seus membros a uma das duas metades. Portanto, o sistema de representações visuais apresenta-se também dual. Como será referido logo a seguir, também o sistema lingüístico enfatiza o dualismo, através de dois conjuntos opostos de palavras, que compõem as categorias téi e ror. Este sistema lingüístico sustenta e reforça, pelo o que compreendi do estudo introdutório que fiz do idioma Kaingang, dois dos três níveis de atuação do sistema de representações visuais (morfológico e gráfico). O idioma Kaingang no geral, e especificamente em seus diversos dialetos, é rico em pares opositores de vocábulos que enfatizam e constroem o contraste e a complementariedade entre as categorias culturais téi e ror. Estes pares opositores estão presentes em várias classes gramaticais, desde adjetivos a verbos, passando por substantivos, indicando a grande importância das duas categorias no nível das representações mentais Kaingang.

\footnotetext{
${ }^{5}$ Veja maiores detalhes sobre matérias-primas e técnicas de confecção de trançados em parágrafos mais a frente.
} 
Como exemplos de pares opositores destas três classes gramaticais temse: téi/ror::watïn (levar objetos compridos)/mbatïn (levar objetos redondos)::wakõtïn (trazer objetos compridos)/mbakõtïn (trazer objetos redondos::na (coisa comprida)/ $n \ddot{i}$ (coisa redonda).

As partículas $n a$ e $n i$ expressam, respectivamente, objetos compridos/longos (téi) e redondos (ror). Ex.: anel (nïgé kã ni, onde nïgé é mão, $k \tilde{a}$ é dentro e $n i$ é coisa redonda).

A tendência geral para a bipolarização opositora e complementar fica reforçada quando se verifica que nos vários dialetos Kaingang estão presentes pares opositores de vocábulos, de uso regional/dialetal, que demonstram as categorias téi e ror. Como exemplos, tem-se ra ioi para expressar, na região de Tenente Portela/RS, área do dialeto Sudoeste (Wiesemann, 1981), a marca comprida e ra kutu para denominar, em Ibirama e Xanxere/SC, região do dialeto Central (idem), a marca redonda. Os vocábulos téi e ror, que venho usando ao longo desta tese, são da área de Nonoai/RS, de abrangência do dialeto Sudeste (idem).

Resumindo, estas representações, centrais para a compreensão da sociedade e da cultura Kaingang, expressas pela linguagem oral, através das categorias téi e ror, por intermédio dos pares opositores de vocábulos e na própria estrutura lingüística, também são encontrados nas suas representações gráficas, morfológicas e de posição/espaço. Como regra geral, os grafismos, morfologias e posições/espaços considerados compridos, longos, altos, abertos são denominados téi e representam a metade Kamé. Já os grafismos, morfologias e posições/espaços vistos como redondos, quadrangulares, losangulares, baixos, fechados são chamados de ror e representam a metade Kainru-kré.

Com relação à estrutura lingüística Kaingang, é importante enfatizar que este padrão cultural de bipolarização contrastante téi/ror, comporta no padrão básico da língua Kaingang uma sub-categoria, que é englobada pela categoria téi. Em outras palavras, a categoria cultural téi possui duas acepções de significado (comprido e longo), que são assumidas pela estrutura lingüística, uma vez que esta última determina que ao expressar objetos morfologicamente téi, na acepção de comprido, eles devam ser referidos, na estrutura da frase, como ië (de pé). Já objetos téi na acepção de longo devem ser referidos como nã (deitado). Completando a estrutura dual, este mesmo 
padrão básico da língua Kaingang sentencia que os objetos ror devam ser referidos como nï (sentado).

Em outras palavras, a classificação téi/ror é fixa com relação a objetos e seres inanimados, revelando-se tripartida na estrutura lingüística. No entanto, para os humanos, no nível da linguagem, a classificação não é rígida, pois obedece à realidade da ação registrada pela língua (homem sentado fala/ homem em pé fala). Mesmo assim, tem-se, sempre, a estrutura contrastiva e complementar.

As pesquisadoras do Summer Institute of Linguistics (Weiseman, 1981; Kindell, 1971:145), embora já tendo se referido a estas particularidades da língua Kaingang, não explicitam seu alcance estrutural: o dualismo expresso na estrutura lingüística. No sistema de representações visuais Kaingang vigoram com força estas estruturas mentais e lingüísticas.

As matérias-primas dos trançados Kaingang, desde sua coleta até seu processamento, bem como suas técnicas de confecção, serão comentadas nos parágrafos que seguem.

Os objetos tufy tradicionais, como flechas, arcos, recipientes de gomo de taquara (salvo os últimos, que caíram em desuso e foram substituídos pelas garrafas tufy), apenas são feitos ocasionalmente para venda externa, acrescidos de outros itens da cultura ocidental, que recebem um tradicional trançado aplicado (tufy) Kaingang: tiaras, prendedores de cabelo, anéis, flautas doces, etc. Nas décadas iniciais deste século, conforme o registro das coleções dos museus do Rio Grande do Sul, era moda a confecção de veintó tufy (bengala com trançado aplicado). Todos estes objetos tufy, como os tradicionais, são produzidos a partir da casca do cipó imbé (kó mrür fãr) com criciúma (kré) e continuam a reproduzir os tradicionais kong-gãr Kaingang, presentes na cerâmica das "tradições locais planálticas" e na arte rupestre, o que será visto no final deste capítulo. 


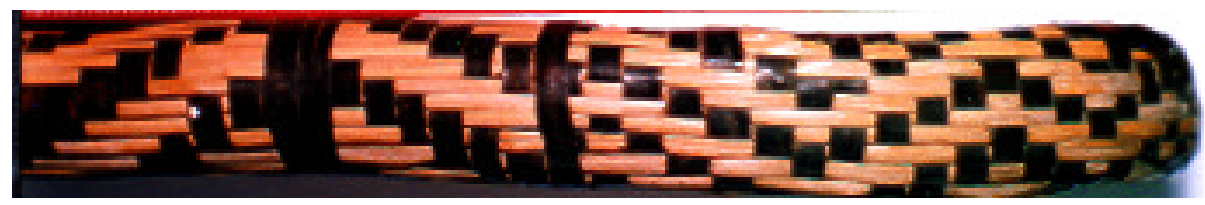

Veintó tufy

confeccionado em kó

mrür fãr e kréLAE/UFRGS

Quanto aos kre (cestos) Kaingang, atualmente, são confeccionados ou com ven (taquara) ou com vários tipos de mrür (cipós). Entretanto, não há nas coleções antigas kre feitos de cipó, existindo um caso (RS) de kre confeccionado em folha de palmeira (tãin féin).

Outros tipos de wõgfy (trançados) utilizam também a matéria-prima vegetal. Dentre eles, as coleções museológicas consultadas registram chapéus (xapë) e esteiras (ru), feitos com ven iuiar (tiras de taquara), e kenka ratfën (leque para abanar fogo), confeccionado com kó mrür iuiar (tira de cipó imbé) e kré (criciúma).

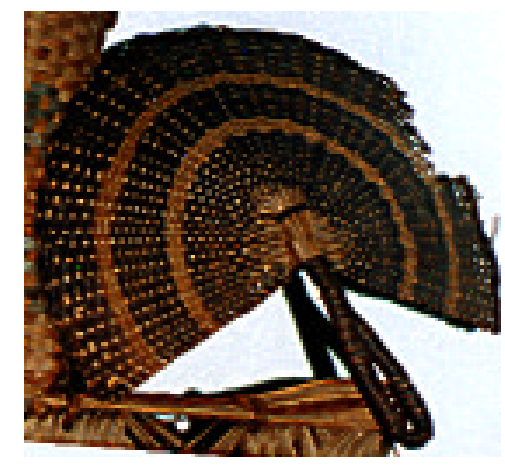

Kenka ratfën feito em kó mrür iuiar e kré. LAE/UFRGS 


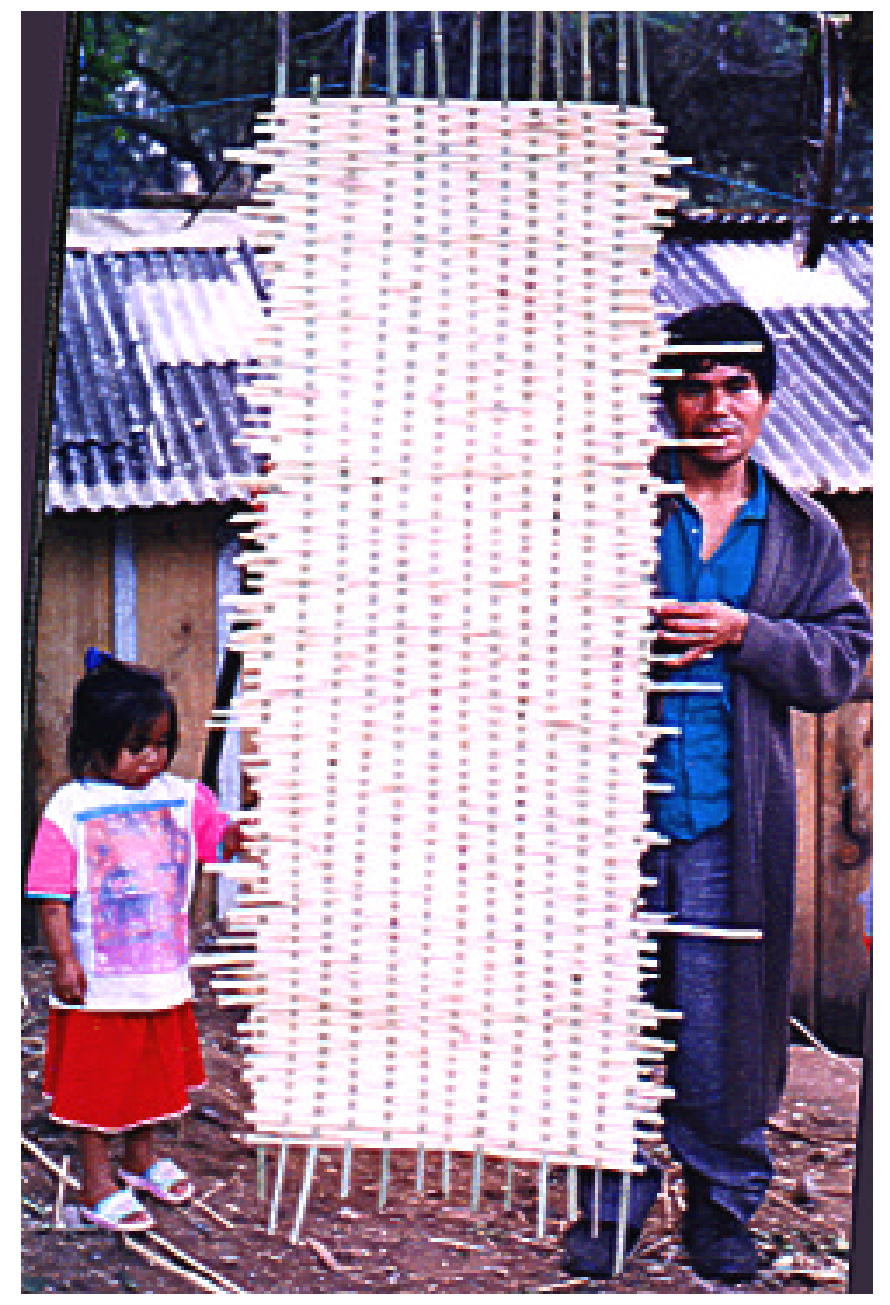

$R u$ confeccionada em ven iuiar. Aldeia da Agronomia

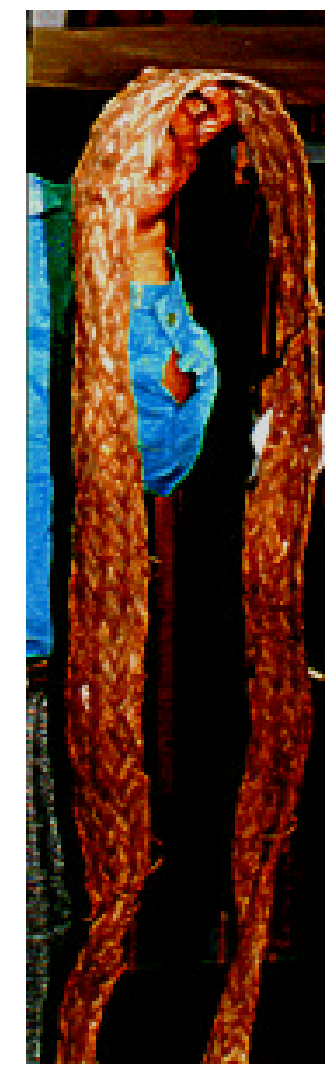

Yer (alça, tira) em embira. Usada em cestos cargueiros ou para carregar crianças. MJC/RS $742 \mathrm{Et}$

Desta forma, as principais matérias-primas para os wõgfy e tugfy Kaingang são: cipós, taquaras, criciúma, embira (para cordas e faixas dos cestos cargueiros ou para carregar crianças), folhas de palmeira (tãin féin), urtiga (ven burfê) e fio vegetal retirado do caule do butiazeiro (para acabamentos nos cestos). 


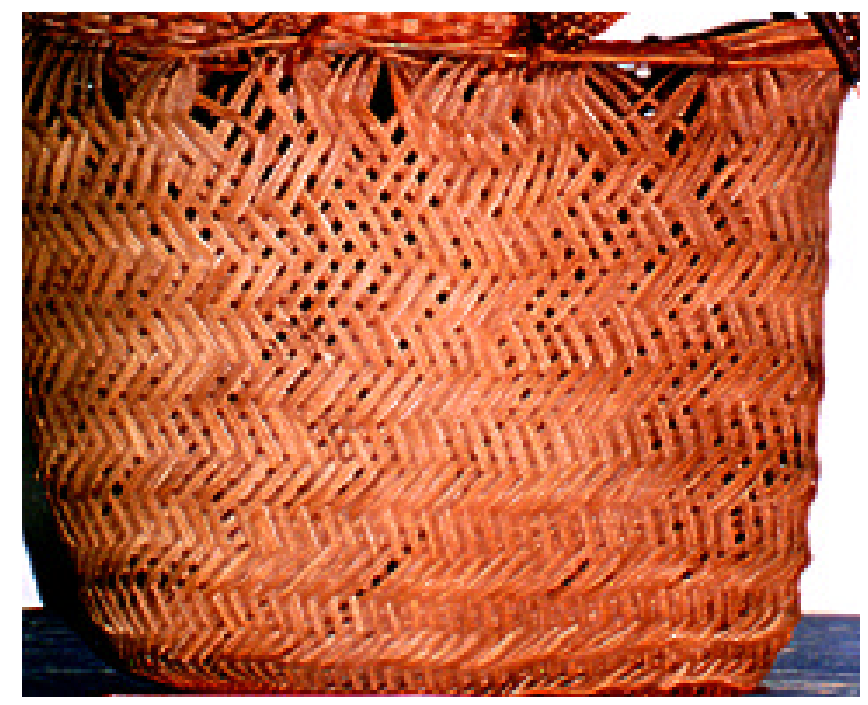

Kre em tãin féin - LAE/UFRGS

Os kaingang diferenciam e utilizam vários tipos de ven (taquara): ven pë (taquara mansa), ven kader (taquara lisa) e ven venxa (taquara braba de espinho).

Da mesma forma, vários tipos de cipó (mrür) são reconhecidos e usados: kó mrür (cipó imbé; não existe na região de Porto Alegre, só no Planalto; dá no alto das árvores), mrür tar (cipó São João; tem em ambas as regiões citadas), mrür marér (cipó amarelo; não tem no Planalto, somente na região de Porto Alegre; é mais grosso que o mrür tar).

A coleta da matéria-prima é realizada pelos homens, que cortam no mato os vegetais que são trazidos para processamento na aldeia. Os cipós são trazidos enrolados (mrür ngrï) e assim armazenados. As taquaras são transportadas em grandes fardos.

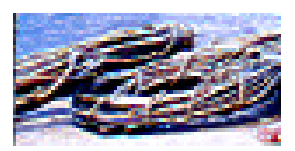

Mrür tar ngrï

O processamento da matéria-prima varia conforme seu tipo e uso pretendido.

O mrür tar (cipó São João) e o mrür marér (cipó amarelo) podem ser trançados apenas após sua secagem ao sol para murchar. As cascas 
destes cipós não são utilizáveis. A casca do mrür tar pode ser raspada, após a secagem, ficando branco (mrür tar fãr tun - cipó São João sem casca).

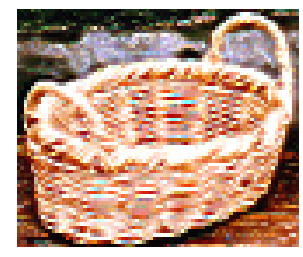

Kre em mrür tar fãr tun

O kó mrür (cipó imbé) necessita de processamento mais apurado: primeiramente, é cortado em quatro porções longitudinais. Após, sofre descascamento. Esta primeira casca (fãr) é denominada kó mrür fãr. A polpa mole, que vem a seguir, não é utilizada. Depois desta polpa, vai-se tirando as kó mrür iuiar (tiras de cipó imbé). Vi apenas um objeto (de coleção de museu) confeccionado com kó mrür iuiar + kré (criciuma): um leque de abanar fogo (kenka ratfën).

As taquaras podem ser raspadas (ou não) e utilizadas em forma de tiras (ven iuiar). Lascas grosseiras, sem raspagem (ven kupar), são usadas para confeccionar cestos cargueiros simples (kóin).

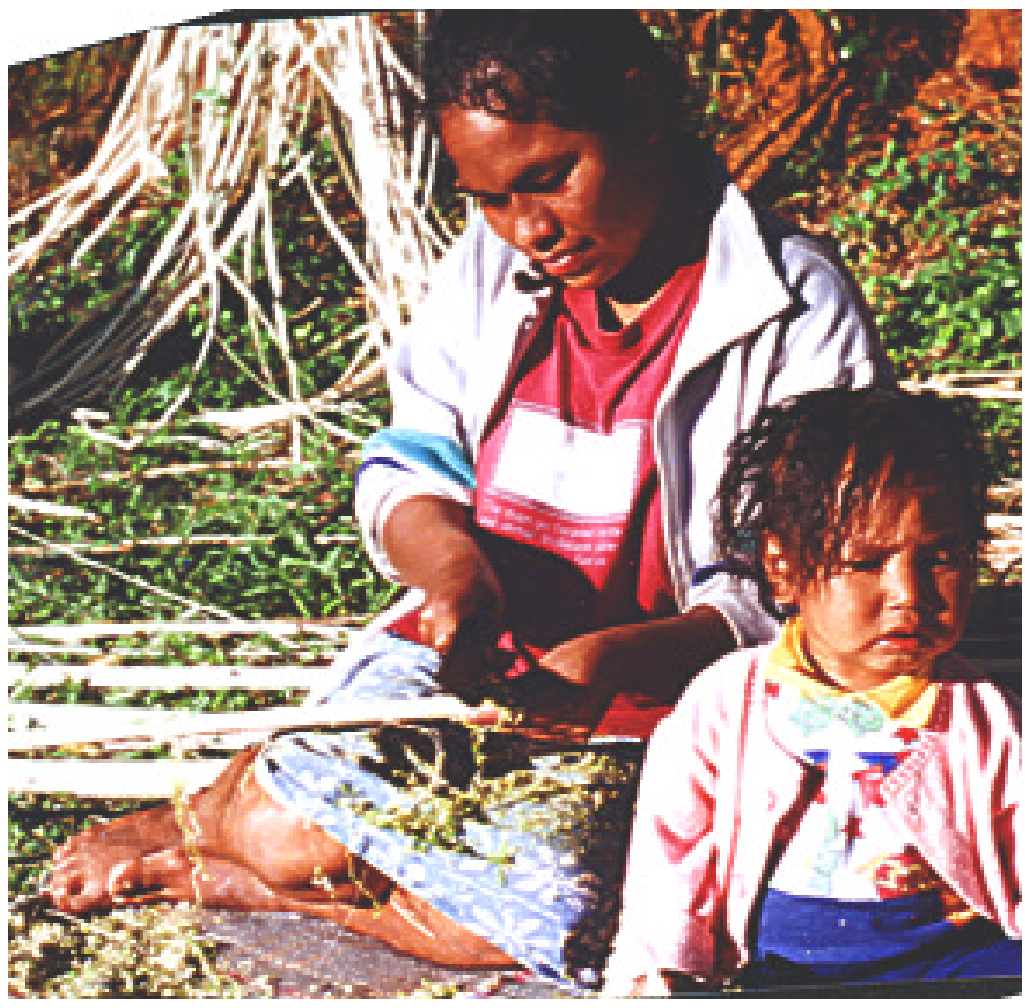

Raspagem da taquara Aldeia da Agronomia 
A embira, usada para fazer cordas e tiras trançadas para cestos cargueiros, é retirada da casca da figueira braba. Após a secagem (dois dias), de sua parte interna retira-se a fibra (embira).

Com referência às partes estruturais de um cesto Kaingang, há correspondência entre elas e os procedimentos técnicos para seu trançado. Em outras palavras, quando quer designar estas partes, um Kaingang refere-se, por exemplo, ao $n g u n i$, a base do cesto, que é o início do procedimento de trançar. O cesto propriamente dito, em seu bojo, é designado pelos nomes ti fãia (tiras de matéria-prima ao redor do cesto, para trançar na horizontal) e ti kuká (tiras de matéria-prima para trançar na vertical). A abertura do cesto é denominada $t i$ ianky (a boca dele), e está ligada aos procedimentos técnicos de acabamento, comentados a seguir. A alça (quando há) é chamada de ti iãn.

As bases dos cestos ( $n g u n i$ ) podem ser de dois tipos: ngu ni kuka pipir ou ngu ni kuka $\hat{e}$, levando a uma bipolarização contrastante e opositora dos dois tipos de técnicas de confecção dos kre.

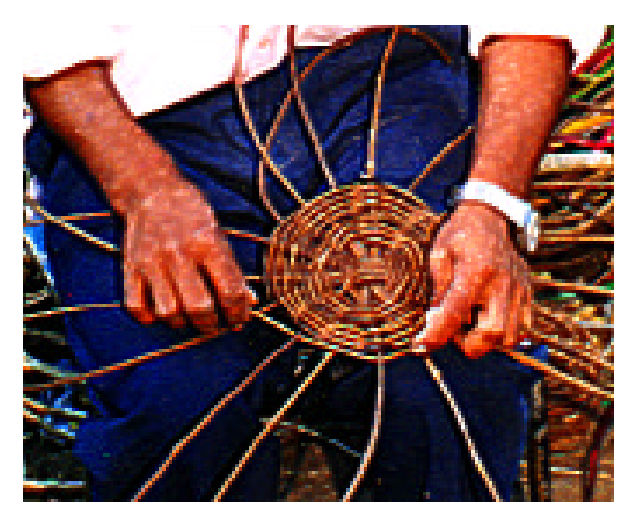

Ngu ni kuka pipir

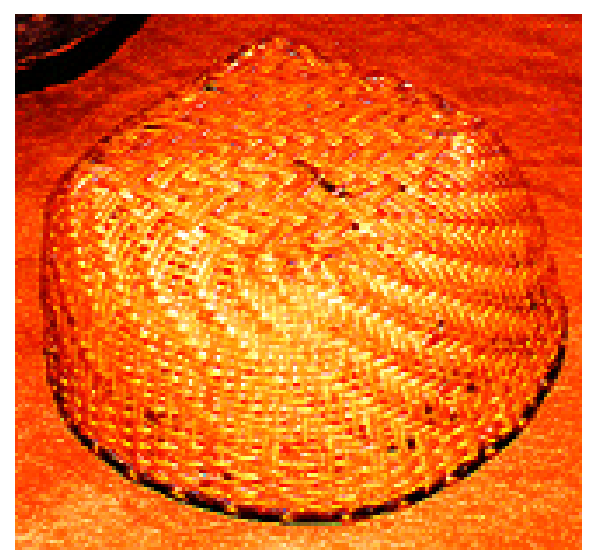

Ngu ni kuka $\hat{e}$ - MJC/RS 1198/147 ET

Os ngu ni kuka pipir são bases com poucas tiras trançadas na vertical ( $t i$ $k u k a ́$ ), levando o artesão, forçosamente, a uma técnica de wõfy (trançado) denominada de wõfy kauã (trançado aberto). 
Já os ngu ni kuka ê são bases com muitas tiras ti kuká, o que dirige obrigatoriamente o artesão à técnica de trançar chamada de wõfy kuty (trançado fechado).

Os wõgfy, quanto à técnica de sua confecção, são classificados, pois, como kuty e kauã : a primeira expressando fechado, e a segunda, aberto. Isto ocorre porque a base (ngu ni) do cesto fechado (kre kuty) é denominada de $k u k a \hat{e}$ (muitas tiras verticais), sendo suas paredes completamente fechadas pelo trançado. Já a base (ngu ni) do cesto aberto (kre kauã) é chamada de kuka pipir (poucas tiras verticais), tendo, portanto, suas paredes abertas (não completamente fechadas). De novo, até mesmo os tipos de bases de seus cestos, e as técnicas de confecção daí derivadas, indicam o dualismo Kaingang: base com poucas tiras verticais/base com muitas tiras verticais :: trançado aberto/trançado fechado :: cesto aberto/cesto fechado.

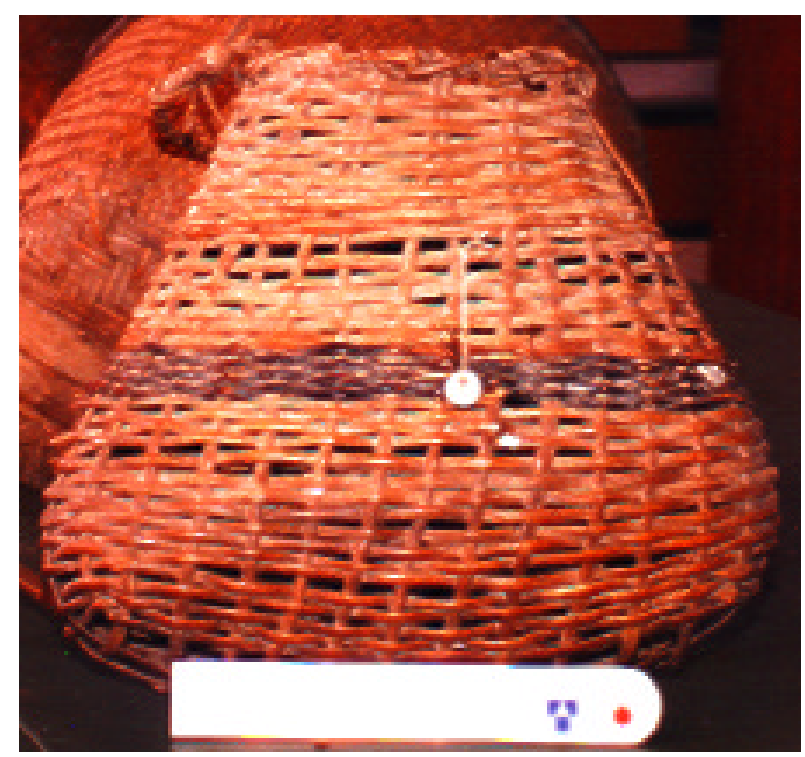

MAE/USP 4098 (wõfy kauã)

Além desta distinção dual, estabelecida a partir dos tipos de bases, a própria técnica de confecção de trançados pode imprimir no cesto grafismo téi ou ror, independentemente do uso de matérias-primas diferentes ou o uso de cores diversas na mesma matéria-prima para formar os grafismos. A técnica de trançar que deixa marcas téi no cesto é designada como wõfy ra téi; ela é vinculada à metade kamé. À outra metade, está ligada a técnica chamada de wôfy ra ror, que deixa grafismos ror no cesto. Desta forma, existem trançados 
com marca téi ou trançados com marca ror (as duas técnicas citadas), além das marcas téi ou ror nos trançados (obtidas com o emprego de matérias-primas diferentes ou com o uso de cores diversas aplicadas sobre a mesma matériaprima).

Ademais, não deve ser confundido wõfy ra téi com wõfy téi. A segunda expressão designa um cesto comprido, que por sua forma é kamé. Ele pode ser tanto de um kamé como de um kainru-kré. A marca de um cesto (nível gráfico do sistema de representações visuais), e não a sua forma (nível morfológico), é que vai ser decisiva para se saber a quem ele está identificado, conforme afirmam os Kaingang de Nonoai.

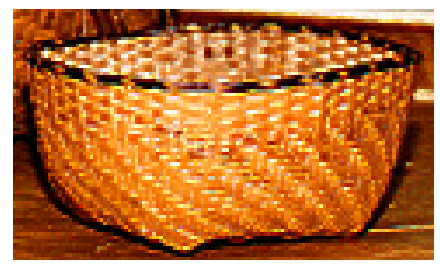
grafismos téi no trançado; neste caso, linhas oblíquas paralelas) e que está identificado a metade kamé MJC/RS 2422/1255 Et

Outra técnica de trançado caracterizada como téi denomina-se tipiti. Pelo seu nome e características, parece ter sido assimilada dos Guarani. Trata-se de trançado sem ti fãia (tiras horizontais), o que lhe dá um aspecto "igual até o fim", "aberto", "sem fim", como é dito pelos Kaingang.
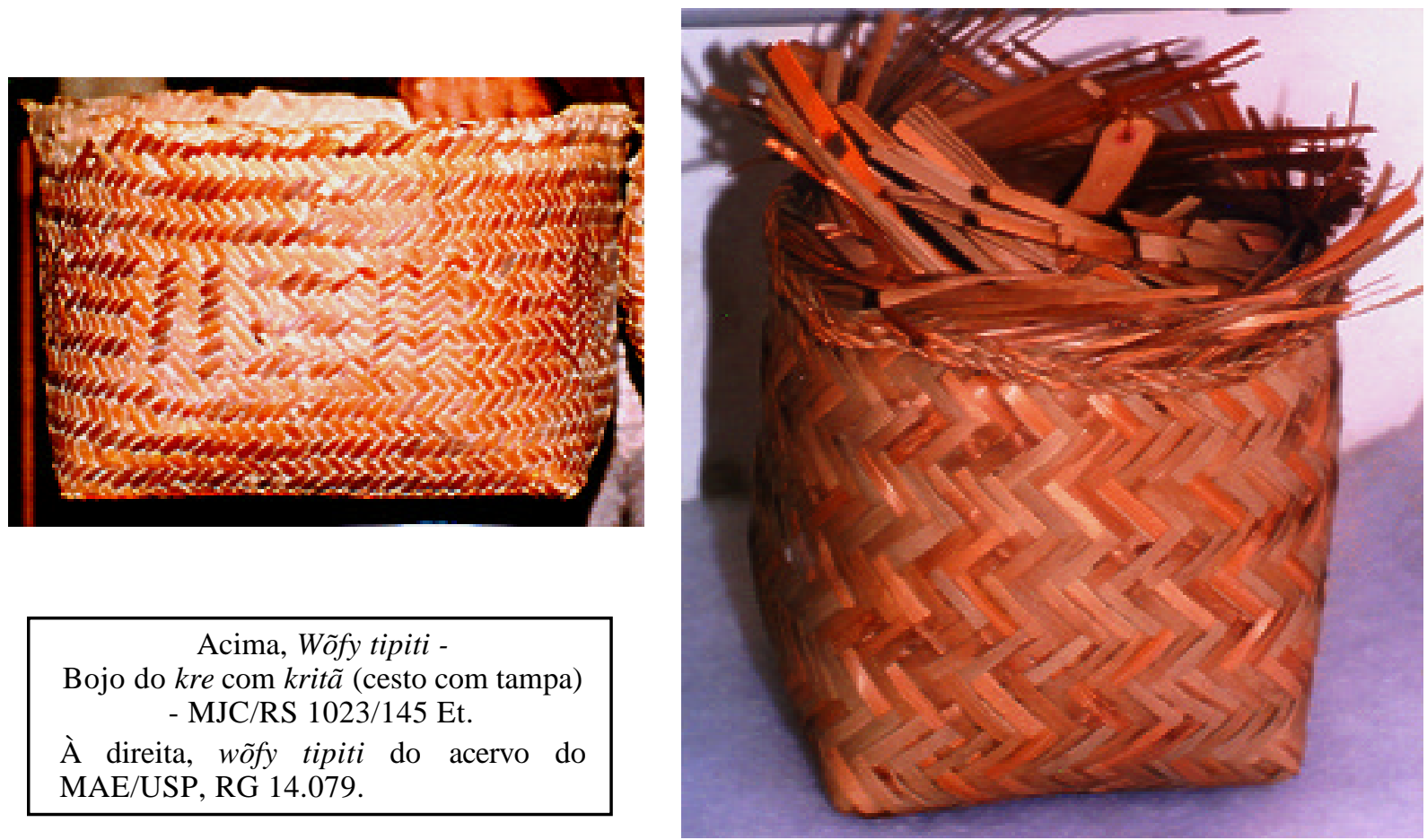

Bojo do kre com kritã (cesto com tampa) - MJC/RS 1023/145 Et.

À direita, wõfy tipiti do acervo do MAE/USP, RG 14.079. 
Do ponto de vista das dificuldades que apresenta ao artesão, a técnica do wõfy ra ror é considerada pelos Kaingang como muito difícil de ser executada, exigindo grande habilidade. Veja a tampa - kritã - da cesta MJC/RS 1023/145 Et, um trançado típico com grafismos ror. Já os wõfy ra téi são considerados como fáceis de trançar, principalmente o tipiti.

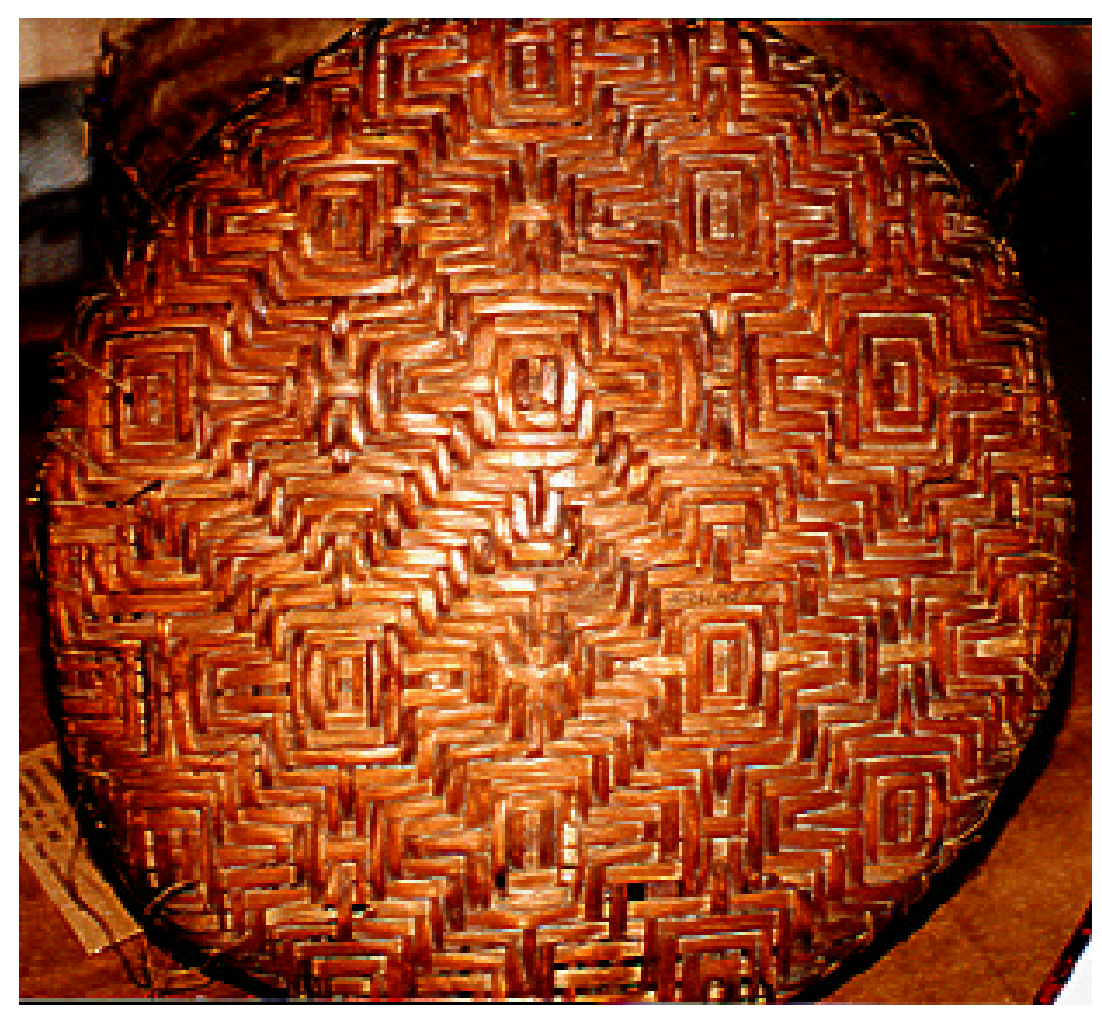

Wõfi ra ror: Kritã (tampa) do kre (cesto) MJC/RS 1023/145 ET

Quanto aos acabamentos nos lábios dos wõgfy, eles são denominados iãn fi. O acabamento no lábio com casca de cipó imbé é chamado de kó mrür fãr tá iãn fi.

Os grafismos (kong-gãr) Kaingang no Rio Grande do Sul apresentam-se, também, de forma dual.

Os Kaingang de Santa Catarina, de acordo com Veiga (1994), apresentam duas patrimetades (Kamé e Kainru), às quais foram agregadas duas seções 
(Wohhétky e Votor) às seções originais, de mesmo nome das patrimetades. Veiga também aponta o princípio da bipolarização contrastiva e complementar, acrescentando subvariantes gráficas para as seções Wonhétky e Votor. Conforme já visto, os grafismos Wonhétky seriam lineares, como os da seção Kamé, mas curvos; e aqueles da seção Votor seriam circulares, como os da seção Kainru, mas apresentariam círculos vazios ( $r a$ ndor - marca do buraco), e não círculos cheios, como os da seção Kainru.

Para os Kaingang do Rio Grande do Sul não existem as sub-divisões das patrimetades (seções, conforme Veiga, 1994). Neste sentido, as pesquisas de campo demonstraram que, para os Kaingang do Rio Grande do Sul, não há diferenciação entre um padrão gráfico linear reto e um padrão gráfico linear curvo, ou, ainda, entre um padrão gráfico circular cheio e um padrão gráfico circular vazado, sem a possibilidade, portanto, de posições intermediárias, como em Santa Catarina.

Conforme já foi descrito, os dois tipos básicos de kong-gãr Kaingang do Rio Grande do Sul são o ra téi (Kamé) e o ra ror (Kainru-kré). As características principais de uma marca Kamé estão relacionadas ao fato de ela ser comprida e aberta; uma marca Kamé "não tem fim". Já uma marca Kainrukré apresenta-se redonda (quadrangular nos wõgfy, por sua especificidade de confecção $\left.{ }^{6}\right)$ e, notadamente, fechada ${ }^{7}$.

Algumas ra téi recebem nomes específicos: ra ionior (marca zigue-zague ou ondulada), ra ionior rangre (marca ziguezague duplo ou ondulada dupla), ra tufy ionior (marca em espiral em trançado aplicado a flechas), véin kõpó (marca cruz ou marca em " $x$ "). Entretanto, meus interlocutores Kaingang não souberam nomear especificamente uma grande parte destes grafismos. Eles foram designados, genericamente, de ra téi (marca comprida/aberta dos Kamé).

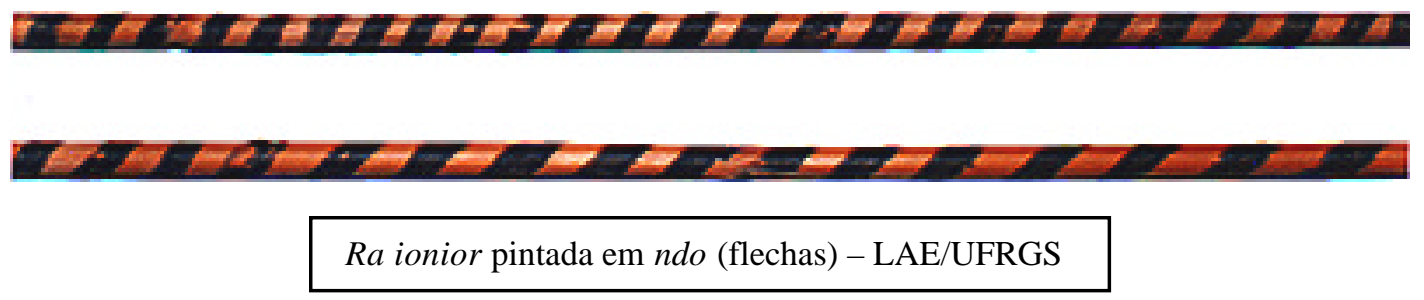

\footnotetext{
${ }^{6}$ Vale a pena comentar que os grafismos dos trançados identificados como "pontos" apresentam estruturas quadrangulares ou losangulares, pela impossibilidade técnica do trançado representar estruturas circulares. Em outras palavras, o discurso Kaingang qualifica como "ponto", no trançado (como também em todos os outros suportes), grafismos de estrutura fechada, em oposição aos de estrutura aberta ("traços").

${ }^{7}$ Para uma comparação dos grafismos da pintura corporal Xerente com os da Kaingang, veja subitem 5.1.2.
} 
Ra ionior em gargalo de garrafa tufy MJC/RS 2891/1872 Et

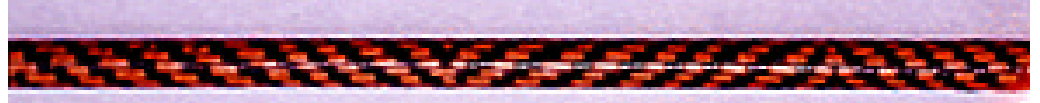

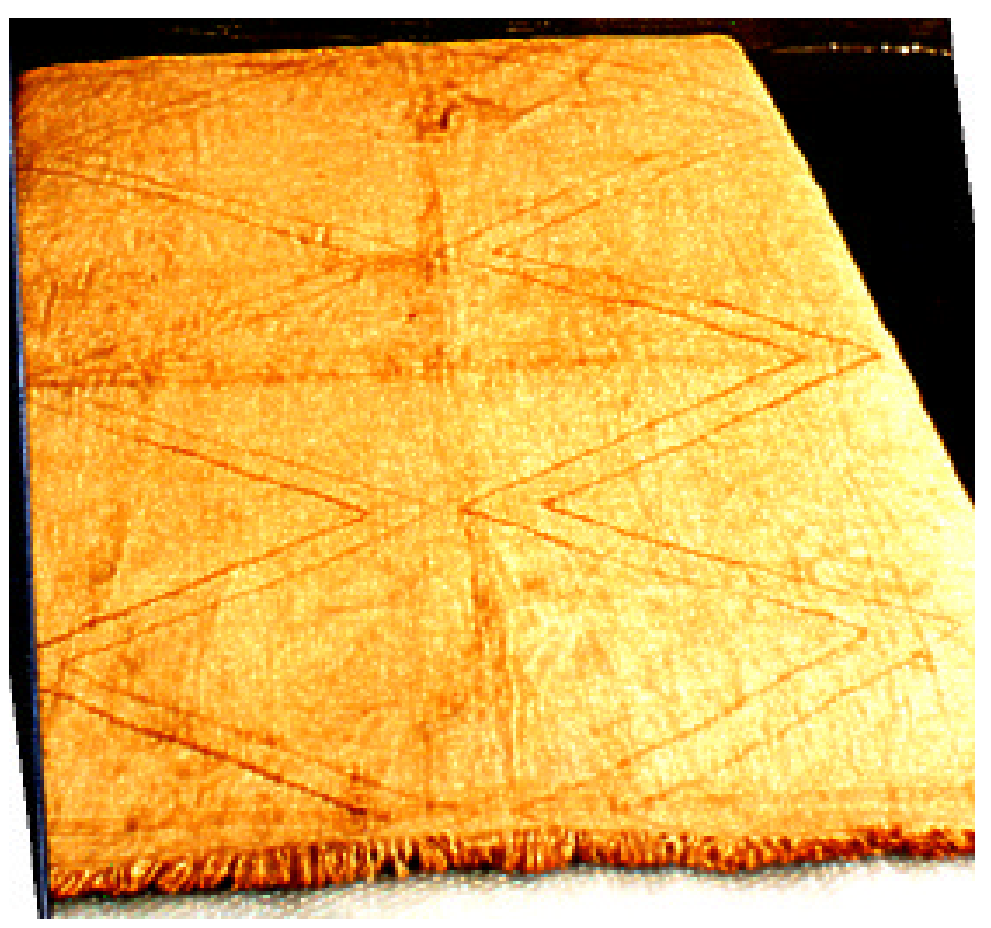

Ra ionior rangrê em kurã (manto de urtiga) MAE/USP 3284

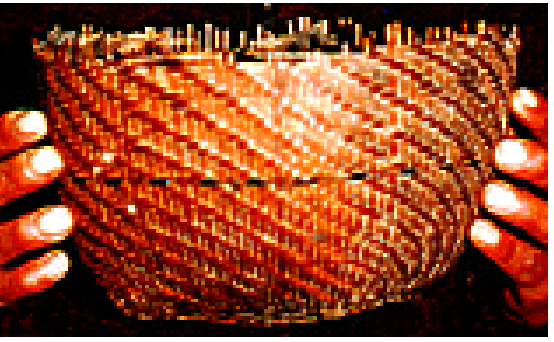

Véin kõpó em ndo kander (flecha com ponta lisa) pintada - MJC/RS 2675/1647 Et
Ra téi em kre ror (cesto redondo) com ndéi (revestido internamente com cera) MJC/RS 2103/740 Et 
O mesmo se passa com as ra ror (marca redonda/quadrangular/fechada dos Kainru-kré): algumas possuem nomes próprios: ra kutu (marca redonda, cheia), ra ndor (marca do buraco/redonda vazia), ra ror pipir (marca dos Kainru-kré sozinha), ra ror ê (marcas [muitas] dos Kainru-kré), ra ror tuxigxá (marcas emendadas dos Kainru-kré) e ra mbrirmbrir (marca "tabuleiro de xadrez"). No entanto, a maioria delas é chamada, simplesmente, de ra ror.

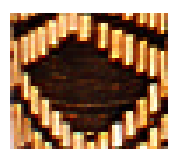

Ra kutu (marca redonda, cheia) em garrafa tufy (trançado aplicado) - MJC/RS 2892/1873 Et

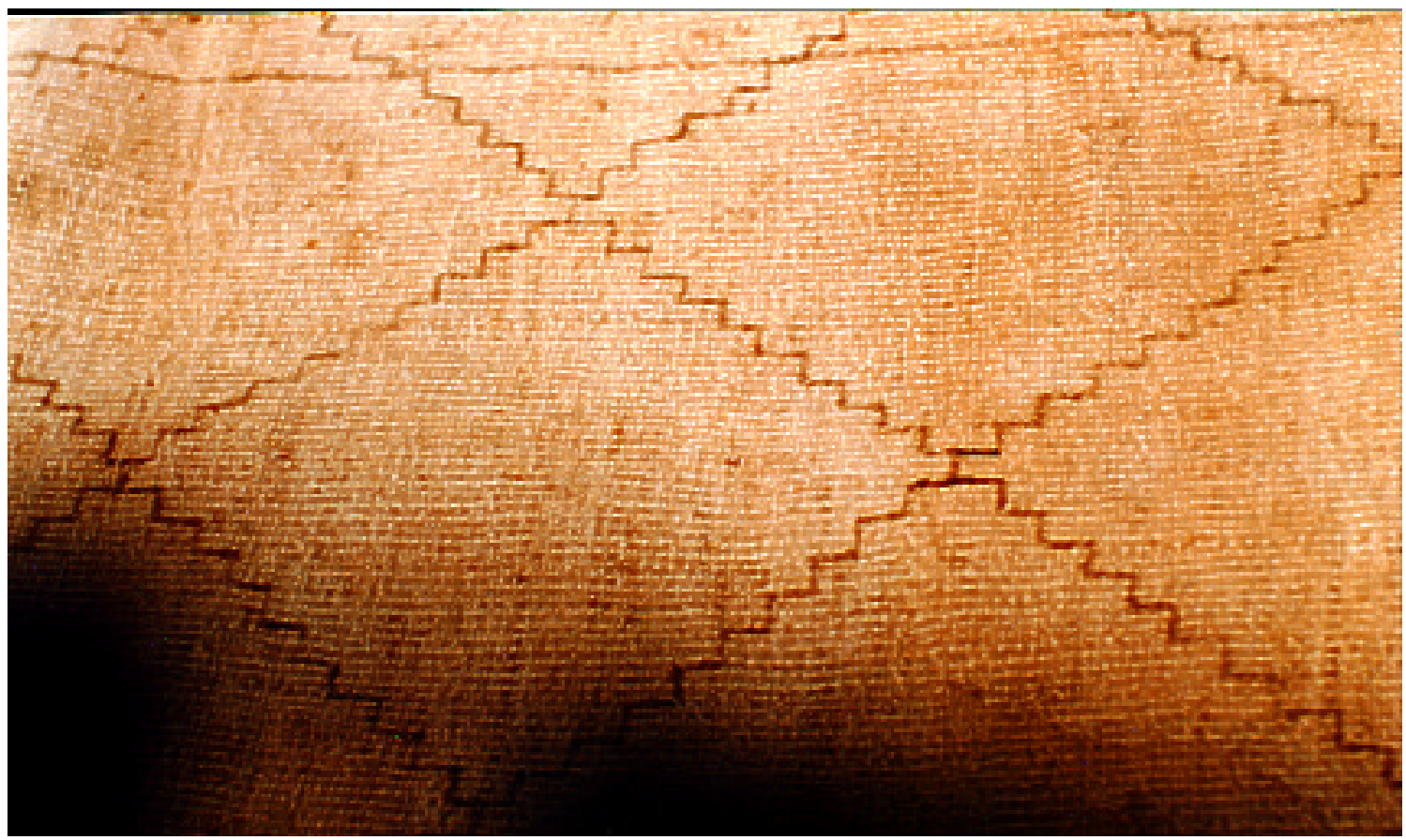

Ra ror $\hat{e}$ (marcas [muitas] dos kainru-kre) em kurã (manto de urtiga) - MAE/USP 3746

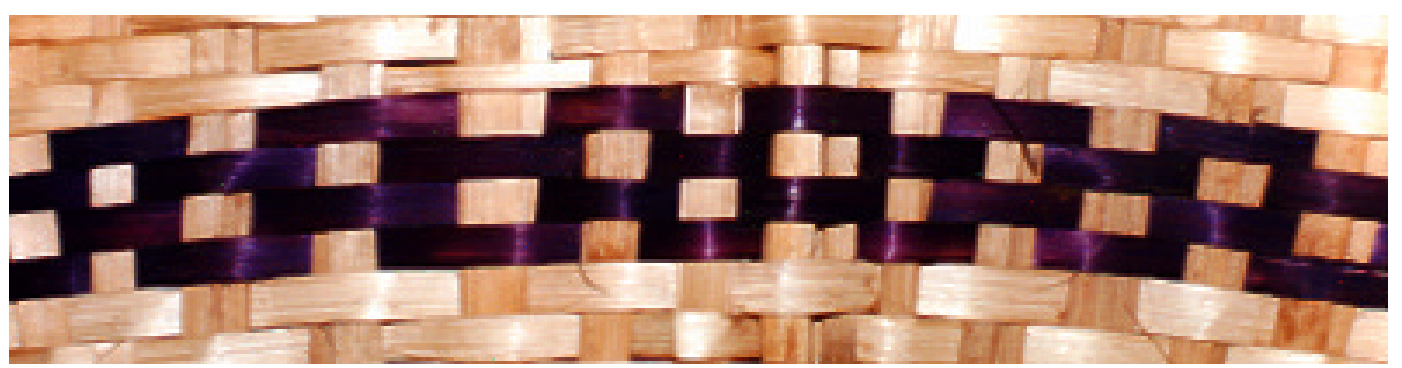

Ra ror tuxigxá em kre (cesto) de Santa Catarina - MAE/USP 14.078 


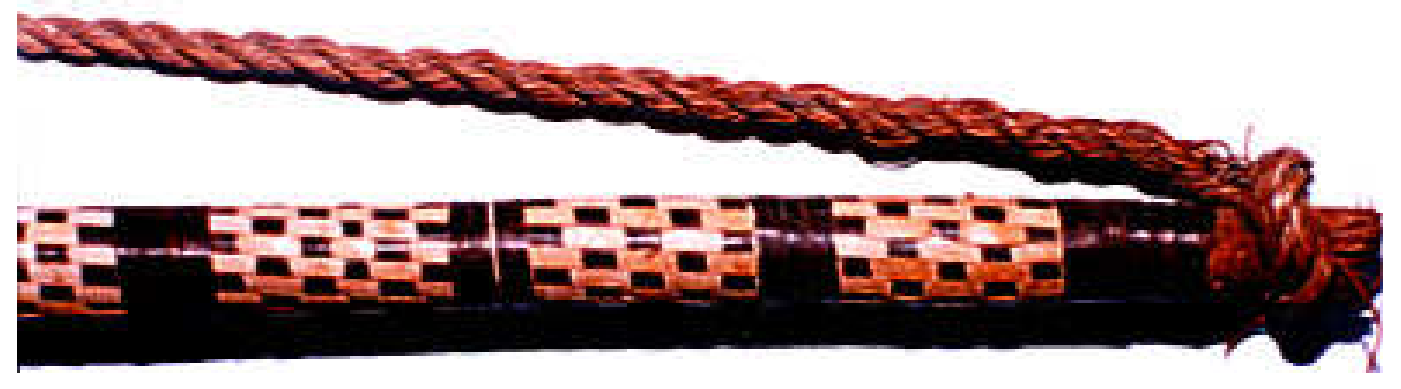

Ra mbrirmbrir em $u y i(\operatorname{arco})-$ LAE/UFRGS

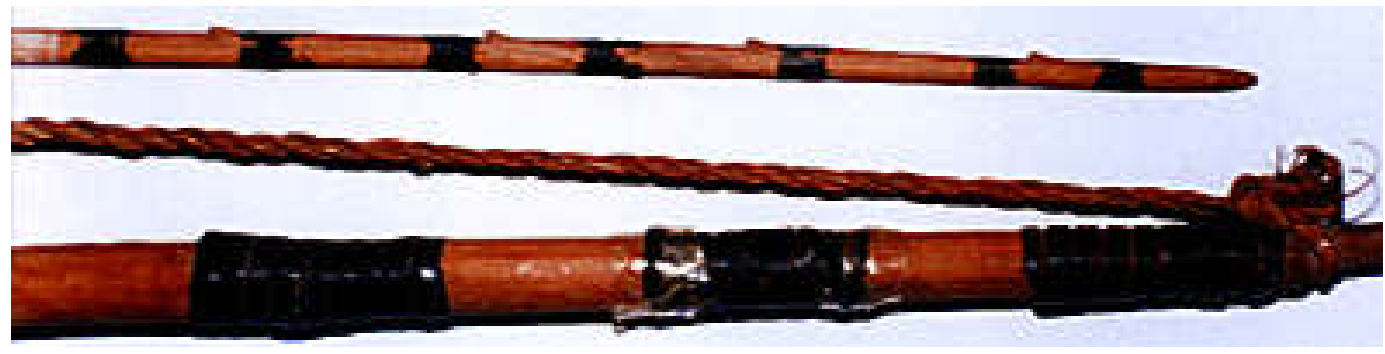

Ra ror pintada em ndo rér (flecha com ponta unisserilhada) e confeccionada com kó mrür fãr (casca de cipó imbé) em uyi (arco) - LAE/UFRGS

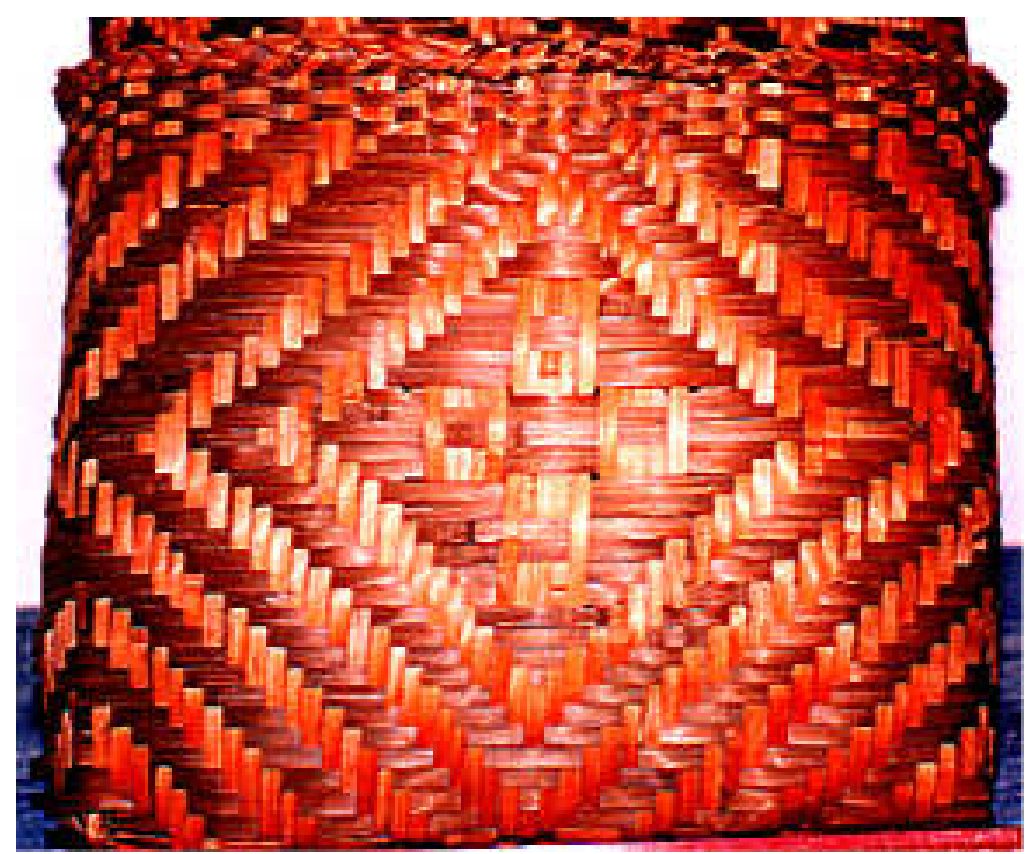

Ra ndor (marca redonda, vazia) em kre (cesto) LAE/UFRGS 
Alguns grafismos apresentam uma fusão entre o padrão fechado e o aberto, representando graficamente tanto a metade kamé como a kainru-kré: são as chamadas ra iãnhiá, assim denominadas porque "misturam" as "marcas". Conforme os Kaingang de Nonoai, a ra iãnhiá (marca misturada) indicaria um indivíduo com "autoridade" sobre as duas metades ${ }^{8}$

Atualmente, esta marca é mais comum na pintura corporal dos Kaingang do Rio Grande do Sul, principalmente os de Iraí.

Entretanto, no século XIX, era usada, pelo menos, ou nos kurã (mantos de urtiga), ou para marcar os limites dos territórios de coleta de pinhão de cada grupo local ${ }^{9}$ ou nas flechas dos caciques, o que poderia ser interpretado, por um lado, como um uso "personalizado" (pessoas com status especial/caciques) ou, por outro, como decorrência do primeiro uso, em contextos também pós-contato, em pleno século XIX, como emblemático de todo um grupo (marcação do território de coleta tribal, conforme Mabilde, [1836-1866] 1983, marca de número 2).

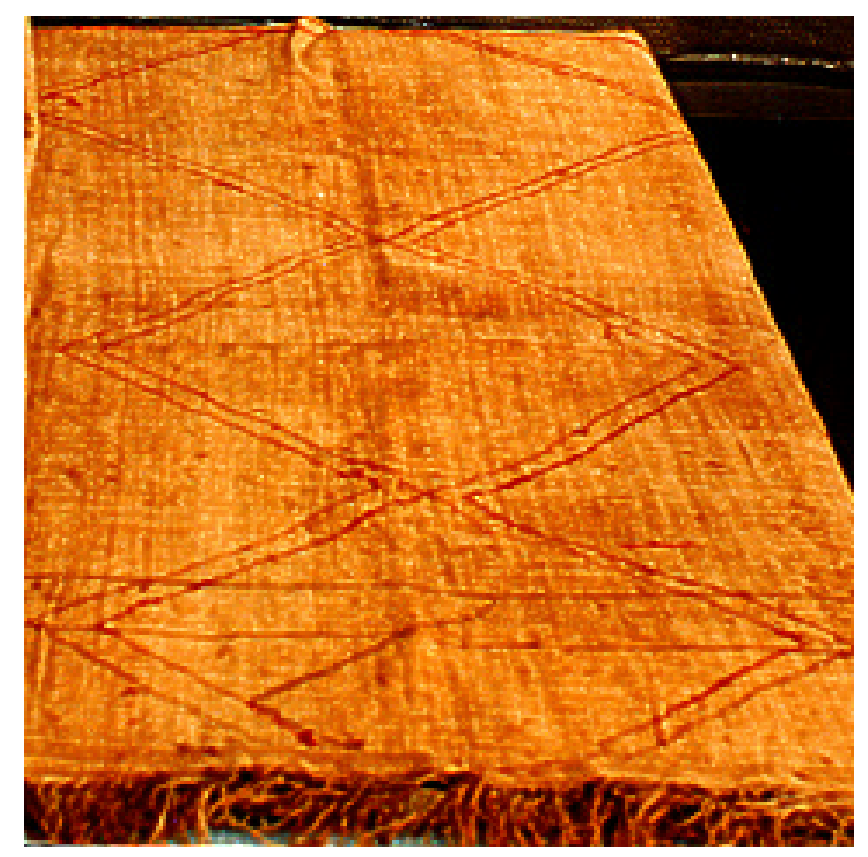

Ra iãnhiá em kurã (manto de urtiga) MAE/USP 3283

\footnotetext{
8 Estas marcas serão melhor analisadas nos parágrafos que tratam da representação gráfica da complementariedade entre as metades.

${ }^{9}$ Veja mais detalhes sobre etno-história Kaingang e grafismos, a seguir.
} 
Estas marcas mistas, "misturadas", conforme os Kaingang de Nonoai e de Iraí não devem ser confundidas com as ra ror ê. Estas últimas entrecruzam linhas paralelas oblíquas alternadas, formando losangos, ou linhas horizontais e verticais, formando figuras retangulares ou quadradas, seu campo gráfico devendo, necessariamente, estar delimitado, formando, no primeiro caso, um losango maior, preenchido por pequenos losangos, ou, no segundo, um retângulo ou quadrado maior, subdividido, conforme o caso, em retângulos ou quadrados menores.
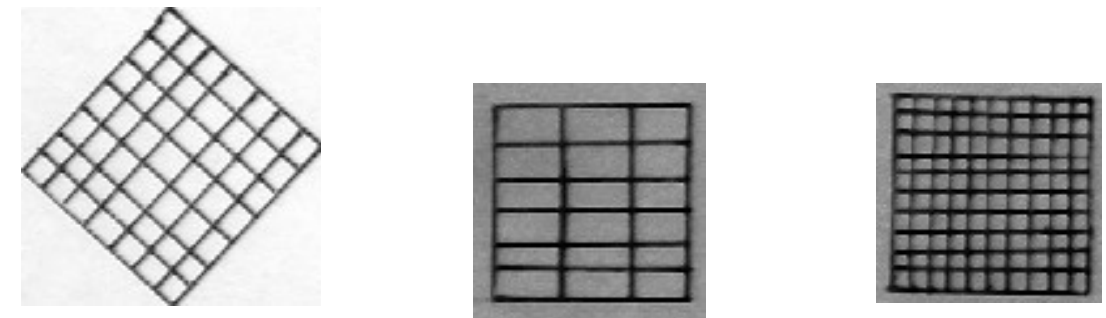

Grafismos ra ror ê: muitas marcas - redondas/fechadas - dos kainru-kré

Já grafismos semelhantes aos acima descritos, mas sem delimitação do campo gráfico, são considerados pelos Kaingang de Nonoai e de Iraí como "marca redonda e na mesma hora marca comprida, mistura de kamé e kainrukré, ra iãnhiâ".
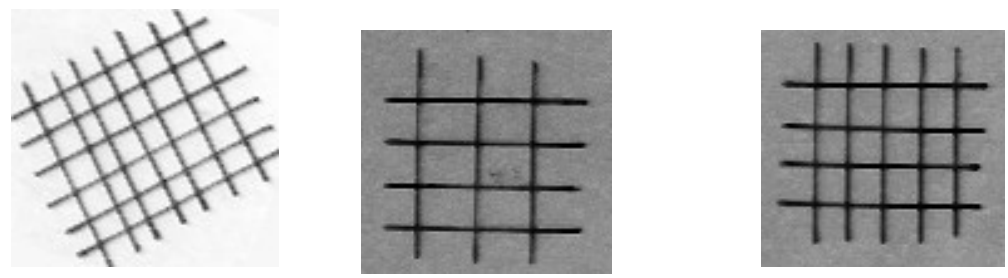

\section{Grafismos ra iãnhiá}

Estas marcas mistas também costumam aparecer com freqüência na cerâmica Proto-Jê meridional e em alguns painéis rupestres do sul do Brasil, como, por exemplo, no Abrigo do Virador, Rio Grande do Sul ${ }^{10}$.

\footnotetext{
${ }^{10}$ Estas ocorrências serão analisadas no final deste capítulo.
} 
Neste sentido, é importante que se ressalte que todos os kong-gãr (grafismos) aqui apresentados não estão presentes apenas nos wõgfy (trançados em geral). Além de aparecerem nos kre (cestos) e nos tugfy (trançados aplicados a arcos, flechas, garrafas, etc.), eles podem ser vistos enquanto pintura nos corpos preparados para o kiki ou para uma apresentação de dança ${ }^{11}$ ou nos mantos de urtiga (kurã) ou nas flechas (ndo - flecha com ponta aguçada - ou $n d a$ - virote) ou nos porongos usados como recipientes (run-ia), que serão vistos mais adiante.

O acervo arqueológico Proto-Jê meridional analisado, incluindo a cerâmica arqueológica e alguns painéis rupestres do sul do Brasil, também apresenta grafismos formalmente iguais a estes kong-gãr (grafismos) Kaingang. Ademais, tanto estes últimos como os primeiros são semelhantes formalmente às marcas dos Coroados apresentadas por Mabilde em meados do século XIX, o que nos permite ligar o passado mais ou menos recuado (ProtoJê) com o presente, através do passado mais recente. Os grafismos Kaingang presentes em seus trançados, tecidos em seus kurã (mantos de urtiga), pintados em suas armas, utensílios, e em seus corpos também já estiveram gravados em alguns painéis rupestres do sul do Brasil ${ }^{12}$ e impressos nas nga ta kukrü (panelas de barro) Proto-Jê.

Portanto, os grafismos do sistema de representações visuais (Proto)Jê meridional, além de estarem presentes em vários suportes, são confeccionados através das mais diversas técnicas: trançado, tecido, pintura, gravação e impressão.

Todos estes kong-gãr (grafismos) pré-históricos, como se verá detalhadamente mais à frente neste capítulo, foram identificados, nomeados e interpretados por meus interlocutores Kaingang como sendo ra téi, ra ror e ra iãnhiá.

Retornando aos grafismos Kaingang, desde o início dos levantamentos de sua cultura material em instituições museológicas, deparei-me com alguns objetos que possuem tanto grafismos lineares como, também, circulares, grafismos estes que representam e identificam metades diferentes. Estes objetos com marcas diferentes (duas marcas) permitiram compreender outras esferas da vida Kaingang: as relações de alianças e o conflito político.

\footnotetext{
${ }^{11}$ Veja item seguinte: 5.1.2.

${ }^{12}$ Item 5.3.
} 
Conforme os Kaingang de Nonoai, quando téi e ror estão juntos o que é mostrado é que estamos diante da representação visual de uma relação de aliança: o objeto onde as duas marcas diferentes estão presentes representa ou a ligação pelo casamento entre um homem e uma mulher ou simboliza a relação entre dois homens, originada pelo casamento da irmã de um deles com o outro. Em ambos os casos, o kong-gãr presente no objeto está representando a relação de aliança entre dois indivíduos pertencentes a patrimetades exogâmicas opostas, isto é, com $r a$ (marcas/pintas) diferentes.

Dois iambré, cunhados, necessariamente possuem ra diferentes, uma vez que pertencem a patrimetades exogâmicas opostas. De acordo com a interpretação dos interlocutores Kaingang de Nonoai, esta relação de afinidade é representada graficamente em objetos que devem ser utilizados, em comum, pelos iambré, notadamente quando têm uso ritual, como é o caso do item comentado: uma garrafa tufy com ra $\hat{e}$ (muitas marcas), possuindo $r a$ téi e ra ror, usada para beber no ritual do kiki, que dramatiza as relações assimétricas e complementares entre as patrimetades Kamé e Kainru-kré.

Garrafa tufy com ra ê (muitas marcas), possuindo ra téi e ra ror (MJC/RS 2891/1872 Et): o objeto que aproxima os opostos

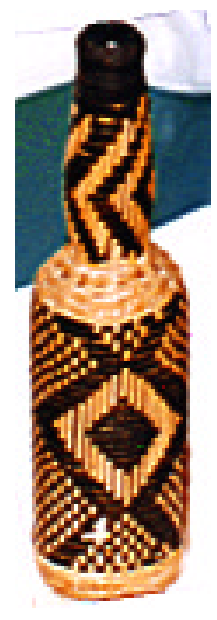

Ainda segundo os Kaingang de Nonoai, a garrafa tufy também é usada em outras situações, não rituais, para armazenar e beber líquidos em geral. Nestes casos, possui apenas a marca de seu dono, ou ra téi ou ra ror, e é de uso exclusivo de seu proprietário. 


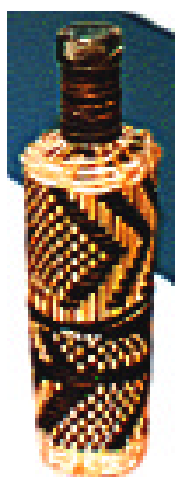

A idéia da garrafa tufy é muito antiga na cultura Kaingang, sendo originalmente confeccionada, conforme meus interlocutores, em gomos de taquara, nos quais eram aplicados trançados: os ven kuië tufy, confeccionados, como as garrafas tufy, com ko mrür fãr (casca de cipó imbé) e kré (criciúma). Tanto umas como outros eram utilizados para tomar o kiki (bebida fermentada feita a partir de vários tipos de mel silvestre) na festa dos mortos (kiki) ou para beber líquidos em outras situações, estas não rituais. No primeiro caso, uso que explica a presença de grafismos opostos no mesmo objeto, o kiki retirado do cocho por um kamé receberia o primeiro gole por parte de um kainru-kré, idealmente e de fato, iambré do homem kamé. Segundo meus interlocutores, "é por isso que algumas garrafas tufy têm $r a \hat{e}$, ao mesmo tempo ra ror e ra téi, pois o iambré precisa tomar junto com o dono". Se o grafismo predominante na garrafa tufy é téi, seu dono, por conseqüência, é um kamé; se o kong-gãr que predominar for ror, trata-se de um objeto pessoal de um kainru-kré.

Em outras palavras, o ato de beber o kiki com o iambré no mesmo recipiente durante o ritual do kiki reforça a complementariedade dos opostos. Esta mesma complementariedade fica representada graficamente, através do 
sistema de representações visuais, no objeto que aproxima os opostos (no caso presente, os iambrê).

Registrei, ainda, um segundo exemplo de objeto com grafismos diferentes: um cesto com tampa que representava, tanto no nível morfológico como no nível gráfico, uma aliança matrimonial.

A regra da exogamia de metades ainda encontra-se idealmente preservada no discurso Kaingang, apesar de ser cada vez menos observada na atualidade. No passado, no entanto, segundo meus interlocutores, era regra seguida à risca: casava-se sempre no outro lado. A aliança matrimonial entre homem e mulher pertencentes a patrimetades diferentes poderia e deveria ser representada visualmente, na cultura material, como indicativo da condição da mulher (se solteira ou casada) e do pertencimento dela e de seu marido a uma das duas patrimetades.

Um kre (cesto) com kritã (tampa) de inícios deste século representa uma mulher kainru-kré casada com um homem kamé: todos os kaingang, conhecidos seus ou não, que a vissem usando seu kre saberiam de sua condição de casada com um kamé, pois na tampa (que representa a mulher) estão presentes kong-gãr (grafismos) kainru-kré, e no bojo (que representa o homem) encontram-se kong-gãr kamé.

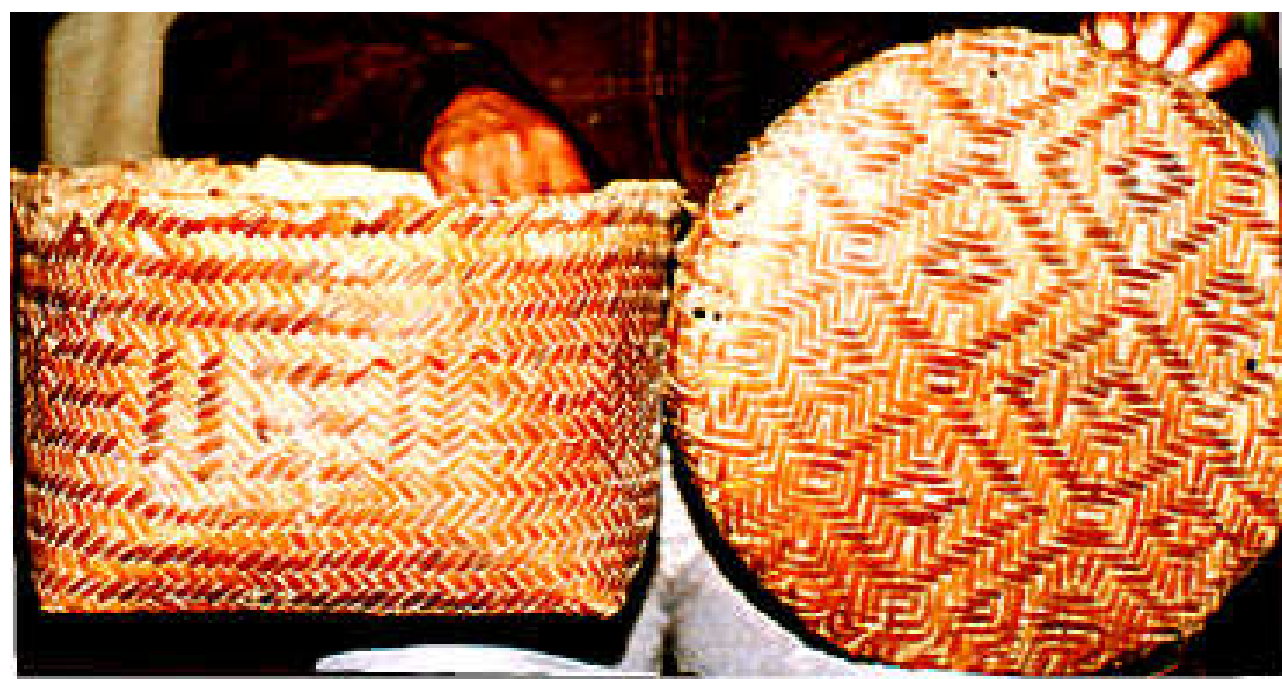

Kre com kritã: laços matrimoniais (MJC/RS 1023/145 Et)

Neste caso específico de objeto com kong-gãr diferentes, tem-se a interferência de dois níveis do sistema de representações visuais: 1. o 
morfológico, através dos signos bojo/homem/parte maior :: tampa/mulher/parte menor, e 2. o gráfico, por intermédio dos kong-gãr téi ou ror, presentes em cada uma destas formas que compõem o kre.

Poder-se-ia, além disso, interpretar a presença, em um mesmo objeto, lado a lado, de kong-gãr opostos, exclusivos das metades, como a representação gráfica das relações de complementariedade que idealmente regem a convivência social de membros de patrimetades opostas e diferentes, como bem demonstram as escolhas matrimoniais, as obrigações rituais com viúvos (as) e/ou falecidos de patrimetades opostas, etc., e que, igualmente, são enfatizadas pelo ideal kaingang de busca de simetria entre opostos. Os objetos com duas marcas (como os acima comentados), ao representar visualmente relações concretas (de afinidade ou matrimoniais), enfatizam também esta complementariedade entre as duas patrimetades.

Esta interpretação parece ficar mais clara e plausível quando nos deparamos com um kong-gãr téi realizado a partir de elementos gráficos ror, como parece ser o caso dos grafismos constantes de dois kurã (mantos de urtiga) e de um ka mror (cacetete/borduna) Kaingang, os primeiros originários um do Paraná e o outro de SP, e o terceiro, de São Paulo, igualmente.
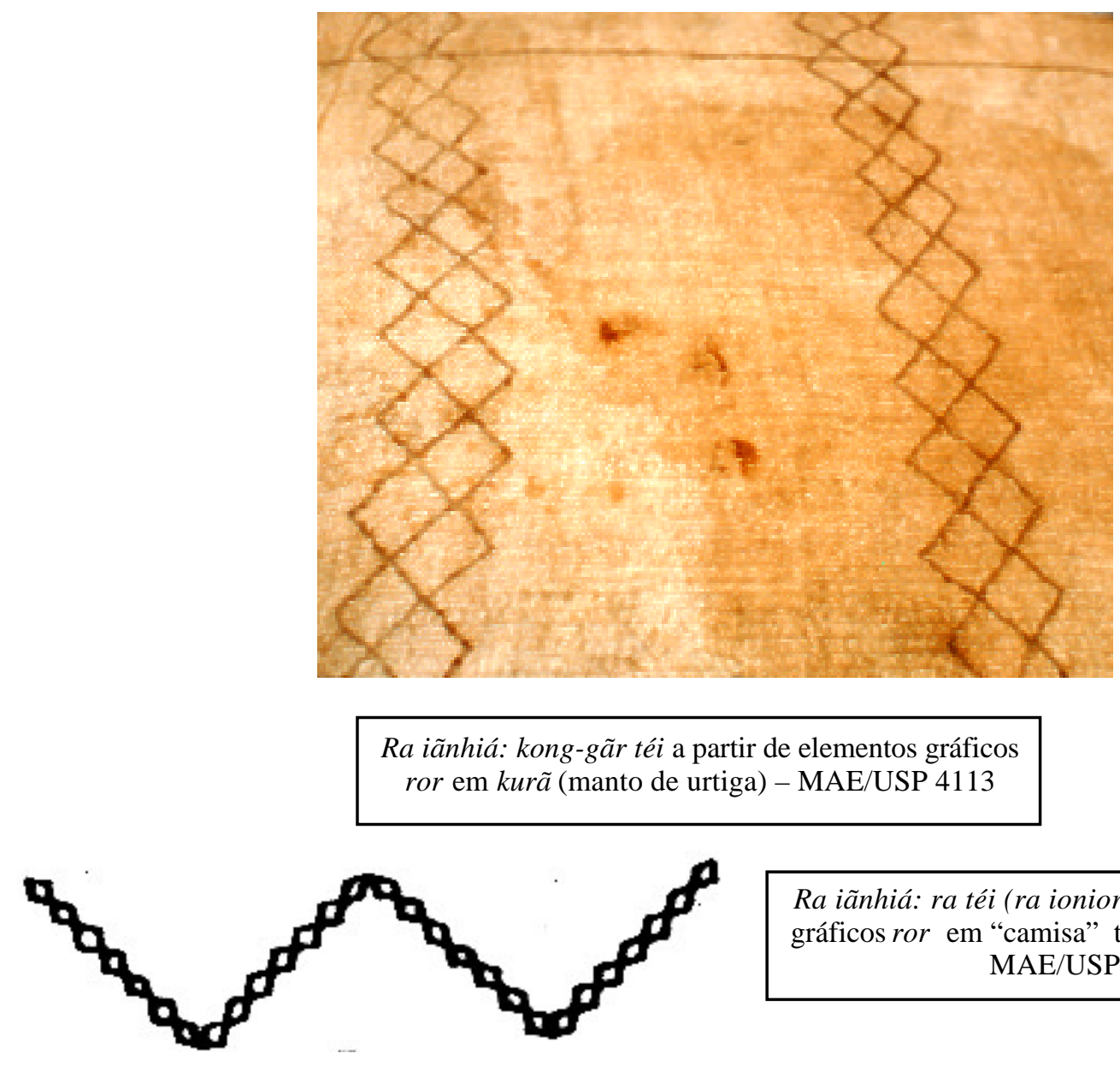

Ra iãnhiá: kong-gãr téi a partir de elementos gráficos ror em kurã (manto de urtiga) - MAE/USP 4113

Ra iãnhiá: ra téi (ra ionior) a partir de elementos gráficos ror em "camisa" tradicional Kaingang MAE/USP 3285 


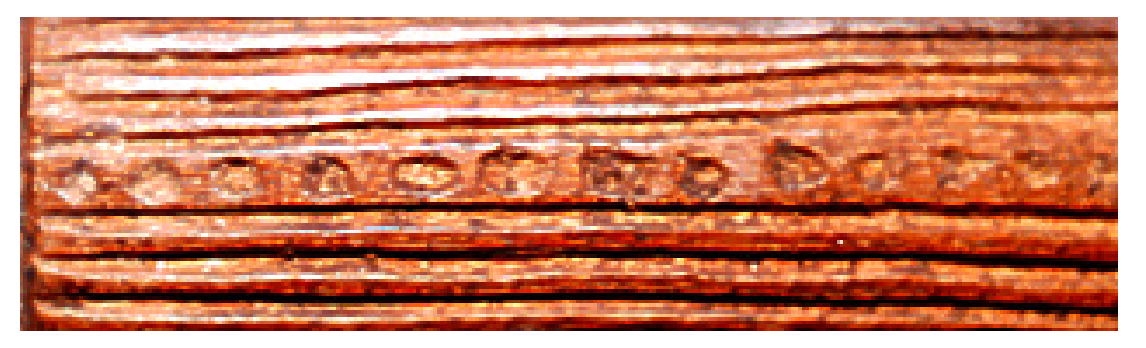

Ra iãnhiá: ra téi em ka mror (borduna) a partir de elementos gráficos ror - MAE/USP 4753

Ao contrário dos dois exemplos citados anteriormente (garrafa tufy e kre com kritã), teríamos nos grafismos presentes nos mantos e na borduna, pura e simplesmente, a representação gráfica das representações mentais Kaingang, que sublinham o ideal de harmonia e de complementariedade entre as duas metades, não mostrando gráfica ou morfologicamente nenhuma relação concreta, mas, sim, a fertilidade e eficácia simbólica da junção/união de princípios contrários. São as denominadas ra iãnhiá (marca misturada), já comentadas. Os Kaingang de Nonoai interpretam-nas como o emblema gráfico de um indivíduo que exerça autoridade e influência sobre ambas metades, como o cacique.

Um exemplo de kong-gãr ror (grafismo representativo da metade Kainru-kré) confeccionado a partir de elementos gráficos téi é a marca de número 2, apresentada por Mabilde (veja a seguir) e presente tanto em materiais históricos, comprovadamente Kaingang (como os kurã do MAE/USP 3283 e 4113 e os kurã apresentados por Fernandes, 1941:215, um deles com grafismo ror - losangular - formado por grafismo téi - véin kõpó), como em painéis rupestres pré-históricos do sul (Virador, por exemplo). Alguns grafismos rupestres de Santa Catarina, aqui considerados Proto-Jê meridionais, poderiam estar representando um kong-gãr ror confeccionado com elementos gráficos téi. O discurso Kaingang, expresso por meus interlocutores, aponta nesta direção, pois, além de reconhecerem estes grafismos rupestres como sendo Kaingang, explicam sua vinculação às metades, denominando-os de ra iãnhiá.

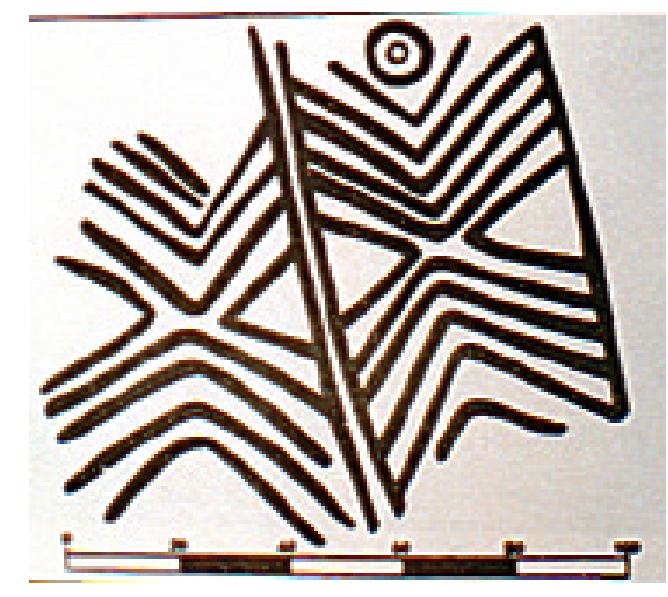

Grafismo rupestre da Ilha do Campeche - SC. Desenho de Rohr, 1969 a. O grafismo da direita, segundo os Kaingang de Nonoai, é ra iãnhiá: elementos gráficos téi (ra ionior) formando kong-gãr ror, pois tem seu campo gráfico delimitado, fechado, por duas linhas verticais. 
Com referência à etno-história dos grafismos Kaingang, os apontamentos do Cel. Mabilde, de meados do século XIX, têm uma grande importância, na medida em que constituem um registro formal e escrito de um dos primeiros observadores que fez referência expressa a grafismos encontrados em dois tipos de suportes: 1. nos pinheirais do Planalto Sul-riograndense para demarcar os limites territoriais de exploração dos mesmos por aldeias Kaingang; e 2. nas flechas. Os primeiros grafismos seriam cortados nas cascas das árvores e os segundos, pintados sobre as flechas dos caciques subordinados $^{13}$ (Mabilde, [1836-1866] 1983:166). Além do registro de sua existência, Mabilde reproduz os dez grafismos por ele observados e denominados de marca, uma das duas formas como os Kaingang atuais traduzem a palavra $\mathrm{ra}^{14}$.

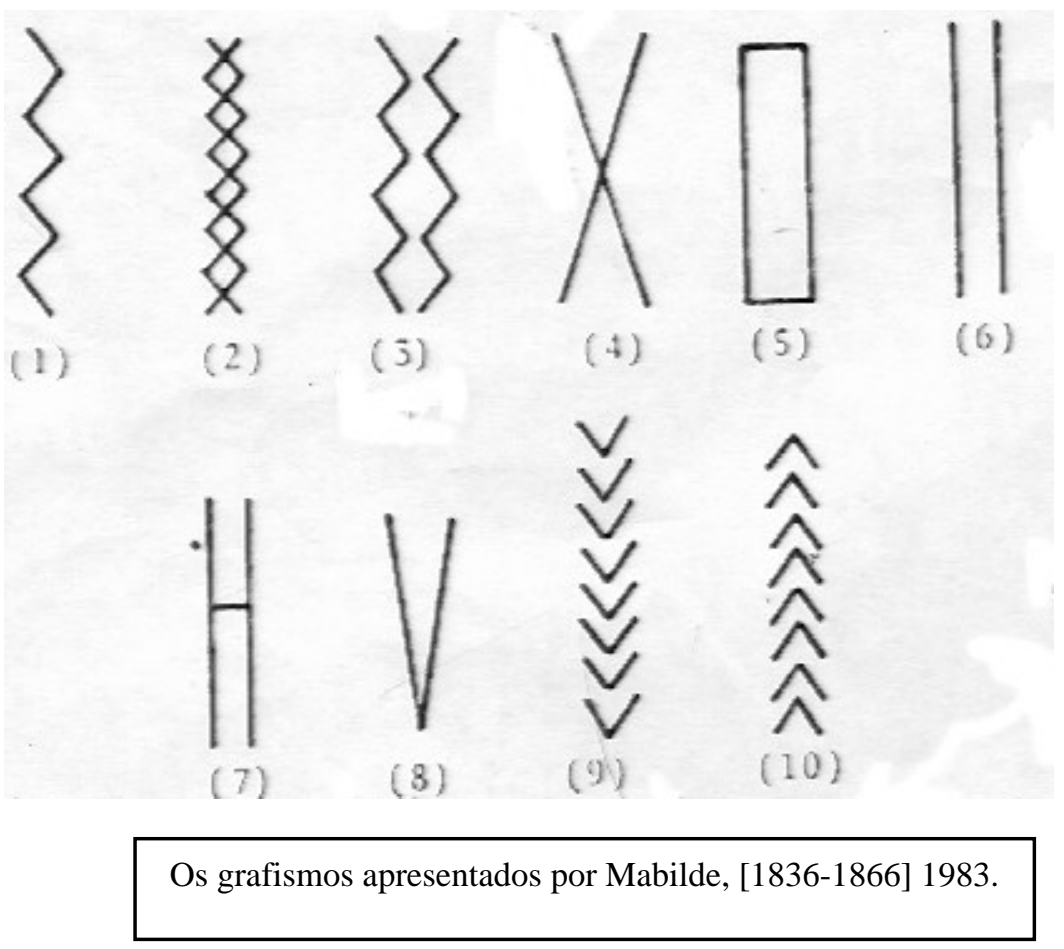

Os dez kong-gãr descritos e reproduzidos por Mabilde foram reconhecidos como Kaingang por meus interlocutores, tendo sido nomeados. Oito entre eles foram classificados como ra téi, tendo sido encarados como uma representação gráfica da patrimetade Kamé. Dentre as dez marcas citadas

\footnotetext{
13 “...está [o grupo] dividido em pequenas tribos constituídas por famílias entrelaçadas e parentes chegados. Cada uma dessas tribos tem o seu chefe. E essas tribos estão sujeitas a uma autoridade superior de quem dependem, que é o cacique principal ou chefe de todas elas, e a quem prestam uma obediência cega". Cf. Mabilde, 1983.

${ }^{14}$ A outra, é "pinta".
} 
pelo autor apenas duas foram identificadas pelos Kaingang como ror e téi, ao mesmo tempo: são as marcas de números 2 e 5, denominadas de ra iãnhiá. Seriam usadas por autoridades "que representam, comandam, os dois grupos". Todas elas são, atualmente, reproduzidas nos wõgfy Kaingang.

1. ra ionior pir - marca em ziguezague ou espiral ou sinuosa ( $r a$ téi);

2. ra iãnhiá - marca misturada ("marca redonda e na mesma hora marca comprida"; "usada por autoridade");

3. ra ionior rangrê - duas marcas sinuosas, ou em espiral, ou em ziguezague ( $r a$ téi);

4. véin kõpó - marca repartida, separada, dividida - ou véin kikru marca da cruz (ra téi);

5. ra rangrênhiá - ("usada por autoridade");

6. ra téi rangrê - duas marcas compridas (ra téi);

7. véin kénki - marca cortada ao meio ( ra téi);

8. ra wendig - marca da forquilha ( $r a$ téi);

9. ra iangérin (ra téi);

10. ra iangérin (ra téi).

A marca de número sete (conforme Mabillde, [1836-1866] 1983:146), está presente em ndo (flecha) Kaingang do acervo do Museu Júlio de Castilhos. Nela, além do véin kénki (a número 7 de Mabilde), há outras marcas, também ra téi, como a ra ionior (espiral). A referência de Mabilde à presença da marca em forma de "H" nos pinheirais, sua citação expressa à existência do mesmo tipo de marca nas flechas dos "caciques subordinados" Coroados, juntamente com sua ocorrência em uma ndo reconhecidamente Kaingang, demonstram a confiabilidade dos registros de Mabilde quanto aos grafismos, além de indicar, pelas informações etnográficas atuais, que as três situações mencionadas (marcas nos pinheirais, marcas nas flechas dos "caciques subordinados" e marcas nas flechas Kaingang) estão ligadas à representação visual, no nível gráfico, da metade Kamé.

Esta última constatação, portanto, leva a crer que as marcas de posse nos pinheirais estavam ligadas às representações gráficas das metades, podendo, ou não, ser individuais. Em outras palavras, algumas marcas poderiam ter uso exclusivo de um indivíduo de "status" elevado, um cacique principal ou um cacique subordinado, cuja presença nos pinheirais indicaria que estas áreas delimitadas seriam território do grupo liderado pelo cacique que tinha o uso exclusivo daquela marca, que, além de representar graficamente toda uma aldeia, ou grupo, enfatizava a metade do seu líder. Se 
esta hipótese for verdadeira, teríamos, pelo menos na época de Mabilde, um maior número de líderes Kamé, já que apenas duas das dez marcas por ele apresentadas não especificam expressamente a patrimetade e, sim, o ideal de complementariedade entre as metades.

Igualmente, Mabilde apresenta três marcas dos Coroados liderados pelo cacique Nhancuiá, habitantes de Cavará-Cuiá, no Rio Grande do Sul, usadas para pintar, "com uma tinta preta, muito reluzente", suas flechas ou para assinalar "o território de pinheiral ocupado pela tribo" (Mabilde, [1836-1866] 1983:146-7).

Estes grafismos também foram identificados e interpretados pelos Kaingang de Nonoai. Dois deles foram nomeados, especificamente. Todos os três foram classificados como ra téi, representações gráficas da metade kamé, o que leva a mesma conclusão anterior sobre a origem dos líderes Kaingang.

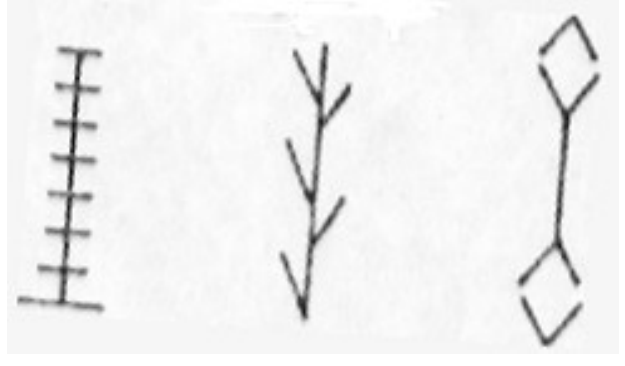

Grafismos dos Coroados do cacique Nhancuiá, apresentados por Mabilde, [1836-1866] 1983.

As denominações destes grafismos, conforme meus interlocutores Kaingang de Nonoai, são ra wendigdig (marca das forquilhas), ra ven katu wendig (marca da forquilha dos dois lados).

Também, Mabilde faz referência às marcas pintadas de vermelho nas flechas dos "botocudos que habitam a parte nordeste das matas desta província", referindo-se ao RS. Estas "marcas diferem essencialmente das dos coroados, porque todas elas são formadas por linhas curvas, do sistema circular" (Mabilde, [1836-1866] 1983:147).
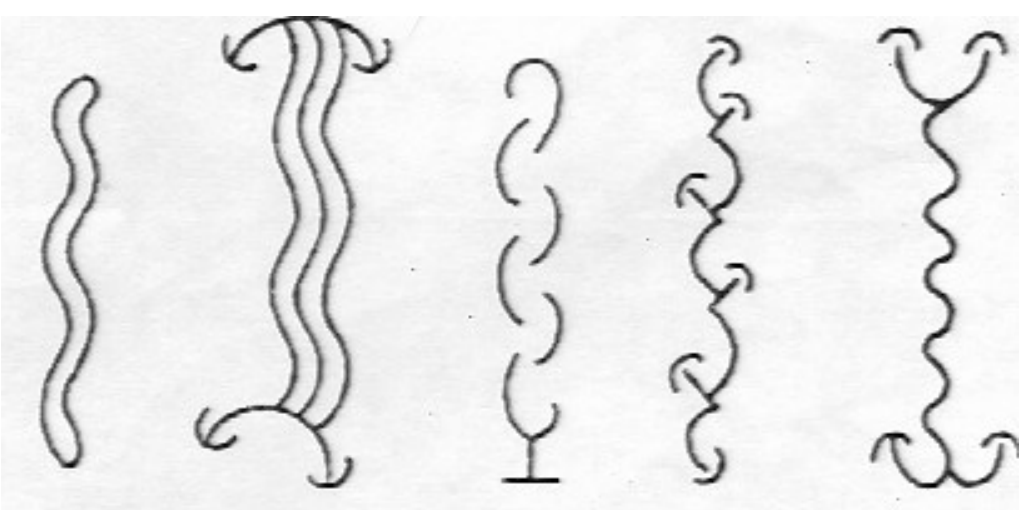

Grafismos em flechas Xokleng, apresentados por Mabilde, [1836-1866] 1983:147. 
Estes cinco grafismos Xokleng não foram comentados pelos interlocutores Kaingang, que afirmaram desconhecê-los: "São muito diferentes das marcas kaingang".

Métraux (1946), coincidentemente, relata a existência de cinco grupos, entre os "Aweikoma-Caingang", com estoques de nomes pessoais e grafismos exclusivos para pintura corporal, que poderiam ser os acima apresentados, conforme Mabilde (op. cit.). Henry $(1964: 59,88)$ diz que os nativos insistiam que pessoas com o mesmo motivo gráfico não podiam casar entre si.

No entanto, alguns grafismos do sistema de representação visual Xokleng, tanto da pintura corporal como presentes em objetos, parecem corresponder aos grafismos abertos, em traços, e fechados, em círculos, do sistema Kaingang ${ }^{15}$.

Além de Mabilde, existe outra referência antiga sobre as representações gráficas dos Kaingang. Trata-se do Dicionário Geográfico do Brasil, de Moreira Pinto, no seu verbete Coroados. Segundo o autor, os anéis de casca de cipó imbé nas flechas representam os "graos dos possuidores". Além desta rápida referência, nada mais é dito, descrito ou reproduzido. Fernandes (1941:185), no seu estudo sobre os Kaingang de Palmas, indaga seus informantes a este respeito, chegando à conclusão que "não há, todavia, entre os nossos Caingangues, qualquer recordação nesse sentido".

No entanto, meus interlocutores (Kaingang de Nonoai e de Iraí) identificaram estas representações gráficas, pintadas ou aplicadas, presentes nas $n d o$ (flechas com pontas aguçadas) $/ n d a$ (virotes) a eles mostradas como ra téi ou ra ror, como será visto a seguir.

As flechas Kaingang analisadas pertencem a acervos de três instituições: Museu de Arqueologia e Etnologia da USP, Museu Júlio de Castilhos/Secretaria Estadual de Cultura do Rio Grande do Sul e Laboratório de Arqueologia e Etnologia/UFRGS.

As flechas Kaingang pertencentes ao acervo do Museu de Etnologia e Arqueologia da Universidade de São Paulo têm proveniência especificada, para cada uma delas, na listagem anexa. As mais antigas foram coletadas pelas

\footnotetext{
${ }^{15}$ Para maiores detalhes, veja item 5.1.2.: Vein kongat - pintura corporal Kaingang.
} 
expedições da Comissão Geológica e Geográfica do Estado de São Paulo aos rios Feio e do Peixe, em 1906, por ocasião dos levantamentos por ela executados para a construção da Estrada de Ferro do Noroeste, refletindo, portanto, os primeiros contatos efetivos com os Kaingang desta região paulista, período conhecido eufeministicamente como "Pacificação". No geral, além deste conjunto referido, o acervo do MAE/USP contém flechas coletadas por H. Baldus e H. Schultz, no final da década de 40, e por F. Lane.

As ndo/nda do acervo do Museu Júlio de Castilhos situam-se temporalmente nas primeiras décadas deste século, na sua maioria. As da coleção do LAE/UFRGS são mais recentes, tendo sido coletadas, na sua maior parte, pelo Prof. Rambo, nas décadas de 40 e 50.

O trabalho de campo permitiu reconhecer as matérias-primas empregadas na sua confecção, suas técnicas de produção, além de ser iniciado um processo de compreensão das expressões estéticas nelas presentes.

As flechas Kaingang são denominadas $n d o$, quando apresentam pontas aguçadas, que provocam perfuração no alvo, ou nda, no caso de possuírem pontas rombudas, denominadas de virote, usadas para atordoar o alvo, não o danificando, sendo utilizada principalmente para abater aves.

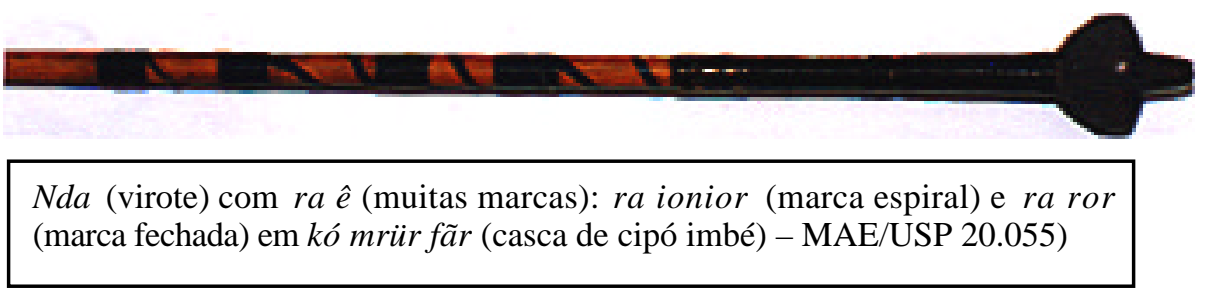

As $n d o$ têm nomes diferenciados de acordo com a matéria-prima e o tipo de sua ponta ativa: ndo rér (flecha de madeira com ponta serrilhada, geralmente uni-serrilhada, usada na pesca), ndo kuka kainhér (flecha com ponta de osso de macaco, para caça e guerra), ndo ky fé ni (com ponta de ferro), ndo iuran/ndo kandér (com pontas de madeira aguçadas) ou simplesmente $n d o^{16}$.

Ndo rér (flecha com ponta unisserrilhada) com ra ionior pintada - MJC/RS

${ }^{16}$ Algumas apresentam ponta de taquara lanceolada. Ver mais adiante. 


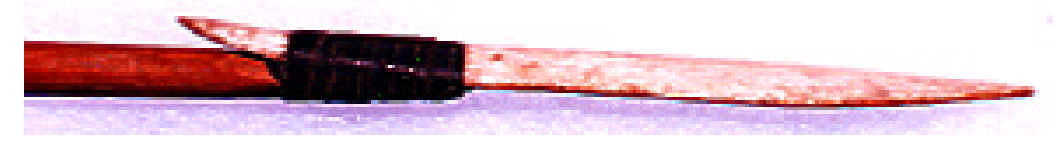

Ndo kuka kainhér (flecha com ponta de osso de macaco, formando farpa) - MAE/USP 2980
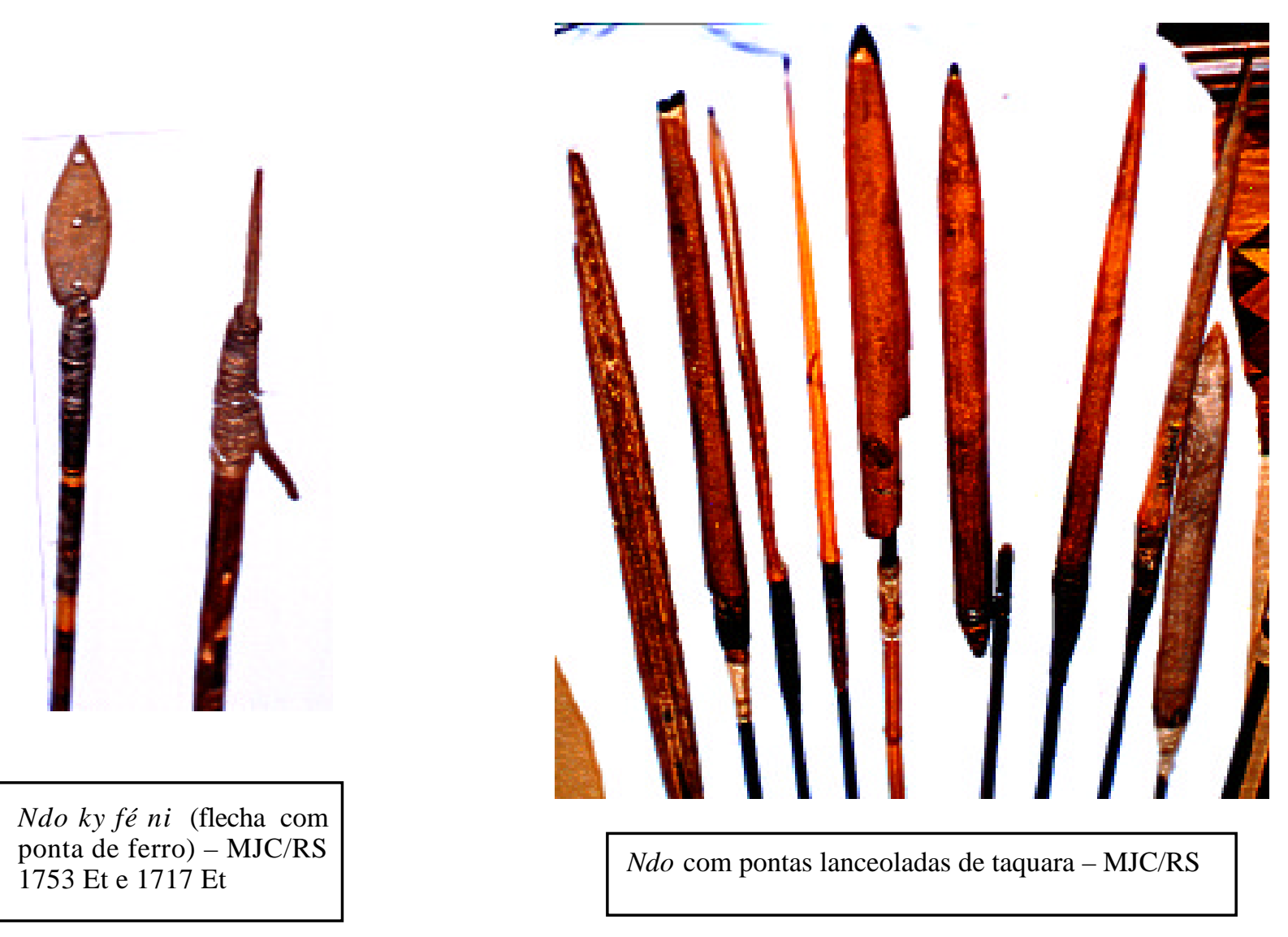

Ndo com pontas lanceoladas de taquara - MJC/RS

Alguns interlocutores Kaingang referem-se ao uso no passado de pontas feitas com material lítico lascado (no caso das $n d o$ ) ou polido (no caso das $n d a)$.

As pontas, segundo sua matéria-prima, podem ser:

1. Kuka kainhér ou óssea bideterminada, confeccionada sobre osso de pequeno mamífero, provavelmente macaco, e fixada ao corpo da flecha com cerol (ndéi) e através do enrolamento de tira de casca de cipó imbé (kó mrür $f \tilde{a} r)$. A parte côncava do osso encontra-se, na maioria das vezes, nivelada com ndéi. O enrolamento para fixação da ponta com casca de cipó imbé é feito de 
tal modo que sua extremidade proximal fique livre e levemente levantada, funcionando como farpa. O tamanho médio da ponta óssea bideterminada, incluindo a farpa, fica em torno de $8 \mathrm{~cm}$. A ocorrência das ndo kuka kainhér, até o momento, fica restrita ao Estado de São Paulo. Vale a pena frisar novamente que estas flechas foram recolhidas por volta de 1906, época dos primeiros contatos com os Kaingang de São Paulo, nos rios Feio e do Peixe.

2. Ferro (ky fé ni); produzida sobre ferro obtido junto aos brancos, malhado a frio e amolado em pedras, conforme meus interlocutores. A parte proximal da ponta de ferro fica incrustada em entalhe feito na vareta de madeira. $\mathrm{O}$ enrolamento para fixação da ponta é feito com kó mrür fãr.

3. Madeira; ocorrem três tipos de pontas de flechas em madeira: $n d o$ rér (ponta unisserrilhada), ndo iuran/ndo kandér (ponta aguçada/ponta lisa) e nda (virote).

\section{Taquara; em forma lanceolada.}

As coleções museológicas de flechas Kaingang do Rio Grande do Sul diferem pouco das do Estado de São Paulo. Nas primeiras, além de não terem sido encontradas ndo kuka kainhér (o que ocorre frequientemente em São Paulo), aparecem flechas cujas hastes e/ou varetas possuem kong-gãr pintados (o que não ocorre em São Paulo). Nas coleções do Rio Grande do Sul, há pontas lanceoladas em taquara. Nas de São Paulo, a maioria das pontas são em osso de macaco, bideterminado e formando farpa, não tendo encontrado nas coleções do MAE/USP nenhuma flecha com kong-gãr pintado. Sua decoração é feita com kó mrür fãr (casca de cipó imbé), como, de resto, também ocorre nas flechas do Rio Grande do Sul.

As partes que compõem uma flecha Kaingang, sua tecnologia de produção e as matérias-primas empregadas na sua confecção, no geral, são idênticas, o que permite fazer uma descrição geral, apontando, sempre que necessário, as exceções.

Tais flechas, cujo comprimento médio situa-se ao redor de $1,80 \mathrm{~m}$, são tecnologicamente compostas por: 1 . uma ponta ativa, 2 . um corpo composto (2.1. uma vareta em madeira e 2.2. uma haste em taquari), 3. o encaixe entre estas duas últimas porções, 4. a emplumação, 5. o entalhe para a corda do arco e 6. a empunhadura, parte livre entre o entalhe e a emplumação. Poucas vezes, o corpo apresenta-se monobloco. A maioria delas possui decoração. 
Normalmente, o corpo é composto de duas porções distintas, mas unidas, feitas de materiais diferentes: a parte proximal ou haste em taquari e a parte distal ou vareta em madeira. Estas duas partes são fixadas com um reforço de tira enrolada de casca de cipó imbé (kó mrür fãr) e cerol (ndéi), que é o encaixe. Há casos em que todo o corpo da flecha é confeccionado sobre uma única vareta de madeira. Mesmo quando isto ocorre, o encaixe reforçado com tiras de casca de cipó imbé está presente, indicando um procedimento tecnológico-funcional e um procedimento estético-decorativo, simbólico, já que representa a metade kamé, segundo a interpretação dos Kaingang, hoje.

Do ponto de vista tecnológico-funcional, o encaixe reforçado com kó mrür fãr (cipó imbé) e ndéi (cerol) serve para unir e fixar a haste de taquari (parte proximal) à vareta de madeira (parte distal), reforçando todo o conjunto. Do ponto de vista estético-decorativo, é uma das principais características das flechas Kaingang, pois mesmo naquelas confeccionadas sobre vareta monobloco de madeira, sem necessidade, portanto, de encaixe, ele está presente. Geralmente, tal encaixe localiza-se aproximadamente na parte central da flecha, mas há casos em que ele encontra-se mais próximo da parte distal, e outros, mais para a parte proximal. Isto deve-se, muito provavelmente, ao tamanho dos materiais disponíveis, que deveriam variar muito. No entanto, é mantido um padrão geral para o tamanho da flecha, como um todo. Da mesma forma, o comprimento do encaixe reforçado com kó mrür fãr mantém-se em $20 \mathrm{~cm}$.

A emplumação é feita com duas penas aparadas internamente, fixadas com fio de fibra vegetal (ven burfê - urtiga) e dispostas de forma levemente helicoidal.

O comprimento da emplumação, incluindo os fios de fibra vegetal que fixam as duas penas, fica ao redor $\operatorname{dos} 25 \mathrm{~cm}$.

No caso das ndo ornamentadas de São Paulo, a maioria delas o são com kó mrür fãr: 1. em faixas de aproximadamente $2 \mathrm{~cm}$ de largura, que ocorrem isoladamente ou em conjuntos, 2. em espirais ou 3. em forma de "x" (véin kõpó). Raramente, ocorrem 4. tufy (trançados com kré [criciúma] e kó mrür fãr [casca de cipó imbé], aplicados à flecha). 
Estes quatro tipos de ornamentação localizam-se, na maioria das vezes, na vareta de madeira - parte distal -, podendo ocorrer também na haste de taquari - parte proximal -, ou em ambas.

Em alguns casos raros, estas ornamentações ocorrem na porção da haste de taquara correspondente à emplumação e compreendida entre as fixações das penas.

Lane (1959:87-88) acreditava que estas faixas de kó mrür fãr - casca de cipó imbé - (ou anéis, como ele as denominava) tinham razões simplesmente funcionais e práticas:

"Nas varetas é comum ocorrerem de 2 a 6 anéis estreitos de imbê, cujo significado é difícil aquilatar. Podem ser uma marca pessoal, mas em alguns exemplares pelo menos parecem apenas desempenhar o papel de reforço da vareta”.

No entanto, Moreira Pinto (1894), citando o Tenente-coronel Ewerton Quadros, acreditava que estas faixas indicavam os "graus" do possuidor ${ }^{17}$, sem acrescentar maiores detalhes.

"No arco e na flecha se vêm anneis, mais ou menos largos, de casca de embira untada de rezina, os quais representam gráos de commando".

Entretanto, meus interlocutores reconheceram tais anéis e espirais em kó mrür fãr das flechas Kaingang paulistas do acervo do MAE/USP como sendo grafismos abertos ( $r a$ téi), fechados ( $r a$ ror) ou "de muitas marcas" (ra $\hat{e})$, este último caso representando graficamente o ideal de buscar a complementariedade entre as metades ${ }^{18}$, conforme mostrado nas pranchas a seguir.

Os tipos de ndo Kaingang de SP, bem como os grafismos nelas presentes, constam do Anexo - Acervo Kaingang do MAE/USP.

Já no corpo das ndo do Rio Grande do Sul, também ocorrem kong-gãr (grafismos) pintados, além das já descritas faixas em kó mrür fãr (casca de cipó imbé). De acordo com o padrão gráfico representado, estes grafismos (obtidos com pintura ou com casca de cipó) foram identificados como téi ou ror, formando padrões ra téi, ra ror e ra ê, conforme é mostrado a seguir.

\footnotetext{
${ }^{17}$ Como se deveria esperar de um militar, acostumado à hierarquia das patentes.

18 "Tem junto os dois lados", conforme os kaingang de Nonoai-RS.
} 


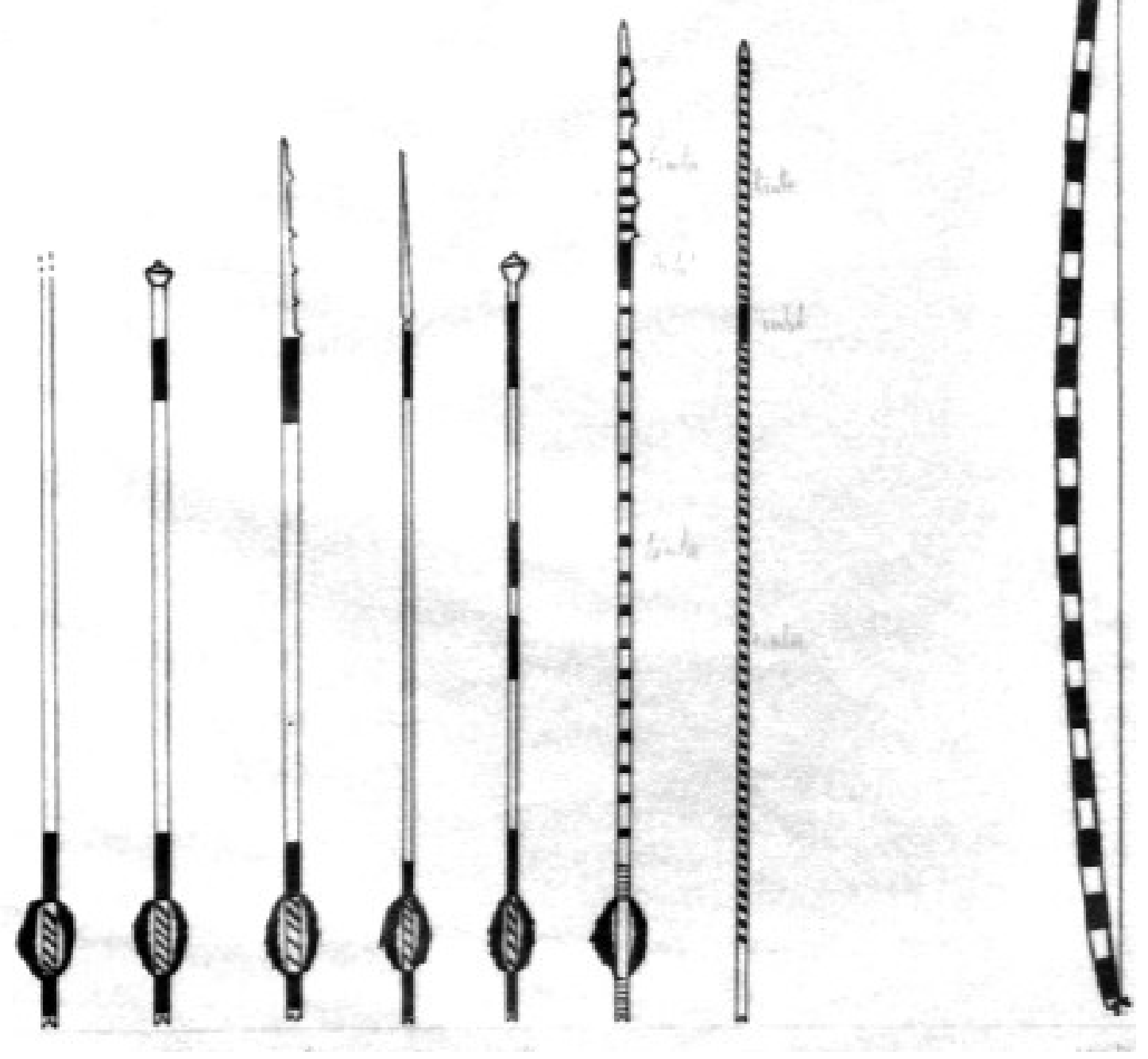

Ndo do Rio Grande do Sul (LAE/UFRGS) com faixas em kó mrür fãr (as cinco primeiras) e pintadas (6a e 7a). Das sete $N d o$, apenas a 6a. possui ra ror, as demais levam marca téi ( $r a$ ionior e ra téi). $\mathrm{O}$ arco (uyi) - extrema direita - apresenta ra ror.

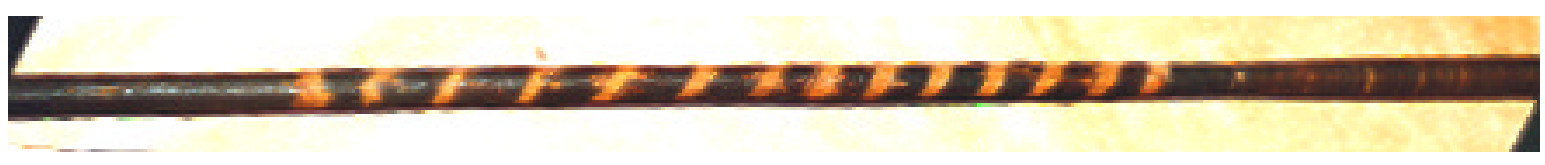

Ra ionior em ndo pintada - MJC/RS 2675/1647 Et

(detalhe da parte proximal da haste de taquara)

Ra téi em ndo pintada - MJC/RS 2675/1647 Et (detalhe da parte proximal, junto à emplumação) 


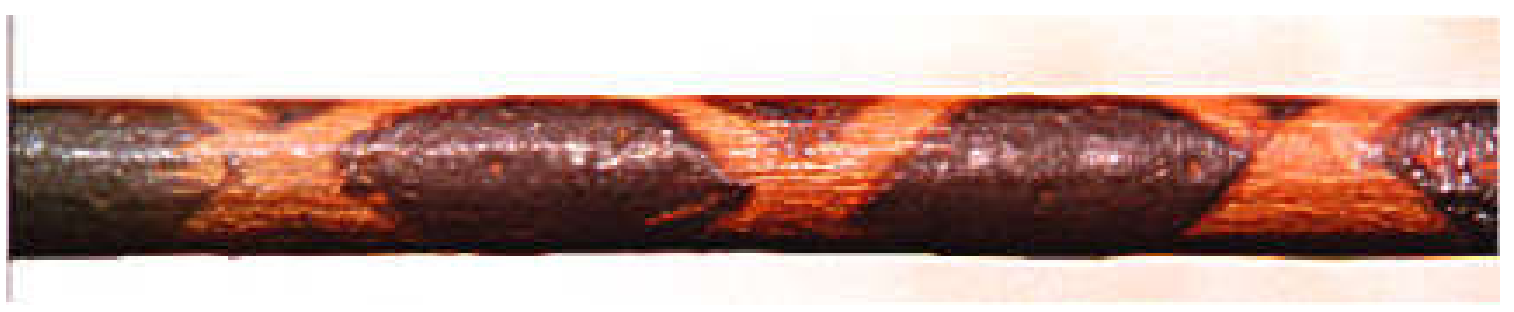

Ndo kandér pintada com ra ror ê (losangos) - MJC/RS 2676/1648 Et - Detalhe da vareta em madeira.

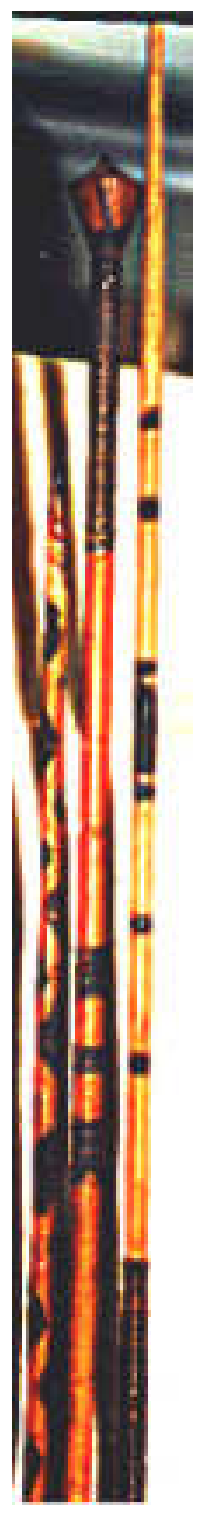

Ndo kandér pintada com ra ror ê (losangos) - MJC/RS 2758/1719 Et Nda pintada com ra ror ê (anéis) - MJC/RS 2779/1740 Et Ndo kandér pintada com ra ror ê (anéis) - MJC/RS 2677/1649 Et 
Com relação aos arcos (uyi) do Rio Grande do Sul, eles apresentam-se revestidos com kó mrür fãr, formando grafismos téi ou ror, ou são uyi tufy, ou seja, arcos que têm trançados aplicados, parcial ou totalmente, ao longo de seu corpo. Como no primeiro caso, estes uyi tufy possuem kong-gãr téi ou ror, representando graficamente as metades.

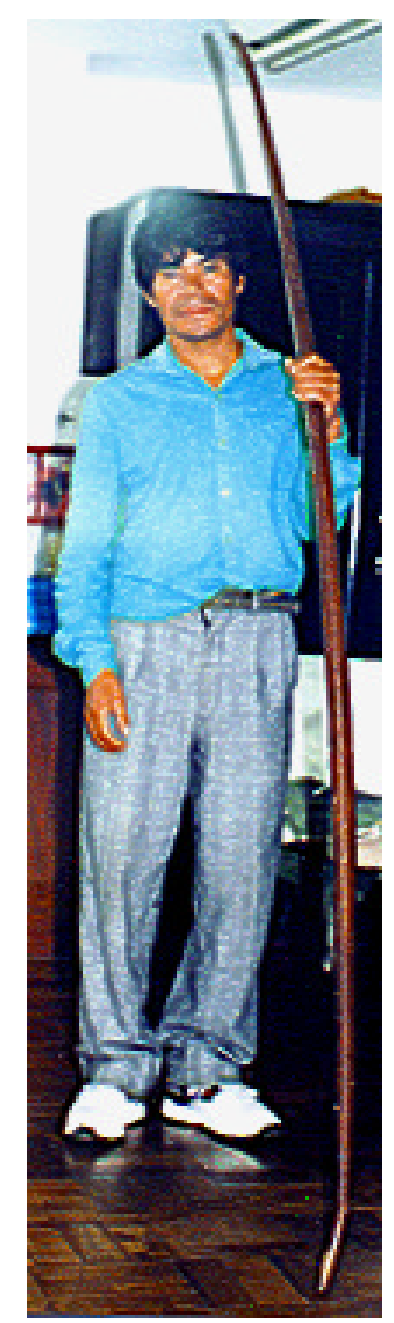

Alguns arcos são totalmente lisos, sem nenhum revestimento sobre a madeira, como o mostrado ao lado (MJC/RS -1694 Et). Nestes casos, denominados de uyi kong-gãr tun (arco sem grafismo), diz-se que ele pertencia a um kuiã (xamã).

O "arco sem marca" do xamã, do ponto de vista nativo, explica-se porque "ele [o kuiã] é pra tudo, ele dá os nomes Kamé e Kainru-kré, ele sabe todos os nomes". Neste sentido, alguns objetos de um kuiã Kaingang não possuiriam marcas.

Estas informações fazem pensar no "ser não tão completo socialmente": o mërokinkandé (líder cerimonial) dos Suyá, uma sociedade Jê setentrional estudada por Seeger (1980:107 e seguintes), cujos xamãs têm seu poder, em última análise, oriundo do mundo da sobrenatureza. No caso dos xamãs Suyá, trata-se de homens cujos espíritos foram retirados de seus corpos por feiticeiros e escondidos em alguma planta ou animal. Após algum tempo, os "homens sem espírito" conseguem ouvir e entender a fala e as canções do ser sobrenatural onde seu espírito reside.

A etnografia levantada no Capítulo 4 sobre os kuiã kaingang dá uma idéia de como seria o xamanismo tradicional entre os Kaingang. A "pista" revelada pelo uyi kong-gãr tun parece adequada, pois a ausência de representação gráfica, téi ou ror, nos objetos do kuiã, está a indicar a negação do seu pertencimento ao mundo social, tão enfatizado nas representações Kaingang em geral (divisão dual da sociedade em patrimetades), seja através do seu sistema lingüístico, seja por intermédio do seu sistema de representações visuais. 
Igualmente, também os xamãs Xerente não usam os grafismos lineares ou circulares da pintura corporal clânica, identificadores das patrimetades exogâmicas desta sociedade ${ }^{19}$. De acordo com Lopes da Silva e Farias (1992:100), os xamãs Xerente pintam seus corpos com a "representação do espírito da natureza (animal ou outro) que o protege e lhe transmite os ensinamentos mágicos que lhe dão o poder de cura e da premonição".

\subsubsection{Vein kongat: pintura corporal Kaingang}

O corpo enquanto categoria de entendimento

Pode-se dizer, de forma genérica, que o corpo humano nas sociedades indígenas brasileiras é percebido de forma diferente de como o representamos na tradição ocidental. Ao contrário do que ocorre nesta última, as sociedades do Alto Xingu, por exemplo, não fazem distinção entre processos fisiológicos e processos sociológicos ou entre transformações corporais e mudanças na identidade social ou na posição social. Na concepção destas sociedades, "o corpo humano necessita ser submetido a processos intencionais, periódicos, de fabricação". Sendo assim, "a natureza humana é literalmente fabricada, modelada, pela cultura" (Viveiros de Castro, 1979, A fabricação do corpo na sociedade xinguana:31-2).

Nestas sociedades alto-xinguanas, é notório que a fabricação de um novo papel social, especialmente nos momentos de transição entre os estados da pessoa (principalmente nascimento, puberdade/maturidade e morte), requer toda uma tecnologia do corpo, através da intervenção da sociedade sobre o indivíduo, submetendo-o a uma normalização sócio-fisiológica (op.cit., pág. 33-4).

Esta tecnologia de criação sócio-cultural do corpo da "pessoa humana" (negando-se a possibilidade de um corpo "não-humano") inclui desde relações sexuais entre os genitores, passando por um "conjunto sistemático de intervenções sobre as substâncias que comunicam o corpo e o mundo: fluidos corporais, alimentos, eméticos, tabaco, óleos e tinturas vegetais" (op. cit., p.31) até a reclusão em espaço doméstico privado.

\footnotetext{
${ }^{19}$ Estes grafismos serão trabalhados no próximo subitem.
} 
Segundo a proposição de Viveiros de Castro, a identidade social ou a posição social de um alto-xinguano não é depositada sobre o corpo como "um suporte inerte", pois este corpo é fabricado, criado. Desta forma, conclui que "a persona xinguana não parece ser facilmente redutível a um dualismo mesmo dialético - de tipo Jê (subsumido na matriz Natureza/Cultura (...)), e muito menos no homo duplex da metafísica durkheimiana" (op.cit., p.32).

É exatamente o que se percebe da leitura de Da Matta. De acordo com este autor (1976:243-4), o dualismo Jê confere à persona Apinayé dois tipos radicalmente separados de relações sociais: 1) as relações fisiológicas, desenvolvidas a partir de um grupo de substância, basicamente a família nuclear, cuja linguagem é a do corpo e cuja lógica é a mistura e da geração física (seus componentes básicos são o sangue, o esperma, o suor, a carne e os ossos; suas qualidades essenciais são os alimentos, os líquidos e os indivíduos); e 2) as relações cerimoniais, que são marcadas por laços de troca e estabelecidas pela nominação que, além de servir como mecanismo de transição de status de uma geração para outra, confere a seu possuidor papéis rituais e o pertencimento a uma das duas metades cerimoniais. Os grupos nas quais estas relações se desenvolvem são cerimoniais, regidos por uma lógica pública, com aspectos jurídicos e políticos. As relações no grupo de substância cancelam as distinções de sexo e idade (regras de abstinência de alimentos e comportamento), enquanto que as relações cerimoniais, baseadas no nome, separam os papéis rituais, que são fixos e bem marcados (op.cit., p.245). Teríamos, assim, uma "oposição complementar entre os 'formadores do corpo' e os 'formadores da máscara social' (ou da pessoa), que as sociedades Timbira atualizam com os laços de substância e os laços de nominação" (op.cit., p.245).

Desta forma, entre os kaingang do RS o desenrolar das relações fisiológicas entre um casal admitem uma linguagem corporal, que se estabelece na esfera doméstica, onde é possível cancelar distinções de afinidade ou, mesmo, criar o corpo. Como exemplo do primeiro caso, temos a categoria corporal kaingang kafy (íngua/cheiro), através da qual marido e mulher, de metades opostas e oriundos de grupos domésticos distintos, passam a criar relações de substância. A relação entre seus corpos faz com que após a morte de um ou de outro muitos preceitos tenham de ser seguidos, principalmente a reclusão do cônjuge vivo - o vokrê - e o uso de remédios do 
mato para "enfraquecer, pra sair tudo aquilo que era do que morreu" 20 . No segundo caso, temos a prática anual (época do milho verde), realizada, pelo menos, até há poucas décadas, de os pais friccionarem no corpo das crianças, até a puberdade, um alimento feito com milho verde (ëmi), com o objetivo de fortalecer e fazer o corpo crescer.

Por outro lado, no desenvolvimento das relações cerimoniais, a lógica reinante é aquela da esfera pública, de aspectos jurídicos e políticos, e que acontece num espaço não-doméstico, num espaço de exibição do corpo, na festa. É o momento onde o corpo é usado como tela, e no caso kaingang, como tela/suporte de significados sociológicos: marcas que indicam as metades e os papéis sociais e rituais advindos da nominação ${ }^{21}$.

A revitalização da festa do kiki pelos Kaingang de Xanxerê - SC, e o surgimento de grupos Kaingang de danças guerreiras, no RS, ambos dentro de um contexto político da retomada das terras e da marcação da diferença sócio-cultural em relação à sociedade envolvente, tem motivado o reaparecimento, nos últimos anos, do sistema de representações visuais Kaingang, notadamente das marcas usadas na pintura corporal. No entanto, no caso de SC, uma simplificação gráfica drástica do sistema classificatório dual parece ter acontecido (como teoricamente explica Carneiro da Cunha, 1986, com os conceitos de situação de intenso contato e cultura de contraste). A rica gama de variantes gráficas do passado, levantada nas pesquisas de campo, descrita e reproduzida nesta tese, que representava os pares opositores e complementares aberto/fechado :: comprido/redondo :: alto/baixo :: longo/quadrangular :: comprido/losangular, ficou reduzida, visualmente, a dois kong-gãr: "/" e "o" (traço e ponto), com as subdivisões que distinguem as seções. Um sub-padrão gráfico linear reto e um sub-padrão linear curvo, para representar as seções kamé, opõem-se a um sub-padrão circular cheio e a um sub-padrão circular vazado, para representar as seções kainru-kré (Veiga, 1994), distinção esta que não ocorre no Rio Grande do Sul, uma vez que não existe a subdivisão das metades em seções.

No entanto, a pintura corporal usada nos dias de hoje pelos Kaingang de Iraí-RS e Nonoai-RS, ressurgida neste contexto político de retomada de suas terras, usada em ocasiões especiais (comemorações, apresentações públicas, festas do "Dia do Índio", etc.), mostra uma grande exuberância e

\footnotetext{
${ }^{20}$ Karein, T.I. de Nonoai: “Então, aquela íngua da mulher também, né?, diz que enquanto tá apodrecendo lá dentro diz que apodrece dentro também da pessoa que tá viva. Então, dá remédio, vai lavando. Banho de erva".

${ }^{21}$ Conforme Lévi-Strauss, T. Turner, Lux Vidal, Aracy Lopes da Silva.
} 
diversificação de temas abertos e fechados, fazendo ressurgir, diante de nossos olhos, nos corpos dos Kaingang, grafismos pré-históricos como os há muitos séculos gravados em rocha ou impressos na argila ainda mole de vasilhas cerâmicas Proto-Jê do sul, conforme será mostrado mais adiante.
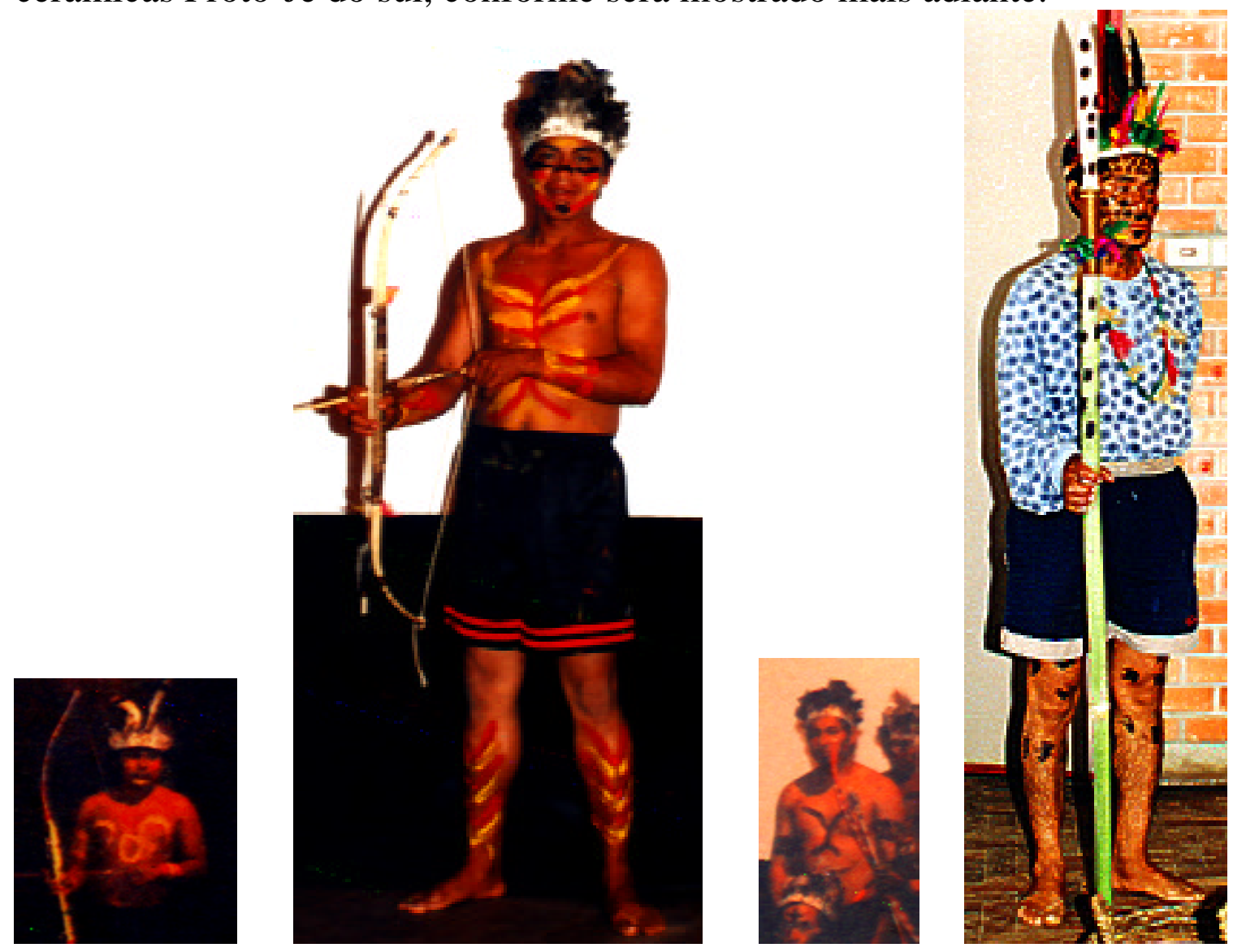

Grafismos corporais Kainru-kré (primeira e última fotos; Guarita - 2000 - e Agronomia - 1999 -, respectivamente) e Kamé (segunda e terceira fotos, ambas de Guarita - 2000). 


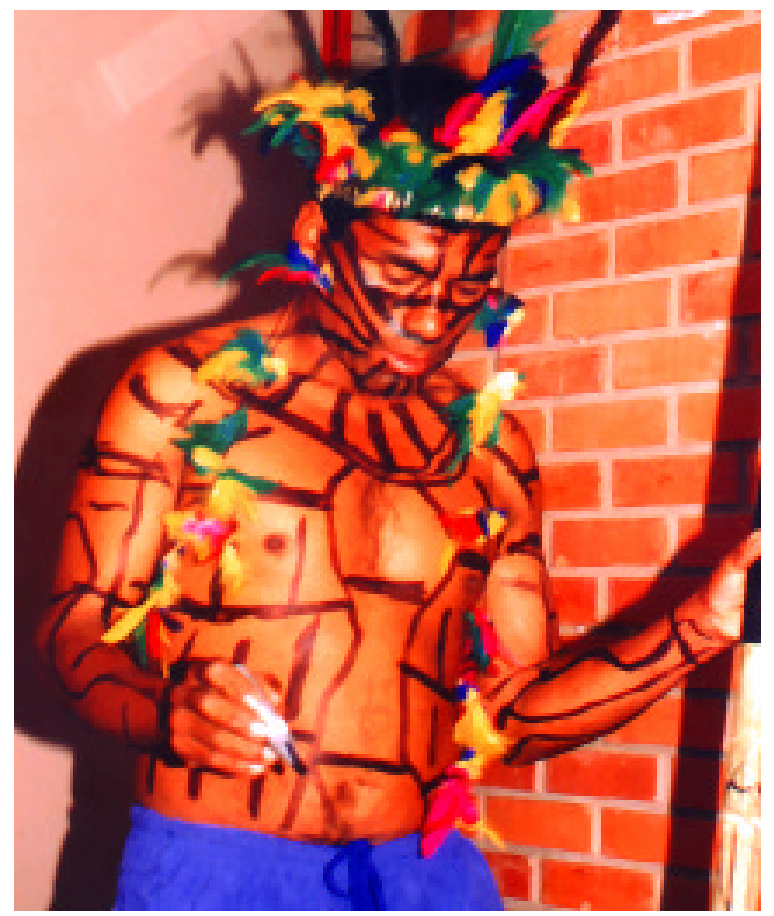

Grafismo corporal Kamé - Aldeia da Agonomia (1999) - Porto Alegre

Com relação à pintura corporal e facial (vein kongat), os interlocutores Kaingang identificaram os grafismos como vinculados diretamente a representações gráficas das metades Kamé e Kainru-kré ("marca/sinal dos Kamé e dos Kainru-kré"). Alguns padrões, que serão discutidos mais adiante, foram identificados como "marca misturada" - ra iãnhiá.

O único argumento dos interlocutores para classificar os grafismos das pinturas corporais como pertencentes às metades Kamé ou Kainru-kré foi o de que "a marca/o sinal Kamé" é composto por "traços" e "a marca/o sinal Kainru-kré" possui "pontos". Sendo características dos primeiros o fato de serem compridos, abertos, não terem fim; os segundos são redondos, fechados.

Em outras palavras, as representações duais expressas pela linguagem oral através das categorias téi e ror, são igualmente encontradas nas representações gráficas da pintura corporal Kaingang.

O padrão losangular, classificado como Kainru-kré, e encontrado em vários suportes, como se viu, merece comentário adicional. Segundo alguns interlocutores, é "sinal Guarani" e, "se fosse Kaingang, seria Kainru-kré". Tal padrão gráfico, como já foi visto, é bastante recorrente nos trançados Kaingang atuais, bem como o é na cestaria, nas flechas e nos kurã (mantos de urtiga) Kaingang da virada do século XIX e das primeiras décadas do século $\mathrm{XX}$, analisados em instituições museológicas. Além disso, é utilizado 
atualmente na pintura corporal. Na cerâmica arqueológica de algumas "fases" das "tradições locais planálticas", como veremos a seguir, este padrão losangular ocorre freqüentemente, indicando, se realmente fosse um "sinal Guarani”, uma incorporação antiga.

Durante o kiki, a pintura facial do(a) viúvo(a) da(o) falecida(o) homenageada(o) distingue-se da dos demais, pois usava as marcas representativas das duas metades: a sua e a de seu cônjuge falecido(a), numa denominada "muitas pintas" ( $r a \hat{e})$. Conforme os Kaingang de Nonoai, na pintura corporal dos demais participantes do kiki não pode ocorrer esta dupla representação gráfica, "porque é um respeito para a gente saber os parentes através das marcas".

Este comentário dos Kaingang nos fornece uma informaçãpo complementar às observações de Veiga, realizadas durante o ritual do kiki de Xapecó-SC. Conforme a autora, na terceira noite, todos são pintados de acordo com sua descendência patrilinear, com exceção de alguns: "se alguém usa um nome da outra metade é pintado com as duas marcas, são os râ rengre" (Veiga, 2000:232).

Também as "marcas misturadas" - ra iãnhiá -, já comentadas, costumam aparecer na pintura corporal dos Kaingang do Rio Grande do Sul, lado a lado com os padrões exclusivamente téi ou ror. No caso do uso da ra iãnhiá, a "pinta", segundo os Kaingang, não é "dupla", (ra ê), mas, sim, uma fusão entre um grafismo aberto e fechado, representando graficamente aquele(a) que tem ascendência sobre os membros de ambas as metades. 


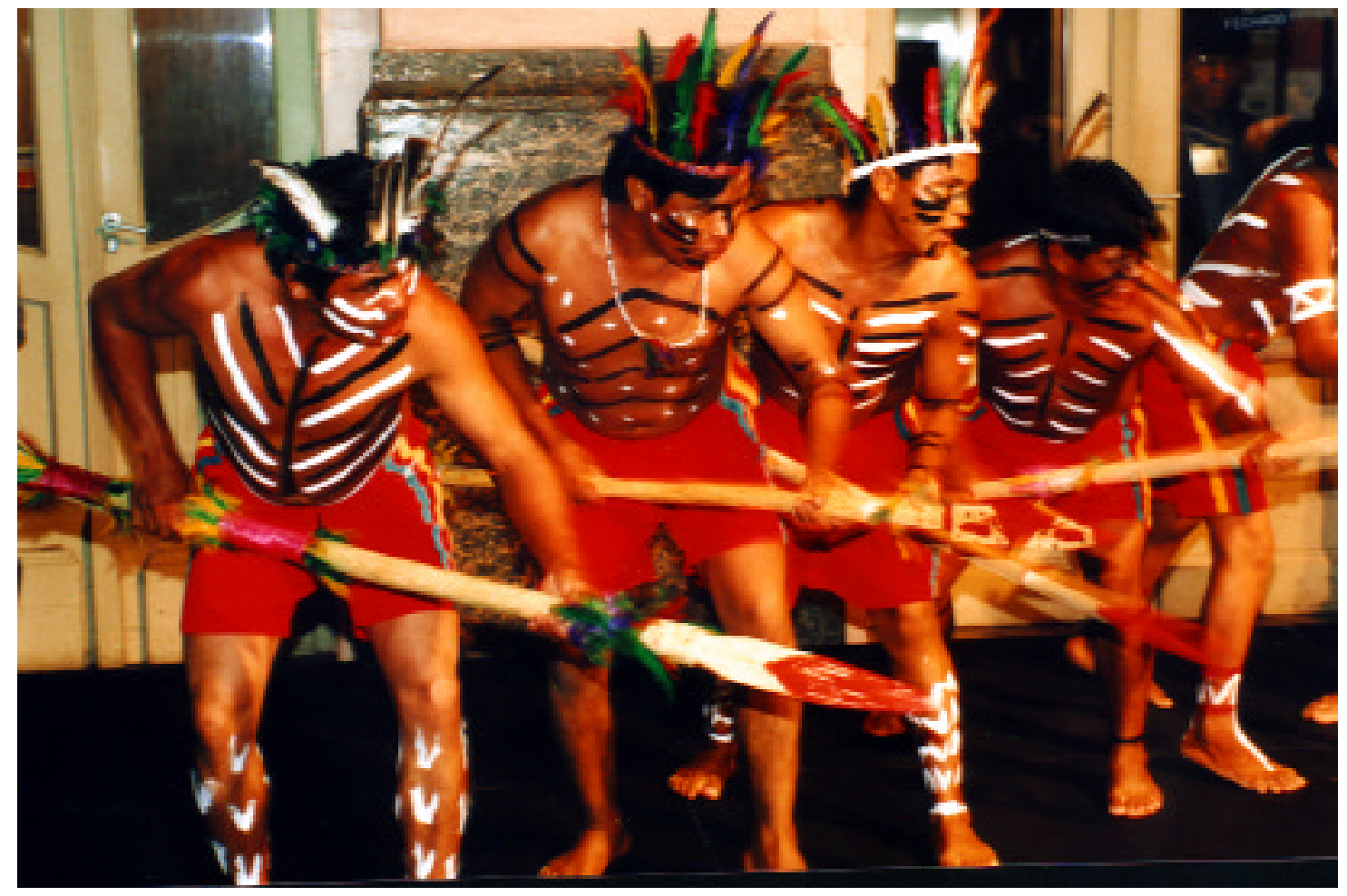

Grafismos corporais considerados téi (Kamé). Observe o segundo, a partir da esquerda, com incorporação de elementos ror: grafismo ra iãnhiá. Notem-se os grafismos nas pernas, conforme o de no. 9 de Mabilde e formalmente semelhantes aos presentes na cerâmica Proto-Jê meridional. Comunidade de Inhacorá-RS (2000).

Como o ritual do kiki não é mais realizado nas áreas indígenas do RS, só pude observar a pintura corporal durante as "apresentações" de grupos Kaingang. Nelas, muitos homens apresentam grafismos corporais que podem ser classificados como ra iãnhiá. O discurso nativo possui versões diferentes para explicá-lo, neste contexto: 1) os kaingang não mais se lembram corretamente das marcas, misturam grafismos abertos e fechados, o que, conforme observei, corresponde à realidade de hoje. As pessoas que expressam esta opinião dizem que, com exceção do corpo, em outros suportes é possível a ocorrência, ao mesmo tempo de grafismos téi e ror, pois eles estariam representando graficamente "os dois lados da família". 2) a fusão entre grafismos abertos e fechados na pintura corporal representa pessoas que possuem autoridade sobre os membros de ambas metades.

Não observei nas mulheres e nas crianças, que também participam destas "apresentações", ra ê ou ra iãnhiá. Suas pinturas faciais (elas pintam apenas o rosto) são ou ra téi ou ra ror, conforme sua descendência patrilinear. 

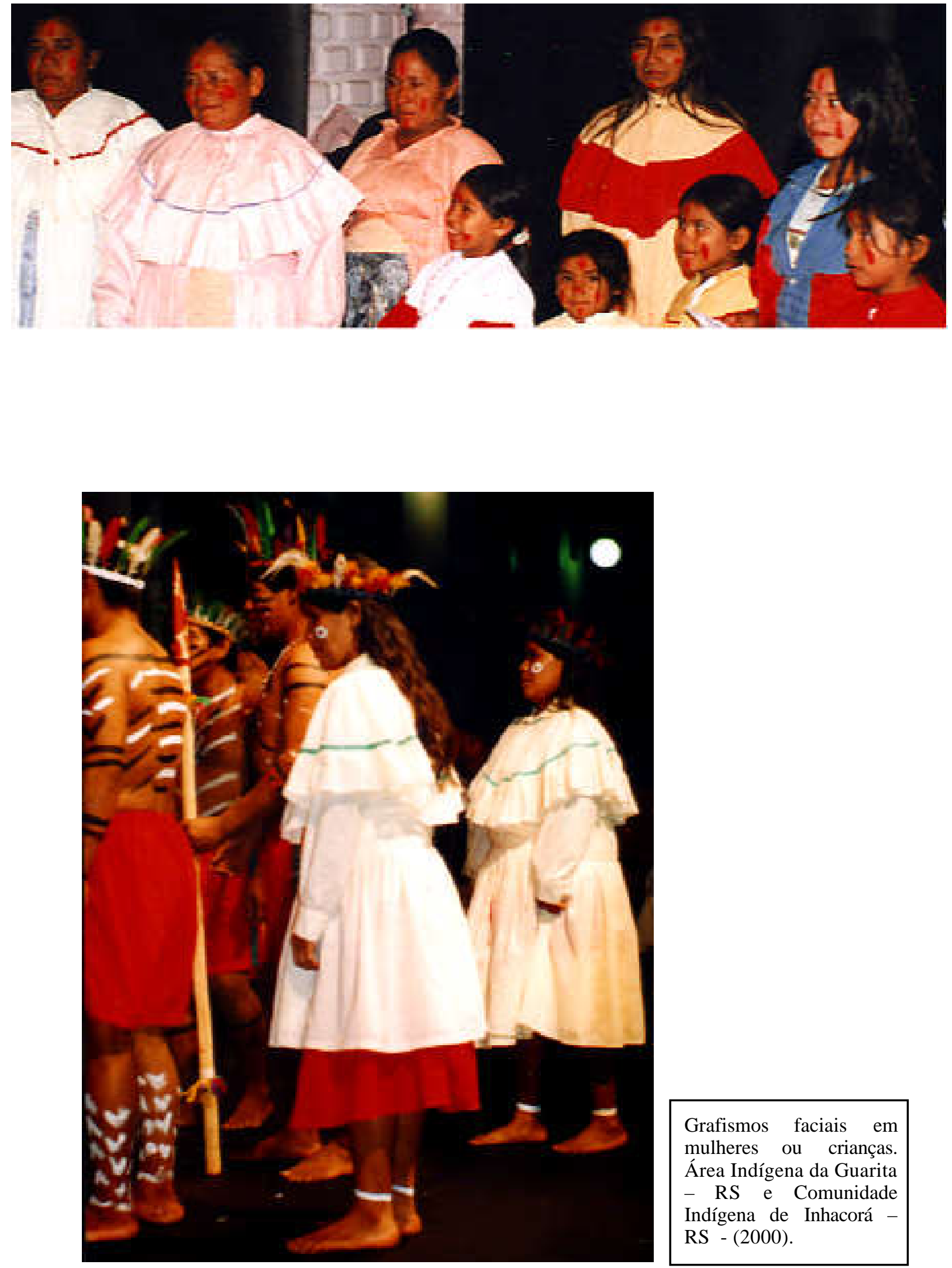

Grafismos faciais em mulheres ou crianças. Área Indígena da Guarita - RS e Comunidade Indígena de Inhacorá RS - (2000). 


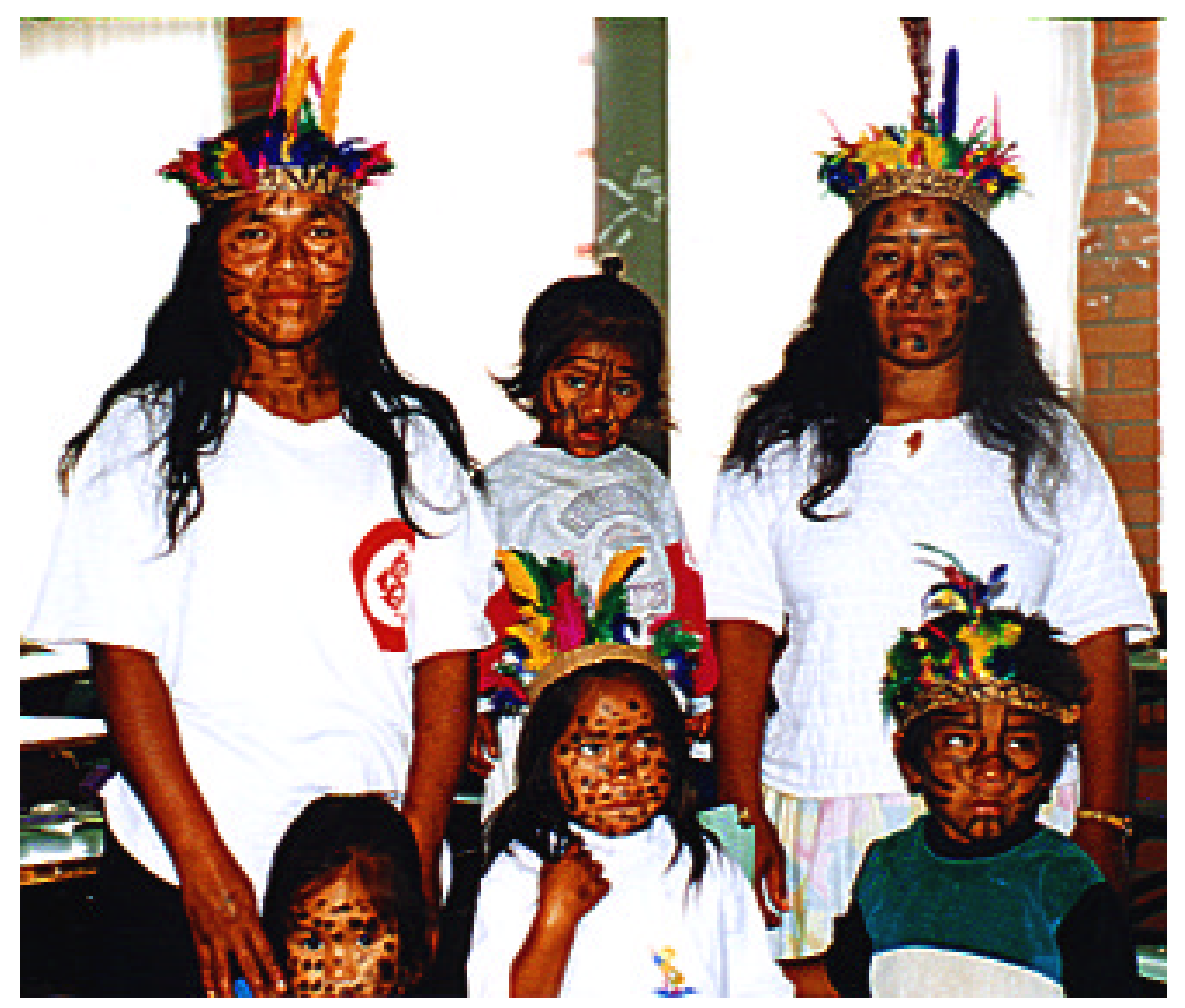

Grafismos faciais. Aldeia da Agronomia - Porto Alegre (1999). Duas mães com seus respectivos filhos. Note-se que estes, pelas regras de descendência, possuem grafismos faciais opostos aos de suas mães.

Os Kaingang paulistas do Posto Indígena de Icatu, com quem mantive rápido contato, não mais se lembram dos grafismos específicos da pintura corporal, mas sabem que existiam, ao modo dos grafismos corporais dos Kaingang de SC, quatro distintas formas de representar graficamente as quatro seções, pertencentes, duas a duas, às duas patrimetades: de um lado, kainru e votoro, e, de outro, pêvi e iangépi. Um dos interlocutores paulistas ainda lembra que os grafismos ligados às duas primeiras seções eram circulares, e os vinculados às duas últimas, lineares.

Maniser, etnólogo russo que estudou os Kaingang paulistas, recém"pacificados",22, observou que eles "pintavam-se apenas para os enterramentos ou para os ofícios dos mortos", ocasiões em que todos "decoravam o rosto com pontos ou pequenos traços negros através da fronte, sobre as bochechas e sobre o queixo" (Maniser, 1930:771). O autor faz referência à "pintura em

\footnotetext{
${ }^{22}$ O Serviço de Proteção ao Índio (SPI), em 1912, conseguiu manter relações com os kaingang paulistas, estabelecendo um "posto" a 2 km da Estação Hector Legru (atual Penápolis), da Estrada de Ferro Noroeste. Lá, Maniser convivou com os kaingang em dezembro de 1914 e janeiro do ano seguinte.
} 
todo o corpo apenas para indivíduos que vinham do cemitério nas festas kiki": ou havia indivíduos com grafismos muito curtos em forma de vírgulas ${ }^{23}$ dispostas sem ordem aparente por todo o corpo ou indivíduos com largas linhas pretas sobre o peito (op. cit., pág. 771).

Evidentemente, além desta relação mais cosmológica e mágica, referida por Maniser ${ }^{24}$, estamos diante da oposição aberto/fechado, característica do grafismo kaingang e, particularmente, representação gráfica das metades.

O autor lamenta-se de não ter podido "esclarecer o significado das variações individuais na pintura corporal" (op. cit., pág. 771). Talvez, esta variação fosse devida à distinção feita pelos kaingang paulistas em relação às subdivisões das metades, conforme me relataram os interlocutores kaingang de São Paulo.

Pelas informações de Maniser, estes grafismos usados no corpo também eram reproduzidos em outros suportes. Numa aldeia abandonada em virtude de morte ali ocorrida, ele observou um "monumento funerário original: era uma estaca facetada, ornada com vírgulas semelhantes àquelas que são pintadas sobre os corpos durante os ofícios dos mortos" (op. cit., pág. 783) ${ }^{25}$.

A pintura corporal clânica dos Xerente também opõe grafismos lineares - wahirê -, cujas variações exclusivas identificam os quatro clãs da patrimetade exogâmica Wairê/Sdakrã, a grafismos circulares - doí -, cujas variações igualmente exclusivas representam os três clãs da patrimetade exogâmica Doi/Sip'tato ${ }^{26}$. Ela é usada somente em situações cerimoniais, nas quais estes grafismos são fundamentais como referência para a localização de cada indivíduo na sua patrimetade e no seu clã. Os heróis míticos Sol e Lua estão associados, respectivamente, às metades Sip'tato/Doi e Sdakrã/Wairê. Já

\footnotetext{
${ }^{23}$ Compar com os grafismos na cerâmica da "Fase” Xaxim, denominado "ponteado arrastado", na pág. 74.

${ }^{24}$ Maniser refere-se, apenas, ao discurso kaingang sobre a pintura corporal: "isto os preserva de uma morte imediata que teria atraído sobre eles a animosidade do espírito maligno do defunto” (op. cit., pág. 771).

${ }^{25}$ No RS, os kaingang de Nonoai ainda lembram de que os troncos das árvores nas quais o féretro parava para descansar, a caminho do cemitério, eram marcados com a "pinta" do morto. Tais árvores eram sempre as mesmas, e após alguns anos seus troncos ficavam tomados pelos grafismos indicativos das metades dos mortos "que por ali passavam". Atualmente, tais locais são marcados com cruzes. Estas "árvores-monumentos funerários" são consideradas locais perigosos, ninguém podendo ali descansar ou parar, exceto nos momentos rituais de enterramento.

${ }^{26}$ Os motivos da pintura corporal clânica são pintados dentro de uma "moldura" fixa, igual para todos os clãs, constituída por uma "gola" e traços grossos, verticais, todos feitos com espátula de taquara (Lopes da Silva \& Farias, 1992).
} 
a pintura corporal das metades rituais ${ }^{27}$, usada durante a realização das corridas com grandes toras de buriti, opõe um grafismo em ziguezague padrão sucuri - da metade Steromkwá a um grafismo triangular - padrão jabuti - da metade Htamhã (conforme Lopes da Silva \& Farias, 1992). Como se vê, o dualismo é o "fio condutor para a compreensão da sociedade Xerente", como aponta Farias (1990).

Para os Xokleng, ao menos pelo que se percebe de fotos do início do século XX, realizadas por J. Rulhand, publicadas por Santos (1997) - o detalhe de uma delas será reproduzido a seguir -, a pintura corporal possui um padrão gráfico linear e outro circular, usados com exclusividade.

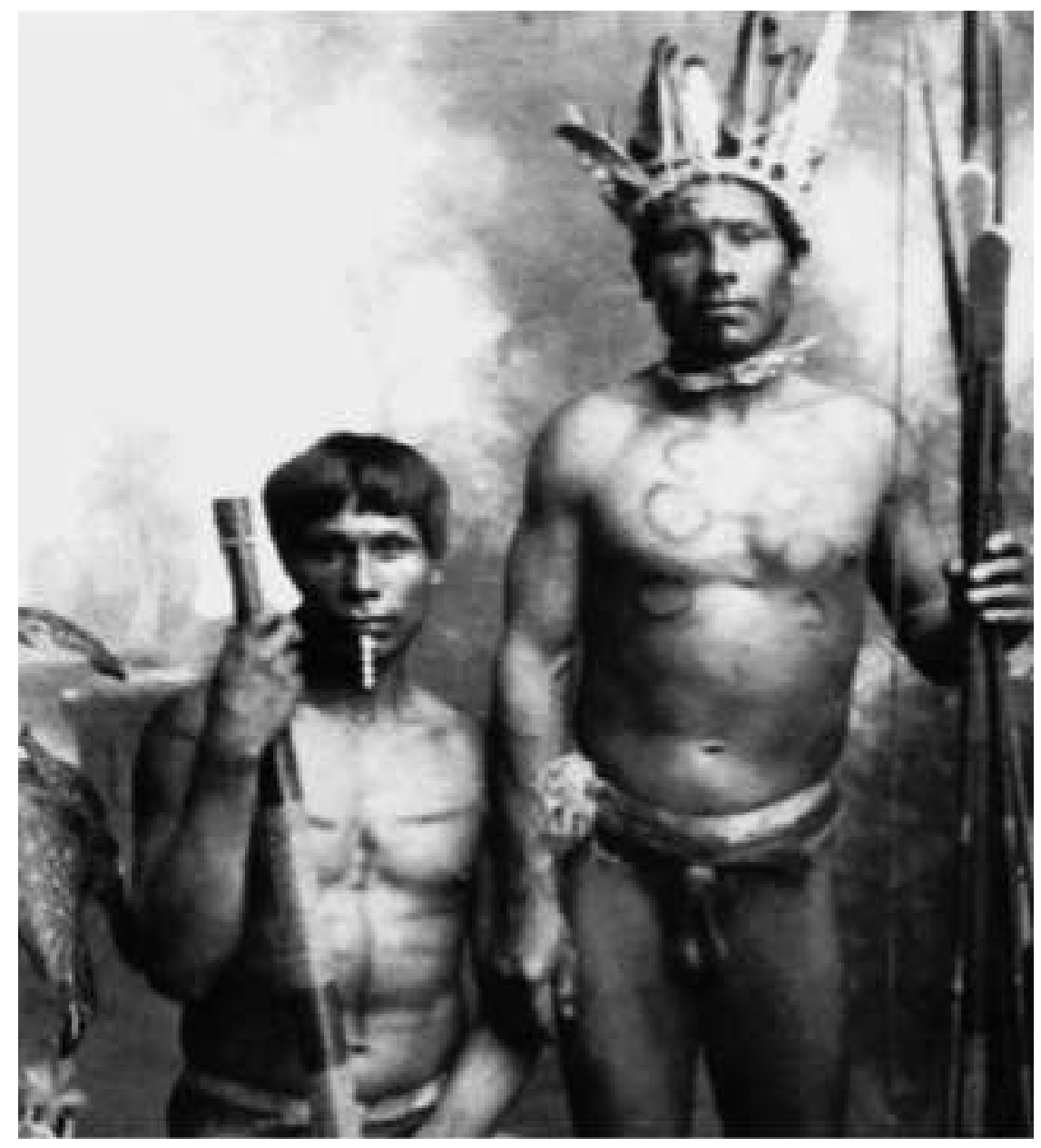

Índios Xokleng. Detalhe de foto de J. Rulhand (aproximadamente, 1920). Acervo do Arq. Hist. José Ferreira da Silva da Fundação Cultural de Blumenau -, publicada por Santos, 1997.

\footnotetext{
${ }^{27}$ Compostas, cada uma, por duas classes de idade, velhos e novos. O pertencimento a uma das metades rituais faz-se mediante a opção do futuro membro e de seus pais.(Lopes da Silva \& Farias, 1992).
} 
Como se pode ver dos exemplos de vein kongat Kaingang (pintura corporal) mostrados a seguir, os grafismos diversificados quanto aos motivos usados na pintura corporal dos Kaingang de Nonoai, de Iraí, da Guarita, da Agronomia e de Inhacoráa ${ }^{28}$, bem como o padrão gráfico mais simples de oposição linear/circular, são muito semelhantes aos grafismos encontrados na cerâmica arqueológica das "tradições locais planálticas", encaradas como Proto-Jê meridionais pela arqueologia, e, igualmente, bastante semelhantes em relação a muitos grafismos rupestres do sul do Brasil, e que estão, estes últimos, "divididos" entre várias "tradições" pelos especialistas em arte rupestre brasileira. Esta amostragem comparativa entre grafismos atuais Kaingang (pintura corporal), grafismos presentes na cerâmica Proto-Jê do sul e grafismos rupestres tem por objetivo fazer, do ponto de vista metodológico, a transição entre os materiais históricos e os arqueológicos, enfatizando, visualmente, as semelhanças formais entre eles.

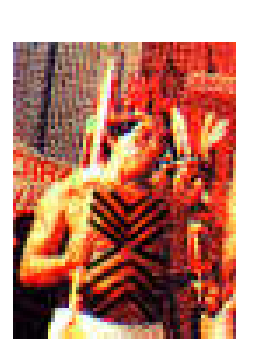

Pintura corporal de Kaingang de Iraí-RS considerada ra téi. A partir de foto publicada no jornal Zero Hora -4.2 .99 , p. 93. Note a semelhança com os grafismos rupestres do litoral de Santa Catarina, abaixo, conforme reprodução dos desenhos publicados por Rohr, 1969 a. Compare com grafismo corporal téi da Guarita $-\mathrm{RS}$.
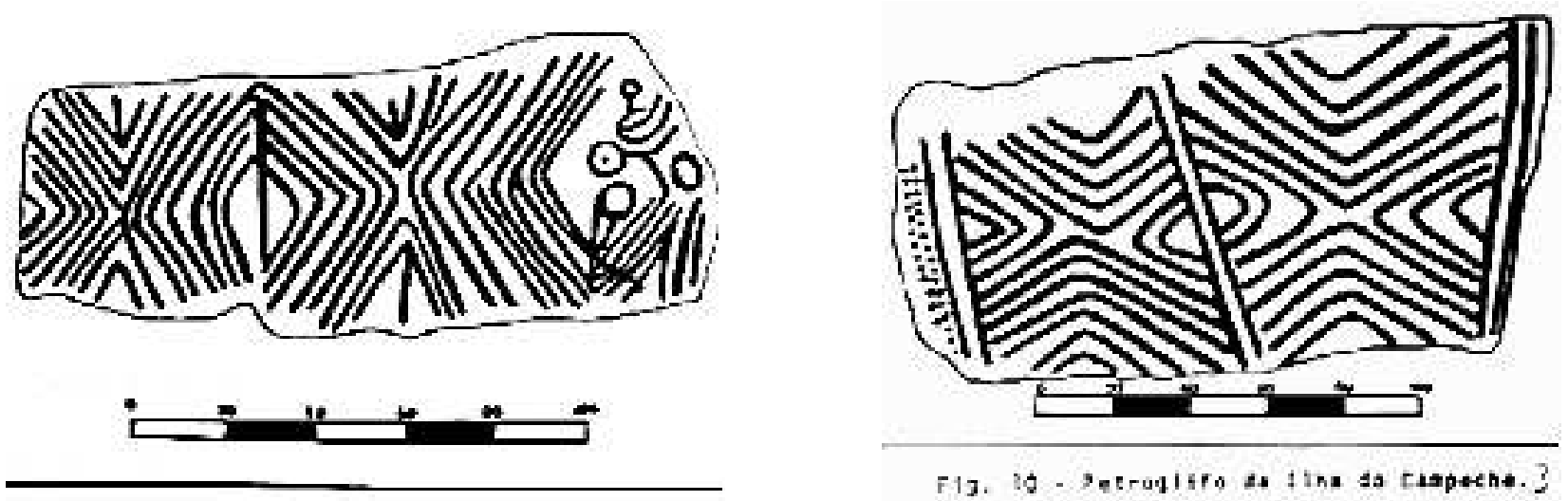

Ftg. 6 - Dotreglifo da tlins de Arroredo.

\footnotetext{
${ }^{28}$ Todas áreas indígenas kaingang no RS.
} 


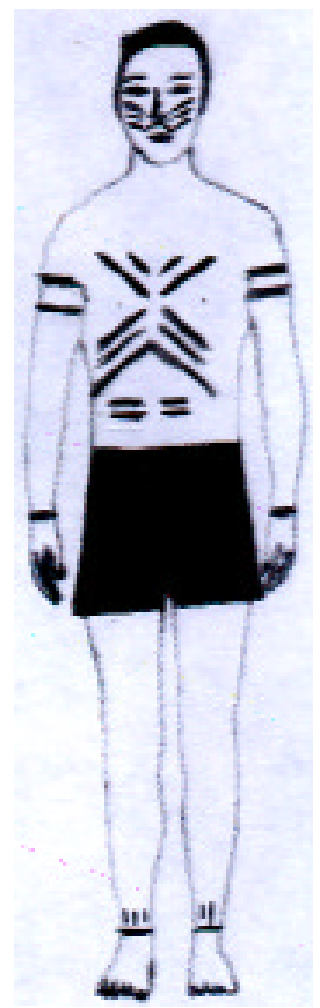

Grafismo corporal téi (Kamé). Guarita - RS (2000). Desenho a partir de imagens de vídeo gravadas pelo autor.
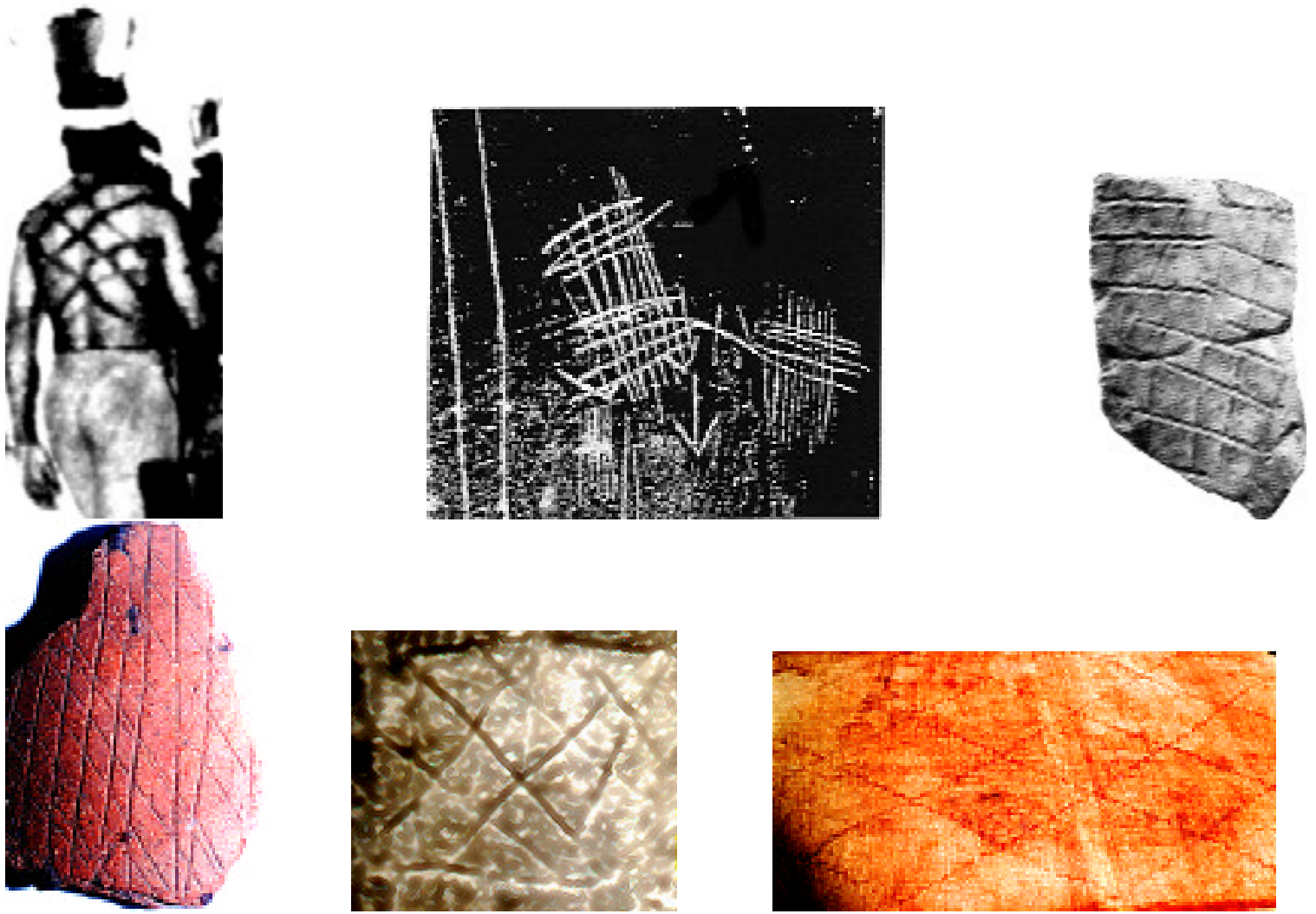

Pintura corporal ror (Iraí-RS-1996); grafismo rupestre na Linha Araçá-RS (reproduzido de Lima, 1998); grafismo na cerâmica arqueológica da "Fase" Guabiju (sécs. XIII a XVII d.C., reproduzido de Ribeiro \& Ribeiro, 1985:estampa 10 - detalhe); grafismo na cerâmica arqueológica da "Fase" Guatambu (sécs. II a XIV d.C.); grafismo rupestre no Morro do Avencal-SC (reproduzido de Rohr, 1972b); grafismo ror em manto de urtiga (MAE/USP 3746). 

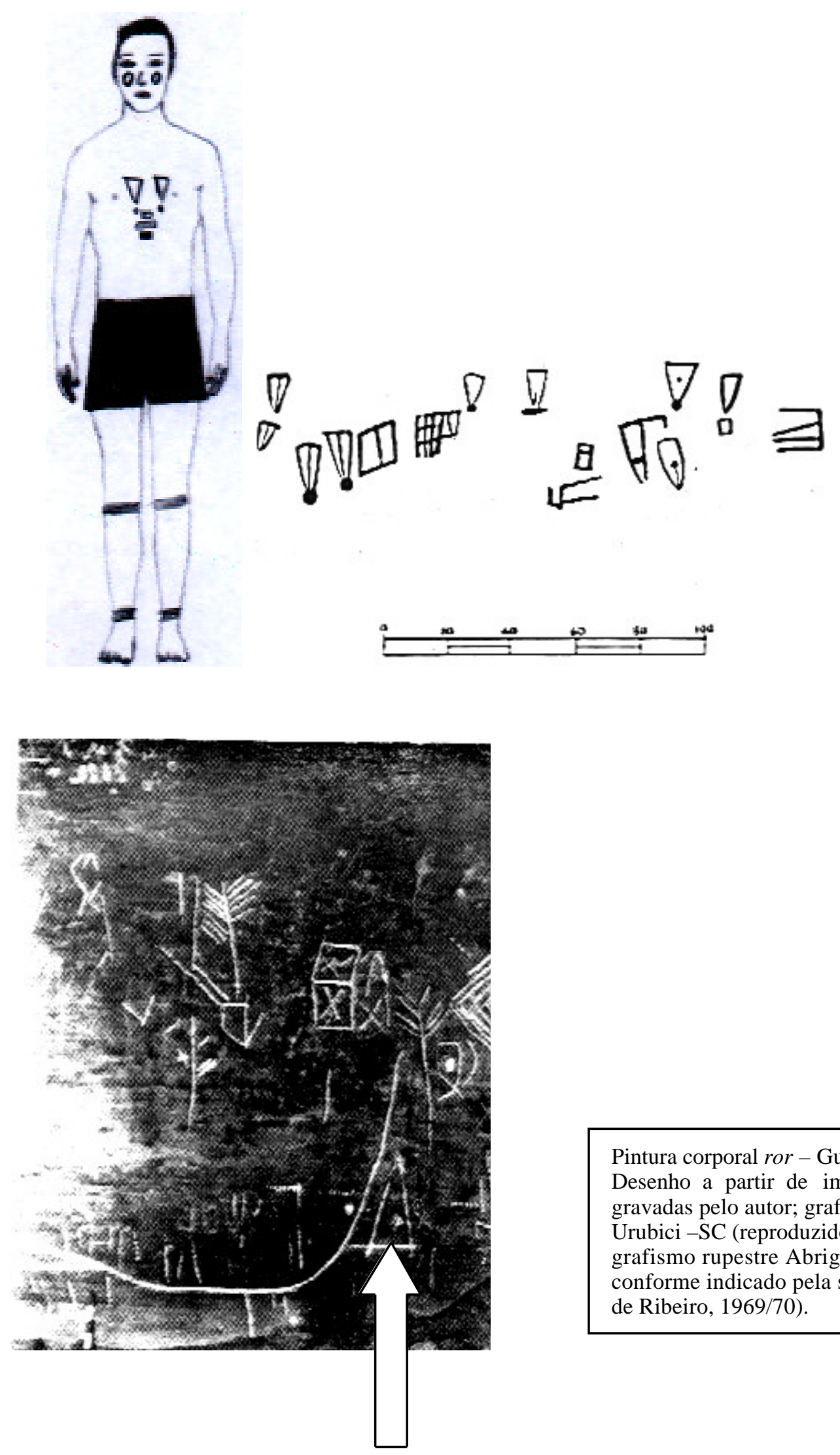

Pintura corporal ror - Guarita-RS (2000). Desenho a partir de imagens de vídeo gravadas pelo autor; grafismo rupestre em Urubici -SC (reproduzido de Rohr, 1971); grafismo rupestre Abrigo Virador - RS, conforme indicado pela seta (reproduzido de Ribeiro, 1969/70). 


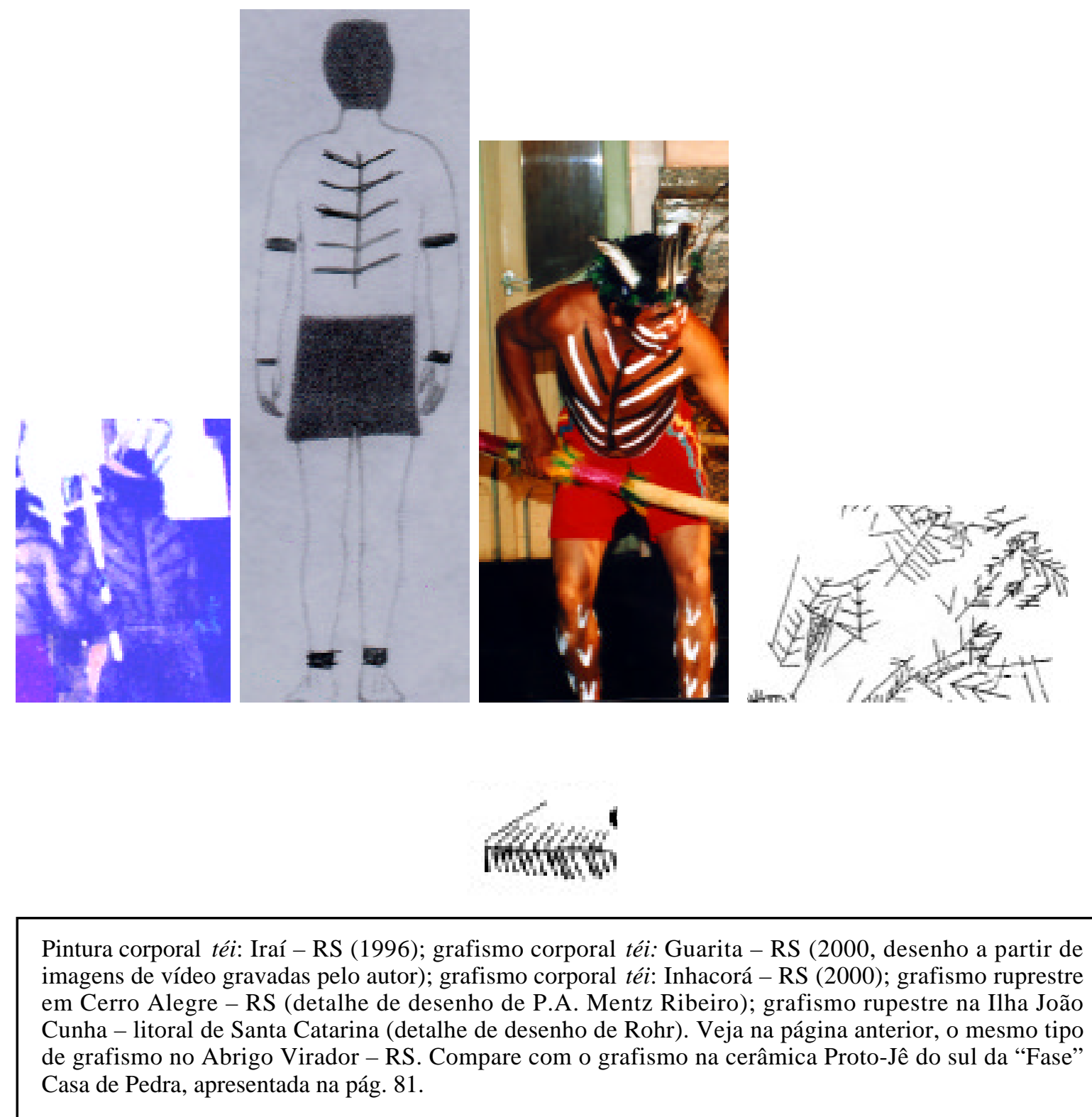

\subsection{Grafismos (Proto)Guarani: algumas comparações}

Antes de apresentar formalmente os grafismos arqueológicos Proto-Jê, e discuti-los, é importante comentar alguns grafismos (Proto)Guarani.

Levando em conta que a pesquisa sobre os Kaingang indicou algumas semelhanças com sociedades falantes de línguas Tupi-guarani, além do fato de este contato entre grupos Proto-Jê meridionais com populações Proto-Guarani 
estar registrado arqueologicamente em toda a área de dispersão das "tradições locais ceramistas planálticas", e também considerando possível as incorporações sucessivas de grupos outros pelas populações Jê migrantes, como as interpretações do mito de origem da sociedade Kaingang permitem indicar $^{29}$, fiquei motivado a investigar o sistema de representações visuais Mbyá-Guarani, objetivando, neste momento, levantar algumas informações que proporcionassem uma comparação entre os sistemas simbólicos gráficos (Proto)Jê do sul, de um lado, e (Proto)Guarani ${ }^{30}$, de outro.

Esta comparação poderá permitir um alargamento das discussões sobre grafismos pré-históricos, especialmente aqueles que tiveram como suporte a cerâmica das duas sociedades pré-coloniais citadas, oportunizando, inclusive, contribuir para um avanço no debate sobre grafismos rupestres, suas autorias sociais e simbolismos ${ }^{31}$. Desta forma, apresento aqui os resultados desta pesquisa, antes das discussões sobre os grafismos Proto-Jê do sul, analisados no item 5.3., a seguir.

Trabalhei com dois grupos Mbyá residentes próximos a Porto Alegre, um proveniente da Argentina ${ }^{32}$, e o outro oriundo de Tenente Portela-RS ${ }^{33}$. A metodologia da pesquisa constou, primeiramente, em perguntar sobre os grafismos presentes em suas cestas (adjaká). Neste momento, alguns

\footnotetext{
${ }^{29}$ Conforme ficou demonstrado anteriormente nos capítulos 3, 4 e início deste capítulo.

${ }^{30}$ Da mesma forma como foi usado na expressão Proto-Jê, o prefixo proto na expressão Proto-Mbyá não foi empregado na mesma acepção que os lingüistas costumam fazê-lo. Utilizo Proto-Guarani para designar as primeiras populações Guarani do sul do Brasil e adjacências, ou seja, os Guarani "pré-coloniais" ou, ainda, os grupos populacionais vinculados à "Tradição ceramista Tupiguarani” ou à Subcultura Guarani da Tradição Policroma Amazônica, como estas populações "pré-contato" costumam ser denominadas pelos estudos arqueológicos. Convém lembrar que emprego o prefixo proto entre parêntesis, antes da designação étnica, para indicar tanto populações "pré-coloniais" como, também, as populações "pós-contato", descendentes das primeiras, pelas razões já expostas na Introdução.

${ }^{31}$ Tocchetto (1996 [1993]) empreendeu um estudo pioneiro sobre as "Possibilidades de interpretação do conteúdo simbólico da arte gráfica Guarani", investigando "uma provável equivalência entre os desenhos pintados nas vasilhas cerâmicas e elementos mitológicos [Guarani]" - op.cit., pág. 36 -, além de realizar analogias etnográficas entre os grafismos cerâmicos e as sociedades Mbyá-Guarani, Asurini e Kaxinawá. A partir desta metodologia de trabalho, que não inclui pesquisa de campo: 1) relaciona a criação e destruição da terra Apopocúva-Guarani, particularmente a "escora da terra" (yvy-itá), com o grafismo em forma de "cruz", recorrente nos grandes recipientes cerâmicos arqueológicos Guarani; e 2) estabelece correspondência entre os grafismos da cerâmica arqueológica Guarani em forma de losangos e os grafismos também losangulares Asurini (relacionados a "favos de mel") e Kaxinawá (relacionados a "cobras"). A estas analogias, que a autora reconhece frágeis pois baseadas em representações de outras sociedades, mesmo que a primeira possua "afinidades culturais" com a Guarani, Tocchetto agrega duas citações sobre serpentes na mitologia Guarani e a analogia etnográfica direta com grafismos losangulares dos cestos Mbyá-Guarani, nomeados por eles como "emblemas de serpente" - conf. Noelli, 1993, apoiado em Cadogan, 1961. Por fim, correlaciona, tentativamente, o grafismo losangular arqueológico Guarani à representação gráfica da cobra.

${ }^{32}$ Três famílias Mbyá-Guarani que residem na Lomba do Pinheiro, Porto Alegre.

${ }^{33}$ Aldeia da Estiva - Viamão-RS.
} 
grafismos foram por eles desenhados ${ }^{34}$ e nomeados. Numa segunda etapa, passei a investigar o nome e o significado dos grafismos que estavam presentes ou nas cestas ou outros tipos de trançados que eles estavam confeccionando ou, ainda nas fotografias previamente tiradas de cestas Guarani, as quais lhes mostrava. Por último, dediquei-me a ouvir o discurso nativo sobre os grafismos presentes na cerâmica arqueológica de "Tradição" Tupiguarani, que lhes foram mostrados através de desenhos e fotos. Apesar de os grupos trabalhados terem procedências geográficas diferentes, as informações registradas são em tudo homogêneas.

\subsubsection{Ipará Mbyá: grafismos sagrados do cosmo}

Independentemente do suporte, os grafismos foram denominados de ipará.

Segundo os Mbyá vindos da Argentina, há dois grafismos diretamente ensinados por Ñanderu: ipará rysy (desenho reto, em fileira) e ipará pirárãinhykã (desenho de mandíbula de peixe). Para os Mbyá da Estiva-RS, apenas o ipará rysy tem origem sagrada. As informações colhidas indicam expressamente que os suportes com estes grafismos não podem ser vendidos aos juruá (brancos). Para ambos os grupos, os demais grafismos foram "inventados" por eles próprios, podendo ser comercializados os cestos ou objetos onde eles estejam presentes.

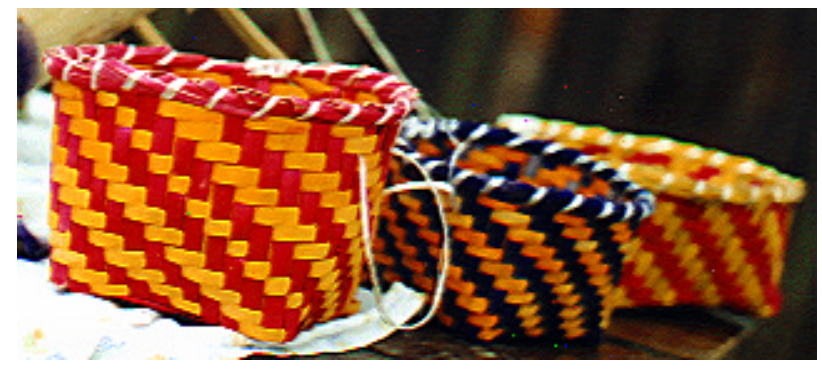

Ipará rysy

\footnotetext{
${ }^{34}$ No meu diário de campo ou em folhas separadas.
} 


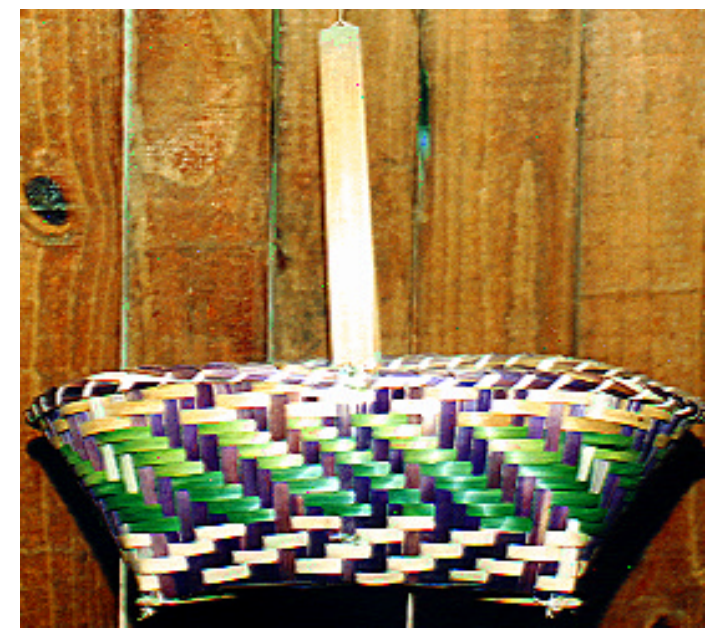

Ipará pirárãinhykã

Entretanto, o uso da palavra ipará para designar todos os grafismos Mbyá trai o caráter sagrado da totalidade deles, apesar de o discurso mostrar que apenas dois deles foram "ensinados" por Ñanderu. Na língua Mbyá, existem, pelo menos, dois tipos de linguagem, ou duas etnolinguagens ${ }^{35}$ : uma usada nas relações terrenas, e a outra divina, utilizada pelos deuses ao se dirigirem aos homens, e que falam pela boca do opyguá ou kuña karaí (xamã, respectivamente homem ou mulher). Segundo os Mbyá, sempre há "a palavra divina e a palavra dos homens" ${ }^{36}$. Assim, tem-se, por exemplo:

\begin{tabular}{|l|l|c|}
\hline----------- & $\begin{array}{l}\text { "Palavra } \\
\text { divina" }\end{array}$ & $\begin{array}{l}\text { "Palavra } \\
\text { humana" }\end{array}$ \\
\hline mãe & semokambuaré & sy \\
\hline "branco" & yvy pó & juruá \\
\hline milho & yvy poty & avati \\
\hline desenho & ipará & angá \\
\hline
\end{tabular}

\footnotetext{
${ }^{35}$ Bridgeman, que estudou "O parágrafo na fala dos Kaiwá-Guarani”, assim se refere aos seus falantes: "os índios distinguem três etnolinguagens que eles designam como: myamyrï nhe'ë 'fala ancestral', te'yi nhe'ë 'fala indígena', e paragwai nhe'ë 'fala paraguaia”. Deve ser observado que a fala ancestral é a língua de prestígio, usada por todas as faixas de idade para propósitos religiosos. É geralmente a segunda língua a ser apreendida, sendo que a fala indígena é a primeira. Em algumas situações, somente a fala ancestral é apropriada. Em outras, somente a fala indígena. A fala paraguaia, embora utilizada, nunca é considerada apropriada e seu uso é muitas vezes negado" (Bridgeman, 1981:11).

${ }^{36}$ Conforme Karaí Iápuá.
} 
A origem dos grafismos considerados sagrados pelo discurso está ligada à origem dos cestos. Kuaray, ou N Namandu, um dos "gêmeos" ancestrais - Sol -, ensinou a confecção de cestos aos Mbyá. Conforme o mito colhido ${ }^{37}$, o adjaká (cesto) Mbyá está relacionado metaforicamente à mulher, e os grafismos nele presentes, à pintura facial feminina.

"No tempo... quando existia o Sol e a Lua... Então, convidaram Añá, o Diabo, para ir pescar, e o Diabo queria casar com a irmã dele, do Sol. E daí foram pescar. Mas o Sol não queria dar a irmã dele para o Diabo. Aí, o Sol enganou o Diabo. Enganou ele por a moça. O diabo foi chorando, foi chorando... Diz: - Que é isso? Perdeu aquela moça, que é irmã do Sol. Chorando, chorando. - Não, não chora, disse o Sol pro Diabo. Nós vamos arranjar outra moça pra ti.

"E fez aquela adjaká. Mas bem pintadinha como aquela moça que botava ysy no rosto, assim (o narrador indica, com três dedos, três linhas inclinadas em cada face).

“- Tá. Você não anda, você não vai andar com ela na água, senão tu vai perder, disse o Sol.

"O Diabo gostava de tomar um banho. Sempre no rio, e levava moça, levava moça.

"Quando foram tomar um banho, o Diabo e a moça junto com ele, virou adjaká (cesto) lá dentro do rio. Mas chorou, chorou... Aquela moça que ele levou era adjaká que táva dentro da água. Ah, mas veio se queixar pro Sol de novo:

"- Mas, e daí?

"Olha, daí eu não sei, o Sol disse pra ele, eu não sei. Onde é que tu andava? Eu disse pra você que não era pra andar sempre no rio, senão tu ia perder tua esposa, que era a adjaká.

"Então, dali que já foi aprendendo aquela adjaká, aí pra diante. A Lua já era sabido. Então a Lua disse: - Eu vou tentar de fazer esse adjaká. Olhou bem como é que é pra fazer. Dali por diante já fizeram, já experimentou fazer adjaká. Ali que vem vindo, vem vindo, até que até hoje tamo fazendo adjaká, igual como era que o Sol fez.

"Ali fez o adjaká; depois, antigamente, os mais antigos faziam de novo, até hoje todos os índios não távam se esquecendo de fazer.

"E não era pra fazer pintura quadrada - ipará korá. É feito pra fazer ipará rysy. É só aquilo que fazia. Depois, daí, é que aprendeu cada vez mais e fez ipará korá. O Sol ensinou ipará rysy, só; não era pra fazer ipará korá. Por sabido é que foi fazendo até que hoje faz tudo isso aí. Já que o pessoal tá mais sabido já fez ipará korá, ipará kurusu e aí por diante, foi inventando".

\footnotetext{
${ }^{37}$ Este fragmento de mito, narrado na Aldeia da Estiva por Turíbio Karaí, nascido em 1911, no RS, explica o surgimento dos grafismos e, sem dúvida, pertence à narrativa mitológica Guarani conhecida impropriamente como do "ciclo dos gêmeos", pois Sol e Lua, ambos do sexo masculino, têm pais diferentes. No seu início, acontece o rompimento definitivo entre o divino e o humano, após Ñanderuvusu abandonar a "terra nova" e sua esposa infiel. A terra, então, torna-se imperfeita, para sempre separada do espaço divino, a Terra Sem Males. Na terra má, sucedem-se as aventuras dos irmãos-deuses - Sol e Lua -, que obstinadamente procuram e conseguem atingir o espaço sagrado, ideal de todos Guarani.
} 
Os demais grafismos são aqueles que os Mbyá designam como "inventados", isto é, os que não teriam sido ensinados pelo filho de Nanderuvusu. Todos estão representados em cestos.

São eles: ipará korá (desenho fechado, pode ser quadrado, losango, redondo), ipará panambi pepó (desenho da asa da mariposa), mboitini ipará (desenho da cascavel), ipará karena (desenho da corrente), ipará kurusú (desenho da cruz), ipará joaçá (desenho cruzado).

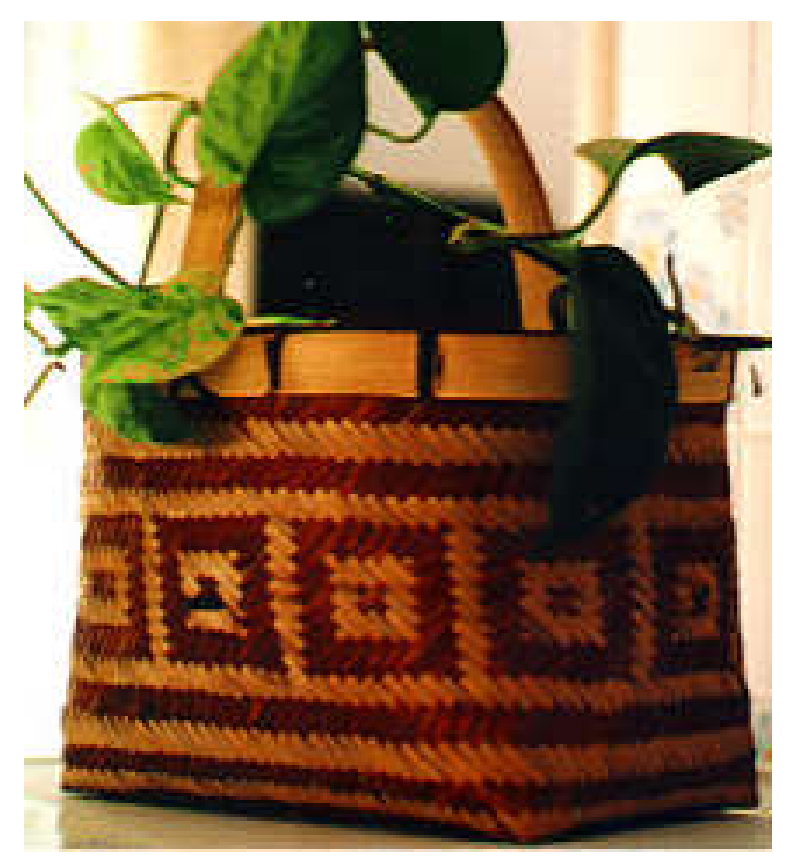

Ipará korá
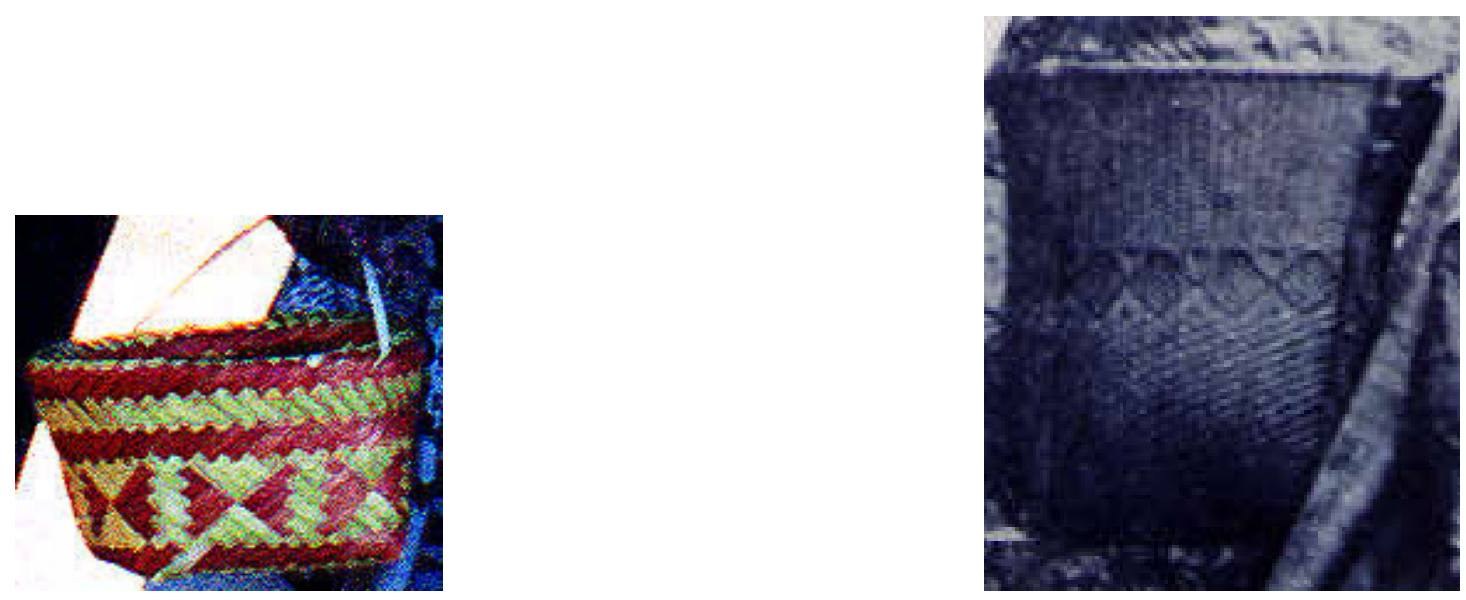

Ipará panambi pepó

Mboitini ipará

- Foto

reproduzida de

E. Schaden, 1962 


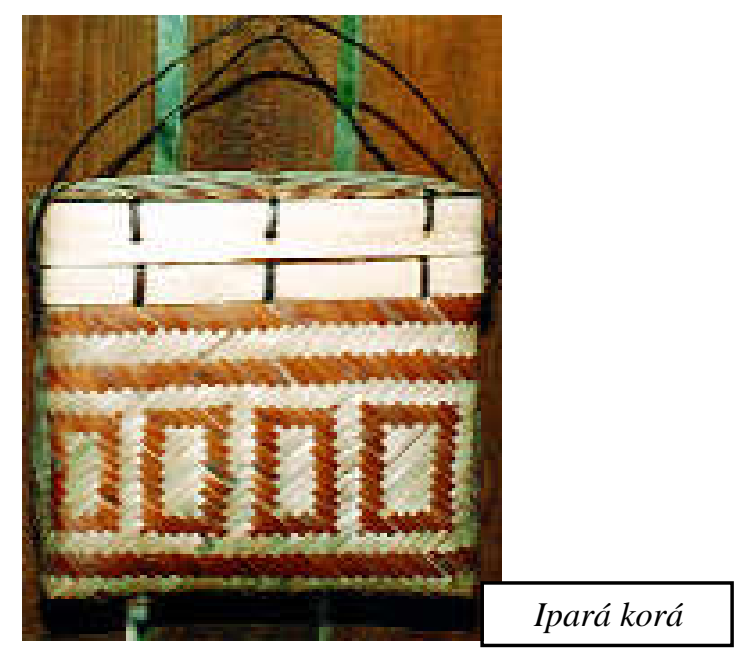

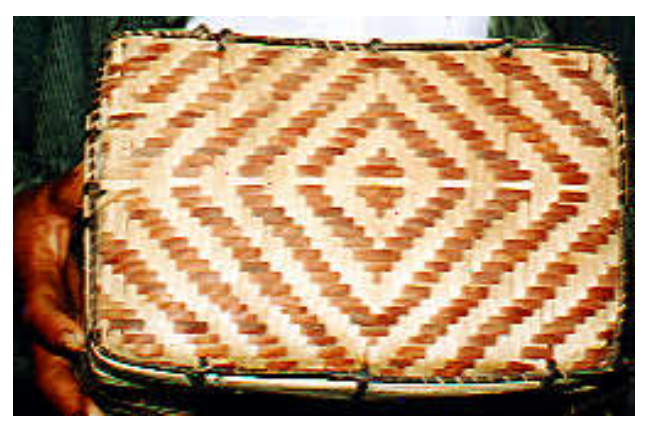

Ipará korá

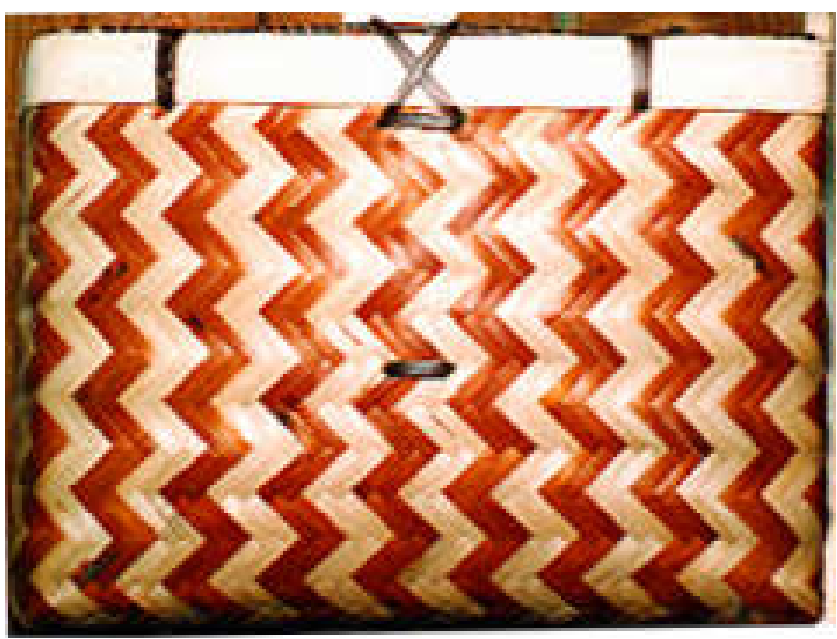

Ipará rysy karé

Ao que tudo indica, mesmo levando em consideração o caráter exploratório do trabalho de campo junto aos Mbyá-Guarani, estamos diante de uma etnoarte que aponta para conceitos cosmológicos, evidenciando em seus padrões gráficos os domínios da natureza e da sobrenatureza, através da representação de seres primordiais. Estes seres, reduzidos a alguns elementos anatômicos, relembram os tempos míticos primevos, nos quais humanos e divinos habitavam a mesma terra.

Desta forma, a etnoarte iconográfica Mbyá-Guarani estabelece uma ponte de comunicação com Ñanderuvuçu, constituindo-se em uma 
"aproximação desejada e controlada pela comunidade com o mundo sobrenatural" (Gallois, 1992:228, referindo-se aos Waiãpi).

Muitas das relações entre os motivos iconográficos (presentes nas cestas atuais) com os seres primevos parecem ter se perdido ou estar aparentemente esquecidas $^{38}$, restando apenas designações que não dão conta desta relação (ipará korá, por exemplo). No entanto, algumas poucas relações entre os motivos e os seres primevos permanecem vivas nas tradições dos dois grupos Mbyá trabalhados: mboitini ipará (desenho da cobra cascavel), ipará pirárãinhykã (desenho da mandíbula do peixe), ipará panambi pepó (desenho da asa da mariposa), arakú pipó (rastro da saracura - veja em pintura corporal, adiante). De qualquer forma, a origem divina dos grafismos, exterior à sociedade, está bem marcada e continua a ser lembrada através da passagem do mito das adjaká, o que evidencia o vínculo entre a ornamentação (das cestas ou dos corpos) e o mundo sobrenatural.

Por outro lado, como se verá no subitem seguinte, se compararmos alguns grafismos Proto-Guarani, presentes na cerâmica arqueológica, com padrões gráficos atuais de outros povos falantes de línguas da Família Tupiguarani, resta confirmada esta tendência à ênfase cosmológica da etnoarte (Proto)Guarani. É o caso da semelhança formal, por exemplo, entre os grafismos Waiãpi (Gallois,1992) e Proto-Guarani que representam o casco do jabuti/quadriláteros circunscritos e a decoração dorsal do sapo morua/cruz.

Além disso, o artesanato atual Mbyá-Guarani em madeira pirogravada revela esta ênfase de sua arte sobre o domínio da natureza (e suas relações com a sobrenatureza). Trata-se de pequenas esculturas figurativas zoomorfas, que não mais reduz estes seres a alguns de seus elementos anatômicos, representando animais (mamíferos, répteis, peixes, aves, etc.), relacionados diretamente a um horizonte ecológico-cultural de florestas tropicais e subtropicais, tradicionalmente ocupado e vivenciado pelos (Proto)Guarani.

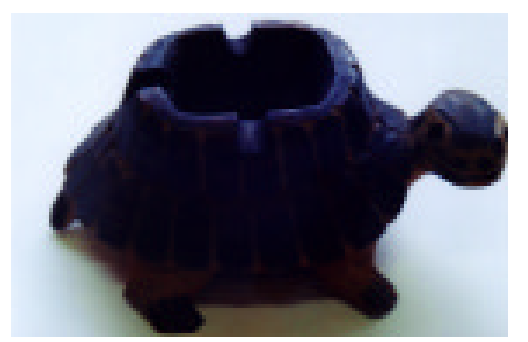

Jabuti (karumbé) em madeira pirogravada Artesanato Mbyá-Guarani - Acervo pessoal - Autor: Tiago Mbyá/1989

\footnotetext{
${ }^{38}$ Ou meu brevíssimo trabalho de campo não chegou a detecta-las, todas.
} 


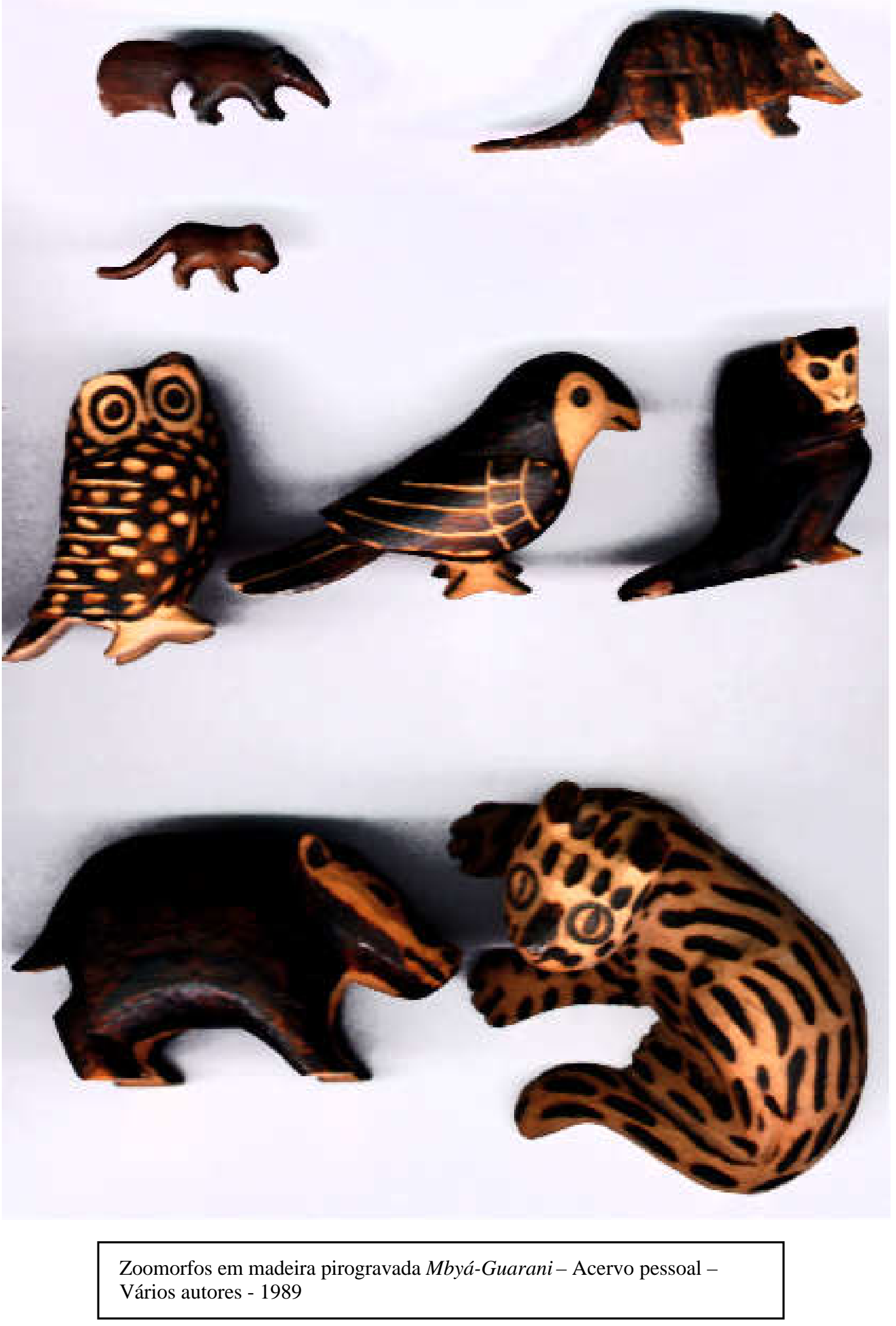




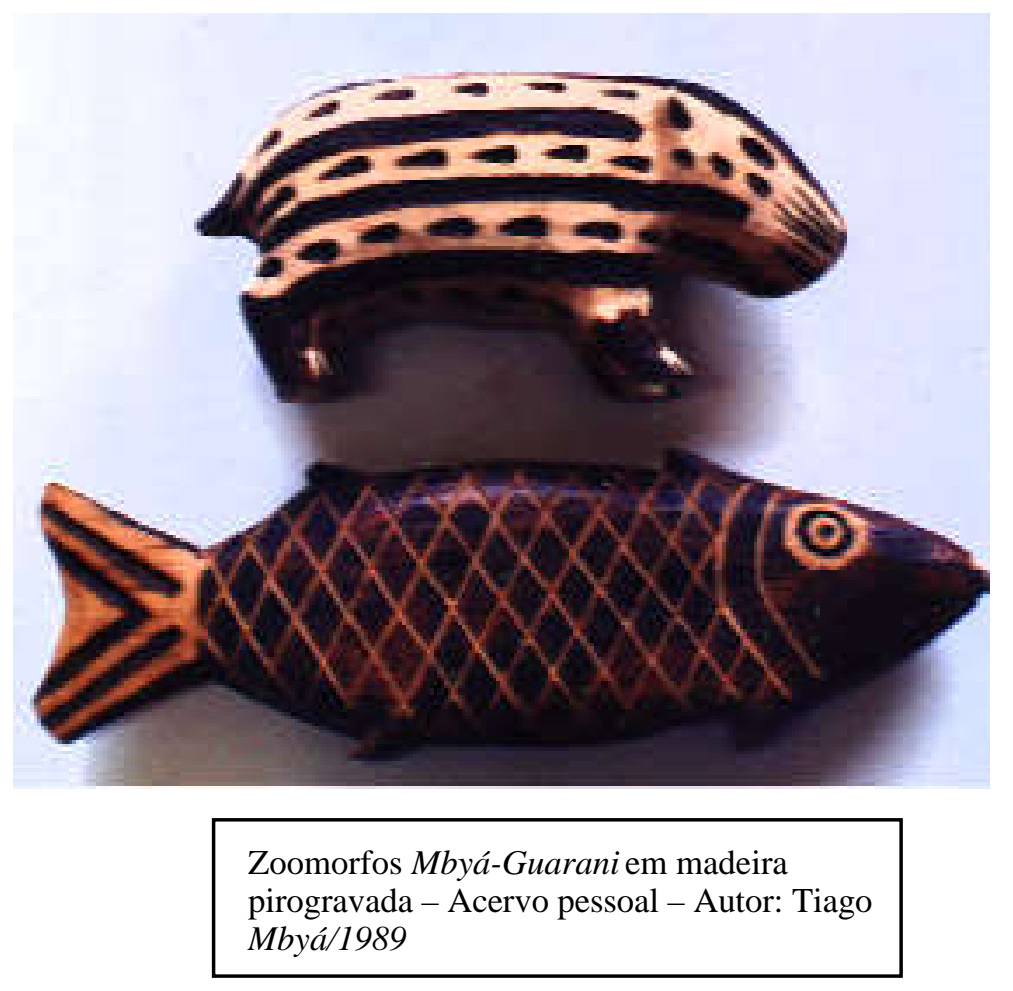

Do mesmo modo, as informações de Garlet \& Soares (1995:8), corroboram minha constatação de que a etnoarte Mbyá-Guarani enfatiza as relações cosmológicas. Os autores fizeram um levantamento sobre os cachimbos (petynguá) atualmente confeccionados pelos Mbyá. De sua leitura, verifica-se que o próprio uso do cachimbo já remete às relações com as divindades e com a fauna e a flora primevas. Além do uso cotidiano, ritualmente, ele é usado nas curas, rezas e, pelo xamã, para entrar em transe. À pasta de argila para confeccionar os cachimbos usados apenas no ritual, e especialmente os de uso do xamã, são adicionados ossos carbonizados e triturados de porco-do-mato - koxi -, considerado animal doméstico de Ñanderu (Garlet \& Soares, 1995:3 e 8). Os autores verificaram que os petynguá "apresentam, tanto nos motivos como na forma, inspiração na flora e na fauna" (op.cit, pág. 8). Cachimbos zoomorfos representam peixes - piráruguái petynguá e jakaré petynguá (peixe cascudo), borboletas - popó petynguá -, aranhas - ñandu petynguá -, tartarugas - karumbé petynguá - e, ao que parece, flores - ivoty ranga (idem, pág. 7 e 8). Da mesma forma, os grafismos registrados pelos autores ("ponteados, feitos com ramos e desenhos em baixo relevo" - 
idem, pág. 8) também apontam na direção da ênfase cosmológica da etnoarte Mbyá-Guarani: são o ivoty ranga - desenho de flor -, "um dos motivos da pintura facial feminina (pé da saracura)" ${ }^{39}$, pindó rogué ranga - folha da palmeira pindó -, pirá kangue - espinha de peixe -, e pirá ranga - imagem do peixe - (idem, pág. 8). Infelizmente, os autores não publicaram os grafismos, o que possiblilitaria sua comparação formal com os colhidos e analisados nesta tese. Mesmo assim, a descrição da produção, uso e materialidade dos cachimbos foi importante para que se pudesse testar e reforçar a hipótese sobre a priorização das relações com as divindades, e a inter-relação destas com os domínios da natureza e da sociedade, no sistema de representações visuais Mbyá-Guarani.

\subsubsection{Grafismos Proto-Guarani}

Após esta primeira etapa da pesquisa, com materiais etnográficos, mostrei aos Mbyá duas estampas publicadas por Schmitz (1985:41-42), com "motivos de decoração da cerâmica pintada, em vermelho sobre branco, ou vermelho e preto sobre branco", ou seja, com grafismos Proto-Guarani.

A grande maioria dos grafismos da primeira estampa foi reconhecida $\mathrm{e}$ nomeada pelos Mbyá. É importante frisar que tanto os dois grafismos sagrados, ditos como "dados por Ñanderu", como a maioria daqueles desenhados e nomeados espontaneamente pelos interlocutores, aparecem nas reproduções dos grafismos cerâmicos da primeira estampa, e foram identificados, inclusive o ipará kurusu, que a princípio pareceu ser um símbolo apropriado do cristianismo e ressemantizado. Desta forma, foram nomeados, após seu reconhecimento, mais alguns ipará Mbyá, estes parece que exclusivamente Proto-Guarani: ipará rysy karé (desenho reto, em fileira, dobrado/torcido), ipará yvoty ty (desenho do lugar onde se planta flor), ipará karé karé (desenho duplamente torcido/dobrado). Entretanto, após a pesquisa com os dois grupos Mbyá, vi este último (ipará karé karé) representado em cesto Guarani (grupo proveniente da Argentina), coletado por mim no final da década de 80. Como não realizei levantamentos em acervos de museus, este fato demonstra que é bem possível que todos os grafismos desta primeira estampa estejam presentes nos trançados Mbyá.

\footnotetext{
${ }^{39}$ Veja subitem 5.2.3., adiante, sobre pintura corporal.
} 


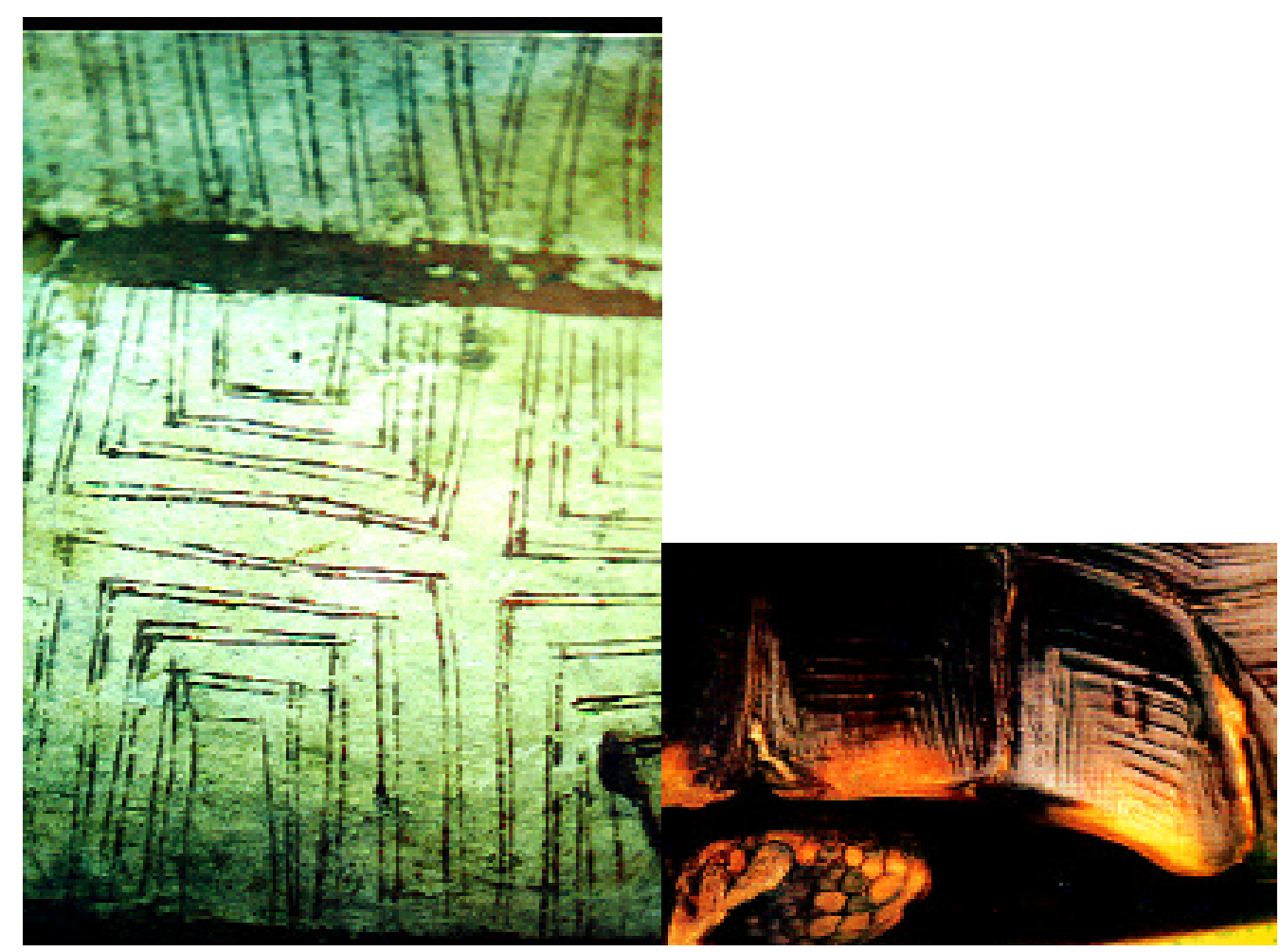

À esquerda, cambuxi Proto-Guarani (detalhe junto ao lábio). Na sua parte superior, grafismo ipará rysy. Mais abaixo, grafismos denominados ipará karé $i$, representação gráfica do jabuti (casco). Informações de Turíbio Karaí. Acervo do MUAE/UFRGS.

À direita, detalhe do casco de um jabuti.

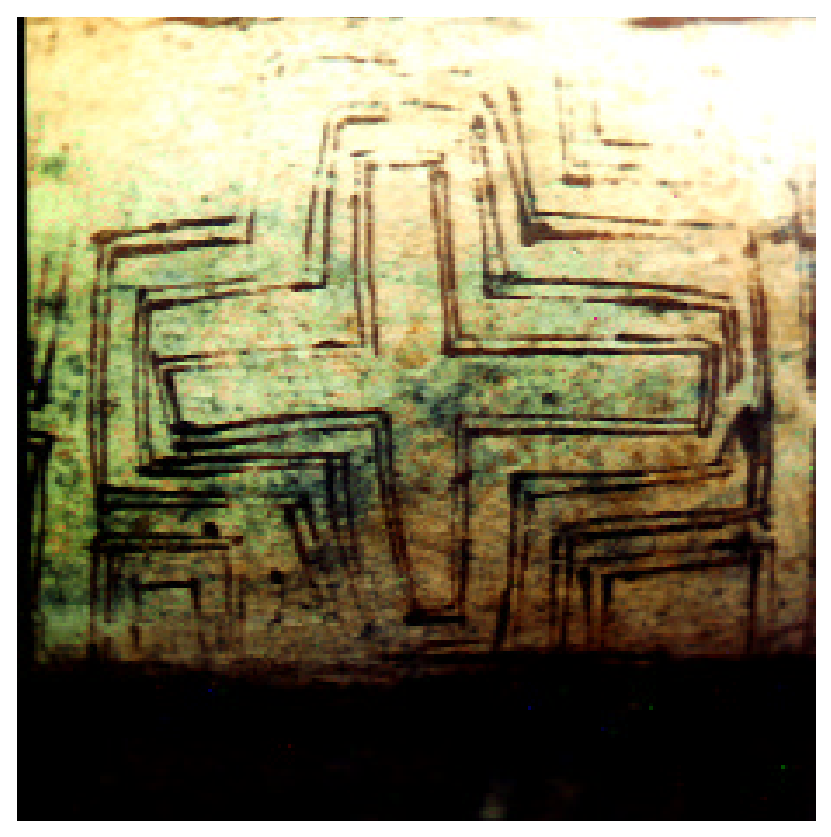

Ipará kurusú: detalhe do mesmo cambuxi mostrado acima. Acervo MUAE/UFRGS. 


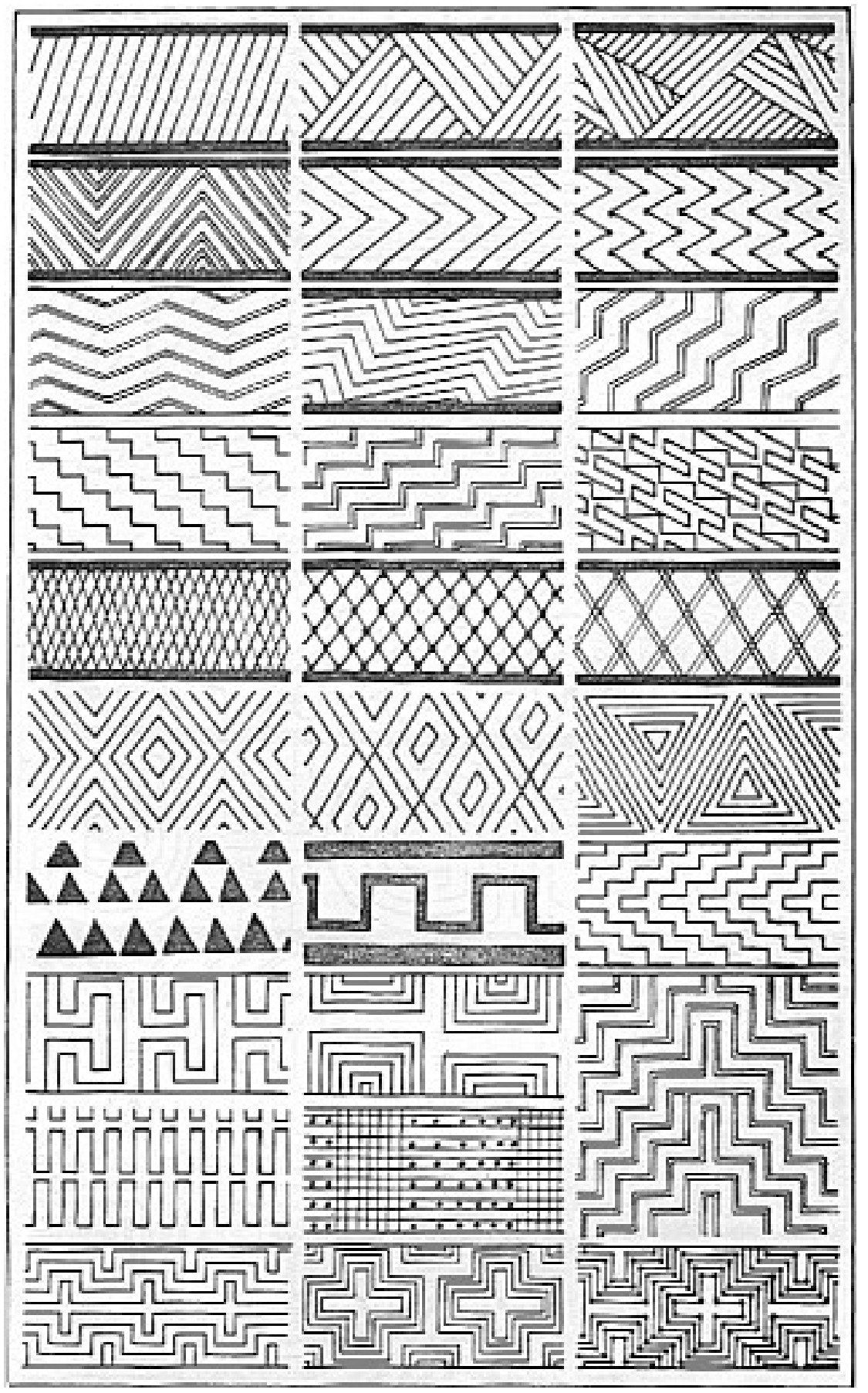

Grafismos na cerâmica Proto-Guarani

"Motivos de decoração da cerâmica pintada, em vermelho sobre branco, ou em vermelho e preto sobre branco". Reproduzido de Schmitz, 1985:41 (primeira estampa). Conforme interlocutores Mbyá-Guarani, a maioria dos grafismos foi reconhecida como Mbyá-Guarani e assim denominada: $1^{\mathrm{a}}$. fileira (de cima para baixo): ipará rysy, ipará rysy ñovaiti, ipara panambi pepó; $2^{\mathrm{a}}$. fileira: ipará rysy karé, ipará pirárãinhykã, ipará karé karé; $3^{\mathrm{a}}$. fileira: ipará rysy karé (para os três grafismos); $4^{\mathrm{a}}$. fileira: sem denominação; $5^{\mathrm{a}}$. fileira: ipará korá (primeiros dois grafismos), pirá pará (imagem do peixe); $6^{\mathrm{a}}$. fileira: ipará korá (três grafismos); $7^{\text {a }}$. fileira: ipará yvotyty (imagem do lugar onde se planta a flor), ipará karena, sem denominação; $8^{\mathrm{a}}$. fileira: sem denominação, ipará karé $i$ (imagem do jabuti); $9^{\mathrm{a}}$. fileira: sem denominação; $10^{\mathrm{a}}$. fileira: ipará kurusu (os três grafismos). O último grafismo das fileiras 8 e 9 não foi reconhecido. 


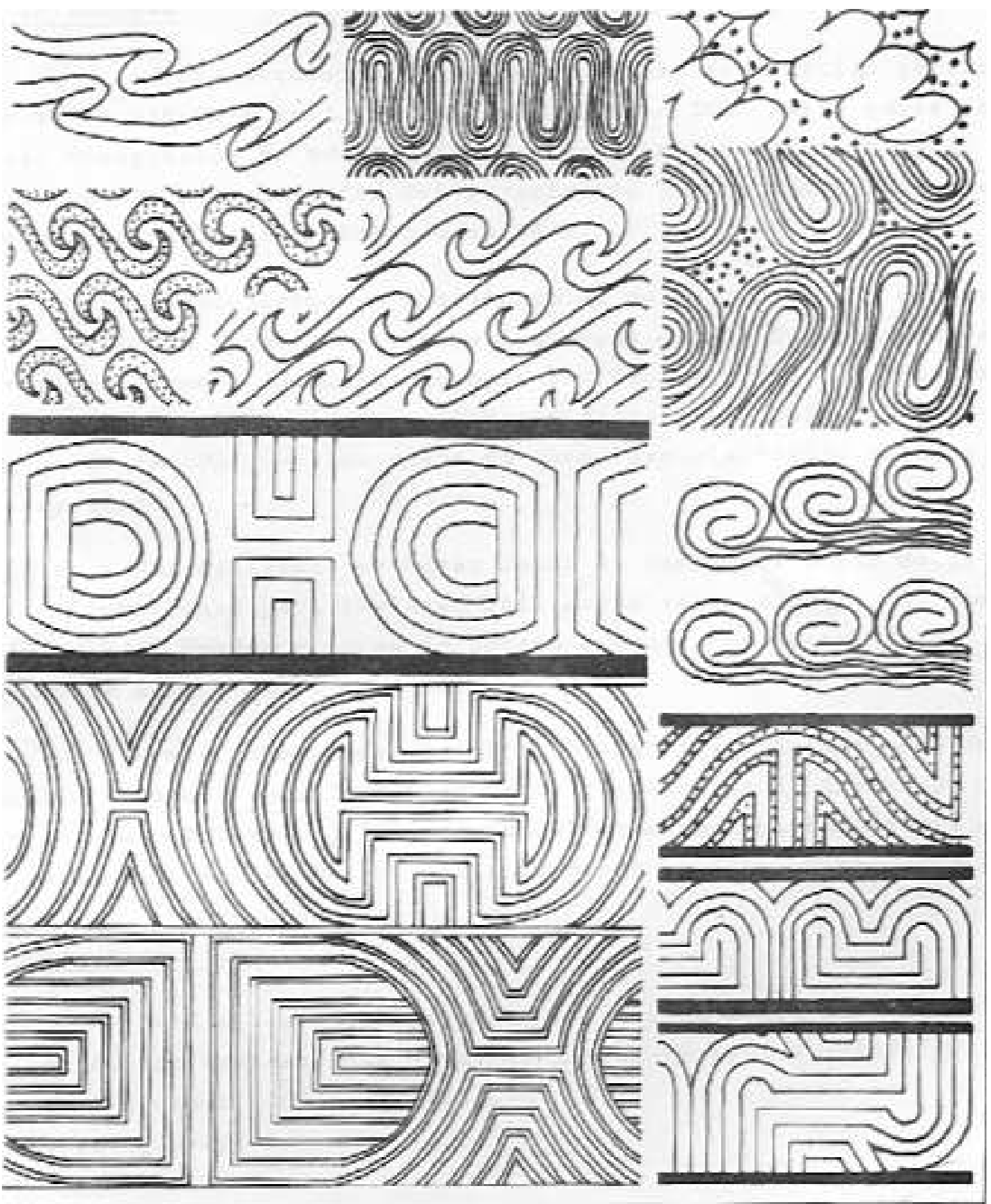

Reproduzido de Schmitz, 1985:42. Segunda estampa.

Os grafismos cerâmicos constantes da segunda estampa (Schmitz, 1985:42), que contêm círculos e/ou linhas curvas, não foram reconhecidos pelos Mbyá com quem trabalhei. 
É extremamente compreensível que isto ocorra. Meus interlocutores Mbyá apenas reconheceram os grafismos pré-históricos que contêm linhas retas ou angulares: eles ainda são reproduzidos nas cestas. Como a tradição de pintura na cerâmica perdeu sua praticidade há muito tempo, juntamente com o abandono de sua confecção, a maioria dos Mbyá não mais tem recordação dos grafismos curvos ${ }^{40}$. Entretanto, os grafismos com linhas retas e angulares ainda estão presentes na tradição de feitura dos adjaká, ainda hoje confeccionados com os grafismos angulares e em linha reta, próprios para este tipo de suporte ${ }^{41}$.

\subsubsection{Ysy: a antiga pintura corporal $M b y a^{42}$}

Um grupo de crianças e adolescentes Mbyá da Estiva, com a participação dos da Aldeia do Cantagalo, também no Município de Viamão, orientados pelo seu professor-bilíngüe, realizaram, em abril de 2000, uma série de apresentações de cantos e danças tradicionais Guarani ${ }^{43}$ em um programa pedagógico denominado "500 anos do descobrimento". Nestas ocasiões, a pedido dos coordenadores do programa, que forneceram urucum aos índios, os Mbyá apresentaram-se com grafismos corporais em vermelho. Com as fotos e vídeo que fiz das apresentações, pedi aos Mbyá que nomeassem os grafismos. "A pinta foi inventada na hora. Foi urucu. Fizeram só um risquinho" - foi a resposta que obtive.

No entanto, de acordo com meus interlocutores, a tradicional pintura corporal Mbyá - ysy-, feita com tinta preta, não foi esquecida, tendo sido praticada constantemente há apenas duas ou três gerações passadas.

A pintura corporal ysy, com motivo ipará rysy, era usada antigamente por mulheres, em sinal de luto de parente próximo. Igualmente, desde pequenas, as mulheres poderiam usá-la, no rosto ou nos pulsos, como proteção contra doenças "do músculo e reumatismo", denominadas de karú guá $a^{44}$.

\footnotetext{
${ }^{40}$ Talvez alguns especialistas em ritual, ou algumas mulheres, tenham memória destes grafismos, o que poderá ser respondido com a seqüência das pesquisas.

${ }^{41}$ Vendo a prancha dos grafismos pintados cerâmicos pré-coloniais retos e angulares, os Mbyá costumavam comentar, fazendo o "cálculo", que eles são passíveis de serem feitos no trançado.

${ }^{42}$ Assim os Mbyá da Lomba do Pinheiro traduziram ysy.

${ }^{43}$ Ao som do mbaraká (violão com afinação Guarani) e do ravé (violino), coreografaram canções como Ñamandu mirin, Avati auã, Sondaro, Ñanderu vixá, etc.

${ }^{44}$ Informação de Karaí Iápuá (Mestre do sono divino).
} 
Além disso, pelas informações colhidas, a pintura corporal também era usada em jovens de ambos os sexos para indicar seu estado liminar nos processos rituais de passagem para a idade adulta.

No rosto e/ou nos pulsos da moça nova, após a primeira menstruação, em ambas as faces, era pintado (com tinta preta confeccionada de cera de abelha jataí com carvão de folha de taquara criciúma ou taquarembó) o grafismo denominado de arakú pisá (dedo da saracura ${ }^{45}$ ) ou arakú pipó (rastro de saracura). Este grafismo corporal feminino também era usado para afastar tanto doenças como as almas de parentes próximos mortos. Mulheres após o parto, usavam-no nas articulações.

A ysy dos homens era o motivo kurusu (cruz), igualmente pintado com tinta preta confeccionada de cera de abelha jataí com criciúma ou taquarembó queimados. Conforme meus interlocutores Mbyá da Lomba do Pinheiro, a kurusu era pintada nos pulsos e/ou na planta dos pés, jamais no rosto dos homens, com a intenção de afastar perigos ${ }^{46}$. Já os Mbyá da Aldeia da Estiva, indicam que a kurusu era utilizada antigamente como pintura facial para marcar nos meninos seu estado liminar nos rituais e para dramatizar a passagem para a idade adulta. Segundo eles, o indicativo físico desta passagem seria a "voz grossa". Os rapazes que atingiam esta condição também pintavam com tinta preta a região acima dos lábios superiores, para mostrar que não eram mais meninos.

A ysy era ainda utilizada pelos recém-casados nas articulações, como proteção.

\subsubsection{Algumas reflexões e comparações}

Uma possível diferença entre a pintura corporal Kaingang e Guarani seria que a última teria ligação com momentos de "crise", de liminaridade, marcando na pessoa processos rituais de passagem, ou com a proteção contra doenças ou infortúnios de toda espécie. Em ambos os casos, a ysy tem ligação direta com a religiosidade Guarani.

No primeiro caso, tem-se os grafismos araku pisá ou araku pipó (dedos ou rastro da saracura) e kurusu (cruz), representando a passagem,

\footnotetext{
${ }^{45}$ É interessante notar que esta ave era interditada como alimento para crianças até 15 anos. Sua ingestão traria graves consequiências para o infrator da interdição.

${ }^{46}$ A kurusu, inclusive, pode ser desenhada no chão, "para desviar um vento, um temporal”, conf. Karaí Iápuá.
} 
respectivamente, da menina para a idade adulta com a menaca ("fica moça") e marcando a transição do menino para as responsabilidades de homem adulto ("engrossa a voz"). Ainda foi relatado que as viúvas usavam ysy com motivo ipará rysy no rosto para marcar o luto em relação a parentes próximos.

No segundo, ambas marcas são usadas para proteger contra doenças.

O araku pipó e a kurusu são grafismos corporais de gênero, o primeiro sendo usado exclusivamente por mulheres, e o segundo, só por homens.

Já a pintura corporal Kaingang não expressa gênero. Apenas marca o pertencimento de homens e mulheres a uma das metades. As marcas abertas (téi) e fechadas (ror) extrapolam sua dimensão social, reguladora dos casamentos, assumindo dimensões precisas na cosmologia dualista, que caracteriza e qualifica todos os seres, coisas e objetos do cosmo.

Como entre os Mbyá-Guarani, os grafismos corporais Kaingang também protegem contra os espíritos dos mortos, especialmente nos rituais ligados à morte. Entretanto, até onde pude ver, não protegem especificamente contra doenças ${ }^{47}$.

Com relação aos grafismos Mbyá presentes em outros suportes, alguns são formalmente semelhantes a grafismos Kaingang: ipará korá com ra ror ê ; ipará rysy karé com ra ionior; ipará pirárãinhykã com ra téi. Estas semelhanças na forma dos grafismos diluem as certezas principalmente com relação a grafismos rupestres pré-coloniais. No entanto, quando estes três grafismos estão presentes em suportes reconhecidamente Proto-Jê do Sul ou Proto-Guarani, poderemos a partir de agora compreender os significados de cada um deles na percepção cosmológica e sociológica de cada uma destas sociedades. No caso dos grafismos rupestres, somente sua contextualização precisa poderá lançar luz sobre suas possíveis significações.

O caso de muitos painéis rupestres com os sinais denominados de "tridáctilos" é interessante de ser comentado. O grafismo corporal Mbyá araku pipó (rastro da saracura) é, formalmente, um "tridáctilo" típico. Como se viu, o araku pipó está ligado, no passado, aos rituais de puberdade feminina entre os Mbyá-Guarani. No Rio Grande do Sul, é comum a presença de "tridáctilos" próximo a sítios arqueológicos de "Tradição" Tupiguarani.

\footnotetext{
${ }^{47}$ Entre os Kayapó, um doente não se pinta, apenas passa tintura de urucu para afastar os maus espíritos (L.Vidal, comunicação pessoal, 2001).
} 
Como será analisado no item seguinte, o arqueólogo André Jacobus (comunicação pessoal, 2000) constatou que nas redondezas dos sítios com grafismos rupestres do RS quase nunca há sítios de "Tradição" Umbu populações pré-históricas de caçadores-coletores consideradas pela bibliografia tradicional arqueológica como os únicos autores dos petróglifos -, mas, sim, sítios de "tradição" Guarani ou Taquara.

Impõe-se, ainda, uma reflexão sobre o grafismo denominado ipará kurusu, que aparece em vários suportes (Proto)Guarani (na cerâmica arqueológica, nas cestas, no corpo masculino, desenhado diretamente no chão) ou com possibilidades de serem Proto-Guarani, quando ocorre em painéis rupestres do sul do Brasil.

Apesar de as ocorrências ditas pré-coloniais não serem completamente confiáveis (pois muitas vezes a cerâmica na qual ela aparece não tem datação absoluta e a arte rupestre não possui nem contextualização cultural nem datas), este grafismo parece representar uma noção genuinamente Guarani: o esteio em forma de cruz para sustentar a Primeira Terra do mito (Yvy Tenondé); os quatro deuses ligados às quatro direções cardeais; o artefato religioso denominado popyguá, usado pelos xamãs, em forma de duas varas de madeira que se cruzam e batem uma na outra ${ }^{48}$. A cruz cristã, de qualquer forma, pode ter potencializado esta noção religiosa Guarani, após sua apropriação e ressemantização pelos Mbyá.

\subsection{Grafismos Proto-Jê meridionais}

A cerâmica das "tradições locais planálticas", e seus grafismos, já foi trabalhada no Capítulo 3. Igualmente o foi, a vinculação desta cerâmica (e dos grafismos nela presentes) com populações Proto-Jê do sul. No subitem seguinte, serão analisados os grafismos rupestres que ocorrem em inúmeros sítios arqueológicos do sul do Brasil, e suas relações com outras representações visuais do sul do Brasil, incluindo os grafismos da cerâmica Proto-Jê e os padrões gráficos das sociedades Jê meridionis.

\footnotetext{
${ }^{48}$ Além disso, a "cruz" é um grafismo geométrico representado por várias sociedades não-ocidentais, anteriormente ao contato com povos europeus. Como exemplo, no Brasil, tem-se a chamada "Fase" Marajoara, 400 a 1350 d.C., cuja cerâmica possui grafismos em forma de cruz. Veja Fundação Nacional de Arte, 1981:83.
} 


\subsubsection{Grafismos rupestres no Brasil Meridional: questões abertas}

Quanto à arte parietal, na ampla região de dispersão das populações vinculadas ao horizonte cultural Proto-Jê do Sul, há uma quantidade significativa de sítios arqueológicos com inscrições gravadas ou pintadas na rocha de abrigos, grutas ou blocos isolados.

Como minha ênfase recai sobre o significado destas inscrições, e não na sua análise estética, denomino-as com o termo genêrico de grafismos rupestres, englobando tanto grafismos rupestres gravados como grafismos rupestres pintados. Estes termos correspondem, respectivamente, aos tradicionalmente usados: arte parietal ou rupestre, petroglifos e pictografias (Prous, 1989:10).

No Rio Grande do Sul, apresentam-se apenas grafismos rupestres gravados. Foram estudados, principalmente, por Ribeiro (1969/70, 1972a, 1972b, 1974, 1975, 1978, 1990, 1991 a, 1991b), Brochado \& Schmitz (1976) e Lima (1998).

Rohr (1969 a, 1971, 1972 a, 1972b), em Santa Catarina, fez os principais levantamentos de grafismos gravados em rochas. Mais recentemente, Rodrigo Aguiar localizou alguns painéis inéditos na Ilha de Santa Catarina.

Chmyz (1968d, 1969, 1971), Laming \& Emperaire (1968) e Blasi (1972) estudaram os grafismos rupestres gravados e pintados do Paraná.

Em São Paulo, entre outros, Aytai (1970) e Uchôa \& Caldarelli (1980) realizaram pesquisas em sítios com grafismos gravados em rocha.

A maioria dos autores que trabalha com grafismos rupestres reconhece as dificuldades de se estabelecer relação entre representação gráfica e cultura material, que identifica as populações pré-históricas, pois muitas vezes o registro gráfico é o único vestígio local encontrado da presença destes grupos (Martin, 1996:211). Por outro lado, a simples ocorrência de um sítio habitação junto a um sítio com grafismos rupestres não comprova a autoria dos últimos pelos moradores do primeiro.

Além desta dificuldade, inerente à natureza do objeto, tem-se, no Brasil, no nível teórico, outro tipo de dificuldades. Uma importante corrente 
de pensamento da arqueologia brasileira acredita que se deva antes trabalhar com os significantes do que com os significados dos grafismos rupestres:

"Tentar extrapolar significados atribuídos em outras épocas recentes ou contemporâneas ao mesmo tipo de cultura material é uma tarefa que não dá garantias devido a seu caráter polissêmico.

"Se faz, então, necessário, centrar o estudo sobre o significante, sobre os vestígios da cultura material, sejam eles objetos ou representações gráficas. Neles deverão ser observados aspectos que permitam extrair componentes das ideologias procuradas" (Pessis, 1994:288).

Da mesma forma, Guidon (1984) opta por uma distinção entre grafismo e sua significação simbólica. Sublinha que o grafismo do símbolo pode representar, ao mesmo tempo, uma manifestação da realidade sensível e uma significação simbólica. Assim, levando em conta as dificuldades para um pré-historiador ("[la] signification ne peut être connue que si nous connaissons la culture à laquelle appartient le support [grafismo]" - op. cit., p. 77), a autora privilegia a interpretação do símbolo em conexão com a realidade sensível, sem levar em conta, portanto, sua significação simbólica.

Discorrendo sobre a circulação de símbolos na América, Guidon afirma que os grafismos puros (também denominados geométricos ou signos, conforme os vários autores) não possuem traços de identificação permitindo um reconhecimento imediato de sua significação ${ }^{49}$. Conforme a autora, são universais, repetem-se indiscriminadamente no tempo e no espaço, não servindo, portanto, no momento atual do conhecimento, como índices de uma circulação (op. cit., p. 77-78).

Por isto, e diante da impossibilidade de "conjecturer sur l'existence d'une signification symbolique identique pour de mêmes supports matériels [grafismos] que l'on retrouve dans des régions differentes" (op. cit., p. 78), Guidon faz uma opção pelo estudo dos elementos gráficos que compõem figuras - antropomorfos, zoomorfos -, cuja interpretação imediata não coloca problemas.

Diante deste quadro teórico metodológico, o que fazer com os grafismos geométricos que abundam na cerâmica das "tradições locais planálticas" e nos painéis das "tradições" e "estilos" da "Arte Rupestre Brasileira"? Copiá-los e descrevê-los, tão-somente?

\footnotetext{
${ }^{49}$ Entretanto, às vezes, estes grafismos puros são também ícones de vários referentes, variando de sociedade a sociedade e segundo os contextos.
} 
Uma corrente mais moderada, e reflexiva, levanta algumas questões importantes:

“...l'existence de tribus indigènes (certaines tout juste contactées, alors que d'autres sont totalement acculturées) facilite le développement, encore très récent, de la recherche etno-archéologique; évidemment, il ne faut pas tomber dans le piège, signalé par W. Chiara \{1978. Contribuição da Antropologia para a interpretação dos resultados de pesquisa em arqueologia pré-histórica. Coleção Museu Paulista, São Paulo, Ensaios 2: 245-274\}, de la comparaison ethnographique 'naïve'. Et surtout comment interpréter les societés indigènes actuelles? Sont elles conservatrices, et depuis quand? Dans l'affirmative, les modèles indigènes (sub) actuels ne pourraientils pas être utilisés pour l'interprétation des vestiges archéologiques? Mais si les cultures furent dynamiques, et si leurs caractéristiques les plus 'classiques' n'étaient que le résultat du contact avec les Blancs (dépopulation, fuite vers des territoires nouveaux, abandon des terres propices à l'agriculture intensive ou tout au moins du mode de vie traditionnel)? La transformation récente des tribus refléterait-elle alors une dynamique adaptative positive? Cette problématique n'est d'ailleurs pas si nouvelle, puisqu'elle était posée aux XIXe. siècle par les tenants d'une décadence des indigènes brésiliens dès la préhistoire (L.Netto), idée reprise par les Evans au milieu du XXe. siècle \{Investigação sobre a arqueologia brasileira, 5 , Archivos do Museu Nacional, Rio de Janeiro, 6\}" Prous, 1993:17-18.

Apesar de se poder relativizar, e mesmo anular teoricamente, o peso das afirmações de Prous, que contêm os "conceitos" de "aculturação" e "decadência" ${ }^{50}$, como fazer, então, diante destes paradigmas teóricos e destas práticas acadêmicas, para avançar o conhecimento, a partir de abordagens teóricas mais sofisticadas para a compreensão destas representações visuais?

Parece-me que se deve tentar articular os conhecimentos da Arqueologia com os da Etnologia Indígena, da História e da Etno-história (principalmente quando se tem a continuidade histórico-cultural entre os registros arqueológico e histórico), optando-se por uma arqueologia cognitiva (Flannery \& Marcus, 1998:47).

Ademais, "A arqueologia brasileira é, forçosamente, uma arqueologia do índio brasileiro" (Simonsem \& Oliveira, 1980:9), e, necessariamente, uma antropologia das diversas e antigas sociedades indígenas no Brasil.

\footnotetext{
${ }^{50}$ Conforme ficou demonstrado no Capítulo 2.
} 
Além de tudo, como já foi discutido no Capítulo 2, se houve mudanças entre um passado pré-histórico e um recente, esta mudança está contida no registro arqueológico, e a arqueologia tem aptidão e capacidade para reconhecê-la (Huffman, 1981).

Portanto, faz-se necessário reverter este quadro teórico-metodológico, no qual "a interpretação dos desenhos, o campo analítico mais complexo, debatido em profundidade durante os anos 50, está abandonado atualmente" (Prous, 1992:511).

As variantes estilísticas dentro da mesma tradição cultural, a variabilidade de significados de uma mesma representação gráfica em diversas tradições culturais e a mudança de significação de um mesmo grafismo ao longo do tempo não devem ser considerados entraves teóricos para uma arqueologia interpretativa, mas, sim, devem servir como alerta contra interpretações apressadas.

Resumindo, o estudo dos grafismos rupestres e aqueles presentes na cerâmica arqueológica deve ser abordado teoricamente de acordo com a ocorrência de uma ou de outra das seguintes situações: 1) quando se tem continuidade histórico-cultural entre os registros arqueológico e etnográfico e 2) quando isto não acontece. Na primeira situação, que é o caso das "tradições locais planálticas" e dos Jê meridionais, pode-se lançar mão da analogia etnográfica para se construir uma abordagem etnoarqueológica, cognitiva, interpretativa e simbólica, elaborando-se um modelo não só dos sistemas de representação visual como de todos os sistemas culturais que puderem ser trabalhados com os dados disponibilizados pela pesquisa arqueológica.

No caso em estudo, além da comprovada continuidade históricocultural, tem-se os grafismos geométricos (rupestres e da cerâmica arqueológica) representados em objetos históricos de reconhecido e certo pertencimento a duas etnias atuais e contemporâneas: Kaingang e Xokleng. Os grafismos puros pertencentes ao sistema pré-histórico de representações gráficas são, formalmente, os mesmos usados nas peças depositadas em museus, nos corpos e na cultura material atual das sociedades Jê meridionais. Resta, apenas, tentar chegar ao significado destes grafismos, o que pôde ser realizado através da pesquisa antropológica e etnohistórica, via etnoarqueologia. 
Nas últimas décadas, Prous \& Piazza (1977) e Prous (1989; 1992) fizeram tentativas de síntese regional e geral em relação aos grafismos rupestres com ocorrência no sul do Brasil.

As ocorrências no Rio Grande do Sul, Santa Catarina, Paraná e São Paulo foram enquadradas por Prous (1989) em quatro "tradições" Meridional, Geométrica, Litorânea Catarinense e Planalto, que serão discutidas nas páginas seguintes.

Conforme Prous (1989:12), a temática da "Tradição" Meridional "é pobre", e comporta dois estilos:

“...figurações geométricas e abstratas com traços sobretudo retos paralelos ou cruzados, havendo também algumas figuras feitas com traços curvos; os chamados tridáctilos são presentes. (...) Em alguns lugares, como Canhemborá, haveria outro estilo, caracterizado por 'pisadas' de felídeos, suspostamente: séries de círculos maiores, cada um rodeado na parte superior por círculos menores em número de três a seis".

O autor dá como exemplo do primeiro "estilo" (A) os grafismos do Sítio D. Josefa, e para o segundo (B) traz o Sítio de Canhemborá, ambos no RS.

Uma gravura de quadrúpede encontrada no Cerro do Baú, também no RS, é considerada atípica por ser achado isolado (Prous, 1989:12). Voltaremos, mais adiante, à questão das representações figurativas, lado a lado com grafismos abstratos em uma mesma tradição estilística e cultural.

Este autor (Prous, 1989:12-13) considera possível que estes dois "estilos" “...possam ser correlacionados mais tarde com (...) [a] tradição geométrica (parte meridional), a qual também apresenta tridáctilos, triângulos com ponto ou barra interna (supostas vulvas) e 'pisadas'...", advertindo, no entanto, que talvez sejam puras coincidências: "as convergências são freqüentes entre tradições caracterizadas por representações geométricas, já que o número de fórmulas simples é relativamente limitado".

\footnotetext{
51 “As unidades rupestres descritivas receberam nomes variados, sendo que a categoria mais abrangente é geralmente chamada 'tradição', implicando uma certa permanência de traços distintivos, geralmente temáticos. 'Estilos' são freqüentemente definidos como subdivisões, particularmente a partir de critérios técnicos, enquanto nas regiões mais estudadas ou mais complexas, a necessidade de chegar até um nível suplementar levou N. Guidon a considerar 'variedades' e A. Prous facies, que corresponde ao mesmo tipo de realidade" (Prous, 1989:12).
} 
A "Tradição" Meridional comporta exclusivamente todos os sítios com grafismos rupestres do Rio Grande do Sul, considerados "geométricos lineares não-figurativos" (Prous, 1989:12), o que a princípio causa estranheza. Que critérios classificatórios permitiriam englobar, neste Estado, sítios mais ao sul a sítios da escarpa do Planalto Meridional Brasileiro ${ }^{52}$ ? Ou, ainda, que critério explicaria a separação dos sítios dos planaltos catarinense, paranaense e paulista da "Tradição" Meridional e sua inclusão na "Tradição" Geométrica, quando ambas "tradições" apresentam grafismos geométricos e quando se sabe qua toda esta região planáltica do sul do atual Brasil foi e é ocupada desde há dois mil anos por populações (Proto)Jê meridionais?

Além disso, como na "Tradição" Meridional ocorre a presença do tema tridáctilo, típico dos painéis rupestres patagônicos e pampeanos da Argentina, a maioria dos autores percebe esta "Tradição" como "a manifestação mais setentrional de um conjunto representado sobretudo fora do Brasil" (Prous, 1989:12). No entanto, a literatura especializada não fala em manifestações ou influências patagônicas ou pampeanas, apesar de o tema tridáctilo também ocorrer nos sítios das "tradições" Geométrica, Litorânea, e mesmo Nordeste (Prous, 1989:18) e São Francisco, as duas últimas localizadas no Nordeste do atual território brasileiro, bem distantes geograficamente, pois, da Patagônia. Neste caso, o critério aplicado para explicar aí a presença dos "tridáctilos" parece ser o da convergência ("coincidência") entre "tradições" caracterizadas por grafismos geométricos.

Este viés de entendimento prejudica a compreensão dos grafismos rupestres com ocorrência no Rio Grande do Sul, na medida em que são vistos como apartados das demais "tradições" brasileiras. A própria localização dos sítios gaúchos é analisada, implicitamente, segundo este viés:

“... são encontrados alinhados na escarpa do planalto, logo ao norte do vale do Jacuí. Até 1978, os sítios conhecidos encontram-se nesta faixa de $350 \mathrm{~km}$ de comprimento, no sentido leste-oeste, e $45 \mathrm{~km}$ de largura, no sentido norte-sul, havendo uma única exceção, bem mais meridional" (Prous, 1989:12) ${ }^{53}$.

\footnotetext{
${ }^{52}$ A área geográfica meridional do RS é bem distinta do Planalto, e foi habitada desde a pré-história por grupos populacionais diferentes, conhecidos historicamente como Charruas e Minuanos, identificados culturalmente com populações mais ao sul, os grupos da grande área pampeana e patagônica.

${ }^{53} \mathrm{O}$ autor refere-se certamente às grutas de Canhemborá e do Lajeado dos Dourados e aos abrigos da Linha Sétima e da Pedra Grande, localizados nas "bocas de serra" do Jacuí e do Topori, e estudados por Brochado \& Schmitz, 1976.
} 
Prous, de forma implícita, parece referir-se à área de sítios rupestres no Rio Grande do Sul como uma possível fronteira. Estes limites, então, teriam sido usados pelos grupos da Patagônia ou da Pampa com seus grafismos para estabelecer e marcar as suas fronteiras de ocupação.

Entretanto, o oposto também é plausível: os ocupantes ao norte desta área, ao invés dos do sul, poderiam ter sido os autores dos grafismos. Inclusive, a prática, já comentada e discutida, de marcar com grafismos gravados nos troncos das árvores o limite dos territórios de coleta dos grupos locais Kaingang nos pinheirais tem registro etnográfico (Mabilde, 1983), o que amplia teoricamente tal possibilidade.

$\mathrm{Na}$ verdade, a comparação destes grafismos rupestres com os grafismos das sociedades Jê do Sul, principalmente Kaingang, e com aqueles presentes na cerâmica arqueológica das "tradições locais planálticas" indicam que a origem da maioria destes painéis rupestres poderia ser Proto-Jê meridional, vinculando-os a tradições culturais e lingüísticas indígenas do território brasileiro, tradicionais habitantes do Planalto Brasileiro, como sugerem os dados arqueológicos e lingüísticos já referidos.

O próprio Prous refere-se à possibilidade de se pensar nas populações Taquara e Itararé como autoras dos grafismos rupestres da "Tradição" Geométrica, "pois gravuras foram encontradas em galeria subterrânea de Santa Catarina" 54 (Prous, 1989:24), mas mantém sua opinião sobre a origem "fora do atual território brasileiro" para a "Tradição" Meridional.

O denominado "estilo de pegadas animais" ou "estilo de pisadas" de Menghin (1957:66-69), os conhecidos "tridáctilos", constitui-se em exemplo perfeito de deslizes teórico-metodológicos que vêm se repetindo há algumas décadas. Tratam-se de grafismos geométricos e biomorfos gravados em rocha, e muito difundidos em sítios arqueológicos desde a Patagônia, passando pelo noroeste argentino, até o sul do Brasil, e assim descritos por Menghin:

"El repertorio de sus motivos es muy variado (...). Predominan los rastros de animales: de un gran felino (del puma y tal vez también del jaguar), del guanaco y del avestruz; ciertas líneas onduladas pueden considerarse como huellas de serpientes. En lo que se refiere a los rastros de avestruz (...) se trata de signos tripartitos que muchas veces se llaman 'flechas'. Esta interpretación no es improbable en casos determinados (...). Entre los motivos animalistas figuran, además, imágenes

\footnotetext{
${ }^{54}$ Galerias estas vinculadas às populações Proto-Jê meridionais.
} 
esquemáticas de cuadrúpedos (lagartos o pumas) vistas de arriba (...). Com frecuencia aparecen pisadas humanas, más raramente manos. A estos elementos zoomorfos y antropomorfos se associan signos simbólicos de carácter geométrico esquemático com líneas, rayas, cruces, círculos simples, concéntricos, ligados por líneas o rayados ('soles'), rectángulos, escaleras y anchas líneas divisorias; a veces estos elementos se combinan com un garabateo indescifrable" (Menghin, 1957:66 e 68).

Esta descrição de Menghin deixa claro que, além dos "tridáctilos" ("rastros de avestruz", "signos tripartitos") e dos "rastros de animales" ("gran felino"), o estilo comporta outras representações (pés e mãos humanos, lagartos, pumas, grafismos geométricos), as quatro primeiras nunca presentes nos painéis rupestres presentes no atual território sul-rio-grandense. Além disto, como será comentado adiante, o estilo não é encontrado em campos abertos da Argentina, Uruguai e RS, nem na savana do Chaco e da Mesopotamia, reaparecendo na borda do Planalto meridional, no RS, em plena floresta (Brochado \& Schmitz, 1976:136), o que estaria indicando uma origem não-patagônica.

No entanto, Ribeiro (1991 a:104;105;122), pensando em parte do "estilo de pisadas" de Menghin (principalmmente os "tridáctilos" e alguns geométricos), que formalmente ocorre no Rio Grande do Sul, mas também nos demais estados, acredita que todos os sítios com arte parietal do estado citado estejam vinculados à "Tradição" arqueológica Umbu, de caçadores e coletores oriundos do sul do continente. Conforme será detalhadamente analisado mais adiante, os pontos frágeis desta hipótese, de início, parecem ser três: 1. apenas muito parcialmente este "estilo de pisadas" ocorre no RS; 2. isto também acontece em ampla área do atual território brasileiro, inclusive na região Nordeste; 3. uma grande área ao sul e a leste do RS, inclusive sua porção mais meridional, não possui sítios com o "estilo de pisadas", evidenciando uma lacuna da influência patagônica e/ou pampeana.

Quanto à "Tradição" Geométrica, Prous (1989:14) agrupa "provisoriamente" sítios num "conjunto heterogêneo", que se estende "desde o planalto catarinense no sul até o Nordeste", "atravessando os estados do Paraná, São Paulo (onde há poucos sítios conhecidos), de Goiás e Mato Grosso (muito mais ricos)". Prous reconhece, pelo menos, duas subdivisões: uma meridional e central (SC, PR, SP e MT), chamada por Prous (1989:14) de "Subtradição" Morro do Avencal, e outra setentrional (Ceará, Pernambuco e, talvez, Goiás). Quanto a esta última, Guidon denominou-a, conforme Prous (1989:14), de "Subtradição" Itacoatiara. 
Os grafismos rupestres gravados da "Subtradição" Itacoatiara são freqüentemente polidos e predominantemente “...'cupuliformes' (depressões hemisféricas ou em calota de esfera)", "figuras (...) quase exclusivamente geométricas", "temas curvilíneos" (Pedra do Ingá, PB), "tridáctilos" (que em alguns sítios são o tema dominante depois dos cupuliformes) e "raros casos onde aparece uma representação biomorfa" (Prous, 1989:14).

Já os grafismos rupestres gravados, às vezes retocados por pintura, da "Subtradição" Morro do Avencal da "Tradição" Geométrica têm como tema dominante,

“o tridáctilo, triângulos (com incisão ou pontos de tipo 'vulvar') morfologicamente aparentados aos tridáctilos, como mostra a publicação do sítio Coronel Ponce por M. Beltrão (1971). As outras figuras incluem ainda cupuliformes e por vezes figuras curvilíneas. No estado de São Paulo, são particularmente freqüentes as 'pegadas' por vezes alinhadas em rastro, seja de aves, seja de veado, além de pés humanos ou de felinos isoladas. Outras manifestações parecem aparentadas: são incisões divergentes a partir de uma depressão cupuliforme; comuns nos paredões de Serra Azul (São Paulo), onde foram descritas por G. Collet, aparecem também em blocos abatidos do norte mineiro (Januária) e até a Paraíba" (Prous, 1989:14).

A “Tradição" Litorânea Catarinense foi divulgada por Rohr em 1969 (Rohr, 1969). Foi determinada a existência de 14 temas: dois biomorfos (representação humana duvidosa), pouco representados e de caráter geométrico, e 12 tipos puramente geométricos, incluindo tridáctilos (Prous, 1989:13-14).

As ilhas que receberam os grafismos (Ilha de Santa Catarina e ilhas adjacentes), estão espaçadas regularmente de 20 a $25 \mathrm{~km}$, levando Prous (1989:13) a aventurar a hipótese de que cada uma delas corresponderia a um "ponto 'ritual' marítimo de uma etnia continental" (Prous, 1989:13). Desde o final do $1^{\text {o. }}$ milênio d.C. até a chegada dos grupos Guarani (conhecidos historicamente como Carijó), que na época da conquista portuguesa eram os senhores do litoral, a costa catarinense era densamente povoada por populações portadoras da ditas "tradições locais planálticas", Proto-Jê meridionais, historicamente denominadas como Botocudos, Aweikoma ou Xokleng. Além disso, as comparações dos grafismos da chamada "Tradição Litorânea catarinense" com as representações gráficas das sociedades Jê do Sul indicam forte semelhança formal, ambos os conjuntos pertencendo a um 
amplo e homogêneo sistema de representações visuais de expressão Jê meridional, como será mostrado mais adiante.

Diante destas constatações, talvez seria melhor compreender estas ilhas com painéis rupestres como locais rituais marítimos de parcialidades ou grupos locais mais ou menos diferenciados de uma mesma etnia ${ }^{55}$, ligada a um horizonte cultural Proto-Jê do Sul, como a análise de outros elementos materiais arqueológicos (cerâmica, padrão de sepultamento) já indicava (Silva, 1989).

Conforme Prous (1989:14), esta "tradição" de grafismos rupestres de localização circunscrita ao litoral catarinense não pode ser comparada com nenhuma outra conhecida. Entretanto, se compararmos seus grafismos com aqueles presentes em materiais etnográficos preservados em museus e de origem comprovadamente Jê meridional ou se os compararmos com os grafismos da pintura corporal das sociedades Jê do sul, a semelhança é surpreendente.

Os registros pré-históricos de grafismos limitam-se geralmente aos painéis rupestres e à cerâmica. No entanto, as populações que criaram estes registros certamente usavam outros suportes, perecíveis, para representar suas idéias: trançados, tecidos, objetos em geral e, até mesmo, seus próprios corpos. Somente poderíamos visualizar estes grafismos se articulássemos a arqueologia das "tradições locais planálticas" com a etno-história e a etnologia Jê do Sul, numa abordagem etnoarqueológica.

Quanto à "Tradição" Planalto, ela agrupa, conforme Prous

"mais de uma centena de sítios espalhados no Planalto Centro-Brasileiro, desde a fronteira entre Paraná e São Paulo - rios Iapó e Tibagi - até o estado da Bahia, sendo que o foco principal parece estar no centro de Minas Gerais" (Prous, 1989:14).

A maioria dos grafismos é pintada (predomina o vermelho; raramente o preto ou o amarelo; às vezes, o branco). É uma "tradição" figurativa: os zoomorfos monocrômicos aparecem com frequiência muito alta, raramente inferior a dos grafismos geométricos associados, que podem ser "nuvens de

55 “...os petroglifos das diversas ilhas são produto de uma e a mesma cultura ou grupo cultural” - Rohr, 1969:3. 
pontos", bastonetes, "pentes", etc.; antropomorfos também monocrômicos estão presentes em pequena quantidade (Prous, 1989:14;16).

Segundo Prous, futuras pesquisas deveriam trabalhar com a hipótese de que esta "tradição" poderia representar uma transição entre populações ProtoJê estabelecidas mais ao norte para outras de mesma origem e que migraram mais ao sul. Representações figurativas cederiam espaço ao estilo geométrico, e a técnica da pintura teria sido substituída, ou sofreria concorrência, do gravado. Os "trocadilhos gráficos" ${ }^{56}$, de ocorrência freqüente nas "tradições" Nordeste e São Francisco, seriam um indicativo desta transição/transformação do figurativo para o geométrico, ao longo das rotas de migração Proto-Jê rumo ao sul do Brasil.

A hipótese de Prous em vincular a "Tradição" Planalto a populações Proto-Jê é bastante viável, como será visto nos subitens 5.3.4 e 5.3.5. No entanto, é interessante repensar as categorias de arte figurativa e arte abstrata. Geralmente, os arqueólogos que estudam a arte parietal costumam opor uma à outra, como se fossem excludentes entre si, sendo, por este motivo, interpretadas como pertencendo a sociedades diferentes. Na verdade, estas categorias andam juntas, e geralmente correspondem a meios de expressão alternativos de uma mesma sociedade.

“...cada um desses tipos de representação gráfica pode corresponder a um meio de expressão privilegiado para noções relativas à realidade concreta, à dimensão sensível do universo, no primeiro caso (arte figurativa), e para noções abstratas ou representações relativas a conhecimentos esotéricos, preservados de não-iniciados ou estrangeiros, na segunda (arte abstrata)" (Vidal \& Lopes da Silva, 1992:284).

Como exemplo disto, temos os Mbyá-Guarani de hoje que ao lado de pequenas esculturas figurativas zoomorfas em madeira, feitas para ser comercializadas, continuam a reproduzir na sua cestaria tradicional grafismos geométricos relacionados aos domínios da natureza, da sobrenatureza e a conceitos cosmológicos mais abrangentes. Os Proto-Jê do sul, por sua vez, deixavam impressos em sua cerâmica tanto grafismos abstratos (em sua maioria esmagadora) como motivos figurativos (zoo e fitomorfos em cerâmica da "Fase" Casa de Pedra, conforme visto no Capítulo 3). Os Kaingang de Ivay (PR), estudados por Telêmaco Borba (1908), desenhavam em chifres de boi antropomorfos e zoomorfos, em meados do século XIX, conforme desenho abaixo, que reproduzi a mão livre a partir de estampa

\footnotetext{
56 “.... séries de figuras que mostram a transformação de um tema em outro, por exemplo, um sapo em sinal geométrico” (Prous, 1989:18).
} 
constante em Borba (1908:168; figuras 58 e 59). Ao lado destes motivos figurativos, os Kaingang continuam a representar nos seus objetos e corpos grafismos geométricos.

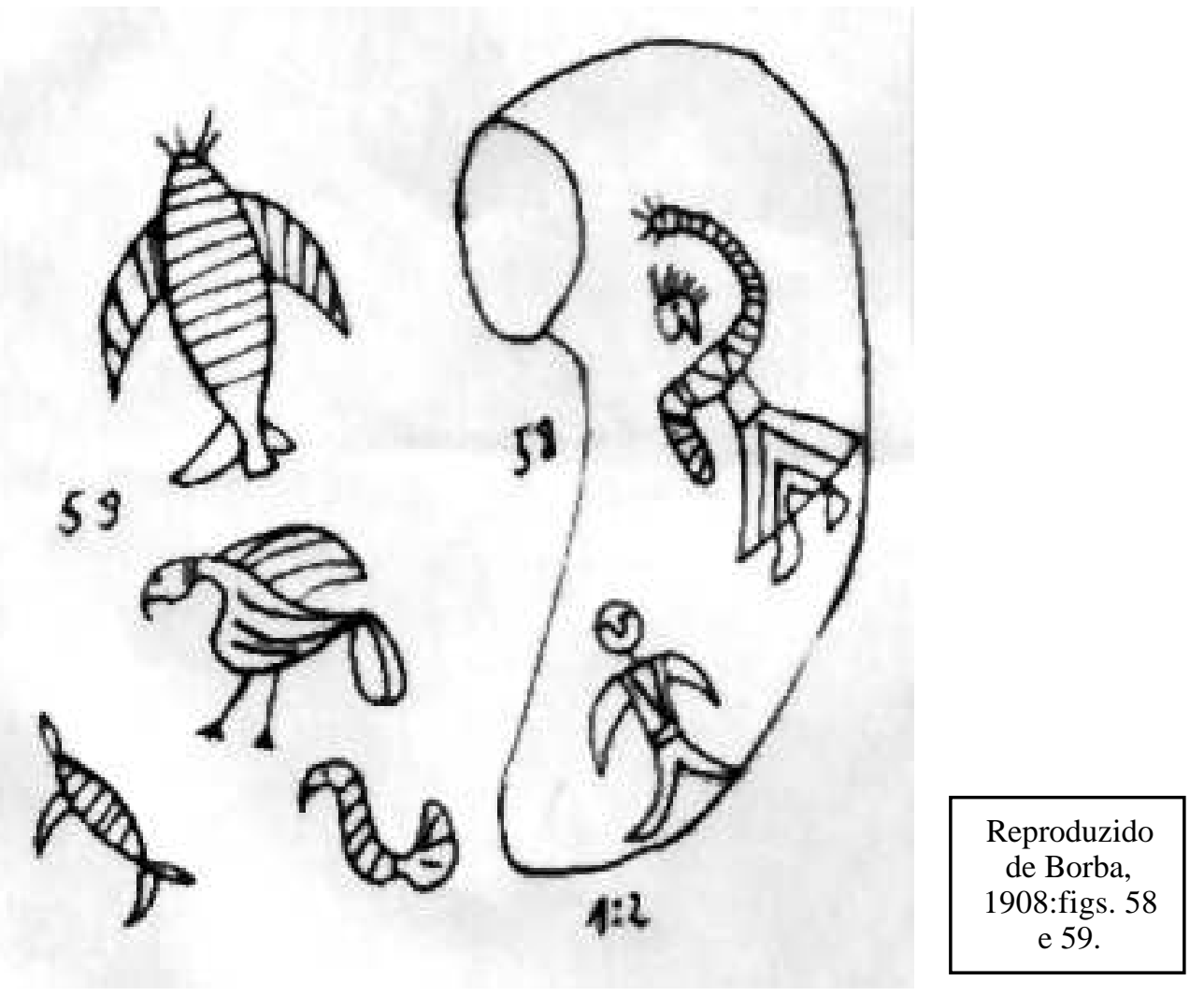

\subsubsection{Grafismos rupestres no Rio Grande do Sul}

Conforme Lima $\left(1998^{57}\right)$, "26 sítios arqueológicos com arte rupestre (...) foram localizados e pesquisados no Estado". Ainda segundo a autora, destes, $40 \%$ foram escavados, $70 \%$ das gravuras foram descritas, e $30 \%$, classificadas.

Este trabalho de 1998 reune a maioria dos dados sobre a arte rupestre no Rio Grande do Sul, incluindo informações sobre escavações, descrições dos grafismos rupestres, e, muitas vezes, reproduzindo desenhos ou fotos constantes das publicações originais dos investigadores dos sítios. Ele constitui-se num verdadeiro "corpus" dos grafismos rupestres rio-grandenses. Neste sentido, utulizei-me dele constantemente como fonte primária.

\footnotetext{
${ }^{57}$ Devido à falta de paginação no exemplar da obra consultada, deixo de indicar o local exato das citações.
} 
Os sítios com grafismos gravados ${ }^{58}$ no arenito ou no basalto localizamse ao norte da planície litorânea (Morro das Pedras - Torres), na encosta do Planalto Sul-brasileiro (Virador, Dona Josefa, Cerro do Baú, Linha Antão, Morro do Sobrado, Linha Araçá, Bom Jardim Velho, Moquém, Macaco Branco, Arroio Grande, Cerro Alegre, Rio Pardo, Mata, 4 abrigos de Montenegro e Abrigo Barreiro) e na região da Campanha (Serra do Caverá, Canhemborá, Linha Sétima, Lajeado dos Dourados, Pedra Grande e Cerro da Panela).

De acordo com a visão de cada arqueólogo consultado, estes grafismos estariam vinculados ou às populações da "Tradição" Umbu, de caçadorescoletores, ou àquelas ligadas à "Tradição" Humaitá. Quanto às origens desta arte rupestre, no entanto, há consenso entre os arqueólogos: elas são buscadas ao sul, na Patagônia argentina, como já comentado. Esta proposição, nunca comprovada e de aceitação generalizada, traz consigo uma desvinculação brusca e profunda da arte parietal sul-rio-grandense com o resto da arte rupestre brasileira. Sua conexão cultural com as populações antecessoras das sociedades indígenas localizadas no atual território brasileiro é negada. Em outras palavras, geralmente, não é levantada a possibilidade de vinculação cultural entre os grafismos rupustres rio-grandenses com as sociedades préhistóricas que habitavam regiões ao norte do atual território do RS.

Na verdade, a questão da autoria dos grafismos rupestres, onde quer que estejam localizados, é complexa e polêmica. No entanto, as opiniões citadas quanto à autoria e às origens da arte parietal no RS têm um embasamento muitas vezes claudicante, pois a contextualização dos grafismos com o material proveniente de camadas escavadas nunca ocorreu de forma satisfatória. A simples evidência de artefatos ligados a qualquer "tradição" arqueológica em cortes estratigráficos realizados nas proximidades dos grafismos não elucida o problema: os autores da arte parietal poderiam não ter habitado o local, tendo-o usado para outras finalidades, sem deixar vestígios arqueológicos outros, além das representações gráficas.

A seguinte citação, faz pensar exatamente desta forma:

\footnotetext{
${ }^{58}$ Por picoteamento, raspagem, polimento e/ou rotação.
} 
“...em onze locais com arte nos quais foram praticados cortes experimentais ou escavações, o material encontrado foi da Tradição Umbu em nove, da Humaitá em quatro, da Taquara em três e da Tupiguarani em quatro.” (Ribeiro, 1991:122) ) $^{59}$.

Além disso, as poucas datações radiocarbônicas para os sítios com arte parietal no RS não esclarecem as questões ligadas à sua origem ou autoria. Em primeiro lugar, porque apenas $20 \%$ dos sítios tem datação ${ }^{60}$. Segundo, porque a datação das camadas estratigráficas ocupadas não se refere, necessariamente, aos grafismos, i. é, tais datações não representam as épocas em que os grafismos foram confeccionados. Apenas registram a cronologia de alguns momentos específicos das estratigrafias dos sítios habitacionais existentes junto a eles. Em terceiro lugar, porque muitos sítios datados foram reocupados em tempos bastante distantes.

Bom Jardim Velho, por exemplo, na camada $43-45 \mathrm{~cm}$, foi datado em 3.705 a.C. (SI-1199). No entanto, camadas superficiais $(7-10 \mathrm{~cm})$ foram datadas de 1205 d.C. (SI-1198). O grande lapso temporal entre as datas não dá indicações seguras quanto a uma possível dedução de autoria baseada nas informações referentes à época e ao local da ocupação.

A mesma situação ocorre com Pedra Grande, com três datas recentes para camadas até $70 \mathrm{~cm}$ de profundidade (1633 d.C., 1305 d.C., 1190 d.C.) e com uma data mais antiga (1075 a.C.) para a camada de 70-80 cm.

Este também é o caso de Canhemborá (765-855 d.C. e 1245-1135 a.C.).

Neste contexto, as datas referentes exclusivamente ao segundo milênio d.C. de Virador I (1320 d.C.) e Linha Sétima (965-1155 d.C.), sozinhas, nada indicam. Junto com outras datas que apontassem exclusivamente o $2^{\circ}$. milênio d.C. poderiam induzir a pensarmos em populações horticultoras, o que fica inviabilizado pela existência, tão-somente, de apenas duas datas nestas condições. É bem verdade, entretanto, que todos os outros sítios, apesar de possuírem, também, ocupações mais antigas, de épocas anteriores ao ano

\footnotetext{
${ }^{59}$ Alguns sítios, como se percebe na citação acima, foram ocupados mais de uma vez, em tempos diversos, por populações vinculadas a "tradições" diferentes, o que torna ainda mais complexa a tarefa de identificar os autores de grafismos rupestres. Lembramos que o autor desta citação acredita que todos os grafismos rupestres no RS estejam vinculados às populações ligadas à "Tradição" arqueológica Umbu.

${ }^{60}$ Apenas cinco sítios com grafismos rupestres no Rio Grande do Sul possuem datação absoluta: três na área mais meridional, a sudoeste (Pedra Grande, Linha Sétima e Canhemborá), e dois na borda do planalto (Virador I e Bom Jardim Velho).
} 
zero (A.D.), revelam, também, datações que apontam para populações que viveram ao longo do $2^{\circ}$. milênio d.C., informação que não pode ser negligenciada.

As datações radiocarbônicas (cf. Brochado \& Schmitz, 1976:121;133)

\begin{tabular}{cccc} 
Pedra Grande & $\begin{array}{c}\text { superfície } \\
30-40 \mathrm{~cm}\end{array}$ & $\begin{array}{l}\text { A.D. 1633-1637 } \\
\text { A.D. 1305-1385 }\end{array}$ & \multicolumn{1}{c}{ método histórico } \\
& correção MASCA: 1002)
\end{tabular}

$\begin{array}{lclc}\text { Linha Sétima } & 30-40 \mathrm{~cm} & \begin{array}{l}\text { A.D. 950-1140 } \\ \text { correção MASCA: 965-1155 }\end{array} & \text { (SI-1196) } \\ \text { Canhemborá } & 40-50 \mathrm{~cm} & \begin{array}{l}\text { A.D. 750-820 } \\ \text { correção MASCA: 765-855 }\end{array} & \text { (SI-1000) } \\ & 60-70 \mathrm{~cm} & \begin{array}{c}1.080-910 \text { a.C. } \\ \text { correção MASCA: 1.345-1135 a.C. }\end{array}\end{array}$

Virador I $\quad 50-60 \mathrm{~cm} \quad 630 \pm 205$ a.P. (A.D.1115-1525) (SI1201)

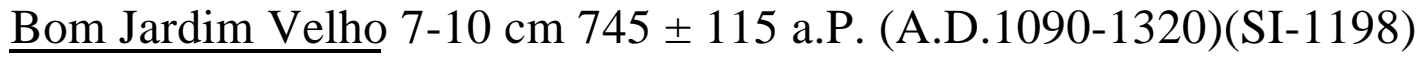

$$
\text { 43-45 cm 5.655 } \pm 140 \text { a.P. (3.705 a.C.) (SI-1199) }
$$

Em resumo, apesar da falta de contextualização cultural dos grafismos rupestres e da incerteza da sua associação com artefatos característicos de uma "tradição" arqueológica específica, costuma-se mencionar na literatura uma ligação formal dos grafismos sul-rio-grandenses com a arte parietal dos caçadores-coletores da Patagônia, sem ter sido empreendida a demonstração de tal ligação.

Para exemplificar esta afirmativa, a seguir serão mais detalhadamente discutidos alguns sítios com arte rupestre no Rio Grande do Sul. Pretendo, também, comparar seus grafismos com aqueles presentes nos sítios de Santa Catarina, Paraná e São Paulo. Ademais, tenho como objetivo mostrar as semelhanças formais existentes entre muitos destes grafismos rupestres tanto com as representações gráficas dos Coroados-Kaingang, comentadas por Mabilde ([1833-1866] 1983), como com os grafismos Kaingang históricos, 
presentes em vários suportes, que foram detalhadamente analisados no item 5.1. Quando for o caso, os grafismos rupestres serão identificados pelos nomes que os Kaingang hoje os denominam. Todas estas situações indicam uma estreita vinculação dos grafismos rupestres no Rio Grande do Sul com o norte e com as sociedades Jê meridionais. Ademais, pequenos detalhes ligados à estratigrafia de alguns sítios ou à especificidade de alguns materiais arqueológicos, usados como "gravadores", muitas vezes não percebidos ou praticamente esquecidos ao longo dos últimos trinta anos, já indicavam na direção das "tradições locais planálticas" como autores sociais de muitos grafismos rupestres do sul do Brasil.

Meus passos seguintes serão, portanto, uma tentativa de relativizar a certeza quanto à origem desta arte (relacionada à Patagônia e à Pampa), por um lado, e de diluir, por outro, as possibilidades da autoria dos grafismos rupestres rio-grandenses entre várias populações pré-históricas, incluindo também as populações Proto-Jê meridionais.

Minha metodologia é unicamente comparativa. A partir dos atuais "corpora" de grafismos Kaingang e Guarani, anteriormente estabelecidos, comparei formalmente estes com as representações gráficas rupestres encontradas no RS. A semelhança formal entre padrões gráficos, isoladamente, não é um critério seguro para estabelecer relações de proximidade cultural entre dois fenômenos, sejam eles quais forem (sítios arqueológicos, painéis rupestres, sociedades indígenas, etc.), uma vez que grafismos formalmente semelhantes, ou mesmo iguais, podem ter significados totalmente diferentes em contextos culturais diversos, conforme já foi exaustivamente comentado. No entanto, devido ao atual estado da ciência arqueológica, segundo o qual a contextualização dos grafismos rupestres ainda não é possível, somente resta este caminho metodológico. Os ganhos de tal tentativa, no mínimo, servirão para contribuir para o avanço (ou início?) da discussão teórico-metodológica sobre o tema, apesar dos riscos.

Conforme será comprovado a seguir através da visualização dos grafismos rupestres e sua comparação com grafismos da cerâmica Proto-Jê e presentes na cultura Kaingang e Xokleng, os resultados obtidos foram os seguintes:

a. a semelhança formal de uma grande quantidade de grafismos rupestres do RS com grafismos que ocorrem em sítios de SC, PR e SP indica uma proximidade da arte parietal rio-grandense com o norte, mostrando seus 
vínculos culturais, também, com populações pré-históricas originárias do atual território brasileiro;

b. muitos grafismos rupestres do RS são formalmente iguais a representações gráficas Kaingang, conforme o corpus levantado nesta tese, ou aos grafismos publicados por Mabilde ([1833-1866] 1983:146-7), ou, ainda, com grafismos presentes na cerâmica Proto-Jê do sul, o que nos possibilita afirmar que talvez tenham sido confeccionados por populações Proto-Jê meridionais;

c. formalmente, alguns grafismos da arte parietal rio-grandense são semelhantes a grafismos Mbyá-Guarani atuais ou Proto-Guarani, de acordo com o corpus levantado e analisado no subitem 5.2. Esta constatação permite levantar a hipótese de que alguns grafismos rupestres do RS sejam de autoria de populações Proto-Guarani.

d. por não possuírem caracerísticas que permitam uma comparação formal nem com os grafismos (Proto)Jê do sul nem com os (Proto)Guarani, alguns grafismos devem estar relacionados a tradição(ões) cultural(is) cujo(s) corpus(ora) gráfico(s) deve(m) ainda ser levantado(s) e estudado(s), talvez relacionado(s) aos Proto-Pampeanos (Charrua/Minuano) ou a grupos patagônicos. Seria o caso dos sítios mais a oeste (Canhemborá, Pedra Grande, etc.).

A própria localização geográfica dos sítios com arte rupestre no RS parece delinear esta situação ${ }^{61}$ :

a. a escarpa do Planalto Sul-brasileiro, que acompanha a Depressão Central, por sua vez cortada por vales e rios, parece ser a fronteira sul de um território Proto-Jê meridional, simbolicamente marcada pela arte parietal, em oposição aos grupos populacionais do sul. Este território aparece, a partir dos inícios da era cristã, como palco de disputas e/ou incorporações, com o surgimento em cena dos migrantes/colonizadores Proto-Guarani. Tem-se neste espaço geográfico sítios com grafismos Proto-Jê e Proto-Guarani, às vezes no mesmo sítio, o que pode significar incorporações ou ocupações em épocas diferentes;

\footnotetext{
${ }^{61}$ É bem verdade que este quadro é muito simplificado, e, por certo, não representa toda a realidade dos sítios com arte parietal em território sul-rio-grandense. Sua complexificação ocorrerá apenas com o avanço dos estudos sobre grafismos rupestres.
} 
b. os campos da Pampa, com sítios com representações gráficas formalmente estranhas tanto à tradição cultural Proto-Jê do sul como à ProtoGuarani, de entendimento ainda muito hipotético e incipiente;

c. o litoral norte, de compreensão aparentemente mais difícil.

Vejamos, portanto, os sítios no RS com grafismos rupestres.

1. Virador I, II e III (RS-C-12).

O sítio arqueológico é constituído por três abrigos sob-rocha no Município de São Sebastião do Caí, localizados na encosta do planalto, a menos de 100 m a.n.m., em uma área de transição entre o planalto e os campos $^{62}$ e apresentando dois tipos de vegetação, aliás, característicos destes dois ambientes: floresta tropical e campos (Ribeiro, 1969/70:115-16).

Os grafismos foram confeccionados por picoteamento (técnica mais freqüente) ou por alisamento (op. cit., pág. 118).

No Virador I e II, há dois níveis de ocupação: um mais antigo, précerâmico, com poucas evidências ("lascas, facas, ossos de animais, coquinhos, conchas, ossos humanos, fogões, etc."), e outro mais recente, com cerâmica de "Tradição" Taquara, além de lítico (lascado, polido), pontas ósseas, ossos animais e sepultamentos. No Virador I, o nível mais recente apresenta cerâmica da "Fase" Taquara, desde a superfície até aos $76 \mathrm{~cm}$ de profundidade, demonstrando uma ocupação continuada no tempo. No Virador II, o nível mais recente, com as mesmas características do mesmo nível do Virador I, apresenta pouca cerâmica Taquara. No Virador III, a camada arqueológica apresentou raros vestígios de ocupação, sem a presença de cerâmica (Ribeiro, 1969/70:129).

Por indicar a camada ocupacional dos autores dos grafismos rupestres, fato importante foi constatado durante a escavação: "no nível II [cerâmico], [foi encontrada] uma lasca que, pelo desgaste de seus bordos, poderia ter sido utilizada para realizar os petróglifos" (Ribeiro, 1969/70:129), o que leva o autor a creditar às populações ligadas à "Fase" Taquara a autoria parcial dos grafismos. No entanto, em seus trabalhos posteriores (inclusive sobre o Virador - Ribeiro, 1975), como já foi indicado, o autor opta por vincular

\footnotetext{
${ }^{62}$ Regiões ocupadas por populações culturalmente distintas, como já se viu.
} 
toda a arte rupestre no Rio Grande do Sul aos grupos vinculados à "Tradição" Umbu, de caçadores-colectores.

Brochado \& Schmitz (1976:133) referem que os petroglifos do Virador I apresentam motivos e dimensões diferentes do estilo de pisadas por eles classificados como "estilo B", situado na faixa temporal ca. A.D. 1100-1500.

Os mesmos autores, com clarividência, apontam para "um interessante problema até agora não solucionado" (Brochado \& Schmitz, 1976:133), ao darem-se conta que o material arqueológico presente no Virador I e no Bom Jardim Velho, ao invés de pertencerem à fase Rio Pardinho, pré-cerâmica e da "Tradição" Umbu, ligada a caçadores-colectores patagônicos, pertencia à "Tradição" ceramista Taquara.

Os padrões dos grafismos presentes no Abrigo Virador são muito semelhantes aos registrados por Rohr para o litoral catarinense (Rohr, 1969), alguns sendo iguais. Entre estes últimos estão os losangos superpostos linear e verticalmente, bem como as linhas concêntricas em ziguezague.

Igualmente, no Virador e no Morro do Sobrado, seis grafismos são idênticos às marcas Kaingang apresentadas em número de treze por Mabilde ([1833-1866]1983).

Abrigo Virador

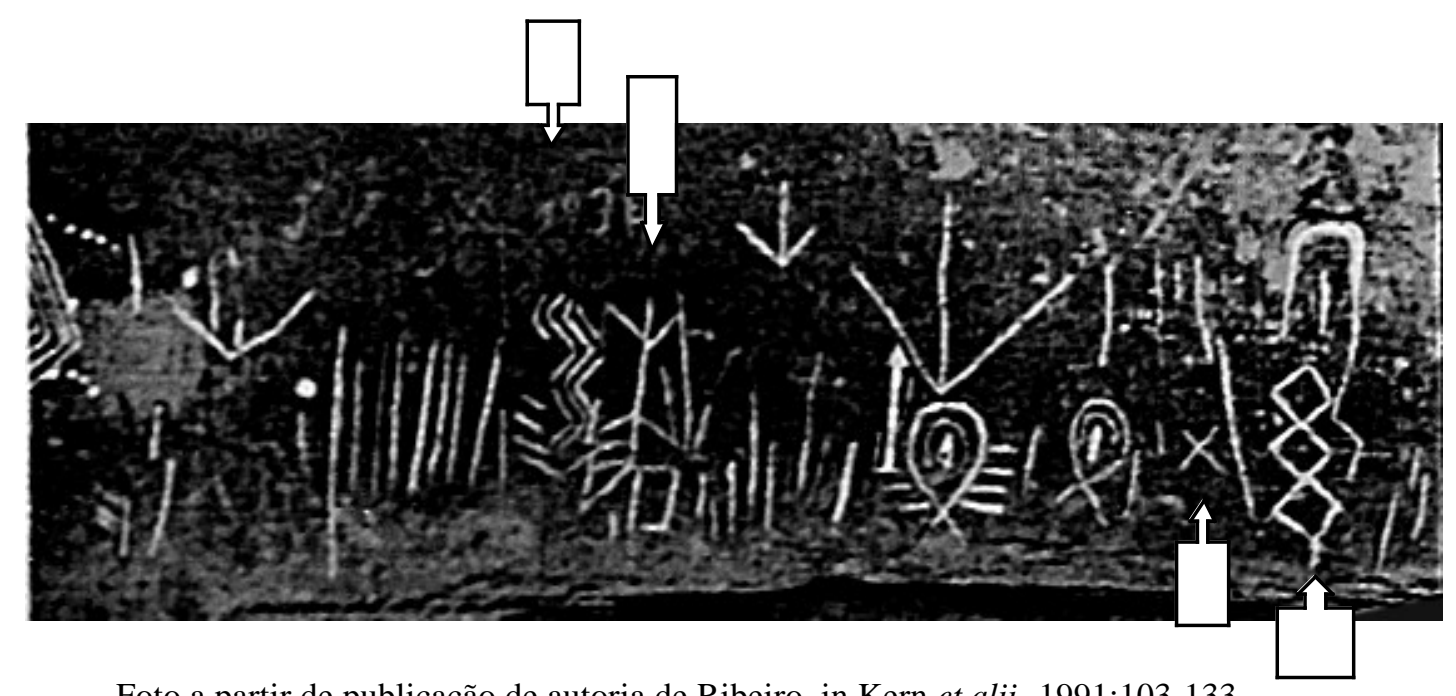

Foto a partir de publicação de autoria de Ribeiro, in Kern et alii, 1991:103-133.

Os grafismos indicados com uma seta larga foram reconhecidos pelos interlocutores Kaingang, da esquerda para a direita, como: ra ionior, ven katu 
wendig, véin kõpó e ra iãnhiá. O segundo citado foi apresentado por Mabilde ([1833-1866] 1983) como sendo característico do grupo do cacique Nhancuiá (de meados do século XIX), e o primeiro, terceiro e quarto grafismos são a primeira, quarta e segunda marcas das dez primeiras de Mabilde ([1833-1866] 1983). Além disso, o grafismo indicado pela primeira seta é característico da cerâmica Proto-Jê do sul.

Formalmente idêntico ao grafismo do Virador assinalado pela segunda seta apresenta-se a representação rupestre de abrigo estudado por Laming \& Emperaire (1968), localizado "no interior do Paraná , perto da fronteira deste Estado e o de São Paulo, no limite dos municípios de Piraí do Sul e de Tibagi” (op. cit., pág. 82), que reproduzimos abaixo.

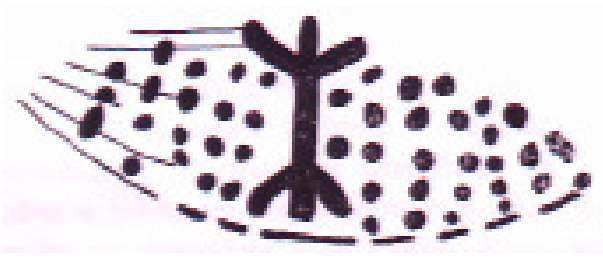

Conforme Laming \& Emperaire (1968).
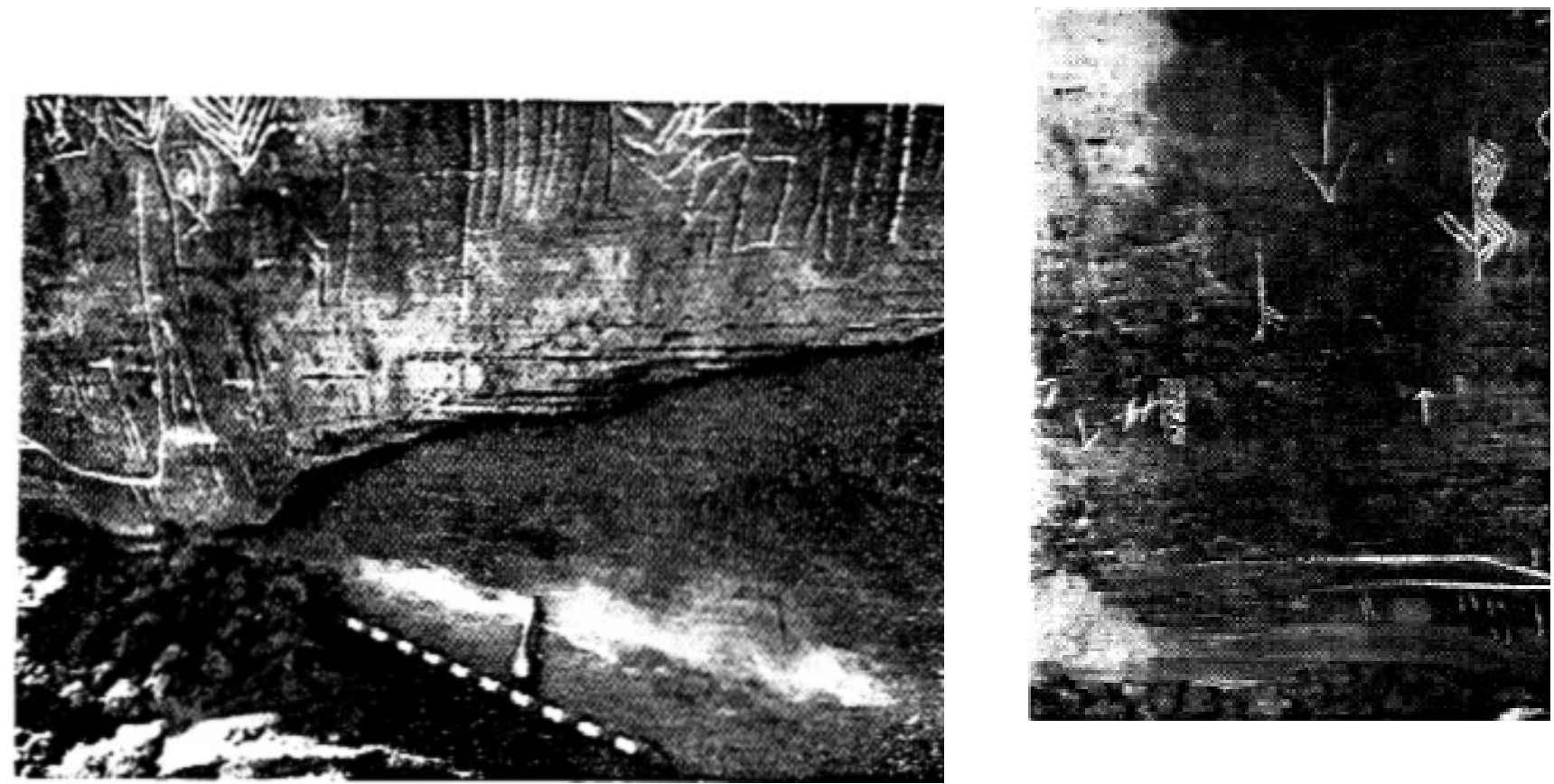

Grafismos do Abrigo Virador. Fotos reproduzidas de Ribeiro, 1969/70:figs.7 e 5. Na primeira, note-se, no canto superior direito, o grafismo número 5 de Mabilde. Na segunda, têm-se à direita, em cima, linhas paralelas em ziguezague, grafismo presente tanto na cerâmica Proto-Jê como na cultura material Kaingang. No centro, à esquerda, note-se o grafismo número 7 de Mabilde, também presente em flechas Kaingang do RS. 

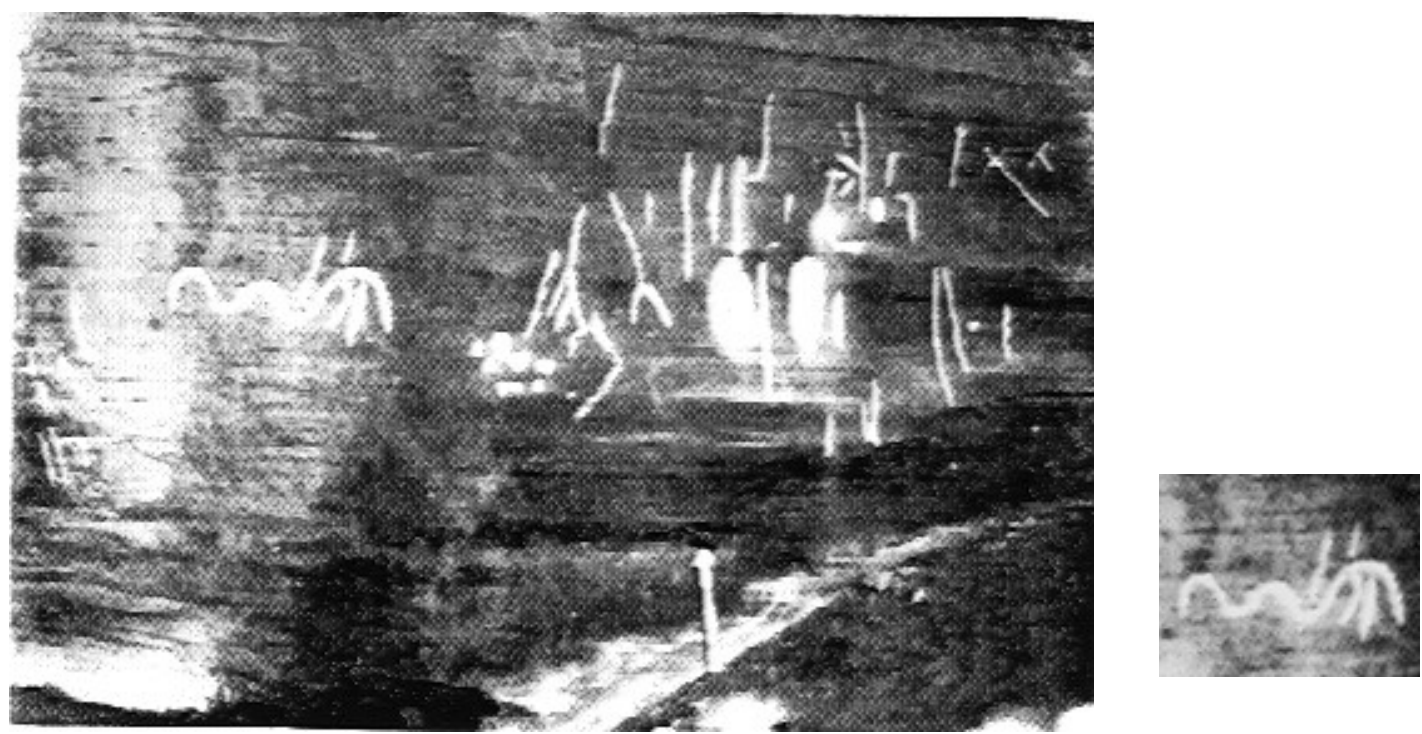

Grafismos do Abrigo Virador. Foto reproduzida de Ribeiro, 1969/70:fig.10. Ao lado direito, detalhe da mesma foto, onde pode ser notado o grafismo de número 1 , apresentado por Mabilde, e designado de ra ionior pelos Kaingang. Na foto maior, à direita, no centro, percebe-se o grafismo número 6 de Mabilde.

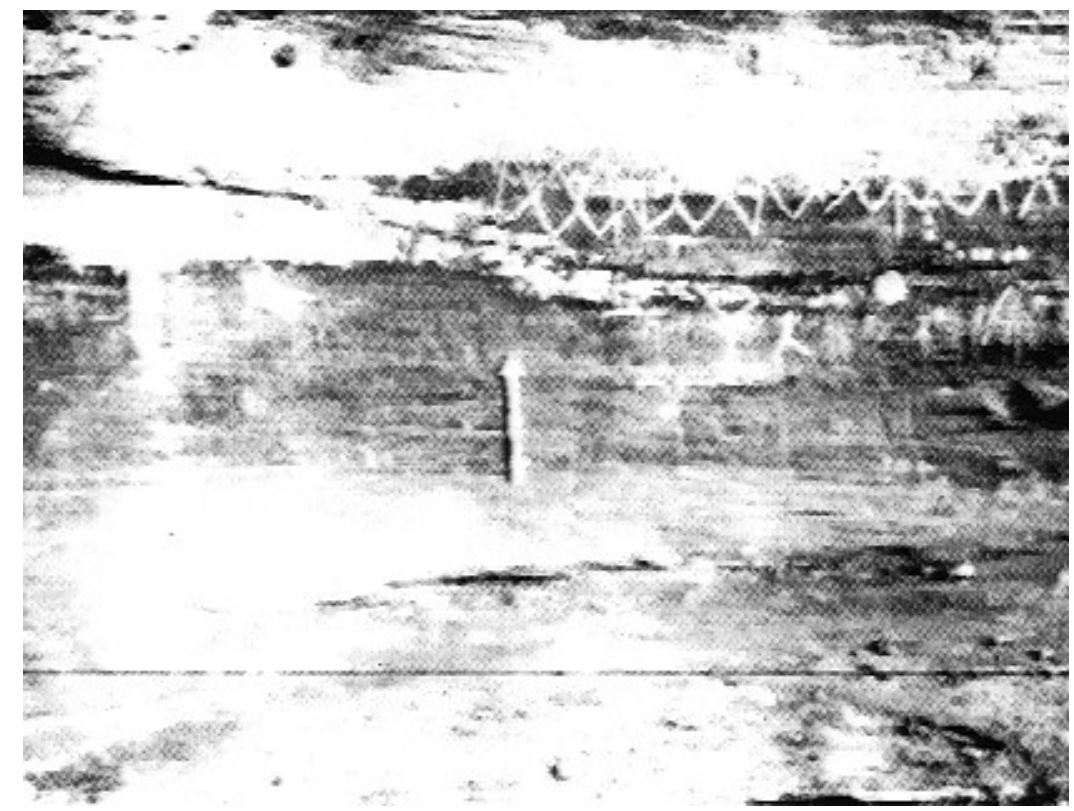

Grafismos do Virador. Foto reproduzida de Ribeiro, 1969/70:fig.13, onde se percebe o grafismo número 2 de Mabilde . 


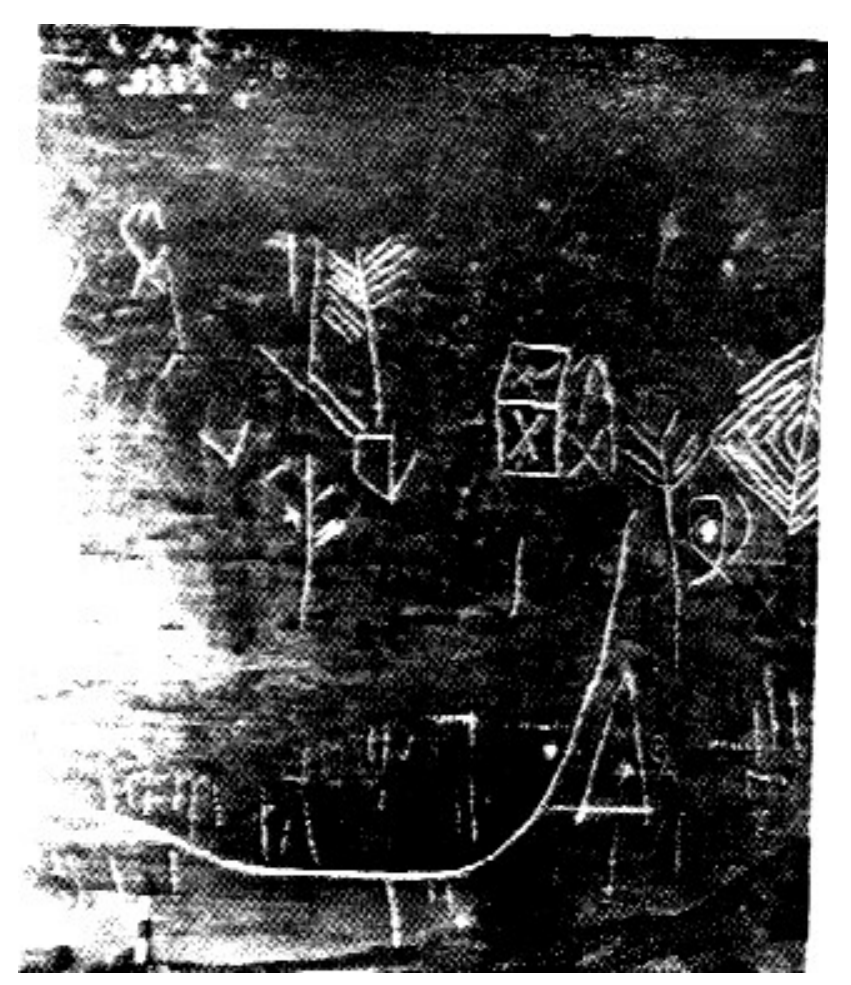

Grafismos do Virador. Foto reproduzida de Ribeiro, 1969/70:fig.6. Notam-se, neste detalhe de painel, as representações gráficas de números 4, 6 e 8, de Mabilde. Ademais, vejam-se os grafismos fitomorfos semelhante à segunda representação gráfica apresentada por Mabilde, relacionada ao cacique Coroado Nhancuiá. O grafismo triangular com ponto central, além de fazer a conexão com os sítios rupestres de Santa Catarina (ligados ao horizonte cultural Proto-Jê do sul), nos remete à pintura corporal dos Kaingang atuais do RS.

\section{Dona Josefa.}

O sítio arqueológico constitui-se de cinco blocos sobrepostos de arenito e parcialmente arenito metamorfizado, localizados em 1967, no Município de Vera Cruz, por membros do Museu do Colégio Mauá de Santa Cruz do Sul. Foram estudados por Ribeiro e outros (1973). 
Ribeiro (op.cit.) descreve os grafismos assim: "tridáctilos"; sulcos paralelos, alguns cortados por outro; linha em ziguezague; "letras" V; linhas isoladas; triângulos com linha interna ligando a base ao vétice; e possível figura humana estilizada. As semelhanças formais com os grafismos apresentados por Mabilde são evidentes, especialmente com relação àqueles por ele designados pelos números 1, 6, e 8. Os grafismos ditos "triângulos com linha no seu interior" são elementos importantes, uma vez que conectam a arte rupestre de Santa Catarina, inclusive a que ocorre em casas e galerias subterrâneas, de inconteste contexto cultural Proto-Jê, com representações rupestres do RS. Além disso, como já se viu, estas representações triangulares estão presentes na pintura corporal e em materiais etnográficos Kaingang.

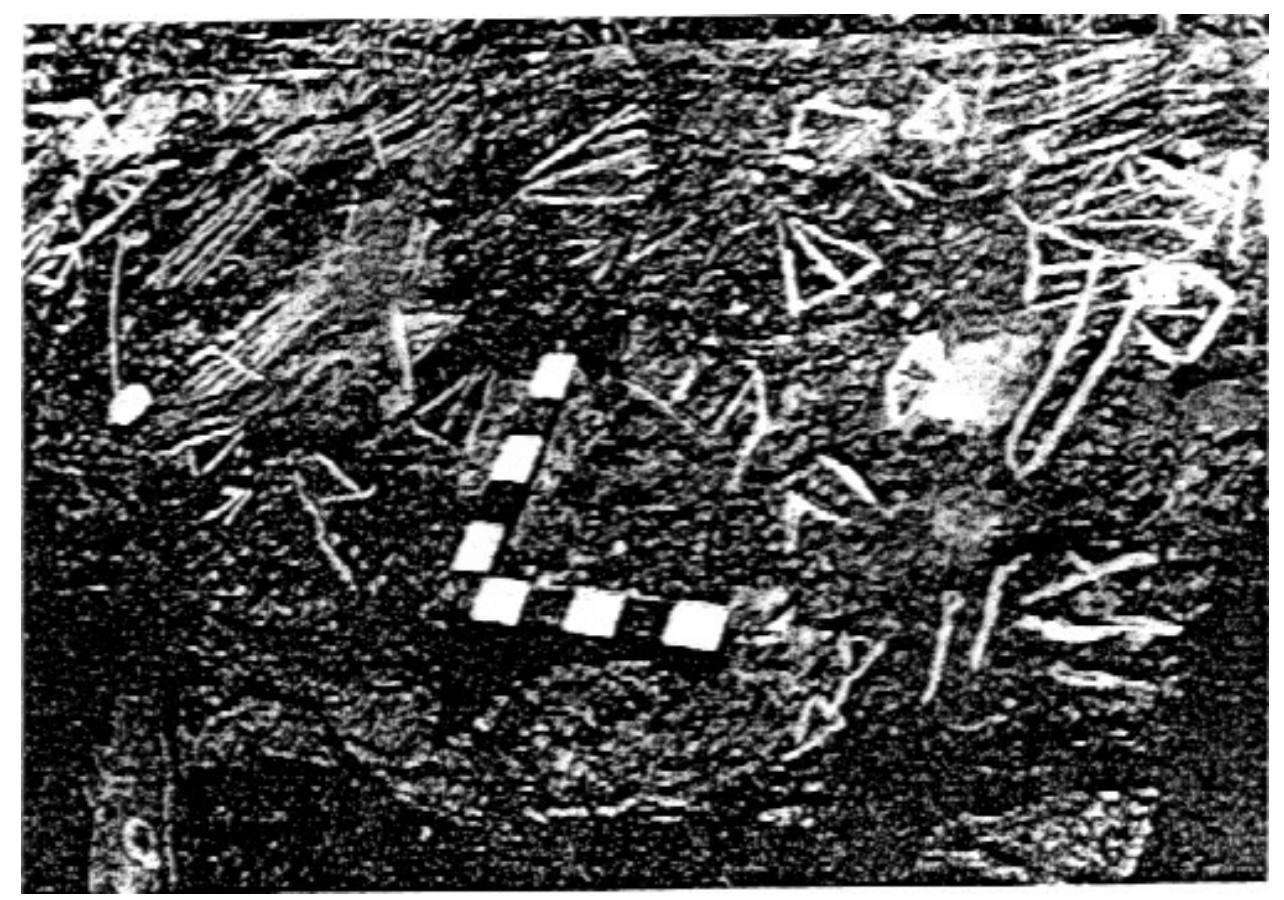

Sítio Dona Josefa. Foto reproduzida de Lima, 1998:fig.15. Notem-se os grafismos rupestres em forma de triângulo, com linha interna unindo a base ao vértice. Estas representações gráficas são recorrentes em sítios de SC, incluindo casa e galeria subterrâneas, além de estar presente na pintura corporal e em material etnográfico Kaingang.

\section{Cerro do Baú.}

Três blocos de arenito na encosta do Cerro do Baú, Município de Venâncio Aires, localizados em 1968 e 1971 por membros do Museu do Colégio Mauá. Ribeiro e outros (1973) estudou o sítio. 
Os grafismos geométricos descritos são: linhas isoladas; linhas paralelas, cortadas ou não por outra; depressão polida; série de pontos (op.cit.), manifestando representações gráficas abertas e fechadas.

Além disso, trata-se de local importante para a arqueologia do sul do Brasil, pois em um dos blocos foi gravado um pequeno zoomorfo estilizado e de tamanho reduzido (7,5 $\mathrm{cm}$ de comprimento por $4 \mathrm{~cm}$ de altura). Conforme já discutido, a possibilidade de motivos figurativos no horizonte Proto-Jê meridional é bastante admissível. Ademais, como se verá, os exemplos de grafismos figurativos ocorreram em outros sítios.

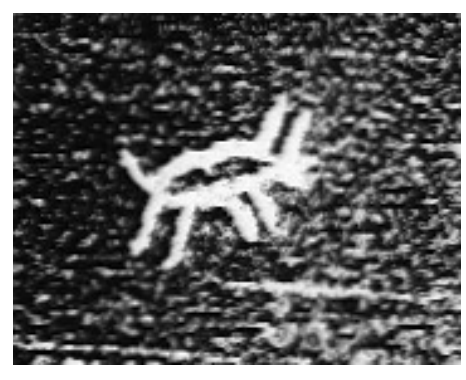

Rreproduzido de Lima, 1998:foto 7.

4. Linha Antão.

Bloco de arenito localizado no Município de Santa Cruz do Sul em 1969.

Ribeiro descreve os grafismos como sete depressões, uma isolada e seis dispostas linearmente (Ribeiro e outros, 1973).

\section{Morro do Sobrado (RS TQ 14).}

Bloco de arenito localizado por Ribeiro (1972 a) dentro da floresta latifoliada tropical na encosta de um morro arredondado (100 m a.n.m.) no Município de Montenegro, a aproximadamente $30 \mathrm{~km}$ em linha reta do Abrigo Virador. Não há material arqueológico associado aos grafismos, nem houve escavação no local.

Quanto à sua localização, o Morro do Sobrado "pertence aos primeiros degraus da zona serrana", estando, em relação à sua vegetação, também em uma zona de transição: "mata latifoliada tropical e as primeiras 'manchas' de campos. O primeiro tipo de vegetação domina em direção norte e o segundo, para o sul" (Ribeiro, 1972 a:4-5). Estas características geográficas e de vegetação são típicas dos sítios com grafismos rupestres da encosta do Planalto Sul-brasileiro: trata-se de uma zona de transição de paisagens e 
fronteira natural entre os grupos mais ao sul, que têm o campo como habitat, e as populações do norte, que têm o planalto como território principal de ocupação.

Numa reflexão circular e frágil, o autor assim argumenta a atribuição da autoria dos grafismos aos caçadores da "Tradição" Umbu:

"Como já estudamos um grupo de petróglifos com as mesmas características e os atribuímos a uma tradição de caçadores cujo centro de dispersão teria sido o norte da Patagônia, Argentina, as do Morro do Sobrado, conseqüentemente, teriam ali também a sua origem". Ribeiro, 1972 a:7.

Morro do Sobrado

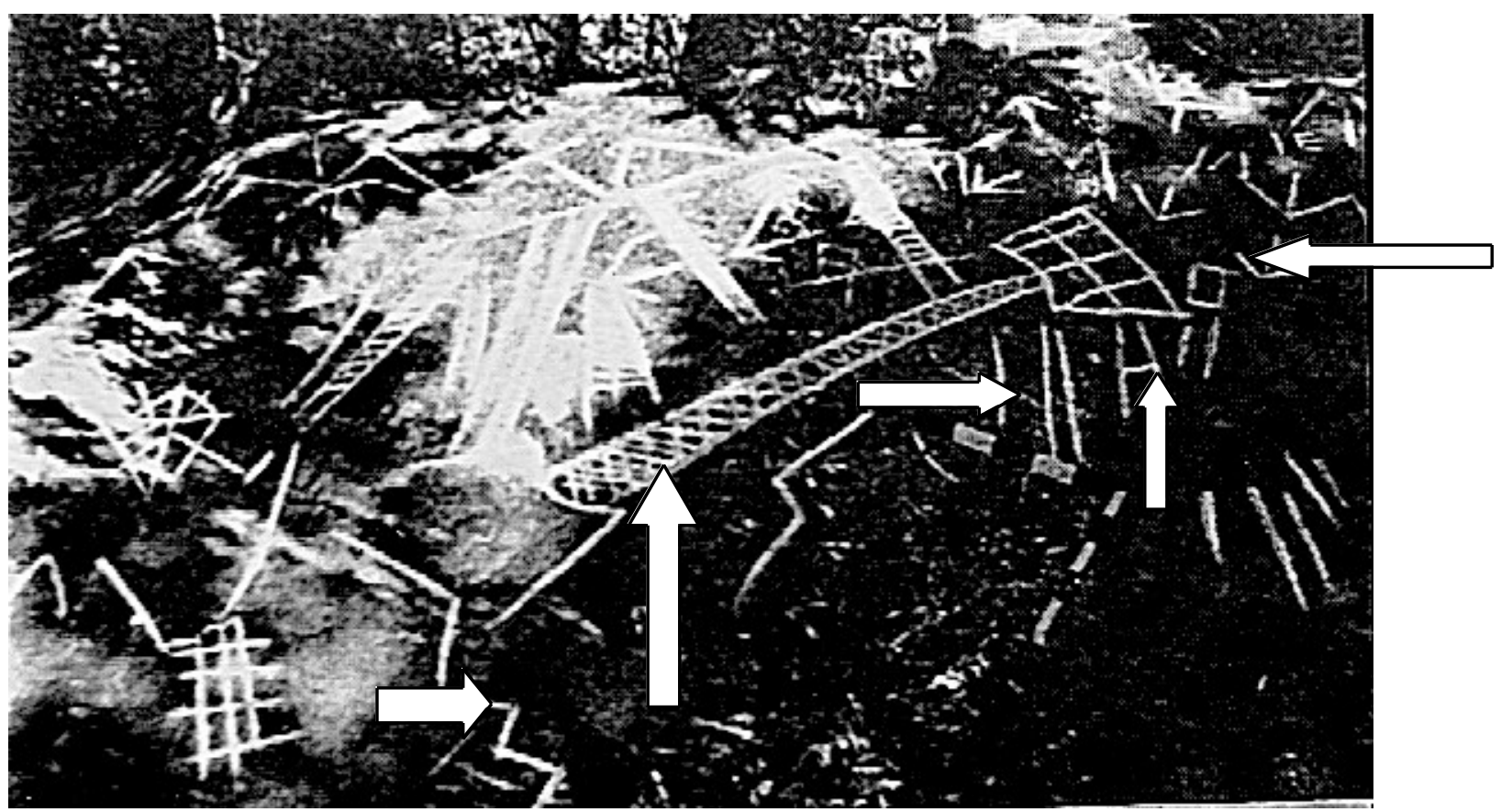

Foto a partir de publicação de Ribeiro, 1991:103-133.

Os grafismos indicados com uma seta larga foram reconhecidos e nominados pelos interlocutores Kaingang, da esquerda para a direita, como: ra ionior, ra ror ê, ra téi réngrë, véin kénky e ra rangrênhiá. O primeiro, terceiro, quarto e quinto grafismos citados correspondem, respectivamente, às 
primeira, sexta, sétima e quinta marcas das dez primeiras apresentadas por Mabilde (1983).

Como se vem demonstrando, as semelhanças formais entre os grafismos rupestres do Rio Grande do Sul e dos Kaingang de meados do século XIX são marcantes, tanto no que diz respeito à temática como em relação ao estilo das representações, e, também, por apresentarem-se conjuntamente. O mesmo pode-se dizer quanto aos grafismos apresentados por Mabilde e os grafismos rupestres do Rio Grande do Sul e Santa Catarina.

No Morro do Sobrado, por exemplo, (Ribeiro, 1972), há uma faixa horizontal formada por losangos, linha em ziguezague, quadrados, formando "grade", quadriláteros, formando "escada", agregados de triângulos, que não se adeqüam às representações gráficas características do chamado estilo de pisadas, mas, sim, aos grafismos catarinenses copiados e estudados por Rohr, especialmente os do litoral catarinense.

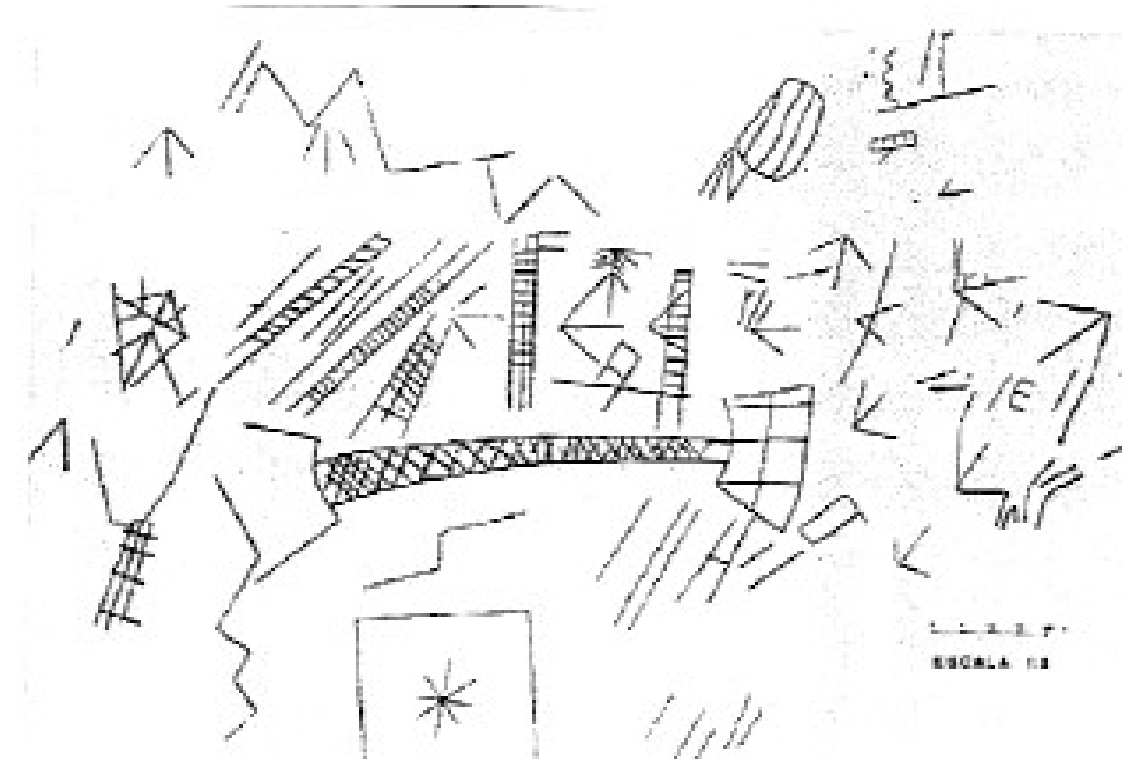

Desenho do painel dos grafismos do Morro do Sobrado. Reproduzido de Lima, 1998:foto 3.

6. Cerro dos Bois.

O sítio apresenta um bloco de arenito localizado no Município de Venâncio Aires, em 1970, em uma mata virgem numa encosta de morro. Nas 
proximidades foram encontrados dois zoolitos (Ribeiro et alii, 1973). Os autores descrevem os grafismos como "tridáctilos", linhas isoladas e linha com três outras linhas oblíquas, paralelas entre si, ligadas à primeira.

\section{Linha Araçá I e II.}

Os sítios estão localizados em um vale em forma de "V" no Município de Santa Cruz do Sul. O primeiro é um bloco dentro de uma sanga tributária do Arroio Castelhano, afluente do Rio Taquari. O segundo é um paredão na mata virgem. Segundo Ribeiro et alii (1973), pode-se descrever os grafismos da seguinte maneira: linhas isoladas; conjuntos de linhas paralelas; conjuntos de linhas paralelas que interceptam outro conjunto de linhas paralelas, formando conjunto de quadriláteros ou losangos. Estes últimos grafismos são recorrentes na cerâmica do horizonte cultural Proto-Jê do sul e na pintura corporal Kaingang (ra ianhiá).

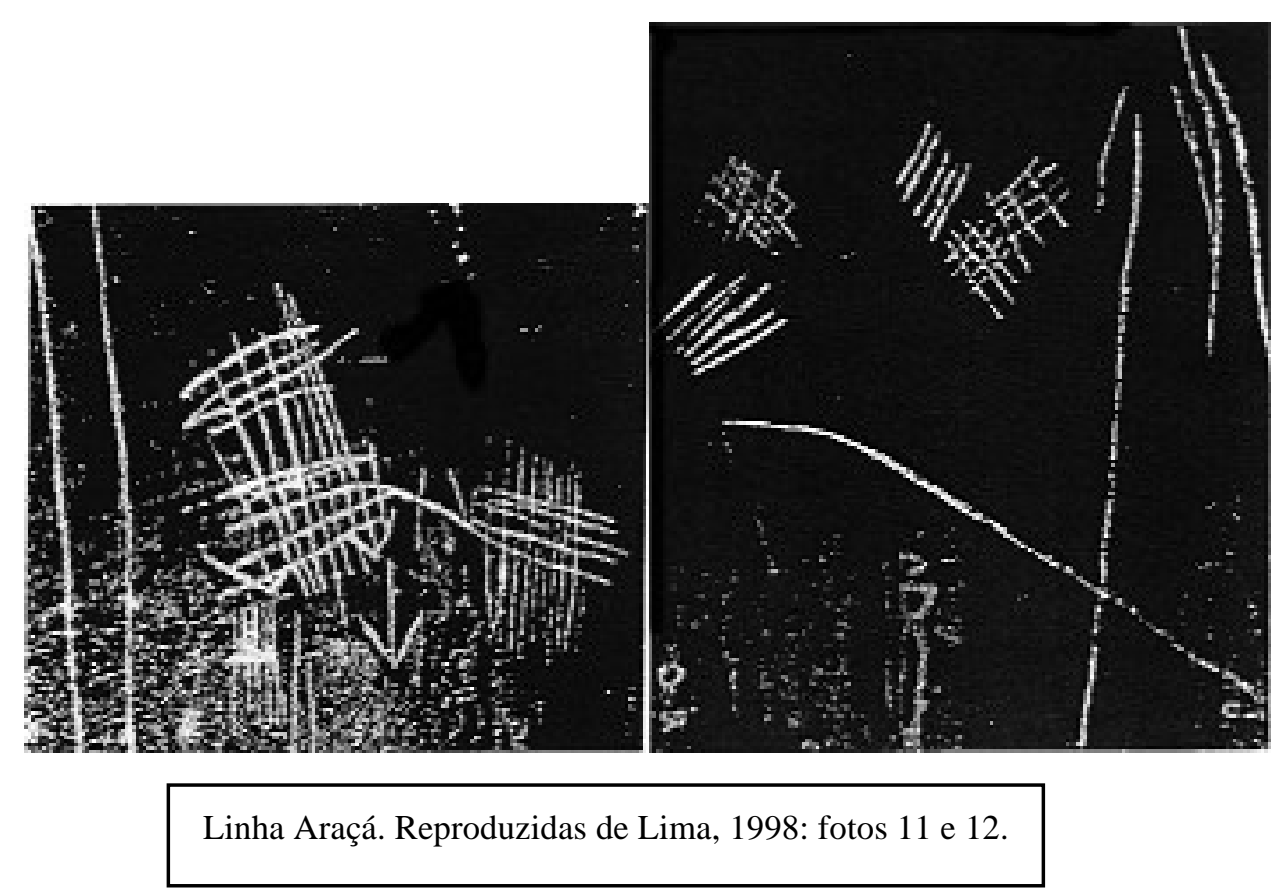

\section{Bom Jardim Velho.}

Abrigo sob-rocha de formação arenítica, localizado em 1970/71, no Município de São Sebastião do Caí, a $6 \mathrm{Km}$ do Virador I. Na frente do abrigo, há curso d'água, com pequena cachoeira, que deságua, 3 a $4 \mathrm{~km}$ abaixo, no Rio Cadeia, principal afluente do Rio Caí (Ribeiro, 1972b). 
Nas camadas superiores (10 cm de espessura), há cerâmica negra da "Fase" Caí da "Tradição" Taquara. As camadas inferiores $(35 \mathrm{~cm}$ de espessura) são pré-cerâmicas: pontas de projétil, raspadores e facas. Na parede do abrigo há grafismo. Um pequeno bloco com grafismos, despreendido da parede do abrigo, foi encontrado na camada de $10-15 \mathrm{~cm}$ de profundidade (Ribeiro, 1972), o que não descartaria a possibilidade de os grafismos terem sido confeccionados pelas populações ceramistas. Mesmo assim, o autor filia os grafismos à "fase" pré-cerâmica, com os seguintes motivos, sempre frágeis e de caráter circular:

"o maior abrigo desta fase, o RS-S-358: Toca Grande, possui petróglifos que julgamos do mesmo grupo; ao mesmo estilo, de 'pisadas', na Patagônia, Argentina, é associado material de caçadores (teuelchense) (MENGHIN, 1957) (SCHOBINGER, 1962/1963); no abrigo Virador (MENTZ RIBEIRO, 1969/1970) encontramos o mesmo estilo e o associamos a caçadores - a escavação do sítio veio confirmar tal suposição; o outro grupo que habitou, tanto o RS-C-12: Virador, como o RS-C-14: Bom Jardim Velho, ambos na camada II, pertencentes à Tradição Taquara, não eram tradicionais confeccionadores de petróglifos, fato confirmado pelo estudo de mais de uma centena de abrigos na Encosta da Serra, Litoral Norte, vales do rio dos Sinos e Caí, Campos de Cima da Serra".

O grafismo na parede do abrigo apresenta-se como seis linhas que convergem para um mesmo ponto central. Os grafismos do bloco despreendido são assim descritos: " 2 séries de pontos, 7 numa linha e 3 em outra, perpendiculares entre si; paralelamente à série de 7 pontos existem 2 traços paralelos entre si” (Ribeiro, 1972b:32-33).

O padrão do grafismo que ocorre na parede do Abrigo, como quer o autor, não é patagoniense, mas, sim, mesopotâmico, conforme o encontrado em Yapeyú, em Corrientes, Argentina, área mais próxima ao amplo espaço geográfico de influência do horizonte cultural Proto-Jê meridional, que, como vimos, incluia áreas a sudeste, na região de Misiones, Argentina.

De acordo com Gradin (apud Brochado \& Schmitz, 1976:133), são os seguintes os grafismos gravados sobre rochas isoladas na margem do Rio Uruguai, na Província de Corrientes: "sulcos profundos retilíneos, paralelos ou entrecruzados, formando cruzes ou estrelas e de sulcos circulares, algumas vezes com outros retilíneos irradiando da periferia". Este parece ser o caso de Bom Jardim Velho: diversos sulcos retilíneos que se entrecruzam formando um "estrela". 
Tal grafismo ocorre nos sítios do Município de Mata-RS e no Morro do Sobrado-RS. Está, igualmente, presente na pintura corporal Kaingang, representando graficamente uma marca téi, aberta.

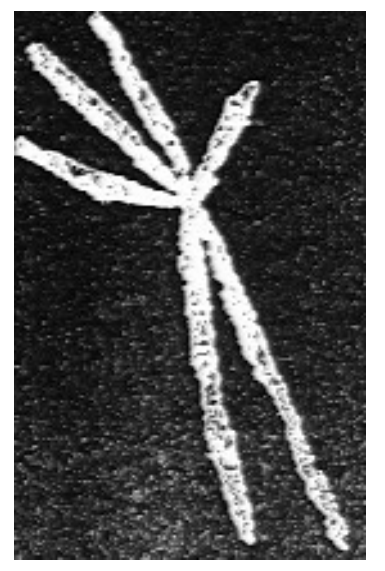

Reproduzido de Lima, 1998:foto 4.

No bloco despreendido, encontrado na camada de 10-15 cm, estão presentes grafismos que são semelhantes aos observados na cerâmica das "tradições locais planálticas" (ponteado) e a grafismos rupestres sul-riograndenses, catarinenses, paranaenses e paulistas (série de pontos dispostos linearmente; linhas paralelas).

Na camada superior àquela onde foi encontrado o bloco despreendido, havia cerâmica Taquara da "Fase" Caí, que, segundo o autor, "é muito parecida com a cerâmica Xokleng recuperada por Santos (1968 e 1969), no PI Duque de Caxias, em Ibirama, Santa Catarina".

\section{Moquém.}

O sítio é formado por um bloco de basalto na encosta de morro. Localizado em 1971 no Município de Taquara. Ribeiro et alii (1973) assim descrevem os grafismos: "dois traços formando vértices " $\mathrm{V}$ " $\mathrm{e}$ "traços paralelos e esparsos". O primeiro grafismo descrito é formalmente idêntico ao de número 8, apresentado por Mabilde.

10. Macaco Branco.

Trata-se de um abrigo sob-rocha de formação arenítica, localizado em 1971 no Município de Portão, estudado por Ribeiro et alii (1973). 


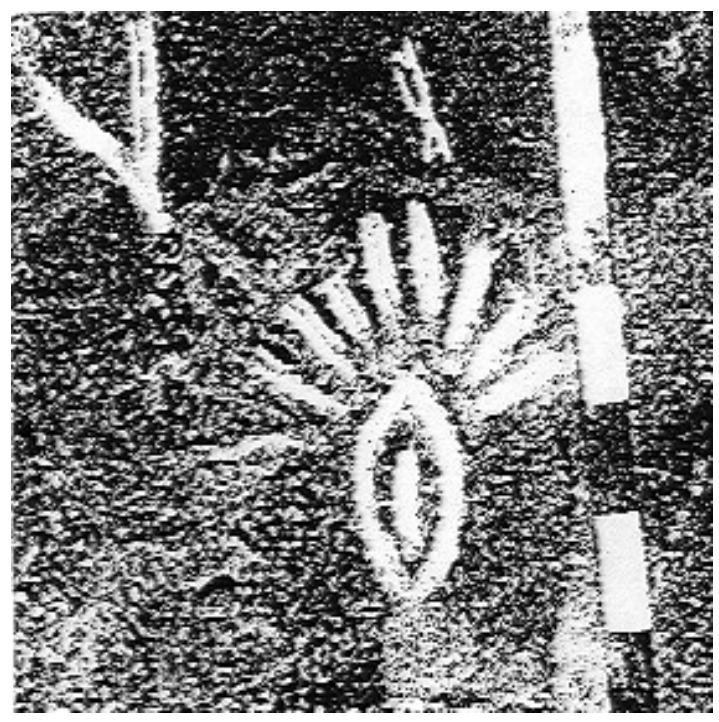

É interessante referir que o grafismo acima foi interpretado pelos Kaingang do RS da seguinte maneira: "é uma cabeça com cocar, com pintura téi”.

\section{Arroio Grande.}

Trata-se de um bloco de arenito localizado em 1971 no patamar de um morro no Município de Santa Cruz do Sul.

Ribeiro et alii (1973) descrevem "tridáctilos" em seqüência; linhas isoladas; conjuntos de linhas; os chamados "gradeados". Além desses, o grafismo descrito a seguir tem especial importância, já que remete às representações gráficas de números 9, 4 e 8, apresentadas por Mabilde: "sete letras ' $\mathrm{V}$ ' cujos vértices estão numa linha formando lados paralelos, indo terminar num ' $\mathrm{X}$ ' (ou 2 ' $\mathrm{V}$ ' cujos vértices se encontram) e, do lado oposto, outro ' $\mathrm{V}$ ' com vétice na direção do ' $\mathrm{X}$ '”.

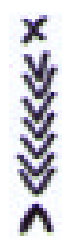

Tentativamente, segundo a descrição de Ribeiro e outros (1973), este seria o aspecto do grafismo rupestre do Arroio Grande. 


\section{Cerro Alegre.}

O sítio é constituído por um bloco de arenito, localizado no Município de Santa Cruz do Sul, em 1973, por Ribeiro (1974), que o descreveu.

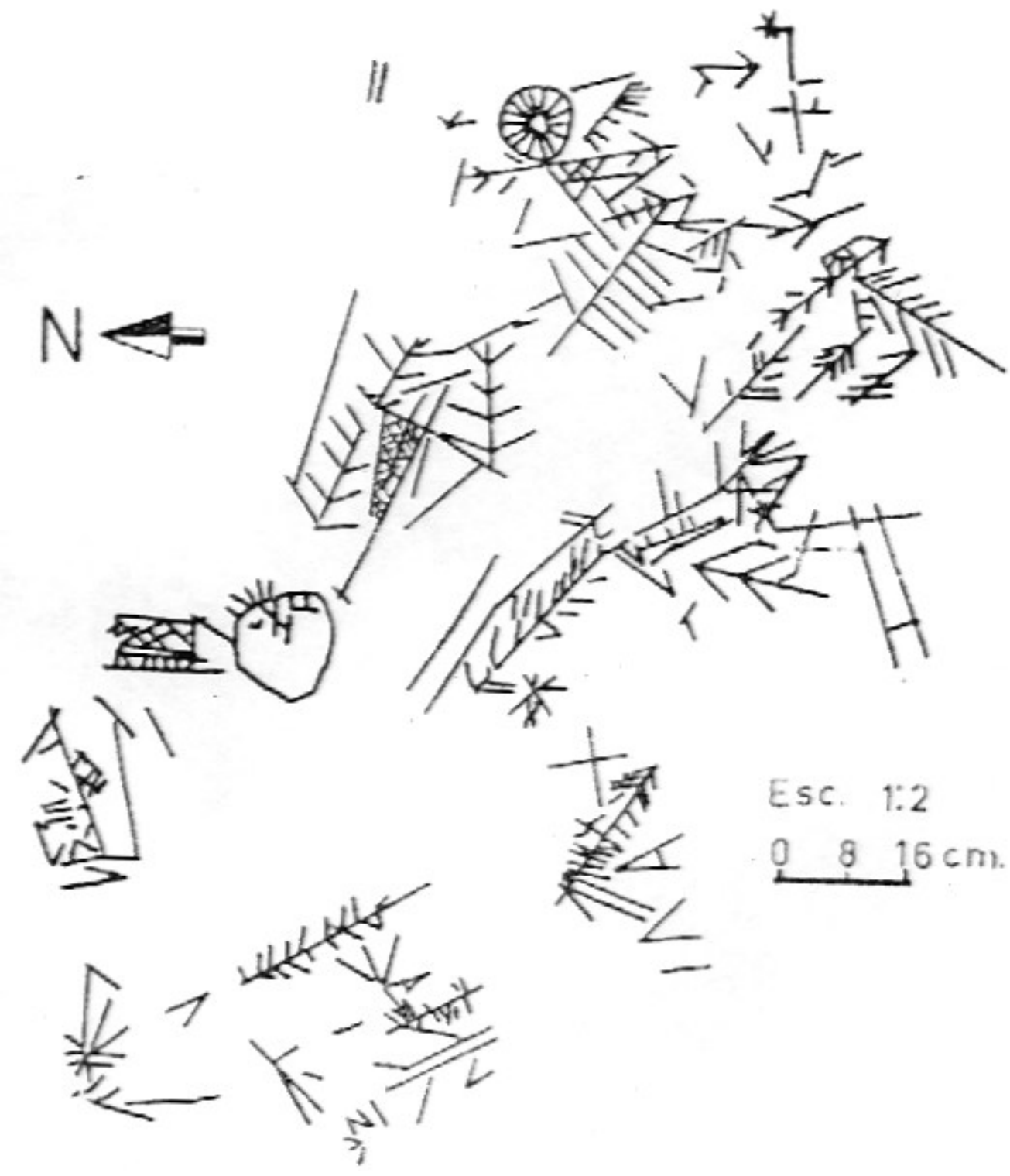

Painel rupestre do Cerro Alegre. Reproduzido de Lima, 1998:foto 16.

Os grafismos presentes neste painel, além de formalmente semelhantes a alguns apresentados por Mabilde (números 4, 6, 7 e 8), demonstram 
conexão com alguns painéis de SC (especialmente o grafismo circular com raios e círculo concêntrico). Além disso, o grafismo linear formado por traço maior ao qual se juntam obliquamente, de ambos os lados, outros traços menores e paralelos entre si é formalmente semelhante a dois dos grafismos do cacique Nhancuiá, apresentados por Mabilde. Este grafismo, igualmente, é muito recorrente em sítios do RS e de SC (João Cunha), bem como ocorreu gravado em fragmento cerâmico da "Fase" Casa de Pedra, do horizonte cultural Proto-Jê meridional. Atualmente, é muito usado na pintura corporal Kaingang, representando graficamente a metade Kamé ( $r a$ téi), uma vez que é considerado como representação do pinheiro $(f \tilde{a} g)$.

\section{Serra do Caverá.}

Abrigo sob-rocha. Município de Rosário do Sul. Informação de Maria Elena Abrahão Schorr, que realizou "uma prospecção que produziu os mesmos resultados encontrados no vale do rio Caí, em Bom Jardim Velho, Macaco Branco e Virador, isto é, 'material de caçadores especializados' com pontas-de-projétil, raspadores, facas, lascas sem e com sinais de utilização, etc." (Lima, 1998).

14. Rio Pardo.

Bloco. Ribeiro, 1978.

15. Município de Mata.

Tratam-se de blocos e de um abrigo com grafismos rupestres, trabalhados por Guilherme Naue, de 1977 a 1982. Foi reestudado por Lima (1998).

A autora estabeleceu 17 tipos de grafismos, os quais reproduzimos a seguir (Lima, 1998:gravuras rupestres de Mata-RS). 


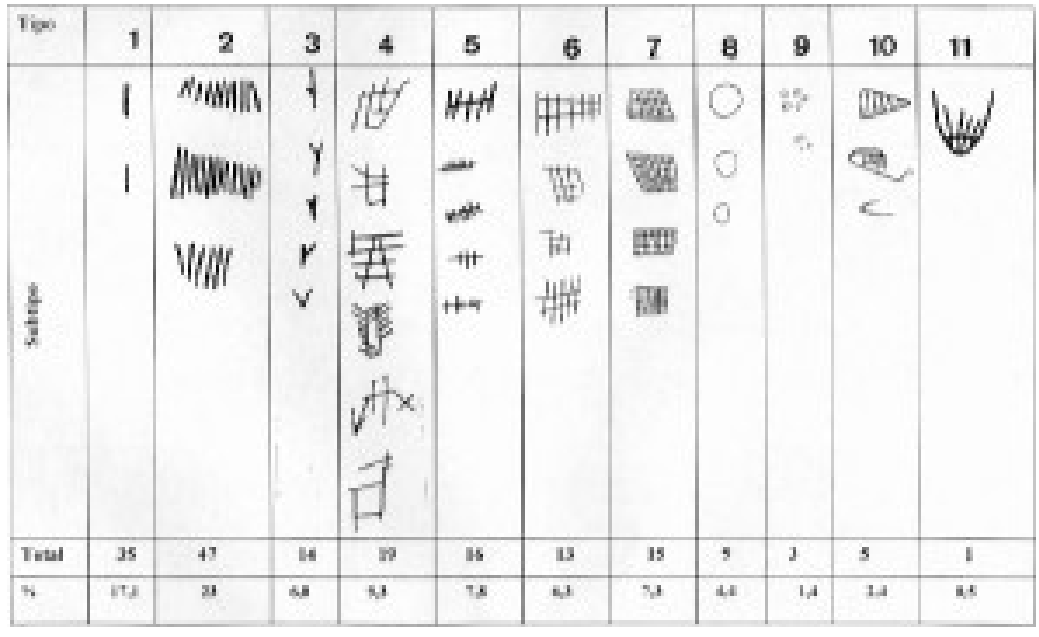

Mata-RS, reproduzido de Lima, 1998.

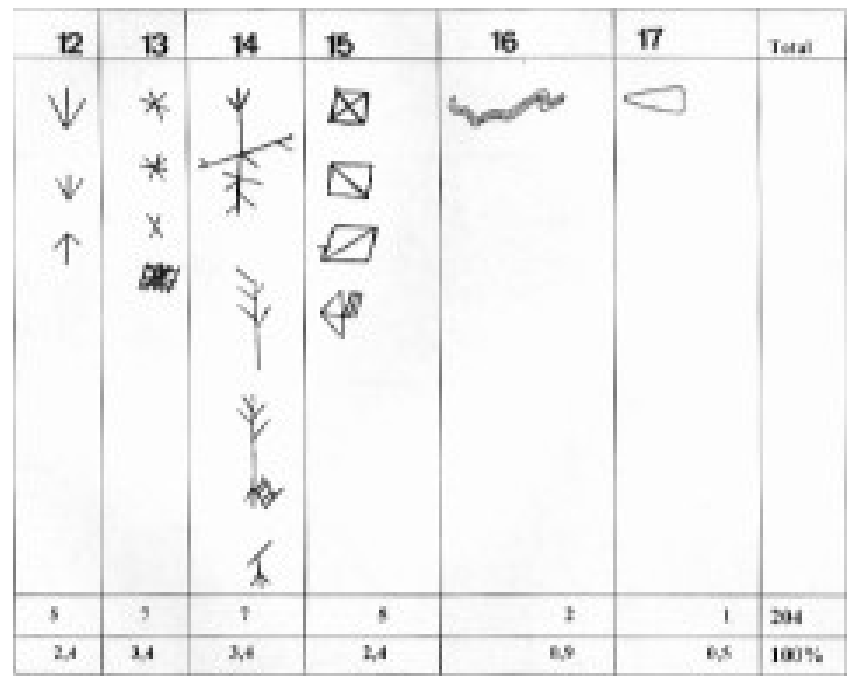

Mata-RS, reproduzido de Lima, 1998.

As semelhanças formais destes grafismos com o sistema de representações visuais (Proto)Jê meridional é bastante evidente. Ressaltem-se, apenas, os grafismos registrados como de tipo 5: formamlmente são idênticos ao primeiro grafismo Coroado do cacique Nhancuiá, apresentado por Mabilde. Os "triângulos", "paralelogramas" e "gradeados" demonstram as conexões com SC.

\section{Cerro da Panela}

Bloco de arenito localizado no Município de Quaraí, foi estudado por Ribeiro \& Soloviy Fénis (1984). Os autores descrevem os grafismos rupestres gravados como "gradeados"; conjuntos de linhas em várias disposições; duas linhas ziguezagueadas paralelas de quatro partes; letra "V"; arco; retângulo, triângulo; "tridáctilo", etc. 
$17,18,19$ e 20.

Quatro abrigos no Município de Montenegro foram trabalhados por Ribeiro et alii (1989). São eles:

O Abrigo Edmundo Diesel que apresenta "estrela estilizada ou junção de 4 tridáctilos formados por 8 traços"; quatro linhas inclinadas, sendo que a da esquerda está cortada por uma linha oblíqua, formando um " $X$ "; depressão alisada elipsóide (op.cit.).

No Abrigo Adão da Silva, foram encontrados "gradeado oblíquo formando pequenos losangos"; linhas retas paralelas; linhas isoladas; 20 pontos paralelos; figura ovóide invertida; cinco depressões elipsóides alisadas (op.cit.).

Os grafismos presentes no AbrigoWaldemar Haustein foram copiados por Alberto Trasel, em 1966. Abaixo, reproduzimos este painel, a partir de Lima, 1998.

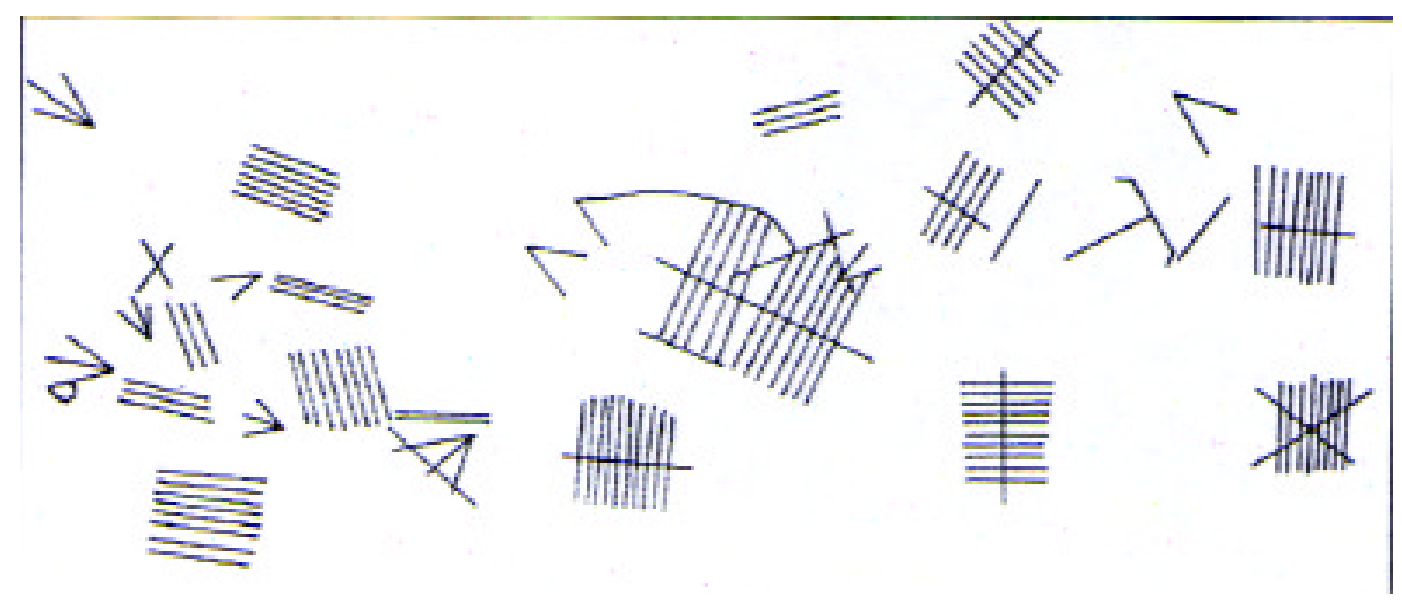

Grafismos rupestres do Abrigo W. Haustein. Reproduzido de Lima, 1998:foto 18.

No Abrigo André Pereira, ocorreram grafismos lineares (linhas isoladas, paralelas), circulares (elipses, círculos) e um "V" (Ribeiro e outros, 1989).

Estes quatro abrigos apresentam grafismos formalmente semelhantes, e já comentados, às representações visuais (Proto)Jê meridionais. 


\section{Abrigo do Barreiro (RS 452-1).}

Localizado por Daniel Cargnin no Município de Ivorá, foi escavado em 1993 por Lima. Os resultados foram publicados em Lima \& Brochado, 1994.

Os grafismos presentes são: linhas retilíneas isoladas; linhas dispostas de várias maneiras; linhas ondulantes; perfurações, depressões, dispostas de vários modos, inclusive alinhadas em fileiras horizontais simples ou paralelas; "tridáctilos", etc. Aparentemente, estas representações gráficas são formalmente semelhantes às pertencentes ao sistema de representações visuais (Proto)Jê do sul, enfatizando a oposição aberto/fechado.

\section{Morro das Pedras (RS-100).}

Localizado no interior do Município litorâneo de Torres, em 1967, por Schmitz. Reestudado por Lima (1998).

A ficha de registro do sítio (Schmitz, apud Lima, 1998) assim descreve os grafismos:

"nas colunas de basalto que cercam o montículo existem ranhuras que Miguel Bombim interpretou como gravações rupestres. Os motivos são geometrizantes: quadriculados; pequenos traços paralelos, dispostos em ângulo em relação com outro maior horizontal; e orbiculares".

Autores antigos, como o pastor protestante da colônia alemã do Forromeco-RS August Kunert, interpretam estes grafismos formados por "pequenos traços paralelos, dispostos em ângulo em relação com um outro maior horizontal" como representações de pinheiros (Kunert, apud Ribeiro, 1969-70:115), árvores que, como vimos, estão ligadas à metade Kamé. Aliás, esta é a interpretação dos próprios Kaingang atuais, que, como já foi mostrado, usam esta "pinta" - ra téi (marca comprida) - para representar graficamente seu pertencimento à metade Kamé. Note-se que no mesmo sítio os outros grafismos presentes são fechados ("quadriculados" e "orbiculares").

A seguir, reproduzimos os 9 tipos de grafismos de Torres, estabelecidos por Lima (1998). 


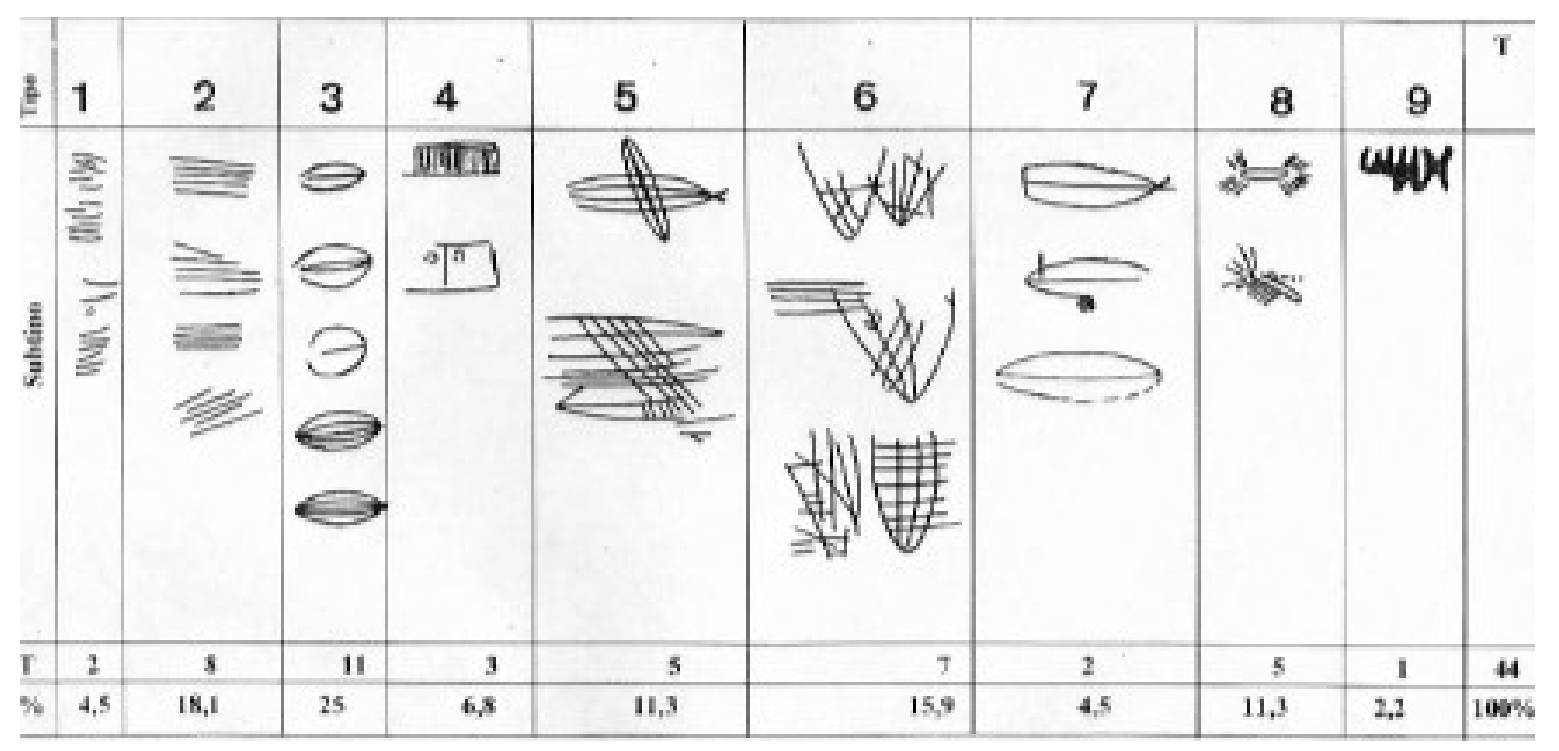

Torres-RS, conforme Lima, 1998:gravuras rupestres de Torres.

23. Canhemborá.

Gruta localizada no Município de Nova Palma. Brochado \& Schmitz, 1976.

\section{Linha Sétima.}

Abrigo situado no Município de Nova Palma. Brochado \& Schmitz, 1976.

25. Lajeado dos Dourados.

Gruta localizada no Município de Sobradinho. Brochado \& Schmitz, 1976.

26. Pedra Grande.

Abrigo situado no Município de São Pedro do Sul. Brochado \& Schmitz, 1976.

Os grafismos rupestres dos quatro últimos sítios, as grutas de Canhemborá e do Lajeado dos Dourados e dos abrigos da Linha Sétima e da 
Pedra Grande, ao que tudo indica, não foram confeccionados por populações Proto-Jê do Sul ou por membros das sociedades históricas Kaingang e Xokleng. Seriam grafismos de origem patagoniense ou subpatagoniense, como pretendem os autores (Brochado \& Schmitz, 1976). É nesta direção que apontam as claras provas estratigráficas, as datações radiocarbônicas, a ausência de materiais arqueológicos das tradições Taquara e Humaitá e, principalmente, a absoluta não-presença de grafismos Jê meridionais característicos.

Brochado \& Schmitz (1976) encaram os painéis rupestres destes abrigos mais a sudoeste como de autoria de populações vinculadas à "Tradição" Humaitá. O consenso estabelece-se com respeito às ditas influências e origens desta arte, que segundo Brochado, Schmitz e Ribeiro estariam na Argentina.

Entretanto, os locais estudados por Ribeiro com grafismos rupestres na escarpa do Planalto Sul-Brasileiro, de 80 a $300 \mathrm{~km}$ mais a leste dos antes citados, parecem indicar alguns padrões gráficos (Proto)Jê meridionais.

O autor, no entanto, tem convicção da origem patagoniense destes grafismos, mas não apresenta provas objetivas da sua conexão com a "Tradição" Umbu ${ }^{63}$, de caçadores-coletores, a não ser a semelhança formal de alguns grafismos (principalmente com os tridáctilos, representações gráficas que ocorrem do sul ao nordeste do Brasil) e o fato de 9 entre 11 abrigos escavados apresentarem material arqueológico ligado a populações caçadoras. Além deste argumento não comprovar que os autores dos grafismos sejam os mesmos que habitaram os abrigos, também existiam materiais da "Tradição" Humaitá em quatro deles; da "Tradição" Taquara em três; e da "Tradição" Tupiguarani em quatro destes mesmos 11 abrigos (Ribeiro, 1991:122 e 1990:143).

No entanto, Brochado \& Schmitz (1976:136) demonstram apreensão, no final deste trabalho, em explicar esta influência em uma ampla superfície territorial, que compreende o territorio atual de três países, principalmente quando não há vestígios de grafismos rupestres do estilo de pisadas na grande área que limita o território argentino ao brasileiro e seu reaparecimento no

${ }^{63}$ Um dos motivos que o autor cita para não considerar como autores de quaisquer painéis rupestres no RS os portadores da "Tradição" Taquara reside no fato de ele afirmar não serem os Kaingang tradicionalmente pintores ou desenhistas. As informações etno-históricas (Mabilde) e o próprio mito de origem desta sociedade, já comentado, registra o ato de pintar com carvão como saber tradicional. 
interior da floresta tropical, ambiente completamente diferente do de origem do estilo, já no Rio Grande do Sul.

"Os petroglifos do estilo de pisadas não são encontrados, como vimos, nem nos campos abertos da Argentina, Uruguai e Rio Grande do Sul, nem na savana do Chaco e da Mesopotamia. Por isso mesmo, parece ainda maior o salto, quando reaparecem no interior da floresta tropical da encosta do planalto meridional, no Rio Grande do Sul, numa área de clima subtropical úmido, com mais de $1500 \mathrm{~mm}$ de chuva" - Brochado \& Schmitz, 1976:136.

Este salto me levou a procurar correlações culturais com as populações estabelecidas ao norte do Rio Grande do Sul, relações estas que já foram mostradas nas páginas anteriores.

No entanto, a maioria dos autores que trabalharam com os grafismos rupestres de SC pensa de forma diferente.

\subsubsection{Grafismos rupestres em Santa Catarina: suas relações com o RS}

Rohr (1969), durante o ano de 1968, copiou os grafismos rupestres localizados, geralmente, em paredões verticais de diabásio negro, na Praia do Santinho, Ilha de Santa Catarina, e nas ilhas do Arvoredo, do Campeche, dos Corais e João Cunha (ou Ilha de Porto Belo). Com exceção da última, onde o paredão com painel encontra-se longe da praia, os demais estão situados nas "praias mais furiosamente trabalhadas pelos vagalhões do oceano" (Rohr, 1969:2).

Como Menghin (1961), Rohr parece acreditar que tais grafismos são obra de grupos tupiguarani, que à época da Conquista ocupavam praticamente todo o litoral catarinense. A hipótese de Menghin (apud Rohr, 1969) baseiase na semelhança de certos "motivos" - linhas onduladas, em zigue-zague, paralelas - com as decorações existentes em urnas funerárias da Tradição ceramista Tupi-guarani.

No entanto, ao descrever os "motivos" mais freqüentes nestes petroglifos, que incluem outros padrões gráficos, além dos citados acima, (círculos concêntricos; conjuntos de linhas paralelas, ou de linhas onduladas paralelas, ou, ainda, de linhas em zigue-zague paralelas; conjuntos de figuras 
ovóides ou triangulares cheias, de quadriláteros irregulares; figuras estilizadas antropomorfas ou zoomorfas), Rohr observa que, pela repetição dos padrões gráficos nos diferentes locais estudados, "os petroglifos das diversas ilhas são produto de uma e a mesma cultura ou grupo cultural" (Rohr, 1969:3; grifo meu).

A princípio, esta constatação de Rohr (maior número de tipos de grafismos, repetição de todo o conjunto de grafismos em todos os locais com petroglifos) enfraquece consideravelmente a pretenção de Menghin. Além disso, Prous discute a segurança da hipótese que identifica as linhas em ziguezague como Tupiguarani, pois elas são "também encontradas em ossos gravados do sambaqui de Matinhos, ou em bula timpânica de baleia em outros lugares" (Prous, 1978/79/80:66), o que nos remete indubitavelmente para um horizonte pré-cerâmico.

Sem entrarmos em maiores detalhes sobre os grafismos rupestres das ilhas de Santa Catarina, aos quais voltaremos a discutir exaustivamente em seguida, passemos a um rápido panorama dos grafismos rupestres do Planalto Catarinense, localizados em sua maioria nas proximidades de Urubici, também estudados por Rohr (1971). Tais petroglifos, diferentemente dos do litoral catarinense, encontram-se gravados no arenito dos abrigos sob-rocha, das galerias subterrâneas e das estruturas subterrâneas.

De maneira totalmente oposta às idéias registradas em seu artigo de 1972, que comentaremos mais adiante, Rohr afirma que o Alto Vale do Itajaí e os Campos de Lages foram ocupados por diferentes "populações de culturas bastante diversas". De maneira equivocada, centrando seu raciocínio no tipo de sítios ocupados, diferencia populações que 1. "moravam em abrigo sobrocha" das que viviam 2. "em casas subterrâneas ou galerias subterrâneas", diferenciando-as, ainda, das que construíram 3. "aldeias com paliçadas protetoras" (Rohr, 1971:10).

Além disso, acredita que "os petroglifos da Ilha de Santa Catarina e ilhas adjacentes diferem dos petroglifos do planalto, tanto nos motivos dos desenhos, como em outros detalhes" (Rohr, 1971:12). Tal afirmativa de Rohr tem como base os seguintes elementos, a seguir resumidos: 


\begin{tabular}{|c|c|c|}
\hline & Planalto & Litoral \\
\hline \multicolumn{3}{|l|}{ Características } \\
\hline 1. Suporte & Arenito & Diabásio preto \\
\hline $\begin{array}{l}\text { 2. Profundidade máxima } \\
\text { x largura máxima }\end{array}$ & $4 \mathrm{~cm} \mathrm{x} 4 \mathrm{~cm}$ & $3 \mathrm{~mm} \times 30 \mathrm{~mm}$ \\
\hline $\begin{array}{ll}\text { 3. } & \text { Rebaixamento } \\
\text { superfície do suporte }\end{array}$ & $\begin{array}{l}\text { Sim, por lascamento }(1 / 2 \\
\text { a } 1 \mathrm{~cm})\end{array}$ & Às vezes, por alisamento \\
\hline 4. Técnica & $\begin{array}{l}\text { Gravado (alguns com } \\
\text { tinta preta) }\end{array}$ & $\begin{array}{lr}\text { Gravado } & \text { por } \\
\text { picoteamento (às } & \text { vezes } \\
\text { por alisamento). } & \text { Sem } \\
\text { vestígios de tinta. } & \\
\end{array}$ \\
\hline 5. Extensão dos painéis & Pequenas superfícies & Grandes superfícies \\
\hline 6. Motivos & $\begin{array}{lr}\text { Triângulos com } & \text { ou sem } \\
\text { ponto; } & \text { círculos; } \\
\text { quadriláteros; retângulos; } & \text { losângulos; r pontos; } \\
\text { antropomorfos; círculos } \\
\text { com ponto no centro. }\end{array}$ & $\begin{array}{l}\text { Círculos concêntricos; } \\
\text { linhas retas paralelas; } \\
\text { linhas } \\
\text { paralelas; linhas enduladas } \\
\text { zigue-zague paralelas; } \\
\text { ovóides; triângulos; } \\
\text { quadriláteros; } \\
\text { antropomorfos. }\end{array}$ \\
\hline
\end{tabular}

No entanto, os aspectos acima, levantados por Rohr e supostamente diferenciadores, não resistem a uma análise mais detida.

Sendo os suportes diferentes, obviamente as técnicas de gravação também o seriam. Sob o ponto de vista de preparação para uso como superfície a ser gravada, é mais eficiente rebaixar um paredão de diabásio duro por alisamento do que por lascamento, o que, na última hipótese, deixaria uma superfície extremamente irregular. Já no arenito mole, parece mais eficiente rebaixar a superfície a ser trabalhada por lascamento do que por polimento, o que, no último caso, demandaria muito tempo e esforço. Pelo mesmo raciocínio (arenito mole x diabásio duro), pode-se explicar a diferença entre as profundidades e larguras máximas dos petroglifos das duas regiões de Santa Catarina. Por outro lado, o autor enfatiza que "os triângulos e paralelogramas" do litoral aparecem cheios, "isto é, em forma de rebaixos triangulares na rocha" (Rohr, 1971:12). No planalto, os mesmos grafismos são vazios, ou seja, "achando-se debuxados na rocha apenas os lados dos triângulos e paralelogramas" (Rohr, 1971:12). Para explicar esta diferença, além de se insistir na diferença de suportes (duro, mole), poder-se-ia acrescentar que se trataria de variações estilísticas dentro da mesma tradição 
cultural: os grafismos, produzidos pelas diferentes técnicas mencionadas, continuam os mesmos... A maior extensão dos painéis no litoral também poderia ser creditada a variações estilísticas. A "ausência" de tinta preta cobrindo os grafismos no litoral, igualmente não parece ser um bom critério para diferenciação em relação aos grafismos do planalto, pois, na primeira região, os petroglifos, com exceção da Ilha de Porto Belo, estão "localizados, de preferência, nos paredões verticais de diabásio negro das praias mais furiosamente trabalhadas pelos vagalhões do oceano" (Rohr, 1969:2, grifo meu), ao passo que, no planalto, encontram-se, uns mais outros menos, ao abrigo da umidade (Rohr, 1971:11-12).

De qualquer forma, o verdadeiramente essencial é a semelhança, que discutiremos mais adiante, dos padrões gráficos que estão representados na rocha, seja ela dura ou mole, seja no litoral ou no planalto.

Neste ponto, é interessante demonstrar as mudanças ocorridas no pensamento de Rohr, após o ano de 1971, diante da continuidade de suas pesquisas no planalto catarinense.

No ano de 1972, Rohr escavou duas estruturas subterrâneas (“casas") no Município de Urubici, Santa Catarina. Eram estruturas feitas no arenito. E "veio então a descoberta mais importante" (Rohr, 1972 a:34): numa delas, na parede, encontrou grafismos rupestres

"...em forma de triângulos, com curta linha reta, partindo de um ponto mais grosso do vértice do triângulo" (Rohr, 1972 a:34-5).

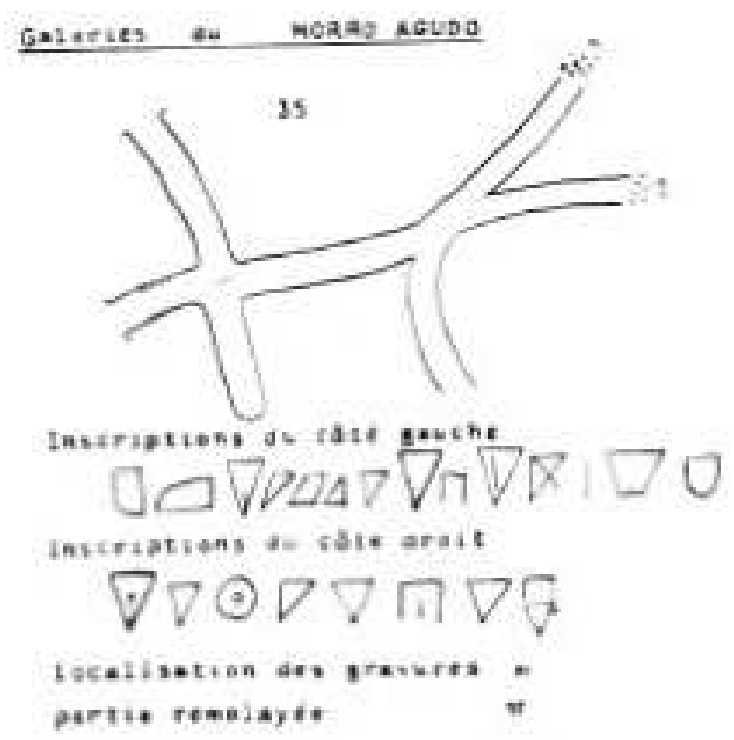


No mesmo artigo, Rohr compara estes grafismos aos das galerias subterrâneas de Urubici, que noticia em outro artigo de divulgação científica, publicado no mesmo ano, juntamente com duas fotos de salas internas às galerias e que contêm grafismos (Rohr, 1972b:105, fotos 4 e 5). Igualmente, compara a cerâmica das estruturas subterrâneas de Urubici (lisa, com incisões em forma de linhas paralelas cruzadas, ungulada, ponteada) à cerâmica de abrigos sob-rocha e sítios em campo aberto e no litoral (cita Jaguaruna).

E a conclusão de Rohr, diante das novas evidências, é totalmente diferente daquelas registradas em 1971:

"Isto prova que as casas subterrâneas eram apenas refúgios ocasionais e que os donos das mesmas habitavam também em outros sítios. No período de inverno, recolhiam-se às casas subterrâneas ou às galerias subterrâneas, abaixo do nível do solo; no verão procuravam lugares mais arejados, abrigos abertos, sob-rocha, e mesmo a zona do litoral. No litoral de Jaguaruna, encontramos cerâmica com as características das casas subterrâneas..." (Rohr, 1972 a:35; grifo meu).

Deste modo, após escavar, em fevereiro de 1972, as estruturas subterrâneas ("casas") em Urubici (que felizmente foram escolhidas por terem sido feitas no arenito, em detrimento de outras, realizadas em solo de argila ou terra) e ter encontrado petroglifos em suas paredes, Rohr apercebe-se que a mesma etnia havia confeccionado os grafismos rupestres das galerias e das estruturas subterrâneas. E, por terem cerâmica igual, conclui que era a mesma etnia que ocupava sazonalmente alguns sítios do litoral catarinense. Infelizmente, não percebe a ligação com os petroglifos da Ilha de Santa Catarina e ilhas adjacentes, que, em 1971, diz serem diferentes dos do planalto catarinense.

De qualque forma, Rohr tinha, no ano de 1972, todos os elementos para aperceber-se da existência de uma ampla tradição cultural no sul do Brasil, vinculada aos Jê meridionais. Apesar disto, não se dá conta da importância de sua comparação expressa no artigo de 1972, que, aliás, era limitada, deixando de fora os petroglifos das ilhas de Santa Catarina. Além do pequeno e quase desconhecido texto de divulgação científica de 1972, nada mais publica sobre o assunto.

É interessante comentar o desconforto causado em Guidon pelos grafismos rupestres copiados e publicados por Rohr em 1969 e 1971 (litoral e 
planalto de Santa Catarina, respectivamente), uma vez que, segundo esta autora, eles não se encaixariam em quaisquer das tradições e estilos de arte rupestre propostos no Brasil (Guidon, 1978/79/80:23).

Além disto, no mesmo trabalho, ao definir as tradições brasileiras de Arte Rupestre, a autora cita a "tradição de gravuras do Rio Grande do Sul", com grafismos geométricos e "muita semelhança com certas coisas que vêm desde a Patagônia" (Guidon, 1978/79/80:23).

Igualmente, ao citar "algumas manifestações pequeninas, que não sabemos onde colocar, como essa do Pe. João Alfredo Rohr no litoral e as que publicou para o Planalto, junto com as casas subterrâneas", Guidon refere-se aos grafismos geométricos de Itapeva em São Paulo, que também causam desconforto, pois não se encaixam em lugar nenhum (Guidon, 1978/79/80:23).

Prous (1978/79/80:65) remete a uma posssível ligação entre os grafismos rupestres de alguns sítios de São Paulo com alguns painéis do planalto catarinense:

"Penso particularmente num dos painéis do Morro do Avencal, onde as pegadas de aves (vamos dizer os tridáctilos) são ligadas também a pontos perfurados. Não são todos os sítios do Planalto Catarinense, mas é um desses painéis feito unicamente de triângulos, de pegadas e de círculos. É um caminho que temos que guardar".

Como se vê, alguns passos ainda precisam ser dados (e este é um dos objetivos desta tese) para definir esta amplíssima tradição cultural do sul do Brasil, vinculada estreitamente aos Jê meridionais e com larga influência desde regiões mais ao sul e sudeste do país.

As representações gráficas de antropomorfos e zoomorfos nos sítios litorâneos de Santa Catarina levantados por Rohr (1969) resumem-se a dez ocorrências, distribuídas em quatro sítios: Arvoredo (dois antropomorfos), Santinho (um zoomorfo), Campeche (cinco antropomorfos) e Corais (um zoomorfo e um antropomorfo).

Os antropomorfos das ilhas do Arvoredo e dos Corais acham-se diretamente associados a representações gráficas de padrão circular.

A aparente diferença dos grafismos rupestres do planalto catarinense em relação aos grafismos do litoral, enfatizada por Rohr, desaparece completamente a partir de um estudo mais detido dos mesmos. Em primeiro 
lugar, os vários padrões gráficos geométricos do litoral estão presentes nas representações gráficas do planalto. Além disso, os grafismos figurativos do litoral também existem no planalto catarinense, através de representações antropomorfas e zoomorfas. Não bastassem estas duas razões, alguns grafismos são iguais aos do litoral, especialmente algumas representações de padrão gráfico quadrangular, circular, linear e losangular. Outra evidência gráfica que indica a vinculação da arte rupestre do planalto de Santa Catarina com uma ampla tradição cultural Jê do sul é a presença constante nesta área do grafismo composto por várias linhas retas inclinadas que interceptam um conjunto de linhas retas inclinadas, na direção oposta das primeiras, formando um conjunto de losângulos. Este grafismo de padrão losangular, junto com suas estilizações - linhas em zigue-zague, por exemplo -, é extremamente comum na cerâmica arqueológica das tradições planálticas, nos kuru (mantos) Kaingang de São Paulo e Paraná, e na pintura corporal Kaingang no Rio Grande do Sul.

Vejamos os grafismos rupestres do Planalto de SC.

Sítio Morro do Avencal, Município de Urubici (SC-Urubici-1)

Primeiro painel

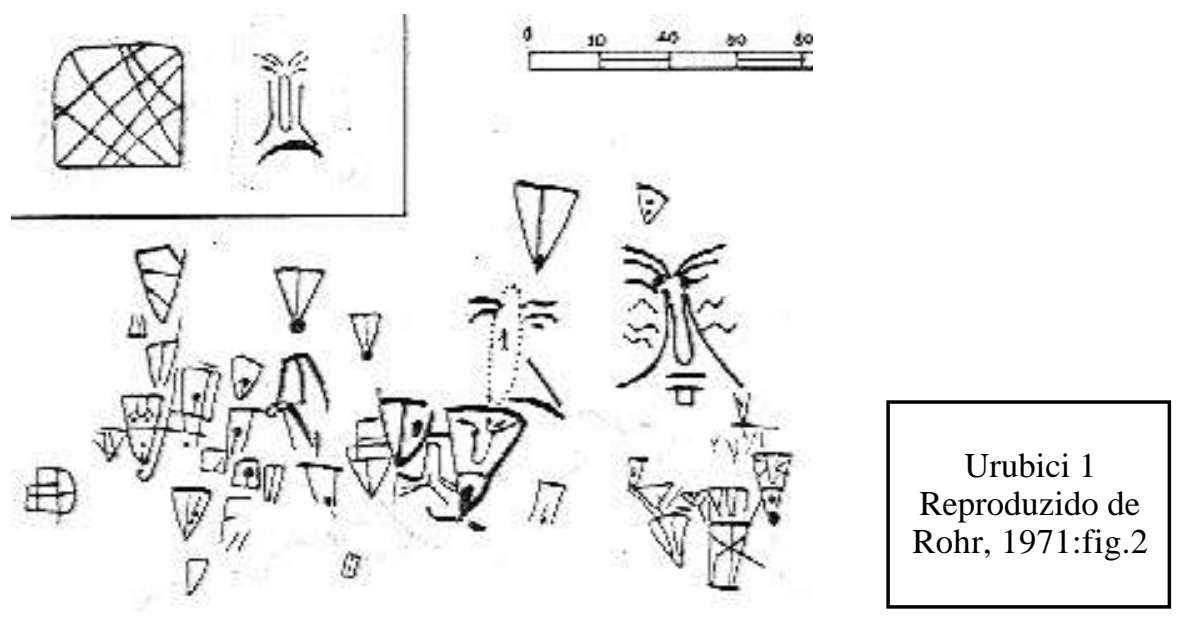

Notem-se, neste painel, os grafismos formados por conjuntos de linhas paralelas que interceptam outro conjunto de linhas também paralelas, formando pequenos quadriláteros ou losangos, dependendo da inclinação das linhas. Este tipo de representação é bastante recorrente na cerâmica das ditas "tradições locais planálticas", inclusive na de Urubici, e muito comum nos materiais etnográficos e na pintura corporal Kaingang. 
Os grafismos triangulares, com ou sem traço interno, com ou sem ponto interno, muito recorrentes nos sítios do Município de Urubici, remetem-nos aos contextos dos sítios com grafismos rupestres no RS, especialmente Virador, Dona Josefa e Mata. Por sua vez, a conexão deste grafismo com o horizonte cultural Proto-Jê meridional é inquestionável, pois estão presentes nas paredes de casa subterrânea do Planalto catarinense ${ }^{64}$ e na Galeria do Morro Agudo, ambas estruturas estando ligadas a este horizonte. $\mathrm{O}$ mesmo grafismo aparece nos painéis rupestres da Ilha dos Corais, litoral de Santa Catarina, indicando a conexão cultural da região planáltica e litorânea deste Estado. A presença deste grafismo nos materiais etnográficos ${ }^{65}$ Kaingang demonstra a continuidade do sistema de representações visuais ao qual esta representação pertence. À mesma conclusão nos leva a ocorrência deste mesmo grafismo na pintura corporal Kaingang do RS, denominado de $r a$ ror e representando graficamente a metade Kainru-kré.

O próprio painel comentado traz dois exemplos de pintura facial. À direita, na zona central, um rosto apresenta-se com grafismos na região das faces. Tratam-se de grafismos lineares, abertos, semelhantes aos de números 1 e 8 de Mabilde, designados atualmente de ra ionior pelos Kaingang, representando a metade Kamé. Nesta mesma área do painel, um pouco mais para baixo, tem-se outro rosto com pintura facial: dois pontos grossos embaixo da boca e no queixo. Estes grafismos circulares, fechados, são atualmente representações gráficas da metade Kaingang Kainru-kré, sendo designados de ra ror. Note-se que a própria forma do rosto gravado com pintura facial feita com pontos é triangular, ou seja, fechada, indicando uma conexão entre ponto e triângulo, grafismos fechados, segundo os Kaingang atuais.

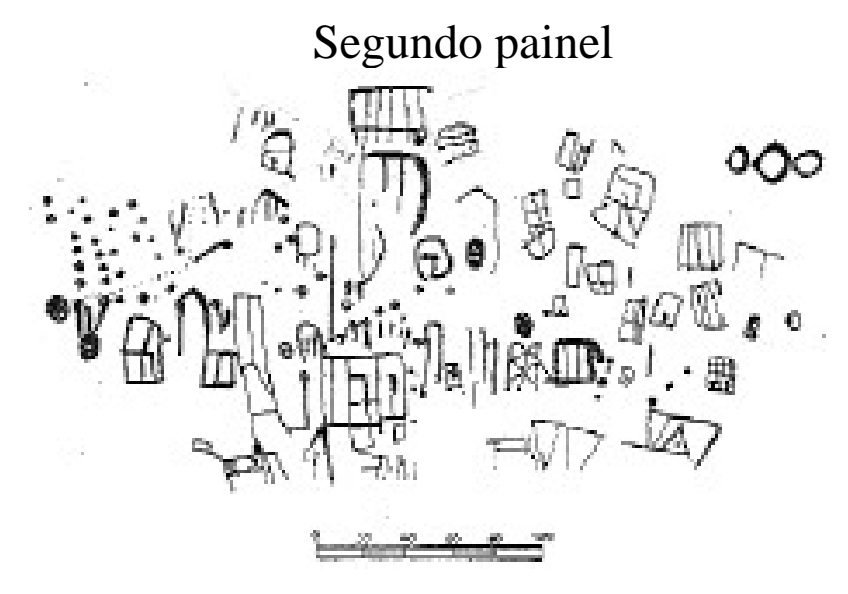

Urubici 1 Reproduzido de Rohr, 1971:fig.3.

\footnotetext{
64 “triângulos, com curta linha reta, partindo de um ponto mais grosso no vértice do triângulo" (Rohr, 1972:34-5).

${ }^{65}$ Veja no Anexo (Acervo Kaingang - MAE/USP) o grafismo triangular constante na cabaça de RG 5.854.
} 
Neste painel, além dos grafismos triangulares, dos conjuntos de linhas paralelas que interceptam outro conjunto de linhas paralelas e dos pontos, isolados, dispostos em linhas simples ou em conjunto de linhas paralelas, todos já comentados, estão presentes alguns grafismos lineares: linhas isoladas ou em grupos.

$\mathrm{Na}$ porção esquerda inferior do painel, dois grafismos figurativos, representando zoomorfos, chamam a atenção. Com formas muito estilizadas e tamanhos reduzidos estão representados um mamífero e uma ave. O estilo esquemático como estes grafismos são confeccionados assemelha-se àquele dos zoomorfos do Cerro do Baú-RS e da cerâmica Proto-Jê meridional da "Fase" Casa de Pedra. Em sítios no Paraná e São Paulo, como será visto a seguir, também ocorrem grafismos zoomorfos em idêntico estilo.

\section{Painel 3}

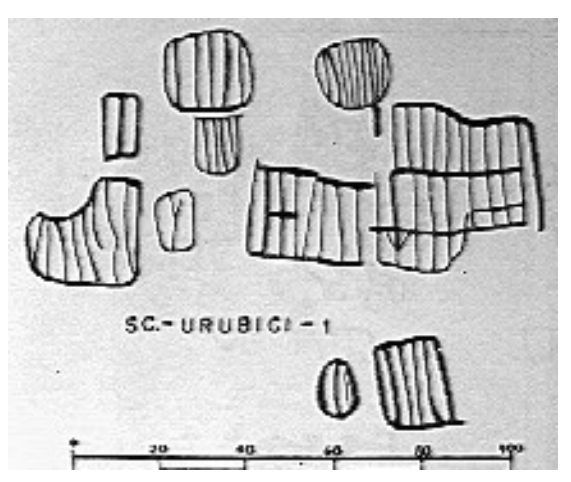

Urubici 1

Reproduzido de Rohr, 1971:fig.4.

Ocorrem neste painel conjuntos de linhas paralelas verticais delimitadas por formas quadriláteras, algumas levemente arredondadas ou subcirculares ${ }^{66}$. Em dois destes conjuntos há linha(s) horizontal(is) interceptando as verticais, o que forma pequenos quadriláteros. Alguns grafismos cerâmicos do horizonte cultural Proto-Jê do sul no RS assemelham-se a estas representações rupestres.

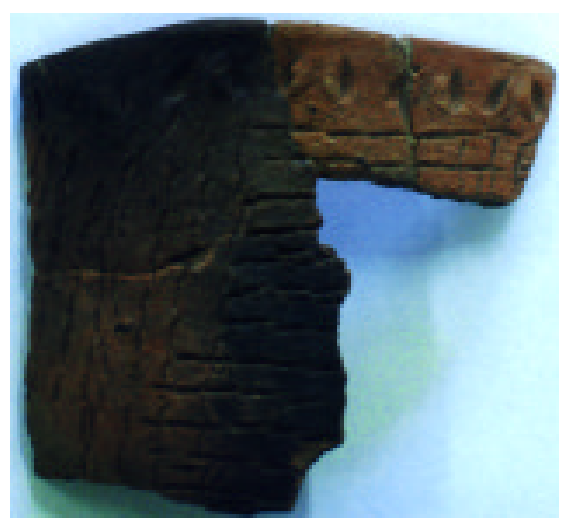

Cerâmica do Morro da Formiga (RS-S-61). MARSUL

\footnotetext{
${ }^{66}$ Grafismo formalmente semelhante ocorre no Morro do Sobrado-RS.
} 
Painel 4

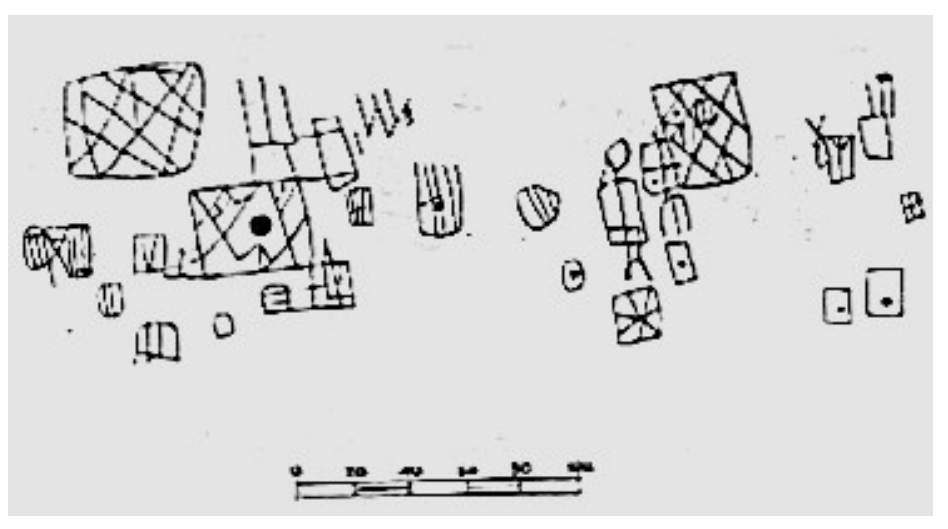

Urubici 1

Reproduzido de

Rohr,

1971:fig.5

A novidade deste painel fica por conta do grafismo antropomorfo, que, como os zoomorfos, apresenta-se altamente estilizado.

Sítio do Morro do Avencal - Fundos (SC-Urubici-2)
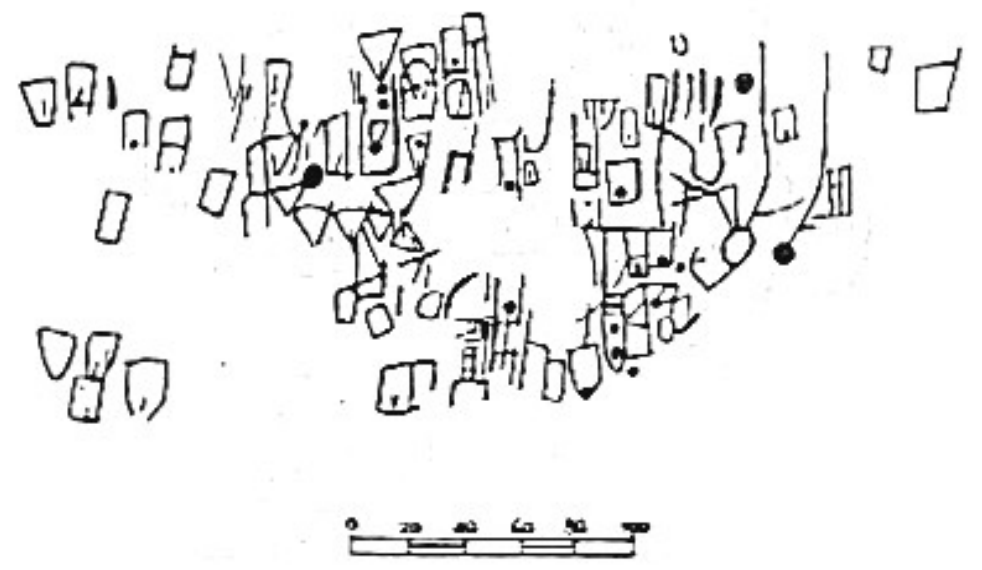

Urubici 2

Reproduzido de

Rohr,

1971:fig.5

Sítio do Morro Pelado (SC-Urubici-14)

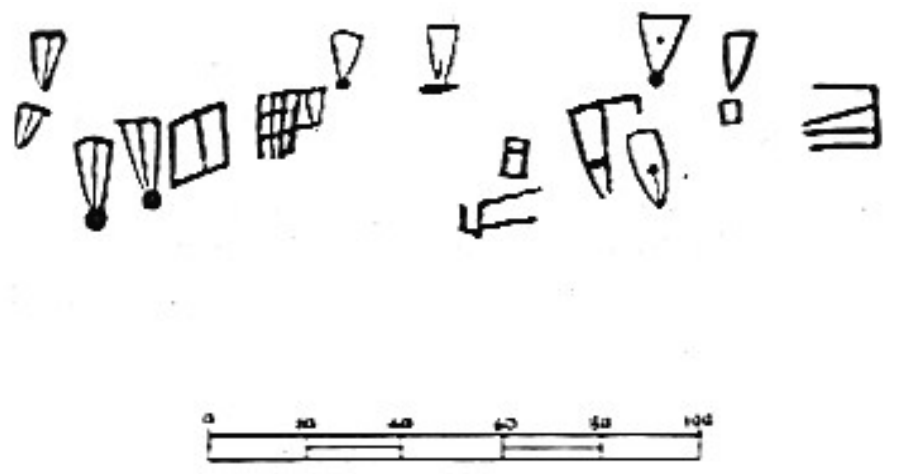


Os painéis dos sítios Urubici 2 e 14 apresentam os mesmos tipos de grafismos já comentados para os quatro painéis do Sítio Urubici 1, o mesmo ocorrendo no painel do Sítio Urubici 34 (São Pedro), mostrado abaixo. Neste último, as formas triangulares e quadriláteras foram confeccionadas com formas menos angulares, mais arredondadas, tendência estilística que já se manifesta nos sítios antes citados, e que será muito forte nos grafismos do litoral de SC, como se verá a seguir.

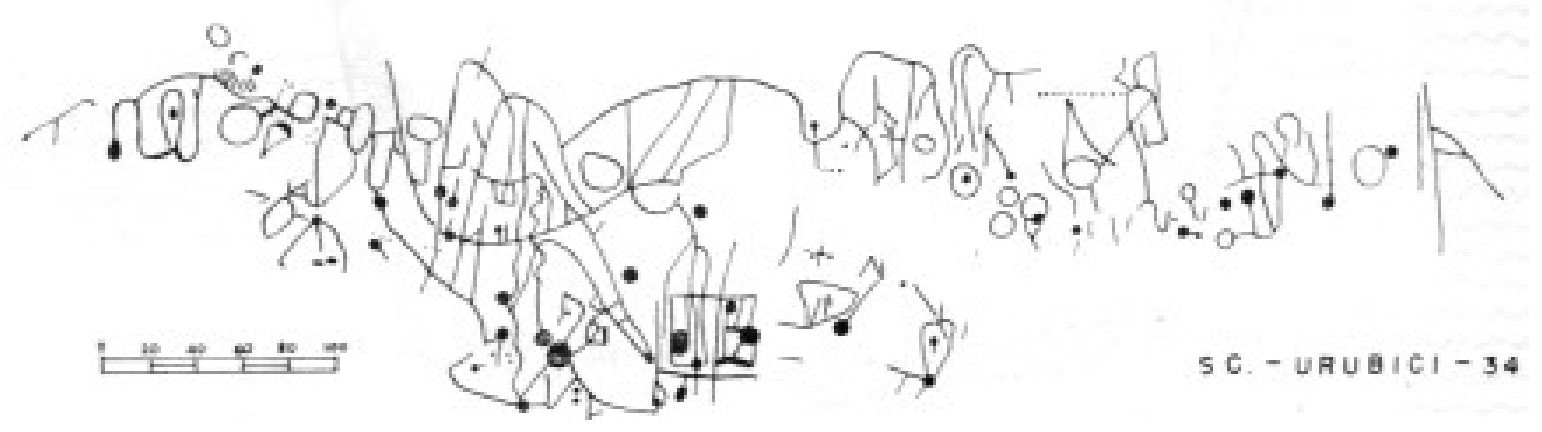

Reproduzido de Rohr, 1971:fig.7.

Os grafismos do litoral de Santa Catarina

Ilha do Campeche

Ocorrem cinco grafismos figurativos antropomorfos no Campeche. $\mathrm{O}$ estilo é bastante esquemático, como para os zomorfos do planalto.

Os grafismos mais característicos são os em forma de triângulo ou losango e as linhas em ziguezague ou onduladas.

Estas linhas em ziguezague ou onduladas ocorrem em quase todos os sítios do RS. A conexão destes grafismos com o sistema de representações visuais Jê do sul, especialmente Kaingang, já foi analisada. Alguns grafismos compostos por linhas onduladas ou em ziguezague sugerem que são estilizações de grafismos losangulares ou triangulares conforme fica evidenciado a seguir ${ }^{67}$.

\footnotetext{
${ }^{67}$ Revelam uma tendência estilística de "arredondamento" das formas angulares, o que já demonstramos para o planalto de SC. Hipoteticamente, e também baseado nos grafismos Xokleng apresentados por Mabilde, todos eles confeccionados em linhas curvilíneas, caberia pensar que estes grafismos rupestres com "estilo arredondado" teriam sido feitos pelos Proto-Xokleng.
} 

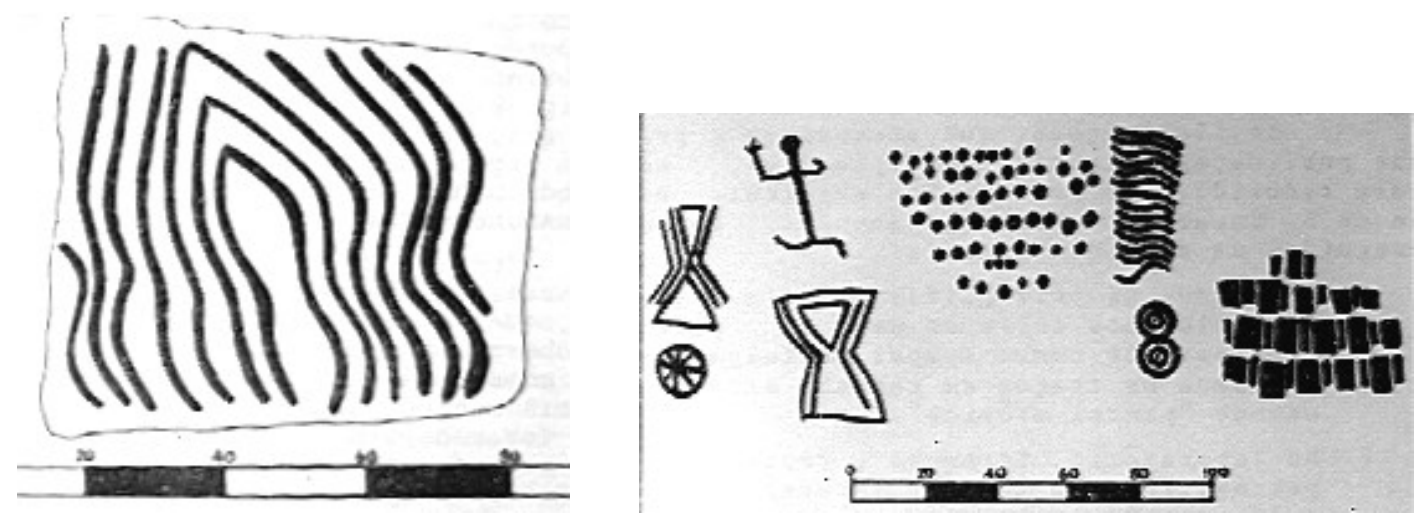

Ilha do Campeche. Reproduzido de Rohr, 1969 a:figs. 9 e 14 .

Esta constatação aproxima Campeche (e os demais sítios litorâneos de $\mathrm{SC}$ ) aos grafismos rupestres do RS (Virador) e, por semelhança formal, aos grafismos de números 1, 2, 3, 4, 8, 9 e 10, apresentados por Mabilde. Igualmente, as representações gráficas que ocorrem nos kurã (mantos) de SP e do PR são formalmente idênticas às aqui comentadas. Apesar de já referida noutro lugar desta tese, é importante enfatizar a conexão destes grafismos com a pintura corporal atual dos Kaingang do RS.

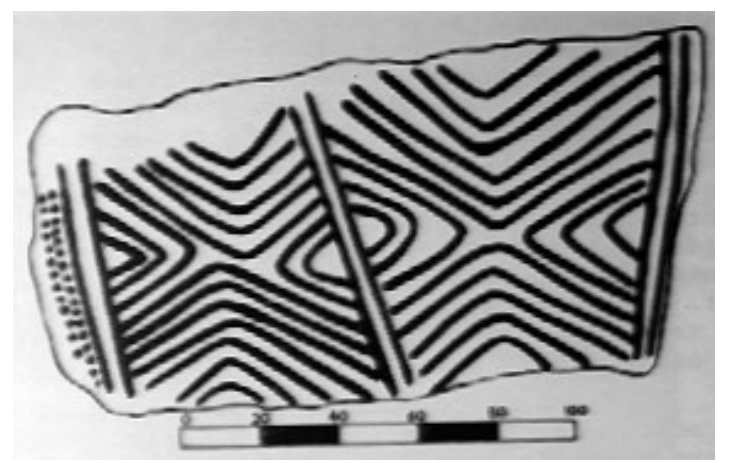

Campeche. Reproduzido de Rohr, 1969 a:fig. 10

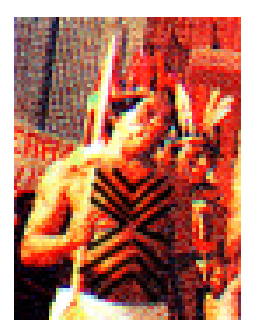

Pintura corporal Kaingang Iraí/RS. Reprozudido de Zero Hora (54.2.99, pág. 23).

Grafismos em forma de quadriláteros, círculos ou pontos estão presentes no Campeche. A princípio, são formalmente semelhantes aos do planalto, conforme se pode ver a seguir. 

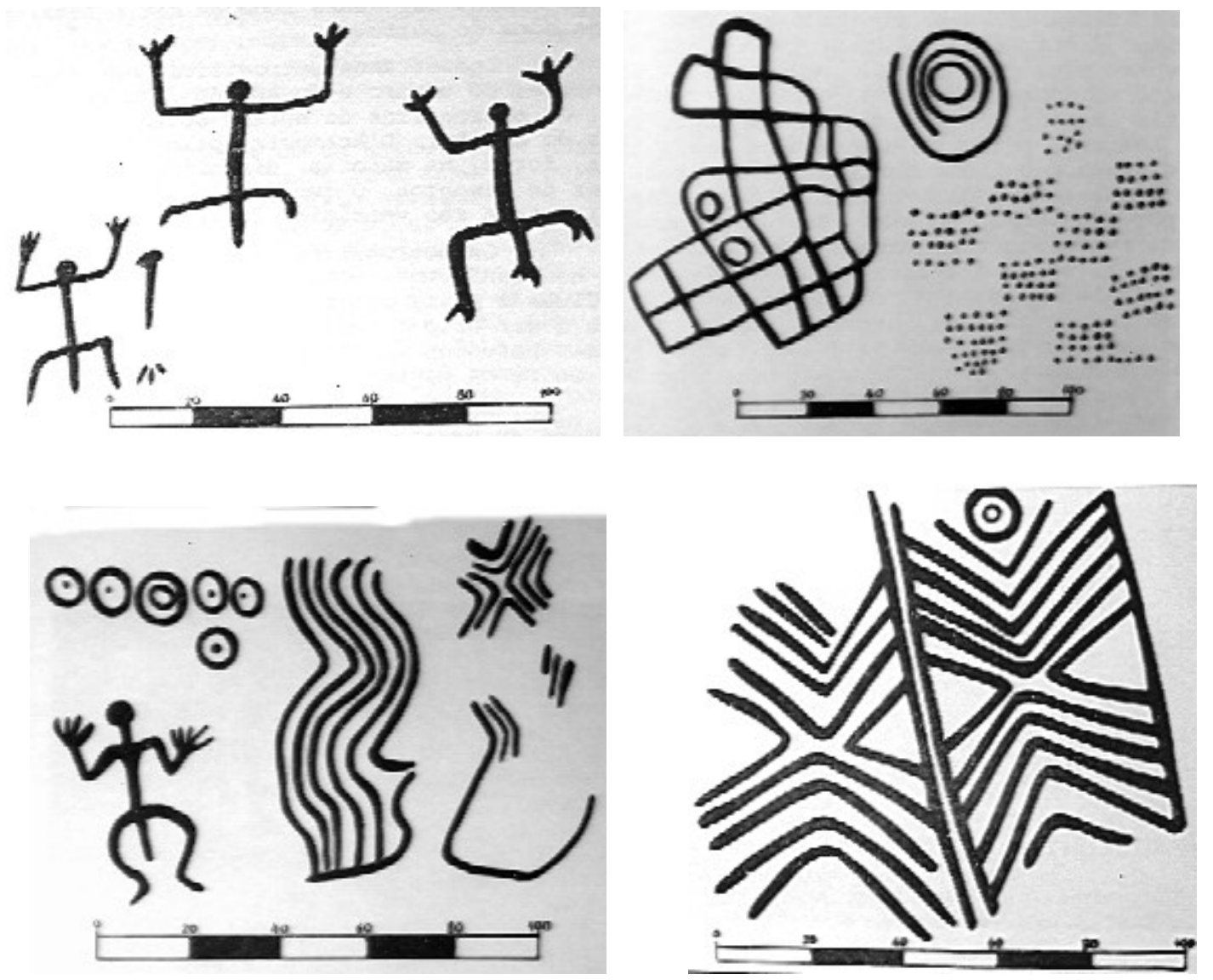

Campeche. Reproduzido de Rohr, 1969 a:figs. 8, 11, 12 e 13, respectivamente.

\section{Santinho}

Os grafismos da Praia do Santinho, abaixo reproduzidos, enquadrar-seiam nesta tendência estilística de "arredondamento" dos padrões losangulares, o que os aproximam das representações rupestres do RS, dos grafismos Coroados de números 1, 2, 3 e 4 registrados por Mabilde, de alguns motivos da pintura corporal Kaingang e da cerâmica Proto-Jê do sul.
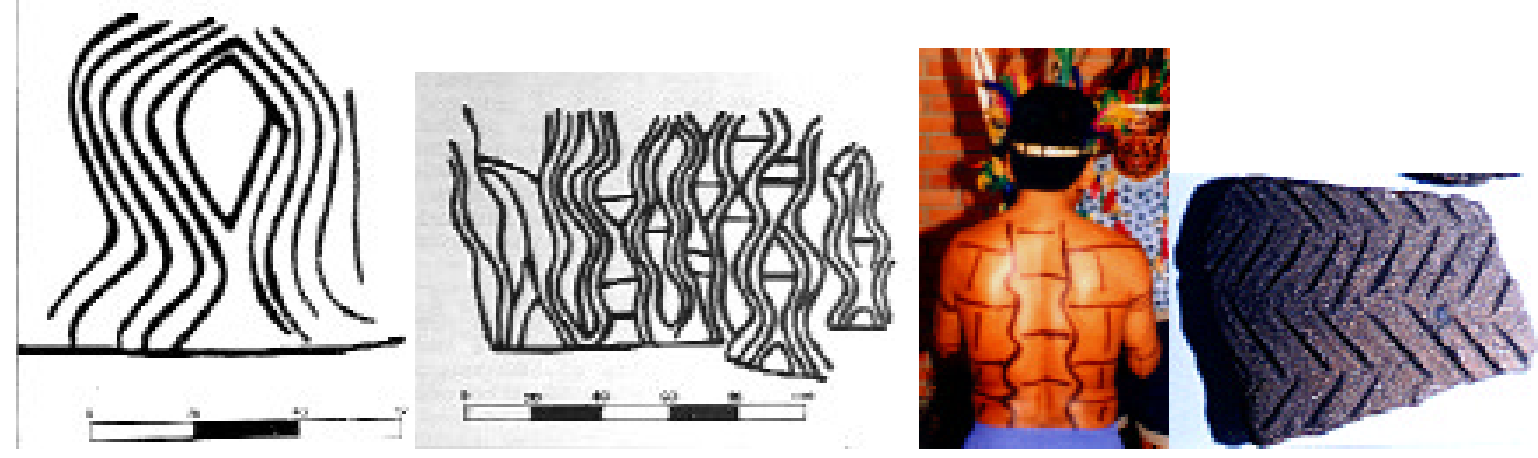

Santinho (Rohr, 1969 a:figs.3 e 5); grafismos corporais Kaingang-RS; cerâmica da "Fase" Guatambu. 
Na Praia do Santinho, igualmente estão presentes grafismos circulares, um possível antropomorfo estilizado e grafismo quadrangular, formalmente idêntico às representações gráficas da cerâmica Proto-Jê meridional.
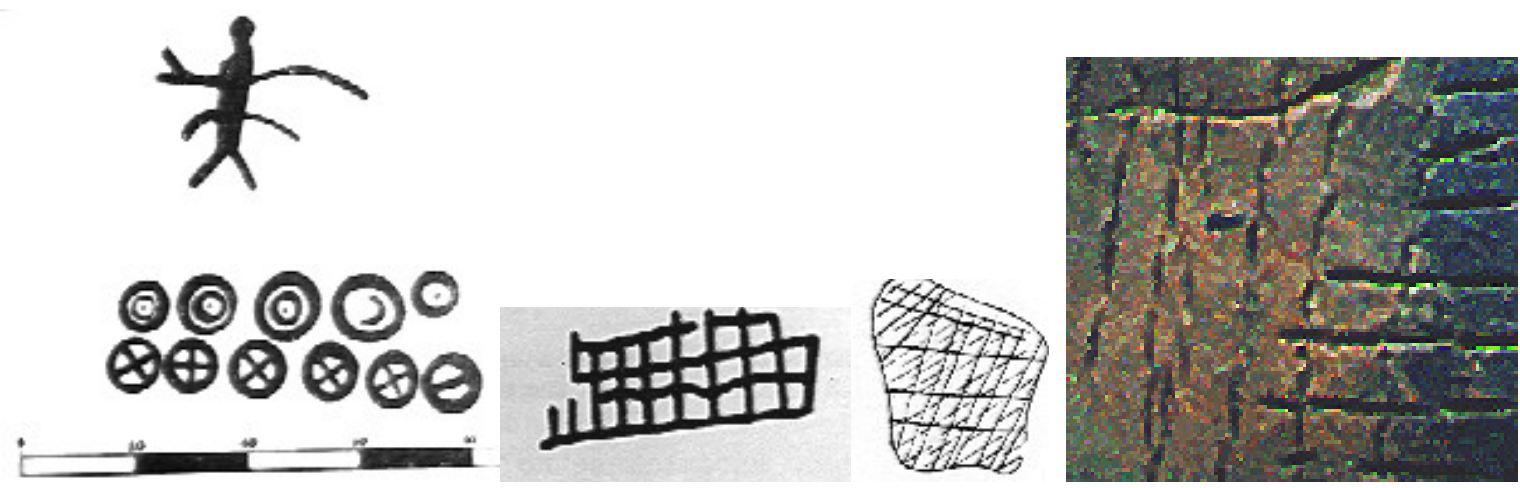

Fotos 1 e 2 - grafismos rupestres da Praia do Santinho (reproduzido de Rohr, 1969 a:figs. 4 e 5 detalhe). Fotos 3 e 4 - grafismos na cerâmica Proto-Jê do sul: Urubici-SC (reproduzido de Rohr, 1971:fig.9) e Morro da Formiga-RS (RS-S-61; MARSUL)

\section{Corais}

No painel rupestre da Ilha dos Corais, ocorrem grafismos antropomorfos estilizados, circulares, triangulares e linhas onduladas paralelas. Ressalte-se o grafismo à direita, parte central do painel, formalmente semelhante aos grafismos de números 9 e 10, registrados por Mabilde. A junção de alguns grafismos circulares com linhas onduladas ou retilíneas lembra uma das representações presentes no Abrigo de Itapeva SP, comentado mais adiante.

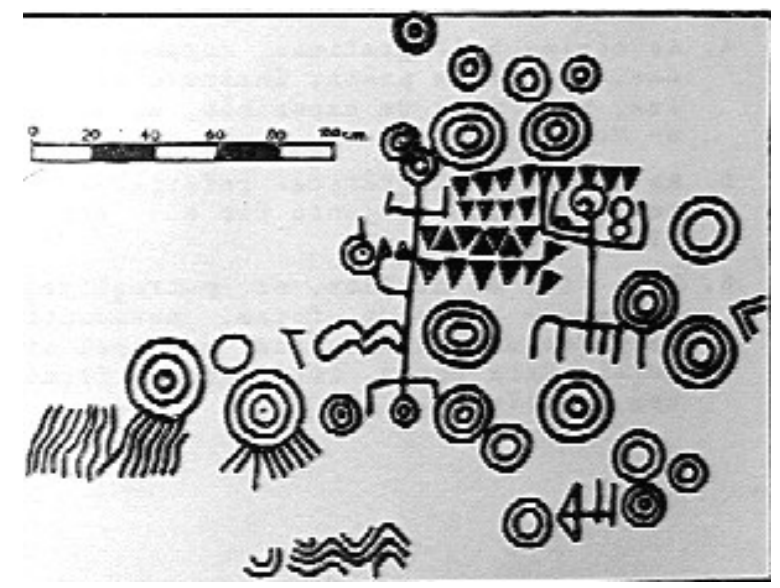
1969 a:fig. 15. 


\section{Ilha João Cunha}

Os grafismos losangulares, isolados, concêntricos, ou dispostos em linha reta (os dois últimos no "estilo arredondado") remetem às conexões com o RS, PR e SP: grafismos rupestres do Virador-RS, representações gráficas de numeros 2 e 3 (Mabilde), e grafismos presentes em kurã (mantos) de SP e $\mathrm{PR}$, além de ocorrerem em objetos kaingang no RS (garrafa tufy).

Da mesma forma, o grafismo fitomorfo (parte inferior esquerda do Painel 1) indica as ligações com o RS: arte rupestre de vários sítios, grafismo do cacique Nhancuiá e pintura corporal (téi - kamé) dos Kaingang. No Paraná, tem-se o mesmo grafismo gravado na cerâmica da "Fase" Casa de Pedra.

Em João Cunha, alguns grafismos quadrangulares, com ou sem ponto no seu interior, fazem a conexão com o planalto catarinense e com o RS. O mesmo acontece em relação aos grafismos lineares, que apresentam-se retilíneos, ondulados e em forma de "Y".
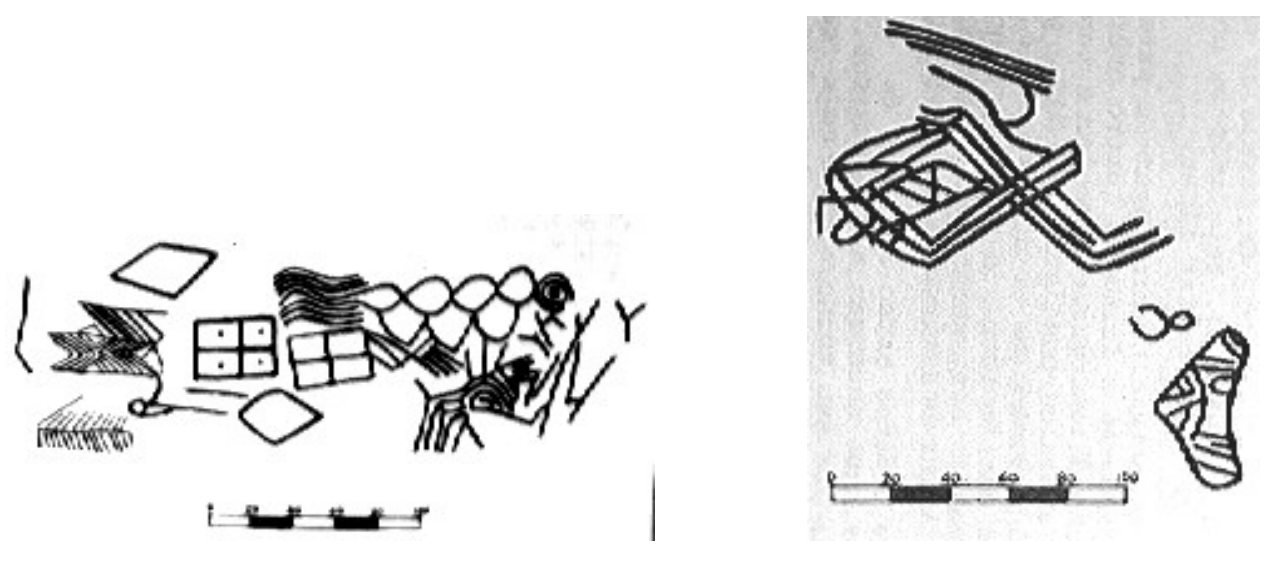

Ilha João Cunha. Reproduzido de Rohr, 1969 a:figs. 1 e 2.

Ilha do Arvoredo

Ambos os painéis da Ilha do Arvoredo, reproduzidos a seguir, apresentam motivos losangulares, cuja importância para fazermos as ligações formais espaço-temporais no sistema de representações visuais Jê do sul já foi trabalhada. O mesmo ocorre em relação aos grafismos em forma de pontos ou círculos, isolados, dispostos linearmente ou alinhados em traços paralelos. Note-se, ainda, a presença de grafismos antropomorfos estilizados. 

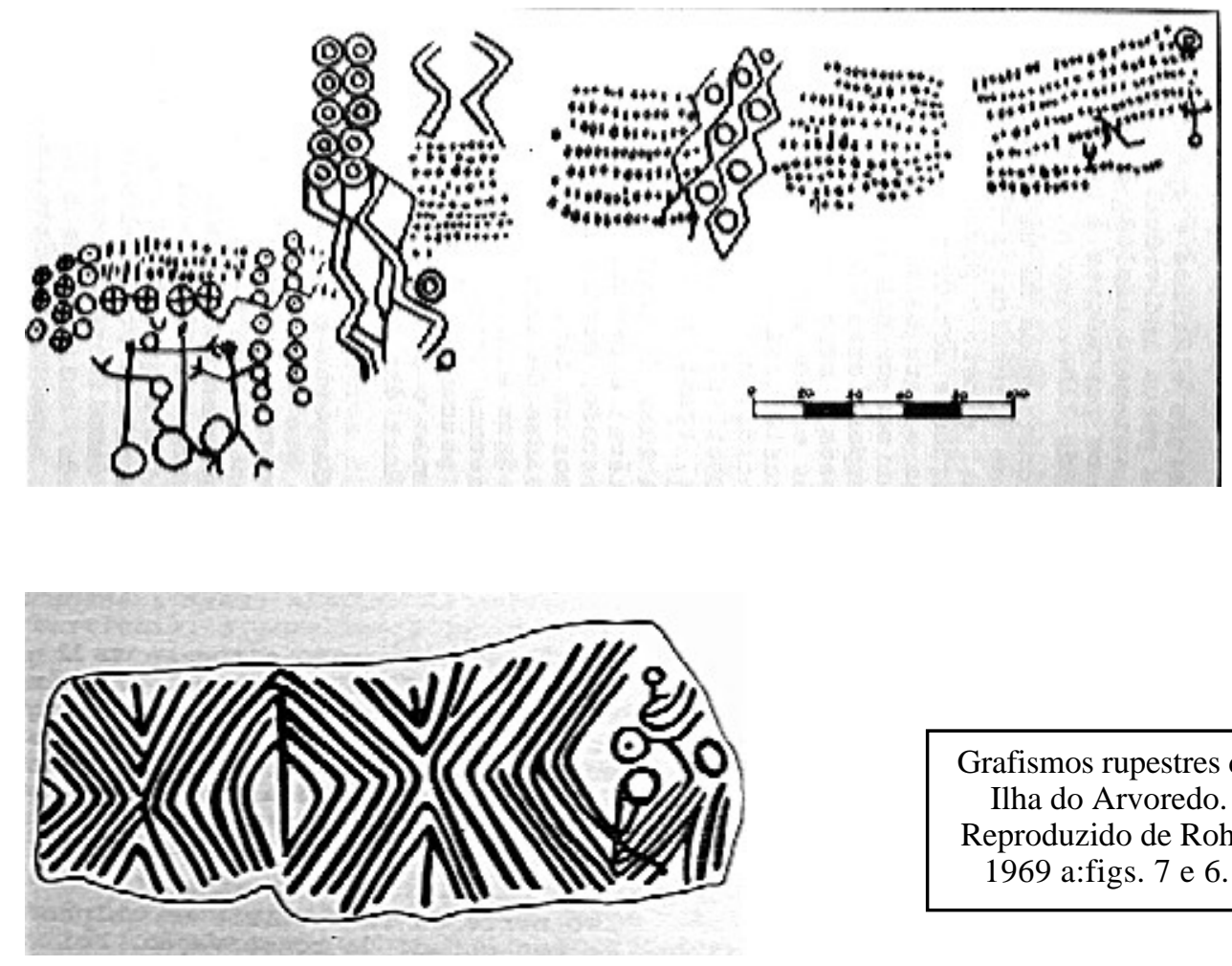

Grafismos rupestres da Ilha do Arvoredo. Reproduzido de Rohr, 1969 a:figs. 7 e 6.

Estas semelhanças entre a arte rupestre encontrada nos estados do RS, SC e PR já haviam sido notadas no passado, nos primeiros anos da arqueologia no sul do Brasil, tanto por Rohr e Chmyz como por Ribeiro, cuja longa citação abaixo confirma. Incompreensivelmente ${ }^{68}$, após estes anos iniciais, esta posição, como já se viu, perdeu sua força, desaparecendo dos meios arqueológicos. Assim, como testemunho histórico desta postura inicial, Ribeiro ponderava em 1969/70, a respeito dos grafismos do Virador-RS:

"Também possuímos desenho de uma inscrição nas proximidades de Montenegro e portanto próximo as por nós encontrado, sinais tridáctilos, linhas em zigue-zague, quadrados contíguos, traço maior com pequenos dispostos obliquamente ao maior e paralelos entre si, etc.

"Em direção norte, encontramos semelhanças no estado de Santa Catarina, na localidade de Ribeirão do Ouro, nas proximidades de Brusque, através de um desenho anotado e colocado dentro de um livro existente no Museu do Homem do Sambaqui e que pertencia a antiga coleção Borhausen. São os tridáctilos, os pontos, letras "V", os mais característicos. Por informação verbal do Padre João Alfredo Rohr, S.J., disse-nos haver certas semelhanças das nossas incrições com o que tem

\footnotetext{
${ }^{68} \mathrm{Ou}$ nem tanto, pois "não são os fracassos em alcançar uma solução que desacreditam um conjunto de teorias. Um paradigma teórico é abandonado quando desaparece num momento histórico o consenso da comunidade científica em torno dele". Conforme Montero (1986:63), baseada em T. Kuhn, A estrutura das revoluções científicas.
} 
encontrado no Planalto Catarinense (arredores de São Joaquim). Comparando com sua última publicação "Petroglifos da Ilha de Santa Catarina e Ilhas Adjacentes" (Rohr, 1969), diríamos que existem semelhanças, no conjunto, apenas com os petroglifos da Ilha "João Cunha", de Porto Belo. Aí vemos losângulos, quadrados contíguos com ponto central, linhas maiores com menores oblíquas a ela e paralelas entre si, letras "Y" em várias posições, linhas que se entrecruzam porém aqui de lados arredondados (nós denominamos losângulos contíguos). Nos demais, apenas a figura isolada do losângulo concêntrico que vemos na figura 6 , relativo a Ilha do Arvoredo.

"Outra informação verbal de existirem certos traços de similitude, foi a do Prof. Igor Chmyz, arqueólogo da Universidade do Paraná. Comparou certos símbolos nossos com os que encontrou no abrigo Casa de Pedra ('O sítio arqueológico PR UV 1 (Abrigo-sob-rocha Casa de Pedra)' - Arqueologia no. 3, 1967 - Universidade Federal do Paraná - Faculdade de Filosofia - Departamento de Antropologia)." (Ribeiro, 1969/70:125)

Vejamos, portanto, os grafismos no Paraná.

\subsubsection{Grafismos rupestres no Paraná: alguns exemplos}

Conforme já foi descrito no Capítulo 3, dois sítios arqueológicos no Paraná contêm grafismos rupestres gravados: Abrigo Bruacas e Sítio TêmQue-Vêr. Outros abrigos, logo a seguir comentados, possuem grafismos pintados.

Chmyz (1969 a) localizou no Município de União da Vitória um abrigo sob-rocha que ele denominou de Abrigo Bruacas (PR UV 17). O sítio foi escavado, e nos $15 \mathrm{~cm}$ superficiais apareceu cerâmica das ditas "tradições locais planálticas" ${ }^{69}$ : 90\% lisa e $10 \%$ com técnicas decorativas que incluem "Bruacas Polido Estriado, Bruacas Pinçado, Bruacas Cestaria Impressa, Pinaré Malha Impressa, Bruacas Escovado, Bruacas Ungulado e Bruacas Ponteado". Esta última técnica, de acordo com o autor, abrange três sub-tipos, segundo a forma deixada na cerâmica pelo instrumento ativo: A - formato retangular com extremidade superior arredondada; $\mathrm{B}$ - forma triangular; e C - forma quadrangular. Todos, portanto, grafismos fechados. Os abertos ficariam por conta das demais técnicas, com exceção dos tipos Bruacas Cestaria Impressa e Pinaré Malha Impressa, dos quais nada pode ser dito, pois não há fotos nem desenhos dos grafismos na publicação.

\footnotetext{
69 "Fase” Candoi da “Tradição" Itararé.
} 
Os grafismos rupestres gravados no Abrigo, também revelam graficamente a oposição aberto/fechado :: comprido/redondo, e são assim descritos pelo autor:

"Os mais freqüentes são os círculos que formam alinhamentos paralelos. Estes círculos têm, em geral, $2 \mathrm{~cm}$ de diâmetro e cerca de $5 \mathrm{~mm}$ de profundidade. Outros conjuntos representavam sulcos alongados como os causados pelo polimento de artefatos de pedra" (Chmyz, 1969:124).

Não há datação absoluta para o local, mas o autor, baseando-se nas evidências materiais, estima entre 650 a 1790 A.D.

Nesta mesma área (Rio Iguaçu), Chmyz (1968d; 1969b) localizou um bloco de diabásio com petroglifos junto a sítio superficial com cerâmica da "Fase" Casa de Pedra (Sítio Têm-Que-Vêr, PR UV 5). O autor achava prematuro estabelecer, naquela época, correlação entre a "Fase" Casa de Pedra e os grafismos rupestres, apesar de perceber "certa semelhança entre o animal estilizado no caco cerâmico e algumas figuras gravadas na rocha", (Chmyz, 1969b:116), especificamente as que ele separa como sendo de grupo "c", conforme abaixo reproduzido.

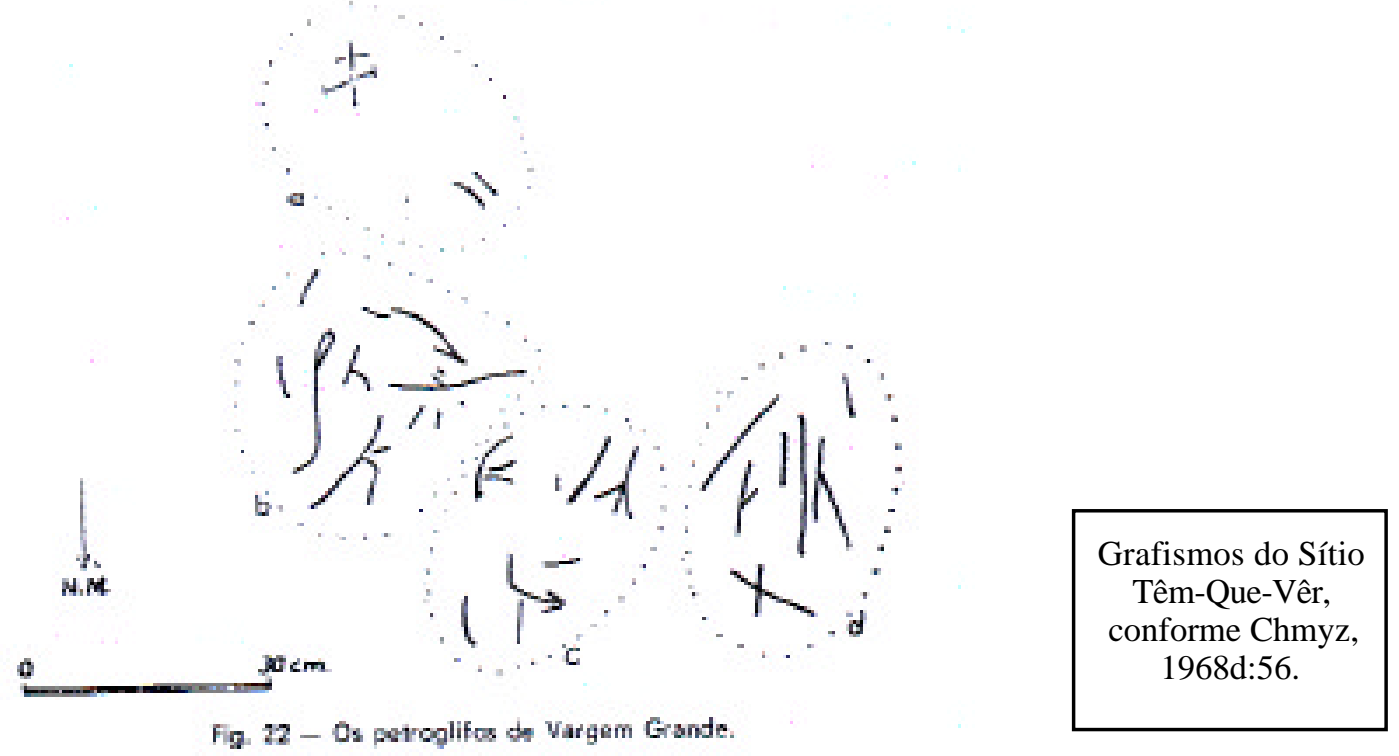




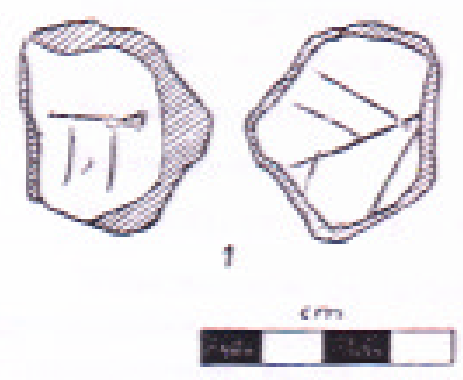

Fragmento cerâmico (frente e verso) com grafismos. Abrigo Casa de Pedra. Reproduzido de Chmyz, 1968d:59.

O animal estilizado no fragmento cerâmico Proto-Jê meridional (do abrigo da "Fase" Casa de Pedra) permite que se possa afirmar que a arte figurativa coexistia com grafismos geométricos desde $1.150 \pm 50$ d.C. (SI141), conforme a datação radiocarbônica para a "Fase" ${ }^{70}$. Além disso, podese estabelecer hipoteticamente a possibilidade de as populações Proto-Jê meridionais serem autoras de painéis com zoomorfos gravados, como é o caso deste bloco de diabásio ligado à "Fase" Casa de Pedra ${ }^{71}$, ou pintados, como passaremos a discutir a seguir. Esta possibilidade, sem dúvida, alarga o horizonte das futuras pesquisas sobre arte rupestre no sul do Brasil ${ }^{72}$.

Blasi (1972) estudou um abrigo-sob-rocha, a Lapa Floriano, próximo à cidade de Tibagi, no Vale do Rio Iapó, rico em pinturas e desenhos de animais (cervídeos, peixes, porcos-do-mato, cobra), quase todos representados em dimensões reduzidas. O sítio foi escavado, revelando material lítico ("perfeitamente ligado às atividades venatórias") e cerâmico, cujos quatro fragmentos encontrados são de "distintas vasilhas (...) de feitura indígena, associadas a artefatos líticos, que foram utilizadas por indivíduos coletores e caçadores, num abrigo de reduzido espaço para habitabilidade" (op. cit., pág. 9). Um dos fragmentos apresenta, na face interna, "leve camada de coloração avermelhada, muito semelhante aos fragmentos de ocre [corantes] encontrados no chão do abrigo" (idem, pág. 14), o que faz o autor suspeitar do possível uso de pequenos recipientes cerâmicos "para a preparação da pasta utilizada na elaboração das pinturas" (ibidem, pág. 14). Tal cerâmica, na época da escavação não foi relacionada explicitamente às "tradições locais planálticas", que iniciavam a ser reconhecidas pelas pesquisas incipientes ${ }^{73}$.

\footnotetext{
${ }^{70}$ Note-se que a na outra face deste fragmento cerâmico ocorre um grafismo geométrico descrito por Chmyz como "as ramificações de um galho de árvore" (Chmyz, 1969:116), tipicamente Jê meridional, conforme já demonstrado.

${ }^{71}$ Junto ao bloco com grafismos foi encontrado, na superfície, material lítico e cerâmico simples (Chmyz, 1968d:59; 62), ligado à "Fase" Casa de Pedra, Proto-Jê meridional.

${ }_{73}^{72}$ Como já visto, no Cerro do Baú-RS, ocorre zoomorfo estilizado de tamanho reduzido gravado no arenito.

${ }^{73}$ Blasi, sem as informações que hoje possuimos, pensava, naquela época, que "os Caingangue, que ocupavam expressiva porção do território paranaense, parecem ter adquirido conhecimentos [cerâmicos] dos próprios Tupi-Guarani, isto pouco antes do início dos tempos históricos" (Blasi, 1972:17).
} 
Certamente, não é cerâmica de "Tradição" Tupiguarani. Pelos desenhos apresentados das formas e das bordas dos recipientes, bem como pela sua descrição, trata-se de cerâmica ligada às populações Proto-Jê meridionais.

Na Lapa Floriano, há desenhos (só contornos) feitos com óxido de ferro e pinturas monocromáticas, realizadas com óxido triturado ao qual foi adicionado algum líquido ou pasta (Blasi, 1972).

Estes fatos indicariam, segundo o autor, a "suposição de que os autores das pinturas e desenhos tenham sido os mesmos que confeccionaram as peças cerâmicas" (op. cit., pág. 14).

Do ponto de vista das evidências arqueológicas demonstradas, tal hipótese é bastante plausível. Além do mais, esta possibilidade se alarga quando nos lembramos que a coexistência de representações figurativas e geométricas é perfeitamente esperada, já tendo sido demonstrada em relação a populações Proto-Jê meridionias (Sítio Têm-Que-Vêr, conforme acima) e no que diz respeito a grupos Kaingang (de acordo com o referido na parte final do subitem 5.3.1.).

$\mathrm{Na}$ Lapa Floriano, há pinturas geométricas ${ }^{74}$ lado a lado com grafismos zoomorfos.

A coexistência de pinturas geométricas com zoomorfos também ocorre na Lapa Ponciano, localizada na mesma margem do Iapó, a $3 \mathrm{Km}$ da Lapa Floriano. Tais pinturas geométricas são formalmente semelhantes aos grafismos (Proto)Jê meridionais. Tratam-se de "conjuntos de traços verticais, equidistantes, quase todos da mesma espessura e altura, sendo que um deles está limitado, tanto na parte superior como na inferior, por traços horizontais" (op. cit., pág. 10) ou "retângulos e semi-círculos, circundados por linhas retas e curvas; série de pontos dispostos paralelamente; traços isolados e em semicírculo com curto traço perpendicular"(idem, pág. 11).

Junto ao instrumental lítico escavado na Lapa Floriano, há gravadores em quartzo, apesar de não haver grafismos rupestres gravados no local. Ao menos, podemos correlacionar tais artefatos às populações Proto-Jê do sul, inferindo, em relação a elas, o uso simultâneo de duas técnicas (gravado, pintura), além da coexistência de dois estilos (geométrico, figurativo).

\footnotetext{
74 “traços, pontos, linhas e outras formas sem sentido definido" (op.cit., pág. 13).
} 

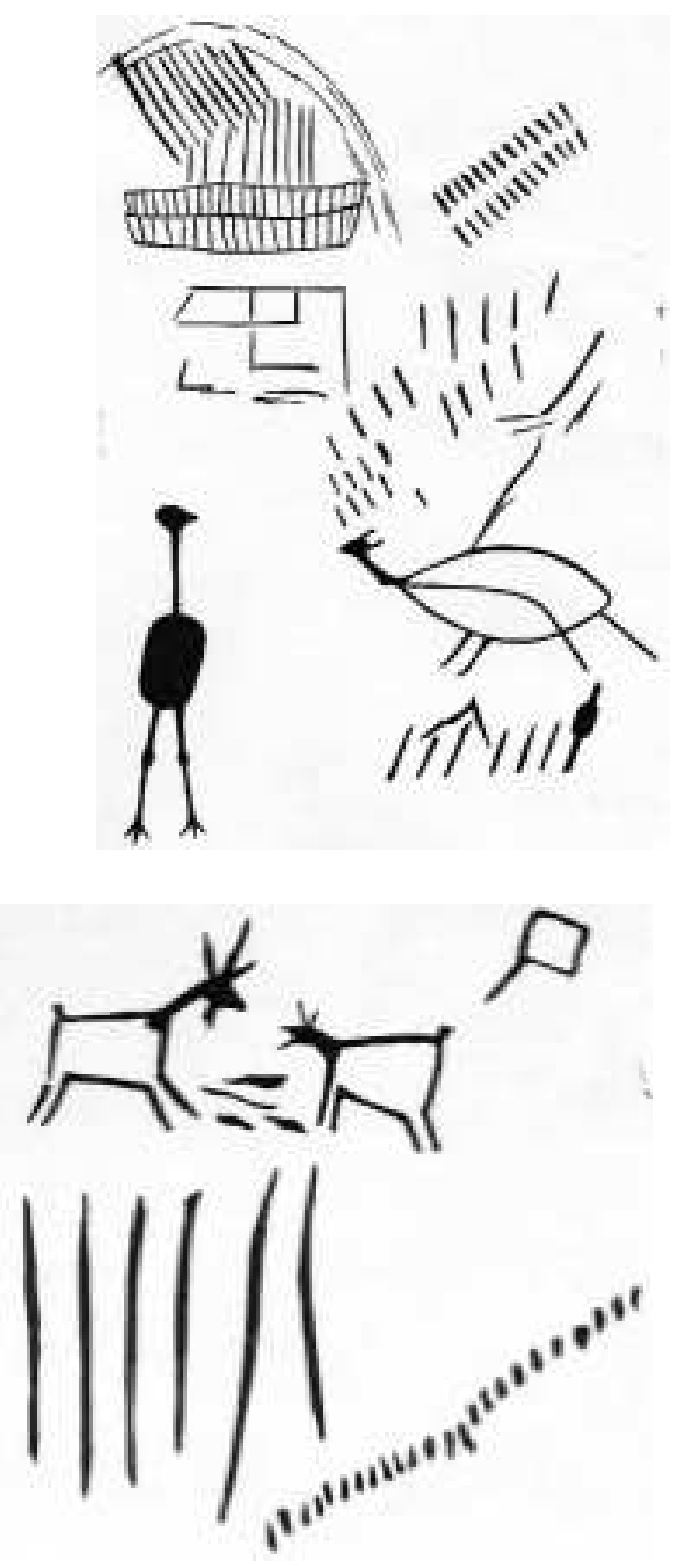
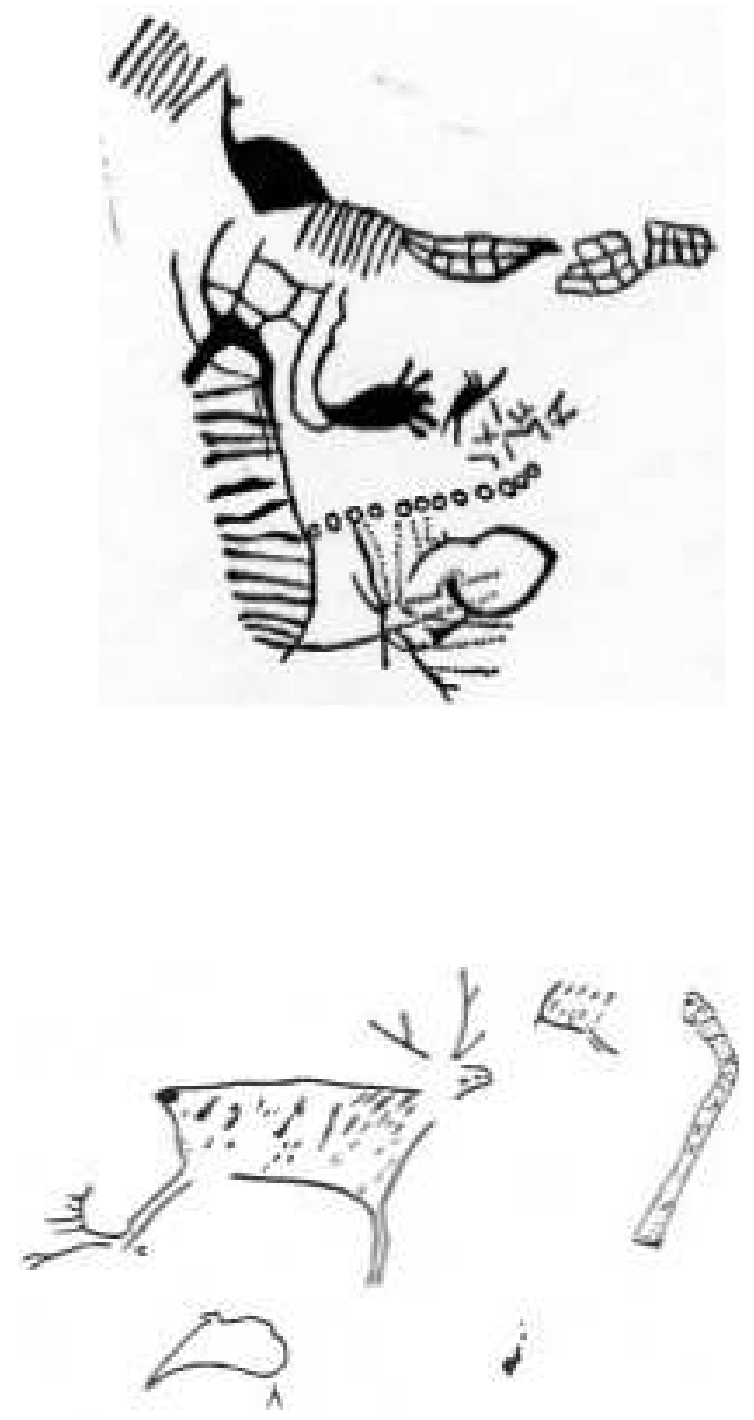

Grafismos do Vale do Iapó-PR. Reproduzidos de Blasi, 1972:figs. 12, 18, 20 e 15, respectivamente. Devido a deficiências no texto original, é impossível estabelecer com precisão a que Lapa (Ponciano ou Floriano) pertence cada grafismo.

Reforçando estas hipóteses, vale lembrar que gravadores em quartzo, ou "gravadores em cristal", também ocorrem nos sítios Barracão e Dionísio Cerqueira (Blasi, 1965), ocupados por populações Proto-Jê do sul da "Tradição" Casa de Pedra, já comentados no subitem 3.2.2., o que nos autoriza a pensar que estas populações possuíam condições técnicas (e os artefatos) para serem as autoras de grafismos rupestres gravados no sul do atual território brasileiro. 
Acompanhados por Blasi, Laming e Emperaire visitaram em fevereiro de 1956 abrigos pintados "no interior do Paraná, perto da fronteira deste Estado e o de S.Paulo, no limite dos municípios de Piraí do Sul e de Tibagi" (Laming \& Emperaire, 1968:82), região próxima ao Vale do Iapó-PR.

Nestes abrigos, estão presentes, lado a lado, o estilo figurativo, representando zoomorfos (cervídeos, aves), e o estilo geométrico. Quanto à técnica, temos a pintura, geralmente vermelha e raramente amarela. A técnica da pintura de zoomorfos tem duas variantes, segundo os autores: a cor pode ser uniformemente espalhada, sugerindo a forma do animal, ou "substituída por traços paralelos e horizontais" (op.cit., pág. 83). É interessante notar que os Kaingang do Ivay (Paraná), na segunda metade do século XIX, conforme já visto, representavam zoo e antropomorfos com esta mesma técnica de preenchimento da forma com traços paralelos.

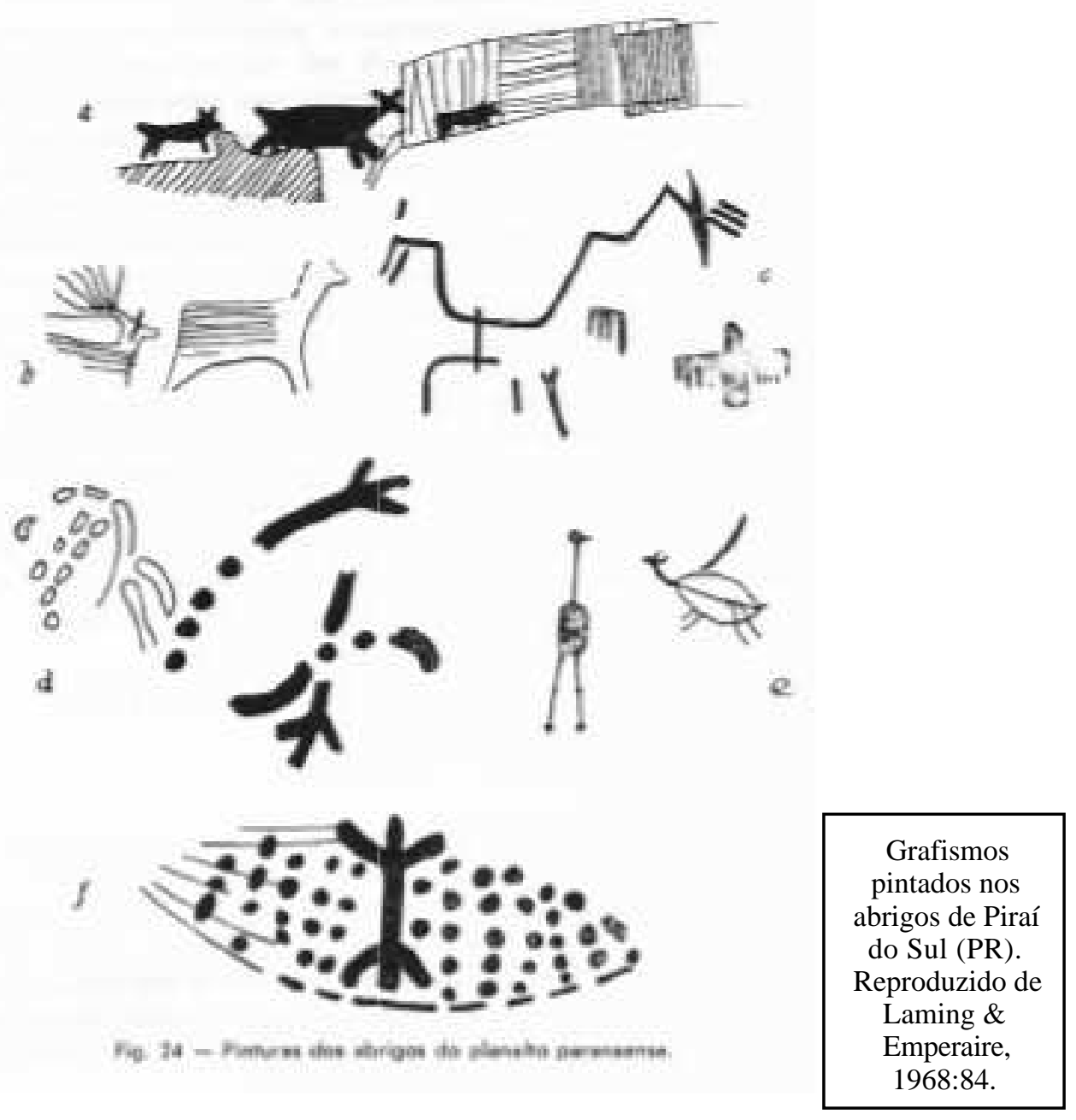


Segundo a descrição que os autores fazem das pinturas zoomorfas, é possível reconhecer uma terceira variante técnica para a sua confecção: "pequenos animais vermelhos desenhados esquematicamente com traço fino" (op.cit., pág. 85). Esta técnica e seus motivos nos remetem ao animal estilizado gravado em fragmento cerâmico Proto-Jê do sul ("Fase" Casa de Pedra) e aos zooformos do Sítio Têm-Que-Vêr, ligado à mesma "Fase".

Os grafismos geométricos pintados dos abrigos de Piraí do Sul podem aparecer na mesma cena dominada pelos zoomorfos. Tratam-se, segundo os autores, de "signos gradeados". Na verdade, tratam-se de grafismos compostos por linhas paralelas, horizontais ou verticais, delimitados por quadriláteros, recorrentes em todo o material (Proto)Jê do sul já analisado. Os grafismos geométricos também estão presentes nos mesmos painéis ou abrigos, sem, aparentemente, participar de uma cena com zoomorfos. São grupos de pontos ${ }^{75}$, "dispostos de várias maneiras, em linha, em círculo, etc.", ou "feixes de traços paralelos" 76 , "diversamente dispostos" (op.cit., pág. 85). Também ocorrem grandes pontos, isolados na rocha.

A semelhança destes conjuntos de grafismos abertos ou fechados, ou das representações simples abertas ou fechadas, com os materiais Kaingang (e Xokleng) atuais seria mera coincidência? Além desta semelhança formal, do uso das técnicas já referidas, e das analogias já comentadas, outro fato levanos a responder negativamente. Idêntico grafismo geométrico pintado presente nos abrigos do Paraná aparece, gravado, no Abrigo Virador ${ }^{77}$, no RS. Ambos assemelham-se formalmente a um dos grafismos dos Coroados do cacique Nhancuiá, apresentados por Mabilde ([1836-1866] 1983).

As idéias expressas no texto de Laming \& Emperaire (1968), publicado originalmente na França em 1956, parecem ser a raiz do modelo que dita (ou dogmatiza?) sobre as "origens" da arte rupestre no Brasil meridional fora do atual território brasileiro, mais para o sul (Patagônia, Pampa). Entretanto, Laming \& Emperaire foram prudentes e humildes:

"O pouco que conhecemos da arqueologia sul americana deixa pressentir que as obras dos altos planaltos se filiam às culturas do sul. Geograficamente as condições de vida da região meridional são muito semelhantes daquelas das estepes argentinas, do que as da região equatorial. Arqueologicamente se conhece nos altos

\footnotetext{
75 "executados com a extremidade do dedo mergulhada na tinta vermelha” (op.cit., pág. 85).

76 "parecem ter sido executados com o auxílio de um pincel fino" (op.cit., pág. 85).

${ }^{77}$ Veja ambos grafismos no subitem 5.3.2.
} 
planaltos: bolas e pontas de flechas idênticas aos mesmos tipos de artefatos, que se encontram em território argentino, em abundância." (Laming \& Emperaire, 1968:92).

Além disso, os autores também avançam outras hipóteses quando constatam a presença de populações com cerâmica no planalto paranaense: "os artistas dos altos planaltos teriam pertencido a populações que praticaram ao mesmo tempo a agricultura e a caça" (op.cit., pág. 92). Esta hipótese nos remete para os inícios do $1^{\circ}$. milênio d.C., isto é, para o horizonte cultural Proto-Jê meridional.

\subsubsection{Grafismos rupestres gravados em São Paulo: três exemplos}

Conforme a sugestão de Prous $\quad(1978 / 79 / 80: 65)^{78}$ e estimulado pelo desconforto manifestado por Guidon $(1978 / 79 / 80: 23)^{79}$, analisamos os grafismos rupestres do Abrigo-sob-rocha de Itapeva, registrados por Aytai (1970). A maioria deles foi gravada no arenito. Aproximadamente na metade deles pode ser ainda percebida tinta vermelha, preta ou amarela no fundo dos sulcos $^{80}$. Os grafismos gravados e pintados são geométricos, exceção feita a apenas três dentre eles, que são figurativos: a representação de um réptil (lagarto?), de uma pegada de macaco e de um pé humano.

Poucas pinturas em vermelho aparecem na mesma parede rochosa. Ao menos a representação de um cervo estava bem preservada. Ao lado desta, possivelmente, havia outro cervo, menor. A pintura do cervo maior foi realizada com a técnica do preenchimento de sua forma com linhas paralelas interrompidas, que como vimos é uma das características técnicas da arte (Proto)Jê meridional.

Aytai (1970), sem se dar conta que os três grafismos figurativos citados foram confeccionados com a técnica do gravado, pensa em autores diferentes para os grafismos gravados e para os pintados, simplesmente por causa dos estilos diferentes, o que teoricamente não faz sentido, como já se viu. Aliás, a

\footnotetext{
78 “...os sítios de São Paulo (...) talvez possam no futuro ser um pouco ligados com alguns sítios do Planalto de Santa Catarina”.

79 "Na realidade, dentro das grandes tradições existem algumas manifestações pequeninas, que não sabemos onde colocar, como essa do Pe. João Alfredo Rohr no litoral e as que publicou para o Planalto, junto com as casas subterrâneas, mais aquelas geométricas de Itapeva (São Paulo)”.

${ }^{80}$ Os grafismos rupestres gravados do planalto catarinense (segundo Rohr, 1971) apresentavam-se pintados com tinta preta.
} 
presença de três motivos figurativos confeccionados pela técnica do gravado desautoriza esta hipótese de autorias sociais diferentes.

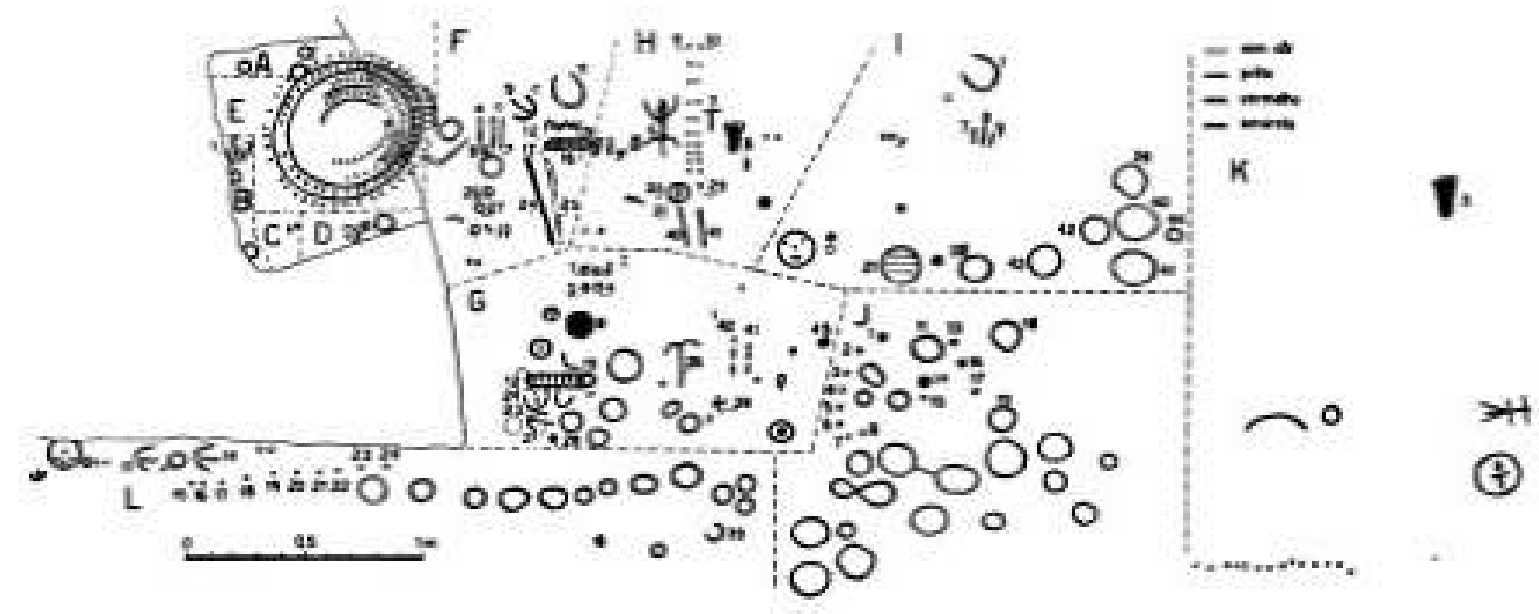

Grafismos gravados (e posteriormente pintados) do Abrigo-sob-rocha de Itapeva (SP). Reproduzido de Aytai (1970:33).

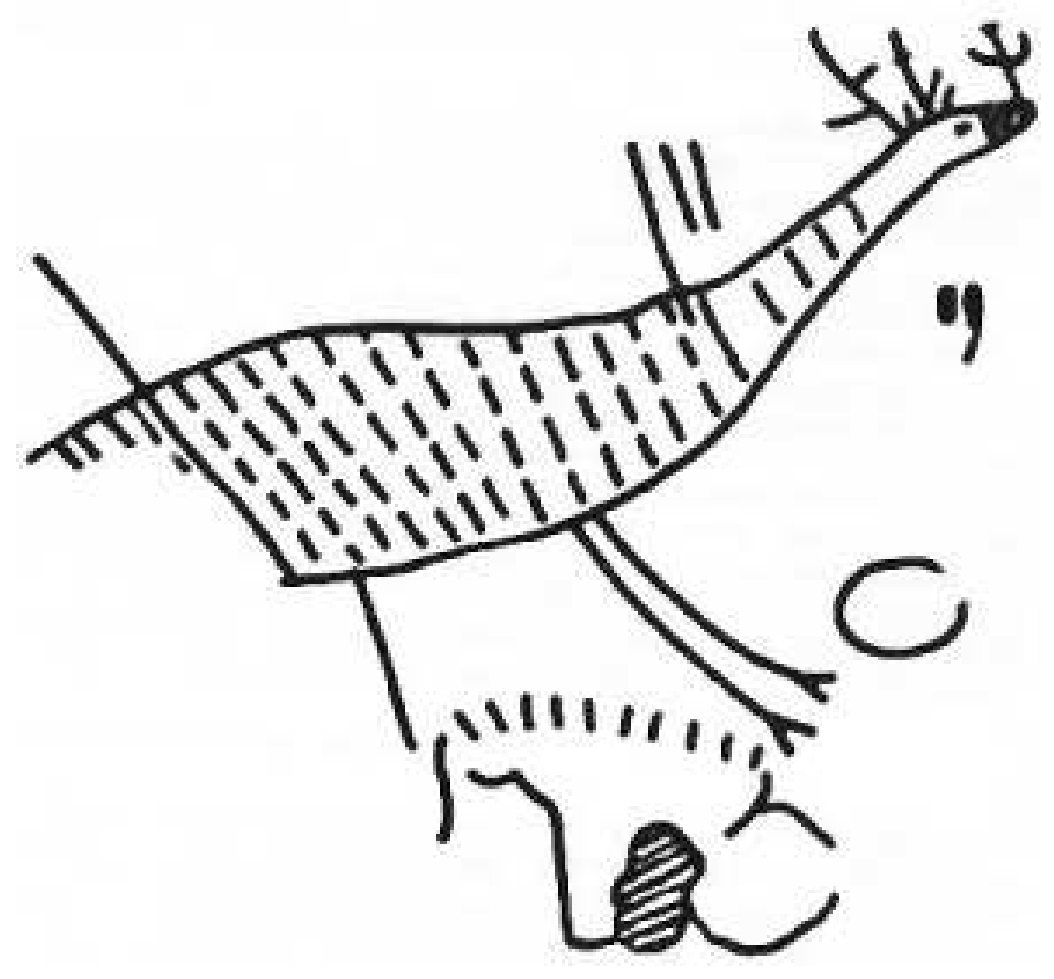

Grafismos rupestres pintados. Abrigosob-rocha de Itapeva - SP. Reproduzido de Aytai, 1970:53.

A cerâmica não-Tupiguarani (Aytai, 1970:37) presente superficialmente no sítio foi assim descrita: 
"Onze fragmentos de cerâmica, todos relativamente finos, - de 3-4 mm de espessura, - bem lisos, alguns com superfície preta dos dois lados, aparentemente de origem indígena. Um caco pertencia à beira de um recipiente só levemente reforçada. Da curvatura das peças, e de sua espessura, temos que concluir que pertenciam a recipientes relativamente pequenos. Todos são bem queimados e de técnica bem desenvolvida" (Aytai, 1970:54).

Pela semelhança entre as cerâmicas, esta descrição autoriza-nos a pensar nas "tradições locais planálticas".

Quanto aos grafismos, os geométricos gravados (e posteriormente pintados) apresentam-se ou como círculos, semicírculos, pontos, na sua maioria, ou linhas, traços, todos dispostos das mais diversas formas ${ }^{81}$. A oposição fechado/aberto, como temática, já nos é conhecida dos Jê meridionais. Ademais, formalmente, as semelhanças com grafismos geométricos gravados de Itapeva com outros sítios do PR, SC e RS são muito fortes. Vejam-se, também, os grafismos localizados na porção F, números 12 a 15, conforme o detalhe da prancha de Aytai (1970), reproduzida abaixo. Eles são bastante semelhantes aos padrões gráficos de Santa Catarina e aos grafismos de números 9 e 10, apresentados por Mabilde ([1836-1866] 1983:146).

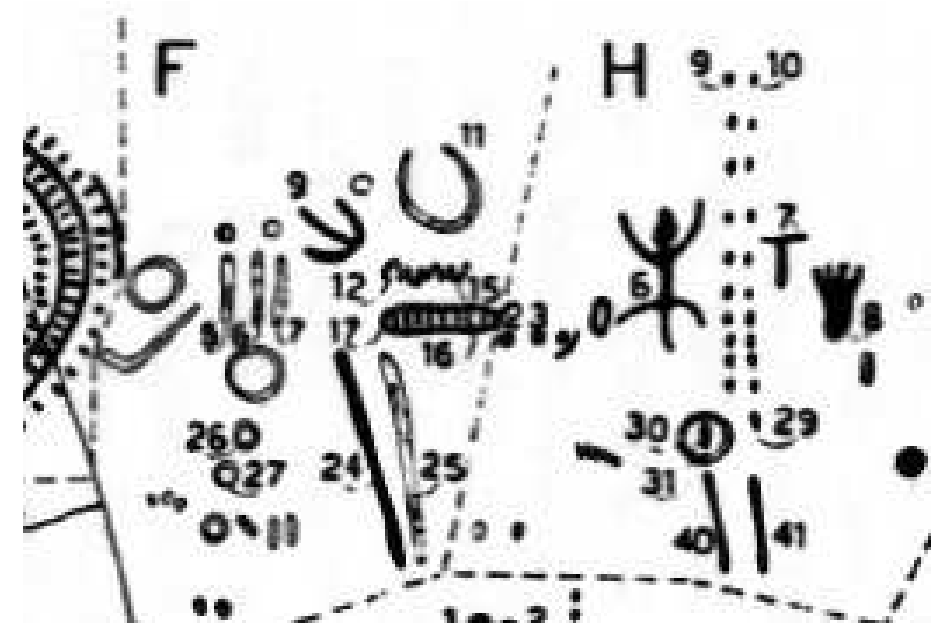

Detalhe da prancha de Aytai (1970:33). Abrigo-sob-rocha de Itapeva

\footnotetext{
${ }^{81}$ Note-se que em Itapeva os "tridáctilos" também estão presentes, apesar de jamais se ter pensado em "origem" patagônica para este painel rupestre.
} 
Segundo Araújo (1994:7), a área onde se localiza o paredão rochoso de Itapeva situa-se "no alto curso do Paranapanema; é uma área de ligação entre o litoral e o planalto, entre o Médio Vale do Ribeira e o Vale do Paranapanema". No seu levantamento arqueológico desta região, o autor registrou a presença de 29 sítios arqueológicos, a grande maioria exclusivamente líticos. Além de Itapeva, onde ocorre cerâmica, foram encontrados mais dois sítios abertos com cerâmica com as mesmas características de Itapeva: de pequena espessura e de coloração castanho-claro ou castanho-escuro. Além disto, foi registrada a presença de três casas subterrâneas na área, uma delas com cerâmica de mesmas características.

Com exceção dos artefatos polidos - mãos-de-pilão, pilões e lâminas de machado -, que já haviam sido recolhidos antes da pesquisa arqueológica pela população local, as características da indústria lítica destes sítios trabalhados por Araújo,

“...colocariam-na no rol das denominadas 'tecnologias expedientes' ou 'oportunistas' onde os produtos de debitagem são obtidos de maneira um tanto assistemática, resultando em coleções líticas compostas em sua maior parte por lascas, sem um conjunto padronizado de artefatos, e com núcleos amorfos (...).

“...a utilização da pedra de modo pouco sofisticado, com o emprego de uma tecnologia expediente que, decerto, deveria atender de maneira bastante satisfatória as necessidades cotidianas de seus fabricantes" (Araújo, 1994:72-3).

Esta indústria lítica "tecno-tipologicamente bastante simples", como ela costuma ser referida, já foi objeto de comentários no Capítulo 3 (págs. 96-7), com referência especial a algumas "fases" da "Tradição" Itararé, e deve ser comparada com os instrumentos "de pedra" dos "bugres", descritos no final do século XIX:

"Os instrumentos de agricultura são de pau: e os fabris, com que os fazem, são de pedra" (Pinto, 1894: 324).

As descrições desta indústria, arqueológica e histórica, parecem fortalecer a idéia de que os artefatos líticos (Proto)Jê meridionais eram na sua grande maioria, exceto as lâminas de machado, pilões e mãos-de-pilão,

\footnotetext{
82 "BUGRES. Nação indígena bastante numerosa. Território: desde o Rio Tietê, em São Paulo, até o Rio Uruguai", conforme Pinto, 1894:324. Citando Ayres de Cabral, Pinto afirma: "Algumas tribos desta nação furam o lábio inferior à guisa dos Botocudos e outras cortam os cabelos em coroas" (op.cit. pág. 324). Fala, ainda, de uma "tribo" que "risca as faces com certa tinta" (idem). A "nação indígena Bugre", então, no final do século XIX, seria uma designação genérica dada às sociedades Jê do sul, "nação" esta que "vagueia pelas serras, ocupando os Estados meridionais" (idem).
} 
passivos, isto é, empregados para confeccionar outros instrumentos, bem acabados e definidos, sobretudo em madeira e, secundariamente, em osso.

Todos estes fatos, somados aos que já foram referidos - de ordem formal e estilística -, indicam a possibilidade de a autoria social dos grafismos rupestres de Itapeva terem sido confeccionados por populações Proto-Jê meridionais. Ademais, Saint-Hilaire (apud Araújo, 1994), em visita à região de Itapeva, em 1820, constatou que os índios Guanhanã habitavam-na. Pelo vocabulário apresentado por Saint-Hilaire, percebe-se que eram grupos Kaingang.

Já no Município de Serra Azul, nordeste de SP, no Vale do Rio Pardo, Uchôa \& Caldarelli (1980) registraram dois sítios com grafismos rupestres gravados por polimento no arenito, distantes apenas $700 \mathrm{~m}$ um do outro: o Abrigo Catingueiro (SP-SA-3) e o Sítio Santo Antônio (SP-SA-2).

No primeiro, os grafismos presentes são: "tridáctilos" (assumidos pelas autoras como pegadas de aves), linha paralelas curtas (interpretadas como rastro bipartido de mamíferos), "sulcos retilíneos isolados ou agrupados, formando figuras complexas" e "depressões circulares", "tanto justapostas como superpostas a esses sulcos" (op. cit., pág. 31-2). As autoras não consideram cronológica a superposição de motivos, interpretando-a como temática.

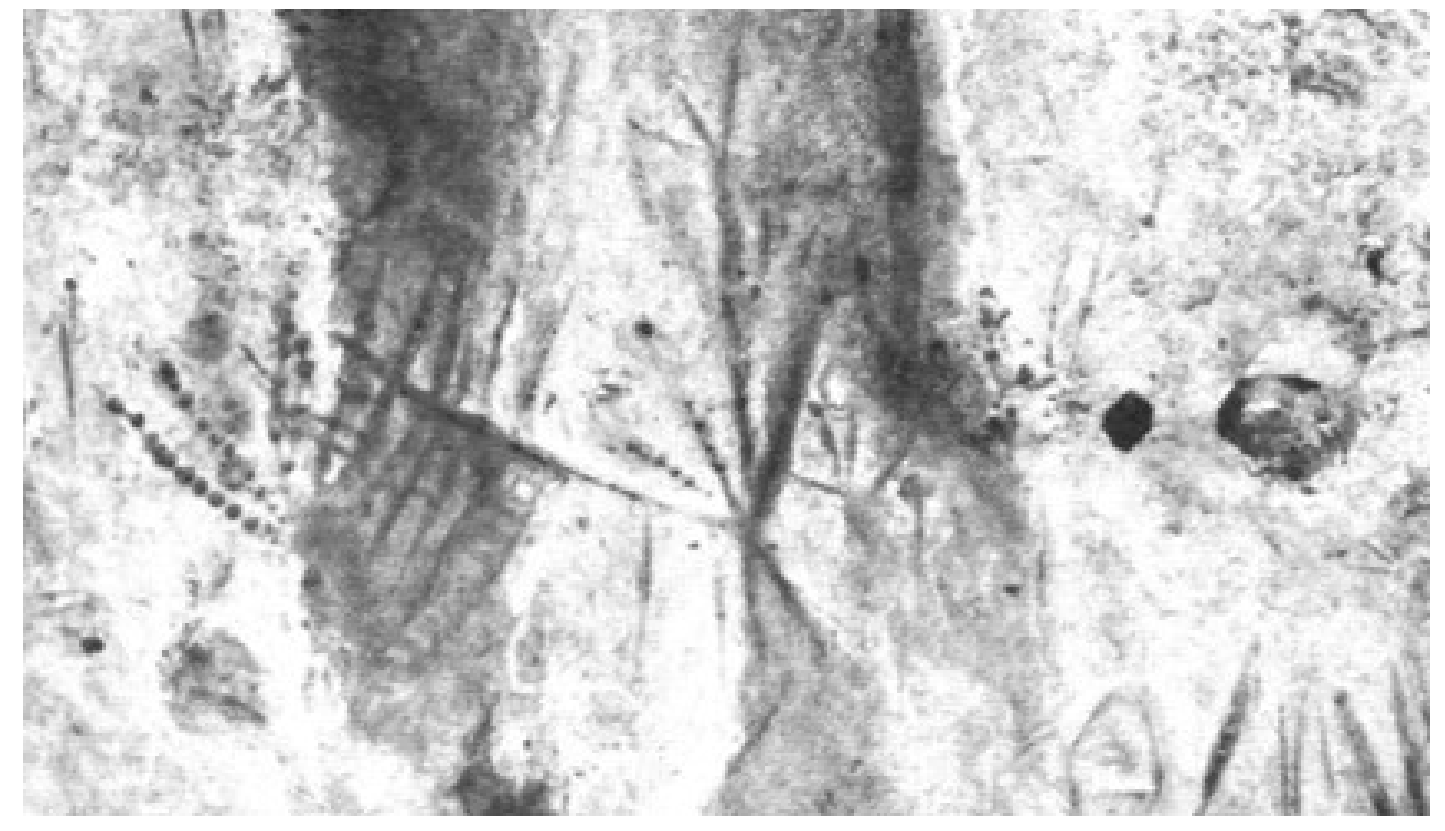

Grafismos do Abrigo Catingueiro. Detalhe do Painel II. Reproduzido de Uchôa \& Caldarelli, 1980:39, fig. 3. 
O Sítio Santo Antônio apresenta "pegadas de aves", "de mamíferos", "de humanos" e "depressões circulares alinhadas" (op.cit., pág. 33). Pelo material que ilustra o texto, pode-se perceber também grafismos lineares longos, isolados ou em conjunto, conforme a figura 6 de Uchôa \& Caldarelli (1980:41), reproduzida abaixo.

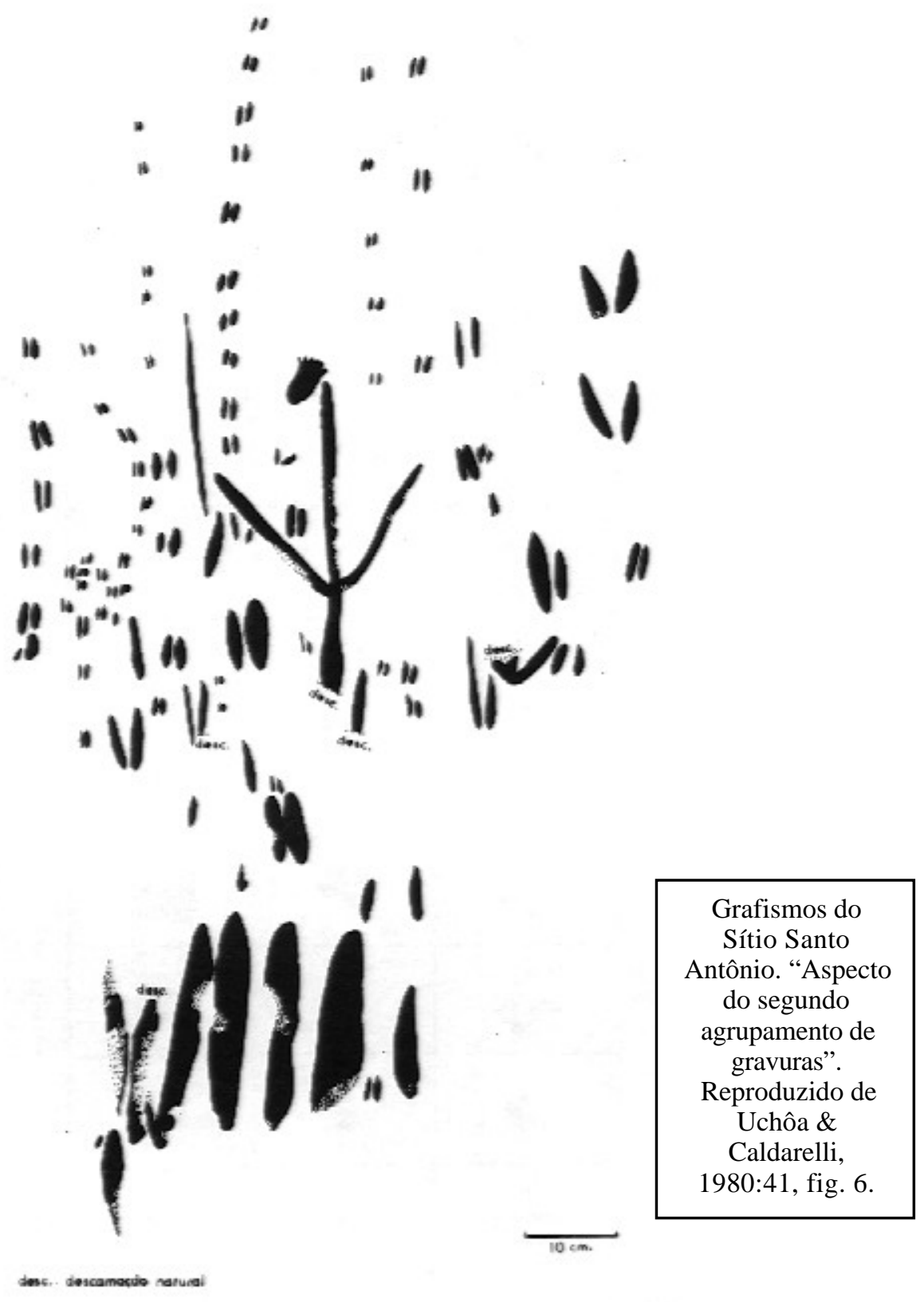


Em ambos os sítios estudados, foram registardos outros grafismos, isolados ou em conjunto, que não foram trabalhados pelas autoras.

À primeira vista, chama a atenção a presença de motivos geométricos lineares/circulares, abertos/fechados, nas composições temáticas onde os grafismos figurativos ("pegadas") ocorrem. Além disso, as semelhanças formais, e de conjunto, dos grafismos do Vale do Rio Pardo (SP) com as representações visuais (Proto)Jê meridionais são marcantes. Veja-se, por exemplo, a reprodução da fig.3 de Uchôa \& Caldarelli (1980:39), onde grafismos lineares compostos são bastante semelhantes aos grafismos de Bom Jardim Velho (RS), Cerro Alegre (RS), entre outros. Quando às representações visuais fechadas, os grafismos da fig. 3, compostos por pontos dispostos linearmente, são recorrentes tanto na cerâmica Proto-Jê do sul como nos materiais etnográficos Kaingang, inclusive na pintura corporal.

De qualquer modo, as pesquisas arqueológicas nestes e noutros sítios com grafismos rupestres no sul do Brasil devem avançar para que se possa compreendê-los mais satisfatoriamente. O modelo etnoarqueológico proposto nesta tese talvez possa auxiliar nesta tarefa.
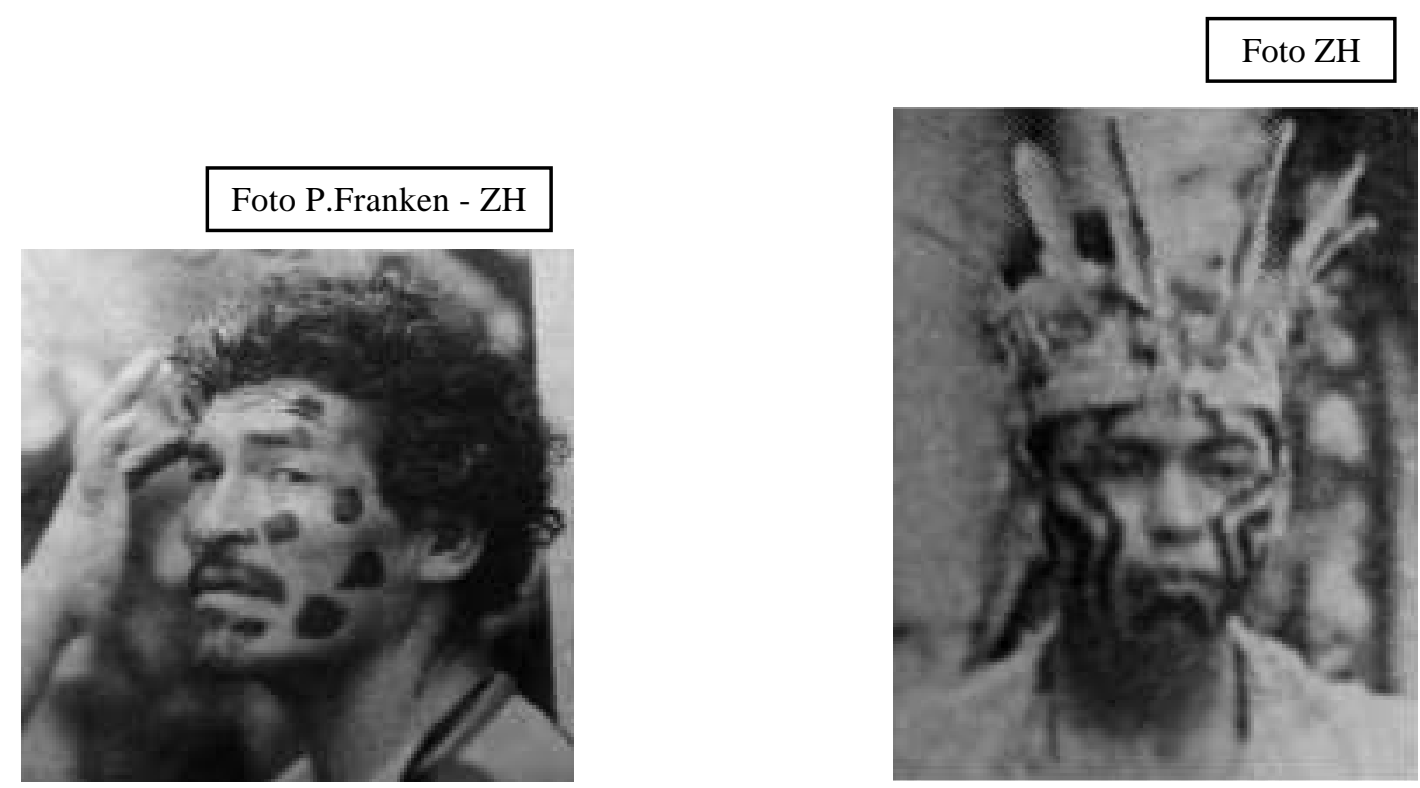

"Caingangues se pintam para reivindicar suas terras de volta", Zero Hora, 13.9.98. Reprodução de detalhe de fotos publicadas na reportagem. 


\section{CONCLUSÕES: O MODELO KAINGANG E O HORIZONTE CULTURAL PROTO-JÊ DO SUL}

O discurso Kaingang estabelece uma classificação dos grafismos geométricos a partir da distinção nativa Kamé/Kainru, única possibilidade de significação dos padrões gráficos apontada pelos interlocutores. Em outras palavras, é a oposição-diferenciação cosmológica Kamé/Kainru que limita, dirige e sublinha o discurso Kaingang a respeito dos padrões gráficos constantes de seus trançados e de sua pintura corporal. Quando o interlocutor não consegue mais reconhecer a oposição Kamé/Kainru presente no grafismo dos trançados, é dito sobre o padrão gráfico, simplesmente, wõfy xinui (trançado bonito, literalmente, ou "enfeite", como os Kaingang a ele referemse em português).

A premissa básica desta classificação nativa dos grafismos geométricos reside nos pares opostos traço/ponto, comprido/redondo, aberto/fechado, que corresponderiam à oposição cosmológica Kamé/Kainru, o que indicaria uma ênfase das representações gráficas no ideal de buscar simetria entre opostos, ou, ainda, de obter fertilidade e eficácia simbólica na união de contrários. Esta constatação tem apoio nas observações de Baldus (1947) com relação à classificação zoológica Kaingang e nas de Nimuendaju (1993 [1913]), onde os tipos de desenhos das pelagens dos animais ou das plumagens das aves indicariam se os mesmos seriam considerados Kamé (desenhos compridos) ou Kainru-kré (desenhos redondos). E como foi exemplificado no Capítulo 4, através da pesquisa de campo, da mesma forma é classificado o mundo vegetal.

A partir destes fatos, constata-se que as oposições aberto/fechado, comprido/redondo são representações mentais dualistas contidas nos grafismos Kaingang, que se limitam a identificar as duas metades percebidas como cosmológicas, opostas e complementares.

Contudo, esta idéia de trabalho possui duas simplificações sobre as representações gráficas Kaingang:

1a.) todo e qualquer grafismo geométrico Kaingang é pensado ou como sendo aberto ou como sendo fechado; 
2a.) todo e qualquer grafismo geométrico Kaingang está ligado única e exclusivamente à divisão dual do cosmo.

A segunda simplificação torna-se mais alargada pelo fato de as seções da metade Kamé e aquelas da metade Kainru-kré possuírem padrões gráficos diferenciados.

No entanto, como trabalhei quase que exclusivamente com os Kaingang do Rio Grande do Sul, onde não há subdivisões das metades, e os Kaingang paulistas do Posto Icatu com quem entrei em contato não mais têm memória precisa dos grafismos destas sessões, não posso acrescentar outros elementos à esta questão.

Por outro lado, as duas simplificações podem ser fruto do atual desconhecimento dos interlocutores Kaingang dos grupos cerimoniais que existiram no passado (tamper - dançarinos, por exemplo), citados na bibliografia mais antiga, memória que meus interlocutores teriam perdido. Há ligeiras indicações na bibliografia de que tais grupos cerimoniais possuiriam padrões gráficos exclusivos (Veiga, 1994) e certamente seriam compostos por membros das duas metades. Há o exemplo do xamã. Alguns de seus objetos não teriam marca. Existem, ainda, as situações rituais em que alguns indivíduos são pintados com as duas marcas, e os casos de objetos com grafismos téi e ror.

No caso dos exemplos baseados nas relações de parentesco, apenas registrei as que se manifestam entre iambré, cunhados, por ser a mais relevante no contexto desta tese e por ser a mais citada pelos interlocutores. Pode, entretanto, haver outro tipo de relações que enfatizem outros aspectos, mas que a pesquisa não revelou.

De qualquer forma, mesmo na hipótese da complexificação (padrões gráficos que identificariam grupos cerimoniais específicos), estaríamos, ainda, diante de uma forte ênfase dualista nas representações mentais, e, conseqüentemente, gráficas da sociedade Kaingang.

Infelizmente, o trabalho de campo quase que exclusivamente com interlocutores Kaingang do RS não conseguiu responder a tais questões no sentido de detalhar e aprofundar a compreensão das suas representações gráficas. 
Refletindo sobre os grafismos Proto-Jê do Sul, que ocorrem na cerâmica arqueológica, nos painéis rupestres do planalto, de sua encosta e no litoral, nas casas subterrâneas e nas galerias subterrâneas, e, ao mesmo tempo, comparando-os com aqueles presentes nos trançados, nos tecidos, na pintura corporal, nas armas e demais materiais etnográficos das sociedades Kaingang e Xokleng do Brasil Meridional, além de compará-los, todos, com aqueles apresentados por Mabilde, percebe-se um conjunto de grafismos comuns, que parecem pertencer a um único e homogêneo sistema de representações visuais, compartilhado por populações Proto-Jê do sul e Jê meridionais, espalhadas pelo tempo e pelo espaço no sul do Brasil e áreas adjacentes.

A percepção deste sistema de representações visuais (Proto)Jê meridional passa pelas seguintes constatações:

$1^{\text {a }}$. Há uma homogeneidade formal entre os grafismos rupestres geométricos do Rio Grande do Sul, de Santa Catarina, do Paraná e de São Paulo, com exceção dos sítios trabalhados por Brochado \& Schmitz (1976), que teriam vinculação patagônica;

$2^{\mathrm{a}}$. Esta vinculação patagônica, ao que tudo indica, parece influenciar os demais grafismos rupestres dos estados sulinos ou parece estar presente, lado a lado, junto aos grafismos Proto-Jê, ou vice-versa, indicando circulação de grafismos, ou movimentos populacionais, ou ambas as coisas ${ }^{1}$;

$3^{\text {a }}$. Os grafismos rupestres do Rio Grande do Sul, de Santa Catarina, do Paraná e de São Paulo estão presentes na cerâmica arqueológica Proto-Jê meridional, inclusive em sítios de São Paulo, do Paraná e de Santa Catarina, onde a maioria das superfícies cerâmicas não recebe grafismos;

4. Alguns padrões gráficos dos materiais etnográficos e da pintura corporal Kaingang e Xokleng são formalmente iguais aos presentes em alguns painéis rupestres e na cerâmica arqueológica do horizonte cultural Proto-Jê do sul nos quatro estados do sul do Brasil;

$5^{\text {a }}$. Há uma correspondência direta entre os grafismos registrados por Mabilde entre os Coroados do final do século passado e aqueles presentes na

\footnotetext{
${ }^{1}$ Pesquisas futuras, mais aprofundadas e detalhadas deverão questionar e delinear com precisão o caráter destas influências. Teria havido movimento de pessoas ou, apenas, uma circulação de grafismos, que, certamente, teriam sido ressemantizados pelas populações do Planalto Sul-Brasileiro? Ou estes grafismos comuns ao Sul do Brasil e à Patagônia são simplesmente grafismos puros, que se repetem indiscriminadamemnte no tempo e no espaço (Guidon, 1984:77-78)?
} 
cerâmica do horizonte cultural Proto-Jê meridional, nos grafismos rupestres do $\mathrm{RS}$ e de SC e nos padrões gráficos presentes na cultura material e na pintura corporal Kaingang e em alguns grafismos da cultura material Xokleng;

$6^{\text {a }}$. Os Kaingang do Rio Grande do Sul reconhecem como tendo sido feitos por seus antepassados, nomeando-os e interpretando-os, alguns grafismos rupestres que ocorrem nos quatro estados do sul do Brasil e aqueles presentes na cerâmica arqueológica Proto-Jê do sul.

$7^{\mathrm{a}}$. Em sítios com arte rupestre no RS, SC, PR e SP aparecem, lado a lado com grafismos geométricos, representações figurativas de animais, que aparecem esquemáticas e com tamanho reduzido. No PR, o mesmo ocorre em fragmento cerâmico da "Fase" Casa de Pedra. Estes fatos alargam nossa compreensão dos grafismos Proto-Jê do sul. Além disso, hipoteticamente, estes zoomorfos seriam grafismos figurativos do sistema de representações visuais (Proto)Jê meridional e poderiam estar relacionados às práticas xamanísticas (representações gráficas dos iangrë - ser que dá poder aos kuiã xamã - Kaingang).

A ligação mais fundamental e importante para a percepção deste sistema de representações visuais é aquela que vincula os grafismos da cerâmica arqueológica (reconhecidamente Proto-Jê do sul) com os grafismos rupestres do Brasil Meridional, possibilitando que o conjunto assim formado possa ser comparado com os grafismos históricos das sociedades Jê meridionais. Tal comparação é amplamente possível em relação aos Kaingang. Quanto aos Xokleng, ela é parcialmente possível.

Tomando-se todo o horizonte cultural Jê meridional, desde suas origens até o momento atual, percebe-se que, temporalmente ou espacialmente, em momentos determinados, foram priorizados determinados suportes em detrimento de outros. Isto é, tal sistema de representações visuais foi e é manifestado em suportes nem sempre iguais a todos os grupos e a todos os momentos particulares do seu longo processo histórico-cultural. Os grafismos estão presentes por vezes na sua cerâmica, por vezes nos seus corpos, por vezes nas suas cestas e nos seus tecidos, na sua arte parietal, ou nos seus monumentos funerários. E, em alguns momentos e/ou alguns grupos, em dois ou mais suportes, como as informações etnográficas atestam ${ }^{2}$.

\footnotetext{
${ }^{2}$ A "Fase" Xagu da "Tradição" Itararé, cuja percentagem de cerâmica com grafismos é consideravelmente superior às demais "fases" da "tradição", corrobora a afirmação de que os grafismos (Proto)Jê meridionais podem aparecer, conforme o grupo local enfocado, a região e o período específicos, em suportes variados. Muitos motivos, dificilmente reconstituíveis, teriam sido responsáveis por estas escolhas locais na ampla
} 
Ao que tudo indica, pode-se inferir esta realidade para alguns grupos Proto-Jê meridionais, cuja cerâmica arqueológica não apresenta grafismos ou técnicas decorativas. Sem as informações etnográficas de Maniser (1930), por exemplo, para os grafismos dos Kaingang paulistas recém-contatados que reproduziam seus grafismos nas pinturas de seus corpos, nos seus cestos, nos seus tecidos e em seus monumentos funerários, mas não sobre sua cerâmica, usando apenas o registro arqueológico $^{3}$, teríamos dificuldades em correlacioná-los com os grupos Proto-Jê meridionais mais ao sul ou com outros atores sociais atuais que decoram vários itens perecíveis de sua cultura material, inclusive seus corpos, e não mais produzem cerâmica ou reproduzem seus grafismos em paredões rochosos.

\section{Diacronia e renascimento Jê.}

Os Kaingang atuais do Rio Grande do Sul, falantes do dialeto do Sudoeste, são um exemplo etnográfico perfeito. Até muito pouco tempo atrás, conservavam o sistema Jê meridional de representações visuais apenas em um suporte: seus trançados. Seus grafismos não mais apareciam nos painéis rupestres, nos tecidos, na cerâmica, nas flechas pintadas, pois todos não são mais práticas realizadas. Entretanto, seus grafismos persistiram nas suas cestas e nos trançados aplicados a suas armas e a alguns poucos objetos. Recentemente, porém, motivados por um momento especial de seu processo histórico-cultural - a luta e retomada de suas terras ancestrais -, estes grafismos ressurgem, com força e variações exuberantes, na pintura corporal retomada. Para mostrar visualmente sua etnicidade e diferença, os Kaingang do Rio Grande do Sul foram espontaneamente buscar, neste sistema Jê meridional de representações visuais, grafismos para pintar seus corpos durante as demonstrações públicas. Os padrões destes grafismos corporais espantam-nos pela semelhança formal com os grafismos da cerâmica ligada aos grupos Proto-Jê do sul, arqueologicamente conhecidos como de "tradição" Taquara, Casa de Pedra ou Itararé, bem como com relação à parte da arte parietal do Brasil Meridional, desde os grafismos rupestres do Planalto Sul-

tradição cultural Jê meridional. De qualquer forma, o realmente importante parece ser a homogeneidade formal dos grafismos, respeitados os estilos locais.

${ }^{3}$ De acordo com a descrição de Robrahn-González \& De Blasis, 1998:64 e 67, é bem verdade que no Baixo Vale do Ribeira de Iguape - SP, de forma excepcional para a área, a cerâmica arqueológica de "Tradição" Itararé apresenta os grafismos comuns a este sistema de representações visuais, conforme ficou demonstrado no Capítulo 3. 
Brasileiro àqueles encontrados nas suas encostas e na Ilha de Santa Catarina e ilhas adjacentes.
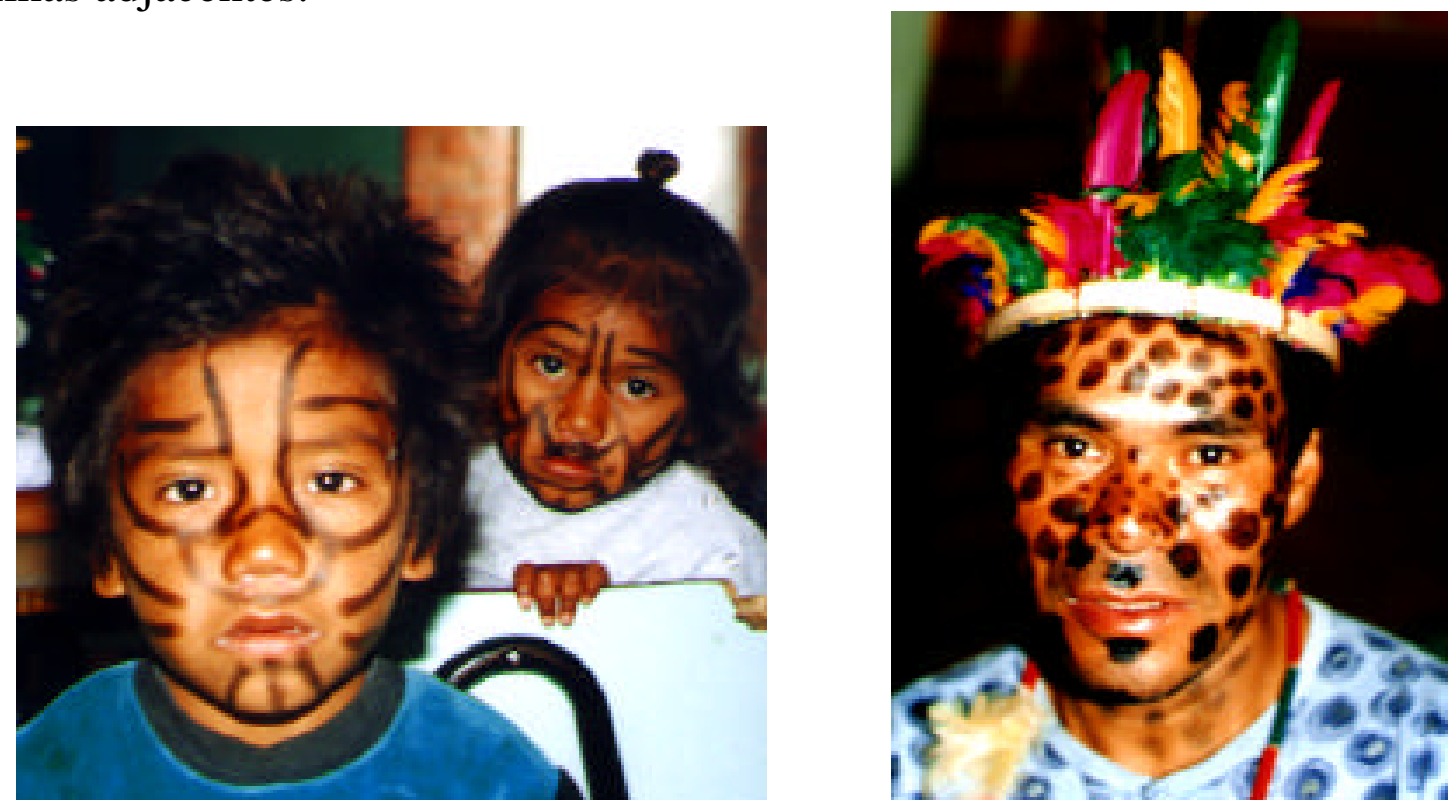

Pintura corporal Kaingang - Agronomia/RS (30.4.99). Grafismos Kamé (filhos de Ningrei) e grafismos Kainru-kré (Arokÿ)

Neste sentido, colocando a dificuldade em perceber hoje na sociedade Xerente a existência de algum tipo de sociedade de mulheres, como Nimuendajú registrou na década de 30, e constatando que Maybury-Lewis observou nas décadas de 50 e 60 que as classes de idade não teriam a importância fundamental que Nimuendaju descreveu, dado o seu "desaparecimento", Lopes da Silva e Farias, diante de seus próprios dados da década de 80, nos quais as classes de idade e as metades rituais surgem aos pesquisadores como uma realidade, fazem o seguinte comentário:

"Os Jê têm demonstrado, inúmeras vezes, sua capacidade de recuperar e revitalizar práticas, rituais, instituições inteiras de sua vida social, que, durante um certo período - por razões certamente históricas -, estiveram obscurecidas, parecendo irremediavelmente perdidas, mortas, dasaparecidas. Renascem em outros momentos históricos, que oferecem condições (quais seriam exatamente?) adequadas" (Lopes da Silva \& Farias, 1992:110).

Estes setenta anos de registros etnográficos sobre a sociedade Xerente, desde Nimuendaju, passando por Maybury-Lewis e chegando às informações de Lopes da Silva e Farias, demonstram a "capacidade que as sociedades Jê têm de renascer, de se redefinir, de se expressar de modos e intensidades 
variados, ao longo do eixo de suas histórias" (Lopes da Silva \& Farias, 1992:111).

Instituições consideradas desaparecidas ou obsoletas renascem em outros contextos históricos revelando não "um sistema que opera agora parcial e precariamente", mas, sim, "a essência de seu próprio modo de ser" (op.cit., pág. 111).

A revitalização do ritual do kiki entre os Kaingang do Xapecó-SC ${ }^{4}$, o ressurgimento do uso da pintura corporal nas "apresentações" de vários grupos Kaingang do Rio Grande do Sul com a recuperação de padrões gráficos registrados desde um passado recuado, arqueológico, e, principalmente, o renascimento deste sistema de representações visuais, centrado na matriz dual, fundamental às sociedades Jê, demonstram que a análise do processo histórico-cultural de quase dois mil anos realizado nesta tese não se inviabiliza pela longa duração do processo. Ao contrário, sua análise registrou, empregando os termos de Lopes da Silva e Farias (op.cit., pág.111) esta "essência" de renascimentos e dos variados modos e intensidades de expressão do fundamental à constituição de sua sociedade, isto é, a matriz dual, de dimensão cósmica.

As comparações efetuadas das representações gráficas das sociedades Kaingang e Xokleng com as representações gráficas existentes em alguns grafismos rupestres do planalto e do litoral dos quatro estados brasileiros sulinos e igualmente presentes na cerâmica arqueológica das "tradições" Taquara, Itararé ou Casa de Pedra comprovam, ao que tudo indica, sua origem cultural comum, justificando falar-se de um horizonte cultural de vários séculos que, através de uma sensibilidade estética coletiva, localmente abrangente, expressou suas idéias a respeito de sua cosmologia e de sua ordem social. A simbologia atual deste sistema de representações visuais foi comprovada etnograficamente e por meio da reconstituição etno-histórica, especialmente com o apoio da cultura material histórica depositada em museus e graças às monografias mais recentes de Veiga sobre os Kaingang, além de minhas próprias pesquisas de campo. Deste ponto de vista, baseado na analogia etnográfica, posso afirmar que as representações gráficas Proto-Jê do sul deveriam ser analisadas e interpretadas sob o prisma deste modelo Jê meridional, com os cuidados devidos, já que estamos tratando de um processo histórico-cultural de quase dois mil anos.

\footnotetext{
${ }^{4}$ Ao fechar a redação desta tese, recebi informações, não confirmadas, de que os kaingang da T.I. de NonoaiRS estariam planejando um ritual do kiki na área.
} 
Apesar de não ser mais possível determinar com precisão o significado pleno e específico de cada representação gráfica Proto-Jê do sul, pode-se afirmar que o sistema simbólico dos grafismos presentes na cerâmica arqueológica e na arte parietal deste horizonte cultural Proto-Jê meridional está codificado em matrizes simbólicas, chaves da percepção do mundo Jê em geral (corpos e nomes, substância e sociedade e a preocupação com o equilíbrio entre opostos e a complementariedade), o que nos leva à questão do dualismo enquanto sociologia/ideologia nativa ${ }^{\mathrm{i}}$, como discutido nos capítulos 4 e 5 .

A interpretação nativa atual de seus grafismos fala-nos das relações de oposição e complementariedade entre as metades cosmológicas, uma das mais importantes matrizes simbólicas do pensamento dual Kaingang e um dos aspectos de sua cultura que com mais força permaneceu ao longo do duro e genocida processo de contato.

No passado, entretanto, estes mesmos grafismos talvez não simbolizassem exatamente as metades tal como se apresentam hoje. Certamente, no entanto, estariam expressando conceitos que estão codificados no princípio fundante Jê: o dualismo enquanto ideologia nativa e a eficácia simbólica e fertilidade da junção de princípios contrários.

Com relação ao modelo para a compreensão do horizonte cultural Proto-Jê, aqui proposto, muitos refinamentos deverão ser efetuados, e o modelo muitas vezes terá que ser testado, com metodologias arqueológicas, nos seus detalhamentos. No entanto, é absolutamente plausível falar-se de uma Tradição cultural Jê do sul, comportando várias sub-tradições, que vincula populações arqueológicas dos quatro estados do sul do Brasil (Proto-Jê meridionais) a seus descendentes históricos atualmente conhecidos como Kaingang e Xokleng (auto-denominados Botocudo).

1. Não compete a este trabalho, que simplesmente tenta articular os estudos arqueológicos à etnologia, discutir a complexa polêmica sobre o dualismo Jê: "Le dualisme est-il une forme institutionnelle ou le principe d'organization qui l'engendre et la déborde? Est-il dans les faits sociaux, dans la réglementation du politique, des mariages, de la cosmologie, ou bien est-il dans la règle qui préside à chacun de ces aspects virtuels? (...) À se fier à la sociologie 'indigène', on se laisse leurrer par ce que, en d'autres circonstances, on appellerait une idéologie. Les moitiés parlent d'égalité et de réciprocité: tentatives peut-être de recouvrir des rapports inavoués de hiérarchie. Lévi-Strauss a depuis longtemps suggéré cette interprétation: le dualisme diametral, celui qui affiche l'équivalence des moitiés, recouvrirait en fait un déséquilibre immanent qui n'est pas l'apanage des seuls Gé mais que l'on retrouve exprimé selon d'autres codes, aussi bien chez les Tupi que chez les Arawak, les Carib, et jusque chez les peuples du nord-ouest américain (Lévi-Strauss, 1991 [Histoire de lynx. Paris, Plon.]). Cf. Carneiro da Cunha, 1993:87. 


\section{BIBLIOGRAFIA}

AMBROSETTI, J.B. 1894. Los índios kaingángues de San Pedro (Misiones). Revista del Jardín Zoológico de Buenos Aires, Buenos Aires, 2(10-12):305-387.

ANDREATTA, M.D. 1968. Notas parciais sobre pesquisas realizadas no planalto e no litoral do Estado do Paraná. Pesquisas, São Leopoldo, Antropologia, 18:65-70.

ARAÚJO, A. G. de M. 1994. Levantamento arqueológico da área Alto Taquari: Estado de São Paulo, com ênfase na abordagem dos sítios líticos. Dissertação de mestrado. MAE, FFLCH, USP.

ARTUSI, L. \& DE MASI, M.A.N. 1985. Implantação dos sítios no relevo e aproveitamento dos recursos naturais pela fase Itapiranga. Boletim do Marsul. Taquara, 3:21-29.

AYTAI, D. 1970. As gravações rupestres de Itapeva. Revista da Universidade Católica, Campinas, 14(33):29-61.

BALDUS, Herbert. 1937. Ensaios de etnologia brasileira. São Paulo, Companhia Editorial Nacional.

. 1947. Vocabulário zoológico Kaingang. In: Arquivo do Museu Paranaense, v. VI.

BAMBERGER, J. 1967. Environment and cultural classification: a study of the northern Cayapó. Tese mimeografada de doutoramento Cambridge, Man.

BARTH, F. 1987. Cosmologies in the making: a generative approach to cultural variation in inner New Guinea. Cambridge, Cambridge University Press. 
BECK, A. A cerâmica dos sambaquis do litoral norte de Santa Catarina. Pesquisas, São Leopoldo, Antropologia, 18:89-100.

1970. Os sambaquis do Brasil Meridional. Litoral de Santa Catarina. Anais do Museu de Antropologia, UFSC, Florianópolis, 3:57-70.

. 1971. Grupos cerâmicos do litoral de Santa Catarina (fase Rio Lessa e fase Enseada). Anais do Museu de Antropologia, UFSC, Florianópolis, 4:25-29.

1973. A variação do conteúdo cultural dos sambaquis do litoral de Santa

Catarina. Tese de doutorado, USP, São Paulo.

1974. O sambaqui de Enseada I - SC-LN-71. Um estudo de tecnologia pré-

histórica. Tese de Livre Docência, UFSC, Florianópolis.

BECK, A. et alii. 1969. Estudos sobre o sambaqui do Rio Lessa (SC-LF-39). Anais do Instituto de Antropologia, UFSC, Florianópolis, 2:139-206.

1970 a. Síntese da Arqueologia do litoral norte de Santa Catarina. Anais do Museu de Antropologia, Florianópolis, 3:23-34.

1970b. A indústria óssea dos sambaquis do litoral norte - fase Enseada. Anais do Museu de Antropologia, UFSC, Florianópolis, 3:35-56.

BECKER, I. I. B. 1976. O índio Kaingang no RS. In: Pesquisas, série Antropologia, n. 29, Unisinos, 331p.

. 1988. O Kaingáng histórico e seus antepassados. In Arqueologia do Rio Grande do Sul, Brasil, Documentos 02. São Leopoldo, Instituto Anchietano de Pesquisas.

- 1994. Formas de enterramento e ritos funerários entre as populações préhistóricas. In: Revista de Arqueologia, São Paulo, 8(1):61-74. 
BECKER, I. I. B. \& SCHMITZ, P. I. 1967. O índio histórico do RS. São Leopoldo, Instituto Anchietano de Pesquisas, (mimeo).

1968. Uma cerâmica do tipo "Eldoradense": Fase Itapiranga. In: Ciência e Cultura. 20(2):458.

. 1969. Uma cerâmica do tipo Eldoradense: fase Itapiranga. In: Estudos de préhistória geral e brasileira. São Paulo, USP, Instituto de Pré-História, p. 499-506.

BLASI, O. 1965. Os indícios arqueológicos do Barracão e Dionísio Cerqueira - Paraná Santa Catarina. Arquivos do Museu Paranaense, nova série, Arqueologia, 2.

. 1972. Cultura do índio pré-histórico- Vale do Iapó - Tibagi - Paraná - Brasil. Arquivos do Museu Paranaense, nova série, Arqueologia, 6.

1973. A pesquisa arqueológica no Estado do Paraná. Dédalo, 17/18.

BOAS, F. 1951. Primitive Art. New York, Capitol.

BOITEUX, L.A. 1911. Notas para a história catharinense. Florianópolis, Editora Moderna.

BORBA. T. M. 1883. Breve notícia sobre os índios Caingangues que, conhecidos pela denominação de Coroados habitam no território compreendido entre os rios Tibagi e Uruguai. Revista Mensal da Secção da Sociedade de Geografia de Lisboa no Brasil. Rio de Janeiro, II:30-36.

. 1904. Observação sobre os indígenas do estado do Paraná. Revista do Museu Paulista, São Paulo, VI:53-62.

. 1908. Atualidade indígena. Curitiba, Typ. e Lytog. a vapor Impressora Paranaense. 
BRIDGEMAN, L.I. 1981. O parágrafo na fala dos Kaiwá-Guarani. Brasília, Summer Institute of Linguistics.

BROCHADO, J. P. 1984. An ecological model of the spread of pottery and agriculture into eastern South América. Illinois. Tese de Doutorado.

BROCHADO, J.P. \& SCHMITZ, P.I. 1976. Petroglifos do estilo pisadas no Rio Grande do Sul. Estudos Ibero-Americanos, Porto Alegre, vol. II, n. 1.

BROCHADO, J. P. et alii. 1969. Arqueologia brasileira em 1968. Publ. Av. Mus. Pa. Emílio Goeldi, Belém 12.

BRYAN, A.L. 1961. Excavation of a brasilian shellmound. Science of Man, Mentone, Califórnia, I, p. 148-151 e 174.

1977. Resumo da arqueologia do sambaqui do Forte Marechal Luz. Arquivos do Museu de História Natural da UFMG, 2:9-30.

CADOGAN, L. 1959. Ayvu Rapyta. Textos míticos de los Mbyá-Guarani del Guairá. Universidade de São Paulo, FFLCH, Boletim n. 227, Antropologia n. 5.

CAMARA JÚNIOR, J.M. 1977. Príncípios de lingüística geral. Rio de Janeiro, Padrão.

CARDOSO DE OLIVEIRA, R. 1968. Problemas e hipóteses relativos à fricção interétnica: sugestões para uma metodologia. América Indígena, XXVIII, 2. México.

1995. Antropologia e a "crise" dos modelos explicativos. Estudos Avançados, 9 (25).

CARNEIRO DA CUNHA, M. 1978. Os mortos e os outros: uma análise do sistema funerário e da noção de pessoa entre os índios krahó. São Paulo, Hucitec. 
1986. Lógica do mito e da ação: o movimento messiânico Canela de 1963. In: Antropologia do Brasil: mito, história e etnicidade. São Paulo, Brasiliense/EDUSP. . 1993. Les études gés. L’Homme, 126-128, avr.-déc., XXXIII (2-4), pp. 77-93.

CARNEIRO DA CUNHA, M. \& VIVEIROS DE CASTRO, E.B. 1985. Vingança e temporalidade: os Tupinambás. In: Anuário Antropológico 85. Rio de Janeiro, Tempo Brasileiro, p. 57-78.

CARTER LAVE, Jean. 1967. Social taxonomy among the krikati: (Gê) of Central Brasil, Unpublished PH.D dissertation;

. 1970. Trendes and cyles in krikati naming practices. University of California, Preliminary.

CASTRO, E. De. 1994. Kaipó dos Krahó: uma abordagem visual. Dissertação de mestrado. USP, FFLCH, PPGAS.

CHIARA, W. 1978. Contribuição da Antropologia para a interpretação dos resultados de pesquisa em arqueologia pré-histórica. Coleção Museu Paulista, São Paulo, Ensaios 2:245-274.

CHMYZ, I. 1965. Prospecções arqueológicas no vale do rio das Antas, Rio Grande do Sul (Brasil). Acta Praehistorica . Buenos Aires, 5/7 (1961/1963): 32-52.

1967 a. Dados parciais sobre a arqueologia do Vale do Rio Paranapanema. Publ. Avulsas Mus. Pa. Emílio Goeldi, 6:59-73.

- 1967b. O sítio arqueológico PR. UV 1 (Abrigo sob-rocha Casa de Pedra). Arqueologia, 3, Curitiba, Centro de Ensino e Pesquisas Arqueológicas.

. 1967c. A ocupação do litoral dos estados do Paraná e Santa Catarina por povos ceramistas. Estudos Brasileiros, 1:7-43. 
. 1968a. Subsídios para o estudo arqueológico do vale do Rio Iguaçu. Revista do CEPA, v. I, Curitiba.

1968b. Dados parciais sobre a arqueologia do Vale do Rio Ivaí. Publ. Avulsas Mus. Pa. Emílio Goeldi, Belém.

. 1968c. Considerações sobre duas novas tradições ceramistas arqueológicas no Estado do Paraná. Pesquisas, Série Antropologia, São Leopoldo, 18:115-125 (Anais do II Simpósio de Arqueologia da Área do Prata).

. 1968d. Breves notas sobre petroglifos no segundo Planalto Paranaense (Sítio PR UV 5). Revista do CEPA. Curitiba, 1:53-63.

. 1969 a. Novas manifestações da Tradição Itararé no Estado do Paraná. Pesquisas, São Leopoldo, 20:121-129.

1969b. Pesquisas arqueológicas no Alto e Médio Rio Iguaçu. In Publ. Avulsas Mus. Pa. E. Goeldi, n. 13.

. 1971. Pesquisas arquológicas no médio e baixo Rio Iguaçu. In Publ. Avulsas Mus. Pa. E. Goeldi, n. 15.

1977. Pesquisas paleoetnográficas efetuadas no vale do rio Paranapanema, Paraná - São Paulo. Boletim de Psicologia e Antropologia, UFPR, Curitiba, vol 5.

CHMYZ, I. (Coord.) 1976. Primeiro relatório das pesquisas realizadas na área de Itaipu (1975/76). Convênio Itaipu _ IPHAN, Curitiba.

1977. Segundo relatório das pesquisas realizadas na área de Itaipu $\underline{\mathbf{( 1 9 7 6 / 7 7 )}}$. Convênio Itaipu - IPHAN, Curitiba.

- 1978. Terceiro relatório das pesquisas realizadas na área de Itaipu (1977/78). Convênio Itaipu - IPHAN, Curitiba. 
. 1979. Quarto relatório das pesquisas realizadas na área de Itaipu (1978/79). Convênio Itaipu - IPHAN, Curitiba.

1980. Quinto relatório das pesquisas realizadas na área de Itaipu (1979/80).

Convênio Itaipu - IPHAN, Curitiba.

1981. Relatório das pesquisas arqueológicas realizadas na área da usina

hidrelétrica de Salto Santiago (1979-80). Eletrosul/Sphan, Florianópolis/Curitiba.

CHMYZ, I. \& SAUNER, Z.C. 1971. Nota prévia sobre as pesquisas arqueológicas no vale do Rio Piquiri. In Dédalo, 13.

CHMYZ, I.; PEROTA, C.; MULLER, H. I.; ROCHA, M.L.F. de. 1968. O programa de salvamento arqueológico do rio Itararé. Revista do Centro de Ensino e Pesquisas Arqueológicas, Curitiba, 1:7-23.

CIMI, (Conselho Indigenista Missionário). Boletim do CIMI, ano 5, n. 29, junho de 1976.

CRÉPEAU, R. 1994. Mythe et ritual chez les indiens Kaingang du Brésil méridional. Religiologiques, n. 10, automne, p. 143-157.

. 1995. Economie et ritual. L'Anthropologie economique. Actes du Coloque, Département d'anthropologie, Université de Montréal, n. 1, p. 19-26.

CHRISTIE-SHULTS, J.J. 1992. Rock art of the Piaroa in Venezuela. Rock art papers. Ken Hedges (ed.), vol. 9(28):39-46. San Diego, San Diego Museun of Man.

CROKER, W, 1963. The Canela messianic movement: an introdution. Atas do Simpósio sobre a Biota Amazônica, 2, p.69-83.

DA MATTA, R. 1967. Mito e autoridade doméstica. In: Revista do Instituto de Ciências Sociais, 4(1), Rio de Janeiro. 
1970. Apinaje social structure, unplublished PH.D. Dissertation Dept. Of Anthropology (Peabody Museum), Harvard University.

1971. O sistema de relações Apinajé: terminologia e ideologia. Museu Nacional. Rio de Janeiro.

. 1976. Um mundo dividido: a estrutura social dos índios Apinajé. Petrópolis, Vozes.

. 1979. Os gaviões. In: Laraia, R. de B.. \& DA MATTA, R. Índios e castanheiros: a empresa extrativa e os índios do médio Tocantins. Rio de Janeiro, Paz e Terra, 1978, p. 113-203.

D’ANGELIS, W. da R. 1999. A língua Kaingang, a formação de professores e o ensino escolar. Texto divulgado no I Seminário de Educação Escolar Indígena da Região Sul, promovido pelo MEC. Balneário Camboriú, 23-24 novembro 1999, 17 pp.

DEMARQUET, S. de A. 1983. Os Xokleng de Ibirama: uma comunidade indígena de Santa Catarina. Boletim do Museu do Índio, 3.

DE MASI, M.A.N \& ARTUSI, L. 1985. Fase Itapiranga: sítios da tradição planáltica. Pesquisas, São Leopoldo, Antropologia, 40:99-121.

DESCOLA, Ph. 1998. Estrutura ou sentimento: a relação com o animal na Amazônia. Mana, v. 4(1)23-45.

DREFUS, S. 1963, Les kayapo du nord: contribuition à l'étude des indiens Gêe. Paris/Haia, Mouton.

DRUMOND, C. \& PHILIPSON, J. 1947. Os túmulos Kaingang de Parapuã. Sociologia, São Paulo, n. 9.

ENCICLOPÉDIA E DICIONÁRIO ILUSTRADO KOOGAN/HOUAISS. 1993. Rio de Janeiro, Edições Delta. 
FARIA, F.S. 1997. Comparação do registro rupestre do médio São Francisco com motivos gráficos do grupo lingüístico Tukâno: um teste para a hipótese xamânica. Revista do Museu de Arqueologia e Etnologia. São Paulo, 7:23-47.

FARIAS, A.J.T.P. 1990. Fluxos sociais Xerente: organização social e dinâmica das relações entre aldeias. São Paulo, FFLCH/USP. Dissertação de mestrado.

FERNANDES, L. 1941. Os caingangues de Palmas. Arquivos do Museu Paranaense, v. $1: 161-223$.

FLANNERY, K.V. \& MARCUS, J. 1998. Cognitive Archaeology. In WHITLEY, D.S. (ed.). Reader in archaeological theory: post-processual and cognitive approaches. London/New Yok, Routledge.

FRICH, A.V. 1957. Indiani Jizni Americy. 5a. ed. Praga.

FRIKEL, P. 1991. Notas suiá (5): segunda parte. Publicações do Museu Histórico de Paulínia, n. 48.

FUNDAÇÃO NACIONAL DE ARTE. 1981.Instituto Nacional de Artes Plásticas. Museu Paraense Emílio Goeldi. Rio de Janeiro. Coleção Museus Brasileiros, 4.

GALLOIS, D. 1992. Arte iconográfica Waiãpi. In Vidal, L. (org.). Grafismo indígena. São Paulo, EDUSP/FAPESP.

GARLET, I.J. \& SOARES, A.L.R. 1995. Cachimbos Mbyá-Guarani: aportes etnográficos para uma arqueologia Guarani. Comunicação apresentada na V Reunião de Antropologia (Merco)Sul - ABA, Tramandaí-RS.

GEERTZ, C. 1957. Ritual and social change: a javanese example. In American Anthropologist, v. 59, n. 1.

1978. A interpretação das culturas. Rio de Janeiro, Zahar. 
1986. L'art en tant que système culturel. In Savoir local, savoir global: les

lieux du savoir. Paris, Presses Universitaires de France.

GODOY, O.R. de. 1947. Esqueletos e utensílios de índios encontrados no estado de São Paulo. In Arquivos da Polícia Civil de São Paulo, v. XIII.

GUIDON, N. 1978/79/80. Temas de Arqueologia Brasileira (4): arte rupestre. In Anuário de divulgação científica, n. 8, Goiânia.

GUIDON, N. e outros. 1984. La circulation des symboles en Amériques. Revista de Pré-História v. VI, USP.

HELM, C.M.V. 1977. Síntese histórica do contacto entre índios e brancos no Paraná. Revista Estudos Brasileiros, Curitiba, n. 4, p. 267-273.

HENRY, Jules. 1964. Jungle people: a kaingang tribe of the highlands of Brazil. New York, Vintage Books.

1975. A Kaingang text. In: International Journal of American Linguistics, v. VIII, N. York, ago./1975, n. 3-4.

HILL, J. 1988. Myth and history. In Hill, J. (ed.) Rethinking history and myth: indigenous south american perspectives on the past. Urbana/Chicago, University of Illinois Press.

HIRATA, E.F.V. 1994-95. Poder político e religião: a documentação arqueológica no estudo de sociedades antigas. Revista de Arqueologia, São Paulo, 8(2):387-399.

HORTA BARBOSA, L. B. 1947. A pacificação dos índios caingangue paulistas. In: $\underline{\mathbf{O}}$ problema indígena do Brasil. Rio de Janeiro, Imprensa Nacional, p. 33-73.

HUFFMAN, T.N. 1981. Snakes and birds: expressive space at Great Zimbabwe. In African Studies, 40:131-50. 
. 1986. Cognitive studies of Iron Age in Southern Africa. In World Archaeology, 18:84-95.

1996. Snakes and crocodiles: power and symbolism in Ancient Zimbabwe. Johannesbug, Witwatersrand University.

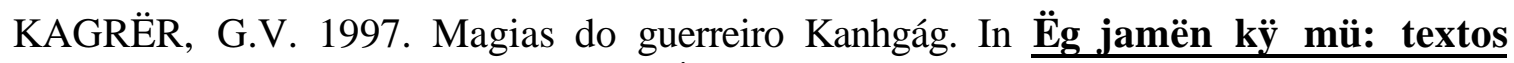
Kanhgág. Brasília, APBKG/Dka Áustria/MEC/PNUD.

KEMPF, W.G. 1947. Notas sobre um grupo de indígenas de Santa Catarina. Revista do Arquivo Municipal. São Paulo, v. CXII, p. 25-34.

KERN, A.A. 1985. Interação cultura e meio ambiente em sítios de habitações subterrâneas no Planalto Sul-rio-grandense (Município de Vacaria, RS). Boletim do MARSUL, Taquara, 3:30-33.

1994. Antecedentes indígenas. Porto Alegre, Ed. da Universidade/UFRGS.

KINDEL, 1971. Kaingang basketry. In Estudos sobre línguas e culturas indígenas. Summer Institute of Linguistics.

KUHN, Th. 1975. A estrutura das revoluções científicas. São Paulo, Perspectiva.

LADEIRA, Maria Elisa. 1983. Uma aldeia Timbira. In: Novaes, S.C. (org.) Habitações indígenas. São Paulo, Nobel/EDUSP, p. 13-31.

LAFFINEUR, R. 1988. Archéologie et religion: problèmes et méthodes. Kernos, 1:129140.

LAMING, A. \& EMPERAIRE, J. 1968. Descobertas de pinturas rupestres nos planaltos paranaenses. Revista do Centro de Ensino e Pesquisas Arqueológicas. Curitiba, 1. 
LANE, F. 1959. Arcos e flechas dos índios Kaingáng do estado de São Paulo. In Revista do Museu Paulista, v. XI.

LAPLANTINE, F. 1987. Aprender antropologia. São Paulo, Brasiliense.

LA SALVIA, F. 1968. Resumo das pesquisas arqueológicas no planalto - Rio Grande do Sul. Pesquisas, São Leopoldo, Antropologia 18:101-113.

. 1983. A habitação subterrânea: uma adaptação ecológica. In VEIMER, G. (org.) A arquitetura no Rio Grande do Sul. Porto Alegre, Mercado Aberto (Série Documenta, 15). P. 7-26.

LA SALVIA, F. \& SCHMITZ, P.I. 1973. Considerações sobre as culturas cerâmicas não Tupi-Guarani do Brasil Meridional. Revista do Instituto de Filosofia e Ciências Humanas. Porto Alegre, UFRGS, 1: 175-201. 1 mapa.

LA SALVIA, F., SCHMITZ, P.I. \& BECKER, I.I.B. 1968. Cerâmica Caingang - Fase Vacaria. In Ciência e Cultura, no. 20(2):457-8.

1970. Cerâmica Caingang - Fase Vacaria. Estudos de pré-história geral e brasileira. São Paulo, Instituto de Pré-História/USP.p. 493-97. Il.

LAVINA, R. 1994. Os Xokleng de Santa Catarina: uma etnohistória e sugestões para arqueólogos. UNISINOS. Dissertação de Mestrado.

LAZZAROTTO, D., SCHMITZ, P. I., BECKER, I.I.B. \& STEINMETZ, R. 1971. Pesquisas arqueológicas no planalto. $\underline{O}$ homem antigo na América. São Paulo, Instituto de Pré-História, USP. P. 79-89. Il.

LAYTON, R. 1985. The cultural context of hunther-gatherer rock art. Man, 20(3):434453.

1987. The use of ethnographic parallels in interpreting upper paleolithic rock art. In Ladislav Holy (ed.). Comparative Anthropology. Oxford, Basil Blackwell. 
1991. The anthropology of art. Cambridge, University Press.

LEÃO, E. A. de. 1910. Subsídios para o estudo dos Kaingangues do Paraná. Curitiba, Tip. da Livraria Econômica.

LE GOFF, J. Memória. 1984. Enciclopédia EINAUDI. Portugal, Impressora Nacional/Casa da Moeda.

LÉVI-STRAUSS, C. 1967. Antropologia estrutural. Rio de Janeiro, Tempo Brasileiro. 1976. O pensamento selvagem. São Paulo, Cia. Ed. Nacional.

LEWIS-WILLIAMS, J.D. 1980. Ethnography and iconography: aspects of southern San thought and art. Man, 15(3):467-82.

. 1982. The economic and social context of southern San rock art. Current Anthropology, 23(4):429-449.

1987. A dream of eland: un unexplored component of San shamanism and rock art. World Archaeology, 19(2):165-177.

1995. Seeing and construing: the making and "meaning" of a southern african rock art motif. Cambridge Archaeological Journal, 5(1):3-23.

LIMA, T.V. 1998. Gravuras rupestres no Estado do Rio Grande do Sul, Brasil: processos de documentação, salvamento e educação para sua preservação e valorização. PUC/RS. Dissertação de mestrado.

LIMA, T.V. \& BROCHADO, J.P. 1994. Petroglifos do Abrigo do Barreiro. In Estudos Ibero-Americanos, PUCRS, v. 20, n. 1.

LOPES DA SILVA, A. (1980) Nomes e amigos, da prática xavante a uma reflexão sobre os Jê. Tese de doutorado em Antropologia Social, USP. 
1983 Xavante: casa - aldeia -chão - terra - vida.. In: Novaes-SC (org), Habitações indígenas. São Paulo, Nobel/EDUSP,p. 33-56.

1988. Tradições, inovações e criatividade: a análise comparativa de cosmologias vistas como processo. Anuário Antropológico 88.

. 1994. Mitos e cosmologias indígenas no Brasil: breve introdução. In: Grupiony. L.D.B. (org.) Índio no Brasil. Brasília, Ministério da Educação e do Desporto, p. 75-82.

LOPES DA SILVA, A. \& FARIAS, A.T.P. 1992. Pintura corporal e sociedade: os "partidos" Xerente. In Grafismo indígena: estudos de antropologia estética. Lux. B. Vidal, org. São Paulo, Estúdio Nobel/Edusp/Fapesp.

LOZANO. 1873-74. História de la conquista del Paraguay, Rio de la Plata y Tucumán. Buenos Aires, Biblioteca del Río de la Plata, Andres Lamas, ed., 5 vol.

LOWIE, R. \& NIMUENDAJÚ, C. 1937. The dual organization of the Ramkokamekra (Canela) of Northern Brasil. American Anthropologist, v. 39, p. 565-582.

. 1939. The associations of the sherente. American Anthropologist, v. 41, p. 408-415.

MABILDE, P.F.A.B. [1836-1866] 1983. Apontamentos sobre os indígenas selvagens da Nação Coroados dos matos da Província do Rio Grande do Sul: 1836-1866. São Paulo/Brasília, IBRASA/INL/Fundação Nacional Pró Memória.

MANISER, H.H. 1930. Les Kaingang de São Paulo. 23th International Congress of Americanists. New York. p. 760-791.

MARCUS, G. 1988. Parody and the parodic in polynesian cultural history. Cultural Anthropology 3(1):68-76. 
MAROIS, R. \& SCATAMACCHIA, M.C.M. 1987. Estudo comparativo de termos franceses, ingleses, espanhóis e portugueses relacionados com as técnicas decorativas da cerâmica pré-histórica. In Dédalo, São Paulo, 25:53-85.

MARTIN, G. 1996. Pré-história do Nordeste do Brasil. Recife, UFPE.

MAYBURY-LEWIS, D. 1975. Sistemas matrimoniais prescritivos. In Dumont, L. Introducción a dos teorías de la antropologia social. Barcelona, Anagrama. P. 255-278.

1984. A sociedade xavante. Rio de Janeiro, Francisco Alves Editora.

MAYBURY-LEWIS, D. (ed.). 1979. Dialectical societies: the Gê and Bororo of Central Brazil. Cambridge/London, Harvard University Press.

MELATTI, J. C. 1958 - Nominadoras e genitoras: um aspecto do dualismo Krahó, Stuttgart.

1970. Sistema social Krahó. Dissertação inétida do doutoramento, USP.

1977. Messianismo Krahó. São Paulo, Herder/EDUSP.

1978. Ritos de uma tribo Timbira. São Paulo, Ática.

MENGHIN, O.F.A. 1957. Estilo del arte rupestre de Patagonia. Acta Praehistorica. Buenos Aires, 1.

1961. Mittei lungen zur kulturkunde. Paideuma, Band VII, Juli.

MÉTRAUX, Alfred. 1946. The caingang. In: Handbook of south american indians. Smithsonian Institution. Bureau of American Ethnology, Boletim 143, p. 445-75.

. 1947. Social organization of the Kaingang and Aweikoma, American Anthropologist, n. 5., v. 49. 
MILLER, E. T. 1967. Pesquisas arqueológicas efetuadas no nordeste do RS. Publ. Av. Mus. Pa. Emílio Goeldi, Belém, 6:15-38.

1969. Pesquisas arqueológicas efetuadas no nordeste do Rio Grande do Sul. Alto Uruguai. Publ. Av. Mus. Pa. Emílio Goeldi, Belém, 10:33-54.

1971. Pesquisas arqueológicas efetuadas no Planalto Meridional. Rio Grande do Sul (rios Uruguai, Pelotas e das Antas). Publ. Av. Mus. Pa. Emílio Goeldi, Belém, 15:37-70.

. 1974. Pesquisas arqueológicas em abrigos sob rochas no nordeste do Rio Grande do Sul. Publ. Av. Mus. Pa. Emílio Goeldi, Belém, 26:11-24.

. S/d. As tradições Taquara, Itararé e Casa de Pedra consideradas como uma única tradição ou de fundo cultural comum. Mimeo.

MILLER Jr., T.O. 1972. Arqueologia da Região Central do Estado de São Paulo. In Dédalo, 16.

.1978. Tecnologia cerâmica dos Caingang paulistas. Arquivos do Museu Paranaense, Nova Série, Etnologia 2.

. 1978/79/80. Temas de Arqueologia brasileira (2): Arcaico do Interior. Anuário de Divulgação Científica, 6 Goiânia.

MONTERO, P. 1986. Magia e pensamento mágico. São Paulo, Ática.

MOTA, Lúcio Tadeu. 1994. As guerras dos índios Kaingang: a história épica dos índios Kaingang no Paraná (1769-1924). Maringá, Editora da Universidade Estadual de Maringá.

MÜLLER, R. 1976. A pintura do corpo e os ornamentos Xavante: arte visual e comunicação social. Tese de mestrado, UNICAMP, Campinas. 
MUNN, N. D. 1973. Walbiri iconography: graphic representation and cultural symbolism in a Central Australian society. Londres, Cornell University Press.

NAMEM, A. M. 1994. Botucudo: uma história de contacto. Florianópolis, Editora da UFSC/Editora da FURS.

NEVES, W.A. 1984. Paleogenética dos grupos pré-históricos do litoral sul do Brasil (Paraná e Santa Catarina). Tese de doutorado, USP, São Paulo.

NEVES, W. A., UNGER, P., SCARAMUZZA, C.A.M. 1984. Incidência de cáries e padrões de subsistência no litoral norte de Santa Catarina. Revista de Pré-História, Instituto de Pré-História, USP, São Paulo, 6:371-380.

NEWTON, Dolores. 1971. Social and historical dimensions of Timbira material culture, Unplublished PH.D. Teses, Cambridge, Massachsetts.

NIMUENDAJÚ, Curt. [1913] 1993. Etnografia e indigenismo, Campinas, Editora da Unicamp.

. [1914] 1987. As lendas da criação e destruição do mundo como fundamentos da religião dos Apapocúva-Guarani. Tradução de Charlotte Emmerich \& Eduardo B. Viveiros de Castro. São Paulo, HUCITEC/EDUSP.

. 1939. The apinajé. The Catholic University of America Press. Whashington, D.C.

1942. The Sherent. Publications of the Frederick Webb Hodge Anniversary Publications Fund, v. 4., Los Angeles, The Southwest Museum Administrator of the fund.

1946. The Eastern Timbira. University of California Press, Berkeley and Los Angeles.

. 1956. Os apinayé. In: Boletim do M. Paranaense. Emílio Goeldi, Tomo XII. 
NIMUENDAJÚ. C. \& GUÉRIOS, R.F.M. 1948. Cartas etno-lingüísticas. Revista do Museu Paulista. São Paulo, Nova Série, (II):207-241.

NOELLI, F.S. 1993. Sem tekoá não há tekó: em busca de um modelo etnoarqueológico da aldeia e da subsistência Guarani e sua aplicação a uma área de domínio no Delta do rio Jacuí-RS. Dissertação de mestrado, PUC/RS.

. s/d. Repensando os rótulos e a História dos Jê no sul do Brasil a partir de uma interpretação interdisciplinar. Mimeo.

. s/d(a). Os Jê do Brasil meridional e a antiguidade da agricultura: na trilha da historicidade de uma prática cultural. Mimeo.

NOELLI, F.S. (Org.) et alii. 1998. Bibliografia Kaingang: referências sobre um povo Jê do Sul do Brasil. Londrina, UEL.

NOVAES, S.C. 1983. As casas na organização social do espaço Bororo. In: Novaes, S.C. (Org.), Habitações índígenas. São Paulo, Nobel/EDUSP, p. 57-76.

1993. Jogo de espelhos: imagens da representação de si através dos outros. São Paulo, EDUSP.

OTTEN, C.M. (ed.) 1971. Introduction. In: Anthropology and art. Readingns in cross-cultural aesthetics. New York, The Nat. History.

PAULA, J.M. de. 1924. Memória sobre os Botocudos do Paraná e Santa Catarina organizada pelo Serviço de Proteção aos Índios sob a inspeção do Dr. José M. de Paula. Anaes do XX Congresso Internacional de Americanistas. (Rio de Janeiro). Rio de Janeiro, v. 1, p. 117-137.

PEREIRA, M., ROHR, J.A., LENGYEL, I., BARRETO, O.C.O.P. 1984. Os grupos sangüíneos $\mathrm{ABO}$ em esqueletos pré-históricos de aborígenes da ilha de Santa Catarina. Ciência e Cultura, São Paulo, 36(9): 1597-1599. 
PESSIS, A-M. 1994. Registros rupestres: perfil gráfico e grupo social. Revista de Arqueologia. São Paulo, 8(1):283-289.

PIAZZA, W. F. 1969a - Notícia arqueológica do vale do Uruguai. Publ. Av. Mus. Pa. Emílio Goeldi, Belém, 10:55-74.

. 1969b. A área arqueológica dos "Campos de Lajes". Publ. Av. Mus. Pa. Emílio Goeldi, Belém,13:63-74.

. 1971. Dados complementares à arqueologia do vale do Uruguai. Publ. Av.. Mus. Pa. Emílio Goeldi, Belém, 15:71-86.

PIAZZA, W.F. \& EBLE, A.B. 1968. Arqueologia do Vale do Rio Itajaí - Sítio arqueológico Rio Plate (SC VI 19). Blumenau em Cadernos. Blumenau, 9:1-14.

PINTO, A.M. 1894. Apontamentos para o Dicionário Geographico do Brazil. Rio de Janeiro, Imprensa Nacional.

PIVETTA, L.D. 1974. O sistema social Kaingang e as relações com a sociedade nacional envolvente. Revista do Ensino. Porto Alegre, n. 154 e 155.

PROUS, A. 1977. Documents pour la préhistoire du Brésil méridional. 2. L’État de Santa Catarina. Cahiers d'Archeologie d'Amerique du Sud 4, Paris.

Temas de Arqueologia Brasileira (4): arte rupestre. In Anuário de divulgação científica, 8, Goiânia.

1979. Première information sur les maisons souterraines de l'État de São Paulo.

Revista de Pré-História, v. 1, n.1.

1989. Arte rupestre brasileira: uma tentativa de classificação. Revista de Pré-

História. São Paulo, 7:7-33.

1992. Arqueologia Brasileira. 
1993. L’Archéologie brésilienne aujourd'hui: problèmes et tendances. Unpublished typescript, February the $11^{\text {th }}$.

RAUTH, J.W. 1963. Nota arqueológica sobre a formação de um sambaqui na ilha das Cobras: observações gerais de um programa de salvamento. Faculdade de Filosofia, Ciências e Letras de Paranaguá, Dep. de Antropologia.

REIS, J.A. 1997 a. Para uma arqueologia dos buracos de bugre: do sintetizar, do problematizar, do propor. Porto Alegre, PUC/RS. Dissertação de mestrado.

. 1997 b. ...Guaianá, buraco de bugre, Kaingang/Xokleng: ... qual ancestralidade? ... qual analogia? ... de que campo pode-se falar? ... Revista do CEPA, 21(26):35-90.

REIS, M. J. 1980. Problemátioca arqueológica das estruturas subterrâneas no planalto caterinense. Dissertação de mestrado, USP, São Paulo.

RENFREW, P. et alii. 1985. The archaeology of cult: the sanctuary of Phylakopi. BSA, suppl. XVIII:1-4.

RIBEIRO, B. G. 1987. A liguagem simbólica da cultura material. In: Suma etnológica brasileira. Arte Índia, Petrópolis, Vozes, FINEP, v. 3.

RIBEIRO, P. A. M. 1969/70. Inscrições rupestres no vale do Rio Caí, RS (Brasil)). (Nota prévia). Anales de Arqueologia y Etnologia, Mendonza, Tomo 24-5:114129.

1972 a. Petroglifos do sítio RS-T-14: Morro do Sobrado, Montenegro-RS-Brasil. Iheríngia, Museu Rio-Grandense de Ciências Naturais, Porto Alegre, Antropologia 2:3-14.

1972 b. Sítio RS-C-14: Bom Jardim Velho (Abrigo sob rocha) - nota prévia Iheríngia, Museu Rio-Grandense de Ciências Naturais, Porto Alegre, Antropologia 2:15-57. 
1974. Os petroglifos de Cerro Alegre, Santa Cruz do Sul, RS, Brasil (Nota Prévia. Revista do CEPA. Santa Cruz do Sul, n. 1.

1975. Os abrigos sob rocha do Virador no estado do Rio Grande do Sul, Brasil. Revista do CEPA, Faculdade de Filosofia, Ciências e Letras de Santa Cruz do Sul, 2.

- 1978. A arte rupestre no sul do Brasil. Revista do CEPA, Faculdade de Filosofia, Ciências e Letras de Santa Cruz do Sul, 7:1-27, il., bibl.

. 1980. Casas subterrâneas no Planalto Meridional, município de Santa Cruz do Sul, Brasil, Revista do CEPA, Faculdade de Filosofia, Ciências e Letras de Santa Cruz do Sul, 9.

- 1983. Sítios arqueológicos numa microregião de área alagadiça na Depressão Central do Rio Grande do Sul, Brasil. Revista do CEPA, Faculdades Integradas de Santa Cruz do Sul, 12.

1990. A tradição Umbu no sul do Brasil. Revista do CEPA, Faculdades Integradas de Santa Cruz do Sul, v. 17, n.20:129-151.

1991 a. Os caçadores pampeanos e a arte rupestre. In Kern, A. (org.). Arqueologia pré-histórica do RS. Porto Alegre, Mercado Aberto.

1991 b. Arqueologia do Vale do Rio Pardo, RS, Brasil. Revista do CEPA, Faculdades Integradas de Santa Cruz do Sul, v. 18, n. 21:1-192.

RIBEIRO, P.A.M. \& FENIS, J. S. 1984. Sítios com petróglifos na Campanha do RS. Revista do CEPA. Santa Cruz do Sul, Faculdade de Filosofia, Ciências e Letras, v.11, n.13:1-32.

RIBEIRO, P. A. M. \& RIBEIRO, C. F. 1985. Levantamento arqueológico no município de Esmeralda, Rio Grande do Sul, Brasil. Revista do CEPA, Faculdades Integradas de Santa Cruz do Sul, v. 12, n. 14:49-105, 1 tab, 18 fig. 
RIBEIRO, P. A. M. \& SILVEIRA, I. da. 1979. Sítios arqueológicos da tradição Taquara, fase Erveiras, no vale do rio Pardo, RS, Brasil. Revista do CEPA, Faculdades Integradas de Santa Cuz do Sul, 8:3-63.

RIBEIRO, P.A.M.; BAUMHARDT, G.; MARTIN, H.E.; HEUSER, L.F. 7 STEINHAUS, R. 1973. Novos petroglifos na encosta centro oriental da Serra Geral RS - Brasil (Nota Prévia). Antropologia, vol.2, Santa Cruz do Sul, Museu do Colégio Mauá.

RIBEIRO, P.A.M.; KLAMT, S.; SILVEIRA, B. \& RIBEIRO, C.T. 1989. Levantamentos arqueológicos na encosta do planalto entre o vale dos rios Taquari e Caí, RS, Brasil. Revista do CEPA, Faculdades Integradas de Santa Cruz do Sul, v.16, n.19:49-89.

RICOEUR, P. 1968. Estrutura e hermenêutica. In LIMA, L.C. (Org.). $\underline{\text { O estruturalismo }}$ de Lévi-Strauss. Petrópolis, Vozes.

1979. The model of the text: meaningful action considered as a text. Interpretative social science: a reader. P. Rabinow \& W.M. Sullivan (eds.). Berkeley/University of California Press.

ROBRAHN, E.M. 1989. A ocupação pré-colonial do vale do Ribeira de Iguape, SP: os grupos ceramistas do médio curso. Dissertação de mestrado, FFLCH/USP.

ROBRAHN-GONZÁLEZ, E.M. 1997. O acervo etnológico do MAE/USP: estudo do vasilhame cerâmico Kaingáng. Revista do Museu de Arqueologia e Etnologia, São Paulo, 7:133-141.

1998. Teoria e métodos na análise cerâmica em Arqueologia. Revista do Museu de Arqueologia e Etnologia, São Paulo, 8:287-294.

ROBRAHN-GONZÁLEZ, E.M. \& DE BLASIS, P. 1998. Investigações arqueológicas no médio/baixo vale do Ribeira de Iguape, São Paulo. Revista do Museu de Arqueologia e Etnologia, São Paulo, 8:57-69. 
ROHR, J. A. 1959. Pesquisas páleo-etnográficas na ilha de Santa Catarina I. A jazida da Base Aérea de Florianópolis. Pesquisas, Porto Alegre, Setor de História, 3:199266.

1966. Pesquisas arqueológicas em Santa Catarina: 1 - Exploração sistemática do sítio da Tapera (Nota prévia). Pesquisas, São Leopoldo, Antropologia, 15:3-20.

. 1967/1968. A aldeia pré-histórica da Praia da Tapera. Revista Vozes, Petrópolis, vol. 61(8):718-722; (9):807-811; (10)909-913; (11):907-1001; (12)10991104; vol.62(2):149-154; (4):325-331.

1969a. Petroglifos da ilha de Santa Catarina e ilhas adjacentes. Pesquisas, São Leopoldo, Antropologia, 19.

. 1969b. Os sítios arqueológicos do município sul-catarinense de Jaguaruma. Pesquisas, São Leopoldo, Antropologia, 22.

. 1971. Os sítios arqueológicos do Planalto Catarinense, Brasil. Pesquisas, São Leopoldo, Antropologia, 24.

. 1972a. As casas subterrâneas pré-históricas. Notícias, Porto Alegre, 114:32-36.

. 1972b. Desvendando o mistério das galerias subterrâneas... Livro da Família, Porto Alegre, 26:104-107.

1973. A pesquisa arqueológica no Estado de Santa Catarina. In Dédalo, 17/18.

1977. Os sítios arqueológicos da Praia das Laranjeiras - Balneário de Camboriu, SC. Notícias, Porto Alegre, 135/136:28-32.

1978. O sítio arqueológico da Praia da Laranjeira - Balneário de Camboriu, SC. Notícias, Porto Alegre, 139/140:62-66. 
. 1979-1982. Pesquisas arqueológicas no município catarinense de Urussanga. Anais do Museu de Antropologia, nos. 12-15.

1984. O sítio arqueológico da Praia das Laranjeiras - Balneário de Camboriu. Anais do Museu de Antropologia, UFSC, Florianópolis, 17:5-76.

ROSA. R.R.J. 1995. Seção ou função cerimonial na sociedade Kaingang. Monografia para a disciplina Minorias Étnicas do PPGAS-UFRGS.

SAHLINS, M. 1985. Islands of history. Chicago, University of Chicago Press.

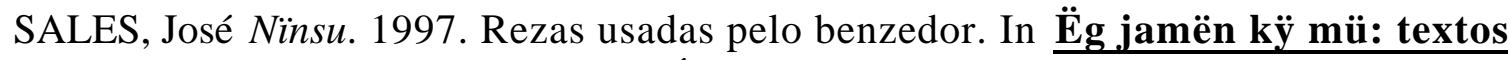
Kanhgág. Brasília, APBKG/Dka Áustria/MEC/PNUD.

SAMPAIO, M.A. 1986. Vocabulário Guarani-Português. Porto Alegre, L\&PM.

SANTOS, S.C. dos. 1970. A integração do índio na sociedade regional: a função dos postos indígenas em Santa Catarina. Florianópolis, UFSC.

1973. Índios e brancos no sul do Brasil: a dramática experiência dos Xokleng. Florianópolis, Edeme.

1997. Os índios Xokleng: memória visual. Florianópolis, Ed. Da UFSC/Ed. Da UNIVALI.

SCHAAN, D.P. 1997. A linguagem iconográfica da cerâmica Marajoara. Porto Alegre, EDIPUCRS.

SHADEN, Egon. 1937. Einiges über die Schokleng von Santa Catharina. In: Pindorama. São Paulo, ano I, Cad. 2 e 3, p. 24 e segs.

1953. A origem dos homens, o dilúvio e outros mitos Kaingang. In: Revista de Antropologia, 1(2), p. 139-141. 
[1954] 1962. Aspectos fundamentais da cultura Guarani. São Paulo, Difusão Européia do Livro.

SCHMITZ, P.I. 1958. Paradeiros guaranis em Osório (Rio Grande do Sul). Pesquisas, São Leopoldo, 2:113-143.

1968. Grandes complexos de cerâmica indígena no sul do Brasil. Anais do II Simpósio de Arqueologia da área do Prata. Pesquisas, Antropologia, São Leopoldo, 18:127-140.

1969. Algumas datas de carbono 14 de casas subterrâneas no planalto do Rio Grande do Sul. Pesquisas, São Leopoldo, Antropologia, 20:163-167.

.1978/79/80. Temas de arqueologia brasileira (5): os cultivadores do Planalto e do litoral. In: Anuário de Divulgação Científica, 9, Goiânia.

1985. O Guarani no Rio Grande do Sul. Boletim do MARSUL, v.2, p. 5 a 42.

1988. As tradições ceramistas do planalto sul-brasileiro. Arqueologia do Rio Grande do Sul: documentos 02, São Leopoldo, IAP/UNISINOS, pp.75-130.

SCHMITZ, P. I. (Coord.) et alii. 1967. Arqueologia no Rio Grande do Sul, Pesquisas, São Leopoldo, 16.

SCHMITZ, P.I. et alii. 1987. Nova contribuição à fase Erveiras, tradição Taquara. In: Arqueologia do Rio Grande do Sul, Brasil, Documentos 01:5-26, Instituto Anchietano de Pesquisas, São Leopoldo.

SCHMITZ, P. I. \& BECKER, I.I. B.1991. Os primitivos engenheiros do planalto e suas estruturas subterrâneas: a tradição Taquara. In: Kern, A. (Org.). Arqueologia préhistórica do Rio Grande do Sul. Porto Alegre, Mercado Aberto, p. 251-289.

SCHMITZ, P. I. \& LA SALVIA, F. 1973. Considerações sobre as culturas cerâmicas não Tupi-guarani do Brasil Meridional. Revista do Instituto de Filosofia e Ciências Humanas. UFRGS, Porto Alegre, ano 1, n. 1, p. 175-201. 
SEEGER, A. 1980. Os índios e nós: estudos sobre sociedades tribais brasileiras. Rio de Janeiro, Campus.

SERRANO, Antonio. 1936. Etnografia de la antígua província del Uruguay. Paraná.

SILVA, Fabíola. s/d. As cerâmicas dos Jê do sul do Brasil e os seus estilos tecnológios: elementos para uma etnoarqueologia Kaingang e Xokleng. Mimeo.

SILVA, Flávio. 1984. Mamíferos silvestres do Rio Grande do Sul. Porto Alegre, FZB/RS.

SILVA, S. B. da. 1989. O sítio arqueológico da Praia da Tapera: um assentamento Itararé e Tupiguarani. PPGAS/UFRGS. Dissertação de mestrado.

1995. Etnoarqueologia proto-Jê meridional através da análise de seu sistema de representações visuais: arte/cultura material e ordenação espacial. PPGAS/USP. Projeto de doutorado.

SILVER, H. 1979. Ethnoart.Ann. Rev. of Antrropology, 8:267-307.

SIMONSEN, I. \& OLIVEIRA, A. de P. 1980. Modelos etnográficos aplicados à cerâmica de Miararré. Goiânia, UFG Editora.

SOUZA, A.B. de D. Paio e. 1956 [1768 a 1774]. Notícia da conquista e descoberta dos sertões do Tibagi. Anais da Biblioteca Nacional, 76.

SULLIVAN, L. E. 1988. Icanchu's Drum: an orientation to meaning in South American. New York, Macmillan Publishing/ London, Collier Macmillan Publishers.

TAVARES, J. da S. 1910. Os Botocudos de Santa Catarina. Brotéria - série de vulgarização científica. Braga, v. IV, p. 277-286. 
TIBURTIUS, G., BIGARELLA, J.R., BIGARELLA, J.J. 1954. Contribuição ao estudo dos sambaquis do litoral norte de Santa Catarina II - Sambaqui do Rio Pinheiros no. 8. Arquivos de Biologia e Tecnologia, Curitiba, 9:141-197.

TOCCHETTO, F.B. 1996. Possibilidades de interpretação do conteúdo simbólico da arte gráfica Guarani. Revista do Museu de Arqueologia e Etnologia. São Paulo, 6:33-45.

TURNER, Terence. 1965. Social structure and political organization among the Northen Cayapo. Unpublisched PH.D, Dissertation, Departament of Social Relations, Harvard University.

UCHÔA, D.P. \& CALDARELLI, S.B. 1980. Petróglifos na região nordeste do Estado de São Paulo. Pesquisas, Antropologia, 31.

URBAN, G. 1978. A model of Shokleng social reality. Chicago, University of Chicago.

. 1992. A história da cultura brasileira segundo as línguas nativas. In: CARNEIRO DA CUNHA, M. (org.). História dos índios no Brasil. São Paulo, Cia. das Letras/FAPESP/SMC.

. 1996. Metaphysical community: the interplay of the senses and the intellect. Austin, University of Texas Press.

VAN VELTHEM, L. 1994. Arte indígena: referentes sociais e cosmológicos. In Grupioni, L.D.B. (org.). Índios no Brasil. Brasília, MEC.

1998. A pele de Tuluperê: uma etnografia dos trançados Wayana. Belém, Museu Paraense Emílio Goeldi.

VASCONCELLOS, D. R. de. Botocudos. Revista da Sociedade de Geographia do Rio de Janeiro. Rio de Janeiro, v. XVII (1904), p. 19-22.

VEIGA, J. 1994. Organização social e cosmovisão Kaingang: uma introdução ao parentesco, casamento e nominação em uma sociedade Jê meridional. Dissertação 
de Mestrado. Programa de Pós-graduação em Antropologia Social, Campinas, Universidade Estadual de Campinas.

. 2000. Cosmologia e práticas rituais Kaingang. Tese de doutorado, UNICAMP.

VIDAL , Lux Boelitz. 1977. Morte e vida de uma sociedade indígena brasileira: os Kayapó-Xikrin do Rio Cateté. Hicitec/EDUSP, São Paulo.

1983. O espaço habitado entre os Kayapó-Xikrin (Jê) e os Parakanã (Tupi), do médio Tocantins, Pará. In: Novaes, S.C. (org.). Habitações indígenas. São Paulo, Nobel/EDUSP, p. 77-102.

1992. Iconografia e grafismos indígenas, uma introdução. In Vidal, L. (org.). Grafismo indígena. São Paulo, EDUSP/FAPESP.

. (Org.). 1992. Grafismo indígena: estudos de antropologia estética. São Paulo, EDUSP/FAPESP.

VIDAL, L.B. \& LOPES DA SILVA, A. 1992. Antropologia estética e contribuições metodológicas. In Vidal, L. (org.). Grafismo indígena. São Paulo, EDUSP/FAPESP.

VIDAL, L.B. \& MÜLLER, R. A. P. 1987. Pintura e adornos corporais. In Suma etnológica brasileira. Vol. 3. Arte índia. Petrópolis, Vozes/Finep.

VIVEIROS DE CASTRO, E.B. 1979. A fabricação do corpo na sociedade xinguana. Boletim do Museu Nacional, 32:2-19.

1986. Araweté: os deuses canibais. Rio de Janeiro, Zahar.

VON IHERING, H. 1895. A civilização pré-histórica do Brasil meridional. Revista do Museu Paulista, vol. I. 
WAGLEY, Ch. 1951. Influências culturais sobre a população: uma comparação entre duas tribos Tupi. In Revista do Museu Paulista, v. V.

WAGLEY, Ch. \& GALVÃO, E. [1949] 1955. Os índios Tenetehara. Serviço de Documentação, MEC.

WERNER, D. W. 1985. Psycho-social stress and the construction of a flood-control dam in Santa Catarina, Brazil. Human organization, (s.1.), v. 44, n. 22. p. 161-7, summer 1985.

WHITLEY, D.S. 1998. New approaches to old problems: archaeology in search of an ever elusive past. In WHITLEY, D.S. (ed.), Reader in archaeological theory: post-processual and cognitive approaches. London/New York, Routledge.

WIESEMANN, U. 1978. Os dialetos da língua Kaingang e Xokleng. Arquivos de Anatomia e Antropologia, vol. III, ano III, Rio de Janeiro.

. 1981. Dicionário Kaingáng - Português / Português - Kaingáng. Brasília, Summer Institute of Linguistics.

WÜST, I. 1992. Contribuições arqueológicas, etnoarqueológicas e etno-históricas para o estudo dos grupos tribais do Brasil Central: o caso Bororo. In Revista do Museu de Arqueologia e Etnologia, São Paulo,2:13-26.

YENGOYAN, A. 1979. Cultural forms and a theory of contraints. In Becker, A.L. \& Yengoyan, A. (orgs.). The imagination of reality: essays in southeast asian coherence systems. New Jersey, Abbex P. Company.

1988. Language, mythe and ontology in aboriginal Australia: the Pitjantjatjara of Central Australia. Anthropology Department Seminar, Harvard University. 


\section{Acervo dos Kaingang paulistas do Museu de Arqueologia e Etnologia da Universidade de São Paulo (MAE-USP)}

Este acervo Kaingang paulista ${ }^{\mathrm{i}}$ foi trabalhado ao longo dos anos de 1996, 1997, 1998 e 1999. Suas peças foram desenhadas, fotografadas e descritas. A documentação a elas referentes (fichas, tombos, etc.) foi consultada e compilada. As fotos e desenhos foram mostrados aos Kaingang do Rio Grande do Sul, que deram nomes aos objetos e aos grafismos neles presentes, bem como revelaram os significados destes últimos. Também falaram da funcionalidade e da tecnologia de produção de muitas peças, além de nomear e descrever os processos de beneficiamento das matérias-primas. A maioria destas informações encontra-se no corpo desta tese. Entretanto, nos itens abaixo, tentou-se condensar as informações mais gerais. Os números citados referem-se aos registros gerais de cada peça no acervo do MAE/USP. Alguns poucos objetos da coleção não puderam ser vistos e analisados, o que fica registrado caso a caso. Na descrição de cada objeto, quando aparece, a barra (/) separa o que foi compilado da documentação do MAE (primeira parte da descrição) daquilo que foi escrito pelo autor. Nesta segunda parte da descrição, estão as interpretações Kaingang, que sempre foram expressamente referidas no texto. Logo após cada entrada, também ocorrem, entre parênteses, descrições gerais do autor ou interpretações nativas, referenciadas.

\section{Amostras de embira, urtiga, imbé, urucu - Vistas e não vistas}

2.589 - Vista. Foto. Na ficha, Baldus, 47; Icatu/SP; embira.

2.590 - Na ficha, Baldus, 47; Icatu/SP; embira.

2.591 - Na ficha, Baldus, 47; Icatu/SP; embira.

3.715 - Na ficha nada consta, exceto "maço de fibra de cipó imbé".

4.120 - Vista. Foto. Na ficha, 1906; CGGSP; Rio Feio; cordão de fibra vegetal.

4.121 - Na ficha, Rio Feio; urucu envolto em embiras e fibras de palmeira.

4.201 - Visto. O Tombo resumido diz ser uma flecha. Não tem ficha. O objeto com este RG é um maço de embira.

4.431 - Na ficha, CGGSP; Rio Feio; cordel de fibra vegetal para tecido.

4.432 - vista. Na ficha, amostra de embira de goimbé; 1906; assalto dos índios à fazenda S. Benedito, da Corredeira do Sr. Joaquim José dos Santos, Bauru/SP.

4.442 - Vista. Foto. Na ficha, urtiga.

9.825 - Vista. Foto. Na ficha, urtiga.

13.767 - Na ficha, col. p/ Baldus, 47. Seda de fibra vegetal. (“Guahuna” Urena Lobata Exv.) "Aramina".

13.768 - Na ficha, Baldus, 47. Fibra de jangada.

13.769 - Na ficha, Baldus, 47. Urtiga.

13.770 - Visto. Na ficha consta: "coroa de cipó”; col. p/ Baldus, 47. Foto. Na realidade é amostra de cipó escada. Veja o Capítulo 4.

\section{Arcos}

1.131 - visto. Na ficha, CGGSP ${ }^{\mathrm{ii}}$,coletado em 25.9.1906. Provavelmente de alburno de guaiuvira; roliço com canaleta longitudinal na face dorsal. Compr.: 2,55 m.

\footnotetext{
${ }^{i}$ Poucos objetos desta coleção são provenientes de Santa Catarina. Quando isto acontece, é feita referência expressa.

ii Comissão Geografica e Geológica de São Paulo.
} 
2.977 - visto. Na ficha, CGGSP; col. em 23.9.906 no local do ataque à turma do Engenheiro Bierremback, no Rio Feio. Kaingang (Coroados).

iii 4.015 - visto. Tombo resumido dá como Meinako. Na ficha, Kaingang (Coroados). Col. em 1906, no local do ataque à turma do Eng. Bierremback, Rio Feio.

4.781 - visto. Nambikuara, provavelmente, na ficha. Compr. 2,62m.

4.876 - visto. Há, tb., flecha Kaingang como mesmo RG. CGGSP.

4.884 - visto. Bororo, provavelmente, na ficha. Tb. consta: 1906, Rio do Peixe,

4.906 - visto. Provavelmente Karajá, na ficha. Na etiqueta, dá como Kaingang.

4.943 - Visto. Não tem ficha. Tombo resumido diz ser arco Kaingang.

5.095 - visto. Ver descrição na flecha de mesmo RG. Bierremback.

5.224 - visto. Na ficha, Rio Feio, 1906, local do ataque à turma do Eng.

5.231 - visto.

5.232 - visto. Apresenta muitas imperfeições, oriundas do processo de retificar a superfície da madeira, que não foi alisada. Não recebeu corda. Compr.: $127 \mathrm{~cm}$. Tombo resumido dá como arco Kaingang. Na ficha, consta provavelmente Kaingang.

5.798 - visto. A etiqueta fixada ao arco registra-o como Kayapó. Tem as mesmas características do arco de RG 5.095 (ver flecha 5.095). Compr.: $233 \mathrm{~cm}$. Tombo resumido dá como arco Kayapó. Na ficha consta como provavelmente Kaingang.

5.865 - visto. Na ficha, 1906.Turma do Rio Feio - Rio Paranapanema, CGGSP. Comprimento 2,45 m. Provavelmente de alburno de guaiuvira. Corte transversal é roliço com canaleta long. de ponta a ponta para dar maior elasticidade.

\section{Arcos ou flechas - Não Vistos}

4.014 - Tombo resumido dá como arco Meinako. Na ficha, consta Kaingang (Coroados), Rio Feio, 1906; arco encontrado no local do ataque à turma do Eng. Bierremback.

4.172 - Tombo resumido dá como flecha Kaingang. Na ficha, flecha p/ pássaros; Rio do Peixe; compr. $160 \mathrm{~cm}$.

4.182 - Tombo resumido dá como flecha Kaingang. Na ficha, col.p/ João Cardoso, 1906; compr. $115 \mathrm{~cm}$.

4.295 - Tombo resumido dá como esteirinha Xavante. Na ficha, diz ter decoração em espiral-linha.

4.907 - Tombo resumido dá como arco Karajá. Ficha, dá como Kaingang.

\section{Armadilhas}

5.298 - vista. Na ficha, 1906; CGGSP; acampamento 15 de nov.; laço para caçar anta.

\section{Armadilhas - Não vistas} $40 \mathrm{~cm}$.

1.134 - Na ficha, Baldus, 47; p/caçar baitacas (vara com laço); compr. 286cm; corda 
1.135 - Na ficha, Baldus, 47; para caçar baitacas (vara com laço); compr. 282cm; corda $40 \mathrm{~cm}$.

5.230 - Na ficha, laço p/ pássaros.

\section{Bodoque (Arco com duas cordas)}

2.982 - visto. Fotografado./ Arco pequeno com duas cordas: no centro das cordas, há dispositivo - apoio -, provavelmente para bola de barro ou pequena pedra. Daí, provavelmente o nome "bodoque" (funda). No centro do arco, há parte mais grossa de madeira, como se fosse uma empunhadura. Os dois dispositivos para fixação das cordas são losangulares. O Livro do Tombo dá como Kaingang e refere à localidade de Pontal, além do nome do objeto (bodoque). Há um problema: ver Bodoque 5.775. Na ficha, Baldus, 47; cordame de tucum; compr. $87 \mathrm{~cm}$; corda $82 \mathrm{~cm}$.

4.745 - Na ficha, consta como provavelmente Guató. Tombo resumido dá como Kaingang. Visto. Semelhante ao descrito acima. Junto aos dispositivos de fixação das cordas há peças em madeira para manter afastadas as duas cordas. Falta dispositivo de apoio. Dispositivo para afastar cordas:

5.233 - Na ficha, s/corda.

5.775 - visto. Igual ao bodoque 2.982. A etiqueta dá como Guarani. Na ficha consta como Kaingang.

Bonecos zoomorfos (paca) de barro - Coletados p/ Baldus e Schultz, $47 \underline{\text { Não }}$ $\underline{\text { vistos }}$

1.145 - Na ficha, feito por m. para criança brincar; compr. $11 \mathrm{~cm}$; figurinha de barro cozido; possui a cara voltada $\mathrm{p} /$ baixo, com olhos e boca escavados, as orelhas bastante toscas são salientes.

1.146 - Na ficha, feito por m. para criança brincar; compr. $16 \mathrm{~cm}$; descrição idem 1.145

\section{Buzina de barro}

3.260 - Na ficha, col. p/ Baldus, 47; feita p/m., usada p/h., uso diário; forma cônica, polida. Vista. Fotos (2), negativo 0775. Compr.: $29 \mathrm{~cm}$; diâmetro abertura: $9,5 \mathrm{~cm}$; compr. do orifício retangular: $2,5 \mathrm{~cm}$; largura do orifício retangular: $1,3 \mathrm{~cm}$. Em cerâmica, que apresenta cor bege-amarronzada na face externa. A interna apresenta crostas pretas de fuligem. A espessura fica em $7 \mathrm{~mm}$. O núcleo é preto $(5 \mathrm{~mm})$, entre paredes de $1 \mathrm{~mm}$ de espessura.

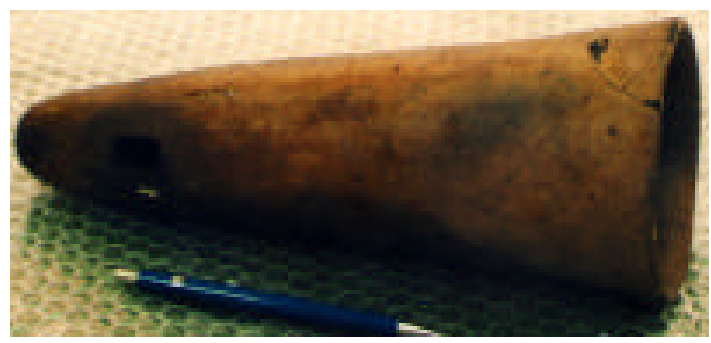




\section{Cabaças}

2.578 - Na ficha, consta como col. p/ Baldus, em Icatu, 1947; para guardar sementes; tampa com sabugo de milho; trançado com cipó imbé envolve a cabaça; alt. $31 \mathrm{~cm}$; diâmetro $3 \mathrm{~cm}$. A casca de cipó imbé ( $k o ́$ mrür fãr) trançada que envolve a cabaça passa por sua face externa, formando losangos e triângulos. Junto à parte do orifício com tampa de sabugo, o trançado termina em alça. Foto (neg. 0775) e desenho.

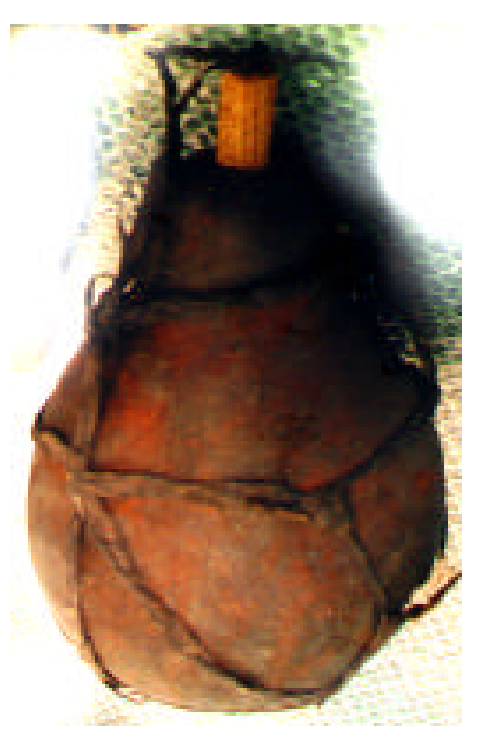

RG. 2.578

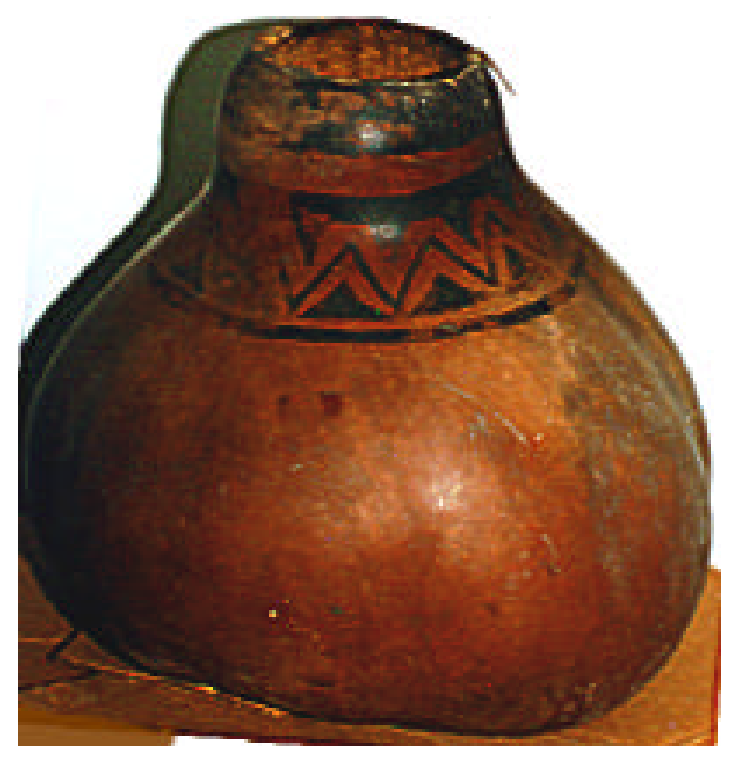

RG. 5.854

5.823 - Vista.

5.854 - Vista. Na ficha, consta como col. por Schultz, 47; usada para guardar sementes de hortaliça; na parte superior tem um "desenho em tinta preta". Totalmente pintado c/ urucu.

5.855 - Vista. Na ficha, "apito", pequeno porongo preto c/ um orifício redondo no corpo e outro na ponta. Alt. $12 \mathrm{~cm}$.

\section{Canoa em miniatura feita de casca de árvore}

4.099 - Não tem ficha. Tombo resumido dá como Kaingang. Vista. Ver documentação M.20/E. 22/P.2. Feita com três tiras de casca de árvore, costuradas entre si. Antes, são feitos furos ao longo das tiras para aí passar a tira vegetal simples. Por dentro da estrutura (na sua concavidade), há muitos reforços de taquara, em forma de arco, para manter a forma da canoa. Ao longo das duas bordas, existem duas varas, também costuradas na casca com tira vegetal simples. O objetivo é o de manter a forma e tornar mais sólida a construção. Foto (neg. 0775) e desenho.

\section{Cestos}

2.579 - visto. Na ficha, trançado de talo de palmeira c/ alça; Schultz, 47; feito por h. e usado por h. e m., para guardar objetos; alt. $44 \mathrm{~cm}$; larg. $33 \mathrm{~cm}$; alça $220 \mathrm{~cm}$. 

ficha.

2.580 - visto. Fotografado. Impermeabilizado internamente com cera. Nada consta na

3.332 - visto. Na ficha, Baldus, 47.

3.333 - Não tem ficha. Tombo resumido dá como cesto Kaingang. Visto. Foto.

3.714 - visto. Na ficha, "Quenhê", jacá (balaio).

3.716 - visto. Na ficha, Schultz, 47; feito por h., usado por m. e h., para guardar objetos.

3.718 - visto. Na ficha, Baldus, 47; feito por mulher e usado por meninos pra guardar bolinhas de barro; trançado espinha de peixe, com broto de palmeira; fibras tingidas de violeta e esverdeado; alt. $3 \mathrm{~cm}$; circ. abert. $20 \mathrm{~cm}$.

3.719 - visto. Na ficha, Baldus, 47; feito por mulher e usado por meninos para guardar bolinhas de barro; trançado espinha de peixe, com broto de palmeira; alt. $3 \mathrm{~cm}$; circ. abert. $16 \mathrm{~cm}$.

3.720 - visto. Na ficha, Baldus, 47; feito por mulher e usado por meninos para guardar bolinhas de barro; trançado espinha de peixe, com broto de palmeira; alt. $3 \mathrm{~cm}$; circ. abert. $22 \mathrm{~cm}$.

3.721 - visto. Na ficha, Baldus, 47; feito por mulher e usado por meninos para guardar bolinhas de barro; trançado espinha de peixe, com broto de palmeira; alt.4,5cm; circ. abert. $20 \mathrm{~cm}$.

3.722 - visto. Na ficha, Baldus, 47; feito por mulher e usado por meninos para guardar bolinhas de barro; trançado espinha de peixe, com broto de palmeira; alt. 3,5cm; circ. abert. $18 \mathrm{~cm}$.

4.097 - visto. Na ficha, Baldus, 47; feito por mulher e usado por menino para guardar bolinhas de barro; trançado espinha de peixe; alt. $4 \mathrm{~cm}$; circ. abert. $20 \mathrm{~cm}$.

4.098 - visto. Na ficha, cesto de junco.

5.818 - visto. Coletado por Baldus, 1947. Feito por m., usado por meninos: brinquedo de meninos; Miniatura de cesto trançado com lascas de taquara. Alt. $7 \mathrm{~cm}$; circ. abertura $25 \mathrm{~cm}$.

5.819 - visto. Col. p/ Baldus, 47. Idem ant. Alt. $3,5 \mathrm{~cm}$; circ. abert. $19 \mathrm{~cm}$.

5.820 - visto. Col. p/ Baldus, 47. Idem ant. Alt. $3 \mathrm{~cm}$; circ. abert. $19 \mathrm{~cm}$.

5.821 - visto. Col. p/ Baldus, 47. Idem ant. Alt. $3 \mathrm{~cm}$; circ. abert. $18 \mathrm{~cm}$.

5.822 - visto. Col. p/ Baldus, 47. Idem ant. Alt. $3 \mathrm{~cm}$; circ. abert. $20 \mathrm{~cm}$.

5.847 - Visto. Col. p/ Baldus, 47. Feito por mulher, usado por meninos para guardar bolinhas de barro. Alt. $3 \mathrm{~cm}$; circ. abert. $19 \mathrm{~cm}$.

5.848 - visto. Idem, idem. Alt. $3,3 \mathrm{~cm}$; circ. abert. $16 \mathrm{~cm}$.

5.849 - visto. Idem, idem. Alt. $3,5 \mathrm{~cm}$; circ. abert. $18 \mathrm{~cm}$.

5.850 - visto. Idem, idem. Icatu-SP. Broto de palmeira. Alt. $3 \mathrm{~cm}$; circ. abert. $17 \mathrm{~cm}$. Tiras tingidas.

5.851 - visto. Idem, idem, idem, idem. Alt. $3,5 \mathrm{~cm}$; circ. abert. $18 \mathrm{~cm}$. Idem.

5.852 - visto. Idem, idem, idem, idem. Alt. $3 \mathrm{~cm}$; circ. abert. $16 \mathrm{~cm}$.

12.618 - visto. Col. P/ Baldus, 47. Feito p/ mulher, usado por crianças. Cestinho trançado de fasquia de taquara c/ alça de embira, c/ tampa. Alt. $7 \mathrm{~cm}$; compr. alça $35 \mathrm{~cm}$; base $10 \times 3,5 \mathrm{~cm}$.

12.619 - visto. Col. P/Baldus, 47. Feito por mulher, usado por criança para guardar bola de barro. Em fasquia de taquara. Alt. $7 \mathrm{~cm}$; circ. abert. $40 \mathrm{~cm}$; base 10 x $5 \mathrm{~cm}$.

12.620 - visto. Idem, idem. Em broto de palmeira. Trançado espinha de peixe. Tingido em cores violeta e esverdeado. Alt. $3 \mathrm{~cm}$; circ. abert. $21 \mathrm{~cm}$. 


\section{Cestos - $\underline{\text { Não vistos }}$}

1.154 - Tombo resumido dá como Kaingang. Na ficha, Baldus, 47; feito p/ h. e usado por $\mathrm{m}$.

3.266 - Tombo resumido dá como Kaingang. Na ficha, base quadrangular; 3 fios horizontais e 3 fios verticais; alt. $57 \mathrm{~cm}$; circ. abert. $36 \mathrm{~cm}$; base $21 \mathrm{~cm}$.

\section{Cestos (Kaingang de SC) Fichas não foram vistas}

14.078 - visto. Fotografado. Em taquara. Livro de Tombo dá como Kaingang de SC. 14.079 - visto. Fotografado. Em taquara. Livro de Tombo dá como Kaingang de SC. 14.080 - visto. Fotografado. Em taquara. Livro de Tombo dá como Kaingang de SC.

\section{Chapéus}

12.615 - visto. Na ficha, col. p/ Baldus, 47.Fotografado. Trançado espinha de peixe. Alt. copa $11 \mathrm{~cm}$; larg. Aba $11 \mathrm{~cm}$.

12.616 - visto. Na ficha, col. p/ Baldus, 47. Fotografado. Feito por homem, usado por homem. Alt. copa $13 \mathrm{~cm}$. Larg. aba $11 \mathrm{~cm}$.

12.617 - visto. Na ficha, col. p/ Baldus, 47. Fotografado. Alt. copa $15 \mathrm{~cm}$. Larg. aba $14 \mathrm{~cm}$.

\section{Colar de ossos de ave}

5.143 - Não tem ficha. Na etiqueta consta: "Colar de ossos de ave. Índios Coroados. Rio do Peixe. São Paulo". Fotografado. No Livro do Tombo consta como Flecha com ponta de madeira. Bororo ou Kayapó. E os nos. MP (Museu Paulista?) 10.470 e 176.470 RUSP.

\section{Colares}

3.264 - visto. Fotografado. Na ficha, Schultz, 47; Dentes de animal presos a fibra vegetal e entrançados nos intervalos com imbé, mais ossinhos, mais dente, mais unhas (?); compr. $10 \mathrm{~cm}$.

3.265 - visto. Fotografado. Colar de crânios e mandíbulas de pequeno macaco. $\mathrm{Na}$ ficha, Rio do Peixe; compr. $330 \mathrm{~cm}$.

4.436 - Visto. Foto. Na ficha, colar com penas.

5.218 - visto. Idem à amostra de embira de RG 4.432. É colar ou amostra de embira? Na ficha, consta colar de cordéis de tucum.

\section{Crânio de macaco para fazer colar}

2.587 - Col. p/ Schultz, 47.

2.588 - Col. p/ Schultz, 47. Ambos parecem não ter sido usados em colares, pois lhes faltava a parte por onde passa a embira do colar. Idênticos aos crânios do colar de RG 3.265 . 


\section{Enfeite de braço, de crina}

4.124 - Não tem ficha. Tombo resumido dá como Kaingang. Visto. Foto.

\section{Escultura antropomorfa - Não vista}

4.114 - Na ficha, Harald Schultz, 45. Doada por João Alves Leite. Entrada em 1945.

\section{Espigas de milho - Coletadas p/ H. Schultz, 47}

1.137 a 1.144. Foram vistas as de RG nos. 1.137, 39, 40, 43 e 44.

\section{Faixas de entrecasca p/ carregar crianças}

2.577 - vista. Na ficha, col. p/ Schultz, 47; compr. $148 \mathrm{~cm}$; larg $6 \mathrm{~cm}$.

3.261 - Na ficha, col. p/ Schultz, 47; feita p/m., usada p/m.

\section{Flauta de madeira}

5.299 - Ficha em branco. Há etiqueta no objeto: "Piracicaba-SP, 1910, flauta de índio. M.P. 4.620". Compr.: $32 \mathrm{~cm}$. Em taquara, recoberta por cordão de fibra vegetal, lado a lado, e, após, formando desenho "fechado". No lado oposto à abertura losangular, foi retirada casca da taquara $(1,5 \mathrm{~cm})$, o que provavelmente indica a embocadura. Fotos (neg. 0775). Desenho.

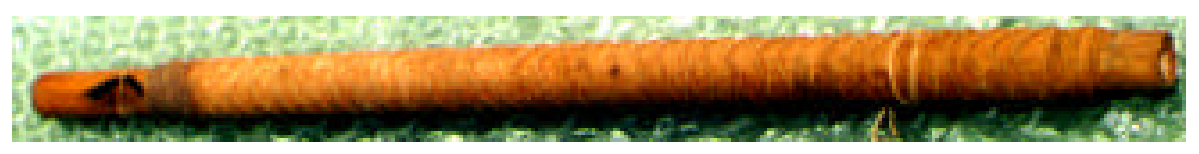

Há outro objeto com mesmo RG: espécie de recipiente retangular, muito comprido e raso, escavado em tronco de arbusto de $6 \mathrm{~cm}$ de diâmetro.

\section{Flechas}

(As pontas ósseas bi-determinadas são feitas de lasca de tíbia de macaco; a cavidade medular é nivelada com resina negra. A palavra "compr." refere-se ao comprimento total da peça.)

1.132 - vista. Na ficha, coletada em 1947; em taquari; para passarinhar; ponta formada por três espeques de madeira presos a um pedaço de madeira, que é unido ao taquari com fios de algodão; no ponto em que termina este enrolamento há outro de cipó imbé de $6 \mathrm{~cm}$; emplumação tangencial; penas presas por fio de algodão; encaixe reforçado com imbé; compr. $170 \mathrm{~cm}$. Há foto de mesmo tipo de ponta descrita acima (RG 4.924). 
2.978 - vista. Na ficha, compr. $176 \mathrm{~cm}$; ponta de ferro com $7 \mathrm{~cm}$.

2.979 - vista. Na ficha, CGGSP, col. em 23.9.906, no Rio Feio; lançada contra a turma do acampamento 15 de novembro; compr. $12 \mathrm{~cm}$; ponta de ferro: $6 \mathrm{~cm}$.

2.980 - vista. Na ficha, CGGSP; 23.9.906; Rio do Peixe; Compr. $185 \mathrm{~cm}$; ponta óssea: $12,5 \mathrm{~cm}$.

2.981 - vista. Na ficha, CGGSP; 23.9.906; Rio do Peixe; Compr. 180cm; ponta óssea: $7,5 \mathrm{~cm}$.

2.983 - vista. Na ficha, para pássaros; cmpr. $150 \mathrm{~cm}$.

2.984 - vista. Tombo resumido dá como flecha p/ pássaros. Na ficha, col. p/ Schultz, 47; para pássaros; ornamentação com imbé; compr. $173 \mathrm{~cm}$. /É nda kamé com ra ionior.

3.406 - vista. Não tem ficha. Tombo resumido dá como flecha Kaingang. Ferro triangular.

4.173 - vista. Na ficha, em x, 1906, Rio do Peixe; para caça, feita por homem, usada por homem; compr. $186 \mathrm{~cm}$; ponta óssea $5 \mathrm{~cm}$.

4.174 - vista. Tombo resumido dá como flecha osso Kaingang. Na ficha, Rio do Peixe, para pássaros; compr. $184 \mathrm{~cm}$; ponta óssea: $5,5 \mathrm{~cm}$.

4.175 - vista. Tombo resumido dá como flecha osso Kaingang. Na ficha, Rio do Peixe; para caça; compr.189; ponta óssea: $9,5 \mathrm{~cm}$.

4.176 - vista. Não tem ficha. Tombo resumido dá como flecha osso Kaingang. Ponta óssea bi-determinada.

4.177 - vista. Não tem ficha. Tombo resumido dá como flecha osso Kaingang. Ponta óssea bi-determinada.

4.178 - vista. Não tem ficha. Tombo resumido dá como flecha osso Kaingang. Ponta óssea bi-determinada.

4.179 - vista. Não tem ficha. Tombo resumido dá como flecha osso Kaingang. Ponta óssea bi-determinada.

4.180 - vista. Não tem ficha. Tombo resumido dá como flecha osso Kaingang. Ponta óssea bi-determinada.

4.181 - vista. Na ficha, Rio do Peixe; para caça; ponta farpada em osso; compr. $187 \mathrm{~cm}$; ponta óssea: $6 \mathrm{~cm}$.

4.183 - vista. Na ficha, Rio do Peixe; coletada por João P. Cardoso, em 1906; compr. $184 \mathrm{~cm}$; ponta óssea farpada: $7,5 \mathrm{~cm}$.

4.184 - vista. Na ficha, Rio do Peixe; col. p/ João P. Cardoso, em 1906; compr. $192 \mathrm{~cm}$; ponta óssea farpada: $7,5 \mathrm{~cm}$.

4.185 - vista. Na ficha, Rio do Peixe, col. p/ João P. Cardoso, em 1906; compr. $184 \mathrm{~cm}$; ponta óssea: $10 \mathrm{~cm}$. I Há outra flecha com o mesmo RG: ponta óssea bi-determinada e anel de imbé na vareta de madeira.

4.186 - vista. Na ficha, Rio do Peixe, 906; Compr. $168 \mathrm{~cm}$; ponta óssea: $8 \mathrm{~cm}$.

4.193 - vista. Na ficha, compr. $185 \mathrm{~cm}$; ponta óssea: $6,5 \mathrm{~cm}$.

4.194 - vista. Na ficha, compr. $183 \mathrm{~cm}$; ponta óssea: $5 \mathrm{~cm}$.

4.195 - vista. Na ficha, compr. $187 \mathrm{~cm}$; ponta óssea: $7,5 \mathrm{~cm}$.

4.196 - vista. Na ficha, compr. $186 \mathrm{~cm}$; ponta óssea: $8,5 \mathrm{~cm}$.

4.197 - vista. Na ficha, col. p/ Frederico Lane; compr. $187 \mathrm{~cm}$; ponta óssea: 7,5cm.

4.198 - vista. Na ficha, col. p/ Frederico Lane; compr. $186 \mathrm{~cm}$; ponta óssea: $10,5 \mathrm{~cm}$.

4.199 - vista. Na ficha, compr. $187 \mathrm{~cm}$; ponta óssea: $8,5 \mathrm{~cm}$.

4.200 - vista. Na ficha, compr. $183 \mathrm{~cm}$; ponta óssea: $6,5 \mathrm{~cm}$.

4.671 - vista. Não tem ficha. Tombo resumido dá como flecha osso Guarani. Descrição: deteriorada. 
4.765 - vista. Ponta de osso apontado. Ver foto das flechas de RGs 4.879 e 4.874. Tombo resumido dá como flecha Kaingang. Na ficha, consta Coroados.

4.772 - vista. Na ficha, decoração em linha espiral; Col. p/ João P. Cardoso, CGGSP, em 906, Rio do Peixe; compr. 187cm; ponta óssea: $8 \mathrm{~cm}$.

4.773 - vista. Na ficha, compr. $190 \mathrm{~cm}$; ponta óssea: $9,5 \mathrm{~cm}$.

4.873 - vista.. Tombo resumido dá como flecha Xavante. Na ficha consta Coroados. / Ndo kander ou iuran

4.874 - vista. Ponta de osso apontado. Foto. Tombo resumido dá como Xavante. Na ficha, consta Coroados.

4.879 - vista. Ponta de osso apontado. Foto. Tombo resumido dá como Bororo. Na ficha, consta Coroados.

4.876 - vista. Há, tb., arco Kaingang com o mesmo RG. 1905, CGGSP, Rio Feio, na ficha. Compr. $181 \mathrm{~cm}$; ponta óssea: $7 \mathrm{~cm}$.

4.924 - vista. Ponta com três varetas de madeira alisada. Mesmo tipo da flecha de RG 1.132. Foto. Tombo resumido dá como flecha Kaingang. Na ficha, 1906, Rio Feio, CGGSP; no local do ataque à Bierremback; compr. $124 \mathrm{~cm}$.

4.925 - vista. Na ficha, CGGSP, col. p/João Cardoso, em 1906; compr. 173cm; ponta óssea $6,5 \mathrm{~cm}$.

4.926 - vista. Na ficha, CGGSP, doada em 931; Rio Feio, lançada no local do ataque a turma do Eng. Bierremback; compr. $180 \mathrm{~cm}$; ponta óssea: 7,5cm.

4.927 - vista. Na ficha, CGGSP, doada em 931; Rio Feio, lançada no local do ataque à turma do Eng. Bierremback; compr. $187 \mathrm{~cm}$; ponta óssea: 7,5cm.

4.928 - vista. Na ficha, CGGSP, doada em 931; Rio Feio, lanç. no local do ataque à turma do Eng. Bierremback; compr. $163 \mathrm{~cm}$.

4.929 - vista. Não possui mais a ponta. Tombo resumido dá como flecha Kaingang. $\mathrm{Na}$ ficha, Rio Feio, CGGSP, no local de ataque à Bierremback.

4.930 - vista. Tombo resumido dá como Kaingang. Na ficha consta Coroados. / Ndo rér.

4.931 - vista. Na ficha, p/ pássaros; ponta óssea $(7 \mathrm{~cm})$; compr. $184 \mathrm{~cm}$.

4.932 - vista. Ndo kander ou iuran. Tombo resumido dá como flecha Kaingang. $\mathrm{Na}$ Ficha, 1906, Rio Feio, no local de ataque à Bierremback; compr. $170 \mathrm{~cm}$; ponta de mad.: $10 \mathrm{~cm}$; taquari: $160 \mathrm{~cm} . \backslash N d o$ rér.

4.933 - vista. 1906, Rio Feio, na ficha (ataque Bierremback); compr.175cm; ponta óssea: $2,5 \mathrm{~cm}$.

4.934 - vista. 1906, Rio Feio, na ficha (ataque Bierrembach); compr. 171; ponta óssea: $5 \mathrm{~cm}$.

4.935 - vista. 1906, Rio Feio, na ficha (ataque Bierremback); compr. $168 \mathrm{~cm}$ (ponta caiu).

4.936 - vista. 1906, Rio Feio, na ficha (ataque Bierremback); compr. $179 \mathrm{~cm}$; ponta óssea: $3 \mathrm{~cm}$.

4.937 - vista. 1906, Rio Feio, na ficha (ataque Bierremback); compr. $180 \mathrm{~cm}$ (ponta caiu).

4.938 - vista. Ponta óssea bi-determinada.. Tombo resumido dá como flecha Kaingang. Na ficha, 1906, Rio Feio, no local do ataque à Bierremback; compr. 188cm; ponta óssea: $6 \mathrm{~cm}$.

4.939 - vista. 1906, Rio Feio, na ficha (ataque Bierrembach); compr. $175 \mathrm{~cm}$; ponta óssea: $7 \mathrm{~cm}$ (a ficha, contraditoriamente, afirma ter a ponta caído). 
4.940 - vista. 1906, Rio Feio, na ficha (ataque Bierremback); compr. 178cm; ponta óssea: $4 \mathrm{~cm}$ (a ficha, contraditoriamente, afirma ter a ponta caído).

4.941 - vista. 1906, Rio Feio, na ficha (ataque Bierremback); compr. 190cm; ponta óssea: $4,5 \mathrm{~cm}$.

5.095 - vista. \Como a de RG 5.295, tem a ponta lanceolada em taquara. Apesar de no Rio Grande do Sul (MJC) aparecer algumas flechas ditas Kaingang com este tipo de ponta, não a considero Kaingang pelos seguintes motivos: Lane recolheu ambas (5.095 e 5.295), e não as cita no artigo de 1959 (Lane, 1959); o Tombo resumido do MAE classifica a primeira como Nambikuara e a segunda, como de origem no Mato Grosso; a de RG 5.295 possuía, conforme a ficha, anéis de pluminhas vermelhas, o que não é característica Kaingang (e sim Xokleng); a emplumação da de RG 5.095, que foge ao padrão Kaingang, possui duas meia-penas coladas com cera preta e costuradas à haste de taquara; apenas duas flechas com este tipo de ponta são encontradas na vasta coleção Kaingang do MAE. Tombo resumido dá como flecha Nambikuara. Na ficha consta como coleta de Fred. Lane, em 1931. Fotos da ponta e da emplumação. Além disso, com o mesmo RG (5.095), há um arco de 191 cm de compr., em madeira preta-acastanhada, lisa, polida, com corda torcida para reposição, de seção plano-plana, sem dispositivo para fixação da corda, que á amarrada diretamente às pontas progressivamente afinadas.

5.227 - vista. Tombo resumido dá como Kaingang. Na ficha, consta Coroados. Ndo kander ou iuran.

5.228 - vista. Tombo resumido dá como Kaingang. Na ficha, consta Coroados. Ndo kander ou iuran.

5.242 - vista. 1906, Rio Feio, CGGSP; sem ponta; compr. 175, na ficha.

5.275 - vista.. Tombo resumido dá como Guarani. Na ficha, consta Coroados. $\backslash N d o$ kander ou iuran.

5.295 - vista. Não são mais vistos os "anéis de pluminhas", referidos na ficha. Não a considero Kaingang (razões expostas na flecha de RG 5.095). Tombo resumido dá como flecha do Mato Grosso. Na ficha, consta coletada por Lane, em 1931; compr. 124cm; taquari: $102 \mathrm{~cm}$; ponta lanceolada: $22 \mathrm{~cm}$; c/ anéis de pluminhas vermelhas. Foto da ponta.

5.304 - vista. Não mais possui a ponta. Tombo resumido dá como flecha Kaingang. Na ficha, compr. 192; ponta óssea: $8 \mathrm{~cm}$.

5.305 - vista. Tombo resumido dá como flecha Kaingang. Na ficha, ponta de madeira p/ passarinhar; compr. $176 \mathrm{~cm}$. Nda kainru-kré (ra ror).

5.306 - vista. Na ficha, compr. $189 \mathrm{~cm}$; ponta óssea: $8 \mathrm{~cm}$.

5.307 - vista. Duas flechas com mesmo RG, no flecheiro 43. Compr. $183 \mathrm{~cm}$; ponta óssea $9 \mathrm{~cm}$.

5.307 - vista. Duas flechas com mesmo RG, no flecheiro 43. Compr. $185 \mathrm{~cm}$; ponta óssea: $9,5 \mathrm{~cm}$.

5.308 - vista. Tombo resumido dá como flecha Kaingang. Na ficha, decoração em espiral. Compr. 192,5 cm; ponta óssea $8 \mathrm{~cm}$. \ Ponta óssea bi-determinada (ndéi ainda presente na parte distal da ponta). Não é mais possível ver os grafismos: deteriorada.

5.309 - vista. Na ficha, compr. $189 \mathrm{~cm}$; ponta óssea: $8 \mathrm{~cm}$.

5.310 - vista. Na ficha, doação em 23.9.23 (provavelmente é de 1906). Compr. 185 $\mathrm{cm}$; ponta óssea: $4 \mathrm{~cm}$.

5.720 - vista. Deteriorada. Tombo resumido dá como Kayuá. Na ficha consta, Coroados.

5.746 - vista. Na ficha, lançada sobre a turma do Rio Feio, na margem esquerda do Córrego Corredeira, em 8.7.1906. Compr. 192cm; ponta óssea $10 \mathrm{~cm}$. 
5.771 - vista. Tombo resumido dá como Kayuá. Na ficha consta, Coroados. \Ndo rér.

5.772 - vista. Tombo resumido dá como Kayuá. Na ficha, consta Coroados. / Ndo kander ou iuran.

5.777 - vista. Tombo resumido dá como flecha Kayuá. Na ficha, consta Kaingang. Descrição idem à 4931. Compr. $181 \mathrm{~cm}$; ponta óssea 4,5 cm. \Possui dois conjuntos de anéis de kó mrür fãr na vareta de madeira.

5.856 - vista. Na ficha, 1906; Rio do Peixe; CGGSP. Compr. 192 cm; ponta óssea 11 $\mathrm{cm}$.

S/RG 20.022 - vista.

S/RG 20.054 - vista.

S/RG 20.055 - vista.

S/RG 20.056 - vista.

S/RG 20.057 - vista.

S/RG 20.058 - vista.

S/RG 20.059 - vista.

S/RG 20.060 - vista.

S/RG 20.061 - vista.

S/RG 20.062 - vista.

S/RG 20.063 - vista.

S/RG 20.064 - vista.

S/RG 20.072 - vista

S/RG 20.073 - vista. 


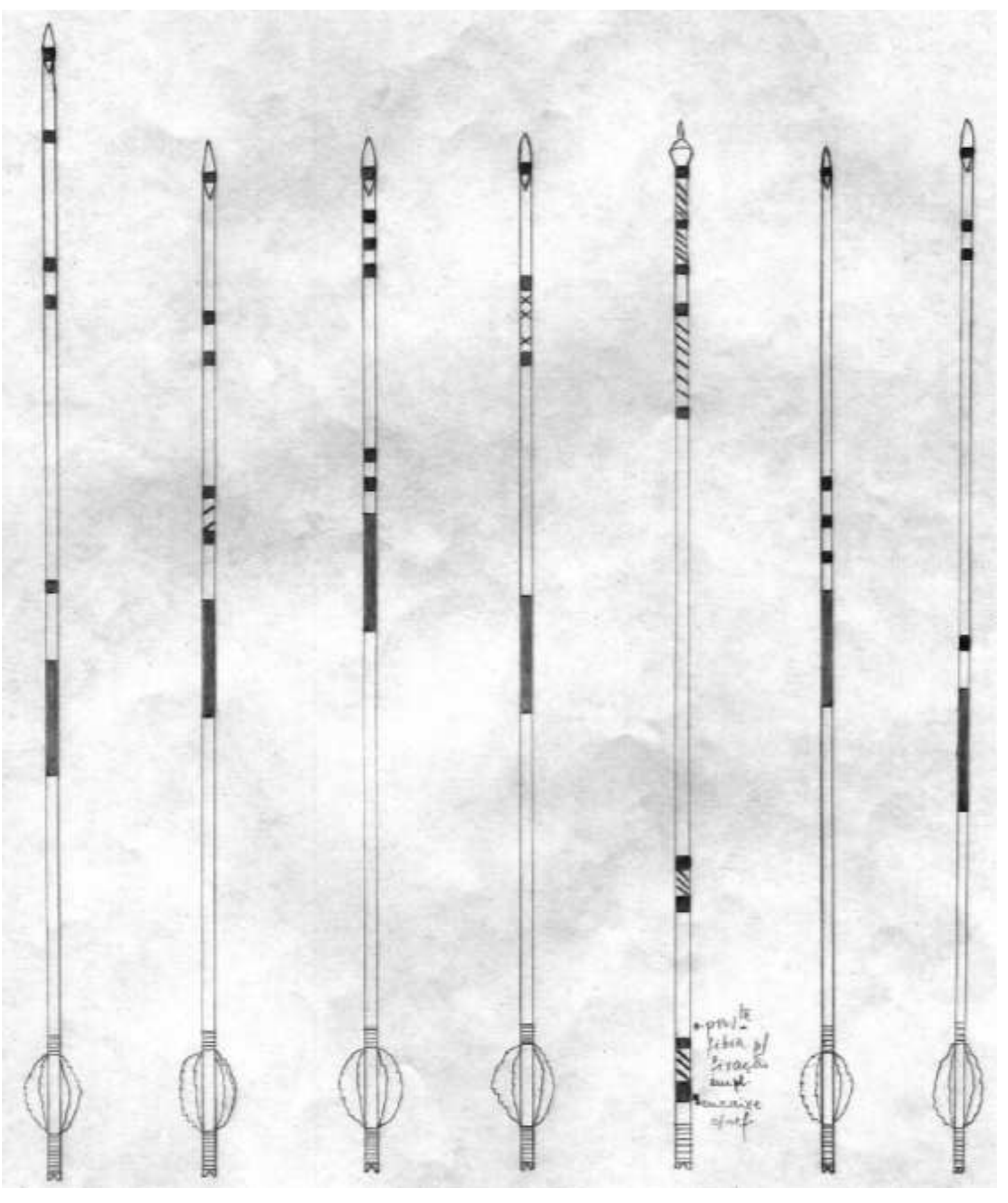

Desenhos das flechas do MAE/USP e de seus grafismos. Escala 1/10. As porções mais escuras, inclusive as paralelas, representam o cipó imbé; as mais finas, e paralelas, indicam fibra vegetal. Os modelos acima correspondem às flechas com os seguintes RGs: $1^{\circ}$. modelo: $4193 ; 2^{\circ} .: 4939 ; 3^{\circ} .: 4934 ; 4^{\circ} .: 4173 ; 5^{\circ} .: 2983 ; 6^{\circ} .: 4933 ; 7^{\circ} .: 5306$. 


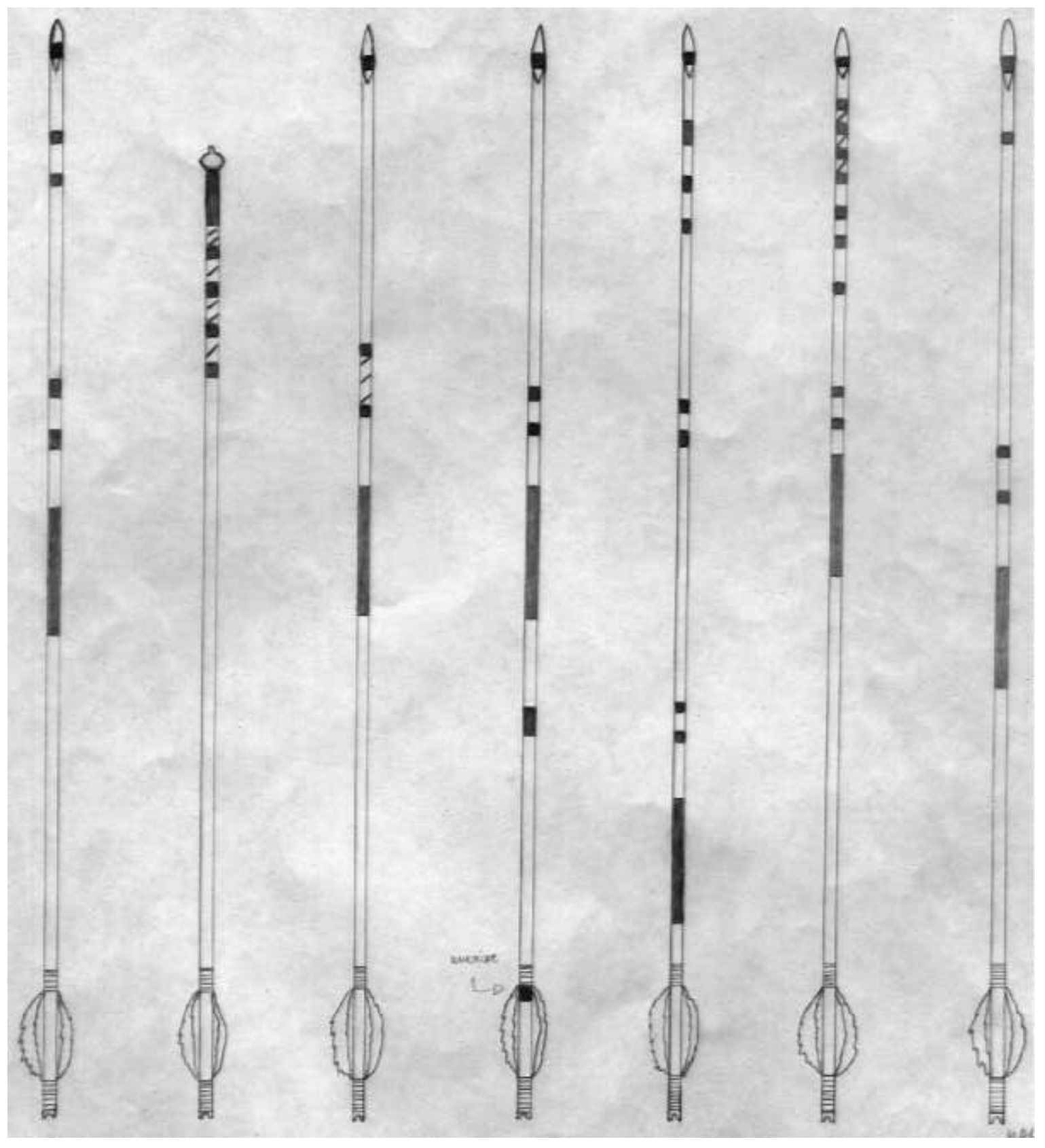

Desenhos das flechas do MAE/USP e de seus grafismos. Escala 1/10. Os modelos acima correspondem às flechas com os seguintes RGs: $1^{\circ}$. modelo: 5856, s/rg20.063, 5242, 4773, 4183, $5307,4931,4178,5777 ; 2^{\circ} .: \mathrm{s} / \mathrm{rg} 20055 ; 3^{\circ} .: \mathrm{s} / \mathrm{rg} 20062 ; 4^{\circ} .: \mathrm{s} / \mathrm{rg} 20059 ; 5^{\circ} .: \mathrm{s} / \mathrm{rg} 20057 ; 6^{\circ} .: 4936 ;$ $7^{\circ}: \mathrm{s} / \mathrm{rg} 20061$. 


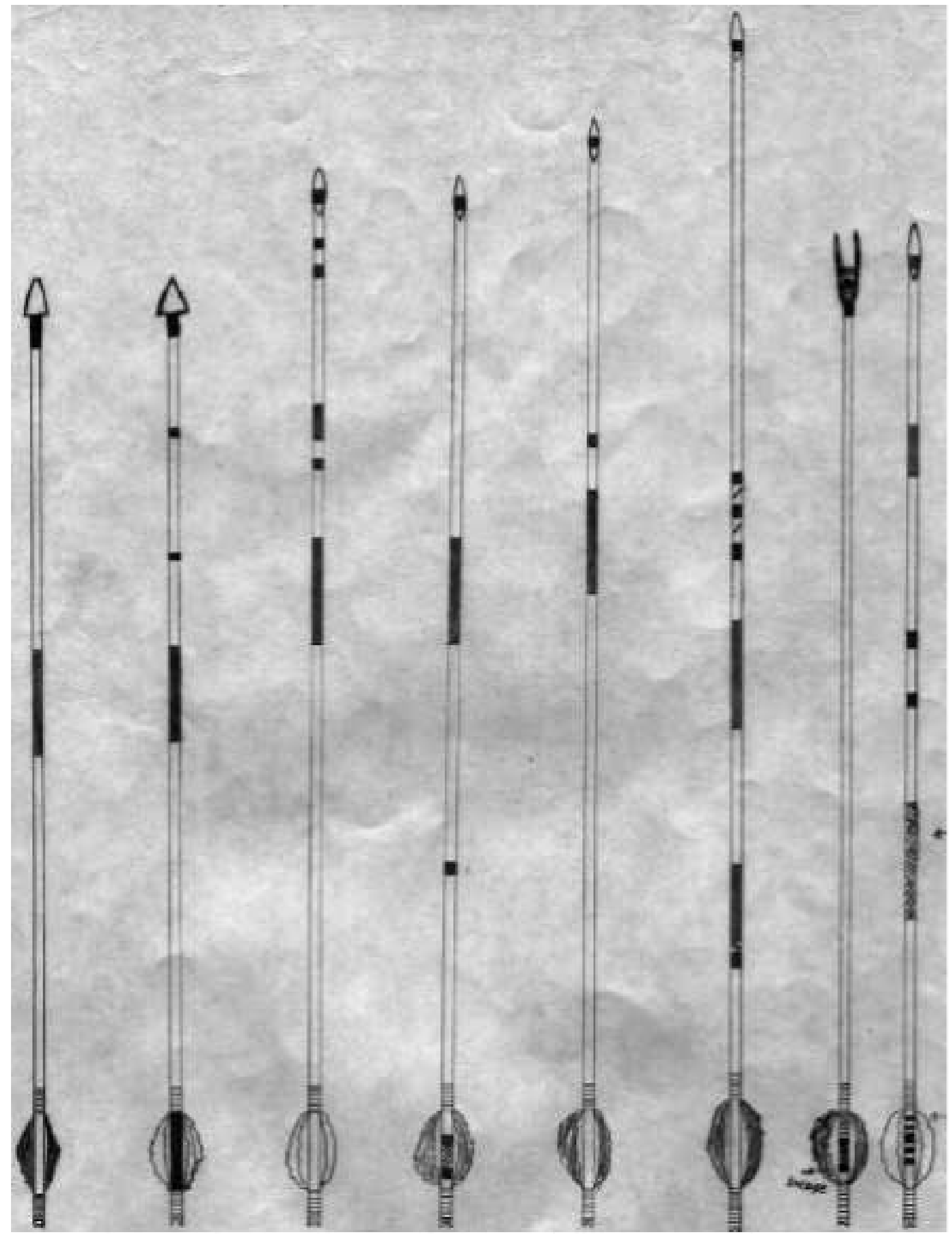

Desenho das flechas do MAE/USP e de seus grafismos. Escala 1/10. Os modelos acima correspondem às flechas com os seguintes RGs: $1^{\mathrm{o}}$. modelo: $3406,2978,4937, \mathrm{~s} / \mathrm{rg} 20073 ; 2^{\circ} .: 2979 ; 3^{\circ} .4194 ; 4^{\circ} .4185$; $5^{\circ} .: 4186,4196,4176,5307,4185 ; 6^{\circ} .: 4197 ; 7^{\circ} .: 1132 ; 8^{\circ} .: 4195$. 


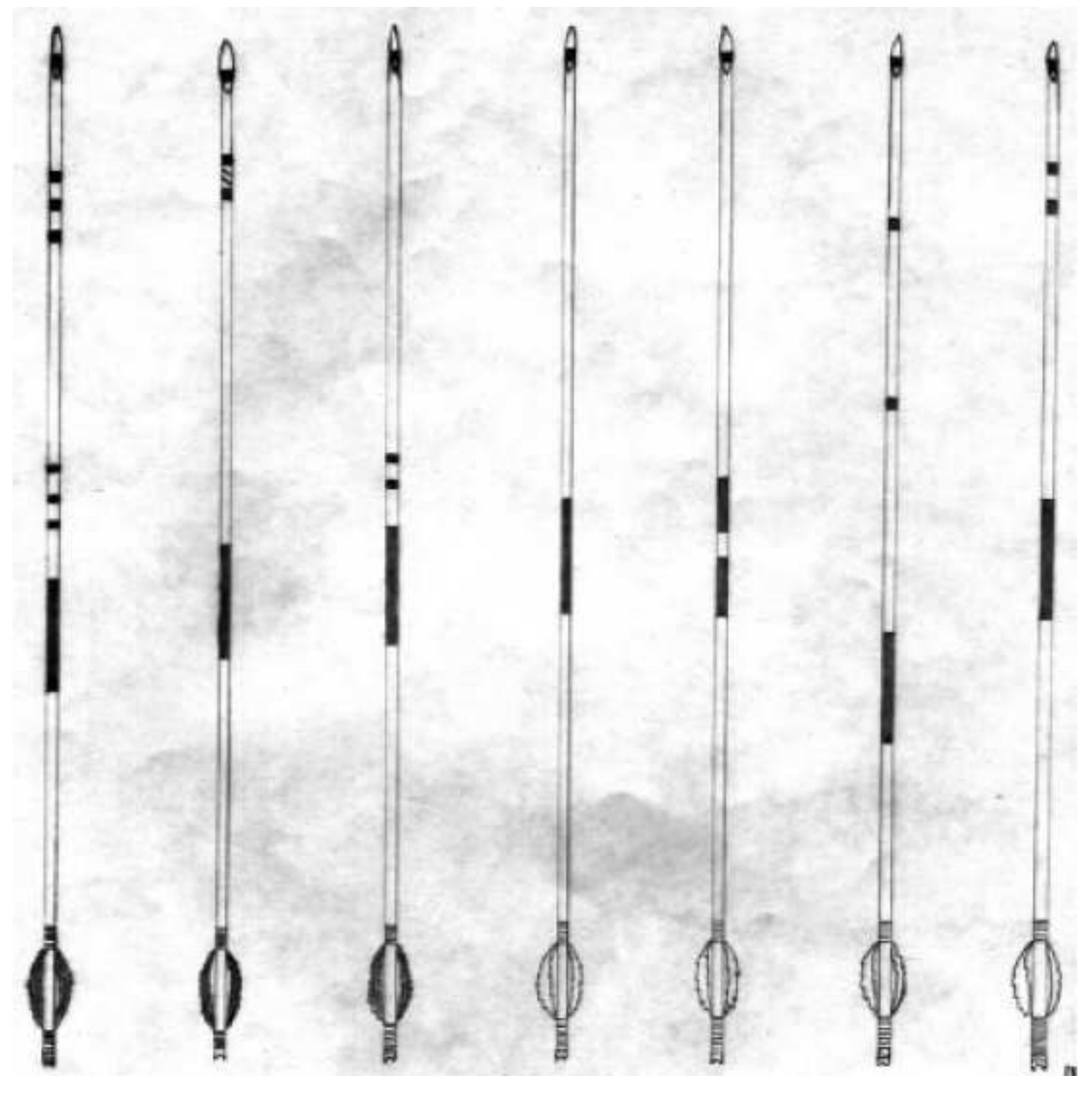

Desenhos de flechas do MAE/USP e de seus grafismos. Escala 1/10. Os modelos acima correspondem às flechas com os seguintes RGs: $1^{\circ}$. modelo: 4940; $2^{\circ}$.: 4177, $4772 ; 3^{\circ}$.: 4199,4174, s/rg20060; $4^{\circ} .: 5310,4179,4181,4927,4198,4935,4184$, s/rg20022, 5746, $4175,2981,2980, \mathrm{~s} / \mathrm{rg} 20072 ; 5^{\circ} .: \mathrm{s} / \mathrm{rg} 20058 ; 6^{\circ} .: 5309, \mathrm{~s} / \mathrm{rg} 20064 ; 7^{\circ} .: 4941,4925$.

\section{Fusos - Não vistos}

1.151 - Na ficha, col. Baldus, 47; feito p/h., usado p/m., p/fiar fios de algodão; compr. $29 \mathrm{~cm}$. 
4.123 - Na ficha, col. Rondon, 23; Kaingang de Mato Grosso; duas peças de madeira; estilete $19 \mathrm{~cm}$; tortual $17 \mathrm{~cm}$.

\section{Machado de pedra}

4.139 - Na ficha, 1905; Rio do Peixe. Compr.: 17 cm; altura máxima: 6 cm. \Lâmina de machado de gume polido, com depressão semi-esférica na face plana e percutor na parte proximal. Há dispositivo polido de encabamento. Seção plano-convexa. Há sinais de uso no gume (negativos de lascas) e na porção proximal (sinais de percussão). Foto (neg.0775). Desenho.

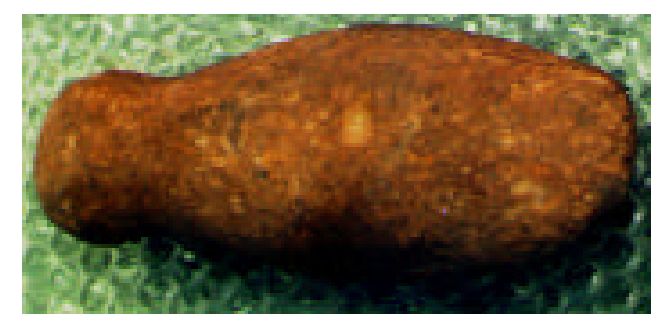

\section{Mão-de-pilão em madeira}

4.883 - Visto. Na ficha consta: "pau com queima". Na verdade, trata-se de mão de pilão com queima. Foto.

\section{Maracá de cabaça ornamentada - $\underline{\text { Não visto }}$}

1.150 - Na ficha, col. p/ Schultz, 47; feito por h., usada por h. na dança ou festa.

\section{Molduras de espelho}

4.315 a 4.326 - vistas. Na ficha consta: "encontradas no local onde foi trucidado o M. Claro H de Mello - Comissão Geográfica e Geológica de São Paulo - 1906".

\section{Panelas e tigelas de barro - A maioria vistas}

1.147 - Na ficha, Baldus, 47; Icatu/SP; achada na margem do Rio Feio, Osv. Cruz; cônica c/ alça de entrecasca; alt. $36 \mathrm{~cm}$; circ. abert. 19cm; esp; $1 \mathrm{~cm}$; alça $48 \mathrm{~cm}$.

1.148 - Na ficha, Baldus, 47; Icatu/SP; cônica, pequena; alt. $14 \mathrm{~cm}$; circ. abert. $16 \mathrm{~cm}$.

1.149 - Na ficha, Schultz, 47; cônica; alt. $14 \mathrm{~cm}$; circ. abert. $16 \mathrm{~cm}$. $18 \mathrm{~cm}$.

1.163 - Na ficha, cônica; feita p/ m. p/ alimentos; alt. 26cm; esp. 1cm; circ. abert.

1.164 - Na ficha, feita p/ m. p/alimentos; alt. 13cm; circ. abert. $12 \mathrm{~cm}$; esp. $1 \mathrm{~cm}$.

1.165 - Na ficha, moringa, feita por m., para água; alt. $19 \mathrm{~cm}$; cir. abert. $3 \mathrm{~cm}$; circ. $49 \mathrm{~cm}$.

1.166 - Na ficha, Baldus e Schultz, 47; Icatu-Sp; feita p/ m. p/alimentos; cônica; alt. $16 \mathrm{~cm}$; circ. abert. $11 \mathrm{~cm}$.

1.167 - Na ficha, Schultz, 47; feita por m., usada p/ m. na cozinha. 
1.168 - Na ficha, Baldus e Schultz, 47; Icatu-SP; feita por m. e usada $\mathrm{p} / \mathrm{m}$. p/alimentos; alt. 14cm; circ. abert. $15 \mathrm{~cm}$.

1.169 - Na ficha, Baldus e Schultz, 47; feita p/ m., usada por m. e h., p/alimentos.

1.170 - Na ficha, Baldus, 47; feita por m., usada p/ m. p/cozer alimentos; cônica, s/alça; alt. $39 \mathrm{~cm}$; circ. abert. $22 \mathrm{~cm}$; esp. $1 \mathrm{~cm}$.

2252 ou2.552 - Na ficha, Baldus e Schultz, 47; feita p/m. e usada p/m., p/alimentos; cônica; alt. $13 \mathrm{~cm}$; circ. abert. $10 \mathrm{~cm}$; esp. $0,5 \mathrm{~cm}$.

2.555 - Na ficha, Baldus e Schultz, 47; feita p/m., usada p/m. e h., p/ alimentos; tigela; alt. $10 \mathrm{~cm}$; circ. abert. $11 \mathrm{~cm}$; esp. $0,5 \mathrm{~cm}$.

2.556 - Na ficha, Baldus e Schultz, 47; feita p/m., usada p/m. e h., p/alimentos; tigela; alt. $20 \mathrm{~cm}$; circ. abert. $19 \mathrm{~cm}$; esp. $2 \mathrm{~cm}$.

2.557 - Na ficha, Baldus e Schultz, 47; feita p/m., usada p/h. e m., p/alimentos; panela cônica; alt. $13 \mathrm{~cm}$; circ. abert. $11 \mathrm{~cm}$; esp. $1 \mathrm{~cm}$.

2.558 - Na ficha, Baldus e Schultz, 47; feita p/m., usada p/m. e h., p/alimentos; panela cônica; alt. $13 \mathrm{~cm}$; circ. abert. $11 \mathrm{~cm}$; esp. $1 \mathrm{~cm}$.

2.559 - Na ficha, col. p/ E. Garbe, 1910; Estação Hector Legru, Estrada de Ferro Noroeste do Basil; feita p/m., usada p/m., p/alimentos; panela cônica; alt. $29 \mathrm{~cm}$; circ. abert. $19 \mathrm{~cm}$; esp. $1 \mathrm{~cm}$.

2.560 - Na ficha, Baldus e Schultz, 47; feita p/m. e usada p/m., p/alimentos; Icatu/SP; panela cônica; alt. $28 \mathrm{~cm}$; circ. abert. $20 \mathrm{~cm}$; esp. $1 \mathrm{~cm}$.

2.561 - Na ficha, CGGSP; 23.11.906; Rio do Peixe; feita p/m., usada p/m., p/alimentos; panela cônica; alt. $27 \mathrm{~cm}$; circ. abert. $20 \mathrm{~cm}$; esp. $1 \mathrm{~cm}$.

2.563 -. Vista. Não tem ficha. O Tombo resumido dá como Kaingang. Base cônica, abertura com lábio extrovertidos. $40 \mathrm{~cm}$ de altura. Desenho. Ver documentação M.14/E15/P.2.

2.564 - Na ficha, 1947; panela cônica; alt. $35 \mathrm{~cm}$; circ. abert. $21 \mathrm{~cm}$; esp. $1 \mathrm{~cm}$.

2.565 - Na ficha, Baldus e Schultz, 47; Icatu/SP; feita p/m. e usada $\mathrm{p} / \mathrm{m}$., p/alimentos; panela cônica c/ vestígios de tinta branca; alt. $41 \mathrm{~cm}$; circ. abert. 23 ; alça $150 \mathrm{~cm}$.

2.566 - Na ficha, Inspetoria do SPI em SP; 19.3.912; Rio Feio; tribo de Vauhin; panela cônica; alt. $36 \mathrm{~cm}$; circ. abert. $24 \mathrm{~cm}$.

2.570 - Na ficha, Baldus e Schultz, 47; Icatu/SP; feita p/m., usada p/m., p/cozer alimentos; panela cônica; alt. $28 \mathrm{~cm}$; circ. abert. $20 \mathrm{~cm}$; esp. $1 \mathrm{~cm}$.

2.571 - Na ficha, Schultz, 47; feita p/m., usada p/m., p/alimentos; panela arredondada com alça de barro; parte superior c/ vestígios de tinta branca; alt. $18 \mathrm{~cm}$; circ. abert. $16 \mathrm{~cm}$; esp. $1 \mathrm{~cm}$.

2.592 - Na ficha, Schultz, 47; feita p/m., usada p/m. e h., p/ alimentos; tigelinha; alt. $10 \mathrm{~cm}$; circ. abert. 11 ; esp. $0,5 \mathrm{~cm}$.

3.723 - Na ficha, Baldus, 47; Icatu/SP; panela arredondada; alt. 11cm; circ. abert. $11 \mathrm{~cm}$; circ. $46 \mathrm{~cm}$.

4.543 - vista. Não tem ficha. O Tombo resumido dá como Kaingang. Ver documentação M.14/E - 14/P.1. Diâmetro abertura: $16 \mathrm{~cm}$; alt.: $19 \mathrm{~cm}$; diâmetro base plana: $11 \mathrm{~cm}$. Cerâmica grosseira; espessura muito grossa. Desenho,

5.833 - Na ficha, Schultz, 47. Feita por m., usada por todos p/ alimentos. Prato de barro. Alt. $8 \mathrm{~cm}$; circ. abert. $24 \mathrm{~cm}$.

5.838 - vista. Fotografada. Schultz, 47. Feita p/ mulher, usada p/ mulher, p/ alimentos. Panela em forma de ânfora. Forma típica: "corpo cônico e bordo nascendo de um estreitamento do corpo". Alt. $41 \mathrm{~cm}$. Esp., $1 \mathrm{~cm}$. Circ. abert. $26 \mathrm{~cm}$. 
13.549 - Na ficha, consta como confeccionada pela índia Candira (nome indígena Levanhesu) do PI Vanuire Tupã, Est. de S.Paulo. Cerâmica doada em 1978 p/ Nair Ghedini, Diretora do Museu Histórico e Pedagógico de Tupã - Rua Aimorés, 1358 - C. Postal 55 Tupã - 17.600. Nome ind. da panelinha cônica de barro é "cocran"; usada para cozer macaco e aves grandes. Na época da doação, Candira tinha 74 anos e era a única na aldeia a fazer cerâmica. Alt. 17,5 cm. Circ. abert. $10 \mathrm{~cm}$. Circ. (sic) $31 \mathrm{~cm}$. Base $12 \mathrm{~cm}$. Circ. maior do bojo $34 \mathrm{~cm}$.

\section{Peneiras miniatura feitas com folha de palmeira}

3.724 - vista. Pelo Livro de Tombo é Kaingang e foi coletada por Baldus, em 47. Na ficha, consta como coleta de Schultz, 47; consta, contraditoriamente, como feita c/ fasquias de taquara (ao mesmo tempo diz que com folha de palmeira); arremate da borda com fio de tucum; fios entrecruzados formando hexágonos; circunf. $15 \mathrm{~cm}$.

3.725 - vista. Pelo Livro de Tombo é Kaingang e foi coletada por Baldus, em 47. Na ficha, consta como coleta de Schultz, 47; consta, contraditoriamente, como feita de fasquias de taquara (ao mesmo tempo diz "com folha de palmeira"); arremate da borda com fio de tucum; fios entrecruzados formando hexágonos; circunf. $14 \mathrm{~cm}$.

\section{Tacape (Bastão de combate)}

2.975 - Na ficha, Rio do Peixe; mad. avermelhada; "suatambú"; compr. 276cm. Não vista.

4.753 - Na ficha, tacape. Vista. Foto.

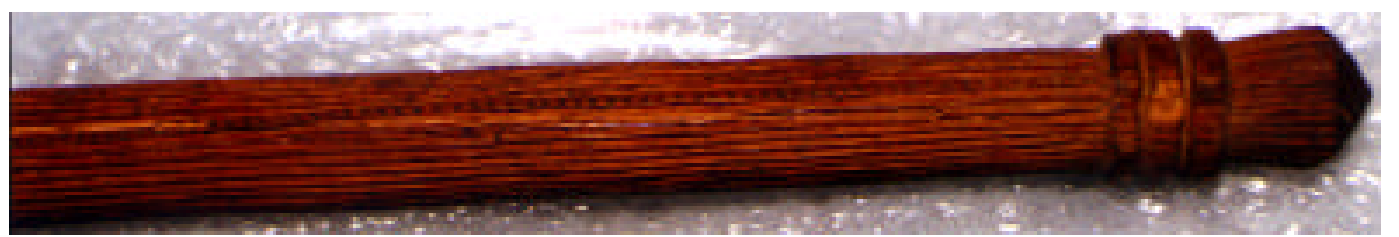

\section{Tecidos}

(Denominados de kurã - roupa quente - e feitos a partir de fios de urtiga -ven burfê. Os fios que dão forma aos grafismos foram tingidos provavelmente com as folhas de um cipó denominado mrür kuxun - cipó vermelho. Informação dos Kaingang de Nonoai).

1.136 - Tombo resumido dá como Kaingang. Na ficha, fios de caraguatá; usado para a dança e como mortalha; doador Érico Sampaio, 1947; alt. 162cm; larg. $133 \mathrm{~cm}$.

3.259 - visto. Tombo resumido dá como Kaingang. Na ficha, com urtiga; ornamentação em ziguezague; compr. $34 \mathrm{~cm}$; larg. $105 \mathrm{~cm}$. / Trata-se de tecido em confecção. Possui padrão gráfico formado por quatro linhas em ziguezague, agrupadas duas a duas, sem oposição. As próprias linhas em ziguezague são formadas por linhas em ziguezague. Os grafismos, feitos com fios tingidos que se destacam sobre o fundo mais claro, foram denominados pelos Kaingang de Nonoai de ra ionior e considerados téi (metade Kamé). Foto.

3.283 - visto. Na ficha, em urtiga; compr. $158 \mathrm{~cm}$; compr. s/franjas: $156 \mathrm{~cm}$. / Possui uma faixa central única de três losangos concêntricos sobrepostos, denominado de ra ianhiá 
(marca misturada) pelos Kaingang de Nonoai, uma vez que representa um grafismo da metade Kainru-kré (ra ror - o losango, neste caso) de maneira alongada, linear, "sem fim", que é a característica dos grafismos da metade Kamé (ra téi). No mesmo kurã, à esquerda, há grafismo linear em ziguezague, ligado à metade Kamé ( $r a$ téi) e chamado especificamente de ra ionior. Os grafismos, feitos com linha industrial vermelha, destacam-se sobre o fundo claro do tecido em urtiga. Junto à porção da franja, os losangos foram iniciados com fio acastanhado, tingido. No sentido do comprimento, possui duas linhas de contorno em cada lado; no sentido da largura, tem quatro linhas de contorno na parte superior e quatro linhas de contorno da porção inferior. Medidas: comprimento sem franja - $150 \mathrm{~cm}$; com franja (que ocorre na porção inferior) $-160 \mathrm{~cm}$; largura $-155 \mathrm{~cm}$. Foto.

3.284 - visto. 1906, na ficha. Na etiqueta: mortalha kaingang. / Possui uma faixa central com quatro linhas em ziguezague, que se opõem duas a duas. Os ângulos das linhas em ziguezague opostas e internas não se tocam, não formando, portanto, losangos. Por sua vez, as próprias linhas em ziguezague são formadas por linhas em ziguezague. O padrão gráfico foi denominado de ra ionior rengrê, tendo sido considerada marca da metade Kamé (ra téi). Possui, no sentido do comprimento, uma linha de contorno em cada lateral;no sentido da largura, tem quatro linhas de contorno na parte superior e quatro linhas de contorno na porção inferior, onde há franjas. Os grafismos, feitos com fío de cor acastanhada, provavelmente tingido, destacam-se no fundo mais claro (fios não-tingidos). Medidas: comprimento sem franja - 1,51 m; com franja - 1,54 m; largura - 1,54. Foto.

3.285 - visto (na vitrine do MAE). Tombo resumido dá como Kaingang. Na ficha, 1906, Rio Feio; feito por mulher e usado por mulher; em urtiga; compr. $95 \mathrm{~cm}$; larg. $40 \mathrm{~cm}$; camisolão. / Possui padrão gráfico de várias linhas em ziguezague, formadas por pequenos quadrados ligados por seus vértices diagonalmente opostos. Trata-se do grafismo denominado de ra ianhiá pelos kaingang de Nonoai, na medida em que "mistura" as marcas fechadas (ror; os pequenos quadrados) com as abertas (téi; a linha em ziguezague - ra ionior). Desenho.

3.746 - visto. Na ficha, manto tecido de fibra de urtiga; compr. $109 \mathrm{~cm}$; larg. $114 \mathrm{~cm}$. / Possui padrão gráfico de losangos intercalados, denominado de ra ror ê, pelos Kaingang de Nonoai. Este padrão gráfico fechado representa a metade Kainru-kré. Os grafismos, feitos com fio de cor acastanhada, destacam-se sobre o fundo mais claro de tecido. Nota-se que o contorno dos losangos é feito com linhas em ziguezague, que, sozinhas, representam a metade Kamé e é denominada de ra ionior. As medidas tomadas foram: largura $100 \mathrm{~cm}$, comprimento $-139 \mathrm{~cm}$. No sentido do comprimento, possui uma linha de contorno em cada lado; no sentido da largura, tem duas linhas de contorno na parte superior e duas linhas de contorno na porção inferior. Foto.

3.747 - visto. Na ficha, 1906; manto tecido de urtiga; compr. $109 \mathrm{~cm}$; larg. $114 \mathrm{~cm} . /$ De forma semelhante ao kurã de RG 3.284, possui padrão gráfico central formado por quatro linhas em ziguezague, opostas duas a duas. Seus ângulos não se tocam, não formando, assim, losangos. As próprias linhas em ziguezague são formadas por linhas em ziguezague. Foi denominado de ra ionior rengrê e considerada marca dos Kamé (ra téi), pelos Kaingang de Nonoai. Possui linhas de contorno duplas em cada lateral, em forma de grega. Como estas linhas "não têm fim", não se encontram, foi considerado pelos Kaingang de Nonoai um motivo "aberto" e, portanto, ra téi. Na parte superior, no sentido da largura, há quatro linhas de contorno; na porção inferior, não há linha de contorno, mas existe franja Os grafismos são feitos com fios tingidos de urtiga, que se destacam sobre o fundo tecido 
com urtiga não-tingida. Medidas: comprimento sem franja $-98 \mathrm{~cm}$; com franja $-104 \mathrm{~cm}$; largura $113 \mathrm{~cm}$. Foto.

4.113 - visto. Na ficha, Paraná, 1897; pano tecido de raiz de urtiga; compr. $123 \mathrm{~cm}$; larg. 99cm; tecida em "twine". / Possui cinco faixas de losangos duplos (de contorno em linha simples), de início ao fim do tecido, feitas com fio de cor acastanhada, que se destaca sobre o fundo mais claro do tecido. O padrão gráfico foi chamado de ra ianhiá (marca misturada) pelos Kaingang de Nonoai, uma vez que representa grafismos fechados (ra ror) de maneira linear, aberta (téi). No sentido do comprimento, possui uma linha de contorno em cada lado; no sentido da largura, tem duas linhas de contorno na parte superior e duas linhas de contorno da porção inferior. Foto.

4.122 - Não tem ficha. Tombo resumido dá como cinto Kaingang tecido de algodão. Visto. Foto.

\section{Tenazes de madeira}

2.574 - B, 47, 2.575 - B., 47, 3.262 (vista - B, 47; Rio Feio; no local do ataque a Bierremback, em 1906; doador: CGGSP, em 1931; compr. $119 \mathrm{~cm}$. Ficha contraditória.), 3.263 (vista), 3.334 (vista - idem RG 3.262), 3.335 (vista - Baldus e Schultz, 47; compr. 149cm.), 3.336 - B. e S., 47; compr. $143 \mathrm{~cm}$., 4.750 (vista - CGGSP; Rio Feio, 1931), 4.751 (vista) e 4.752 (vista).

\section{Vara}

4.942 - Vista. É uma vara pouco espessa, frágil, não podendo ter sido usada como bastão de combate (como parece querer indicar a ficha). Numa das pontas, possui corda de fio vegetal que termina por um pequeno fragmento de madeira no qual está encravado um arame curvo semi-enferrujado. Cópia de vara de pesca ocidental?

\section{Materiais avulsos, não vistos, que constam como Kaingang no Tombo Resumido (não possuem ficha)}

1.133 - s/ especificar objeto

2.553 - cerâmica

2.554 - cerâmica

2.562 - cerâmica

2.567 - cerâmica

2.568 - cerâmica

2.569 - cerâmica

2.572 - cerâmica

2.573 - tenaz

2.576 - faixa de entrecasca

$2.593-$ ?

$2.594-$ ?

$2.596-?$

$2.597-?$

$2.598-?$

$2.599-$ ?

2.976 - bastão de combate. 


\section{Acervo Xokleng do MAE-USP}

\section{Arco MAE (Xokleng)}

*13.504 - visto. Na ficha, col. por Egon Schaden, em 1958, no PI Duque de Caxias, Ibirama, SC. Possui trançado de criciúma e imbé aplicado ao arco. Fotografado. Provavelmente de "Tabebuia sp". Compr. total $205 \mathrm{~cm}$; circ. ao centro $11 \mathrm{~cm}$; nas extremidades $6 \mathrm{~cm}$; compr. dos segmentos envolvidos por trançados $18,5 \mathrm{~cm}$.

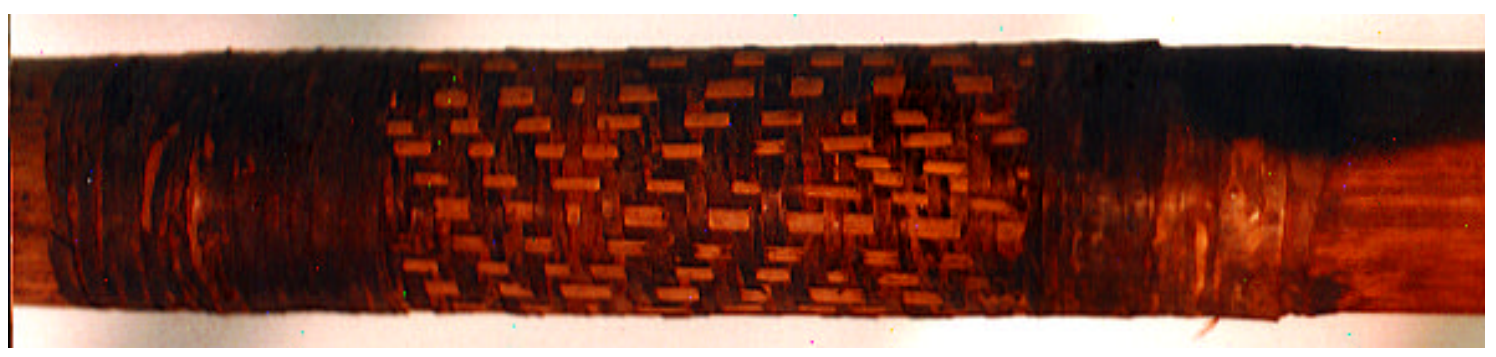

\section{Cerâmica MAE (Xokleng) _ Não vista}

13.765 - Na ficha, col. E. Schaden, em São Bonifácio, SC; peça em forma circular, apresentando 4 orifícios no corpo da vasilha.

\section{Colar MAE (Xokleng) Não visto}

13.763 - Na ficha, col. p/ E. Schaden, em 25, na reg. de Canudos, sul de SC, na localidade de Santo Antônio, há cerca de 30km de São Bonifácio, atual sede do município. Fios de tucum c/ sementes pretas e dentes de animais.

\section{Cordel de cintura MAE (Xokleng)}

13.764 - Visto. Foto. Na ficha, col. p/ E. Schaden, em 1925, na região de Canudos, sul de SC, perto da local. de Santo Antônio, há cerca de 30 km de São Bonifácio, atual sede do município.

\section{Flechas MAE (Xokleng)}

13.505 - Vista. Foto. Na ficha, col. E. Schaden, 58, PI Duque de Caxias, SC. $\mathrm{P} /$ pássaros, com pluminhas amarelas, vermelhas e pretas. Compr. total $159 \mathrm{~cm}$; ponta 5,5 $\mathrm{cm}$; emplumação $41 \mathrm{~cm}$; entalhe $1,2 \mathrm{~cm}$.

13.506 - Vista. Foto. Na ficha, col. E. Schaden, 58, PI Duque de Caxias, SC. Ponta de metal. C/ plumas. Compr. total 150; ponta $15 \mathrm{~cm}$; empl. $46 \mathrm{~cm}$; entalhe 1,5 cm.

13.507 - Vista. Foto. Na ficha, col. E. Schaden, 58, PI Duque de Caxias, SC. Compr. $176 \mathrm{~cm}$; ponta $26 \mathrm{~cm}$; empl. $42,5 \mathrm{~cm}$; entalhe $1 \mathrm{~cm}$.

13.508 - Não vista. Na ficha, col. E. Schaden, 58, PI Duque de Caxias, SC. 
13.509 - Vista. Foto. Na ficha, col. E. Schaden, 58, PI Duque de Caxias, SC. Compr. total $109 \mathrm{~cm}$; ponta $63 \mathrm{~cm}$; emplumação $21 \mathrm{~cm}$.

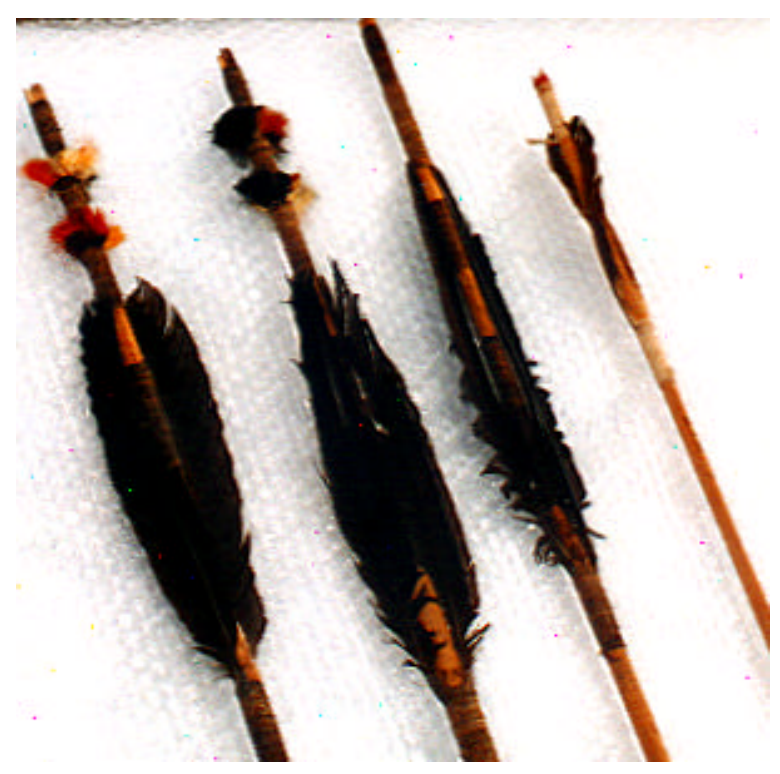

Da esquerda para a direita, RGs. números 13505 , 13506,13507 e 13509.

\section{Lança MAE (Xokleng)}

13.503 - Vista. Foto. Na ficha, col. E. Schaden, 58, PI Duque de Caxias, SC; possui lâmina de ferro e aplicado de trançado de criciúma e imbé.

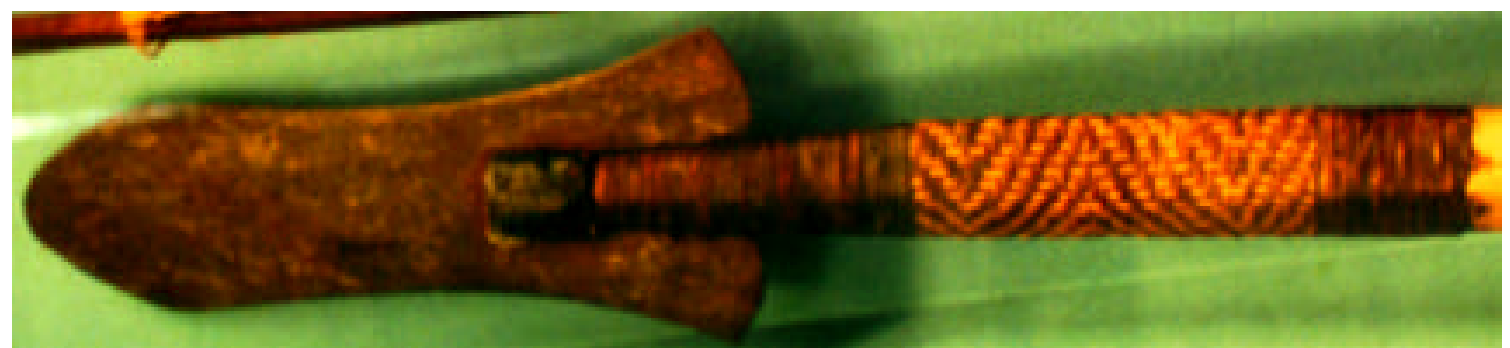

